\title{
Development of a Risk-Based Approach to Hanford Site Cleanup
}

June 1995

\author{
W. A. Hesser \\ Pacific Northwest Laboratory

\section{P. A. Baynes} \\ Westinghouse Hanford Company \\ P. M. Daling \\ Pacific Northwest Laboratory \\ T. F. Demmitt \\ Bechtel Hanford Inc. \\ R. D. Jensen \\ Westinghouse Hanford Company \\ L. E. Johnson \\ Westinghouse Hanford Company
}

L. D. Muhlstein

ARES Corporation

S. M. O'Toole

Westinghouse Hanford Company

A. L. Pajunen

Westinghouse Hanford Company

M. B. Triplett

Pacific Northwest Laboratory

\section{J. L. Waite}

Westinghouse Hanford Company

T. M. Wintczak

Bechtel Hanford Inc.

Prepared for

the U.S. Department of Energy

under Contract DE-AC06-76RLO 1830

Pacific Northwest Laboratory

Richland, Washington 99352 


\title{
DISCLAIMER
}

This report was prepared as an account of work sponsored by an agency of the United States Government. Neither the United States Government nor any agency thereof, nor Battelle Memorial Institute, nor any of their employees, makes any warranty, express or implied, or assumes any legal liability or responsibility for the accuracy, completeness, or usefulness of any information, apparatus, product, or process disclosed, or represents that its use would not infringe privately owned rights. References herein to any specific commercial product, process, or service by trade name, trademark, manufacturer, or otherwise does not necessarily constitute or imply its endorsement, recommendation, or favoring by the United States Government or any agency thereof, or Battelle Memorial Institute. The views and opinions of authors expressed herein do not necessarily state or reflect those of the United States Government or any agency thereof.

\author{
PACIFIC NORTHWEST LABORATORY \\ operated by \\ BATTELLE MEMORIAL INSTITUTE \\ for the \\ UNITED STATED DEPARTMENT OF ENERGY \\ under Contract DE-AC06-76RLO 1830
}

Printed in the United States of America

Available to DOE and DOE contractors from the

Office of Scientific and Technical Information, P.O. Box 62, Oak Ridge, TN 37831;

priced available from (615)576-8401.

Available to the public from the National Technical Information Service, U.S. Department of Commerce, 5285 Port Royal Rd., Springfield, VA 22161 


\section{DISCLAIMER}

Portions of this document may be illegible in electronic image products. Images are produced from the best available original document. 


\section{Acknowledgments}

The authors wish to thank Jim Honeyman, Steve Liedle, and Bill Stillwell for their guidance and support while serving as the Steering Committee for this study.

We also acknowledge the assistance provided by members of our advisory group, especially Rick Wojtasek, Eric Gerber, Duane Bogen, Gary Franz, Dave Seaver, Gary McNair, Ben Johnson, and Tom Varljen.

A special thanks goes to Wayne Toebe, who helped write the section on regulatory impacts, and Bob Henkle, who helped on the land use analysis. Other contributors included risk assessment personnel from both WHC and PNL, including Barbara Harper, Bill Farris, John Buck, Dennis Strenge, Dale King, Mary King, Dennis Stiles, Dick Smith, and Nancy Lane.

Finally, we acknowledge the contributions of DeeAnn Peterson, Debbie Schulz, and Leiloni Reed-Page, who were instrumental in the preparation of the briefing materials and report. Their hard work made delivery of the report on schedule possible. 


\section{Executive Summary}

In response to a request from Mr. Thomas Grumbly, Assistant Secretary of Energy for Environmental Management, the Hanford Site contractors developed a conceptual set of risk-based cleanup strategies that (1) protect the public, workers, and environment from unacceptable risks; (2) are executable technically; and (3) fit within an expected annual funding profile of 1.05 billion dollars.

These strategies were developed because (1) the U. S. Department of Energy and Hanford Site budgets are being reduced, (2) stakeholders are dissatisfied with the perceived rate of cleanup, (3) the U.S. Congress and the U. S. Department of Energy are increasingly focusing on risk and riskreduction activities, (4) the present strategy is not integrated across the Site and is inconsistent in its treatment of similar hazards, (5) the present cleanup strategy is not cost-effective from a risk-reduction or future land use perspective, and (6) the milestones and activities in the Tri-Party Agreement cannot be achieved with an anticipated funding of 1.05 billion dollars annually.

The risk-based strategies described herein were developed through a systems analysis approach that (1) analyzed the cleanup mission; (2) identified cleanup objectives, including risk reduction, land use, and mortgage reduction; (3) analyzed the existing baseline cleanup strategy from a cost and risk perspective; (4) developed alternatives for accomplishing the cleanup mission; (5) compared those alternatives against cleanup objectives; and (6) produced conclusions and recommendations regarding the current strategy and potential risk-based strategies.

This analysis produced a framework and a set of tools that are available for dealing with changes to anticipated funding levels, changes in risk cleanup standards, and Congressional initiatives and inquiries. The tools include land-supply curves, cost profiles, risk profiles, mortgage-reduction curves, and minimum operations costs. The primary results of the study, are (1) the identification of the principal environmental, worker safety, and public health risks; (2) a description of what risk-based cleanup strategies look like; and (3) a description of the implications of adopting a risk-based strategy at the Hanford Site.

This report describes the methodology used to develop mortgage-based, risk-based, and land-based cleanup strategies and how those strategies differ in terms of the work to be performed, its sequence, and the resulting end states. The report also describes what a composite cleanup strategy would look like, as well as a more risk-oriented approach to comply with the current strategy.

\section{Principal Findings}

\section{Can cost-reduction efforts alleviate projected budget constraints and allow Hanford to meet} its commitments?

- Cost reduction efforts alone cannot achieve the necessary savings. Changes in schedules and/or scope of cleanup work will be required. Eliminating unnecessary costs and improving efficiencies, however, must be essential elements of any successful path forward for the Hanford Site. 
- A 50 percent reduction in the cost of cleanup must be immediately achieved and sustained to meet existing commitments and schedules with the projected $\$ 1.05$ billion budget. This reduction would require significant savings from some combination of privatization, productivity enhancements, and regulatory relief.A potential alternative is to extend, in time, the existing strategy driven by the Hanford Federal Facility Agreement and Consent Order ${ }^{(a)}$ (Tri-Party Agreement). Completion of cleanup would be deferred 15 to 20 years. This approach, however, would still require dramatic cost savings (e.g., perhaps a 50 percent reduction in tank waste treatment and disposal costs) and would focus, in the near-term, on mortgage reduction, with minimal effort placed on environmental restoration activities that provide more visible cleanup results.

2. Are there other opportunities to free up funds that can be used to accelerate cleanup progress?

- The Hanford Site committed, nondiscretionary costs necessary to maintain safe operations are estimated to be 500 to 700 million dollars annually. Achieving this level of nondiscretionary funding would require aggressive cost cutting.

- Nondiscretionary costs can be further reduced by investing in high pay-back mortgage reduction efforts. For example, deactivation of PUREX, N Reactor, and B Plant could be completed in three to five years for an additional cost of about 65 million dollars. Over the next 20 years, this investment would save almost 1.3 billion dollars compared to maintaining these facilities in the current conditions. These savings could be reinvested in other cleanup efforts. Without such actions, very little discretionary funding will be available to accelerate cleanup progress.

3. What are Hanford's most urgent hazards and what should be done about them?

- The most significant near-term release hazards from radionuclide sources are the $\mathbf{N}$ fuel stored in $\mathrm{K}$ Basins, cesium and strontium capsules stored in Waste Encapsulation and Storage Facility, the debris in the 324 Building B cell, the safety issue high-level waste tanks, and plutonium in the Plutonium Finishing Plant. While the absolute risk from each source is estimated to fall within the goal of the DOE Nuclear Safety Policy ${ }^{(b)}$, these sources contain large inventories of radionuclides stored in vulnerable or deteriorating conditions. These hazards should receive the highest priority for transition to more stable conditions, in which the potential for radionuclide release has been reduced. Options for providing safe, low-cost, interim storage of these inventories should be evaluated.

- Long-term release hazards through the groundwater pathway are dominated by seven longlived, mobile constituents (C-14, Tc-99, I-129, Np-237, carbon tetrachloride, nitrate, and uranium). If there were no treatment or isolation of existing hazards, carcinogenic risks appear to be about two to three orders of magnitude higher than acceptable limits, while

(a) Ecology, EPA, and DOE, 1994, Hanford Federal Facility Agreement and Consent Order, as amended, Washington State Department of Ecology, U.S. Environmental Protection Agency, and U.S. Department of Energy, Olympia, Washington.

(b) DOE, 1991, Nuclear Safety Policy, SEN-35-91, U.S. Department of Energy, Washington, D.C. 
non-carcinogenic risks (chiefly nitrate) appear to be four to five orders of magnitude higher than acceptable limits. Remediation of existing environmental contamination is not urgent as current land use and access restrictions protect public health and safety.

4. How should worker and ecosystem hazards be managed to ensure that we do no harm during cleanup?

- Some remediation activities pose substantial incremental risks to workers, particularly retrieval of buried and tank waste and decontamination and decommission of some facilities. Where public risk reduction benefits are low, in-place disposal options should be pursued.

- Some remediation actions require extensive construction of new facilities or roads or disposal of treated and excavated waste materials in previously undisturbed lands. These actions should be minimized where public risk reduction benefits are minimal. Co-disposal of waste materials in entombed facilities should be examined as an option for minimizing disruption of new land.

5. What is the relationship between cleanup activities and future land use?

- Long-term risk reduction and future land use determination are interdependent and must be managed jointly, not independently. The value of alternative future land uses should be balanced against the cost required to achieve the cleanup levels necessary to enable those uses. This balance must first be set for areas of the Site that have future use value, including portions of the 600 Area, the 300 Area, and the 100 Area.

- Achieving unrestricted use of all Hanford Site land is not economically feasible given the expected annual funding profile of $\$ 1.05$ billion and the limitations of cleanup technology.

- The Hanford Site has traditionally used a piecemeal approach to making waste-disposal decisions. Numerous prior decisions established portions of the 200 Area as permanent waste disposal sites (e.g., low-level waste burial grounds and disposal of submarine reactor compartments). Yet, there is no comprehensive policy that sets consistent, risk-based standards to govern all disposal practices in the 200 Area. A consistent environmental management policy that explicitly recognizes use of the central plateau for waste disposal is required.

- Endstate standards must consider post-closure risks from potential inventories of both radionuclides and hazardous chemicals. In setting endstate disposal standards, realistic future use scenarios should be considered. Risk acceptance should be predicated on assumptions of restricted use of the 200 Area.

\section{What are the key decisions critical to any risk-based strategy?}

- Four decisions are critical to any risk-based strategy. These decisions are (1) retrieval/ treatment versus in-place disposal of tank waste, (2) retrieval/treatment versus in-place disposal of solid waste, (3) entombment versus removal of major facilities and reactors, and (4) treatment and restoration versus restricted access to groundwater. The key risk considerations for these decisions are "what interim endstates make sense for high-consequence hazards?", "what standards should be used to determine acceptable risks?", "what is the 
tradeoff of increased worker risk and reduced risk to the public?", "what actions provide the biggest risk reduction for cleanup dollars?", and "how should progressive relaxation of landuse restrictions be balanced with risk-reduction efforts?".

7. What are the implications for specific environmental management activities, if a risk-based strategy were adopted?

- By adopting a risk-based strategy like those described in this study, the Site would continue to protect the environment, workers, and the public from unacceptable risks; however, the choice of cleanup activities and their priority would be determined primarily through cost-risk-benefit analyses. For specific waste materials, the following would apply:

Nuclear Materials. Near-term risks associated with these materials would be given priority in the near-term. Given the lack of a national policy for ultimate disposition of these materials, the Hanford Site strategy must plan to manage them safely and efficiently for an indefinite period. An overall strategy for providing long-term, low-cost storage for nuclear materials should be developed and implemented.

Tank Waste. The resolution of tank safety issues and prevention of release of contamination would be given priority. Tank waste disposal and related activities would be delayed, pending the determination of the best solution and the resolution of higher-priority cleanup activities. In-situ disposal of tank waste would be the preferred option. Technology for in-situ disposal should be developed.

Solid Waste. A consistent set of standards must be developed and applied for management of solid waste. In general, buried solid waste would not be retrieved and stored solid waste would be disposed in-place.

Environmental Contamination (groundwater and soils). Groundwater treatment with present technology is not cost effective and would not be pursued. Access and use restrictions and monitoring would continue while natural processes work to restore the groundwater and technology is developed. Contaminated soils would be capped, covered, and disposed in-place.

Environmental restoration activities would be prioritized by benefit per investment dollar. Priorities should be given to $1100 / 3000$ Area, 600 Area from the Columbia River to the perimeter road, 300 Area, 400 Area, and 100 Area.

Facilities. Major facilities would be used for waste disposal and entombed in place. Reactors would be entombed in place. Ongoing mortgage-reduction activities (especially PUREX, N Reactor, and Fast Flux Test Facility) would continue. Other mortgage-reduction activities with high benefit-to-cost ratios (e.g., B plant and $\mathrm{T}$ plant) would be accelerated.

Recommendation: How should the Hanford Site proceed to develop, adopt, and implement a risk-based strategy?

- This study recommends adoption of a Site-wide strategy to accomplish Hanford Site cleanup objectives. Tri-Party Agreement signatories should begin the stakeholder and regulatory process to determine how a new cleanup strategy could be developed and implemented. The 
DOE also must initiate, focus, direct, and support the technical tasks needed to develop the strategy. The methodology and tools used in this study should be used by the DOE and stakeholders in development of a new cleanup strategy.

- Adoption of a risk-based strategy will require hard decisions by all parties involved in and affected by the cleanup. Funding priorities and schedule commitments will change.

Regulatory and statutory modifications will be required, including renegotiation of the Tri-Party Agreement. Cleanup activities, ultimate endstates, and uses of the land will have to be consistent with expected funding profiles. Resolution of these and other issues will require the involvement of stakeholders, including regulators, tribes, and Congress.

- To implement a new, risk-based strategy, Site funding allocation for cleanup activities must reflect and be based upon that strategy. 
•

•

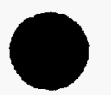




\section{Contents}

Executive Summary $\ldots \ldots \ldots \ldots \ldots \ldots \ldots \ldots \ldots \ldots \ldots \ldots$ iii

1.0 Introduction $\ldots \ldots \ldots \ldots \ldots \ldots \ldots \ldots \ldots \ldots \ldots \ldots \ldots \ldots \ldots \ldots$

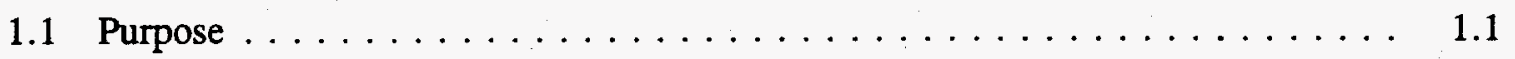

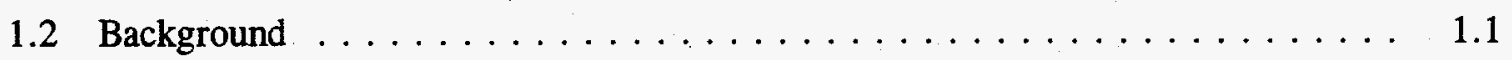

1.3 Scope of the Study $\ldots \ldots \ldots \ldots \ldots \ldots \ldots \ldots \ldots \ldots \ldots$

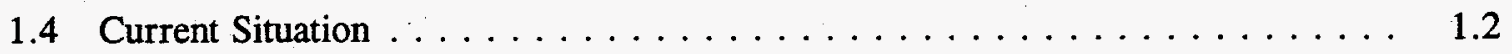

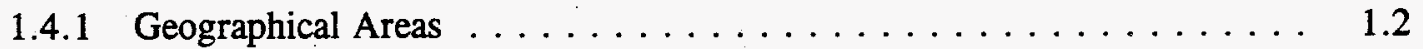

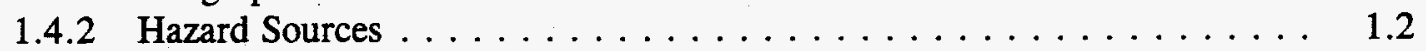

1.4 .3 Funding Shortfalls $\ldots \ldots \ldots \ldots \ldots \ldots \ldots \ldots \ldots \ldots \ldots \ldots$

1.4 .4 Lack of a Consistent Risk Policy . . . . . . . . . . . . . . . . . . 1.4

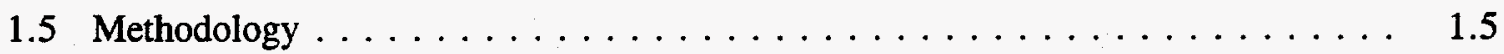

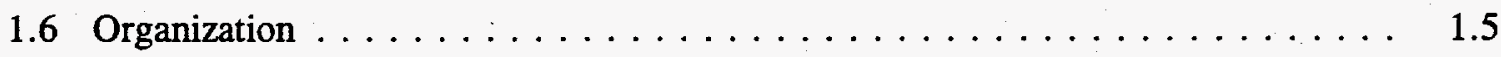

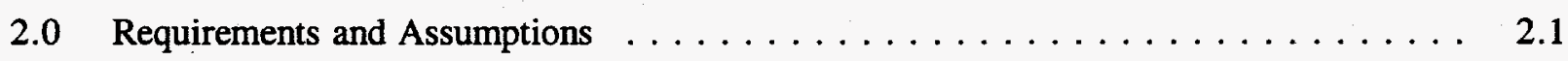

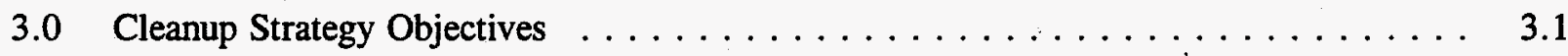

4.0 Mortgage-Reduction Analysis $\ldots \ldots \ldots \ldots \ldots \ldots \ldots \ldots \ldots \ldots \ldots \ldots$

4.1 Minimum Operations $\ldots \ldots \ldots \ldots \ldots \ldots \ldots \ldots \ldots \ldots \ldots \ldots \ldots \ldots$

4.2 Program Nondiscretionary Costs $\ldots \ldots \ldots \ldots \ldots \ldots \ldots \ldots \ldots \ldots$

4.3 Use of Nondiscretionary Costs $\ldots \ldots \ldots \ldots \ldots \ldots \ldots \ldots \ldots \ldots \ldots$

4.4 Mortgage-Reduction Impacts $\ldots \ldots \ldots \ldots \ldots \ldots \ldots \ldots \ldots \ldots \ldots \ldots$

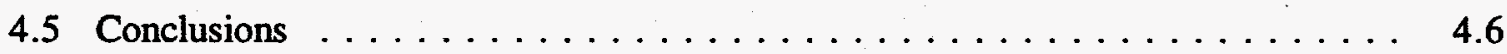

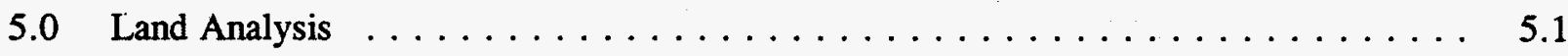

5.1 Land Use Versus Cleanup Levels $\ldots \ldots \ldots \ldots \ldots \ldots \ldots \ldots \ldots$

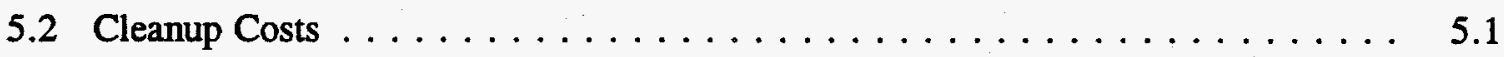

5.3 Land Use Versus Risk Reduction . . . . . . . . . . . . 5.1 


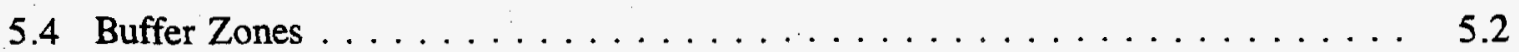

5.5 Progressive Land Use Process $\ldots \ldots \ldots \ldots \ldots \ldots \ldots \ldots \ldots \ldots \ldots$

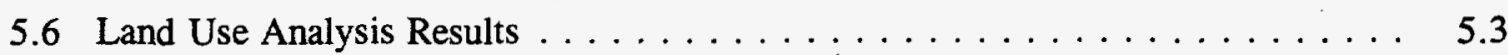

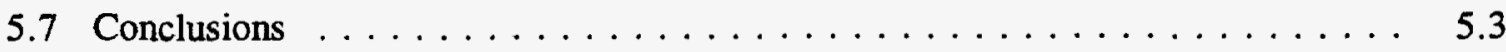

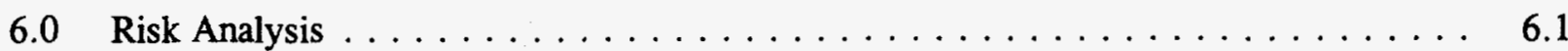

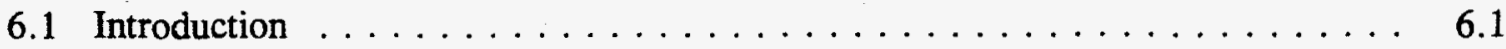

6.2 Near-Term Release Hazards $\ldots \ldots \ldots \ldots \ldots \ldots \ldots \ldots \ldots \ldots \ldots$

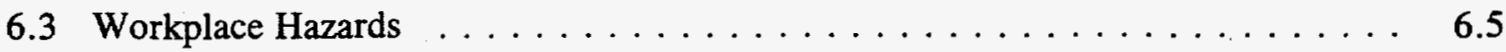

6.4 Long-Term Release Hazards . . . . . . . . . . . . . . . 6.5

6.5 Ecosystem Hazards $\ldots \ldots \ldots \ldots \ldots \ldots \ldots \ldots \ldots \ldots \ldots$

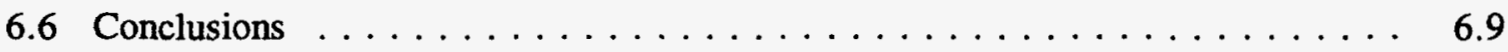

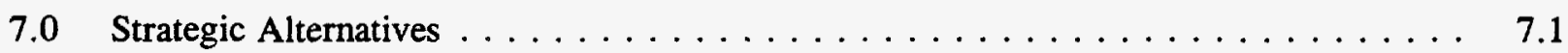

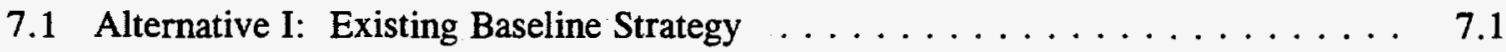

7.1 .1 General Description . . . . . . . . . . . . . . . . 7.1

7.1.2 Development of the Existing Baseline Strategy . . . . . . . . . . 7.2

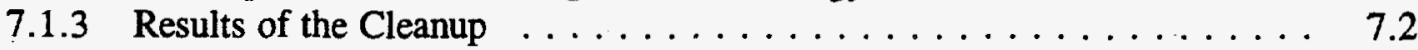

7.1.4 Environmental, Safety, and Health Risks $\ldots \ldots \ldots \ldots \ldots \ldots . \ldots \ldots$

7.1 .5 Land Use . . . . . . . . . . . . . . . . . . 7.3

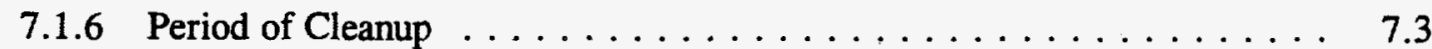

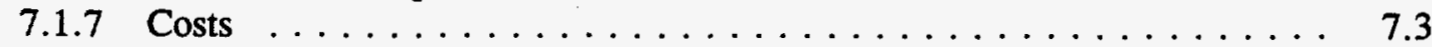

7.1 .8 Programmatic Risks $\ldots \ldots \ldots \ldots \ldots \ldots \ldots \ldots \ldots \ldots \ldots \ldots . \ldots \ldots$

7.1.9 Stakeholder Issues and Regulatory Impacts $\ldots \ldots \ldots \ldots \ldots \ldots \ldots \ldots$

7.2 Alternative II: Baseline Extended Strategy $\ldots \ldots \ldots \ldots \ldots \ldots \ldots$

7.2 .1 General Description . . . . . . . . . . . . . . . . 7.5

7.2.2 Development of the Baseline Extended Strategy $\ldots \ldots \ldots \ldots \ldots \ldots \ldots . . .5 .5$

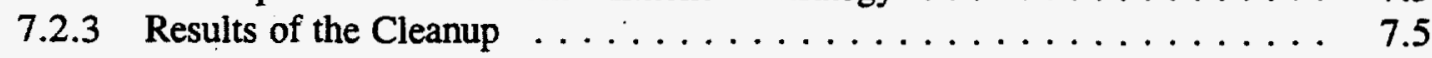

7.2.4 Environmental, Safety, and Health Risks $\ldots \ldots \ldots \ldots \ldots \ldots \ldots . \ldots . \ldots . \ldots$

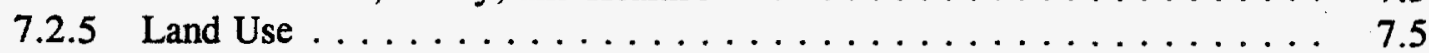

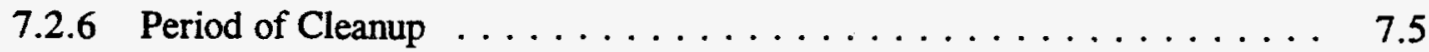

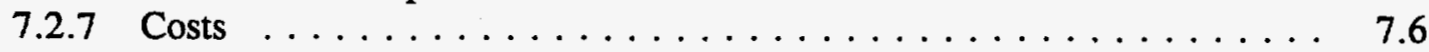

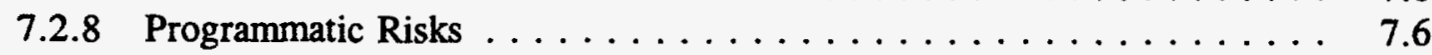

7.2.9 Stakeholder Issues and Regulatory Impacts $\ldots \ldots \ldots \ldots \ldots \ldots \ldots .7$ 
7.3 Alternative III: Risk Strategy $\ldots \ldots \ldots \ldots \ldots \ldots \ldots \ldots \ldots \ldots \ldots .7 .7$

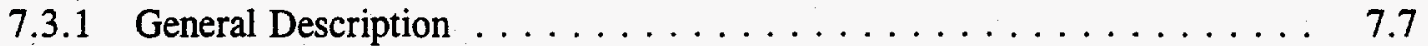

7.3.2 Development of the Risk Strategy $\ldots \ldots \ldots \ldots \ldots \ldots \ldots \ldots \quad 7.7$

7.3.3 Results of the Cleanup $\ldots \ldots \ldots \ldots \ldots \ldots \ldots \ldots \ldots \ldots .7 \ldots \ldots \ldots$

7.3.4 Environmental, Safety, and Health Risks $\ldots \ldots \ldots \ldots \ldots \ldots \ldots \quad 7.8$

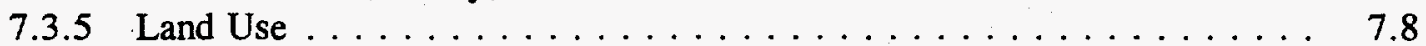

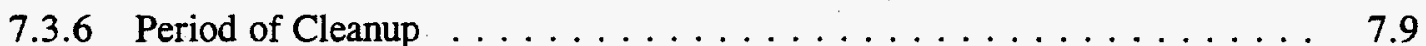

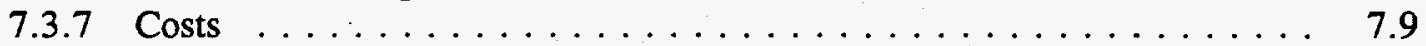

7.3 .8 Programmatic Risks $\ldots \ldots \ldots \ldots \ldots \ldots \ldots \ldots \ldots \ldots . \ldots .10 \ldots$

7.3.9 Stakeholder Issues and Regulatory Impacts $\ldots \ldots \ldots \ldots \ldots \ldots \ldots 7.10$

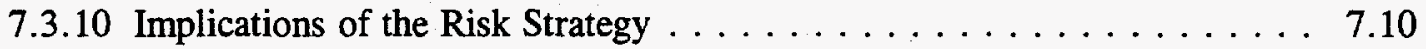

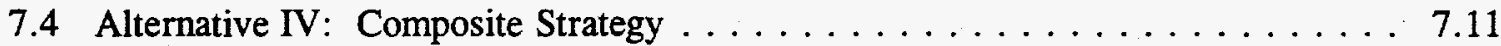

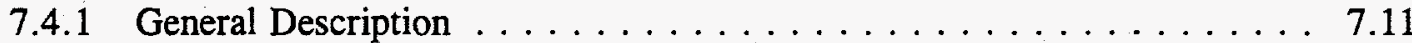

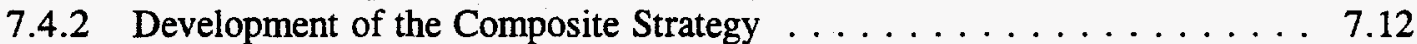

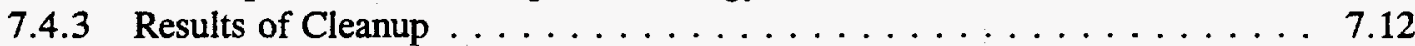

7.4.4 Environmental, Safety, and Health Risks $\ldots \ldots \ldots \ldots \ldots \ldots \ldots .7 .13$

7.4 .5 Land Use . . . . . . . . . . . . . . . . . . . . . 7.13

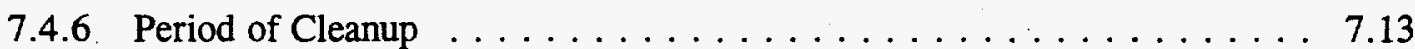

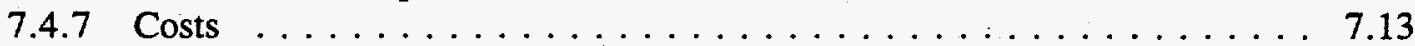

7.4 .8 Programmatic Risk . . . . . . . . . . . . . . . . . . . 7.13

7.4.9 Stakeholder Issues and Regulatory Impacts $\ldots \ldots \ldots \ldots \ldots \ldots \ldots 7.13$

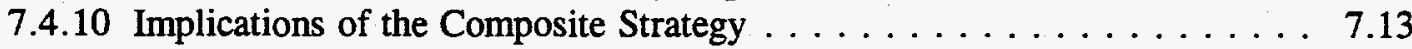

8.0 Comparison of Alternatives $\ldots \ldots \ldots \ldots \ldots \ldots \ldots \ldots \ldots \ldots \ldots \ldots .8 .1$

8.1 Summary Comparison $\ldots \ldots \ldots \ldots \ldots \ldots \ldots \ldots \ldots \ldots \ldots .1$

8.2 Preferred Alternative $\ldots \ldots \ldots \ldots \ldots \ldots \ldots \ldots \ldots \ldots \ldots .3$

8.3 Sensitivity Analysis $\ldots \ldots \ldots \ldots \ldots \ldots \ldots \ldots \ldots \ldots \ldots \ldots$

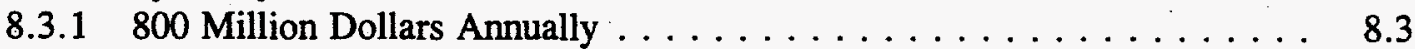

8.3.2 1.25 Billion Dollars Annually $\ldots \ldots \ldots \ldots \ldots \ldots \ldots \ldots \ldots .4 .4$

8.3.3 Sensitivity to Tank Disposal Requirements $\ldots \ldots \ldots \ldots \ldots \ldots .8 .5$

8.4 Schedule Comparisons $\ldots \ldots \ldots \ldots \ldots \ldots \ldots \ldots \ldots \ldots \ldots .6 .5$

9.0 Principal Findings, Conclusions, and Recommendations $\ldots \ldots \ldots \ldots \ldots . .1$

9.1 Principal Findings and Conclusions $\ldots \ldots \ldots \ldots \ldots \ldots \ldots \ldots \ldots .1$

9.1.1 Existing Baseline Strategy Conclusions $\ldots \ldots \ldots \ldots \ldots \ldots \ldots \ldots .9 .1$

9.1.2 Mortgage Reduction Conclusions $\ldots \ldots \ldots \ldots \ldots \ldots \ldots \ldots .9 .1$

9.1.3 Land Use Conclusions $\ldots \ldots \ldots \ldots \ldots \ldots \ldots \ldots . \ldots \ldots . \ldots \ldots$

9.1.4 Public, Worker, and Environmental Risk Conclusions . . . . . . . 9.2

9.1.5 Cleanup Activities and Strategies Conclusions . . . . . . . . . . . 9.3

9.1.6 Conclusions About the Adoption of a Risk-Based Strategy $\ldots \ldots \ldots .9 .3$ 
9.2 Recommendations . . . . . . . . . . . . . . . . . . . 9.4

9.2.1 Recommendations Regarding Adoption of a New Cleanup Strategy . . . . 9.4

9.2.2 Recommendations Regarding Costs and Funding . . . . . . . . . . . . 9.5

9.2.3 Recommendations for Land Use . . . . . . . . . . . . . . . 9.5

9.2.4 Recommendations for the DOE Richland Operations Office . . . . . . . 9.5

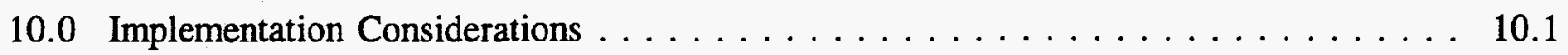

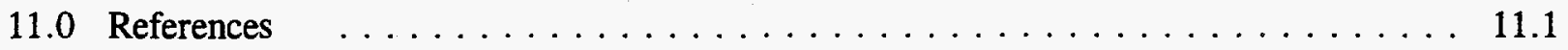

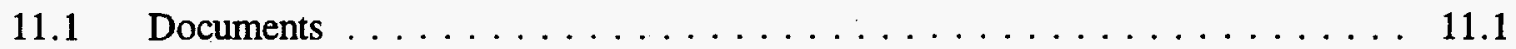

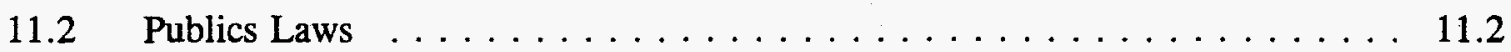

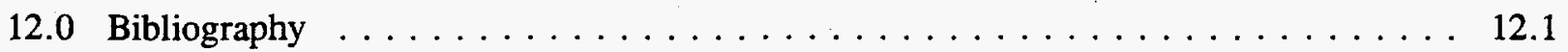

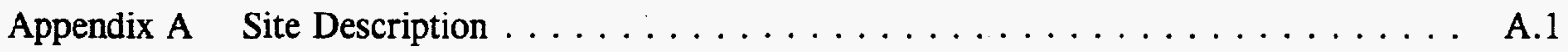

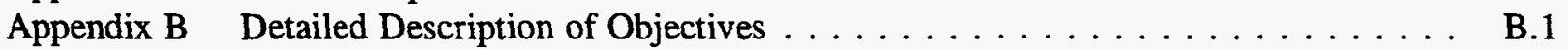

Appendix C Minimum Operations Cost Analysis $\ldots \ldots \ldots \ldots \ldots \ldots \ldots \ldots \ldots \ldots \ldots$

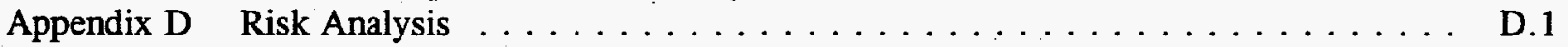

Appendix E Alternative I: Existing Baseline Strategy $\ldots \ldots \ldots \ldots \ldots \ldots \ldots \ldots$. . . . .

Appendix F Alternative II: Baseline Extended Strategy $\ldots \ldots \ldots \ldots \ldots \ldots \ldots \ldots \ldots$ F.1

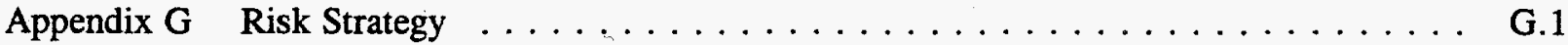

Appendix $\mathrm{H}$ Composite Strategy $\ldots \ldots \ldots \ldots \ldots \ldots \ldots \ldots \ldots \ldots \ldots \ldots$

Appendix I Comparison of Alternatives $\ldots \ldots \ldots \ldots \ldots \ldots \ldots \ldots \ldots \ldots$

Appendix $\mathrm{J} \quad$ Tri-Party Agreement and Regulatory Analysis $\ldots \ldots \ldots \ldots \ldots \ldots \ldots$ 


\section{Figures}

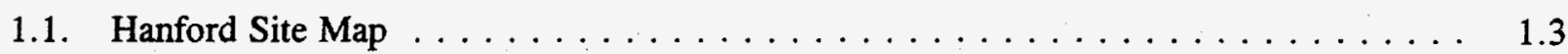

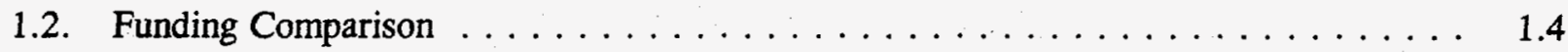

1.3. Methodology for Strategy Development $\ldots \ldots \ldots \ldots \ldots \ldots \ldots$

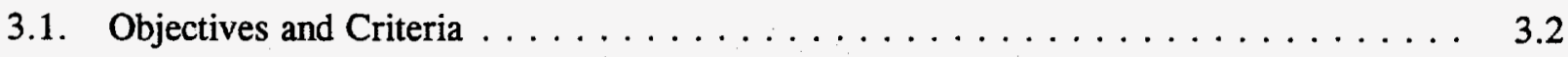

4.1. PUREX Mortgage-Reduction Alternative $\ldots \ldots \ldots \ldots \ldots \ldots \ldots \ldots$

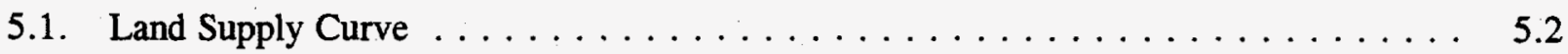

6.1. Parameters Used in Determining Risk $\ldots \ldots \ldots \ldots \ldots \ldots \ldots \ldots$

6.2. Contributions to the Risk to an Average Member of the Public $\ldots \ldots \ldots \ldots .3$

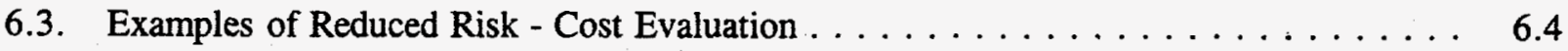

6.4. Radiological and Carcinogenic Risks $\ldots \ldots \ldots \ldots \ldots \ldots \ldots \ldots \ldots \ldots$

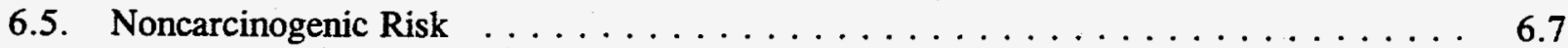

7.1. Existing Baseline Strategy Funding Profile $\ldots \ldots \ldots \ldots \ldots \ldots \ldots$

7.2. Baseline Extended Strategy Funding Profile $\ldots \ldots \ldots \ldots \ldots$

7.3. Risk Strategy Funding Profile $\ldots \ldots \ldots \ldots \ldots \ldots \ldots \ldots \ldots$

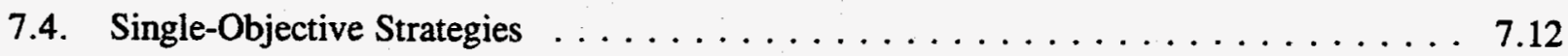

7.5. Composite Strategy Funding Profile $\ldots \ldots \ldots \ldots \ldots \ldots \ldots \ldots \ldots$

8.1. Discretionary Funding Available for Different Budgets $\ldots \ldots \ldots \ldots \ldots$ 


\section{Tables}

4.1 Program Nondiscretionary Costs $\ldots \ldots \ldots \ldots \ldots \ldots \ldots$

4.2 Characteristics of Selected Cleanup Actions as Mortgage Reduction Alternatives . . . . 4.5

8.1 Summary Comparison of Alterative Strategies $\ldots \ldots \ldots \ldots \ldots$

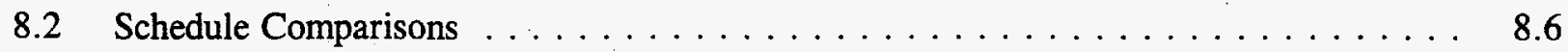




\subsection{Introduction}

\subsection{Purpose}

This report has three purposes: (1) provide insight into an integrated Hanford Site risk-based cleanup strategy; (2) analyze Hanford Site risks; and (3) illustrate the impacts of a risk-based strategy on Hanford Site objectives, budget, schedule, and stakeholder interests. This report is provided to Hanford Site management (i.e., the U.S. Department of Energy [DOE] and contractor principals) to assist in the resolution of issues resulting from dramatic budget reductions, potential changes in regulatory environment, and the need to demonstrate cleanup progress.

\subsection{Background}

The Hanford Site is at a crossroads. Budgets have been cut substantially and more cuts are expected in the future. The DOE is being scrutinized by the U.S. Congress, the Defense Nuclear Facility Safety Board, and the National Academy of Science. Challenges have been made to the Hanford Federal Facility Agreement and Consent Order (Ecology et. al 1994) (Tri-Party Agreement) such as those in Train Wreck Along the River of Money -- An Evaluation of the Hanford Cleanup (Blush and Heitman 1995), and stakeholders are increasingly dissatisfied with the rate of progress.

Hanford Site contractor personnel met with the Assistant Secretary for Environmental Management, Mr. Thomas Grumbly, in December 1994, to discuss the impact of budget cuts on current Hanford Site activities. Realizing the situation, Mr. Grumbly requested a risk-based cleanup strategy be developed for the Site for the entire cleanup period. Acting on this request, a multi-contractor team from Westinghouse Hanford Company; Pacific Northwest Laboratory; and Bechtel Hanford, Incorporated was established to prepare a risk-based strategy. A charter was developed and approved in January 1995, and the task team was assembled in early February.

\subsection{Scope of the Study}

This effort focuses on the Hanford Site cleanup mission and addresses all material inventories at the Site for the entire cleanup period. The scope of the cleanup mission includes those processes that:

- Reduce or maintain the health, safety, and environmental hazards associated with the Site to acceptable levels;

- Convert hazards to safe, stable forms;

- Maintain or disposition existing materials, facilities, and waste inventories; and

- Restore the land to enable future uses. 
Cleanup is complete when the above conditions are met and when only post-closure monitoring activities continue.

In this study, a cleanup strategy is a set of statements that describes the actions that must be taken to accomplish the Hanford Site cleanup mission. A strategy describes the sequence and priority of cleanup activities and the amount of resources that will be applied to those activities over the cleanup period. A strategy specifically ties resources to objectives. A cleanup strategy states (1) what will be done, (2) when it will be done, and (3) what the result will be.

\subsection{Current Situation}

The Hanford Site has been used for production of defense nuclear materials for almost 50 years. The legacy of the defense production mission includes large quantities of nuclear materials, liquid waste, solid waste, environmental contamination (e.g, soils, groundwater), and several facilities contaminated with radionuclides and other hazardous materials. These Site features present a risk to the public, workers, and environment.

\subsubsection{Geographical Areas}

The Hanford Site is approximately 560 square miles and has historically been divided into geographical areas. The 100,200,300, and 400 Areas have been developed and maintained with an extensive infrastructure that could be attractive for non-government industrial activities. Figure 1.1 provides a map of the areas. See Appendix A for a more detailed description.

\subsubsection{Hazard Sources}

The hazard sources on the Hanford Site have been aggregated into the following general categories. Appendix A provides a more detailed description.

- Nuclear materials include unirradiated uranium, irradiated fuel, special nuclear material, and cesium and strontium capsules.

- Liquid waste includes tank waste, $\mathrm{K}$ Basin and N Basin water, and liquid effluents.

- Solid waste includes pre-1970 unsegregated buried waste, post-1970 segregated nontransuranic buried waste, transuranic retrievably-stored waste, facility. stored waste, and newly-generated (future) waste.

- Environmental contamination includes solid waste sites, liquid disposal sites, contaminated soil, and contaminated groundwater.

- Facilities include two general categories: radiological and nonradiological. Radiological facilities include reactors, fuel fabrication facilities, fuel reprocessing plants, hot laboratories, tanks, and basins. Nonradiological facilities include steam plants, maintenance shops, and office buildings. 


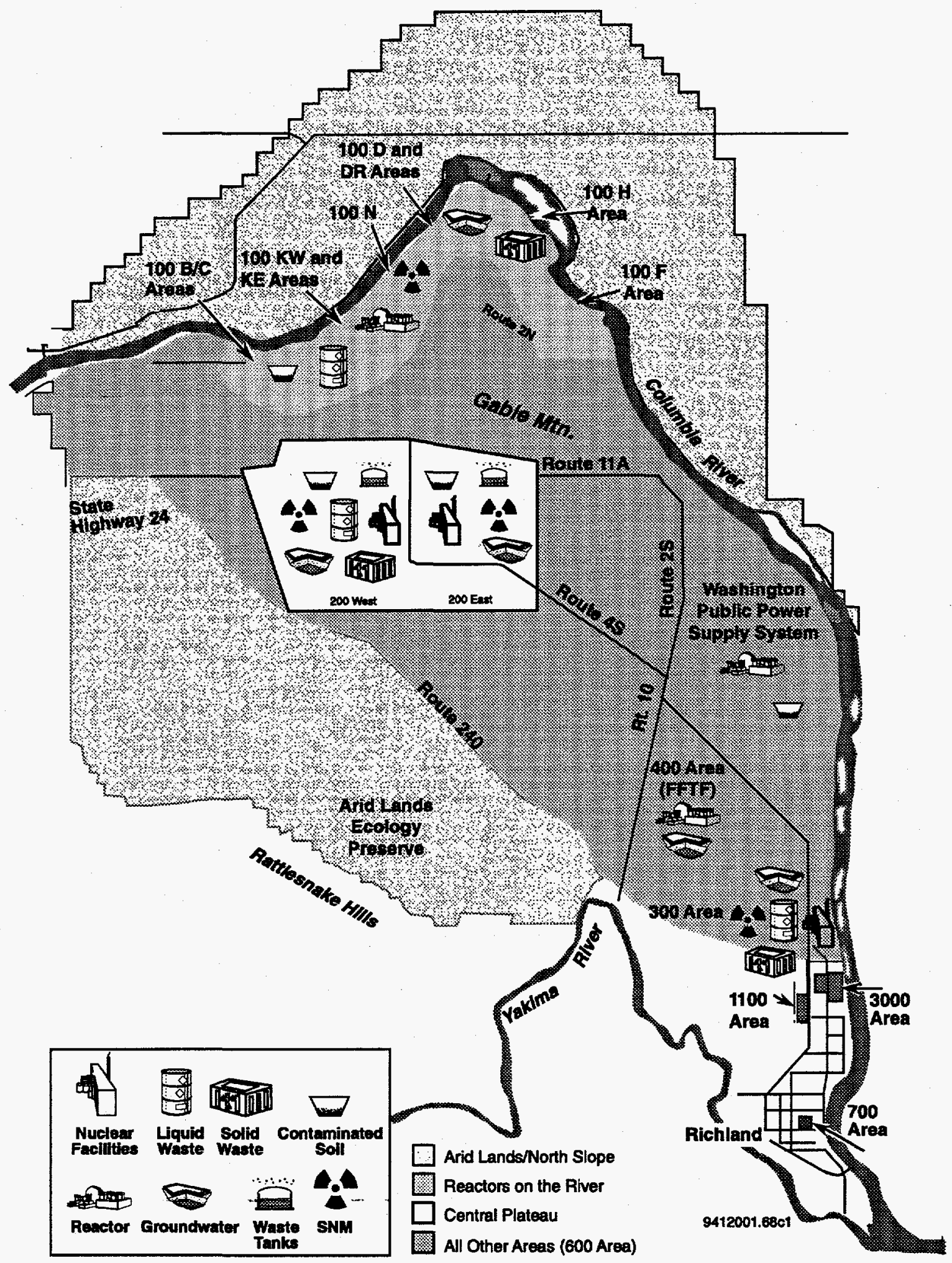

Figure 1.1. Hanford Site Map 


\subsubsection{Funding Shortfalls}

Figure 1.2 contains a comparison of the funding needed to support the existing cleanup strategy with anticipated funding limits. Funding shortfalls exceed one billion dollars annually for about 30 years unless anticipated costs are reduced through cost efficiencies, productivity enhancements, privatization, and other measures.

\subsubsection{Lack of a Consistent Risk Policy}

Current Hanford Site cleanup plans are not consistent in addressing environmental, worker safety, and public health risk. There is not a national or Site policy for risk reduction, and plans for cleanup activities in the same area do not lead to a consistent risk endstate. Cleanup plans are not generally based on risk or risk-reduction goals and there is not general agreement on quantifiable standards for cleanup.

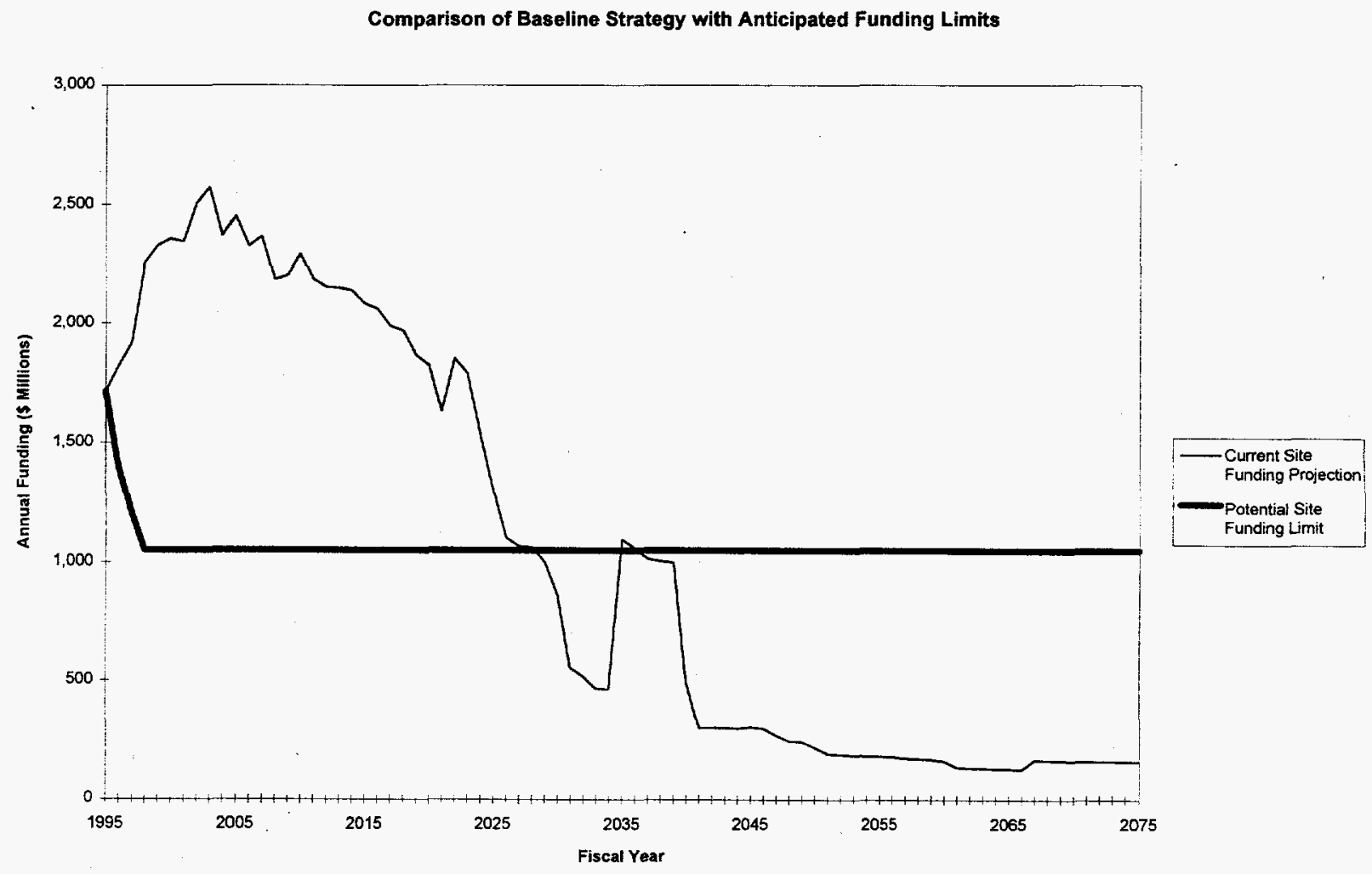

Figure 1.2. Funding Comparison 


\subsection{Methodology}

Figure 1.3 illustrates the systems approach used in this study.

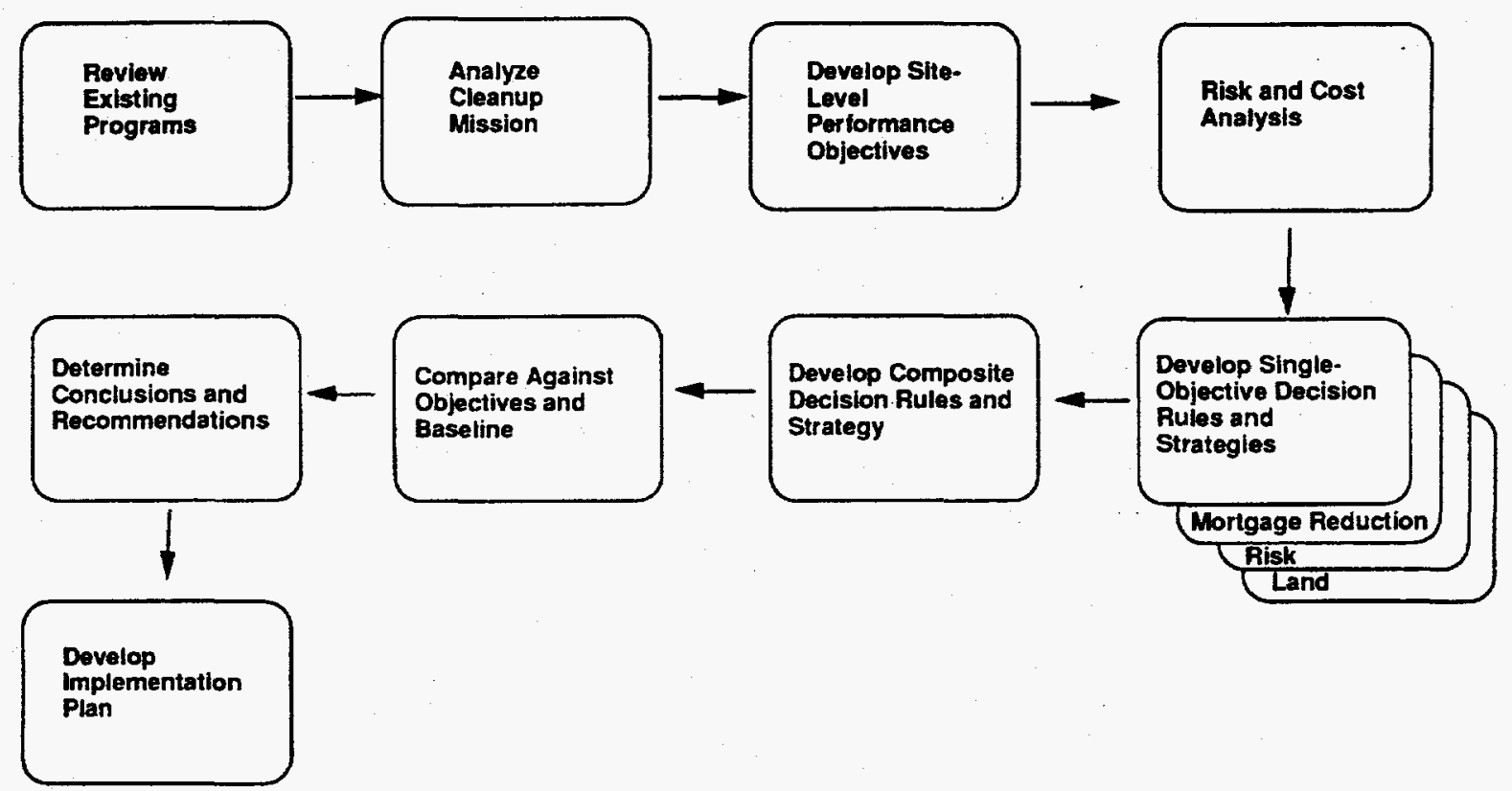

Figure 1.3. Methodology for Strategy Development

\subsection{Organization}

This report contains two parts: Main Report and Appendixes. The Main Report is organized in accordance with the methodology of the study. Requirements and assumptions are presented in Section 2.0, followed by cleanup objectives in Section 3.0. The analyses regarding mortgage reduction, land use, and risk are developed in Sections 4.0, 5.0, and 6.0, respectively. Section 7.0 describes the four alternatives considered in the study, followed by a comparison of those alternatives against cleanup objectives in Section 8.0. Principal findings, conclusions, and recommendations are presented in Section 9.0, and a short description of implementation actions and key decisions concludes the Main Report in Section 10.0. The Appendixes contain detailed analyses that support the summary findings, conclusions, and recommendations in the Main Report. 


\subsection{Requirements and Assumptions}

Any Hanford Site cleanup strategy is required to (1) protect the public, workers, and environment from unacceptable risks; (2) be executable technically; and (3) fit within the anticipated funding profile. The following assumptions were used in the development of a risk-based cleanup strategy.

- Funding will decrease from current levels to 1.05 billion dollars in fiscal year 1998. From then on funding is level for the period of cleanup. Escalated dollars were used through fiscal year 1998, after which constant dollars were used.

- Funds can be moved across program lines.

- Regulatory waivers or modifications, including statutory changes, can be obtained, if necessary, to execute the strategy.

- The Tri-Party Agreement can be renegotiated, if necessary.

- All aspects of the current Hanford Site cleanup strategy can be changed, if warranted. This includes all treatment, storage, and disposal activities, including off-site shipment of certain materials and Site development plans. 


\subsection{Cleanup Strategy Objectives}

Cleanup objectives and criteria were used to compare strategic alternatives. The Hanford Site strategic planning documents, including the Fiscal Year 1995 Hanford Mission Plan (RL 1994), and documents that reflect stakeholder values, including The Future for Hanford: Uses and Cleanup (Working Group 1992), were used to develop the cleanup strategy objectives. Information from these documents and more recent guidance from DOE were used to develop a new set of cleanup strategy objectives. Figure 3.1 shows the objectives and associated criteria. Note that stakeholder values are reflected throughout the figure, not just under the Maximize Stakeholder Confidence objective (e.g., stakeholder values include minimizing risks and demonstrating progress). Appendix B contains a detailed description of the objectives, criteria, and metrics used to evaluate the alternatives.

The fundamental objectives of the Hanford Site cleanup strategy are: (1) reduce risk and (2) make land available for other uses. These two objectives are shown in Figure 3.1 as Minimize Environmental, Safety, and Public Health Risks and Maximize Land Use Potential. The release of land for other uses has generally not been stated as a specific objective of the cleanup program in earlier planning documents, but it is considered key to making progress, meeting stakeholder demands, and determining an endpoint for a new risk-based strategy.

The Maximize Progress, Maximize Cost Effectiveness, Maximize Likelihood of Success, and Maximize Stakeholder Confidence objectives are means to the ends of reducing risk and making land available. For example, without stakeholder acceptance a strategy cannot be implemented. Similarly, the reduction of costs dedicated to surveillance and maintenance activities makes funds available for other cleanup activities.

Figure 3.1 also contains criteria associated with the objectives. Criteria are used to measure the degree to which an objective is achieved.

Figure B.1 (Appendix B) shows the Site cleanup objectives and the weights associated with those objectives. These weights were set by DOE Richland Operations Office senior managers during a value-elicitation session on December 5, 1994. The weights were used in this study to determine the order in which activities could be executed for two of the strategic alternatives: Baseline Extended Strategy and Composite Strategy. These weights come from the Revised Priority Planning Grid in Attachment B1 (Appendix B). It should be noted that these weights are generally consistent with those of organizations around the DOE complex (e.g., public health is the most important, worker safety is second, and protecting the environment is third).

The study analyzed three of the cleanup objectives to understand their impact on a cleanup strategy: (1) Mortgage Reduction, (2) Land Use, and (3) Risk. These analyzes are summarized in the following three sections of the report and are described in detail in Appendices C, H, and D, respectively. 


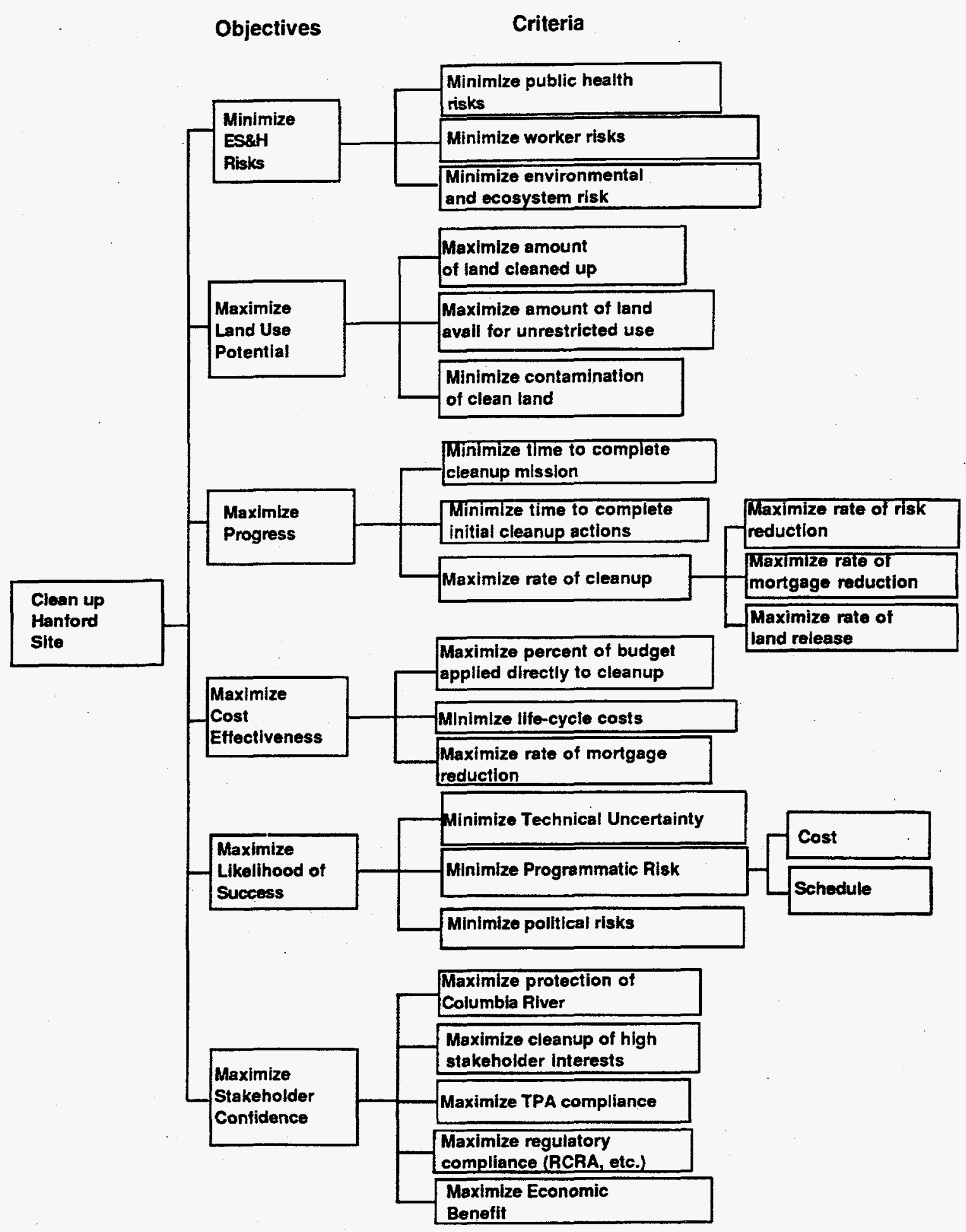

Figure 3.1. Objectives and Criteria 


\subsection{Mortgage-Reduction Analysis}

Cost profiles were used to determine the impact of funding constraints on cleanup alternatives. The minimum Hanford Site operation costs were estimated based on surveillance and maintenance of facilities and materials in the current configuration. These minimum operation costs were considered "nondiscretionary," necessary to protect the public and workers from exposure to the stored materials and wastes.

Cleanup actions that further reduce risks or make land available were considered as blocks of costs that could be shifted to satisfy a specified budget profile. These actions were treated as "discretionary" costs to the extent that some flexibility was available to shift the activities in time (assuming continued surveillance and maintenance) without significantly impacting near-term public or worker risks. Completion of some discretionary actions also reduces minimum operations cost by changing facility or material storage configurations or by reducing surveillance and maintenance funding requirements. These actions have been termed "mortgage reductions."

The following discussion summarizes the estimated nondiscretionary costs that were used as a starting point for developing alternative Site cleanup strategy cost profiles. The discussion also describes the influence of mortgage-reduction activities on the minimum operation costs. Additional information on minimum operation costs is provided in Appendix $\mathrm{C}$, and details of the mortgagereduction actions are provided in Appendix $H$.

\subsection{Minimum Operations}

In the context of this report, minimum operations are those surveillance, maintenance, and support costs required to control existing material, waste, and facilities in a safe, stable condition. No remediation, stabilization, or disposal will occur, and new activities required to comply with regulatory agreements will not be completed at the minimum operation funding level. Current routine reporting activities necessary to satisfy public and worker safety regulations for surveillance and maintenance are embedded in current operations estimates.

\subsection{Program Nondiscretionary Costs}

The Hanford Site nondiscretionary costs to maintain minimum operations are currently estimated to range from 500 to 700 million dollars per year. Table 4.1 provides a summary of estimated nondiscretionary costs by program, assuming the above definition. A range of funding is shown because costs estimates for minimum operations that exclude new actions for regulatory compliance are not readily available from current plans. A point estimate of approximately 600 million dollars per year was used in this study for the minimum operations cost to build alternative strategy cost profiles.

The difference between the committed, nondiscretionary costs and the anticipated budget constraint represents funding available to make progress in cleanup. Assuming a constrained budget, funding available for cleanup actions increases as the nondiscretionary costs decrease. If the future budget is 
Table 4.1. Program Nondiscretionary Costs

\begin{tabular}{|c|c|c|c|}
\hline \multicolumn{2}{|r|}{ Activity } & Range, \$M & $\begin{array}{l}\text { Estimate used for } \\
\text { planning, } \$ M\end{array}$ \\
\hline \multicolumn{2}{|c|}{ Liquid effluent } & $10-15$ & 11 \\
\hline \multicolumn{2}{|c|}{ RCRA and OPS monitoring } & $10-15$ & 13 \\
\hline \multicolumn{2}{|c|}{ Pacific Northwest Laboratory (WM) } & $15-25$ & 20 \\
\hline \multicolumn{2}{|l|}{ Landlord } & $15-25$ & 21 \\
\hline \multicolumn{2}{|c|}{ Facility transition (EM-30) } & $25-35$ & 33 \\
\hline \multicolumn{2}{|c|}{ Fast Flux Test Facility } & $30-40$ & 35 \\
\hline \multicolumn{2}{|c|}{ Analytical services } & $30-40$ & 36 \\
\hline \multicolumn{2}{|c|}{ Spent nuclear fuels (K Basins) } & $35-45$ & 42 \\
\hline \multicolumn{2}{|c|}{ Environmental restoration } & $30-50$ & 42 \\
\hline \multicolumn{2}{|l|}{ Solid waste } & $40-60$ & 48 \\
\hline \multicolumn{2}{|c|}{$\begin{array}{l}\text { Administration (RL, HEMP, planning, } \\
\text { HAMMER, transportation) }\end{array}$} & $55-85$ & 70 \\
\hline \multicolumn{2}{|c|}{ Facility transition (EM-60) } & $80-110$ & 98 \\
\hline \multicolumn{2}{|c|}{ Tank Waste Remediation System } & $120-150$ & 143 \\
\hline \multicolumn{2}{|l|}{ Site total } & $495-695$ & 612 \\
\hline \multicolumn{4}{|c|}{$\begin{array}{ll}\text { HAMMER } & =\text { Hazardous Materials M } \\
\text { HEMP } & =\text { Hanford Environmenta } \\
\text { M } & =\text { million. } \\
\text { OPS } & =\text { operations. } \\
\text { RCRA } & =\text { Resource Conservation } \\
\text { RL } & =\text { DOE Richland Operati } \\
\text { WM } & =\text { waste management. }\end{array}$} \\
\hline
\end{tabular}

limited to 1050 million dollars per year, current nondiscretionary costs would allow approximately 450 million dollars per year to be directed toward cleanup actions.

The estimated nondiscretionary costs were not developed with the intent to model a complete strategy with Site activities supporting only minimum surveillance and maintenance activities. The point estimate used in the evaluations does not consider factors such as deteriorating facilities that would continue to increase future surveillance and maintenance costs, nor does it consider that some facility deactivation could occur at a much slower pace at the minimum operations cost and eventually reduce minimum surveillance and maintenance requirements from current levels. In addition, contributions to support infrastructure and other indirect costs necessary to operate the Site were assumed available based on a total annual budget of approximately 1000 million dollars. Fixed costs associated with these activities would need to be added to a stand-alone estimate of nondiscretionary costs. Therefore, it is best to consider nondiscretionary costs as a tool to help examine different strategies and not as a strategy itself. 


\subsection{Use of Nondiscretionary Costs}

Cost profiles were constructed from the point estimates for minimum operations by combining blocks of costs for cleanup activities with a prioritization list developed from decision rules for each strategy. As a cleanup action was completed, the resultant reduction in nondiscretionary costs was tracked. Blocks of cleanup actions were added on top of the costs according to the priority list until the budget constraint was observed, adjusting the out-year impacts on minimum operation requirements. This procedure was repeated until all the identified cleanup actions for a strategy had been included. Treating the cleanup actions as blocks allowed approximation of the action delays or acceleration that could be accommodated within the funding constraint.

Each alternative to the baseline strategy was constructed to satisfy the Site funding constraint under evaluation. The cost data used to model cleanup actions originate from multiple sources (e.g., program plans, environmental impact statements, engineering studies) with cost profiles modified to approximate constant dollars starting in 1998 . The results should be considered to present rough order-of-magnitude costs, not budget quality estimates. The resultant cost profiles are not in themselves as important as a discriminator among alternatives as the schedule implications for major cleanup actions derived from the profiles.

\subsection{Mortgage-Reduction Impacts}

Many cleanup actions are projected to reduce the current minimum operations cost by changing facility or material storage configurations. Typically, a resource investment in excess of the estimated minimum operations cost for a particular facility is required to realize reduced surveillance and maintenance costs. The simplest examples of this concept are provided by facility deactivation, such as that currently in progress at PUREX.

Figure 4.1 indicates projected cost profiles assuming funding for PUREX is either reduced to minimum operations in its current configuration or assuming it is deactivated according to current plans. Without deactivation, a significant surveillance and maintenance staff would be required to ensure the residual facility inventory is maintained within the defined plant safety boundaries. This includes maintaining controls on the spread of contamination using the existing ventilation system configuration with multiple effluent monitoring points and utility support systems. Maintenance of the current configuration requires routine access by Site personnel that further increases the number of active facility systems (e.g., water, steam, fire protection, lighting) required to maintain a safe working environment. These activities result in estimated annual surveillance and maintenance costs of about 36 million dollars.

Investing approximately 12 million dollars in excess of the minimum operations cost over fiscal years 1996 and 1997 allows for completion of deactivation activities that reduce the plant residual inventory and reconfigure contamination control systems. The revised configuration will eliminate most high-maintenance support systems and minimize routine personnel access, allowing further deactivation of the primary utilities. These actions are estimated to reduce annual surveillance and maintenance costs to two million dollars. Therefore, assuming the resources are invested, completion of PUREX deactivation would reduce the Site minimum operations cost by approximately 34 million dollars. This would begin to be realized in fiscal year 1998. 


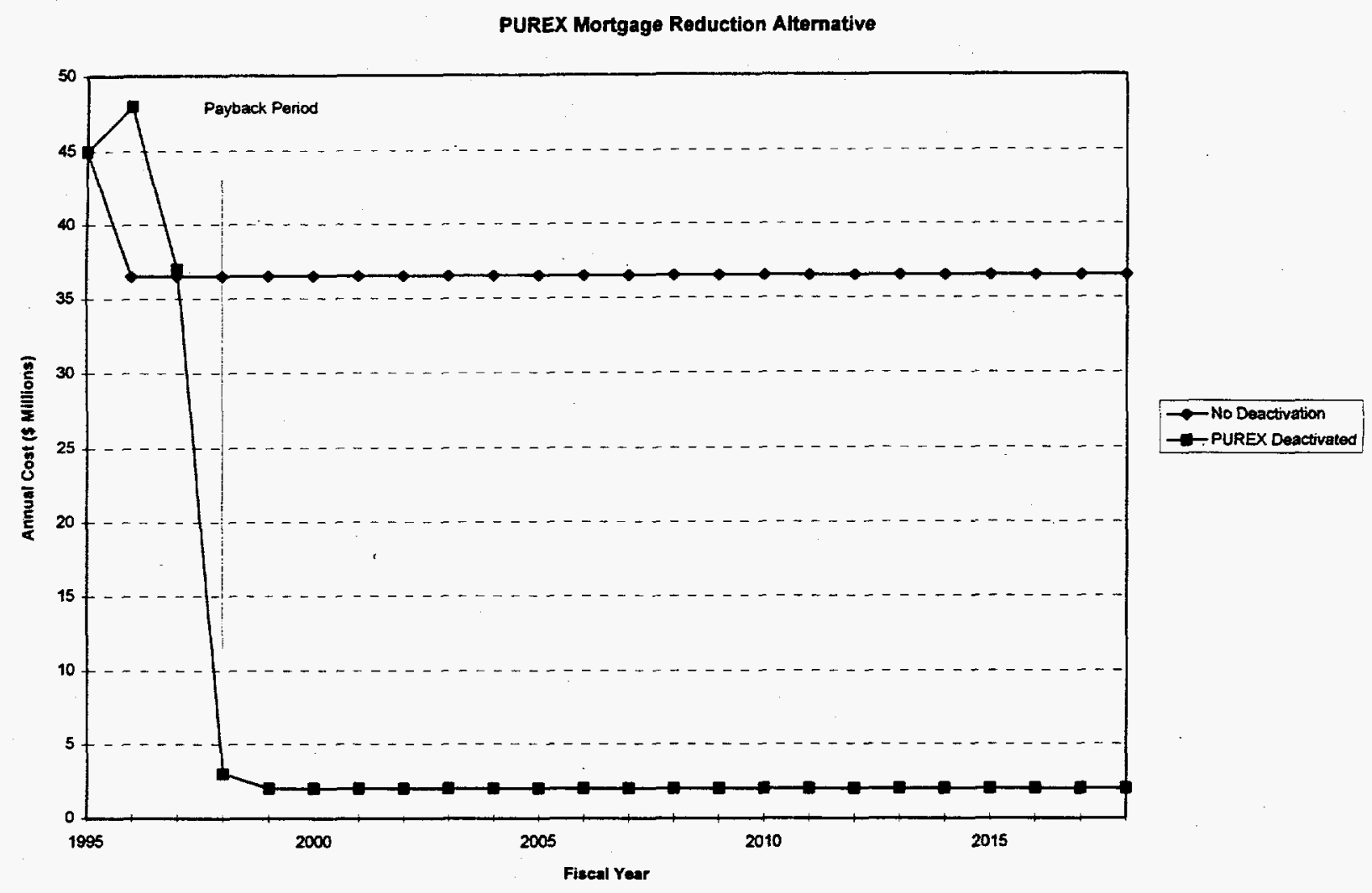

Figure 4.1. PUREX Mortgage-Reduction Alternative

Similar comparisons were developed for other Site cleanup activities. These are described in Appendix $H$. Table 4.2 provides a summary of the characteristics of cleanup actions found to have the most significant potential to reduce the minimum operations cost. These cleanup actions are dominated by deactivation of former production facilities. Table 4.2 indicates the current surveillance and maintenance costs included in the program minimum costs shown in Table 4.1. The potential reduction in minimum operation costs for each action represents the difference between current surveillance and maintenance costs and surveillance and maintenance costs after completion of the facility deactivation.

The investment required to achieve surveillance and maintenance cost reductions are estimated as described in the example for PUREX. In some cases, significant investment spread over a number of years is required to achieve the reduced surveillance and maintenance cost configuration. These variations impact the attractiveness of cleanup actions as a mortgage-reduction alternative. Therefore, a benefit-to-cost ratio was defined to compare the alternatives.

The cleanup actions in Table 4.2 are listed in order of a benefit-to-cost ratio, which is defined as the sum of annual cost savings realized through the year 2018 divided by the total deactivation cost in excess of current surveillance and maintenance costs. Additional discussion of this comparison and cost curves for each cleanup action listed in Table 4.2 are provided in Appendix $\mathrm{H}$. 
Table 4.2. Characteristics of Selected Cleanup Actions as Mortgage Reduction Alternatives

\begin{tabular}{|c|c|c|c|c|c|}
\hline Cleanup action & $\begin{array}{c}\text { Current } \\
S \& M \text { cost } \\
(\$ M / y r)\end{array}$ & $\begin{array}{l}\text { S\&M cost after } \\
\text { cleanup action } \\
(\$ M / y r)\end{array}$ & $\begin{array}{l}\text { Potential reduction in } \\
\text { minimum operations Cost } \\
(\$ \mathrm{M} / \mathrm{yr})\end{array}$ & $\begin{array}{l}\text { Total deactivation cost in } \\
\text { excess of current } S \& M^{(a)} \\
(\$ M)\end{array}$ & $\begin{array}{l}\text { Benefit to cost ratio } \\
\text { through } 2018^{(\text {b) }}\end{array}$ \\
\hline PUREX deactivation & 36.5 & 2 & 34.5 & 12 & 60 \\
\hline N Reactor deactivation & 16.5 & 3 & 13.5 & 22.5 & 12 \\
\hline B Plant deactivation & 29 & 11 & 18 & 32 & 11 \\
\hline FFTF deactivation & 37 & 12 & 25 & 70 & 6.5 \\
\hline T Plant deactivation & 23 & 2 & 21 & 60 & 5.3 \\
\hline Other 300 Area facilities & 5 & 0 & 5 & 18 & 5.0 \\
\hline WESF deactivation & 11 & 3 & 8 & 28 & 3.1 \\
\hline 300 Area fuel supply buildings & 4 & 1.8 & 2.2 & 27 & 1.4 \\
\hline PFP deactivation & 60 & 25.4 & 34.6 & 351 & 1.3 \\
\hline K Basins (accelerated SNF path forward) & 42 & 1.5 & 40.5 & 466 & 1.2 \\
\hline TWRS safety/efficiency upgrades & 143 & 87 & 55.7 & 950 & 1.0 \\
\hline 100 Area reactor support buildings & 3 & 0 & 3 & 150 & .34 \\
\hline
\end{tabular}

(a) Total of costs in all years funding exceeds current minimum S\&M costs to complete actions that result in the minimum operations cost reduction presented.

(b) Benefit-to-cost ratio is defined as the sum of savings from S\&M cost reductions observed through 2018 divided by the cost of deactivation activities in excess of the current S\&M costs.

FFTF = Fast Flux Test Facility

$M \quad=$ million.

PFP = Plutonium Finishing Plant.

SNF $=$ spent nuclear fuel.

$S \& M=$ surveillance and maintenance.

TWRS $=$ Tank Waste Remediation System.

WESF $=$ Waste Encapsulation and Storage Facility. 
Accumulation of cost-savings from cleanup actions that reduce the Site mortgage can significantly reduce the minimum operations cost in future years. For example, the first three actions listed in Table 4.2 (PUREX, N Reactor, and B Plant deactivation) are estimated to cost an additional investment of 65 million dollars over two to three years. When complete, the Site minimum operations cost is estimated to be reduced by approximately 65 million dollars a year, and the money would then be available to fund other cleanup actions instead of supporting facility surveillance and maintenance. This savings totals approximately 1.3 billion dollars available for use in other cleanup actions over a 20 -year period.

\subsection{Conclusions}

The cost analysis shows the Site has annual nondiscretionary costs between 500 and 700 million dollars and has about 350 to $\mathbf{5 5 0}$ million dollars available to apply to cleanup, assuming a future funding constraint of 1050 million dollars. The funding available for future cleanup actions will be significantly less than this range unless the Site is able to drive nondiscretionary costs down. To achieve this level of nondiscretionary cost (1) some programs must be reduced to minimum levels, (2) some compliance actions cannot be supported, (3) some ongoing cleanup activities must stop, and

(4) regulatory waivers must be obtained to approach the minimum operations costs used by this study. Resistance to these changes (internal and external) should be expected. Mortgage-reduction actions allow funds currently committed to surveillance and maintenance to be shifted to support other cleanup activities. 


\subsection{Land Analysis}

The objective of this analysis is to understand the important concepts of land use that should be applied to any cleanup strategy at the Hanford Site. Land use refers to Hanford Site land available for various uses once cleanup is complete. There are many different uses proposed for Hanford Site land after cleanup, and each is directly linked to specific cleanup criteria. For example, recreational use requires cleanup to levels that are different than levels for residential use. Jointly defining land use and cleanup criteria is key to establishing cleanup actions and priorities. The following outlines the principal concepts of land use.

\subsection{Land Use Versus Cleanup Levels}

A specific post-cleanup use for an area of Hanford Site land determines the level of cleanup that must be accomplished. Conversely, defining cleanup levels for areas of land will determine what the land can be used for. The level of cleanup directly affects the cost of cleanup, and many cleanup activities can be too costly. For example, unrestricted land use in a severely contaminated area may drive the cleanup levels beyond what is technically and financially achievable. A more suitable approach would be to determine what levels of cleanup are appropriate for an area based on factors such as cost, technical achievability, and progressive land use process, and then let those cleanup levels define the eventual land uses.

\subsection{Cleanup Costs}

There is a wide range in average cost per square mile to clean the various Site areas (see Figure 5.1). Some areas of land at the Site can be made available for other uses quickly and inexpensively while other areas will require substantial cleanup. The 600 and 3000 Areas will be relatively inexpensive to clean while, on the other hand, the cost to clean the $400,300,100$ and 200 Areas will be increasingly expensive.

Note that these costs do not include groundwater cleanup. Groundwater cleanup is not cost-effective, considering the extent of contaminated plumes, types of contaminants, and available technology. Money taken for groundwater will slow transfer of land for other uses.

\subsection{Land Use Versus Risk Reduction}

Cleanup activities that support making land available for other uses are generally counter to those required to address Site risk issues. Land use focuses on land that is quick and economical to clean and is important to users. These-areas generally do not involve significant risks and, therefore, are lowpriority for risk reduction. For example, areas such as the 200 Area central plateau have significant radiological and chemical hazards but reducing those risks contributes almost nothing to land release. 


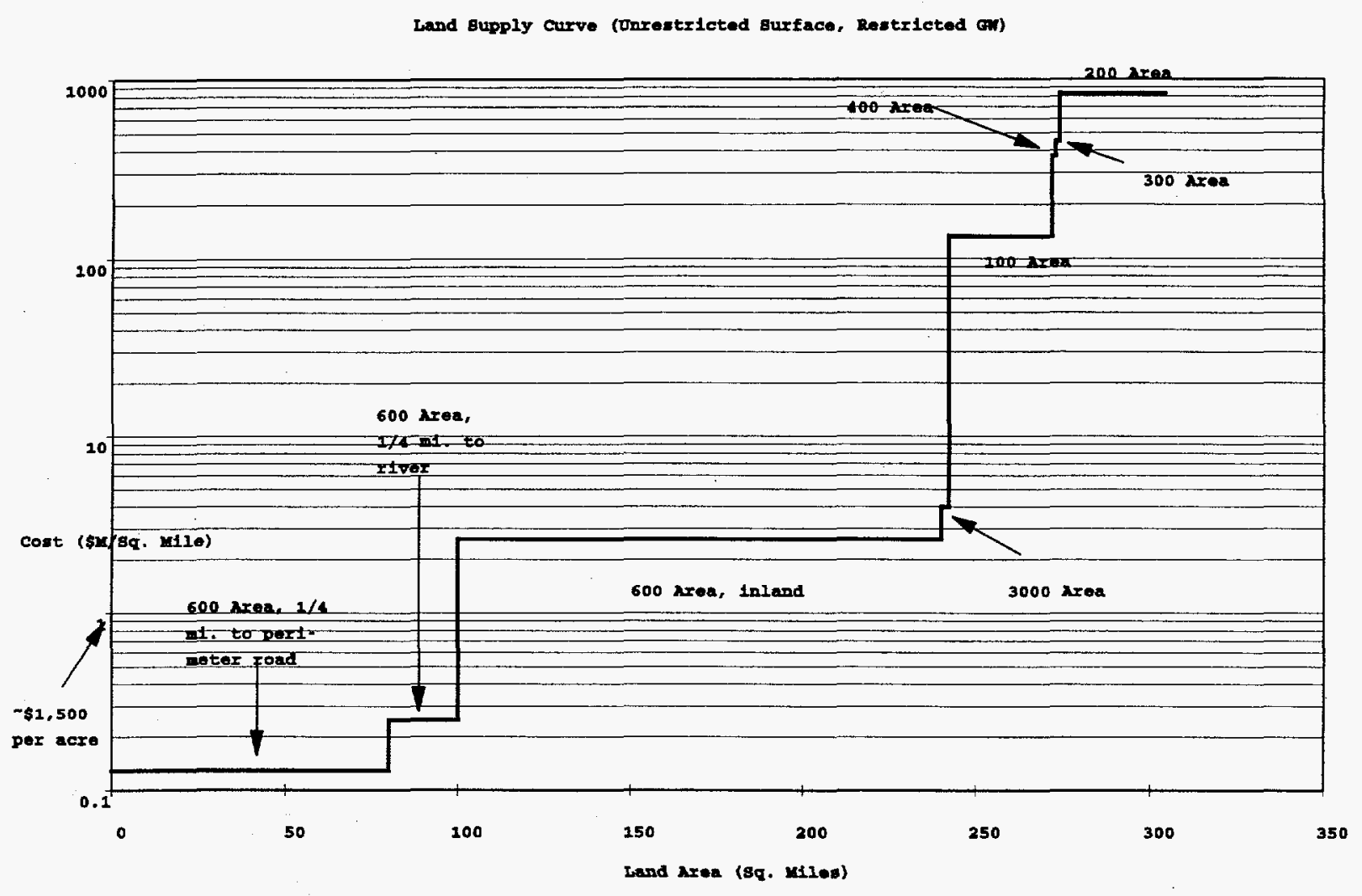

Figure 5.1. Land Supply Curve

\subsection{Buffer Zones}

Although land will be cleaned up and available for other uses, some areas may have to remain restricted and utilized as buffer zones around high-risk areas. This will ensure the safety of the public while major environmental management activities are still ongoing. As land is made available and public access gets closer to cleanup and operations activities, it will be necessary to ensure that adequate buffer zones between public access and any significant hazards are maintained. This will be a primary issue for the 200 Area, N Basins, and K Basins. Major environmental management activities will continue in the 200 Area for some time, thus requiring a buffer zone around the plateau. The land surrounding $\mathrm{N}$ Basins and $\mathrm{K}$ Basins, including the Columbia River shoreline downstream, will be restricted until the basins can be cleaned. Buffer zones may also be required around the 100,300, and 400 Areas, depending on cleanup schedules.

\subsection{Progressive Land Use Process}

Progressive land use can be a cost-effective approach and should be employed whenever possible. This process allows land initially to be made available for limited use (e.g., recreational). As natural 
processes and decay reduce the levels of radionuclides and other hazardous materials, uses of the land can be expanded. This progressive use would limit the exposure for any individual. Recreational use is based on an exposure rate of two weeks per year, industrial use is five days a week continuously, and residential use is full-time.

\subsection{Land Use Analysis Results}

The Land Use Evaluation (Appendix H, Attachment H3) provides an example of land cleanup priority based on benefit-to-cost analysis. It focuses on land that is economical and expedient to clean and is of the most benefit to non-DOE users. The priority of the cleanup activities is as follows.

- 600 Area. Columbia River to perimeter road. Remove solid and liquid waste sites and move all waste materials to the 200 Area.

- 3000 Area. Dismantle all facilities and remove all wastes and contaminated soils.

- 600 Area inland. Remove all wastes and contaminated soils.

- 300 Area. Consolidate the lab facilities and dismantle all other excess structures. Most solid and liquid waste sites will be capped in-place.

- 100 Areas. Entomb the reactors and dismantle all auxiliary buildings. Cap all solid and liquid waste sites near the reactors and retrieve other sites and move waste materials to the 200 Area.

- 400 Area. Entomb the reactor and dismantle all other nuclear facilities. Make nonnuclear facilities available for other uses (i.e., industrial) and cleanup all other sources.

- 200 Area Plateau. Used for long-term storage of nuclear materials and as a permanent waste disposal site. Final 200 Area cleanup does not contribute to land release.

- Groundwater. Defer groundwater cleanup indefinitely in all areas.

\subsection{Conclusions}

Land use analysis provides some powerful concepts that can be successfully integrated into a riskbased strategy or any other strategy. Effective land use transfer will require consideration of Site cleanup criteria and associated costs, balancing land use objectives with those of risk reduction, utilizing buffer zones and progressive land use processes, and applying benefit-to-cost analysis for prioritization of cleanup activities. 


\subsection{Risk Analysis}

\subsection{Introduction}

Environmental, worker safety, and public health risks were analyzed to determine their impact on cleanup activities. In general, risks were analyzed to provide relative risk rankings among Site activities. The purpose of this section is to summarize the analyses and most important conclusions; details are contained in Appendix D. The terms "acceptable" and "unacceptable" risks are relative to the criteria used in each of the analyses in Appendix D, and there is no attempt to establish a common standard for risk in this report. It is realized that different groups and individuals could have different standards for what is acceptable or unacceptable risk.

Risk is the potential of a hazard to cause both immediate and long-term harm to a receptor. It is the product of (1) the consequences resulting from a receptor being exposed to a hazard and (2) the likelihood of an occurrence. A graphical representation of the parameters used in the risk analysis is presented in Figure 6.1.

The harm or consequences to a receptor are related to the hazard source in terms of the quantity of material and its toxicity, form, and dispersability. The likelihood of release is related to the available energy sources, release processes, and functioning barriers. Pathways by which a receptor can be exposed to hazards are air, soil, groundwater, and surface water.

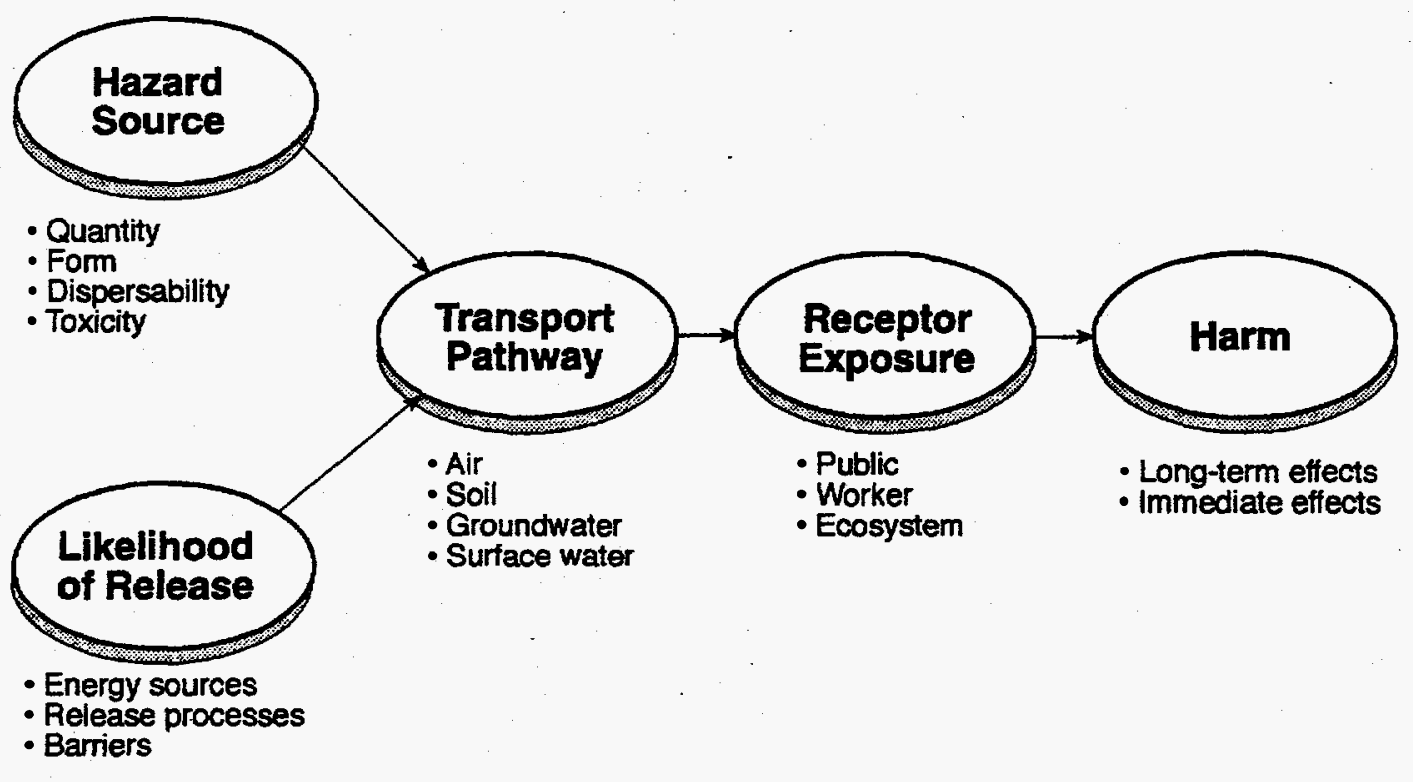

$9412001.100 a$

Figure 6.1. Parameters Used in Determining Risk 
In order to understand fully and examine all of the time- and receptor-dependent risk elements, four hazard categories were defined.

The three time periods are (1) current state, (2) remediation phase, and (3) post-closure phase. The periods are defined as follows.

- Current State. Present state where existing hazard sources are managed in their current form, condition, and location.

- Remediation Phase. Phase when actions are taken to transition existing hazards to a safer condition.

- Post-Closure Phase. Phase when actions are taken to manage the Site after the cleanup mission has been completed.

The hazard categories are near-term release hazards, workplace hazards, long-term release hazards, and ecosystem hazards. These are defined as follows.

- Near-Term Release Hazards. Those hazards with potentially large consequences where release of radionuclides and chemical contaminants could occur through the current or remediation phase. Although these hazards have potentially large consequences, they are relatively unlikely.

- Workplace Hazards. Those hazards associated with all aspects of worker activities.

- Long-Term Hazards. Those hazards where harm to the public results from the transport of radionuclides and chemical contaminants through the groundwater slowly over very long time periods (e.g., 100s or 1000s of years).

- Ecosystem Hazards. Those hazards where harm results from chemical and radionuclide contamination of plant and animal life and from physical disruption of natural habitats. The hazards to cultural, archeological, and historical resources are included in this category.

\subsection{Near-Term Release Hazards}

Near-term releases refer to those hazards with potentially large consequences, when the release to the receptor could occur during the current state or remediation phase. The near-term releases would cause an exposure of radionuclides to the public, workers, and environment. For near-term releases and the associated analysis, the primary focus is exposure of the public by inhalation of radionuclides transported through the air pathway. The risk to the environment from these potentially large consequence events is mirrored in the risk to the public. Prevention and/or mitigation of the potentially large consequence events to protect the public also protects the workers and the environment.

The model used for the near-term release analysis, Modular Risk Analysis for Assessing Multiple Waste Sites (Whelan et. al 1994), was developed by Pacific Northwest Laboratory and used in the Integrated Risk Assessment Program: Methodology and Results from Qualitative Evaluation of Current Hanford Site Risks to the Public (Mahaffey et. al 1994). The quantity of radionuclides, total release 
fractions for the air exposure pathway, unit risk factors, and event frequency were developed for an average member of the public (within $50 \mathrm{~km}$ ) and a calculational receptor at 0.5 kilometers in the direction of the largest dispersion coefficients. Both the public and a calculational receptor were used in the analysis because of potential changes in the population distribution with time and the potential for the public to eventually occupy some of the Hanford Site. The DOE Nuclear Safety Policy (DOE 1991) was used as the basic criterion of acceptable public risk.

The largest Hanford Site contributors to the risk to an average member of the public are (not in order of importance) the $\mathrm{N}$ fuel stored in the $\mathrm{K}$ Basins, the cesium and strontium capsules stored in the Waste Encapsulation and Storage Facility, the debris in the 324 B cell, and the high-level waste in underground storage tanks. The contributions to the public risk from these activities are represented in Figure 6.2 by an ellipse in the frequency-consequence space of the risk acceptance criteria (see Appendix D, Section D.2.5). Within the accuracy of these calculations, the current risk to the public from each of these activities is within the acceptable risk criteria. These activities, however, are specifically identified as the largest risk contributors, primarily because of the quantity of radionuclides involved and their potential health effects, and because the radionuclide inventory exists in deteriorating facilities. For example, the debris in the $324 \mathrm{~B}$ cell represents a significant contribution to the risk to an average member of the public because of the public's close proximity to the 300 Area.

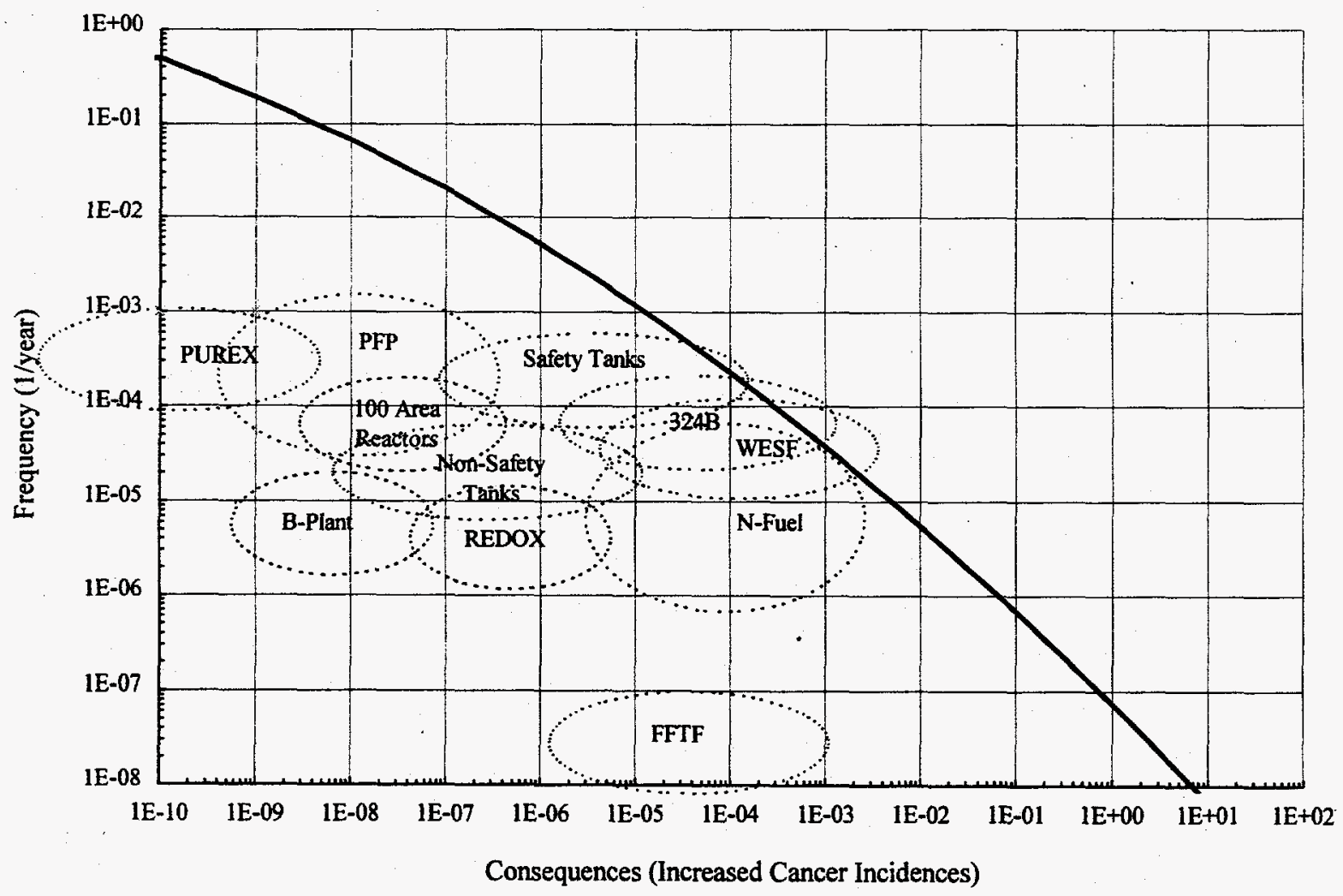

Figure 6.2. Contributions to the Risk to an Average Member of the Public (Present Population Distribution) 
The cesium and strontium capsules represent a significant contribution to the risk because of the large inventory of radionuclides and the potential deterioration of their present storage location. The plutonium in the Plutonium Finishing Plant also represents a significant contributor to the public risk, primarily because of the amount of plutonium and its toxicity. PUREX, 100 Area reactors, B Plant, REDOX, Fast Flux Test Facility, and nonsafety high-level waste tanks present less risk to the public.

An appropriate intermediate remediation state would be where the quantities of Cs-137, Sr-90, Am-241, Pu-238, Pu-239, and Pu-240 have been eliminated, reduced, placed in a form that is immobile, or placed in more-effective barriers. Evaluating reduced risk versus the costs required to reduce the risk is an effective cost-benefit tool that can be used to evaluate various risk reduction alternatives. Figure 6.3 is an example that illustrates how several potential intermediate states with reduced risk and potential costs could be evaluated to determine the most cost-effective intermediate state. Each action identified in Figure 6.3 reduces the risk (in annual latent cancer fatalities) of the radionuclides in their present state to an acceptable risk, but for different costs. From a risk perspective, the only requirement is to reduce the public risk to acceptable levels (shown by the solid line in Figure 6.3). From a long-term remediation or waste disposal perspective, there may be additional requirements that may further reduce the risk. Once the risk has been reduced below the safety goal, further risk reduction should be considered based on other potential cost benefits.

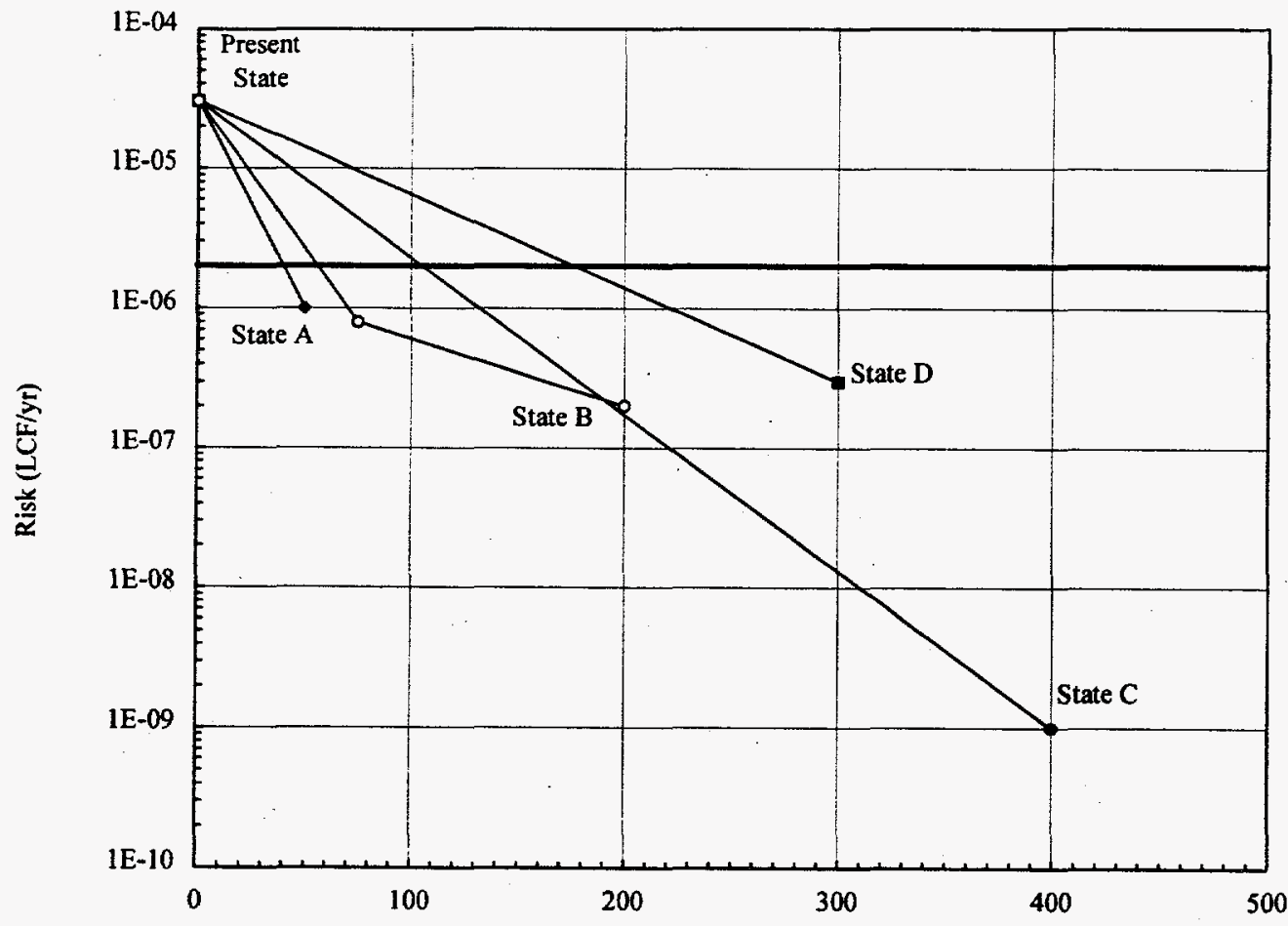

Delta Costs (\$M)

Figure 6.3. Examples of Reduced Risk - Cost Evaluation 


\subsection{Workplace Hazards}

Workplace hazards consist of the potential harm to workers from radiological and hazardous chemical sources and industrial accidents. Workplace hazards are most relevant in the current state and during the remediation phase. The workplace hazard analysis identifies and characterizes the sources of hazards, types of hazards, and worker activities for the current state and during remediation.

Sources of workplace hazards in the current state include activities in the deteriorating reactor buildings, canyon buildings, and support facilities. These facilities are sources of industrial, radiological, and chemical hazards. During remediation, the key sources of workplace hazards would include activities in the old facilities; construction of new facilities; and cleanup actions involving tank wastes, buried solid wastes, contaminated soils, and special nuclear materials. Workplace hazards during the post-closure state are not significant because only a small workforce will remain on-site.

Individual worker hazards will be reduced through appropriate controls (e.g., individual radiation exposure limits), training and qualifications, and personal protective equipment (e.g., safety harnesses, anti-contamination equipment). Individual workers will not be subjected to life-threatening conditions or activities without adequate precautions. Controlling workplace hazards can be viewed as a cost issue. On the other hand, cumulative worker risks can be viewed as an indication of the level of hazards workers can be exposed to during an activity. Cumulative industrial hazards to workers are measured in terms of fatalities associated with the various remediation options. The following are observations relative to worker risk.

- Alternatives involving removal and retrieval of wastes and subsequent treatment will result in larger worker risks than in-place disposal alternatives. Therefore, a fundamental tradeoff exists between increases in worker risks and reductions in public risk in (1) retrieval and treatment versus in-place disposal of tank wastes; (2) retrieval and treatment versus in-place disposal of buried solid wastes, former liquid disposal sites, and contaminated soil; and (3) demolition and removal of old facilities versus entombment.

- An increase in short-term worker (and public) risk is one cost necessary to achieve long-term public risk reduction.

- Facility deactivation may be considered a workplace hazard mortgage reduction. Deactivation results in significantly lower occupancy requirements in old facilities, which leads to lower exposures to industrial, radiological, and chemical hazards.

- Facility upgrades may be necessary to control and/or minimize hazards to workers performing monitoring duties and completing decontamination and decommissioning; however, the facility upgrades could result in a temporary increase in near-term worker risks.

\subsection{Long-Term Release Hazards}

Long-term release hazards include those mechanisms that release contaminants slowly over very long periods. These hazards can exist in all three phases of cleanup: current state, remediation, and 
post-closure. This study focuses primarily on the relative contributions of post-closure materials to public risk through the groundwater pathway.

A hierarchy of potential hazard sources was considered in the identification and evaluation of long-term releases. These sources included (1) existing plumes of contaminated groundwater, (2) deep soil contamination sites that actively feed contaminants to groundwater, (3) other near-surface soil sites and burial grounds that may be releasing contaminants, (4) waste and materials that are presently contained but are vulnerable to future release to the soil, and (5) future disposal sites.

The radionuclides and hazardous chemical constituents selected for analysis were Np-237, Pu-239, Pu-240, I-129, C-14, Tc-99, Sr-90, Cs-137, U-235, U-238, nitrate, uranium, carbon tetrachloride, and arsenic. These contaminants fell into three groups: (1) those that are long-lived and mobile, (2) those that are long-lived and relatively immobile, and (3) those for which the large quantity warrants attention.

The central conclusion from the assessment of existing long-term release hazards is that the correction of these hazards is not urgent. Contributions of Site contaminants to airborne, groundwater, and surface water exposures to the public are much lower than background levels. Institutional controls are adequate to manage risks for the foreseeable future.

The effects of groundwater exposure to a calculational residential receptor with a well 1000 feet down gradient from the source were analyzed for five carcinogens (C-14, I-129, Tc-99, Np-237, and $\mathrm{CCl}_{4}$ ). This analysis compared results for a "no action" case, in which no credit is given for potential waste forms or engineered disposal systems (e.g., infiltration barriers). Figure 6.4 shows the primary contaminants from each major waste type that contribute to carcinogenic risk through the groundwater pathway. The combined carcinogenic risk from all waste tanks (including prior tank leaks) is about 20 percent, which represents the increased lifetime cancer probability for an individual exposed to the peak concentration of each contaminant, where peak concentrations occur from 1000 to 10,000 years in the future. Tc-99 is the largest contributor to this risk. For buried waste, the combined carcinogenic risk is about six percent with $1-129, \mathrm{Tc}-99$, and C-14 the most significant contributors. The combined carcinogenic risk for existing soil and groundwater contamination is also about six percent, with $\mathrm{CCl}_{4}$ the largest single contributor. Total carcinogenic risk for the former production reactors is estimated to be about two percent.

The non-carcinogenic hazard for four waste types and several important contaminants was analyzed. Non-carcinogenic hazard is measured by a hazard quotient, which is a ratio of the maximum projected dose through the groundwater pathway to the reference dose (i.e., below which no toxic effects would be expected). Figure 6.5 shows the primary contaminants from each major waste type that contribute to non-carcinogenic risk through the groundwater pathway. The nitrates in the waste tanks and in existing soil and groundwater contamination dominate the non-carcinogenic hazard.

The carcinogenic risk for four buried solid waste inventories resulting from the three dominant long-lived mobile radionuclides (Tc-99, I-129, and C-14) was evaluated. The estimated risk from existing low-level waste burial grounds is two to three orders of magnitude greater than that for the pre1970 unsegregated waste and the post-1970 retrievably-stored transuranic waste. 


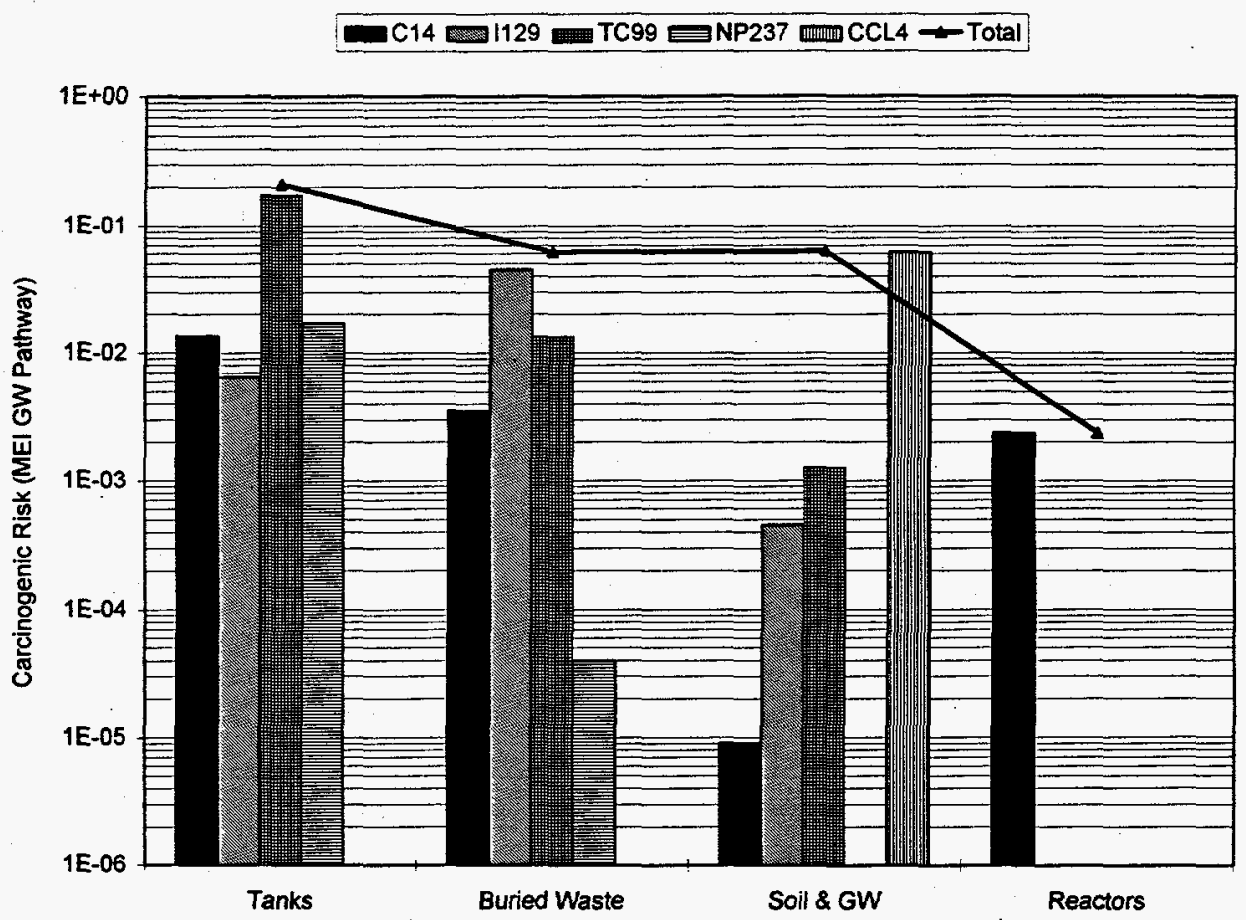

Figure 6.4. Radiological and Carcinogenic Risks

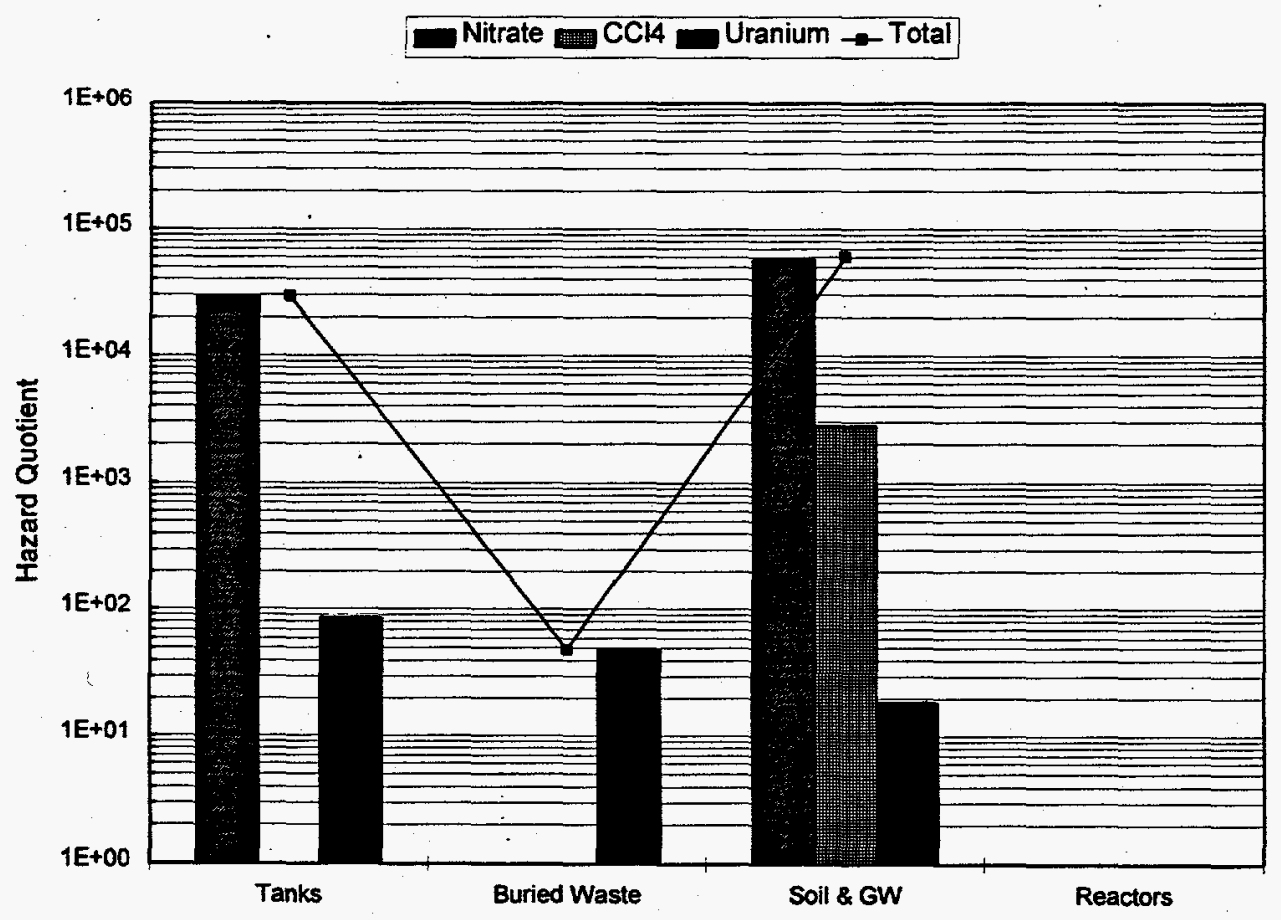

Figure 6.5. Noncarcinogenic Risk 
The long-term radiological hazard for each waste tank was analyzed by considering long-term exposure through the groundwater pathway to a residential receptor. Ordering the tanks from highest to lowest risk (for the mobile constituents, Tc-99, I-129, and C-14) results in the cumulative distribution of radiological hazard that demonstrates over 99 percent of the long-term groundwater risk is contained in less than $\mathbf{4 0}$ tanks. This suggests that a risk-based strategy for treating waste tanks should recognize that the tank-to-tank risk contribution varies by several orders of magnitude.

The risk-reduction effects of several tank treatment options were analyzed. The results demonstrate that the largest radiological risk reduction comes from waste retrieval from about 40 tanks. After retrieval of waste from about 100 tanks there is no further reduction in estimated risk, since the inventory estimates for the remaining tanks show no presence of the long-lived mobile radionuclides of concern. The one-percent residual waste (assuming 99 percent retrieval) from the first 40 tanks contributes more to the risk than the entire contents of the remaining 130-plus tanks. The potential risk contribution from the past tank leaks is estimated to be between one and two percent of the existing tank contents; consequently, there is an additional limit below which further tank retrieval will not have a significant effect on long-term radionuclides risk reduction. In situ treatment alternatives vitrify the tank waste and the residuals (and potentially the surrounding soils); in situ vitrification may provide greater risk reduction than other alternatives.

Potential post-closure inventories were also compared relative to intruder dose limits. These limits were established by a recent Hanford Site performance assessment (Wood et. al 1994) and provide a useful benchmark for comparing post-closure inventories. In general, these inventories fall within the limits, provided a Hanford Site barrier is used to restrict accidental or intentional intrusion for at least 500 years. Some double-shell tank inventories (Am-241 and $\mathrm{Pu}-239$ ) exceed limits, assuming no treatment, by a factor of two, and the post-1970 retrievably-stored transuranic waste exceeds limits for Pu-239 by a factor of about four.

\subsection{Ecosystem Hazards}

Ecosystem hazards include the contamination of plant and animal wildlife from chemicals and radionuclides and the physical disruption of natural habitats. Hazards to cultural, archeological, and historical resources are also included in this category. These hazards typically arise from physical disruptions and other intrusions by humans. The receptors are primarily plant and animal species. Exposure routes include (1) direct ingestion and inhalation of contaminated materials and (2) uptake from groundwater and surface water. Prior studies and analyses were reviewed for results that would be applicable to the current assessment.

Current and past ecological exposures from Hanford Site operations are low. Because of the Site isolation for the last $\mathbf{5 0}$ years, both plant and animal species have been protected and have flourished; however, the potential for adverse ecosystem impacts from remediation activities is substantial. A primary potential impact to the ecosystem would result from the physical disruption of the habitat by soil and waste excavation and by construction of new facilities (e.g., disposal facilities, treatment facilities, roads). These actions would also pose a threat to historically protected ecological and cultural resources. The potential for new harm to ecological and cultural resources could also occur following remediation with the loss of access restrictions. 


\subsection{Conclusions}

The major conclusions of this risk analysis are as follows. Appendix D contains the detailed discussion of the analysis and methodology.

- The most significant near-term hazards are from radionuclide sources associated with the $\mathbf{N}$ fuel stored in the $\mathrm{K}$ Basins, the cesium and strontium capsules stored in the Waste Encapsulation and Storage Facility, the debris stored in the 324 B cell, the safety high-level waste tanks, and the plutonium in the Plutonium Finishing Plant. These hazards are dominated by the quantity of the radionuclides Sr-90, Cs-137, and Am-241. While the absolute risk from each source is estimated to be within the goal of the Nuclear Safety Policy (DOE 1991), these sources contain large inventories of radionuclides stored in vulnerable or deteriorating conditions.

- Increased worker risk during remediation is one of the costs associated with reducing long-term public risk.

- Maintaining acceptable worker risks will usually be associated with increased costs; however, some remediation alternatives could result in significantly increased worker risks compared to other remediation alternatives.

- Long-term release hazards through the groundwater pathway are dominated by seven long-lived, mobile constituents (C-14, Tc-99, I-129, Np-237, carbon tetrachloride, nitrate, and uranium).

- The potential contributions of long-term risk to groundwater contamination from tank waste, buried solid wastes, and existing environmental releases are roughly of the same order of magnitude.

- The long-term release hazard posed by existing low-level waste burial grounds is roughly two orders of magnitude higher than that posed by the pre-1970 unsegregated buried waste and the post1970 retrievably-stored transuranic waste.

- If there were no treatment or isolation of existing hazards, carcinogenic risks appear to be about two to three orders of magnitude higher than acceptable limits, while non-carcinogenic risks (chiefly nitrate) appear to be four to five orders of magnitude higher than acceptable limits.

- For tank waste, (1) the near-term risks are dominated by those few tanks that have the highest Cs137, Sr-90, and Am-241 contents; (2) roughly one-fourth of the tanks contribute more than 99 percent of the long-term release risk; and (3) the residual contamination following retrieval and the contamination from prior tank leaks place a lower limit below which risk cannot be reduced without some form of in-situ treatment.

- The greatest risk to the ecosystem and cultural resources is from physical disruption during demolition, construction, retrieval, and transport operations. 


\subsection{Strategic Alternatives}

This section describes the cleanup alternatives that were developed for comparison against the objectives. Each alternative is summarized with the decision rules, how the strategy was developed, and the associated cleanup activities and their sequence. Impacts and implications of each strategy are also described. The four following alternatives were considered.

I: The Existing Baseline Strategy as described in 1995 plans and the Tri-Party Agreement.

II: The Baseline Extended Strategy, a new strategy that performs the same actions and achieves the same endstate as the Existing Baseline Strategy at lower total cost.

III: A Risk Strategy that focuses on a single objective: protecting the public, workers, and environment.

IV: A Composite Strategy designed to support all objectives.

Each of these strategies is summarized in this section. Appendixes $\mathrm{E}$ through $\mathrm{H}$ provide more detailed descriptions of the strategies.

\subsection{Alternative I: Existing Baseline Strategy}

\subsubsection{General Description}

The objective of the Existing Baseline Strategy is to address imminent safety hazards and comply with current regulatory agreements. The activities identified in the agreements represent one approach for reducing near-term and long-term risks while progressing toward reducing the Site land area committed to environmental management activities. The cleanup approach is renegotiated as new information is accumulated on Site cleanup actions. Since the Tri-Party Agreement includes processes for renegotiation of cleanup activities, the Existing Baseline Strategy reflects only the current status of the agreement.

A clear set of decision rules that includes major cleanup activities is not apparent in the Existing Baseline Strategy. The focus of the strategy is to complete cleanup actions on parallel paths, assuming unlimited funding and schedule. Decision rules for prioritization of major actions against one another are embedded in the consensus-building process used during Tri-Party Agreement milestone negotiations; however, the negotiations typically consider one major group of activities at a time rather than considering Site cleanup as a single entity.

The Existing Baseline Strategy endstate uses the 200 Area and the 200 Area central plateau for the collection, storage, and disposal of waste materials that will remain on-site. In general, waste outside of the central plateau would be recovered and transported to the central plateau. Former defense facilities outside of the central plateau would be demolished and waste would be transported to the central plateau. Tank waste and post-1970 transuranic solid waste would be retrieved and prepared for storage and eventual disposal. Transuranic and high-level wastes would be disposed at off-site 
repositories. Nuclear materials and irradiated fuel would be consolidated in the 200 Area as an interim measure until they were disposed off-site. Groundwater plumes would be pumped and treated to

remove contaminants. The land outside the central plateau would be made available for non-DOE uses.

In general, the Existing Baseline Strategy attempts to reduce all risks to an acceptable level, disposition all facilities, cleanup all the land, and satisfy all stakeholder and regulatory requirements. A complete description of the Existing Baseline Strategy is contained in Appendix E.

\subsubsection{Development of the Existing Baseline Strategy}

The Existing Baseline Strategy was developed from the latest Tri-Party Agreement negotiations and from current Hanford Site program plans.

\subsubsection{Results of the Cleanup}

Results of the baseline strategy cleanup can be discussed by (1) geographic area and (2) hazard sources. These are outlined below.

The baseline strategy would consolidate and dispose waste on the 200 Area central plateau. Highlevel waste and retrievably-stored transuranic waste would be treated, packaged, and shipped to off-site repositories. The central plateau land (approximately 50 square miles) will remain restricted. Land outside of the central plateau (approximately 510 square miles) will be available for unrestricted use. Restrictions will remain on the groundwater for the foreseeable future, even with the treatment activities. Hazard sources will be addressed as follows.

- Nuclear materials, including unirradiated uranium, cesium and strontium capsules, irradiated fuel, and special nuclear material, will be stabilized and stored in the 200 Area pending future disposition off-site.

- Tank waste will be retrieved, separated into high-level waste and low-level waste fractions, and vitrified. The high-level waste will be stored on-site and later shipped to the high-level waste repository. The low-level waste will be disposed in the 200 Area. The tank structures and contaminated soils will be disposed in-situ.

- Solid low-level waste will be disposed in the 200 Area. Transuranic solid waste will be retrieved, processed, and stored in the 200 Area pending future disposition off-site.

- Contaminated soil outside the 200 Area will be retrieved and disposed in the 200 Area, and contaminated soil in the 200 Area will be disposed in-situ.

- Groundwater outside the 200 Area will be remediated using pump-and-treat systems to the extent technically practical. Barriers will isolate the 200 Area contaminated groundwater.

- Contaminated facilities outside the 200 Area will be demolished and the contaminated waste disposed in the 200 Area (the reactors will be a one-piece removal after a 75-year waiting period). Major facilities in the 200 Area (e.g., canyon buildings) will be partially demolished and then entombed. 


\subsubsection{Environmental, Safety, and Health Risks}

Major sources of long-term risk due to long-lived radionuclides (tanks and transuranic storage facilities) would be retrieved, processed, and eventually shipped to off-site repositories. The inventory in the 200 Area would be reduced and the waste sites would be stabilized and capped. Some sources of long-lived radionuclides would remain on-site, as would large quantities of low-level waste. These would require restrictions in the 200 Area, possibly for centuries. Worker risk is higher during remediation due to increased exposure from extensive retrieval, processing, handling, and transport activities associated with this strategy.

\subsubsection{Land Use}

The Existing Baseline Strategy assumes the 200 Area would remain restricted through and beyond the cleanup period. Most areas outside the central plateau would be released for unrestricted use; however, unrestricted groundwater utilization outside the 200 Areas is not explicitly required by the Tri-Party Agreement. The 300 Area would be available for industrial use.

\subsubsection{Period of Cleanup}

The cleanup period is estimated to be 80 years, through 2075 . This period is driven by retention of reactor cores in-place for 75 years to permit radiological decay. It is estimated that a majority of cleanup activities would be completed by 2028 , after completion of tank waste vitrification.

\subsubsection{Costs}

Figure 7.1 shows the profile associated with the Existing Baseline Strategy. Total costs are about 84 billion dollars through 2075. Because the costs exceed the assumed annual funding constraints of 1.05 billion dollars, the Existing Baseline Strategy is not considered a viable alternative.

\subsubsection{Programmatic Risks}

Although the Site is pursuing efforts to reduce costs through productivity initiatives and privatization, it is clear the Existing Baseline Strategy cannot be executed on the currently planned schedule and may not be executable at all. Other programmatic risks are associated with (1) the disposition of high-level waste and transuranic waste off-site in national repositories; (2) the ultimate disposal of plutonium; and (3) the technology for the retrieval, separation, and vitrification of tank waste.

There are numerous technical risks associated with the baseline strategy. The technology is complex for waste retrieval, vitrification, reactor block transportation, and groundwater treatment. Pump-and-treat technologies have not been demonstrated for several contaminants. 


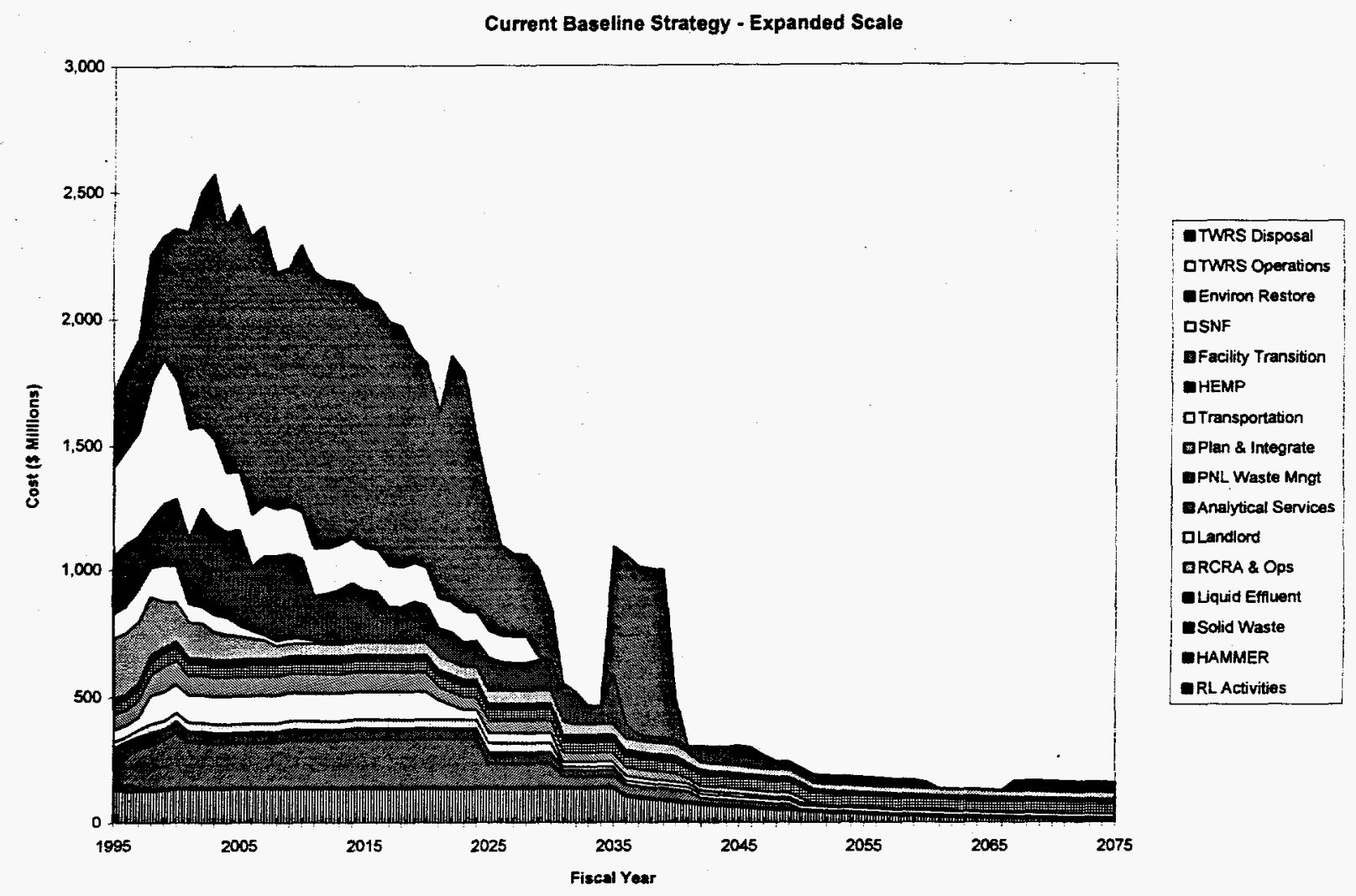

Figure 7.1. Existing Baseline Strategy Funding Profile

\subsubsection{Stakeholder Issues and Regulatory Impacts}

The Existing Baseline Strategy was developed with local stakeholder input and reflects a majority of their interests. This strategy addresses, to the extent practical, the regional stakeholder's primary concerns of protecting the Columbia River and addressing the groundwater issues. Major sources of contamination are moved away from the river, and pump-and-treat technology is applied to reduce groundwater contamination.

It is anticipated that national stakeholders would oppose this strategy and probably would not fund it. The Existing Baseline Strategy is primarily a compliance-based strategy. If funded, its execution will meet regulatory requirements, including the Tri-Party Agreement. 


\subsection{Alternative II: Baseline Extended Strategy}

\subsubsection{General Description}

The objective of the Baseline Extended Strategy is to achieve the same endstate as the Existing Baseline Strategy within the constrained funding profile. The detailed description of this strategy is in Appendix F. This strategy was developed using the following decision rules to set priority: (1) address near-term risk situations; (2) address high benefit-to-cost ratio actions that are already in progress to facilitate mortgage reduction and enable additional cleanup actions to be executed earlier; and (3) address high benefit-to-cost ratio actions until the endstate is achieved.

The Baseline Extended Strategy endstate and endstate risks are identical to those in Section 7.1.1 for the Existing Baseline Strategy. This strategy is constrained by the projected budget profile while driven by regulatory requirements, primarily the Resource Conservation and Recovery Act of 1976 (RCRA), the Comprehensive Environmental, Response, Compensation, and Liability Act of 1980 (CERCLA), and the Tri-Party Agreement. Execution of this strategy would require renegotiation of the sequence and individual milestone dates in the Tri-Party Agreement.

\subsubsection{Development of the Baseline Extended Strategy}

The development of the Baseline Extended Strategy began with the Existing Baseline Strategy. A series of productivity improvements ( 20 percent reduction in costs and construction of a Tank Waste Remediation System single disposal facility), schedule delays/extensions, and reprioritizing work were considered to achieve the endstate while matching the budget profile.

\subsubsection{Results of the Cleanup}

Results of the Baseline Extended Strategy cleanup would be the same as those described in Section 7.3 for the Existing Baseline Strategy.

\subsubsection{Environmental, Safety, and Health Risks}

Overall environmental, safety, and health risks would be similar to those in the Existing Baseline Strategy.

\subsubsection{Land Use}

Future land use implications would be the same as described in Section 7.1.5 for the Existing Baseline Strategy.

\subsubsection{Period of Cleanup}

The cleanup period for this strategy would extend through 2058, with completion of 200 Area facility disposition (through 2075 including reactor disposition). Shipment of high-level waste to a repository would be completed in 2045 . 


\subsubsection{Costs}

The total lifecycle cost to complete this strategy would be approximately 56 billion dollars through 2075. Figure 7.2 illustrates the Baseline Extended Strategy funding profile. See Appendix F for a complete description of how this funding level was achieved.

\subsubsection{Programmatic Risks}

The technical risks associated with the Baseline Extended Strategy would be similar to the Existing Baseline Strategy. Programmatically, this strategy would have much less risk than the Existing Baseline Strategy because it would fit the anticipated funding profile.

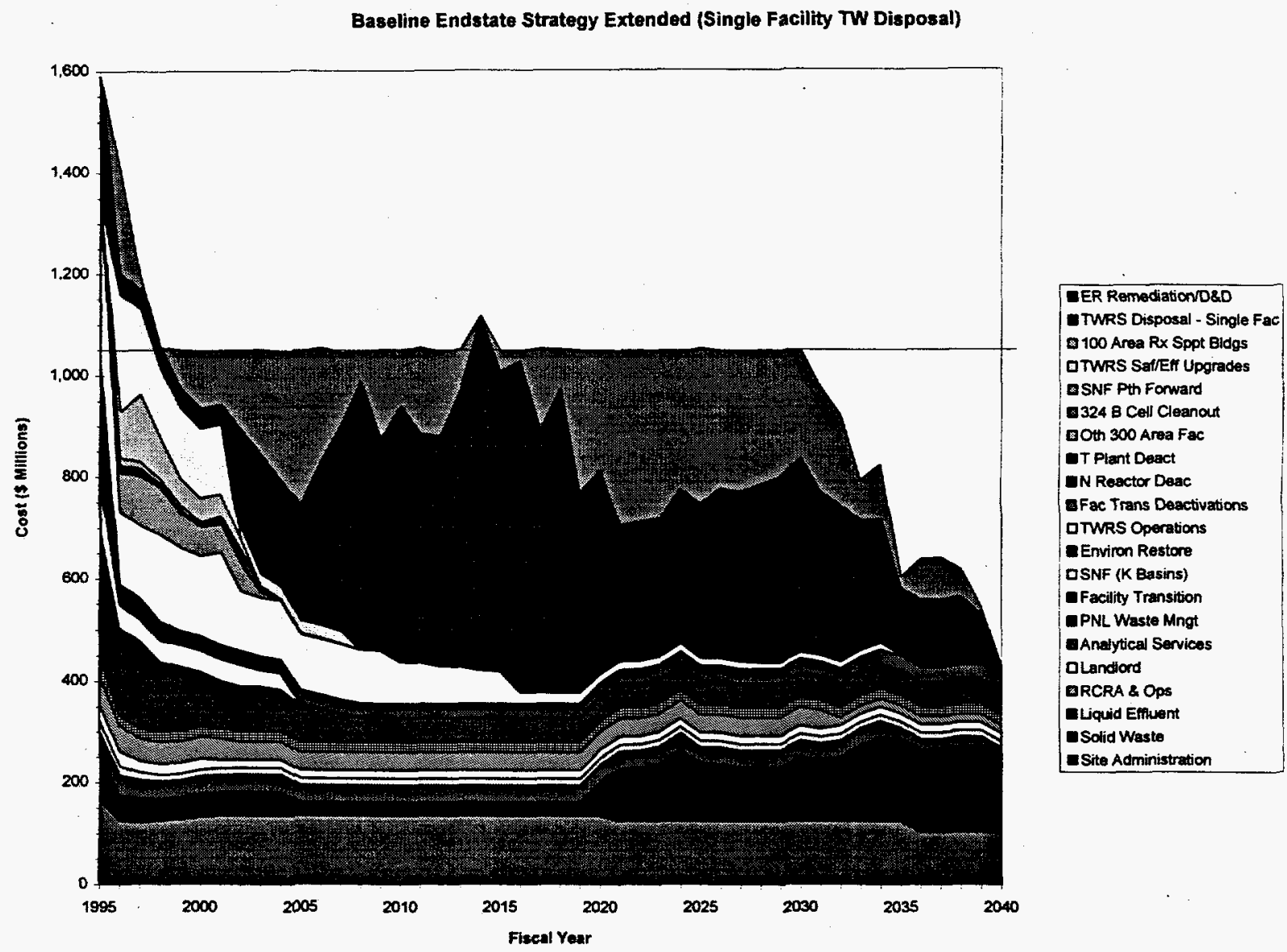

Figure 7.2. Baseline Extended Strategy Funding Profile 


\subsubsection{Stakeholder Issues and Regulatory Impacts}

Stakeholder and regulatory impacts would be the same as those described in Section 7.1.9 for the Existing Baseline Strategy, except for the need to negotiate delays in major actions. This strategy would comply with the applicable regulations, provided the milestones in the Tri-Party Agreement are renegotiated to permit the longer completion schedule.

The benefit-to-cost ratios calculated for this strategy are based on the Revised Priority Planning Grid (Appendix B, Attachment B1), which has weights reflecting DOE Richland Operations Office management values. Stakeholders may not share the same values, which could shift the priorities and sequence of execution. Stakeholder participation would be required to develop a new set of values that could be used to prioritize cleanup activities.

\subsection{Alternative III: Risk Strategy}

\subsubsection{General Description}

The Risk Strategy addresses risks on the Hanford Site to the public, workers, and environment from radionuclides, toxic and dangerous chemicals, and industrial hazards. The single objective of this strategy is to reduce the risks from the Hanford Site to acceptable levels for the public, workers, and environment. The key elements of the Risk Strategy are as follows.

- All reactors would be entombed as permanent disposal sites. Liquid and solid waste sites outside the 200 Area would be capped, covered, and disposed in-place. The central plateau would be a permanent waste disposal site for entombed nuclear facilities, liquid and solid waste disposal sites (capped and covered), and pre- and post-1970 transuranic waste and tank waste (both of which are disposed in-place). Access to the 200 Area would be controlled indefinitely, and access to groundwater would be controlled for the foreseeable future.

- Spent nuclear fuel and special nuclear materials would be removed from current locations and placed in interim storage in the 200 Area, pending final disposition.

- Facilities outside the 200 Area would be dismantled, as appropriate, or consolidated to reduce operation and maintenance costs.

- Groundwater would not be treated.

\subsubsection{Development of the Risk Strategy}

This strategy was developed by considering the contributions to risk from each of four hazard categories: near-term releases, workplace hazards, long-term releases, and ecosystem hazards (see Appendix D). A general set of cleanup alternatives was defined, and risks for the various alternatives were analyzed. The following rules were used to make decisions relative to the Risk Strategy, endstate, and sequence of cleanup activities. 
- Reduce the potential for near-term, high-consequence releases that may pose unacceptable risks to the public, workers, and environment.

- Protect workers from unnecessary and unacceptable workplace hazards.

- Minimize the use of remediation activities that pose high risks to workers but provide only minimal reduction of public or environmental hazards.

- Provide on-site waste management and disposal systems that protect current and future generations and the environment by achieving a consistent set of risk-based treatment and disposal standards.

- Protect ecological and cultural resources during remediation.

\subsubsection{Results of the Cleanup}

Most of the Hanford Site land area could be released for other uses in the endstate of the Risk Strategy; however, the 200 Area would not be available for other uses, and use of the groundwater in all areas would be restricted for the foreseeable future. The 100 and 400 Areas would be used for long-term disposal of major facilities and environmental contamination. The 200 Area would be used for long-term disposal of tank waste, solid waste, and major facilities, as well as long-term storage of nuclear materials.

Implementation of this strategy would result in (1) nuclear material consolidated and stored on-site pending final disposal, (2) liquid waste disposed in-situ, (3) solid waste disposed in-situ, and (4) major facilities entombed in-place. This strategy would leave the environmental contamination in-place (capped and covered, as necessary). A more detailed description of the waste material endstates is provided in Appendix G.

\subsubsection{Environmental, Safety, and Health Risks}

The Risk Strategy is focused on reducing environmental, safety, and health risks. Detailed descriptions are contained in Appendix D and in Section 6.

\subsubsection{Land Use}

The 200 Area would be a permanent disposal site with controlled access. Groundwater access throughout the remainder of the Hanford Site would be controlled and monitored for the foreseeable future (about 200 years). The area along the Columbia River would be available for recreational use and the 100,300, and 400 Areas would be available for limited industrial use. Use of the 600 Area would be restricted until waste management operations were completed in the 200 Area. The 600 Area would then be made available for other uses progressively. 


\subsubsection{Period of Cleanup}

For the Risk Strategy, the cleanup period would extend to 2043; however, most of the cleanup would be accomplished by 2030 with completion of tank waste disposal. Most waste sites would be remediated by 2026.

\subsubsection{Costs}

The costs to implement the Risk Strategy would be considerably lower than the costs to implement the Existing Baseline Strategy because much of the waste would be disposed in-place. The cost estimate assumes 10 billion dollars for in-situ disposal of tank waste and nine billion dollars for environmental restoration. The total cleanup cost is estimated at 44 billion dollars. Figure 7.3 illustrates the Risk Strategy funding profile.

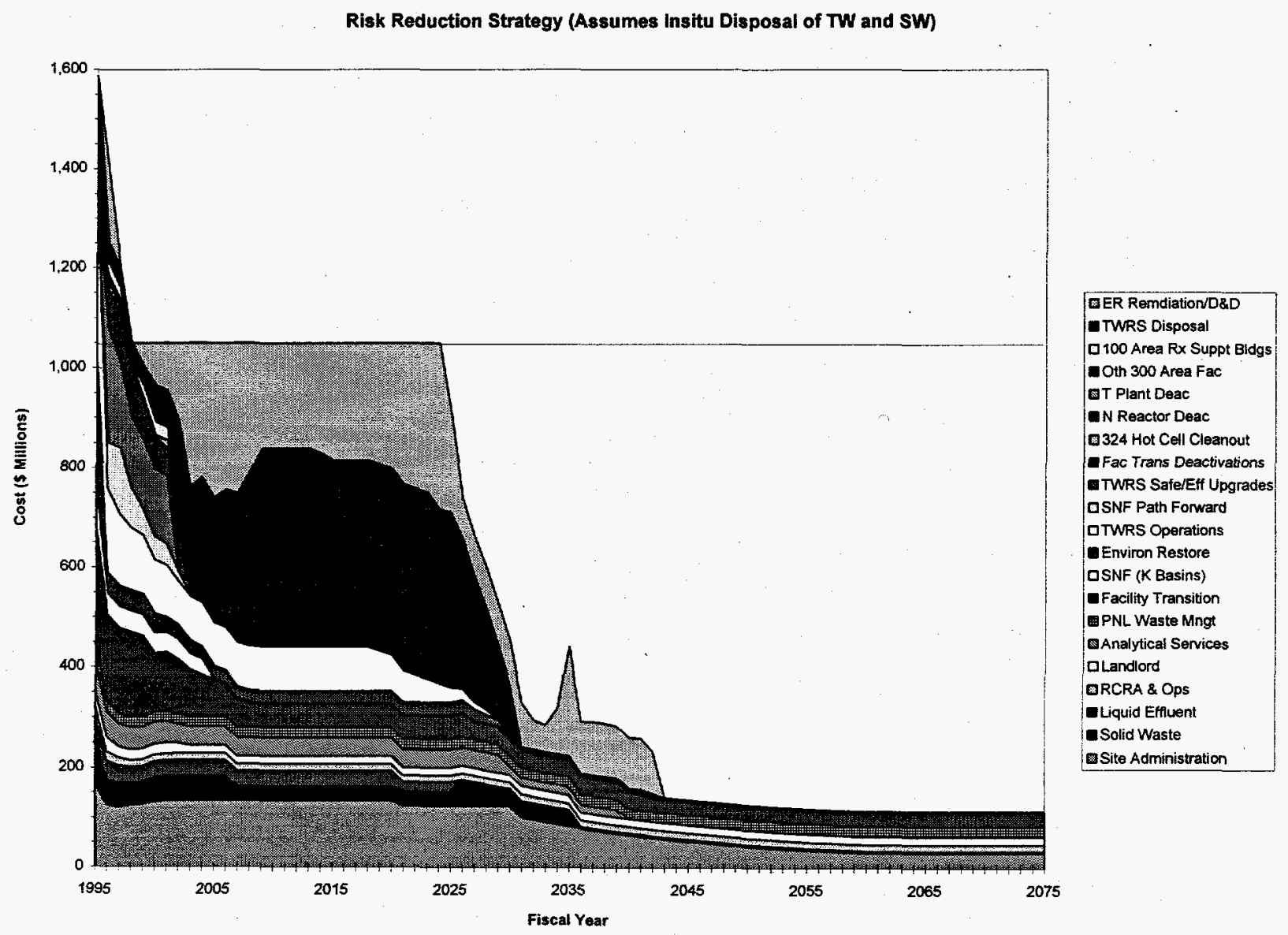

Figure 7.3. Risk Strategy Funding Profile 


\subsubsection{Programmatic Risks}

The Risk Strategy would be less costly and could be implemented sooner than the Existing Baseline Strategy because the waste would be disposed in-place. There would be, however, technology issues associated with in-place disposal of tank waste. Technology development and proof-of-concept would need to be established.

Technical risks would be mostly associated with in-place disposal of tank waste. This strategy would not require in-situ vitrification (although the 10 billion dollar tank disposal costs are associated with that option); however, if vitrification is determined to be the preferred treatment, there may be significant technical risk. Experts are divided on the estimate of technical risk for in-situ vitrification. Most estimate it higher than retrieval, separation, and ex-situ vitrification of high- and low-level fractions, although retrieval itself is not without technical risk.

Politically, the risk strategy would face considerable uncertainty. It would take the best efforts of planners and managers to implement the strategy because it is likely many different factions would oppose parts of it. Political pressure would be brought to bear mainly on issues of retrieval versus in-place disposal, groundwater treatment, and entombment of facilities and reactors.

\subsubsection{Stakeholder Issues and Regulatory Impacts}

The on-site disposal options in the Risk Strategy would not satisfy some of the stakeholder values. Appendix $G$ provides a more detailed discussion relative to some of the values from the Future Site Uses Working Group.

It is anticipated that stakeholders would support the early resolution of near-term, public health risks; however, it is anticipated many local stakeholders would not be comfortable with any strategy that leaves high-level waste in the ground in the 200 Area. It is also anticipated many would not like entombment of the reactors. Regional stakeholders want the Columbia River protected at all costs, so any decision to stop pump-and-treat of groundwater would not be viewed favorably. Restrictions on the use of the land would be opposed by many local stakeholders. Nationally, it is anticipated stakeholders would find much in the strategy to like, as it reduces costs and provides earlier cleanup. The U.S. Congress, representing all constituents, is expected to find the strategy generally attractive.

It is also anticipated that several regulations might need to be modified to allow for Risk Strategy implementation. Some of the major regulations that would need to be evaluated are RCRA, CERCLA Nuclear Waste Policy Act of 1982, and the Washington State Administrative Code (Ecology 1995). See Appendix $\mathbf{J}$.

\subsubsection{Implications of the Risk Strategy}

If the Risk Strategy is adopted for the Hanford Site, cleanup activities must support that strategy. This implies the following.

- Near-term releases with potential large consequences should be given priority in the near term. These include (1) removal of spent fuel from K Basins; (2) cleanout of 324 B cell debris; 
(3) stabilization of single-shell tanks, resolution of tank safety issues, and completion of tank safety upgrades; and (4) removal of plutonium requiring stabilization from Plutonium Finishing Plant former processing areas.

- Damage to the environment and ecosystem during remediation operations should be minimized.

- Near-term risks associated with nuclear materials would be given priority. Given the lack of a national policy for ultimate disposition of these materials, the Hanford Site must plan to manage them safely and efficiently for an indefinite period. An overall strategy for providing long-term, low-cost storage for nuclear materials should be developed and implemented.

- Tank waste would be stabilized and the minimum safety upgrades would be completed. Tank waste disposal would be delayed, pending determination of final solution. In-situ disposal of tank waste would be the preferred option. Technology for in-situ disposal of tank waste should be developed.

- Buried solid waste would not be retrieved, and stored solid waste would be disposed in-place.

- Access to groundwater would be controlled and monitored. Groundwater would not be pumped and treated. Contaminated soils would be capped, covered, and disposed in-place.

- Reactors and canyon facilities would be entombed in-place. Canyon facilities would be considered for waste disposal.

\subsection{Alternative IV: Composite Strategy}

A Composite Strategy was the fourth alternative evaluated. This strategy was constructed after single-objective strategies were developed for risk, mortgage reduction, and land use objectives.

\subsubsection{General Description}

The Composite Strategy was developed to maximize the total benefit across all six objectives described in Section 3.0 and Appendix B. The following rules were used to define the Composite Strategy endstate and sequence of cleanup activities.

1. Address the near-term, high-consequence events first (e.g., K Basin spent nuclear fuel).

2. Priority is then given to ongoing, high benefit-to-cost activities (e.g., deactivation of PUREX).

3. Other activities are prioritized in terms of their benefit-to-cost ratio.

The Composite Strategy is similar to the Risk Strategy, except for the priority and sequence of effort and the retrieval of contaminated solid and liquid waste sites outside the 200 Area. The key cleanup activities in the Composite Strategy are the same as those for the Risk Strategy. 


\subsubsection{Development of the Composite Strategy}

The Composite Strategy was developed in two steps: (1) analysis of single-objective strategies and (2) construction of a Composite Strategy from the single-objective strategies. Figure 7.4 illustrates this process.

The task team developed a Mortgage Reduction Strategy and a Land Use Strategy to gain insights into the cleanup activities and the priorities for these strategies. Attachments $\mathrm{H} 2$ and $\mathrm{H} 3$, (Appendix $\mathrm{H}$ ) describe these strategies in detail. The third single-objective strategy, risk, is described in Section 7.3 and is detailed in Appendix $\mathrm{G}$.

The Composite Strategy is very similar to the Risk Strategy. Although most cleanup activities would be the same as the Risk Strategy, there would be some major differences in the priority of those activities. The Revised Priority Planning Grid (Attachment B1) was used to determine the order in which cleanup actions should be executed. All activities were scored to determine their benefit across the six cleanup objectives, and a benefit-to-cost ratio was calculated to order the workscope. Appendix $\mathrm{H}$ describes the development of the Composite Strategy in detail.

\subsubsection{Results of Cleanup}

The cleanup results for the Composite Strategy would be the same as the Risk Strategy, except solid and liquid waste sites outside the 200 Area would be retrieved and disposed on the central plateau.

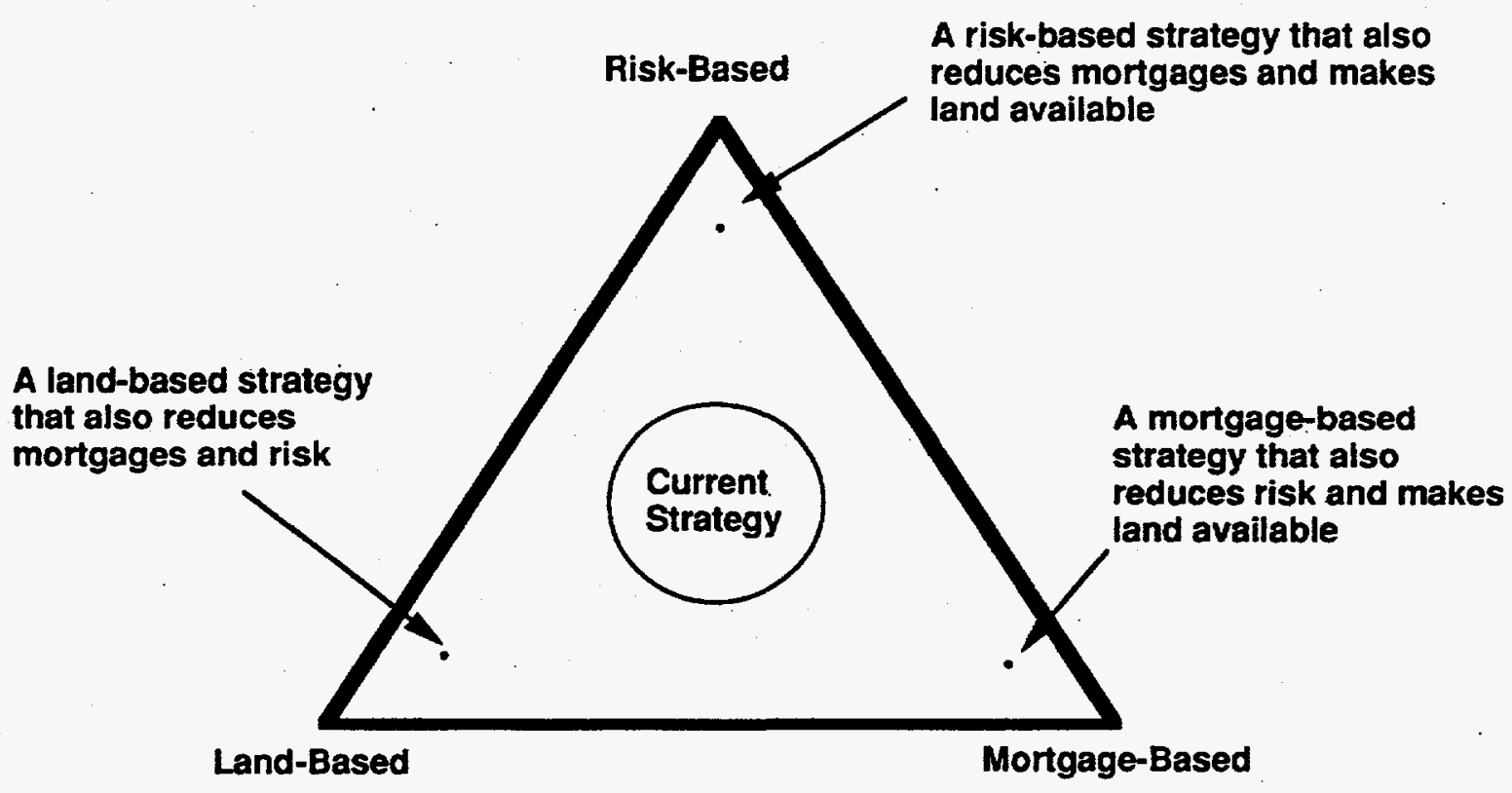

Figure 7.4. Single-Objective Strategies 


\subsubsection{Environmental, Safety, and Health Risks}

The environmental, safety, and health risks for the Composite Strategy would be comparable to those of the Risk Strategy, particularly in the 200 Area and K Basins; however, the Composite Strategy would impact environmental risk slightly by retrieving solid and liquid waste sites outside the 200 Area central plateau. Like the Risk Strategy, the choices of solid and tank waste disposal in-place and the entombment of canyons and reactors would reduce overall worker risk significantly.

\subsubsection{Land Use}

The land use implications for the Composite Strategy would be the same as the Risk Strategy, except there would be fewer restrictions for industrial use in the 100 and 300 Areas.

\subsubsection{Period of Cleanup}

The Composite Strategy would extend to approximately 2045; however, most of the cleanup would be accomplished by 2034 , with completion of waste disposal. Like the Risk Strategy, most waste sites would be remediated by 2026 .

\subsubsection{Costs}

Figure 7.5 is a cost profile for the Composite Strategy. The profile assumes in-situ disposal of tank waste at a cost of ten billion dollars and total environmental restoration costs at nine billion dollars. Total lifecycle costs would be about 45 billion dollars for the Composite Strategy cleanup period.

\subsubsection{Programmatic Risk}

Programmatic risk for the Composite Strategy would be the same as for the Risk Strategy.

\subsubsection{Stakeholder Issues and Regulatory Impacts}

Composite Strategy stakeholder issues and regulatory impacts would be the same as those for the Risk Strategy, except retrieval of waste and contaminated soil from solid and liquid waste sites outside the 200 Area is anticipated to be viewed favorably by stakeholders. Appendix J contains a discussion of regulatory impacts of various cleanup decisions.

\subsubsection{Implications of the Composite Strategy}

If a risk-based cleanup strategy similar to the Composite Strategy described in this study is adopted for the Hanford Site, cleanup activities must support that strategy. The implications of adopting the Composite Strategy would be the same as the Risk Strategy, plus the following.

- Ongoing mortgage-reduction activities (especially PUREX, N Reactor, and Fast Flux Test Facility) should continue. Other mortgage-reduction activities with high benefit-to-cost ratios, (e.g., B Plant and $T$ Plant) should be accelerated. 


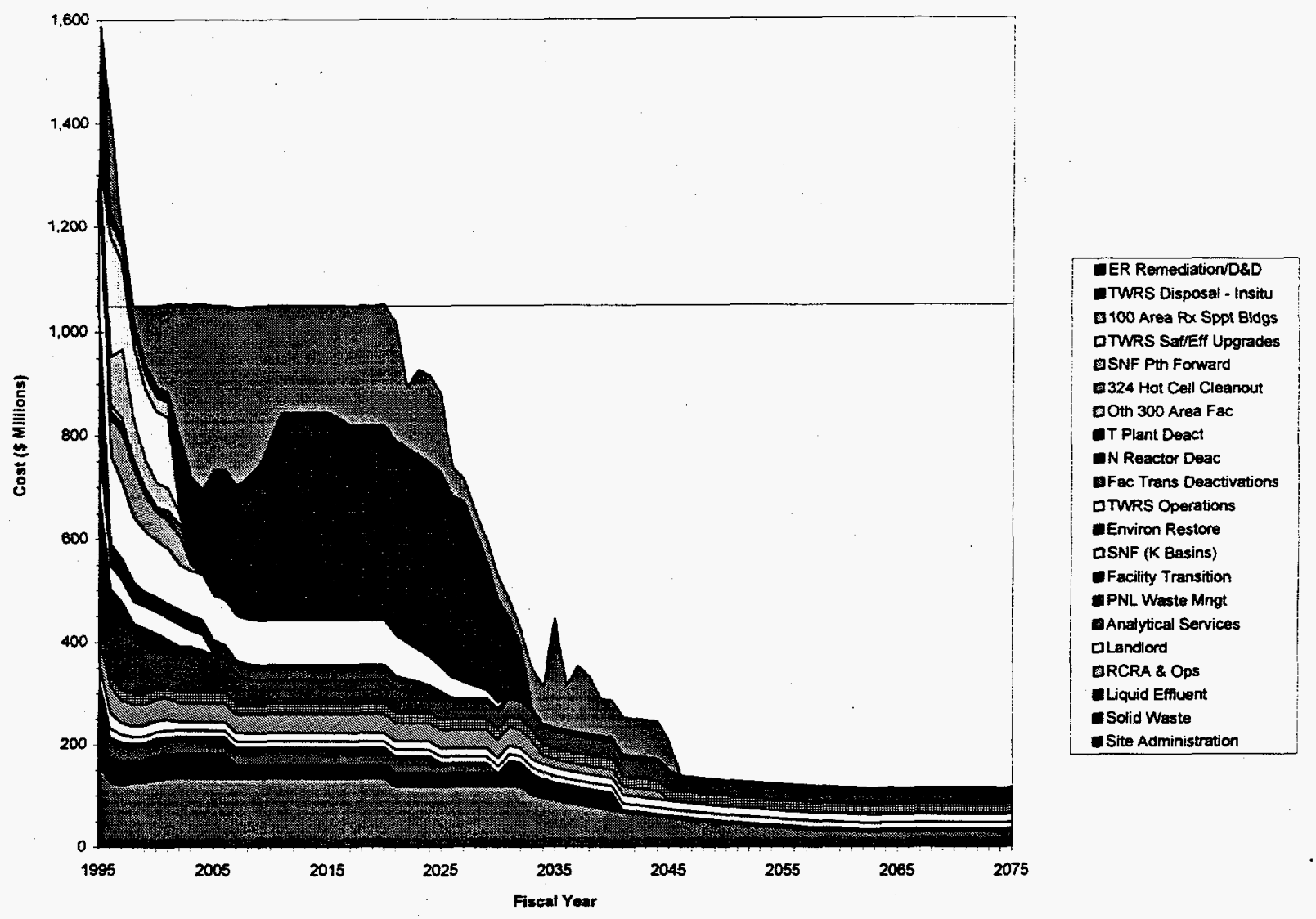

Figure 7.5. Composite Strategy Funding Profile

- Environmental restoration activities designed to make land available should be prioritized, based on benefit per investment dollar, as follows: (1) 1100/3000 Areas, (2) 600 Area from the Columbia river to the perimeter roads, (3) 300 Area, (4) 400 Area, and (5) 100 Area. Environmental restoration activities in the 200 Area should be consistent with the aforementioned policy for waste storage. In general, these activities are not recommended, except for the Environmental Restoration Disposal Facility (if necessary).

- The 300 Area should be given priority for cleanup activities that lead to its use as a science, technology, and industrial area. Contractors should concentrate their activities into fewer facilities; obsolete facilities should be deactivated and demolished; and the area should be made available for other uses as soon as possible. 


\subsection{Comparison of Alternatives}

The strategic alternatives (see Section 7.0) were compared against the cleanup objectives (Appendix B). Data used to compare alternatives were of several types. In some cases, especially risk estimates, information from the Final Environmental Impact Statement Disposal of Hanford Defense High-Level, Transuranic and Tank Wastes (DOE 1987) was used to compare alternatives. This was appropriate in those cases where in-situ disposal of solid or tank waste was part of a strategy. Other hard data (e.g., costs and schedule) were derived from the analyses. Some data were simply discussions of how the alternatives differed and reflected subjective evaluations (e.g., technical complexity), and some data were simply yes or no.

Data were not available for some objectives. Specifically, information to determine rates of progress for cost and risk reduction and land release was not available. The contamination of new land or uncertainties of cost and schedule that contribute to programmatic risk were also not considered.

Appendix I contains a detailed description of the comparison of alternatives, including a data matrix. In the final analysis, only nine criteria were determined to be major discriminators across the alternatives. Table 8.1 shows these criteria and a summary of the data. Table 8.1 does not contain the Existing Baseline Strategy because that strategy fails to meet the budget constraint and is not considered a viable alternative.

\subsection{Summary Comparison}

Overall, the Risk Strategy and the Composite Strategy would provide more protection for workers, would be more economical, and would have earlier completion dates than the Baseline Extended Strategy, making them more likely to be supported by Congress. The Risk and Composite Strategies would be more restrictive of land use and may be opposed by local stakeholders. These strategies may have higher technical risk and would require significant regulatory and Tri-Party Agreement modifications.

The Baseline Extended Strategy would have higher worker risk, would cost more, and would have longer completion dates than either the Risk or Composite Strategies; however, it would be more acceptable to local stakeholders (but probably not to Congress), except for delays due to budget cuts. There would probably be less technical risk and considerably less impact on regulatory requirements and the Tri-Party Agreement.

As compared to the Risk Strategy, the Composite Strategy would be slightly more costly and would take a little longer; however, it should be more acceptable to stakeholders because it would address areas outside the 200 Area central plateau that are more in accordance with current plans and would require less regulatory modification. It would also make the 300 Area available for industrial use sooner: 
Table 8.1. Summary Comparison of Alternative Strategies (Major Discriminators Only)

\begin{tabular}{|c|c|c|c|}
\hline Cleanup criteria & Baseline Extended & Risk & Composite \\
\hline Worker risks & $\begin{array}{l}880 \text { workdays } / 8 \text { fatalities; } \\
15,000 \text { man-rem }\end{array}$ & $\begin{array}{l}110 \text { workdays } /<1 \text { fatality; } \\
2400 \text { man-rem }\end{array}$ & $\begin{array}{l}110 \text { workdays / < } 1 \text { fatality; } \\
2400 \text { man-rem }\end{array}$ \\
\hline Land use & $\begin{array}{l}200 \text { Area disposal facility; } \\
\text { unrestricted outside } 200 \text { Area }\end{array}$ & $\begin{array}{l}200 \text { Area disposal facility; } \\
\text { restricted outside } 200 \text { Area; } \\
\text { restricted groundwater }\end{array}$ & $\begin{array}{l}200 \text { Area disposal facility; } \\
\text { restricted outside } 200 \text { Area; } \\
\text { restricted groundwater }\end{array}$ \\
\hline Schedule & $2058^{*}$ & 2043 & 2045 \\
\hline Tank waste disposal & $2000-2041$ & $2000-2030$ & 2002-2034 \\
\hline$\sim$ Costs & $\$ 56 \mathrm{~B}$ & $\$ 44 B$ & $\$ 45 B$ \\
\hline Technical risk & Moderate & Significant & Significant \\
\hline Political risk & $\begin{array}{l}\text { Supported locally; opposed } \\
\text { nationally }\end{array}$ & $\begin{array}{l}\text { Supported nationally; } \\
\text { opposed locally }\end{array}$ & $\begin{array}{l}\text { Supported nationally; } \\
\text { opposed locally }\end{array}$ \\
\hline Regulatory impact & Minor & Significant & Significant \\
\hline Stakeholder acceptance & $\begin{array}{l}\text { General acceptance; will } \\
\text { oppose delays }\end{array}$ & General opposition & General opposition \\
\hline
\end{tabular}

*Reactor disposition extends to 2075.

$\mathrm{B}=$ billion. 


\subsection{Preferred Alternative}

Overall, a Composite Strategy such as that described in this report is preferred over the Risk and Baseline Extended Strategies if technology uncertainties and significant regulatory impacts can be overcome and if stakeholders are willing to accept the endstate. These are major concerns and if they cannot be addressed successfully the Baseline Extended Strategy is preferred.

\subsection{Sensitivity Analysis}

Since a principal driver for this study was the recently reduced Hanford Site funding profile, this study examined what would happen to the preferred strategy under different annual funding levels: 0.8 billion dollars and 1.25 billion dollars. The 0.8 billion dollars was chosen because that figure had been discussed by Senator Bennett Johnson (D-LA) as a potential Congressionally-mandated limit. The 1.25 billion dollars was chosen because that is the approximate level anticipated in fiscal year 1997 and because it is another funding limit that has been discussed. Attachment 12 (Appendix I), contains bar graphs and budget profiles illustrating the impact of different budget profiles on the Composite Strategy and on the Baseline Extended Strategy.

Figure 8.1 illustrates the amount of discretionary funding available for Site cleanup for different funding levels. It is clear that in the near-term (through about 2005), a budget limit of 800 million dollars would provide less than 200 million dollars annually for cleanup. The other 600 million dollars would be committed to minimum-operations. Cleanup would be extended as well. Increasing available funding to 1.25 billion dollars would make significantly more money available for cleanup, with the result that by 2043 minimum Site operations are at the maintenance level of approximately 100 million dollars.

\subsubsection{Million Dollars Annually}

An annual funding level of 800 million dollars would have a major impact on the Composite Strategy. At this level there would be very little discretionary funding initially, and much of what would be available would have to be used for the high-consequence, near-term release risks. The removal of fuel from $\mathrm{K}$ Basins and removal of debris from $324 \mathrm{~B}$ cell would be supported. PUREX and $\mathrm{N}$ Reactor deactivation would continue on schedule, as would minor environmental restoration activities in the 600,1100 , and 3000 Areas.

Other high-priority cleanup activities would be impacted significantly at this level of funding. These activities include extending the Tank Waste Remediation System safety upgrades one year, delaying the cleanout of Plutonium Finishing Plant by six years, and delaying removal and storage of cesium and strontium capsules by one year.

At 800 million dollars annually there would be major delays on the deactivation of major facilities, such as B Plant (six years), Fast Flux Test Facility (six years), and T Plant (six years). Lower-priority activities (e.g., environmental contamination and tank waste disposal) would slip even more.

Remediation of environmental contamination in the 200 Area and tank disposal area would not be able to begin until at least 2013. Tank waste disposal would extend to 2053 (including tank farm closure) 


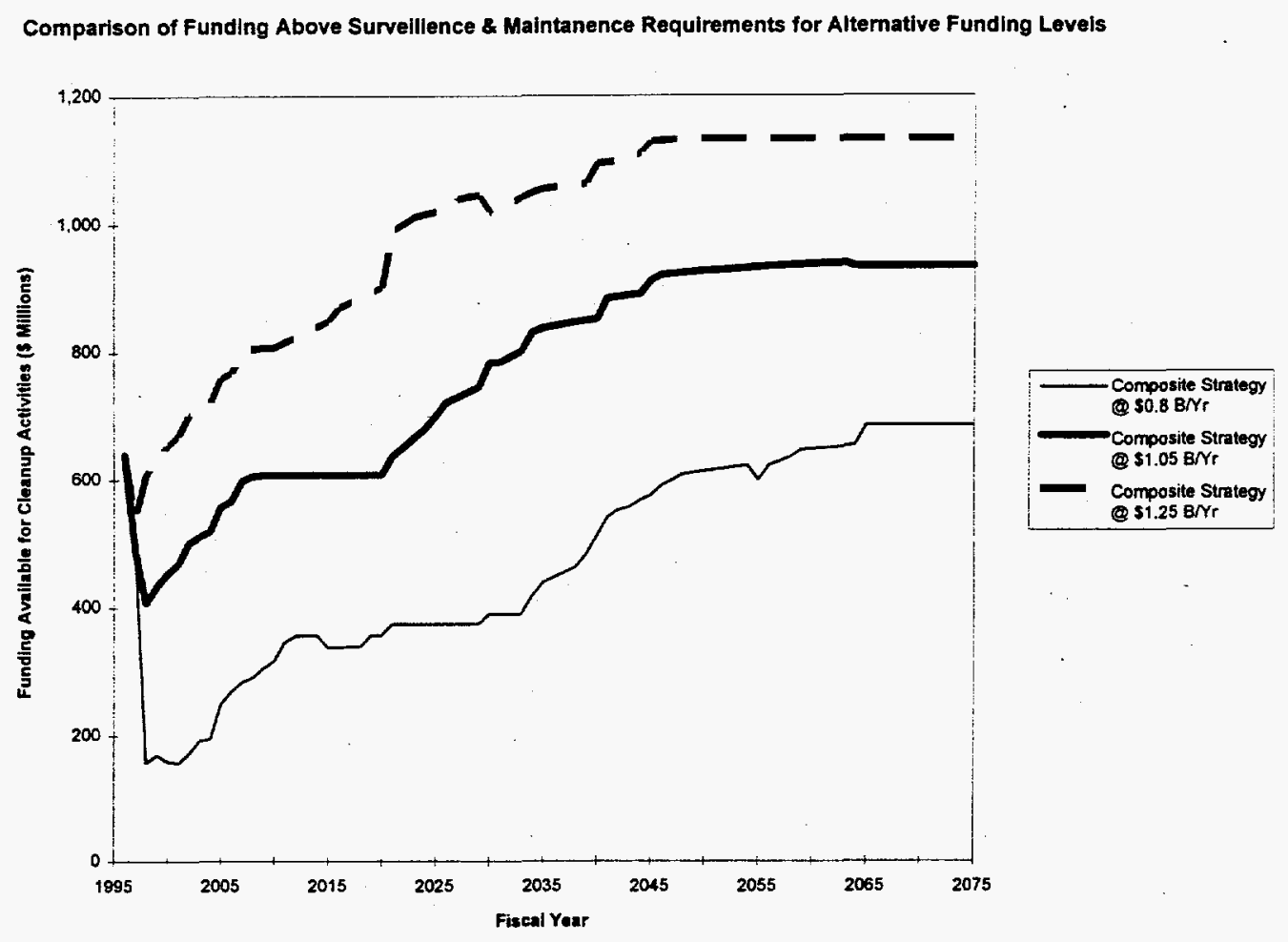

Figure 8.1. Discretionary Funding Available for Different Budgets

and environmental restoration would extend to 2058. Most waste site remediation actions would be completed before 2047. The Baseline Extended Strategy is not considered achievable at 800 million per year.

\subsection{Billion Dollars Annually}

Compared to the 1.05 billion dollar funding constraint, 200 million dollars more annually for the Composite Strategy would provide substantial positive impact on low-priority activities. High-priority actions (e.g., spent nuclear fuels, waste tank remediation safety upgrades) would still be executed as under the 1.05 billion dollar annual budget. Note that no assumptions were made about the ability to execute some programs earlier if more money were available. Even under the 1.25 billion dollar budget level, spent nuclear fuel cleanup would still take about eight years. There may be some programs that could be executed faster, but many likely could not.

An additional 200 million dollars would positively impact the environmental restoration program in the very near term. For example, 100, 300 and 400 Area cleanup would be completed earlier. The biggest impact, however, would be on tank waste activities. Tank operations and tank disposal could be completed ten years earlier. Overall, a funding level of 1.25 billion dollars annually would significantly increase stakeholder acceptance of the Composite Strategy, accelerate environmental restoration and tank waste activities, and enable cleanup completion much sooner. The bulk of the work could be completed by 2028 . 
Additional funding for the Baseline Extended Strategy would enable environmental contamination programs, in particular, to start sooner and would save over ten years for 200 Area remedial actions and facility disposition. Most cleanup activities could be completed around 2040.

\subsubsection{Sensitivity to Tank Disposal Requirements}

The previous strategies developed by this study assumed that the stored volume of liquid waste would not exceed available stored capacity while deferring tank waste disposal activities to satisfy funding constraints. Waste will continue to be added to the tank waste system as facility deactivation and stabilization activities are pursued. The cost data developed for strategies assume that the stored tank waste volume can be controlled within existing capacity by operation of the existing waste evaporator. A limit exists beyond which this volume control method becomes ineffective, requiring either construction of additional tanks or removal of stored tank waste via a disposal system.

Some waste volume projection data indicate waste volume capacity will be approached around 2004; however, the projection of stored waste volume is dependent on a wide range of assumptions that cause uncertainty in the required storage estimates. The uncertainty of projections resulted in excluding funding for new tanks or continued disposal from the minimum operations estimate in this study. The following discussion indicates the potential impact of a waste storage constraint requiring continuation of tank disposal activities.

A cost model of a partial retrieval scenario for control of stored waste volume was developed based on target funding estimates for the tank disposal program. This funding profile was assumed to provide a demonstration capability for removal and vitrification of the low-level fraction of tank waste (corresponding to the large volume portion of tank waste), with a capacity of up to two tanks per year. It was assumed that the removal capability would operate between 2000 and 2010 to provide additional waste volume space in double-shell tanks. After 2010, the tank waste was assumed to be disposed via an in-situ disposal system. The results of the constraint on tank waste disposal as compared to the Composite Strategy with annual site funding limited to 1.05 billion dollars would be as follows: Deactivation of B Plant, Fast Flux Test Facility, and some 300 Area facilities would be delayed by one year. Deactivation of 300 Area fuel supply buildings and T Plant would be delayed by two years. The start of 300 Area remedial actions, 400 Area remedial actions, and 100 Area Reactor Support Building demolition would be delayed by three years. 100 Area remedial actions would be suspended to be restarted in 2002 . Overall Hanford Site lifecycle costs would increase by approximately 1.2 billion dollars.

This approach was estimated to provide for the retrieval and vitrification of low-level waste fractions from approximately 20 waste tanks that would be disposed on-site in a solid waste form.

\subsection{Schedule Comparisons}

Table 8.2 displays the schedule variances for the four alternative strategies, including changes associated with the 0.8 billion dollar and 1.25 billion dollar budgets for the Baseline Extended Strategy and the Composite Strategy. 
Table 8.2. Schedule Comparison

\begin{tabular}{|c|c|c|c|c|c|c|c|c|}
\hline Strategy & $\begin{array}{l}\text { Existing } \\
\text { Baseline } \\
\end{array}$ & \multicolumn{3}{|c|}{ Baseline Extended } & Risk & \multicolumn{3}{|c|}{ Composite } \\
\hline Funding & Per plan & $\$ 0.8 \mathrm{~B}$ & $\$ 1.05 \mathrm{~B}$ & $\$ 1.25 \mathrm{~B}$ & $\$ 1.05 \mathrm{~B}$ & $\$ 0.8 \mathrm{~B}$ & $\$ 1.05 \mathrm{~B}$ & $\$ 1.25 \mathrm{~B}$ \\
\hline $\begin{array}{l}\text { Tank waste disposition } \\
\text { (includes SST closure) }\end{array}$ & $1996-2028$ & not achievable & $2000-2041$ & $1996-2036$ & $2000-2030$ & $2014-2053$ & $2002-2034$ & $2001-2028$ \\
\hline Waste site remediation* & $1996-2018$ & 2009-2062 & 2002-2034 & 1998-2019 & $2000-2026$ & $2002-2047$ & $1999-2026$ & 1996-2020 \\
\hline Solid waste retrieval & 2025 & 2060 & 2048 & 2046 & $\mathrm{n} / \mathbf{a}$ & $\mathbf{n} / \mathbf{a}$ & $\mathrm{n} / \mathbf{a}$ & $n / a$ \\
\hline $\begin{array}{l}200 \text { Area facility } \\
\text { disposition }\end{array}$ & post 2028 & 2071 & 2058 & 2049 & 2043 & 2058 & 2045 & 2043 \\
\hline Reactor disposition & 2075 & 2075 & 2075 & 2075 & 2043 & 2058 & 2045 & 2043 \\
\hline
\end{tabular}

*Includes non-200 Area facilities except for reactors.

$\mathrm{B}=$ billion.

n/a $=$ not applicable.

SST $=$ single-shell tank. 


\subsection{Principal Findings, Conclusions, and Recommendations}

The following summarizes the principal findings, conclusions, and recommendations of the study.

\subsection{Principal Findings and Conclusions}

This study concludes that Hanford Site cleanup has two fundamental products: (1) reduced environmental, safety, and health risks and (2) land available for other uses. Cost effectiveness, demonstration of progress, stakeholder acceptance, and likelihood of success are Site objectives that are means to producing these products.

\subsubsection{Existing Baseline Strategy Conclusions}

- The Existing Baseline Strategy is driven primarily by safety, regulatory compliance, and stakeholder desires as reflected in the Tri-Party Agreement. In general, the Existing Baseline Strategy does not establish priorities among cleanup activities and does not have a specific set of decision rules by which activities and their priorities are established.

- A 50 percent reduction in near-term costs through privatization, cost efficiencies, regulatory relief, and productivity enhancements is required to execute the current cleanup strategy within anticipated funding levels and schedules. Unless that level of reduction happens, a combination of changes in both approach and schedule would be necessary to achieve the same endstate.

\subsubsection{Mortgage Reduction Conclusions}

- Currently, nondiscretionary funding necessary to maintain safe operations is estimated to be 500 to 700 million dollars annually. Unless nondiscretionary costs can be controlled at these levels, limited funding will be available for cleanup decisions.

- Nondiscretionary costs can be reduced through high payback mortgage reduction efforts. These efforts are an essential component of any viable strategy because mortgage reductions make funds available (e.g., each dollar invested in PUREX deactivation now will make 60 dollars available for cleanup by 2018).

- Many mortgage reduction activities, especially facility deactivation, are major contributors to risk reduction.

\subsubsection{Land Use Conclusions}

- Early agreement on cleanup levels and land use is essential to determining cleanup actions and to establishing priorities. Without such agreement, it is impossible to determine a cleanup strategy that produces a specific endstate. 
- There is a wide range of costs per acre associated with Hanford Site cleanup. Some areas are relatively inexpensive (e.g., 600 Area); others are prohibitively costly (200 Area). Achieving unrestricted use of all Hanford Site land is not economically feasible given the expected funding profile and the limitations of cleanup technology.

- Cleanup activities that free land for other uses generally do not also result in significant risk reduction. This produces a natural tension between environmental restoration operations (that produce land for other uses) and waste management operations (that primarily reduce risk).

- For all combinations of land release, risk reduction, and mortgage reduction strategies, the 200 Area is needed as a permanent disposal area with restricted access.

- A portion of the 600 Area inside the boundary roads will be needed to provide a buffer zone while major environmental management activities are ongoing. Release of the buffer zone will be dependent upon the remaining risks. Similarly, the use of the Columbia River shore downstream would be restricted until $\mathrm{K}$ and $\mathrm{N}$ Basins are cleaned out.

\subsubsection{Public, Worker, and Environmental Risk Conclusions}

- There is not a consistent policy for cleanup activities for similar material, especially for retrieval or in-situ disposal decisions (e.g., leaving pre-1970 suspect transuranic waste but retrieving post-1970 transuranic waste and retrieving 99 percent of tank waste but leaving soil contaminated by tank leaks).

- The principal near-term risks are from nuclear materials, tank waste, and nuclear facilities (i.e., spent nuclear fuel in K Basins, 324 B cell debris, safety issue tanks, plutonium in Plutonium Finishing Plant, and cesium and strontium capsules). While the risk from each source is estimated to fall within the goal of the Nuclear Safety Policy (DOE 1991), these sources contain large inventories of radionuclides stored in vulnerable or deteriorating conditions. These hazards are dominated by the quantity of the radionuclides Sr-90, Cs-137, and Am-241.

- Some worker risks--dominated by industrial accidents, inhalation pathways, and immersion--are expected as a part of doing business. Increased worker risks will show up as increased costs that include personnel, safety systems, and protective clothing. In general, remediation actions increase worker exposure and industrial accidents. Some increases in worker risk are often necessary to achieve long-term public risk reduction.

- Risk from long-term release hazards is mainly from public exposure through the groundwater pathway. These risks are dominated by a few long-lived mobile constituents (C-14, Tc-99, I-129, $\mathrm{Np}-237, \mathrm{CCl}_{4}$, nitrate, and uranium).

- Risks posed by contaminated groundwater and soil sites are very long term, therefore, actions to remedy existing environmental contamination are not urgent. Existing land use restrictions and access controls are sufficient for protection of public health. 
- If there were no treatment or isolation of material potentially disposed on-site, then carcinogenic risks would be about two to three orders of magnitude higher than acceptable limits to the public, while non-carcinogenic risks (chiefly from nitrates) are four to five orders of magnitude higher than acceptable limits.

- The principal long-term chronic risks to the public through the groundwater are about the same for buried solid waste, tank waste, and environmental contamination. About 25 percent of waste tanks contain over 99 percent of radiological risks to the groundwater. The 1-2 percent residue from tank retrieval and existing soil contamination limits the potential for total risk-reduction. For buried waste, risks to groundwater from existing and planned low-level waste are roughly two orders of magnitude greater than the combined risk from pre-1970 and post-1970 transuranic waste.

- Other than threats to groundwater, the greatest damage to the environment and ecosystem is associated with demolition, construction, retrieval, and transport operations.

\subsubsection{Cleanup Activities and Strategies Conclusions}

- Removal of spent fuel from $\mathrm{K}$ Basins meets several cleanup objectives. It reduces risks, provides mortgage relief, helps make land available, demonstrates progress, addresses stakeholder values, and meets regulatory requirements.

- Technical uncertainty for in-situ vitrification of tank waste is probably greater than for retrieval; however, retrieval itself is not without technical risk. The tank disposal program will require technology development or proof-of-principle for whatever option is chosen.

- Environmental, worker protection, and public risks are major determinants in choosing among cleanup strategies. Of the three risks, public risks due to near-term hazards have the most influence on cleanup priorities, but worker risks have the greatest impact on the choice of cleanup activities.

- Near-term hazards to the public, workers, and environment are not discriminators among cleanup strategies because they must be addressed as a matter of priority in all cases.

- Entombment of reactors in place poses less risk to workers and the ecosystem and is more economical.

\subsubsection{Conclusions About the Adoption of a Risk-Based Strategy}

- The Baseline Extended, Risk, and Composite Strategies developed in this report are only three of several that could be considered risk-based. Development and implementation of any final riskbased strategy would require participation by Tri-Party Agreement signatories and other stakeholders.

- Adoption of a risk-based strategy similar to those described in this report (1) does not address all primary stakeholder interests and is anticipated to be opposed by some local stakeholders, although it may be supported by DOE Headquarters and Congress; (2) would require regulatory modification and relief, including renegotiation of the Tri-Party Agreement; (3) would have major impacts on fiscal year 1996 and out-year funding allocations; and (4) could have major near-term impacts on 
environmental restoration activities unless nondiscretionary costs are reduced, as those activities would be delayed to fund risk-reduction and mortgage-reduction efforts.

- The risk-based strategies described in this report lead to the following implications about land use: (1) the 200 Area is needed as a permanent disposal area with controlled access and post-closure monitoring; (2) access to groundwater is controlled and monitored for the foreseeable future; (3) 100,300 , and 400 Areas would be available for limited industrial use in the near term; (4) land near the Columbia River would be available for recreational use in the near term; and (5) access to inland 600 Areas would be controlled until the end of cleanup activities in the 200 Area.

- Four decisions are critical to any risk-based strategy. These decisions are (1) retrieval or in-situ treatment of tank waste, (2) retrieval or in-situ treatment of solid waste, (3) entombment or removal of major facilities and reactors, and (4) treatment or controlled access of groundwater. The key risk considerations for these decisions are "what interim endstates make sense for high-consequence hazards?", "what standards should be used to determine acceptable risks?", "what is the tradeoff of increased worker risk and reduced risk to the public?", "what actions provide the biggest risk reduction for cleanup dollars?", and "how should progressive relaxation of land-use restrictions be balanced with risk-reduction efforts?".

- A risk-based strategy further implies that near-term releases with potentially large consequences would be first priority; damage to the environment and ecosystem would be minimized; nuclear materials would be transformed to more safe, stable conditions where the potential for release has been reduced; further releases of liquid waste would be minimized and tank waste would be disposed in-place; buried and stored solid waste would be disposed in-place; groundwater would not be treated, but use and access would be controlled; contaminated soils would be capped and covered; and reactors and canyon facilities would be entombed in-place.

\subsection{Recommendations}

The task team recommends the following actions.

\subsubsection{Recommendations Regarding Adoption of a New Cleanup Strategy}

- This study recommends Tri-Party Agreement signatories determine whether or not they want to adopt a new Site-wide cleanup strategy. If they do, they must establish a process by which that strategy will be developed and implemented. If they do not, they should determine how to execute the existing strategy within anticipated funding profiles. The methodology, tools, and information in this study are recommended as aids in developing a new strategy.

- The prioritization of cleanup activities should be based on a risk-benefit-cost analysis. 


\subsubsection{Recommendations Regarding Costs and Funding}

- There should be continued emphasis on cost reduction to make funding available for cleanup activities, especially indirect costs.

- A cost and regulatory analysis team should examine the activities of every Hanford Site program to identify the minimum level of operations that provide public, worker, and environmental protection. Activities in support of regulatory requirements should be specifically identified. Based upon that information, programs should be funded at a minimum operations level. Funding above that level should be provided only for specific cleanup or support activities approved as part of the overall cleanup strategy.

\subsubsection{Recommendations for Land Use}

- All parties involved in land use determination should come to an early agreement on cleanup levels and how the Hanford Site will be used.

- The study recommends (1) the 200 Area be formally recognized as a permanent waste disposal area; (2) access to groundwater throughout the Site be controlled for the foreseeable future; (3) 100,300, and 400 Areas be made available for limited industrial use as soon as possible; (4) 600 Areas from the boundary road to the Columbia River be released for recreational use as soon as possible; (5) access to and use of the interior 600 Area be restricted to provide a buffer zone until cleanup operations are completed.

\subsubsection{Recommendations for the DOE Richland Operations Office}

- The Site Management Board should take ownership of this study, including working with regulators and stakeholders to obtain agreement on any Site cleanup strategy.

- The Hanford Strategic Plan (RL 1994a) and Fiscal Year 1995 Hanford Mission Plan (RL 1994b) should reflect any new, agreed upon, cleanup strategy and endstate.

- The Strategic Plan and Mission Plan should indicate the two fundamental products of cleanup are risk reduction and land made available for alternative uses.

- The DOE Richland Operations Office should establish a formal policy of consistency in environmental management operations. That is, like materials will be treated consistently. A procedure should be established for the Hanford Site (especially the 200 Area) that implements that formal policy, with a focus on in-place disposal instead of retrieval. Negotiations with regulators to this end should begin as a matter of priority.

- This work should be used as the basis for a mission analysis upon which future detailed Hanford Site systems engineering work is bāsed. 


\subsection{Implementation Considerations}

The DOE and stakeholder participation in the development and approval of a risk-based strategy is needed. The first decision of whether to develop and implement a risk-based strategy is the responsibility of the Assistant Secretary of Environmental Management. Given the Assistant Secretary of Environmental Management supports the development of a risk-based strategy, DOE and stakeholders will develop a follow-on process. The process will most likely require additional analyses of alternatives, risk, cost, schedule, technology, regulations, and land availability. The DOE and stakeholders will develop recommendations on objectives, decision rules, endstates, interim states, and actions. Several key decisions are needed to define the endstate, the interim state, and the actions to support those states. The major decisions identified by the alternatives examined in this report are as follows:

- Retrieval/treatment versus in-place disposal of tank waste

- Retrieval/treatment versus in-place disposal of post-1970 transuranic waste

- Treatment/confinement versus restriction of the contaminated groundwater

- Demolition/removal versus entombment of major facilities

The DOE and stakeholder recommendations will serve as the basis for Tri-Party Agreement negotiations and amendments and will be captured in the Hanford Strategic Plan (RL 1994a) and Fiscal Year 1995 Hanford Mission Plan (RL 1994b) to initiate technical and program baseline developments that lead to implementation of the actions. A parallel National Environmental Policy Act of 1969 process would be initiated to obtain a record of decision on the Site-wide strategy, endstate, and the actions proposed. This would be required to initiate major new projects or revise existing actions consistent with the strategy. 


\subsection{References}

\subsection{Documents}

Blush, S. M., and T. H. Heitman, 1995, Train Wreck Along the River of Money -- An Evaluation of the Hanford Cleanup, a report for the U.S. Senate Committee on Energy and Natural Resources, Blush Consulting, Washington, D.C.

DOE, 1987, Final Environmental Impact Statement (EIS) Disposal of Hanford Defense High-Level, Transuranic and Tank Wastes, DOE/EIS-0113, U.S. Department of Energy, Washington, D.C.

DOE, 1991, Nuclear Safety Policy, SEN-35-91, U.S. Department of Energy, Washington, D.C.

Ecology, EPA, and DOE, 1994, Hanford Federal Facility Agreement and Consent Order, as amended, Washington State Department of Ecology, U.S. Environmental Protection Agency, and U.S. Department of Energy, Olympia, Washington.

Ecology, 1995, Washington State Administrative Code, Washington State Department of Ecology, Olympia, Washington.

Mahaffey, J. A., B. L. Harper, T. A. Ikenberry, R. D. Stenner, J. W. Buck, J. S. Dukelow, Jr., L. H. Staven, P. S. Kaae, S. F. Snyder, N. C. Batishko, G. M. Gelston, S. W. Gajewski, N. C. Van Houten, K. J. Castleton, B. R. Warren, and M. S. Peffers, 1994, Integrated Risk Assessment Program: Methodology and Results from Qualitative Evaluation of Current Hanford Site Risks to the Public, PNL-10154, Pacific Northwest Laboratory, Richland, Washington.

RL, 1994a, Hanford Strategic Plan, RL-D94-048, U.S. Department of Energy Richland Operations Office, Richland, Washington.

RL, 1994b, Fiscal Year 1995 Hanford Mission Plan, Volume 1, "Site Guidance," DOE/RL-93-102, U.S. Department of Energy Richland Operations Office, Richland, Washington.

Whelan, G., J. W. Buck, and A. Nazarali, 1994, Modular Risk Analysis for Assessing Multiple Waste Sites, PNL-SA-24239, Pacific Northwest Laboratory, Richland, Washington.

Wood, M. I., R. Khaleel, P. D. Rittmann, A. H. Lue, et al. '1994. Performance Assessment for the Disposal of Low-Level Waste in the 200 West Area Burial Grounds. WHC-EP-0645, Westinghouse Hanford Company, Richland, Washington.

Working Group, 1992, The Future for Hanford: Uses and Cleanup, prepared by the Hanford Future Site Uses Working Group for the U.S. Department of Energy, U.S. Environmental Protection Agency, and the State of Washington. 


\subsection{Public Laws}

Comprehensive Environmental, Response, Compensation, and Liability Act of 1980, 42 USC 9601, et seq.

National Environmental Policy Act of 1969, 42 USC 4321, et seq.

Nuclear Waste Policy Act of 1982, 42 USC 10101, et. seq.

Resource Conservation and Recovery Act of 1976, 42 USC 6901, et seq. 


\subsection{Bibliography}

40 CFR 300, "National Oil and Hazardous Substances Pollution Contingency Plan," U.S. Code of Federal Regulations, as amended.

Abrams, C. W., J. C. Abbott, R. S. Fowler, S. W. Gajewski, C. R. Merritt, J. M. Paananen, M. R. Peterson, K. M. Probasco, and B. S. Rush, 1995, Hanford Site-Wide Activities Database, Draft Final Report, Pacific Northwest Laboratory, Richland, Washington.

Anderson, B. C., 1989, Stored, Contact-Handled Transuranic Waste Characterization at the Hanford Site, WHC-EP-0223, Westinghouse Hanford Company, Richland, Washington.

Anderson, B. C., J. D. Anderson, J. A. Demiter, D. R. Duncan, and D. C. McCann, 1990, ContactHandled Transuranic Waste Characterization Based on Existing Records, WHC-EP-0225, Westinghouse Hanford Company, Richland, Washington.

Baker, D. A., M. A. Chamness, M. E. Crist, C. E. Cushing, R. M. Fruland, D. W. Harvey, D. J. Hoitink, E. B. Moore, T. M. Poston, H. E. Seely, R. R. Wahlstrom, B. K. Wise, and M. K. Wright, 1994, Hanford Site National Environmental Policy Act (NEPA) Characterization, PNL-6415, Rev. 6, Pacific Northwest Laboratory, Richland, Washington.

Bergsman, K. H, 1994, Hanford Spent Fuel Inventory Baseline, WHC-SD-SNF-TI-001, Rev. 0, Westinghouse Hanford Company, Richland, Washington.

Bilyard, G. R., S. M. Gajewski., C. S. Glantz, B. L. Harper, and P. L. Miller, 1994, Hanford Risk Data Gap Analysis, Draft. Pacific Northwest Laboratory, Richland, Washington.

Boomer, K. D., et al., 1992, Attachment 1 to the Technical Options Report for the Characterization, Tank Safety and Mitigation, Separations, and On-site and Off-site Treatments -- Tank Waste Radionuclide and Chemical Compositions, Westinghouse Hanford Company, Richland, Washington.

Boomer, K. D., S. K. Baker, A. L. Boldt, M. D. Britton, J. D. Galbraith, J. S. Garfield, C. E. Golberg, B. A. Higle, L. J. Johnson, M. J. Kupfer, R. M. Marusich, R. J. Parazin, M. G. Piepho, A. N. Praga, G. W. Reddick, E.J. Slaathaugh, L. M. Swanson, T. L. Waldo, and C. E. Worcester, 1993, Tank Waste Systems Engineering Study, WHC-EP-0405, Rev. 0, Westinghouse Hanford Company, Richland, Washington.

Buck, J. W., M. S. Peffers, and S. T. Hwang, 1991, Preliminary Recommendations on the Design of the Characterization Program for the Hanford Site Single-Shell Tanks -- A System Analysis, Volume 2 -Closure Related Analyte Priorities, Concentration Thresholds, and Detection Limit Goals Based on Public Health Concerns, PNL-7575, Vol. 2, Pacific Northwest Laboratory, Richland, Washington. 
Buck, J. W., G. Whelan, J. G. Droppo, Jr., D. L. Strenge, K. J. Castleton, J. P. McDonald, C. Sato, and G. P. Streile, 1995, Multimedia Environmental Pollutant Assessment System (MEPAS) Application Guidance - Guidelines for Evaluating MEPAS Input Parameters for Version 3.1, PNL-10395, Pacific Northwest Laboratory, Richland, Washington.

Carlson, A. B., D. M. Caum, D. C. DeRosa, D. R. Duncan, K. L. Hladek, P. H. Jacobsen, R. S. Kelley, Jr., B. A. Mayancsik, and W. L. Willis, 1994, Solid Waste Program Technical Baseline Description, WHC-SD-WM-RPT-060, Rev. 0, Westinghouse Hanford Company, Richland, Washington.

Chatters, J. C., D. L. Hadley, D. J. Hoitink, S. J. Marsh, T. M. Poston, A. C. Rohay, and R. W. Wallace, 1991, Characterization of the Hanford Site and Environs, PNL-7668, Pacific Northwest Laboratory, Richland, Washington.

Coles, G. A., M. V. Shultz, and W. E. Taylor, 1994, Risk Management Study for the Retired Hanford Site Facilities Qualitative Risk Evaluation for the Retired Hanford Site Facilities. WHC-EP-0619, Volumes 2 through 4, Westinghouse Hanford Company, Richland, Washington.

Dirkes, R. L., R. W. Hanf., R. K. Woodruff, and R. E. Lundgren, 1993, Hanford Site Environmental Report for Calendar Year 1993, PNL-9823, Pacific Northwest Laboratory, Richland, Washington.

DNFSB, 1994, "Recommendation 94-2 to the Secretary of Energy Pursuant to 42 USC $§ 2286 a(5)$, Atomic Energy Act of 1954, as amended," letter to Hazel O'Leary, Secretary of Energy, September 8, 1994 from John T. Conway, DNFSB Chairman, Defense Nuclear Facilities Safety Board, Washington, D.C.

DOE, 1994a, Hanford Remedial Action - Draft Environmental Impact Statement, Volume 1 of 2, DOE/DEIS-0222, U.S. Department of Energy, Washington, D.C.

DOE, 1994b, Plutonium Working Group Report on Environmental, Safety and Health Vulnerabilities Associated with the Department's Plutonium Storage - Volume I: Summary, DOE/EH-0415, U.S. Department of Energy, Washington, D.C.

DOE, 1995, Volume II: Site Summaries March 1995, Estimating the Cold War Mortgage, The 1995 Baseline Environmental Management Report, U.S. Department of Energy, Washington, D.C.

Dresel, P. E., S. P. Luttrell, J. C. Evans, W. D. Webber, P. D. Thorne, M. A. Chamness, B. M. Gillespie, B. E. Opitz, J. T. Rieger, and J. K. Merz, 1994, Hanford Site Ground-Water Monitoring for 1993, PNL-10082, Pacific Northwest Laboratory, Richland, Washington.

Driver, C. J., 1994, Ecotoxicity Literature Review of Selected Hanford Site Contaminants, PNL-9394, Pacific Northwest Laboratory, Richland, Washington.

Droppo, Jr., J. G., J. W. Buck, J. S. Wilbur, D. L. Strenge, and M. D. Freshley, 1991, Single-Shell Tank Constituent Rankings for Use in Preparing Waste Characterization Plans, PNL-7572, Pacific Northwest Laboratory, Richland, Washington. 
Droppo, Jr., J. G., J. W. Buck, D. L. Strenge, and Siegel, 1990, Analysis of Health Impact Inputs to the U.S. Department of Energy's Risk Information System, PNL-7432, Pacific Northwest Laboratory, Richland, Washington.

Ecology, EPA, and DOE, 1994, Tentative Agreement on Environmental Restoration Refocusing TriParty Agreement Negotiations, Washington State Department of Ecology, U.S. Environmental Protection Agency, and U.S. Department of Energy, Olympia, Washington.

Ecology, EPA, and DOE, 1995, Tentative Agreement on Facility Transition Tri-Party Agreement Negotiations, Washington State Department of Ecology, U.S. Environmental Protection Agency, and U.S. Department of Energy, Olympia, Washington.

EPA, 1989, Risk Assessment Guidance for Superfund Volume 1 Human Health Evaluation Manual (Part A), Interim Final, EPA/540/1-89/002, U.S. Environmental Protection Agency, Washington, D.C.

Finucane, E. W., Definitions, Conversions, and Calculations for Occupational Safety and Health Professionals, Lewis Publishers, Library of Congress ISBN 0-87371-863-1.

Forward, M. M., D. A. King, J. L Buelt, A. J. Villegas, J. M. Paananen, R. I. Hansen, J. J. Toth, S. R. Billingsley, C. Johnson, G. P. Streile, L. J. Angel, N. C. Williams, and P. L. Miller, 1994, Methodology for Selecting Technologies and Estimating Waste Volumes, Costs, and Labor Requirements for Environmental Restoration, Draft, PNL-XXXX, Pacific Northwest Laboratory, Richland, Washington.

Fulton, J. C., 1994, Hanford Spent Nuclear-Fuel Project Recommended Path Forward -- Volume II Alternatives and Path Forward Evaluation, WHC-EP-0830, Vol. 2, Rev. 0, Westinghouse Hanford Company, Richland, Washington.

GAO, 1990, Nuclear Energy, Consequences of Explosion of Hanford's Single-Shell Tanks are Understated, GAO/RCED-91-34, U.S General Accounting Office, Washington, D.C.

Gerber, M. S., 1993a, Multiple Missions: The 300 Area in Hanford Site History, WHC-MR-0440, Westinghouse Hanford Company, Richland, Washington.

Gerber, M. S., 1993b, The Hanford Site: An Anthology of Early Histories, WHC-MR-0435, Westinghouse Hanford Company, Richland, Washington.

Government Institutes, 1989, Environmental Law Handbook (ELH), 10th ed, ISBN: 0-86587-766-1, Government Institutes, Inc., Rockville, Maryland.

Government Institutes, 1989, Environmental Statutes (ES), 1989, ISBN: 0-86587-768-8, Government Institutes Inc., Rockville, Maryland.

Grumbly, T.P., 1995, Statement of Thomas P. Grumbly, Assistant Secretary for Environmental Management, U.S. Department of Energy, before the Committee on Energy and Natural Resources, U.S. Senate. March 22, 1995, Washington, D.C. 
Grygiel, M. L., M. A. Cahill, J. S. Garfield, M. J. Kupfer, G. A. Meyer, J. H. Roecker, L. K. Holton, and M. B. Triplett, 1991, Tank Waste Disposal Program Redefinition, WHC-EP-0475, Westinghouse Hanford Company, Richland, Washington.

Holmes, J. J., 1994, Systems Engineering Functions and Requirements for the Hanford Cleanup Mission: First Issue, WHC-EP-0722, Westinghouse Hanford Company, Richland, Washington.

Kautzky, Jim, 1995, "Grumbly Risk Initiative Hanford Response - Meeting with DDs March 22, 1995," presented by Jim Kautzky, U.S. Department of Energy, Richland, Washington to Thomas P. Grumbly, U.S. Department of Energy, Environmental Management, Washington, DC.

Kincaid, C. T., J. W. Shade, G. A. Whyatt, M. G. Piepho, K. Rhoads, J. A. Voogd, J. H. Westsik, Jr., M. D. Freshley, K. A. Blanchard, and B. G. Lauzon, 1994, Performance Assessment of Grouted Double-Shell Tank Waste Disposal at Hanford, WHC-SD-WM-EE-004, Rev. 1, Westinghouse Hanford Company, Richland, Washington.

Knepp, A. J., B. H. Ford, D. K. Tyler, F. N. Hodges, V. G. Johnson, R. E. Peterson, and G. L. Kasza, 1994, Hanford Sitewide Groundwater Remediation Strategy, (Draft A), Department of Energy, Richland, Washington.

Lansing, K. A., 1994, Westinghouse Hanford Company Health and Safety Performance Report, Fourth Quarter Calendar Year 1993, WHC-SP-0564-32, Westinghouse Hanford Company, Richland, Washington.

McBeath, R. S., 1989, Characterization Study of Low-Level Mixed Waste in Retrievable Storage Units, WHC-EP-0245, Westinghouse Hanford Company, Richland, Washington.

McClain, L., S. Robinson, R. Freeberg, J. Erickson, J. Goodenough, T. Ferns, S. Weissburg, H. Forsen, R. Wyer, J. Nemec, and M. Wollin, 1994, Hanford Environmental Restoration FY 1994 Year End Review, Westinghouse Hanford Company, Richland, Washington.

McConville, C. M., 1995, In Situ Treatment and Disposal of Radioactive Waste in Hanford Site Underground Storage Tanks Engineering Data Package for the Tank Waste Remediation System Environmental Impact Statement, WHC-SD-WM-EV-101, Rev. B, Draft, Westinghouse Hanford Company, Richland, Washington.

Napier, B. A., N. C. Batishko, D. A. Heise-Craff, M. F. Jarvis, and S. F. Snyder, 1995, Identification of Contaminants of Concern - Columbia River Comprehensive Impact Assessment Draft, PNL-10400, Pacific Northwest Laboratory, Richland, Washington.

ORNL, 1987, Environmental Compliance Program (ECP) Reference Book, Comprehensive Environmental Responses, Compensation, and Liability Act, Rev 5, Oak Ridge National Laboratory, Oak Ridge, Tennessee.

Pajunen, A. L., C. K. Allen, A. B. Carlson, et al., 1994, Hanford Strategic Analysis Study, WHC-EP-0549, Westinghouse Hanford Company, Richland, Washington. 
PNL, 1992, Hanford Integrated Plan: A Preliminary Analysis of End Point Criteria for Select Chemicals and Radionuclides, Pacific Northwest Laboratory, Richland, Washington.

Rinne, C. A., and K. S. Daly, 1993, Hanford 200 Areas Development Plan, DOE/RL-92-29, U.S. Department of Energy Richland Operations Office, Richland, Washington.

Scanlon, P. L., H. Hampt, and W. A. Skelly, 1995, Closure Technical Data Package for the Tank Waste Remediation System Environmental Impact Statement, WHC-SD-WM-EV-107, Rev. B, Draft, Westinghouse Hanford Company, Richland, Washington.

Shultz, M. V., and G. A. Coles, 1994, 1994 Qualitative Risk Evaluation Update for the Retired Hanford Site Facilities, BHI-00052, Rev. 00, Bechtel Hanford, Inc., Richland, Washington.

Strenge, D. L., and P. J. Chamberlain, 1994, Evaluation of Unit Risk Factors in Support of The Hanford Remedial Action Environmental Impact Statement, PNL-10190, Pacific Northwest Laboratory, Richland, Washington.

Thorne, P. D., M. A. Chamness, F. A. Spane, Jr., V. R. Vermeul, and W. D. Webber, 1993, Three-Dimensional Conceptual Model for the Hanford Site Unconfined Aquifer System, FY 1993 Status Report, PNL-8971, Pacific Northwest Laboratory, Richland, Washington.

Thorne, P. D., M. A. Chamness, V. R. Vermeul, Q. C. Macdonald, and S. E. Schubert, 1994, ThreeDimensional Conceptual Model for the Hanford Site Unconfined Aquifer System, FY 1994 Status Report, PNL-10195, Pacific Northwest Laboratory, Richland, Washington.

RL, 1992, Hanford Integrated Planning Process 1992 Hanford Mission Plan (HMP), DOE/RL-92-07, U.S. Department of Energy Richland Operations Office, Richland, Washington.

RL, 1993, Hanford Site Baseline Risk Assessment Methodology, DOE/RL-91-45, Rev. 3, Redline Draft, U.S. Department of Energy Richland Operations Office, Richland, Washington.

RL, 1994, Richland Environmental Restoration Project Plan, DOE-RL-92-08, U.S. Department of Energy Richland Operations Office, Richland, Washington.

RL, 1995, Closure Report for the N Reactor Facility, DOE/RL-94-152, U.S. Department of Energy Richland Operations Office, Richland, Washington.

Streile, G. P., and L. J. Angel, 1994, Letter Report for the Engineering Support Task of the Programmatic Environmental Impact Statement (PEIS) Project Code: A Computer Code for the Estimation of Contaminated Soil Depths at DOE Waste Disposal and Spill Sites, Draft, Pacific Northwest Laboratory, Richland, Washington. 
Valero, O. J., L. L. Armacost, T. J. DeForest, K. J. Templeton, and N. C. Williams, 1994, Solid Waste 30-Year Volume Summary, WHC-EP-0768, Westinghouse Hanford Company, Richland, Washington.

Wurstner, S. K., and J. L. Devary, 1993, Hanford Site Ground-Water Model: Geographic Information System Linkages and Model Enhancements, FY 1993, PNL-8991, Pacific Northwest Laboratory, Richland, Washington. 


\section{Appendix A}

Site Description 
-

-

O 


\section{Contents}

\section{Appendix A - Site Description}

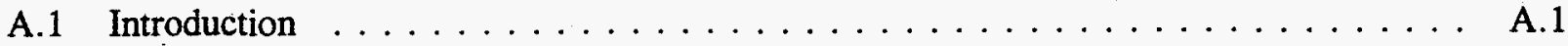

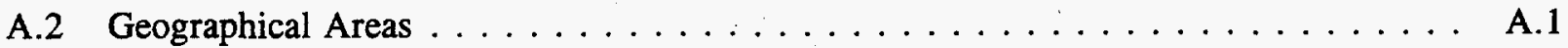

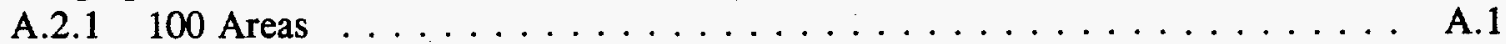

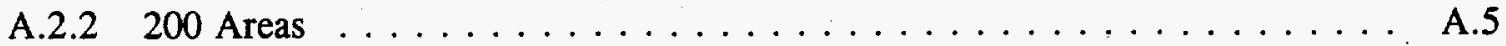

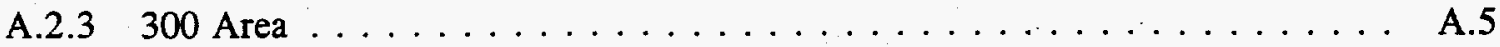

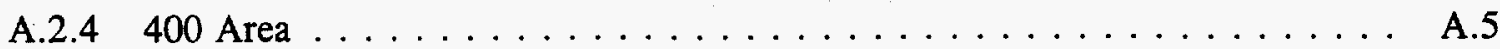

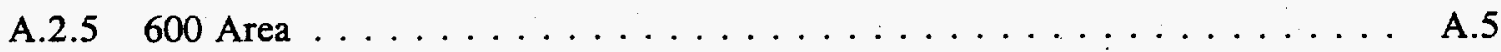

A.3 Hazard Sources $\ldots \ldots \ldots \ldots \ldots \ldots \ldots \ldots \ldots \ldots \ldots \ldots \ldots \ldots$ A.10 $\ldots \ldots \ldots$

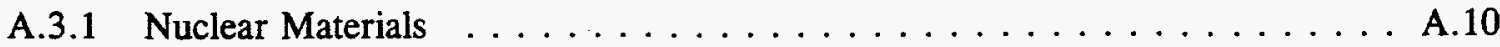

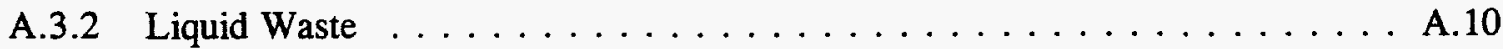

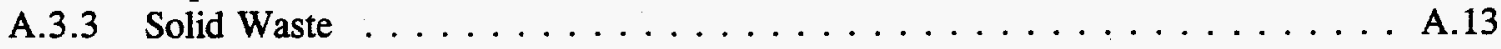

A.3.4 Environmental Contamination $\ldots \ldots \ldots \ldots \ldots \ldots \ldots \ldots \ldots \ldots$ A.17

A.3.5 Facilities $\ldots \ldots \ldots \ldots \ldots \ldots \ldots \ldots \ldots \ldots \ldots \ldots \ldots \ldots \ldots \ldots \ldots \ldots \ldots \ldots .18$

\section{Figures}

A.1. Hanford Site - Current Conditions $\ldots \ldots \ldots \ldots \ldots \ldots \ldots \ldots \ldots \ldots \ldots$ A.2

A.2. Illustration of the 100 Areas $\ldots \ldots \ldots \ldots \ldots \ldots \ldots \ldots \ldots \ldots$ A.3

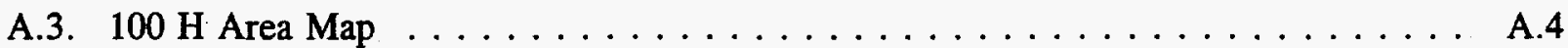

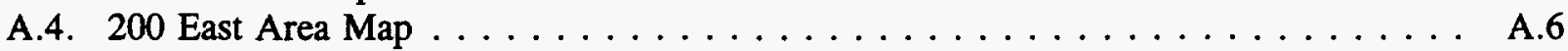

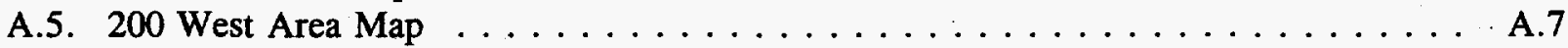

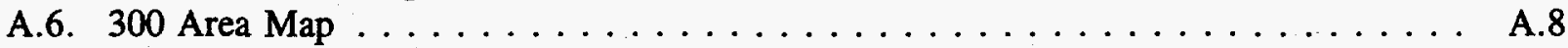

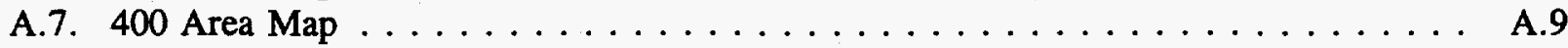

A.8. Waste Encapsulation and Storage Facility Pool Cells $\ldots \ldots \ldots \ldots \ldots \ldots \ldots$ A.11

A.9. Nuclear Materials Fact Sheet $\ldots \ldots \ldots \ldots \ldots \ldots \ldots \ldots \ldots \ldots \ldots$ A.12

A.10. Tank Farm Descriptions $\ldots \ldots \ldots \ldots \ldots \ldots \ldots \ldots \ldots \ldots \ldots \ldots$ A.14

A.11. Single- and Double-Shell Tank Fact Sheet $\ldots \ldots \ldots \ldots \ldots \ldots \ldots \ldots \ldots$ A.15

A.12. Photograph of a Solid Waste Disposal Trench . . . . . . . . . . . A.16

A.13. Photograph of an Environmental Contamination Site $\ldots \ldots \ldots \ldots \ldots \ldots$. . $\ldots \ldots$

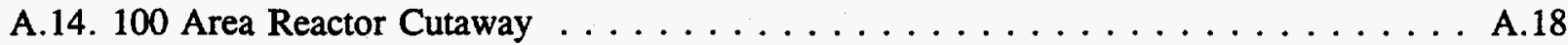

A.15. Photograph of B Plant $\ldots \ldots \ldots \ldots \ldots \ldots \ldots \ldots \ldots \ldots \ldots \ldots \ldots \ldots$ A.19

A.16. Cutaway of the 221-B Canyon Building $\ldots \ldots \ldots \ldots \ldots \ldots \ldots$ A.19

A.17. Photograph of the 400 Area Facilities $\ldots \ldots \ldots \ldots \ldots \ldots \ldots \ldots$ A.20 


\section{Appendix A}

\section{Site Description}

\section{A.1 Introduction}

The Hanford Site has been used for production of defense nuclear materials for over 50 years. The legacy of the defense production mission includes large quantities of nuclear materials, liquid waste, solid waste, environmental contamination (e.g., soils and groundwater), and several facilities contaminated with radionuclides and other hazardous materials. These Site features potentially expose the public, environment, and the workforce to unacceptable risks and, in the current conditions, preclude most non-DOE uses of the Hanford Site.

\section{A.2 Geographical Areas}

The Hanford Site is approximately 560 square miles and has historically been divided into geographical areas (see Figure A.1). In the 100, 200, 300 and 400 Areas the Site has developed and maintained an extensive infrastructure that could be attractive for non-DOE and industrial activities. There are available roads, and utilities and the areas are somewhat isolated from town but close enough for daily commuting. Sections A.2.1 through A.2.5 provide summary discussions and maps of five of the areas. The summary discussions include general area use and condition.

\section{A.2.1 100 Areas}

The 100 Areas are approximately 30 square miles and are bordered by the Columbia River. These areas were used primarily for the defense production reactors. There are nine reactors, designated $\mathrm{B}, \mathrm{C}, \mathrm{D}, \mathrm{DR}, \mathrm{F}, \mathrm{H}, \mathrm{KE}, \mathrm{KW}$, and $\mathrm{N}$, and their associated support facilities in the 100 Areas. The locations of the nine reactors along the Columbia River are illustrated in. Figure A.2. Solid waste from reactor operations was buried in 28 burial sites in the 100 Areas from 1944 through 1973. Liquid waste from Reactor Operations was discharged directly to the environment in the 100 Areas. Currently, N Reactor fuel is stored underwater in the KE and KW Basins. Radiological and chemical contaminants have reached the groundwater and the Columbia River from operations in the 100 Areas. A map of the $100 \mathrm{H}$ Area is included as Figure A.3, as an example of a typical 100 Area Site. 


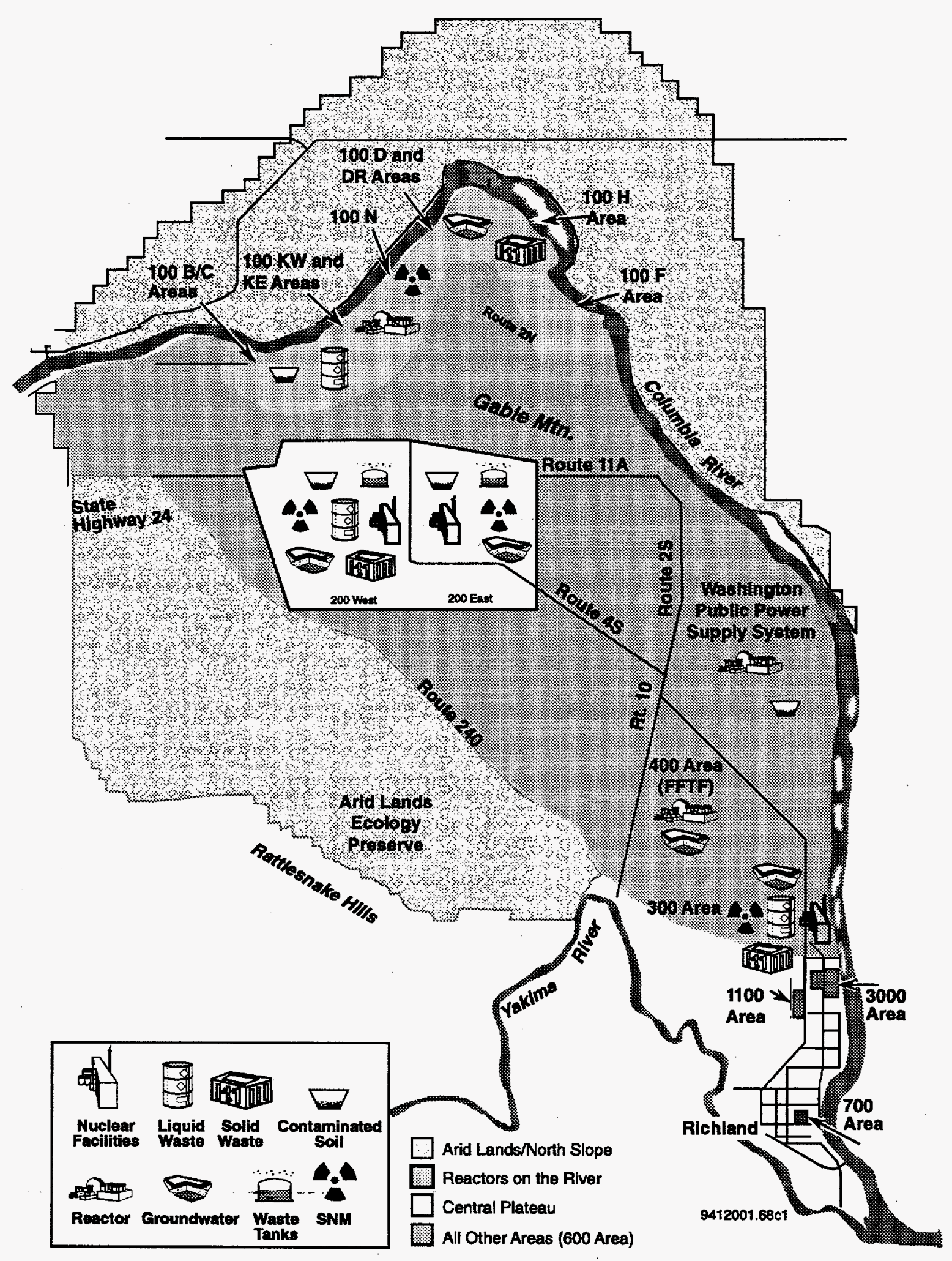

Figure A.1. Hanford Site - Current Conditions 


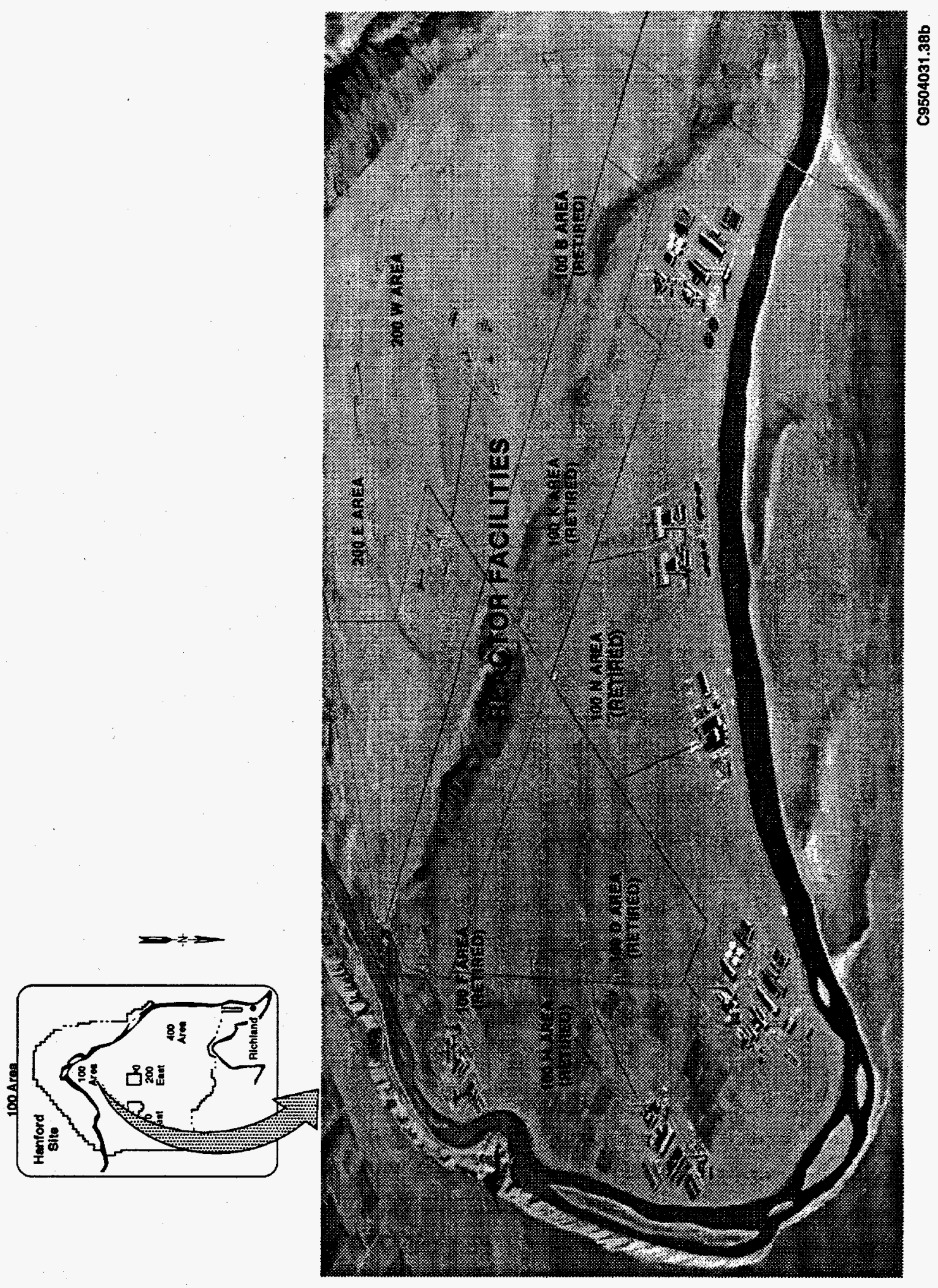

Figures A.2. Illustration of the 100 Areas 


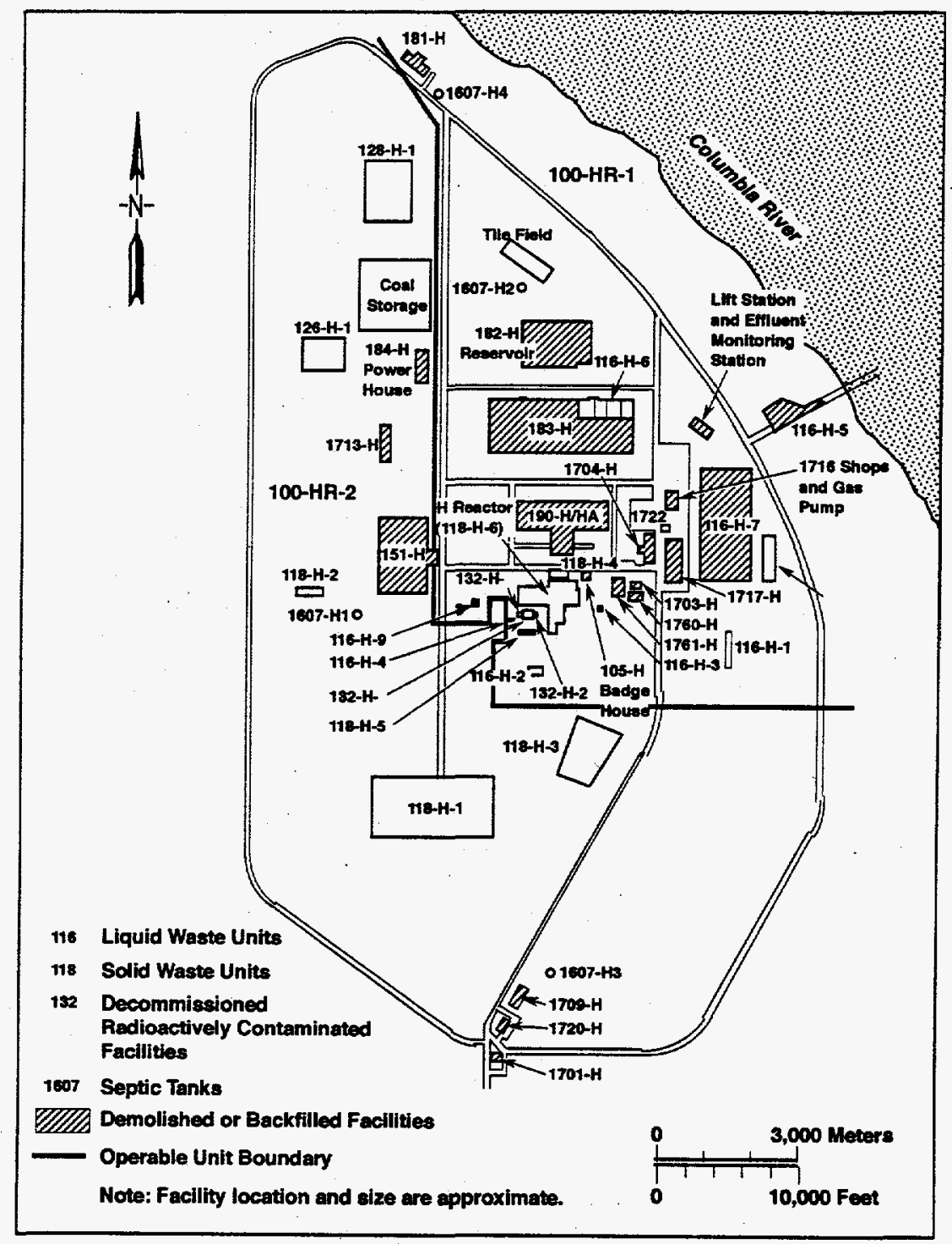

C9504031.26

Figure A.3. 100 H Area Map 


\section{A.2.2 200 Areas}

The 200 Areas are approximately 30 square miles located on the central plateau. There are six fuel reprocessing facilities and associated support buildings. There are 149 single-shell tanks and 28 double-shell tanks storing a total of 212,000 cubic meters (56 million gallons) of waste. There are 34 active and retired solid waste burial grounds in the 200 areas. Liquid effluent was discharged directly to the soil column and, as a result, contaminants have reached the groundwater. Maps of the 200 East and 200 West Areas are included as Figures A.4 and A.5, respectively.

\section{A.2.3 300 Area}

The 300 Area is approximately one square mile bordered by the Columbia River and is close to Richland, Washington. This area was used for fuel fabrication in support of the reactors and as a science and technology center in support of Site operations. There are several contaminated facilities and soil sites in the 300 Area. The groundwater is also contaminated. A map of the 300 Area is included as Figure A.6.

\section{A.2.4 400 Area}

The 400 Area is approximately one square mile. This area was used for the Fast Flux Test Facility and support facilities. Liquid and solid waste were not directly disposed in the 400 Area. The groundwater under the 400 Area has been contaminated as a result of other Site operations. A map of the 400 Area is included as Figure A.7.

\section{A.2.5 600 Area}

The 600 Area consists of the approximately 240 square miles of the Site that are not included in one of the other areas. It does not include the Arid Land Ecology Reserve or the North Slope. The 600 Areas are generally clean, except for the groundwater, which has been contaminated as a result of Site operations in other areas, and some solid waste disposal sites. 


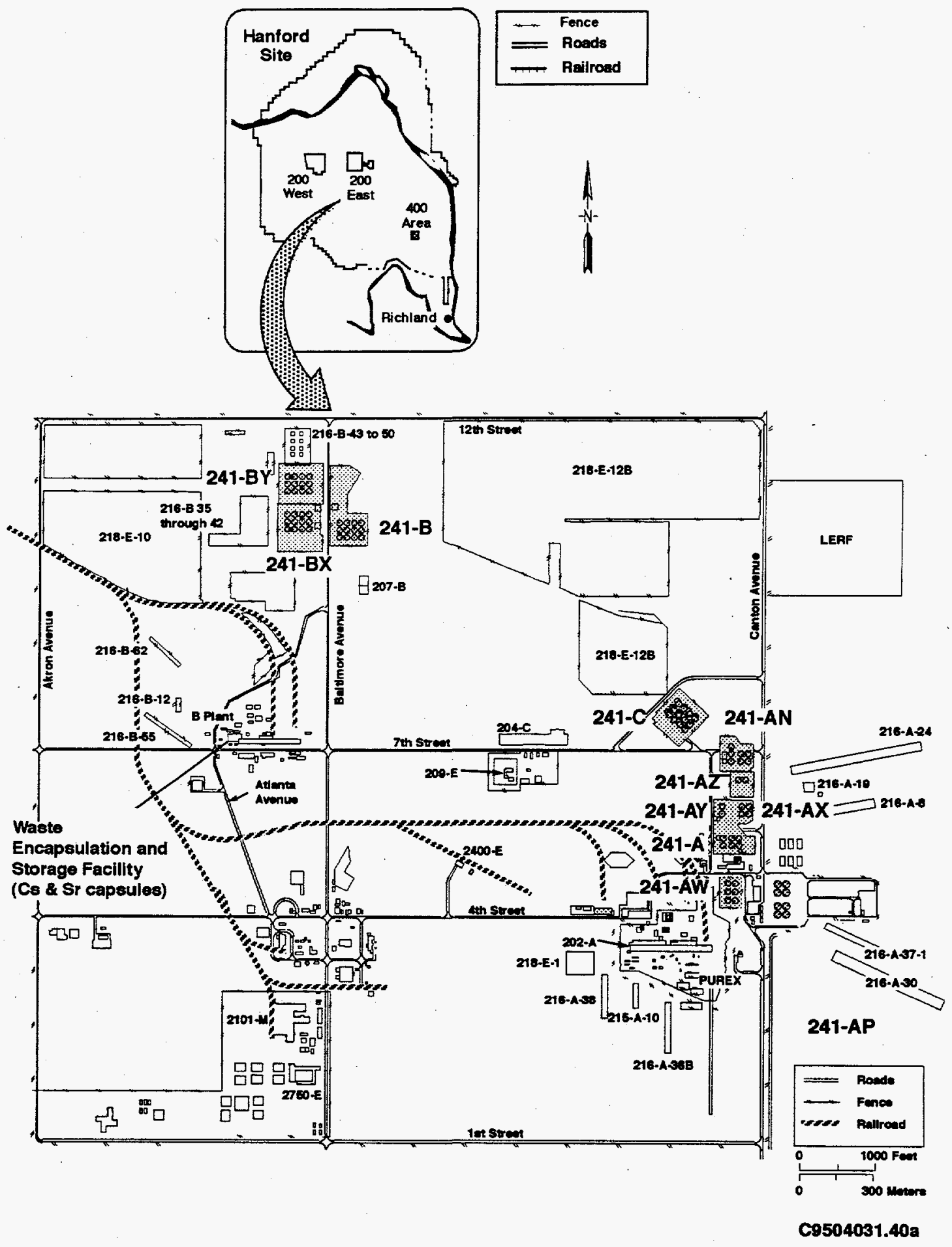

Figure A.4. 200 East Area Map 


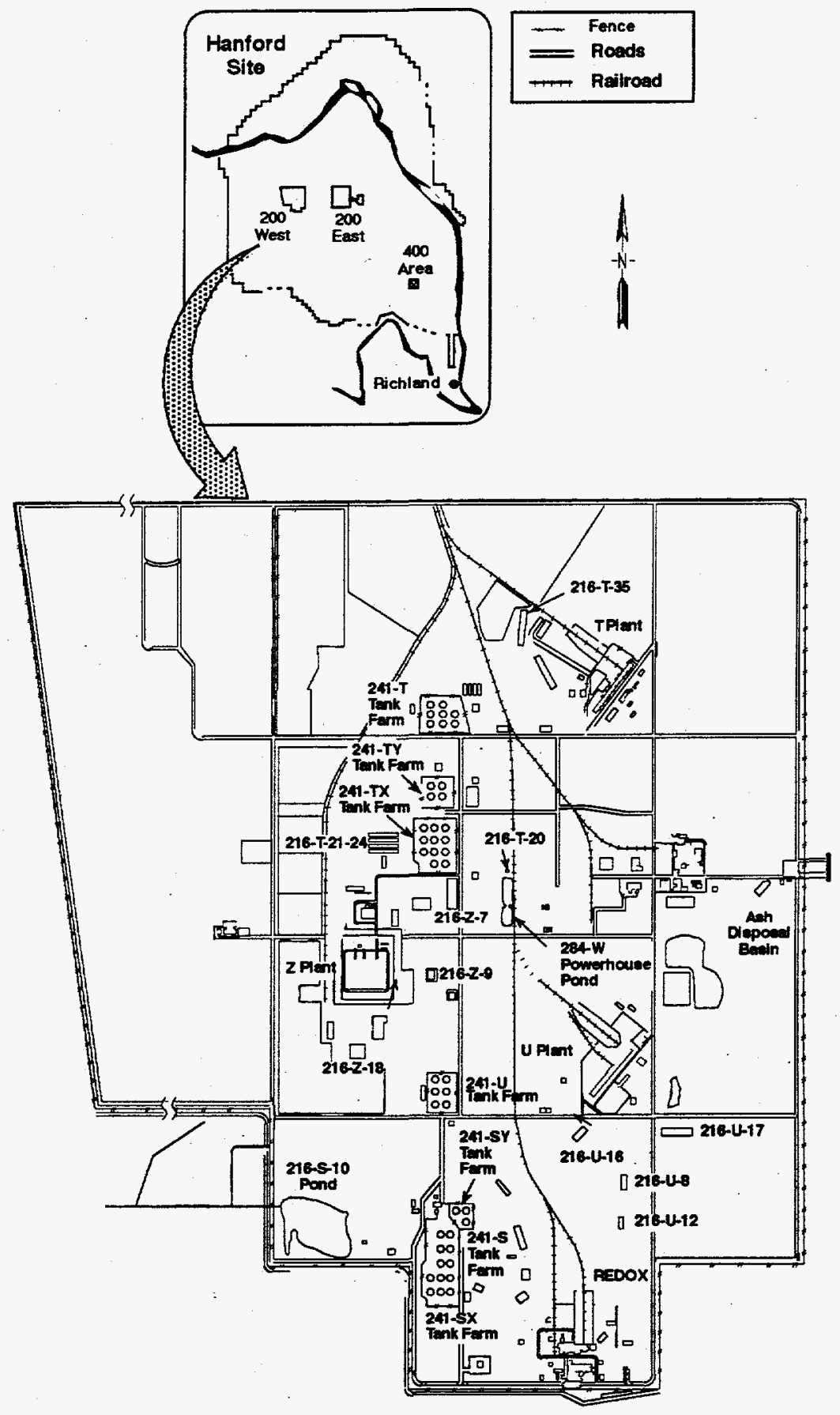

C9504031.37a

Figure A.5. 200 West Area Map 


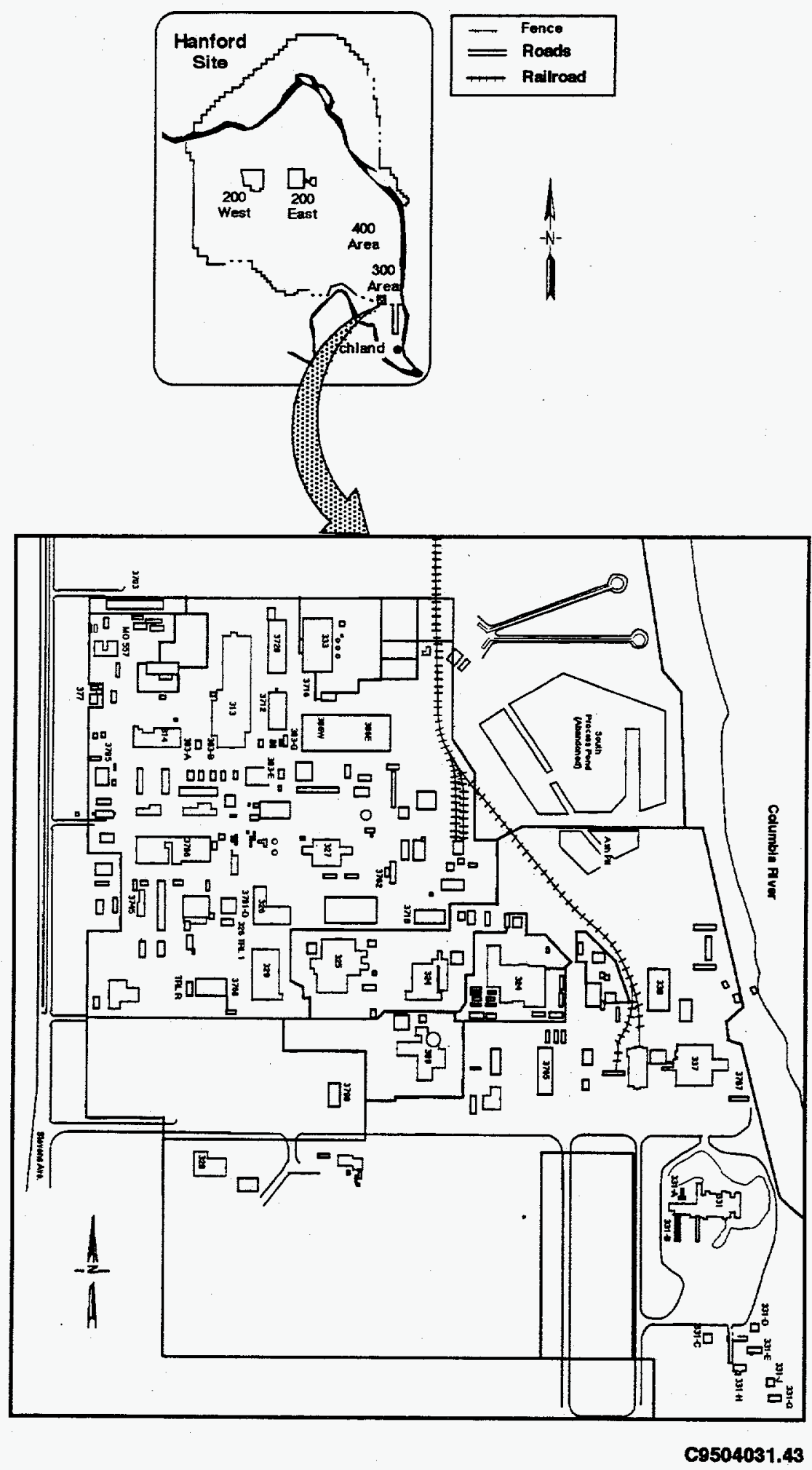

Figure A.6. 300 Area Map 


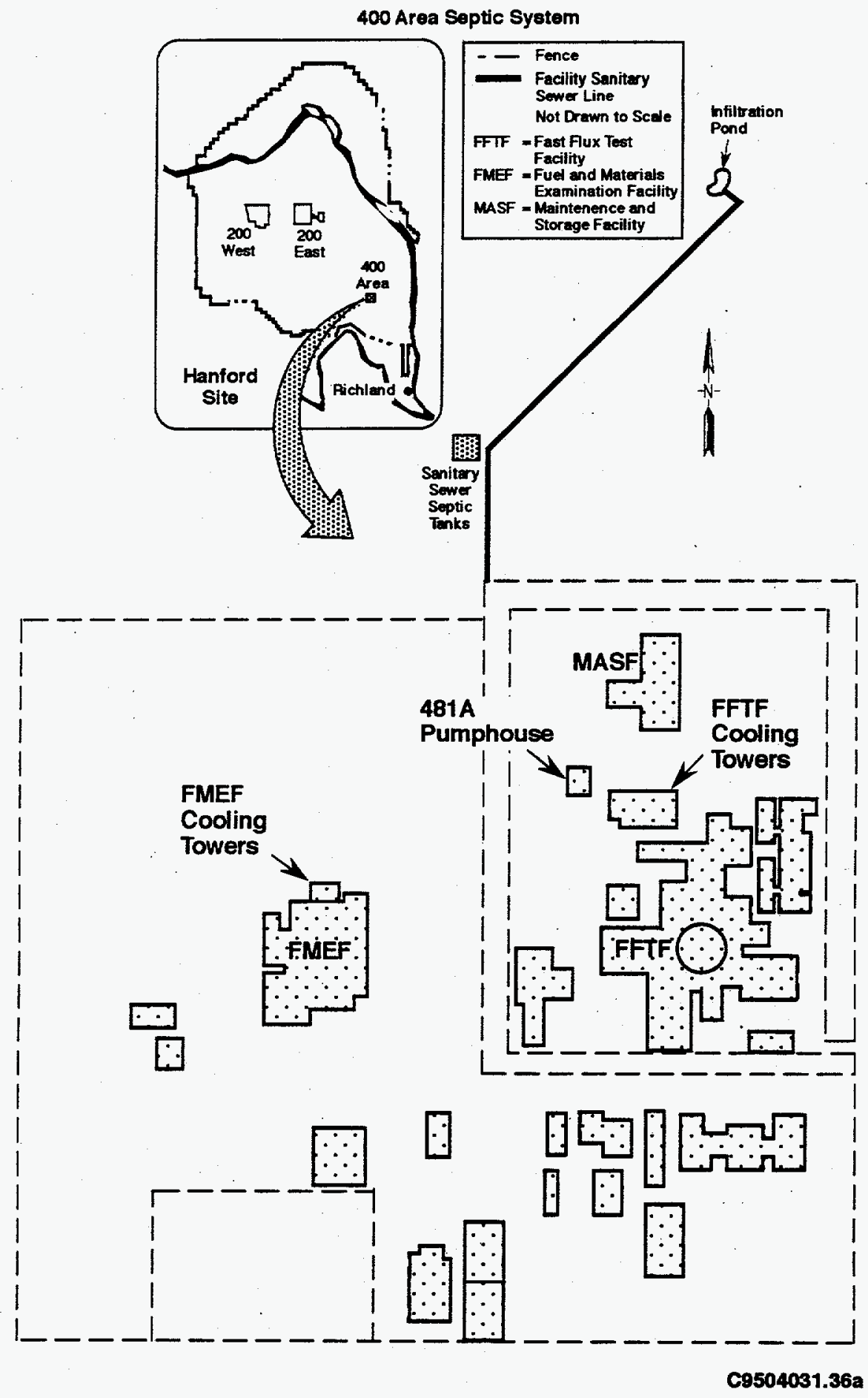

Figure A.7. 400 Area Map 


\section{A.3 Hazard Sources}

The hazard sources on the Hanford Site have been aggregated into five general categories. They are:

- Nuclear materials including unirradiated uranium, irradiated fuel, special nuclear material (e.g. plutonium and small quantities of enriched uranium), cesium and strontium capsules.

- Liquid waste including tank waste, $\mathrm{K}$ and $\mathrm{N}$ Basin water, and liquid effluents.

- Solid waste including pre-1970 unsegregated, post-1970 retrievably-stored transuranic waste, stored waste, buried low-level radioactive waste, low-level mixed waste, and newly-generated waste.

- Environmental contamination including solid waste sites, liquid waste sites (cribs, ponds, ditches), contaminated soil under tanks, and contaminated groundwater.

- $\quad$ Facilities include two general categories, nuclear and nonnuclear. Nuclear facilities include reactors, fuel fabrication facilities, fuel reprocessing plants, hot laboratories, tanks, and basins. Nonnuclear facilities include steam plants, maintenance shops, and office buildings.

Sections A.3.1 through A.3.5 provide summary discussions and selected illustrations of the hazard sources currently on the Hanford Site.

\section{A.3.1 Nuclear Materials}

Nuclear materials generally consist of discrete packages of separated radionuclides currently stored on-site. These materials include spent nuclear fuels, special nuclear materials, encapsulated cesium and strontium, and inventories of non-irradiated uranium that are located in a variety of facilities in the $100,200,300$, and 400 Areas. The material generally represents the most concentrated forms of radionuclides on-site. Combined with the relatively unstable or dispersable chemical form of a portion of the inventory, this material presents the primary risks of near-term releases. Storage in facilities that are currently 25 to 50 years old result in maintaining relatively high-cost administrative and physical systems to control the materials to present standards. Figure A.8 is a photograph of one of the Waste Encapsulation and Storage Facility pool cells where the cesium and strontium capsules are stored. Figure A.9 is a fact sheet on the $\mathrm{N}$ fuel and the $\mathrm{K}$ Basins.

\section{A.3.2 Liquid Waste}

Liquid waste is currently stored in the 100 Area $\mathrm{K}$ and $\mathrm{N}$ Basins and in the 200 Areas tank farms. The liquid waste in the $\mathrm{K}$ Basins has leaked to the environment in the past and, under accident conditions, the liquid waste could be released and spread throughout the environment. The liquid waste in the 200 Area tank farms has also leaked to the environment in the past, and is likely to leak in the future due to continued deterioration of the tanks. In addition, significant safety issues have been identified for several of the tanks. 


\section{Cesium and Strontium Capsules}

- WESF Constructed in 1976

- Capsules filled between 1976 and 1985

- 1577 total Cs capsules - 245 offsite, won't be returned

- 640 total Sr capsules

- 4 offsite, won't be returned

- As of 12/31/93

Cs - $106 \mathrm{MCi}$

$245 \mathrm{~K}$ watts

$\mathrm{Sr}-47 \mathrm{MCi}$

$152 \mathrm{~K}$ watts

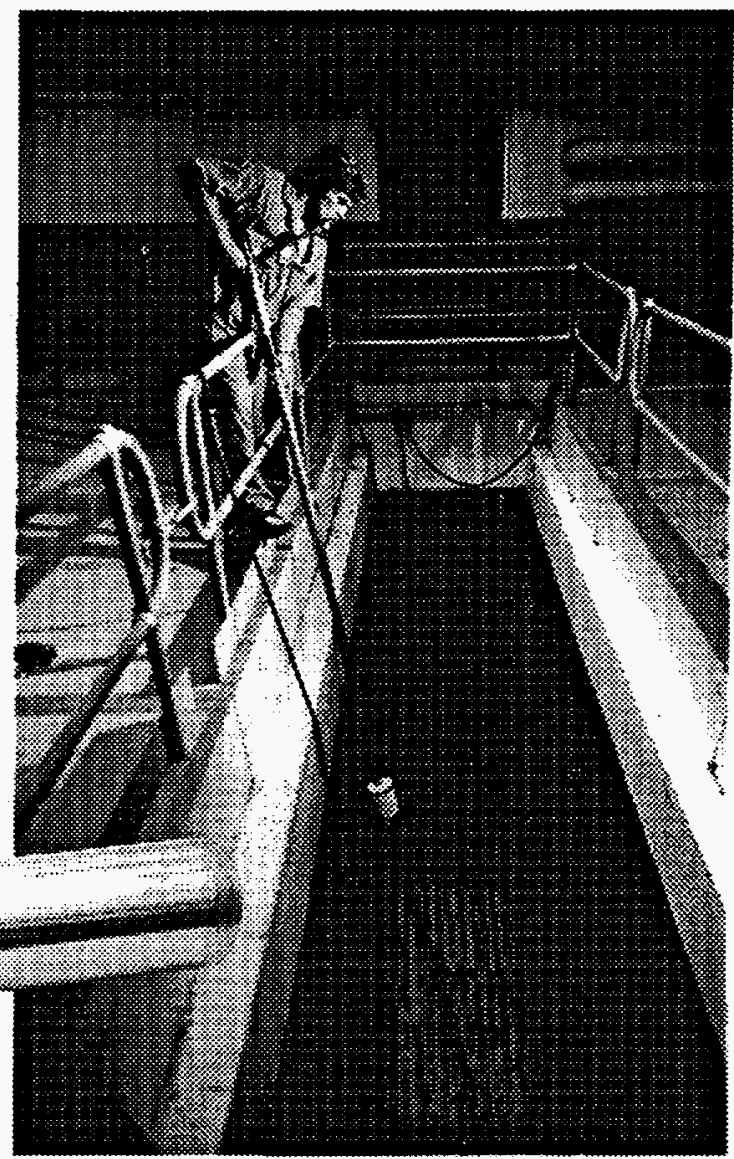

7942008.15b

Figure A.8. Waste Encapsulation and Storage Facility Pool Cells 


\section{K-Basins Today}
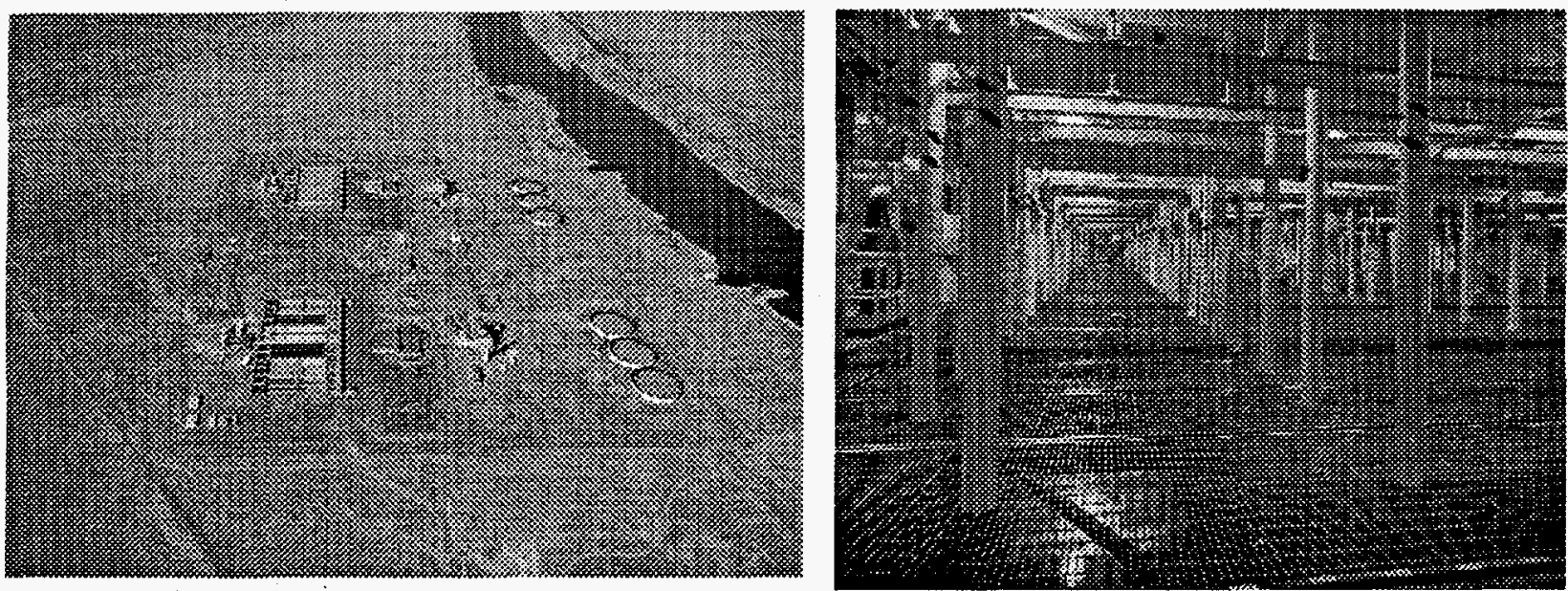

The K-Basins, located near the Columbia River in the 100K Area of the Hanford Site, were built in the 1950s. Long term storage of fuel in the K-Basins was never intended and the basins lack earthquake resitance and safety features required of modern facilities.

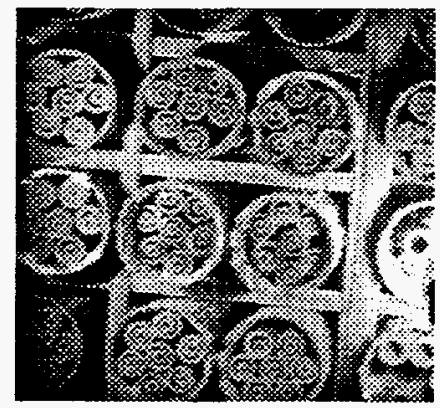

There are two K-Basins, providing underwater storage of $\mathbf{2 1 0 0}$ tons of spent nuclear fuel, some for which has been stored there for 20 years. Much of the fuel is damaged or corroding.

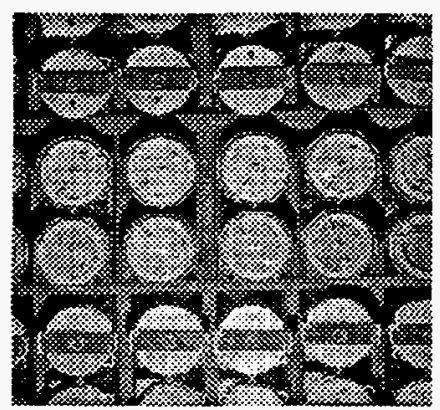

The fuel in the K-Basins is housed in metal canisters. Those in the K-East Basin are open canisters, allowing radioactivity release from the corroding fuel to contaminate the surrounding basin water. The K-West canisters, of later design, are closed, providing better confinement.

Figure A.9. Fact Sheet on the N Fuel Currently Stored in the K Basins 
Highly radioactive liquid wastes have been stored in large underground storage tanks at Hanford since 1943. Approximately 212,000 cubic meters ( 56 million gallons) of waste are currently stored in 177 tanks, including 149 single-shell tanks and 28 double-shell tanks.

The radioactive waste in these tanks has come from various sources: (1) plutonium and uranium recovery processing of approximately $100,000 \mathrm{Mtu}$ of irradiated fuel, (2) radionuclide recovery processing of tank waste, and (3) miscellaneous sources (e.g., laboratories and reactor decontamination solutions). The caustic wastes consist of many different chemicals and waste forms including liquids, slurries, salt cake, and sludge. The waste contains sodium nitrate and nitrite, sodium hydroxide, sodium aluminate, sodium phosphate, large amounts of organic materials, and approximately $208 \mathrm{MCi}$ of various radioactive isotopes as of 12/31/93 (reference, Integrated Database Report, Rev. 10 Oakridge RW-006, December 1994).

The singe-shell tanks, first placed in service in 1943, are reinforced-concrete tanks with carbon steel liners. The single-shell tanks have capacities ranging from 208 cubic meters $(55,000$ gallons) to 3785 cubic meters ( 1 million gallons). Sixty-eight of the single-shell tanks have leaked or are suspected of leaking approximately $3785 \mathrm{~m}^{3}$ (1 million gallons) to the surrounding soil. Unless the contaminated soils are remediated, they may be a dominant contributor to long-term releases. The pumpable liquids have been removed from many of the single-shell tanks so that the remaining waste is primarily sludge and salt cake.

The double-shell tanks, first placed in service in 1971, consist of a carbon steel primary tank, an annular space, and a secondary steel tank encased in concrete. The double-shell tanks have a nominal capacity of 3785 cubic meters (1 million gallons). No evidence exists that any of the double-shell tanks have leaked.

Figure A.10 is a schematic of the 200 Area tank farms (notice the large amount of underground transfer lines). This version was obtained from the Waste Tank Summary Report for Month Ending February 28, 1995 (Hanlon 1995). This is a report that is updated on a monthly basis. Figure A.11 is a fact sheet on the single-shell and double-shell tanks.

\section{A.3.3 Solid Waste}

Solid wastes have been placed in excavated trenches and caissons in the 100,200,300, and 600 Areas. Prior to 1970 all waste was disposed on-site in un-lined trenches without being segregated. After 1970 solid wastes were segregated into transuranic and non-transuranic portions. The transuranic wastes were stored in a retrievable manner and the non-transuranic wastes (i.e., low-level radioactive wastes) were disposed in unlined trenches. In 1987, the Hanford Site stopped disposing of low-level radioactive waste that is contaminated with dangerous waste constituents (i.e., mixed waste) and began storing it in above-ground facilities. 


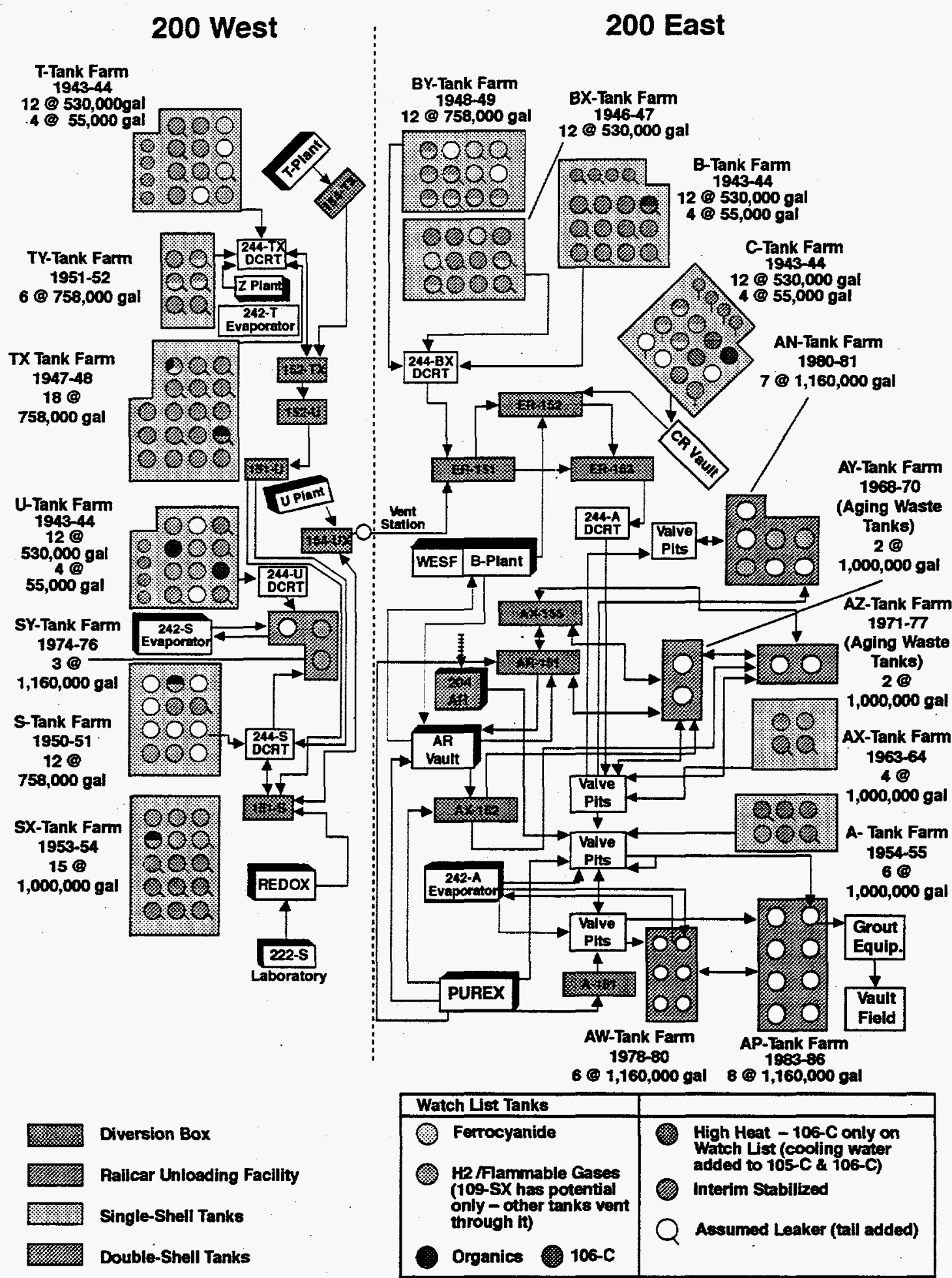

29111004.1C

Figure A.10. Tank Farm Descriptions 


\section{Single-Shell Tanks}

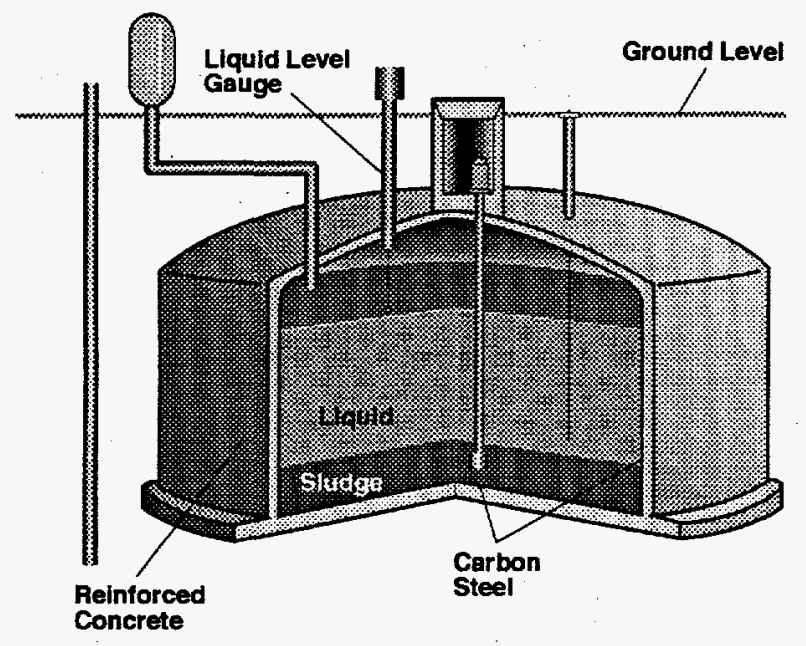

- 149 Tanks Constructed 1943-64

- $-210 \mathrm{~m}^{3}$ to $3,800 \mathrm{~m}^{3}$ Capacity (55 kgal to $1 \mathrm{Mgal}$ )

- Bottom of Tanks at Least $50 \mathrm{~m}$ (150 Feet)Above Groundwater

- No Waste Added to Tanks Since 1980

- Tanks Currently Contain:

$\sim 136,800 \mathrm{~m}^{3}$ (36 Mgal) of Salt Cake, Sludge, and Liquid

$-460 \times 10^{16} \mathrm{~Bq}(124 \mathrm{MCi})$ (12/31/93 Basis)

- 68 Have Leaked $\sim 3,800 \mathrm{~m}^{3}$ ( $\left.-1 \mathrm{Mgal}\right)$

\section{Double-Shell Tanks}

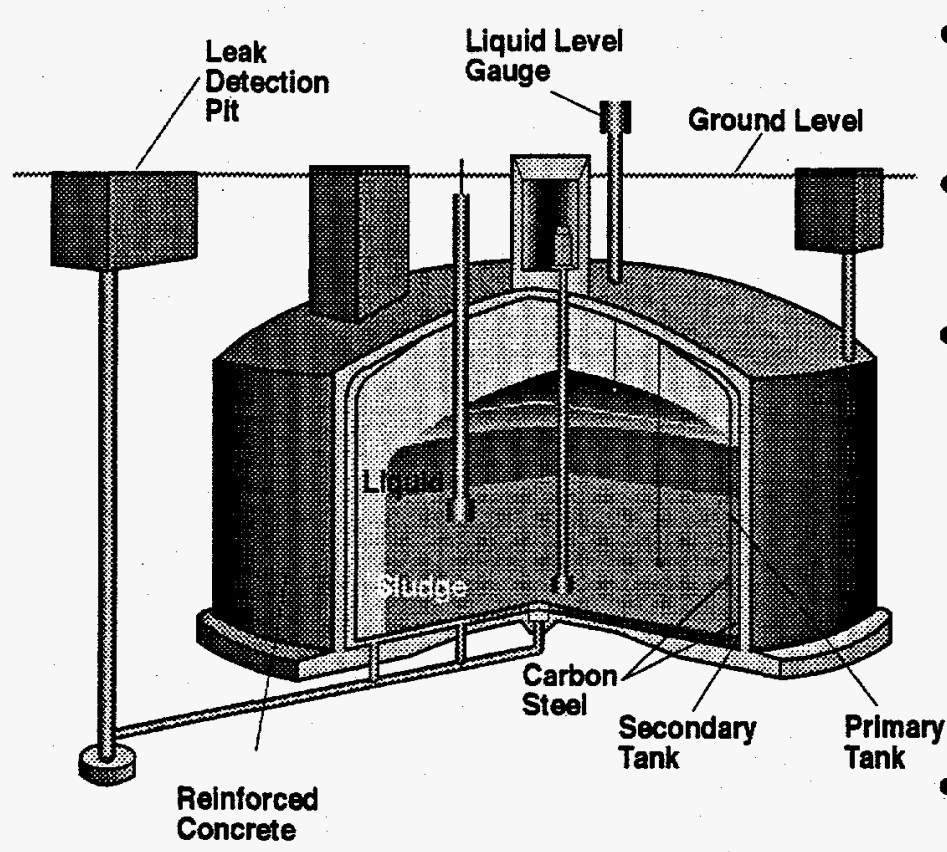

- 28 Tanks Constructed Between 1968-86

- $\sim 3,800 \mathrm{~m}^{3}$ to $4,300 \mathrm{~m}^{3}$

(1 to 1.14 Mgal) Capacity

- Tanks Currently Contain

$\sim 80,000 \mathrm{~m}^{3}$ (21 Mgal) of Mostly Liquids (Also Sludges and Salts)

$\sim 300 \times 10^{16} \mathrm{~Bq}$ (84 MCi) (12/31/93 Basis)

- None Has Leaked

Figure A.11. Single- and Double-Shell Tanks Fact Sheet 
Low-level radioactive solid wastes continue to be disposed in shallow trenches on the Hanford Site. Solid waste materials other than low-level radioactive wastes are stored as discrete packages (e.g., 210-Liter drums) in buildings that have been specifically constructed for storage or that have been adapted for storage by retrofitting. The storage facilities are primarily located in the 200 Areas and are generally of recent construction. Additional solid waste will continue to be generated by ongoing Site surveillance and maintenance activities and new cleanup actions. The solid waste primarily consists of inert materials contaminated with small quantities of radionuclides, hazardous chemicals, or both. The inert materials that become waste vary across a wide range of inorganic and organic material types (e.g., metals, paper, plastic, cloth, rubber, soil, biological solids, and structural material). The material does not generally represent a large risk to the public due to the low concentration of contaminants; however, when the large mass of waste is combined with the low-contaminant concentration, significant total quantities of radionuclides and hazardous chemicals are estimated to be stored in solid waste. Figure A.12 is a photograph of one of the solid waste disposal trenches.

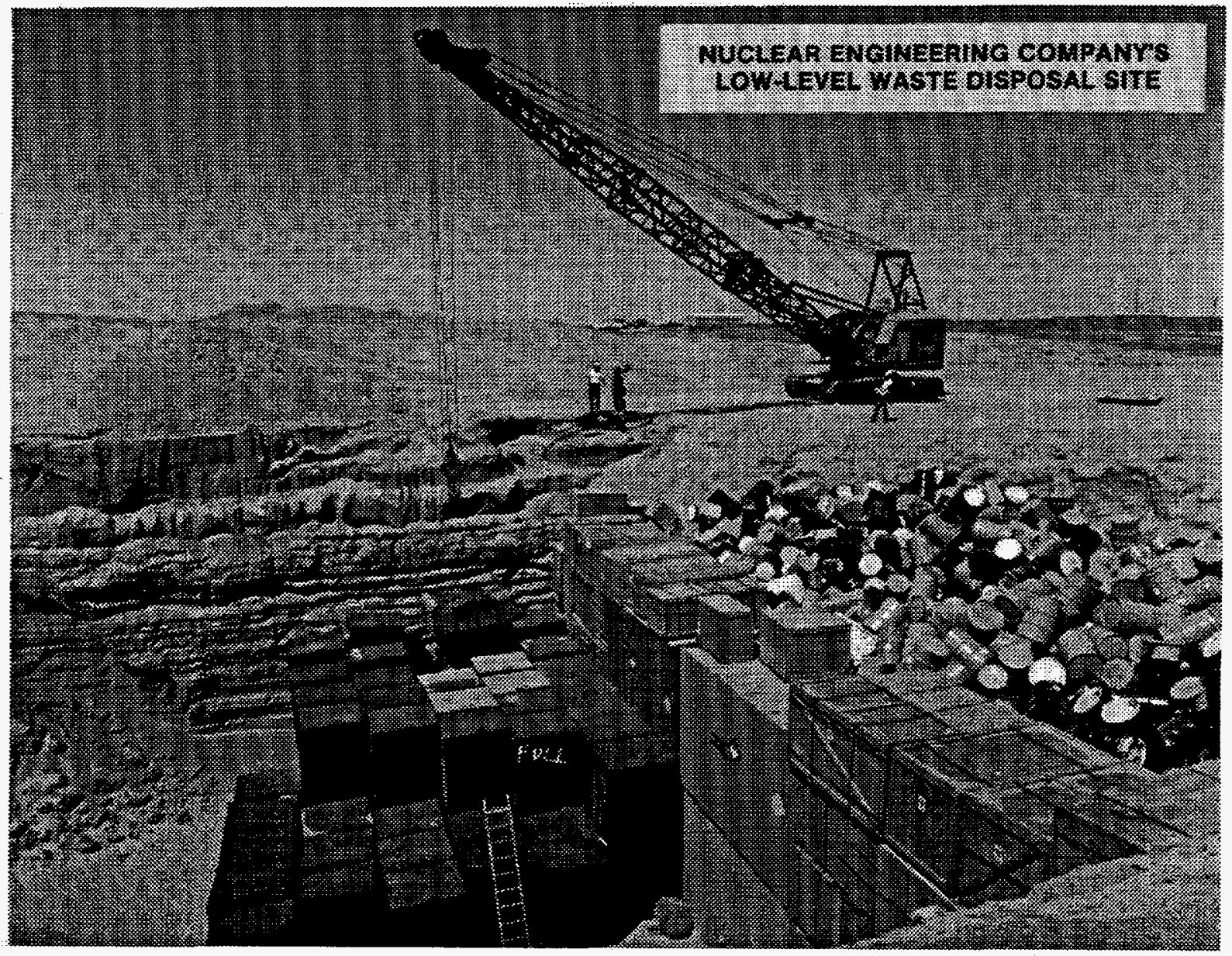

Co504031.32

Figure A.12. Photograph of a Solid Waste Disposal Trench 


\section{A.3.4 Environmental Contamination}

Environmental contamination is the result of past discharges (intentional and accidental) of liquid and solid wastes. Contaminants have reached the soil, groundwater, and the Columbia River. Direct discharges of liquid to the soil has been greatly reduced in the past five years. Figure A.13 is a photograph of one of the solid waste disposal sites that required remediation.

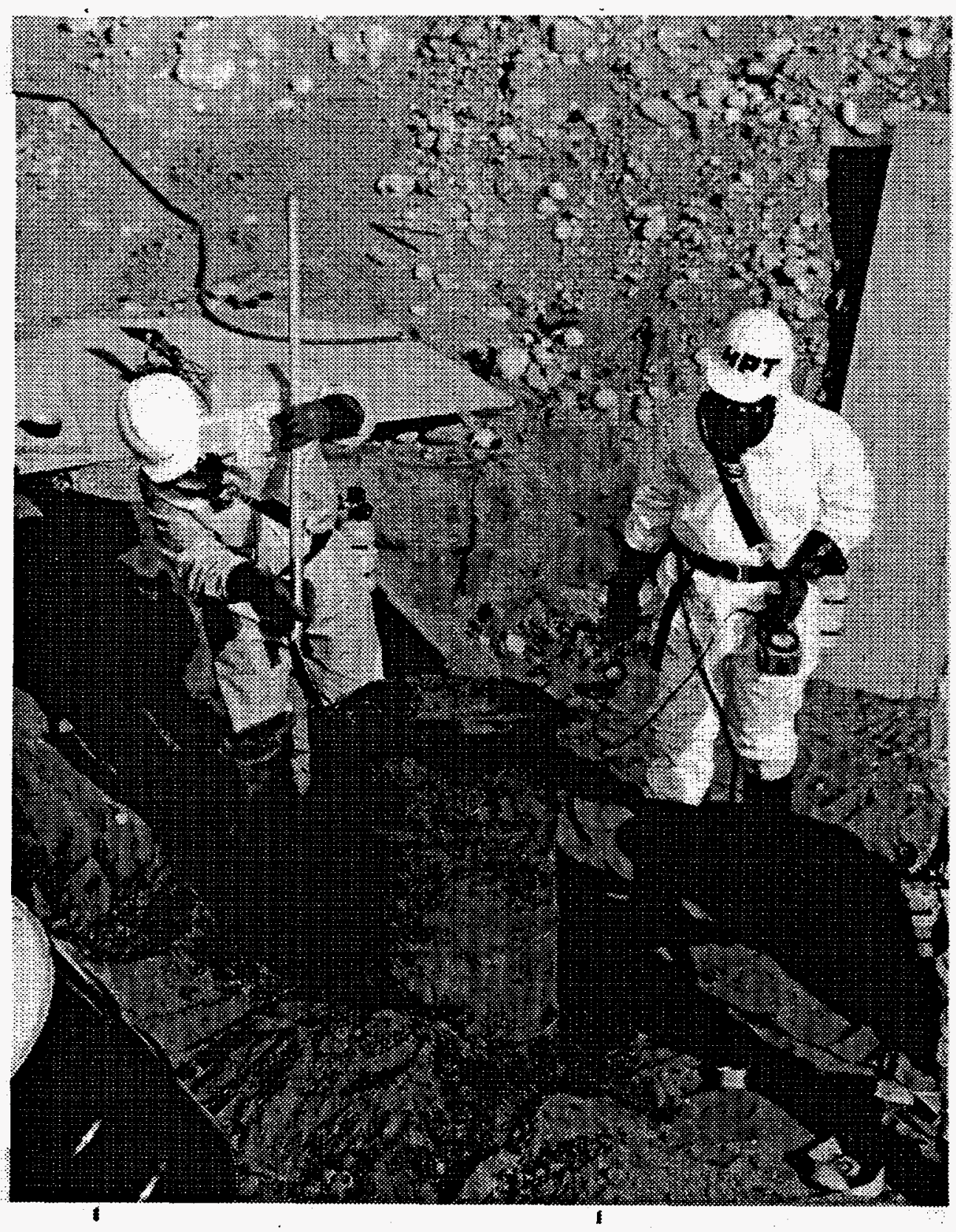

Figure A.13. Photograph of an Environmental Contamination Site 


\section{A.3.5 Facilities}

The facilities include the nine reactors in the 100 Areas, six fuel re-processing facilities in the 200 Areas, miscellaneous fuel fabrication and hot cell facilities in the 300 Area, and the Fast Flux Test Facility in the 400 Area. The facilities also include the nonnuclear support facilities (e.g., steam plants, maintenance shops, office buildings).

Figure A.14 is a cut-away view of a typical 100 Area reactor. Figure A.15 is a photograph of a typical canyon facility (B Plant) and Figure A.16 is a cut-away view of the B Plant Canyon.

Figure A.17 is a photograph of the Fuels and Materials Examination Facility and Fast Flux Test Facility.

\section{A.4 Reference}

Hanlon, B.M., 1995, Waste Tank Summary Report for Month Ending February 28, 1995,

WHC-EP-0182-83, Westinghouse Hanford Company, Richland, Washington.

December 1994, Integrated Database Report, Rev. 10, Oakridge RW-006.

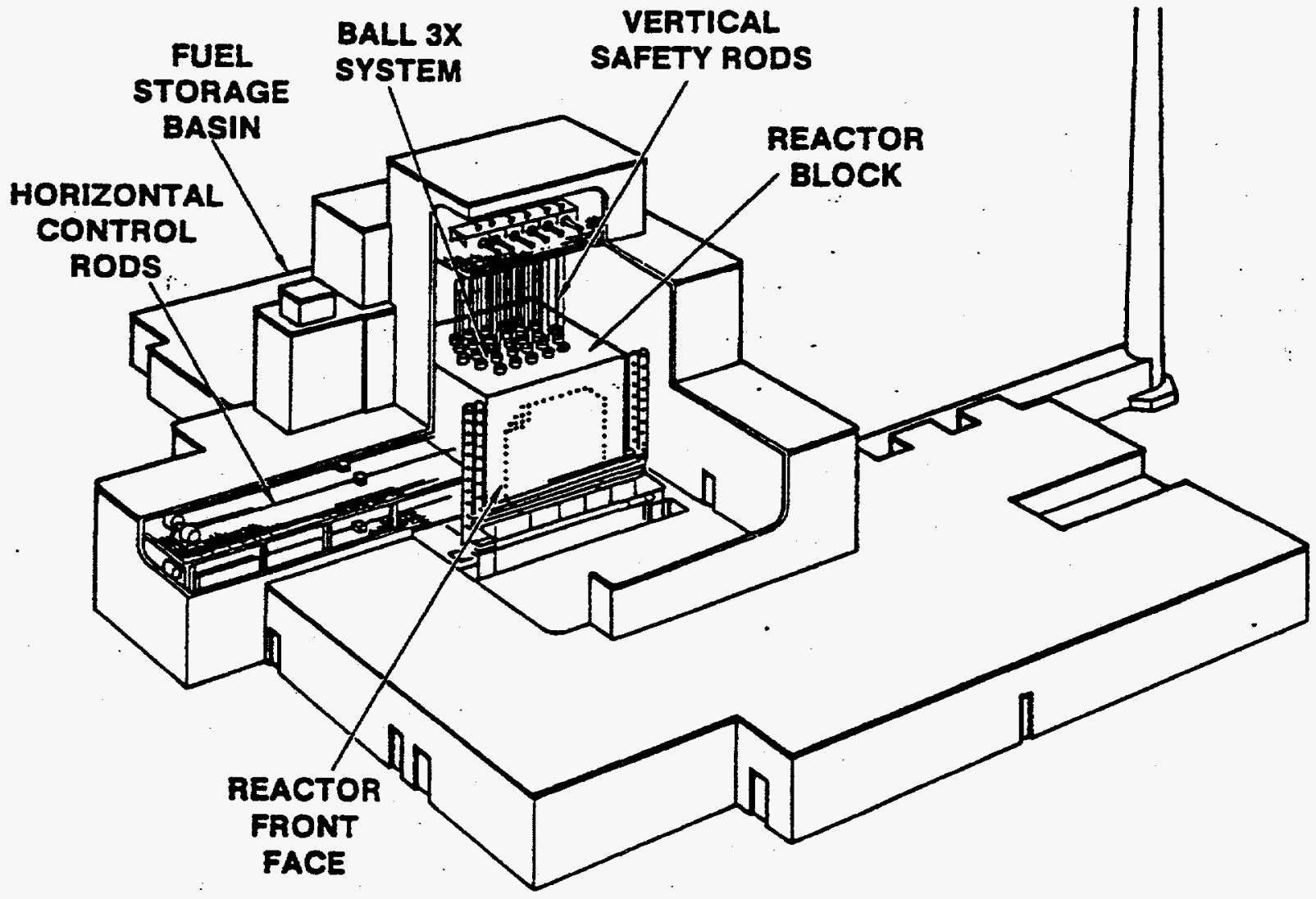

Figure A.14. 100 Area Reactor Cutaway 


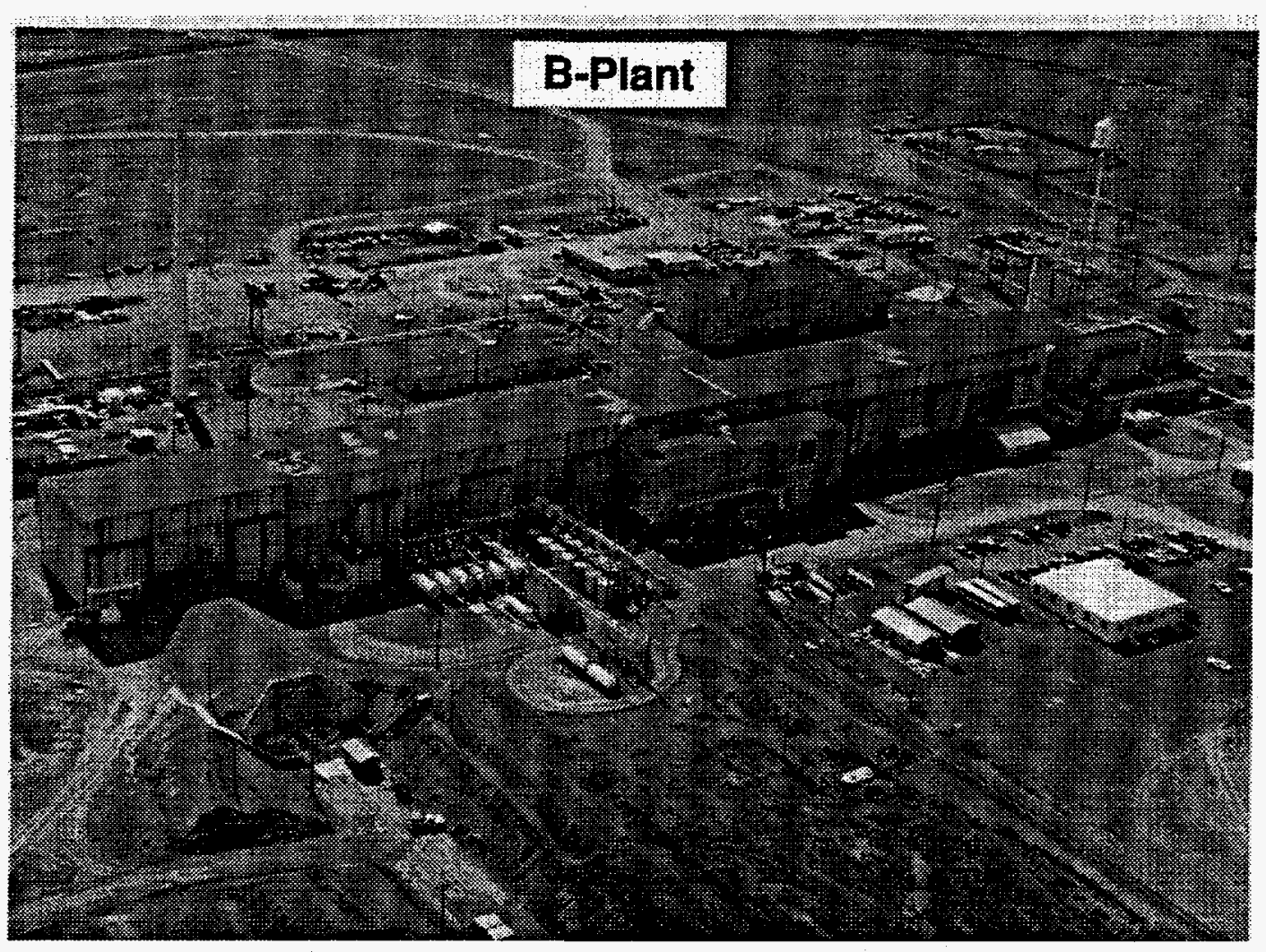

Figure A.15. Photograph of B Plant

\section{1-B Canyon Building}

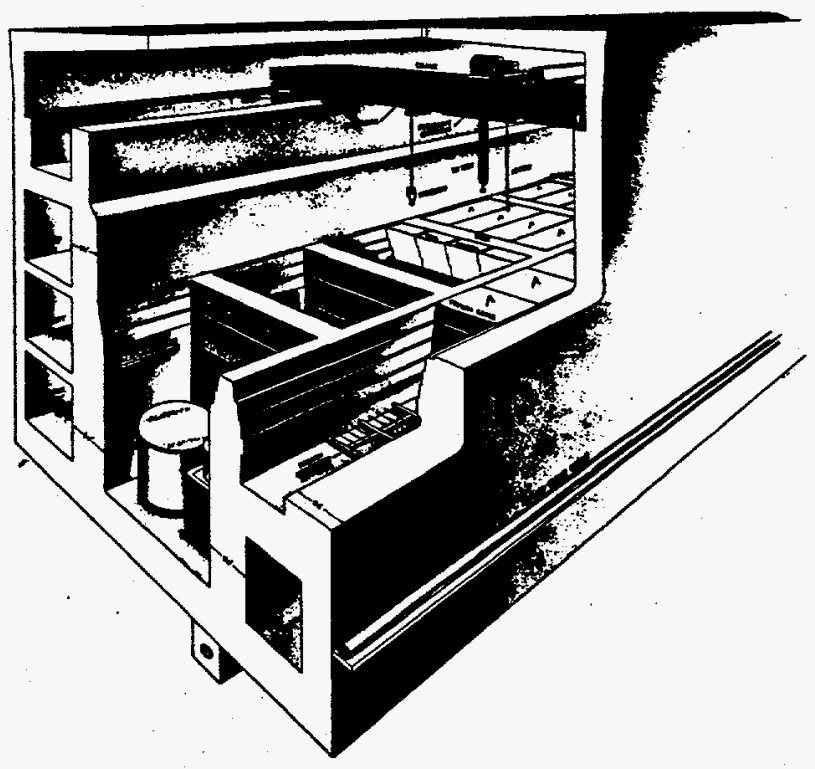

Figure A.16. Cutaway of the 221-B Canyon Building (B Plant) 


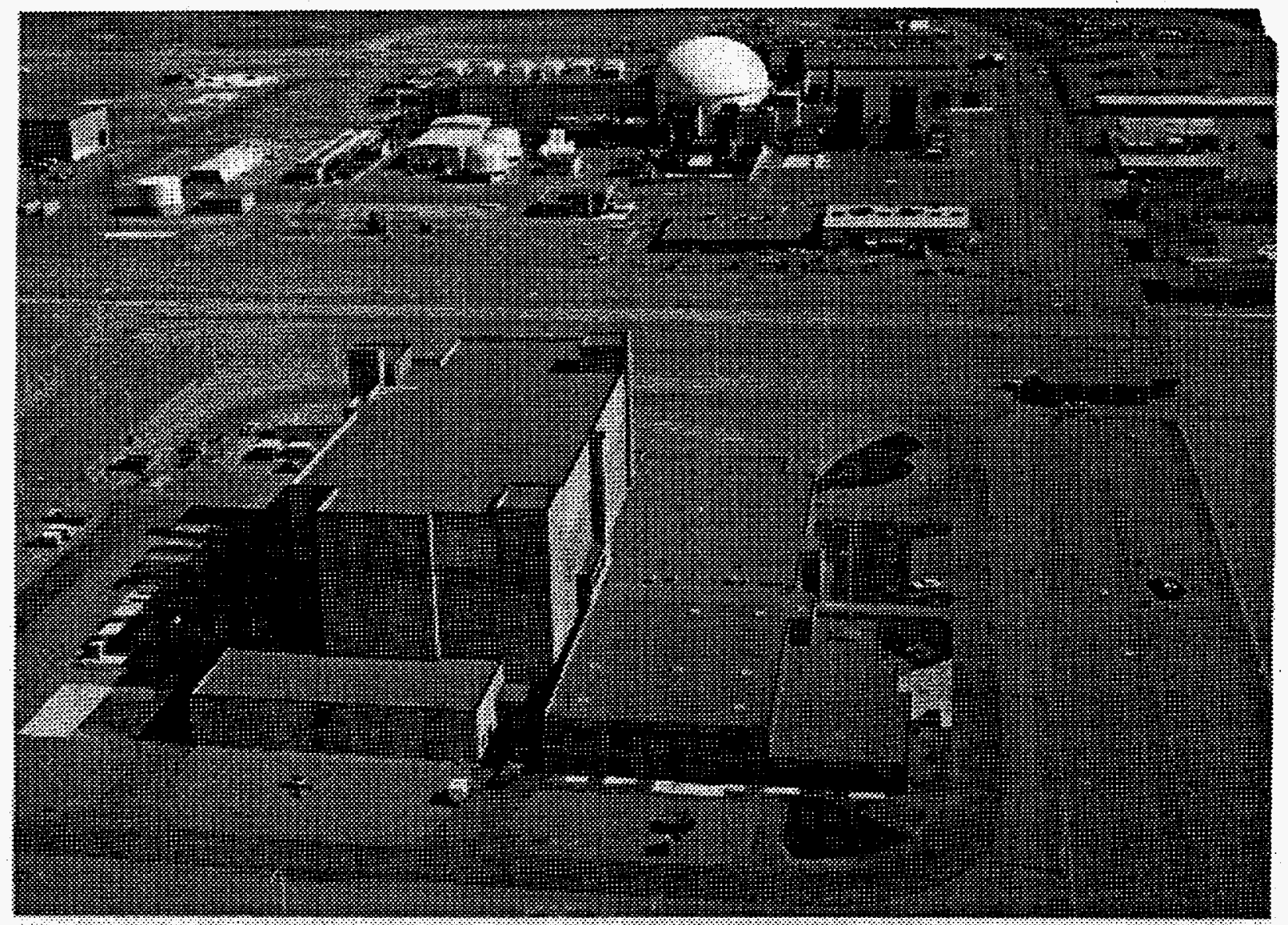

Co504031.33

Figure A.17. Photograph of the 400 Area Facilities 


\section{Appendix B}

\section{Detailed Description of Objectives}




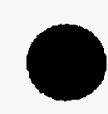

-

○ 


\section{Contents}

\section{Appendix B - Detailed Description of Objectives}

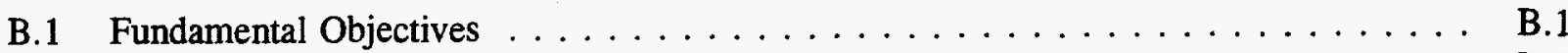

B.1.1 Minimize Environmental, Safety, and Health Risks . . . . . . . . . . B.3

B.1.2 Maximize Land-Use Potential $\ldots \ldots \ldots \ldots \ldots \ldots \ldots \ldots \ldots \ldots$

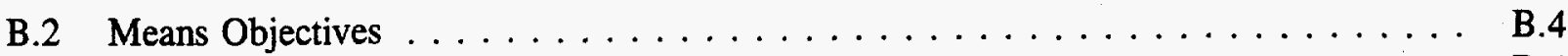

B.2.1 Maximize Progress . . . . . . . . . . . . . . . . . . . . . . .

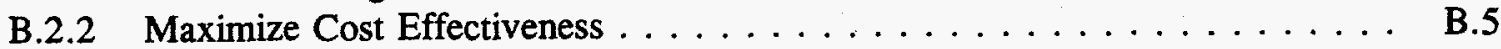

B.2.3 Maximize Likelihood of Success $\ldots \ldots \ldots \ldots \ldots \ldots \ldots \ldots \ldots \ldots$

B.2.4 Maximize Stakeholder Confidence $\ldots \ldots \ldots \ldots \ldots \ldots \ldots$. . . . . . .

B.3 References $\ldots \ldots \ldots \ldots \ldots \ldots \ldots \ldots \ldots \ldots \ldots \ldots \ldots \ldots$

Attachment B1 Revised Priority Grid $\ldots \ldots \ldots \ldots \ldots \ldots \ldots \ldots \ldots \ldots$

Figures

B.1 Objectives and Associated Criteria $\ldots \ldots \ldots \ldots \ldots \ldots \ldots \ldots \ldots \ldots$ 


\section{Appendix B}

\section{Detailed Description of Objectives}

The Fiscal Year 1995 Hanford Mission Plan: Site Guidance (RL 1994a) contains Site mission statements, strategic goals, and endstate goals. Previous documents, including the Hanford Strategic Plan (1994b), the Environmental Restoration and Waste Management Fiscal Year 1993 Site Specific Plan for the Richland Field Office (RL 1993), and RL (1994a) contain strategic objectives, as well. Cleanup objectives are also incorporated into the Revised Priority Planning Grid (Attachment B1), which was used to help prioritize cleanup activities for the fiscal year 1997 Activity Data Sheets submission.These documents were reviewed to derive a new set of objectives specifically focused on the cleanup mission. These objectives reflect stakeholder values and concerns, which have been published in such documents as The Future for Hanford: Uses and Cleanup (Working Group 1992) and the Tank Waste Task Force.

Figure B.1 shows the new set of objectives and associated criteria. Note that stakeholder values are reflected throughout the figure, not just under the objective of Maximize Stakeholder Confidence. The numbers on the objectives and criteria are weights assigned to those objectives by the U.S. Department of Energy (DOE) Richland Operations Office senior managers during a value-elicitation session on December 5, 1994. The weights were used to determine the order in which activities would be executed for two of the strategic alternatives: Baseline Extended Strategy and Composite Strategy. These weights were originally incorporated into the Revised Priority Planning Grid (Attachment B1). Of the 1745 possible points in the grid, these objectives account for 1670 of them. The remainder of the points are associated with other objectives not reflected in Figure B.1 (e.g., science and technology). The shaded boxes on the figure represent criteria for which insufficient data were available. These criteria were not used in the comparison of strategic alternatives.

\section{B.1 Fundamental Objectives}

Two objectives were considered the "products" of any cleanup strategy: (1) reduce risk and (2) make land available for other uses. These two fundamental objectives are shown in Figure B.1 as Minimize Environmental, Safety and Public Health Risks and Maximize Land Use Potential. These objective are discussed in this section. The other objectives shown in the figure are "Means" objectives and are discussed in Section B.2. 


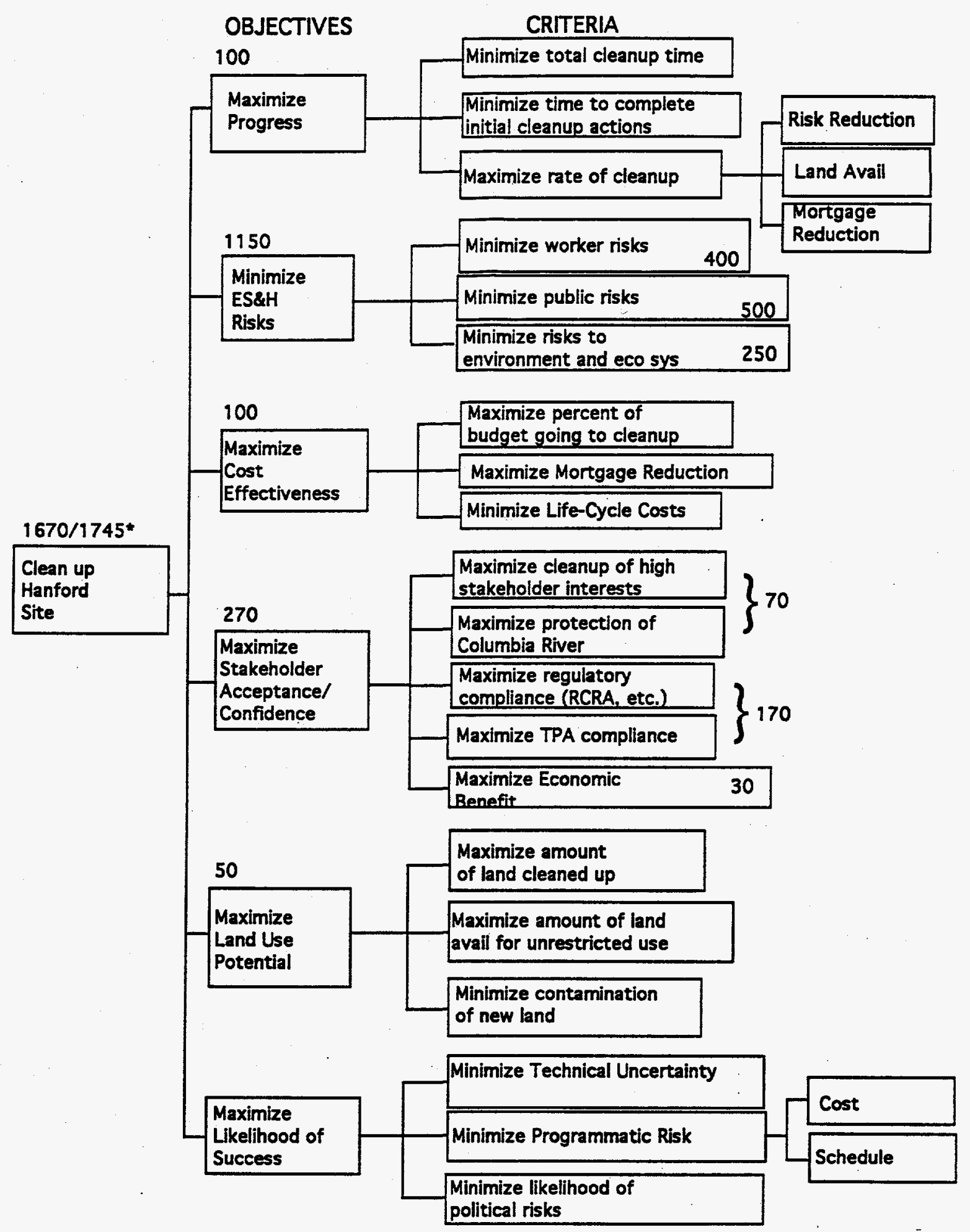

Figure B.1. Objectives and Associated Criteria

B.2 


\section{B.1.1 Minimize Environmental, Safety, and Health Risks}

The principal objectives in this area are to: (1) reduce the existing Hanford Site risks to acceptable levels for the public, the workers, and the environment, and (2) not injure the ecosystem or cultural resources more than is necessary to reduce the existing Hanford Site risks to acceptable levels. These principal objectives are separated into three sub-objectives, as follows.

- Minimize Public Health Risks. Risks to the public involve exposure to radiological and chemical hazards through various pathways. The risks vary over time based on several factors (e.g., waste form, condition of barriers, quantity and toxicity of hazardous materials, radionuclides half-life).

Metrics: latent cancer deaths, radiological exposure in rem, acute event likelihood.

- Minimize Worker Risks. Risks to workers involve direct exposure to radiological and chemical hazards while performing work, as well as other more familiar industrial hazards (e.g., electrocution, tripping, falling). The risks will vary over time based on several factors (e.g., how often radionuclides and chemicals are handled, the condition of the facilities and infrastructure, process designs, the work culture).

Metrics: lost workdays, worker exposure in rem, worker deaths.

- Minimize Environmental and Ecosystem Risk. Risks to the environment and ecosystem involve spread of radionuclides and chemicals through the air, surface water, soil, and groundwater. Risks vary over time based on several factors (e.g., waste form, condition of barriers, quantity, and toxicity of hazardous materials, radionuclide half-life). Risks to the ecosystem and cultural resources involve disruption of natural habitat for flora and fauna. The risk of further injuring the ecosystem will primarily occur during remediation activities.

Metrics: area of land disturbed and area of land contaminated.

\section{B.1.2 Maximize Land-Use Potential}

The principal objective is to provide benefit to society by making the Hanford Site available for other uses. This was divided into three sub-objectives as follows.

- Maximize Amount of Land Cleaned Up. The Hanford Site will be cleaned up when the hazardous materials have been either exhumed and disposed or disposed in-place. The cleanup will proceed in a manner that will cleanup the largest possible land area.

Metrics: area of land cleaned up (square miles). 
- Maximize Amount of Land Available for Unrestricted Uses. When the land has been restored and determined to be clean, DOE could make it available for other uses.

Metrics: area of land available for unrestricted surface use, groundwater use.

- Minimize Contamination of Clean Land (Criterion Not Used). The cleanup actions should not contaminate existing clean land to the point that it cannot be made available for other uses and user groups.

Metrics: area of clean land disturbed by the cleanup actions (square miles).

\section{B.2 Means Objectives}

These objectives are not fundamental objectives, but rather, they are means to achieving the fundamental objectives of reducing Hanford Site risk and making land available.

\section{B.2.1 Maximize Progress}

Progress on Site cleanup must be demonstrated. Progress can be defined by the amount of risk reduction and land released for non-DOE uses, as well as the rate at which those actions occur. Progress also includes the concept of schedule; earlier is better, especially for high-value activities. The objectives in this area are as follows.

- Minimize Time to Complete the Cleanup Mission. The cleanup mission is complete when the only waste management activities remaining are those for post-closure monitoring.

Metrics: time when majority of cleanup activities are completed (not including reactors).

- Minimize Time to Complete Initial Cleanup Activities. Specific cleanup actions must be completed as quickly and as safely as possible to demonstrate early progress.

Metrics: time to complete specific cleanup actions (Plutonium Finishing Plant, tank disposal, PUREX transition, and Waste Encapsulation and Storage Facility deactivation).

- Maximize Rate of Cleanup (Criteria not used). Specific cleanup actions must be completed as quickly as possible to demonstrate early progress.

- Maximize Rate of Risk Reduction. One of the keys to cleaning up the Site is reducing the inherent risks to acceptable levels consistent with the planned land use. 
- Maximize Rate of Mortgage Reduction. One way to make progress and make additional funding available for further cleanup is to reduce the mortgage costs associated with managing the hazardous materials in its existing state. This can be done by transitioning the hazards into safe, stable, long-term, minimum-cost conditions.

- Maximize Rate of Land Release. One of the keys to cleaning up the Site is releasing the land for other uses. Progress can be measured by the rate at which land is released.

\section{B.2.2 Maximize Cost Effectiveness}

Cost effectiveness is reflected in the amount of funding actually used for cleanup activities, as well as total costs over all. Cost effectiveness can also be improved by measuring the rate of cleanup per dollar invested. The objectives in this area are as follows.

- Maximize Percent and Amount of Budget Applied Directly to Cleanup. The Hanford Cleanup Program is a large, complex program. It is essential that the focus of resource and budget allocation be directed to cleanup actions.

Metrics: [(Total costs - Min-Safe Costs)/Total costs]*100, Total costs - Min-Safe Costs.

- Minimize Lifecycle Costs. Cost minimization is focused on doing the necessary work to reduce risks and release land at minimum costs (including use of cost-effective technology) and minimizing operations and maintenance costs.

Metrics: total lifecycle costs.

\section{B.2.3 Maximize Likelihood of Success}

Planning for cleanup must include a technically feasible and fiscally viable approach.

- Minimize Technical Uncertainty. The technical risks for the cleanup program are based on developing or deploying adequate technologies for Site remediation and disposal.

Technological risk may involve elements such as the suitability of a waste form for long-term disposal, the adequacy of barriers for long-term disposal, and the performance of a treatment technique. Likelihood of program success can be maximized by using available technology.

Metrics: technology maturity, complexity of technical solutions. Does technology currently exist to implement remediation activities?

- Minimize Programmatic Risks (Criteria not used). The programmatic risks for the cleanup program are based on developing adequate plans, schedules, and cost estimates, so that the 
decision makers clearly understand the funding and resource commitments required to complete the program. The likelihood of proceeding through cleanup within cost and schedule estimates must be maximized.

- Minimize Political Risks. The political risks for the cleanup program are based on developing and maintaining credible strategies. The likelihood of proceeding through cleanup within changing political environments must be maximized.

Metric: subjective evaluation of the acceptance or resistance to a strategy: locally, regionally, and nationally.

\section{B.2.4 Maximize Stakeholder Confidence}

Stakeholder confidence and trust are essential for making progress in cleaning up the Site. The stakeholders include regional and national interests. These objectives are measured by a subjective evaluation of stakeholder positions on each of the criteria.

- Maximize Protection of the Columbia River. Protection of the Columbia River has been identified as a high stakeholder value. Cleanup activities that support this objective will improve stakeholder confidence.

Metric: treatment, storage, and disposal of source terms near the Columbia River.

- Maximize Regulatory Compliance. Regulations were written to ensure that businesses, individuals, and the government manage their activities in a responsible manner. While there are always questions about the applicability and interpretation of the regulations, once they have been resolved it is imperative that DOE and its contractors comply. Strategies that comply with regulations will normally be more accepted by local stakeholders.

Metric: required regulatory changes, legal actions.

- Tri-Party Agreement Compliance. The Hanford Federal Facility Agreement and Consent Order (Tri-Party Agreement) (Ecology et. al 1994) was negotiated to ensure DOE, Washington State Department of Ecology, and U.S. Environmental Protection Agency agreed on criteria for cleaning up the Site and to ensure DOE manages activities in a responsible manner. While there are always questions about the applicability and interpretation of the TriParty Agreement, once they have been resolved, it is imperative DOE and its contractors comply with commitments. Strategies that do so will normally be more accepted by local stakeholders.

Metric: requires negotiated changes to the Tri-Party Agreement. 
- Maximize Economic Benefit. The federal government bears some responsibility for ensuring the regional economy remains reasonably stable at completion of Hanford Site cleanup. The economic impact on the region will be estimated appropriately.

Metric: areas available for industrial and other uses, especially in the near-term.

- Maximize Cleanup of High Stakeholder Interests. Stakeholder confidence will be improved when areas that are of high interest to them (e.g., Columbia River, groundwater, PUREX, Plutonium Finishing Plant, K Basins) are cleaned up and available for other uses, where appropriate.

Metrics: years to remove fuel from $\mathrm{K}$ Basins, task waste retrieved $(\mathrm{Y} / \mathrm{N})$ ?, groundwater treated $(\mathrm{Y} / \mathrm{N})$ ?, solid waste retrieved $(\mathrm{Y} / \mathrm{N})$ ?, Indian access $(\mathrm{Y} / \mathrm{N})$ ?

\section{B.3 References}

Ecology, EPA, and DOE, 1994, Hanford Federal Facility Agreement and Consent Order, as amended, Washington State Department of Ecology, U.S. Environmental Protection Agency, and U.S. Department of Energy, Olympia, Washington.

RL, 1993, Environmental Restoration and Waste Management Fiscal Year 1993 Site Specific Plan for the Richland Field Office, DOE/RL-92-27, U.S. Department of Energy Richland Operations Office, Richland, Washington.

RL, 1994a, Fiscal Year 1995 Hanford Mission Plan, Volume 1, "Site Guidance," DOE/RL-93-102, U.S. Department of Energy Richland Operations Office, Richland, Washington.

RL, 1994b, Hanford Strategic Plan, RL-D94-048, U.S. Department of Energy Richland Operations Office, Richland, Washington.

Working Group, 1992, The Future for Hanford: Uses and Cleanup, prepared by the Hanford Future Site Uses Working Group for the U.S. Department of Energy, U.S. Environmental Protection Agency, and the State of Washington.

Tank Waste Task Force, 1993, Hanford Tank Waste Task Force Final Report, Chairman Marshall Drummond, Submitted to Washington State Department of Ecology, U.S. Department of Energy, and U.S. Environmental Protection Agency. 


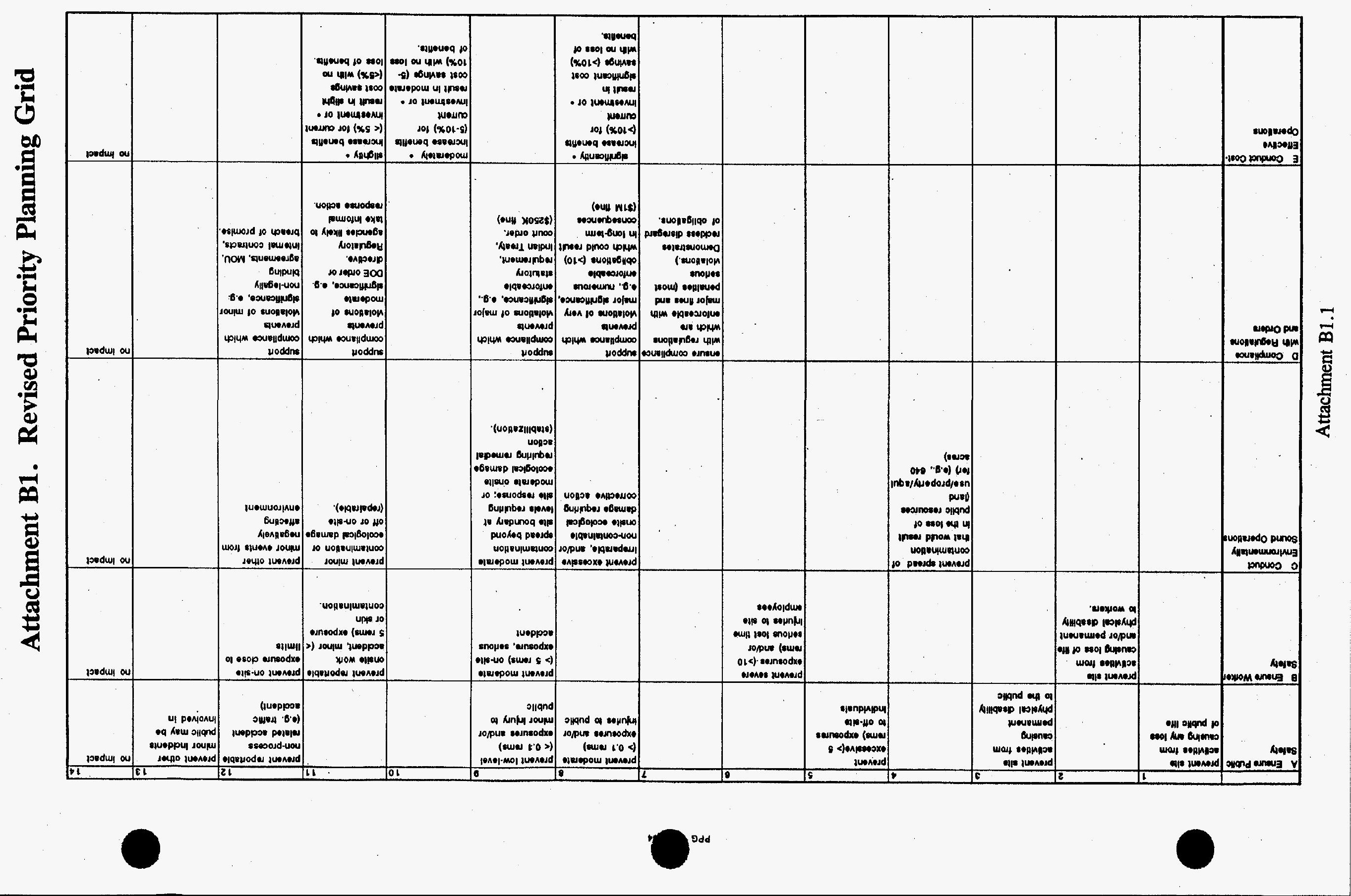




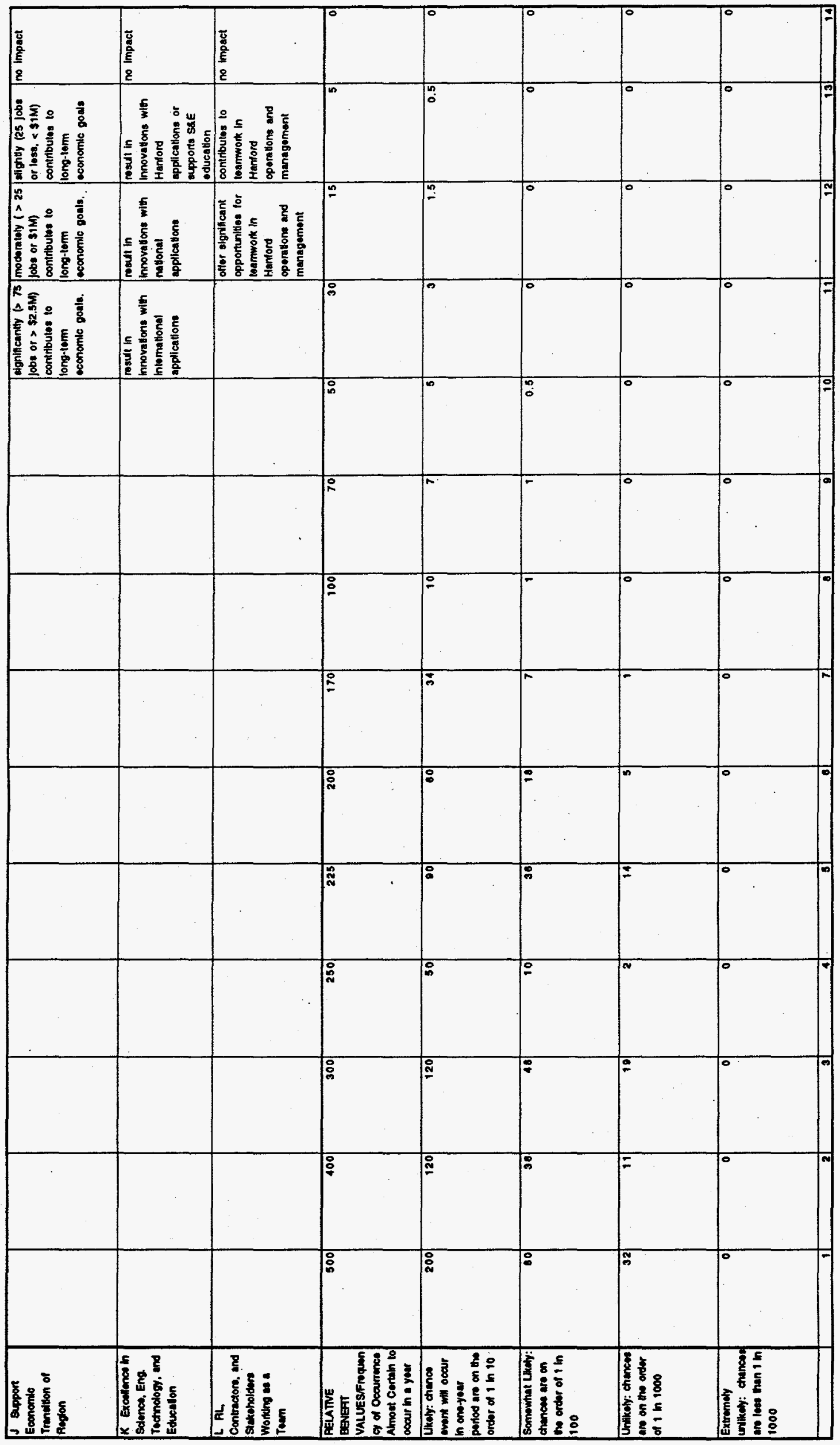

Attachment B1.3 


\section{Appendix C}

\section{Minimum Operations Cost Analysis}




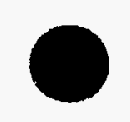

0 


\section{Contents}

\section{Appendix C - Minimum Operations Cost Analysis}

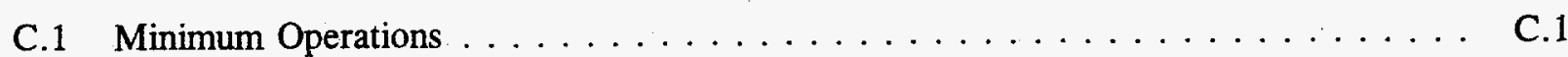

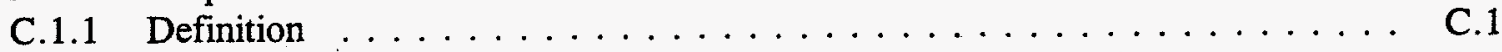

C.1.2 Program Discretionary Costs . . . . . . . . . . . . . . .

C.2 Use of Minimum Operations Cost $\ldots \ldots \ldots \ldots \ldots \ldots \ldots \ldots \ldots$

C.3 Conclusions $\ldots \ldots \ldots \ldots \ldots \ldots \ldots \ldots \ldots \ldots \ldots \ldots \ldots$

C.4 References $\ldots \ldots \ldots \ldots \ldots \ldots \ldots \ldots \ldots \ldots \ldots \ldots \ldots$

Figures

C.1. Minimum Operation Estimate - Without Mortgage Reductions $\ldots \ldots \ldots$. . . . . C.5

C.2. Minimum Operation Estimate - Potential Change with Time . . . . . . . . . . C.6

\section{Tables}

C.1 Estimated Minimum Operations Cost for Current Site Configuration . . . . . . . . C.2

C.2 Basis for Minimum Operations Cost Elements $\ldots \ldots \ldots \ldots \ldots \ldots$

C.iii 


\section{Appendix C}

\section{Minimum Operations Cost Analysis}

The development and evaluation of cost profiles were used as a mechanism for displaying the projected influence of alternative strategies on Hanford Site cleanup, assuming potential Site budget constraints. The cost analysis was performed by estimating the minimum operating costs for the Site in its current configuration and identifying an estimated cost for blocks of cleanup activities. The blocks of cleanup activity costs were considered as a series of discretionary program activities with the potential to be shifted in time to satisfy a specified Site budget profile. Completion of the cleanup activities also impacts the estimated minimum operations costs, such that discretionary funding can increase as high-cost surveillance and maintenance activities are transitioned to lower-cost surveillance and maintenance configurations.

\section{C.1 Minimum Operations}

\section{C.1.1 Definition}

The minimum operations cost for the Site was defined as those surveillance, maintenance, and support costs required to control existing material, waste, and facilities in a safe, stable condition. No remediation, stabilization, treatment, or disposal would occur at the minimum operations funding level and new activities required to comply with regulatory agreements would not be completed. However, current routine reporting activities required to satisfy current regulatory compliance requirements for surveillance and maintenance are imbedded in the minimum operations estimates.

\section{C.1.2 Program Discretionary Costs}

Table C.1 provides a summary of the minimum operations cost estimate for the Site by major program. Current funding directed toward maintaining adequate controls on stored materials and waste in the existing Site facilities is estimated to range from 500 to 700 million dollars. A point estimate for the minimum operations cost of 612 million dollars was developed based on the assumptions listed in Table C.2. The remainder of the assumed Site budget represents an estimate of funding that is available to be reallocated among the programs based on alternative prioritization strategies. Therefore, if the overall annual Site budget is projected at 1050 million dollars, approximately 450 million dollars is available for allocating to alternative cleanup activities over the next few years. 
Table C.1. Estimated Minimum Operations Cost for Current Site Configuration

\begin{tabular}{|c|c|c|}
\hline Activity & $\begin{array}{l}\text { Range, } \\
\cdot \$ M\end{array}$ & $\begin{array}{l}\text { Estimate Used } \\
\text { for Planning, \$M }\end{array}$ \\
\hline Liquid effluent & $10-15$ & 11 \\
\hline RCRA \& OPS monitoring & $10-15$ & 13 \\
\hline Pacific Northwest Laboratory (WM) & $15-25$ & 20 \\
\hline Landlord & $15-25$ & 21 \\
\hline Facility transition (EM-30) & $25-35$ & 33 \\
\hline Fast Flux Test Facility & $30-40$ & 35 \\
\hline Analytical services & $30-40$ & 36 \\
\hline Spent nuclear fuel ( $\mathrm{K}$ Basins) & $35-45$ & 42 \\
\hline Environmental restoration & $30-50$ & 42 \\
\hline Solid waste & $40-60$ & 48 \\
\hline $\begin{array}{l}\text { Administration (RL, HEMP, } \\
\text { planning, HAMMER, transportation) }\end{array}$ & $55-85$ & 70 \\
\hline Facility transition (EM-60) & $80-110$ & 98 \\
\hline Tank Waste Remediation System & $120-150$ & 143 \\
\hline Site total & $495-695$ & 612 \\
\hline
\end{tabular}

$\begin{array}{ll}\text { HAMMER } & =\text { Hazardous Materials Management and Emergency Response. } \\ \text { HEMP } & =\text { Hanford Environmental Management Program. } \\ \text { M } & =\text { million. } \\ \text { OPS } & =\text { Operations. } \\ \text { RCRA } & =\text { Resource Conservation and Recovery Act of } 1976 \\ \text { WM } & =\text { Waste Management. }\end{array}$


Table C.2. Basis for Minimum Operations Cost Elements

\begin{tabular}{|c|c|}
\hline Cost Element & Change description \\
\hline General & Based on adjustments to 1997 ADS planning numbers \\
\hline $\begin{array}{l}\text { Tank Waste Remediation } \\
\text { System }\end{array}$ & $\begin{array}{l}\text { - No retrieval or disposal elements } \\
\text { - Excludes characterization, safety upgrades, program management, and O\&M. } \\
\text { O\&M in ADS assumed to model ramp-down to minimum operations in } 1995 \text { to } 2001 \text {, constant at } 2001 \text { after } \\
\text { that. } \\
\text { - Program management reduced by ratio of new total to planning total }\end{array}$ \\
\hline Environmental restoration & $\begin{array}{l}\text { - No TSD facility, remediation, or decontamination and decommissioning } \\
\text { - Estimated program management plus S\&M at } \$ 25 \mathrm{M} \text { for ER sites and surplus facilities, plus } \$ 16.5 \mathrm{M} \text { for } \mathrm{N} \text { Reactor } \\
\text { S\&M until N Reactor deactivated. }\end{array}$ \\
\hline Spent nuclear fuel & $\begin{array}{l}\text { - K Basin costs only from Hanford Spent Nuclear Fuel Project Recommended Path Forward (Bergman 1994). } \\
\text { - No Path Forward costs. }\end{array}$ \\
\hline Fast Flux Test Facility & $\begin{array}{l}\text { - Assumed only current S\&M per estimates provided by Facility Transition Program. } \\
\text { - No deactivation. }\end{array}$ \\
\hline EM-60 transition & $\begin{array}{l}\text { - PUREX, PFP, and } 300 \text { Area fuel supply facilities at current S\&M plus general plant support pius safeguards and } \\
\text { security per estimates provided by Facility Transition Program. } \\
\text { - No deactivation, stabilization, storage/treatment, or demolition. }\end{array}$ \\
\hline EM-30 transition & $\begin{array}{l}\text { - B Plant S\&M, WESF O\&M, capsule recovery, and program management only per estimates provided by } \\
\text { Facility Transition Program. } \\
\text { - No deactivation or compliance. }\end{array}$ \\
\hline HEMP & - Deleted, assumed covered with Site administration below. \\
\hline Transportation & - Deleted \\
\hline Planning and integration & - Deleted, assumed covered with Site administration below. \\
\hline PNL Waste Management & $\begin{array}{l}\text { - Based on target estimates in } 1997 \text { ADS input. } \\
\text { - Deleted environmental oversight, cultural resources, and ecological compliance } \\
\text { - Deleted cleanouts to retain only S\&M of PNL facilities. }\end{array}$ \\
\hline Analytical services & - Deleted all but laboratory operations and upgrades. \\
\hline Landlord & - Reduced to target numbers in 1997 ADS. \\
\hline RCRA and Ops monitoring & - Reduced to \$13M per year as indicated in 1997 ADS. \\
\hline Liquid effluent & $\begin{array}{l}\text { - Reduced to } \$ 11 \mathrm{M} \text { per year based on input from the Liquid Effluent Program assuming the } 200 \text { Area Liquid Effluent } \\
\text { Trearment Facility is not started up. }\end{array}$ \\
\hline Solid waste & $\begin{array}{l}\text { - Retained only Solid waste S\&M and T Plant S\&M } \\
\text { Solid waste minimum operation S\&M estimated from review of itemized } 1996 \text { ADS, eliminating disposal } \\
\text { support activities. Projected to provide minimal support to receive additional solid waste. } \\
\text { No T Plant upgrades, WRAP facility starup/operation, retrieval, or other new facilities. }\end{array}$ \\
\hline HAMMER & - Deleted. \\
\hline $\begin{array}{l}\text { Site administration } \\
\text { (primarily } R L \text { activities) }\end{array}$ & ced to funding level in 1997 ADS and deleted stakeholder/TPA support. \\
\hline
\end{tabular}

\footnotetext{
ADS = activity data sheet.

ER = environmental restoration.

HAMMER = Hazardous Materials Management and Emergency Response.

HEMP = Hanford Environmental Management Program.

$\mathrm{M} \quad=$ million.

O\&M = operation and management.

PFP = Plutonium Finishing Plant.

PNL = Pacific Northwest Laboratory.

RL = DOE Richland Operations Office.

S\&M = surveillance and maintenance.

TPA $=$ Tri-Party Agreement.

WESF $\quad$ Waste Encapsulation Storage Facility.
} 
A number of the Site cleanup activities are projected to reduce the minimum operating costs required for major Site program elements. Deactivation of the former production facilities is the simplest example of this type of activity, where the facilities are transitioned from a relatively high surveillance and maintenance cost in their current configuration to a lower-cost surveillance and maintenance configuration awaiting final decontamination and decommissioning. Facility transition and tank waste operations represent approximately 50 percent of the minimum operations cost. Transition of these program elements to lower-cost surveillance and maintenance configurations provide the largest potential to free up additional funding for actions that support cleanup progress. As these and other transitions occur, the point estimate for the minimum operations cost will change with time, depending on the order of completing transition actions, and will ultimately increase the fraction of the total Site budget available for additional cleanup activities.

The cost range indicated for the minimum operations estimate indicates significant uncertainty in defining a minimum operations cost for strategic planning purposes. The uncertainty results from a difficulty in separating costs for activities required to maintain safety envelopes from costs for reporting activities, good management practices, and maintenance anticipated to prevent potential future problems. Basing estimates on a more detailed breakdown of Site funding estimates would potentially improve the minimum operations cost estimate. This effort would benefit from evaluation by a dedicated team that could ensure use of a common basis for compiling minimum operation funding requirements. The level of effort required to do this was beyond the scope of activities defined for this analysis.

\section{C.2 Use of Minimum Operations Cost}

The minimum operations cost estimate, as shown in Figure C.1, is used as a starting point for constructing cost profiles that indicate the cost and schedule impacts of pursuing alternative strategies. The minimum operations cost by itself is not intended to represent a complete long-term strategy for Site activities. While not evaluated quantitatively, Figure C. 2 provides an indication of the potential for the minimum operations cost to change with time if the current configurations for material and waste storage were merely retained at the defined surveillance and maintenance levels. Some program elements would be expected to complete transitions to a lower cost surveillance and maintenance configuration, but at a slower pace than that achieved by a complete cleanout program; however, continued facility degradation requiring replacement of equipment and facilities would be anticipated to eventually overwhelm a slower-paced cost-reduction profile from the current minimum operations point estimate. This would result in a growing commitment of resources to maintain the current inventory of stored materials and waste in essentially the same configuration.

Cost profiles were constructed from the point estimate for minimum operations starting in fiscal year 1996 by combining blocks of cleanup activity costs with a prioritization list developed for each alternative strategy. As a cleanup action was completed, the resultant reduction in the surveillance and maintenance cost was tracked. Blocks of cleanup were added on top of the minimum operating cost according to the prioritization list until the budget limitation was observed, adjusting the out-year impacts on minimum operating costs. This procedure was repeated in successive years 


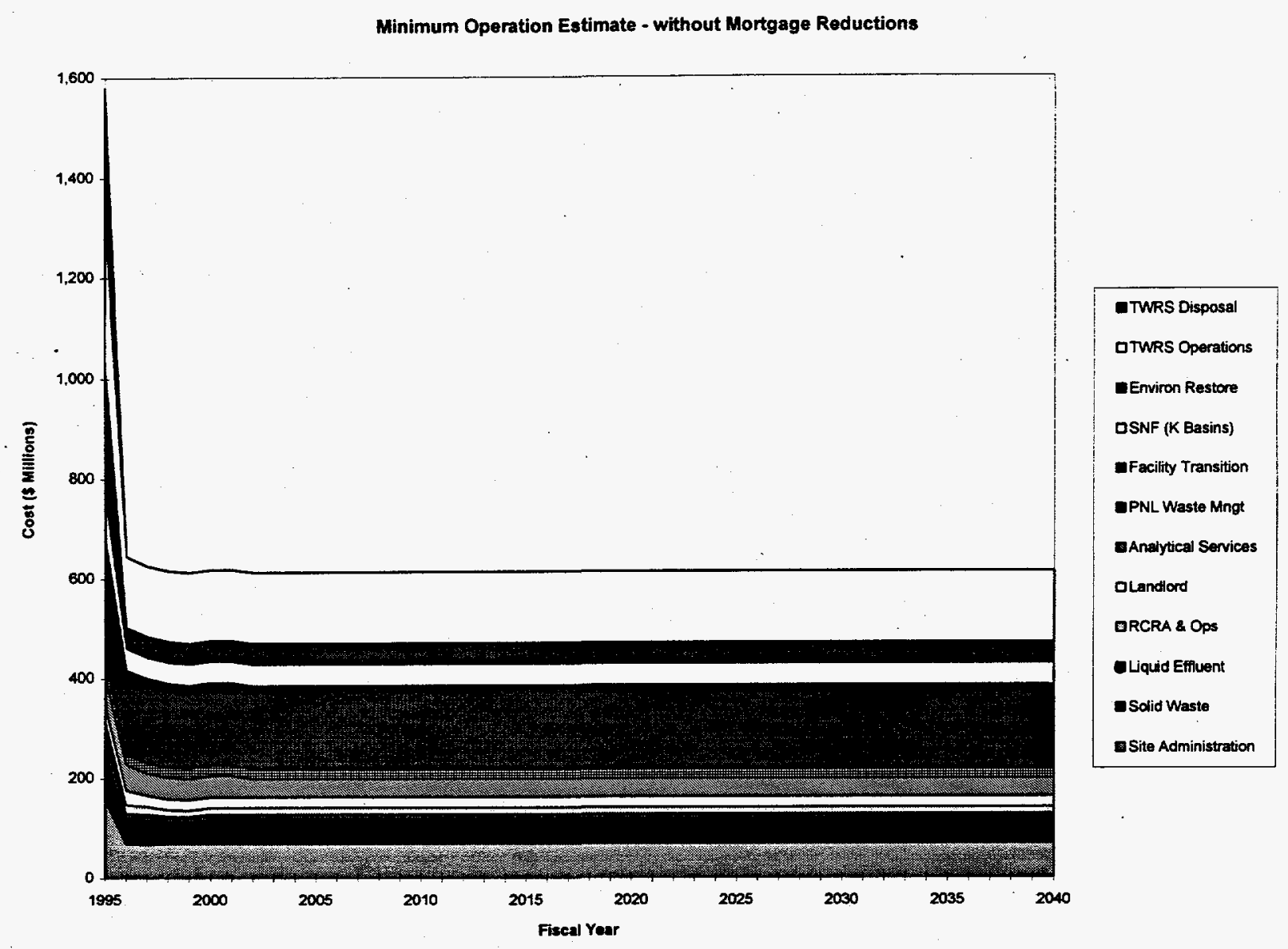

Figure C.1. Minimum Operation Estimate - Without Mortgage Reductions 


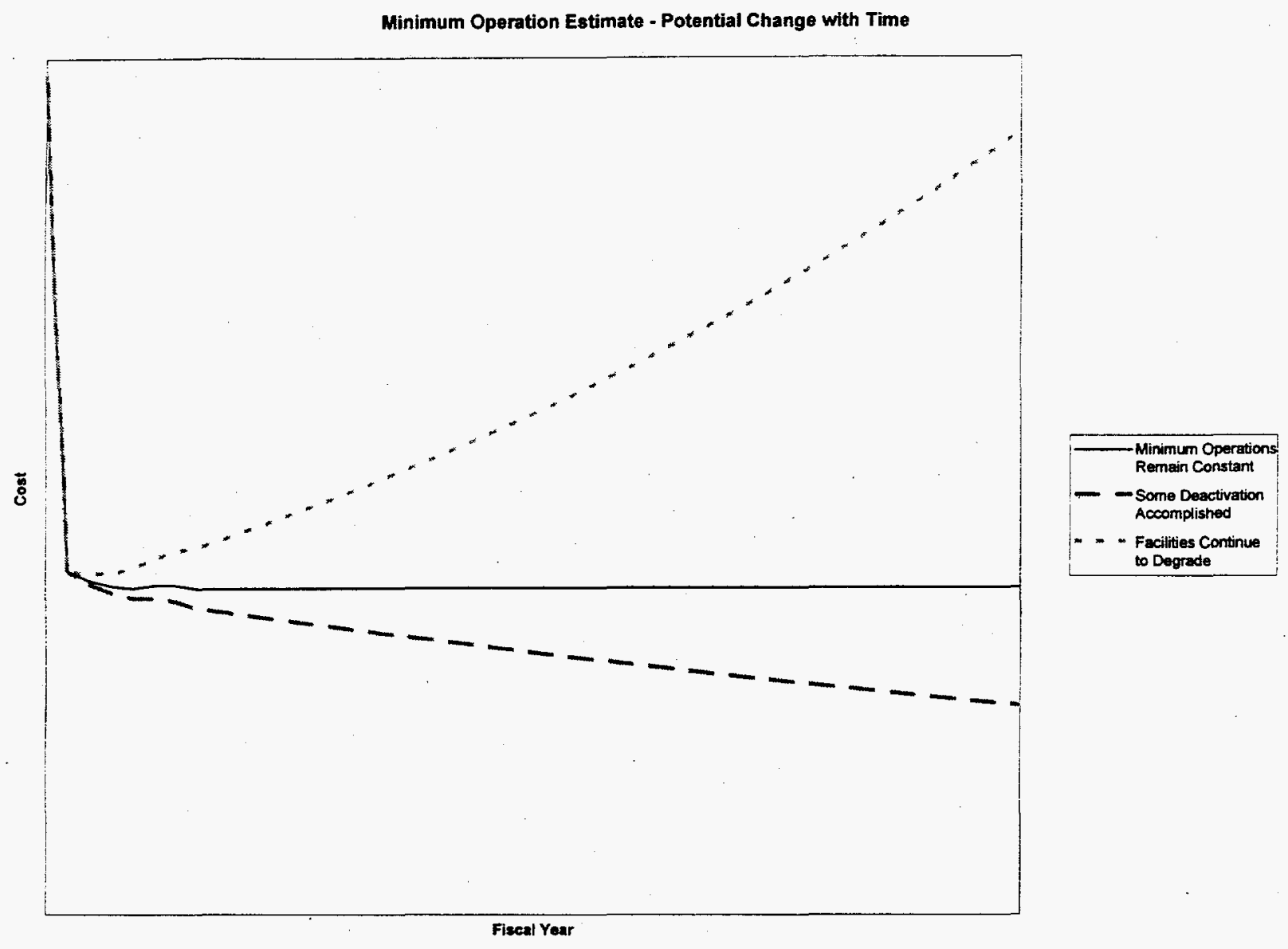

Figure C.2. Minimum Operation Estimate - Potential Change with Time

until all the cleanup actions in the strategy had been included. Treating the cleanup actions as blocks allowed approximation of the action delays or acceleration that could be accommodated in the funding limit under evaluation.

Each strategy evaluated was constructed to approximately satisfy the projected Site funding profile limit under evaluation. Therefore, the resultant cost profiles were not, in themselves, as important as a discriminator between alternatives as the schedule implications for major cleanup actions that were derived from the profiles. 


\section{C.3 Conclusions}

The development of a point minimum operating cost for Site activities provides a basis for constructing cost profiles that describe alternative strategies; however, the minimum operating cost, as developed, is not considered a definition of a complete Site program with all future activities reduced to minimum surveillance and maintenance activities. The point estimate of minimum operations that can be used for building an overall annual Site budget of approximately 1000 million dollars ranges from 500 to 700 million dollars, leaving on the order of 300 to 500 million dollars for cleanup activities. If the cost of minimum surveillance and maintenance activities for program elements that are deferred as part of a particular strategy cannot be driven down to levels approximated by the minimum operating cost, cleanup progress will be further delayed from the projections developed in this analysis.

\section{C.4 References}

Resource Conservation and Recovery Act of 1976, 42 USC 6901, et seq.

Bergman, T.P., Hanford Spent Nuclear Fuel Project Recommended Path Forward, Volume I, WHC-EP-0830, rev. 0, Westinghouse Hanford Company, Richland, Washington. 
-

○ 


\section{Appendix D}

Risk Analysis 
-

-

0 


\section{Contents}

\section{Appendix D - Risk Analysis}

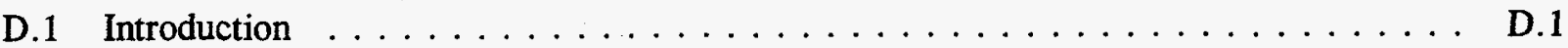

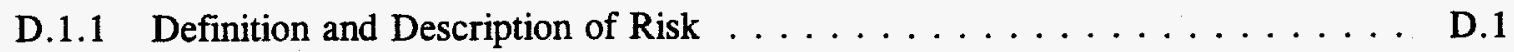

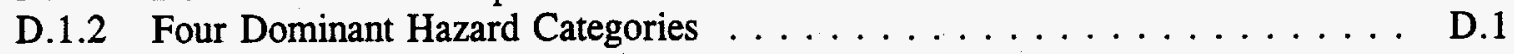

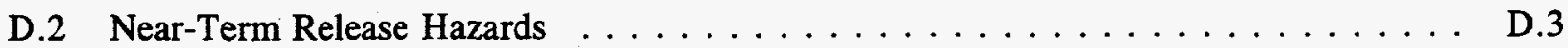

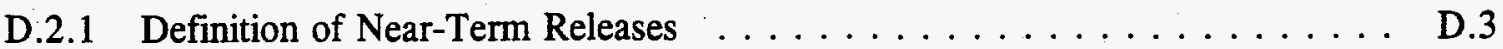

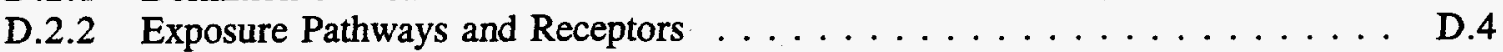

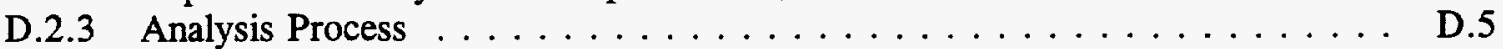

D.2.4 . U. S. Department of Energy Nuclear Safety Policy Criteria . . . . . . . . D.10

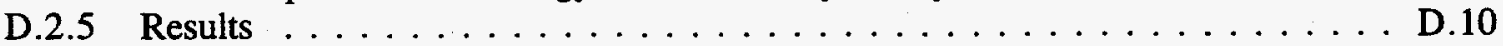

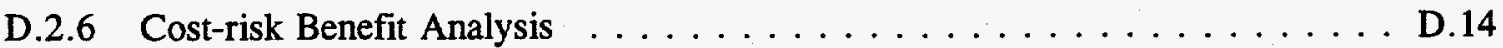

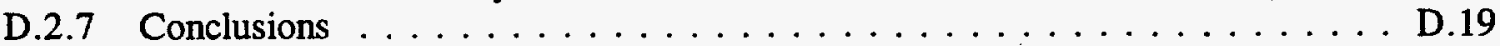

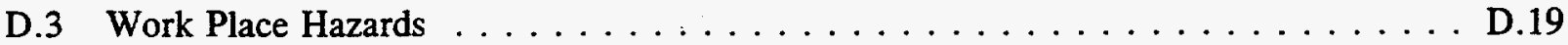

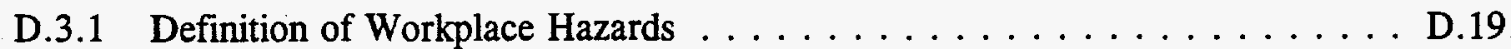

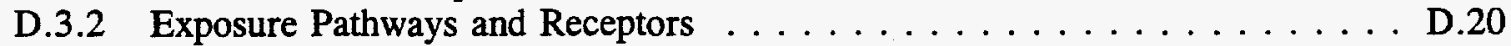

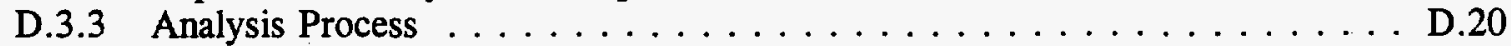

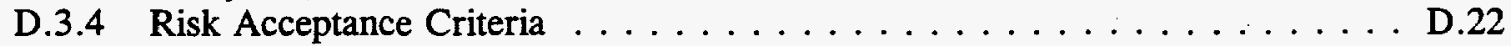

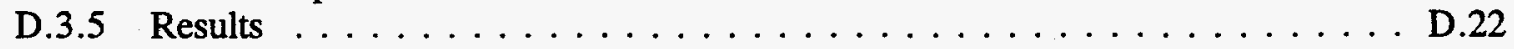

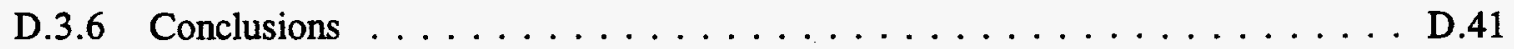

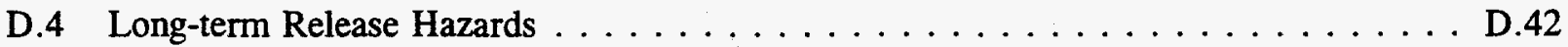

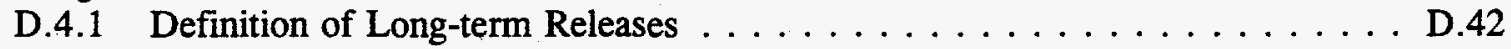

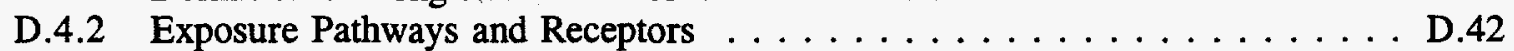

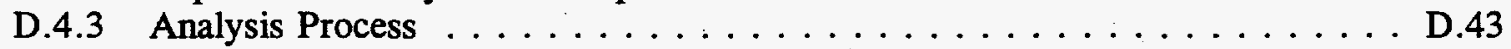

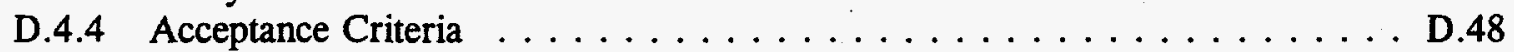

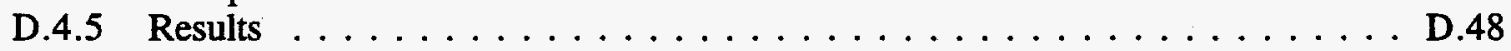

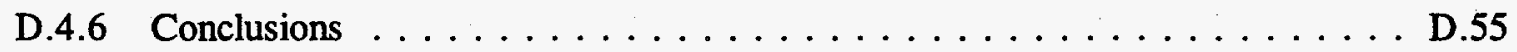

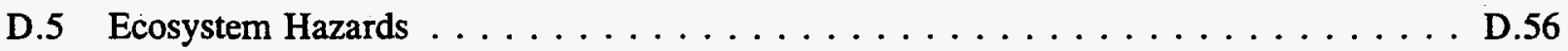

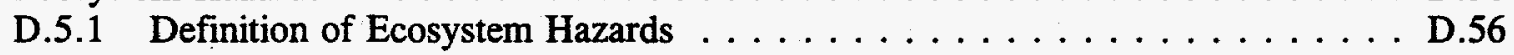

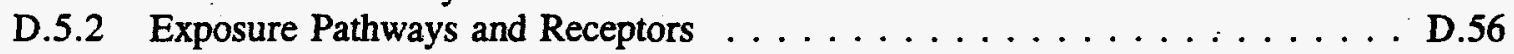

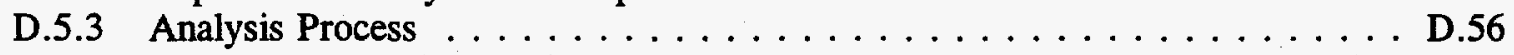

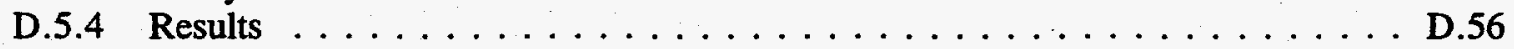

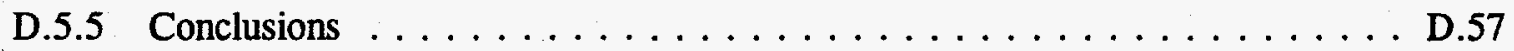

D.6 Major Risk Considerations $\ldots \ldots \ldots \ldots \ldots \ldots \ldots \ldots \ldots \ldots \ldots \ldots \ldots$

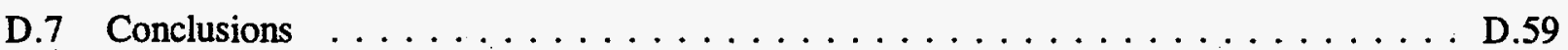

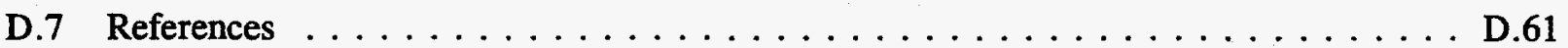

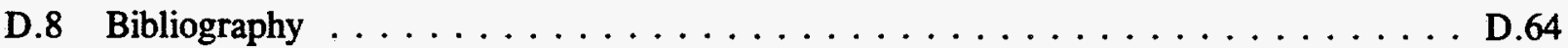




\section{Figures}

D.1 Parameters Used in Determining Risk $\ldots \ldots \ldots \ldots \ldots \ldots \ldots \ldots$

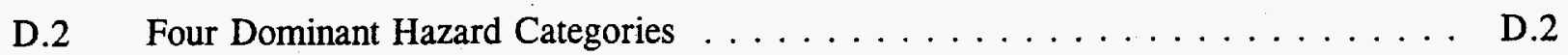

D.3 Event Tree Used to Develop Event Frequencies $\ldots \ldots \ldots \ldots \ldots \ldots$

D.4 Frequency-Consequence Space with Risk Acceptance Criteria . . . . . . . . D.11

D.5 Example of Risk Results for an Average Member of the Public . . . . . . . D.13

D.6 Contributions to the Risk to an Average Member of the Public from Listed

Activities or Facilities . . . . . . . . . . . . . . . . . 14

D.7 Contributions to the Risk to the Calculational Receptor from Listed

Activities or Facilities . . . . . . . . . . . . . . . . D.15

D.8 Changes in the Contributions to the Risk to the Calculational Receptor

by Choosing Acceptable Intermediate Remediation States . . . . . . . . . D.16

D.9 Examples of Reduced Risk - Cost Evaluation $\ldots \ldots \ldots \ldots \ldots \ldots$

D.10 Reduced Risk - Cost Considerations $\ldots \ldots \ldots \ldots \ldots \ldots \ldots \ldots \ldots$

D.11a Annual Industrial Hazards for $\mathrm{N}$ Reactor Deactivation $\ldots \ldots \ldots \ldots \ldots \ldots$

D.11b Cumulative Industrial Hazards for $\mathrm{N}$ Reactor Deactivation $\ldots \ldots \ldots \ldots \ldots$

D.12 Annual Routine Radiological Exposures for N Reactor Deactivation $\ldots \ldots \ldots$. . . D.26

D.13 Cumulative Radiological Exposures for N Reactor Deactivation . . . . . . . . D.27

D.14 Cumulative Industrial Hazards for PUREX Deactivation . . . . . . . . . . D.28

D.15 Cumulative Radiological Exposures for PUREX Deactivation $\ldots \ldots \ldots \ldots$. . . . D.30

D.16 Tank Waste Remediation Industrial Hazards for Retrieval and

Two In-Situ Disposal Options . . . . . . . . . . . . . . . . . . D.31

D.17 Tank Waste Remediation Occupational Exposures for Retrieval and

Two In-Situ Disposal Alternatives $\ldots \ldots \ldots \ldots \ldots \ldots \ldots$ D.32

D.18 Industrial Hazards for Remediation of Soil, Liquid, and Solid Waste Disposal

Sites for Two Risk Targets . . . . . . . . . . . . . . . . D.34

D.iv 
D.19 Industrial Hazards by Area for Remediation of Soil, Liquid, and

Solid Waste Disposal Sites . . . . . . . . . . . . . . . . D.34

D.20 Comparison of Industrial Hazards for Two D\&D Options for the

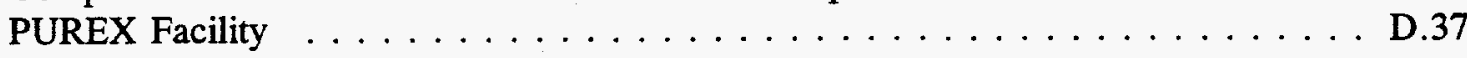

D.21 Comparison of Routine Exposures for Two D\&D Options for the PUREX Facility

D.22 Illustration of Tradeoffs Between Worker and Public Risks for an N Reactor

Fuel Remediation Example Alternative . . . . . . . . . . . . . . . D.40

D.23 Radiological and Chemical Carcinogenic Risks $\ldots \ldots \ldots \ldots \ldots \ldots$

D.24 Non-carcinogenic Risk $\ldots \ldots \ldots \ldots \ldots \ldots \ldots \ldots \ldots \ldots$

D.25 Radiological Risk for Buried Waste $\ldots \ldots \ldots \ldots \ldots \ldots \ldots \ldots$

D.26 Fraction of Radiological Hazard by Number of Waste Tanks . . . . . . . . . D.52

D.27 Risk Sensitivity for Tank Treatment Options $\ldots \ldots \ldots \ldots \ldots \ldots \ldots$

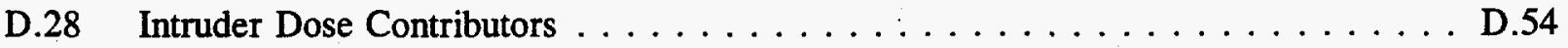

D.29 Ratio of SST Inventories to Intruder Limits from 200 W PA $\ldots \ldots \ldots \ldots \ldots$

\section{Tables}

D.1 Applicable Hazard Sources by Hazard Category and Time Frame $\ldots \ldots \ldots$. . . D.4

D.2 Unit Risk Factors for Population Exposures $\ldots \ldots \ldots \ldots \ldots \ldots$

D.3 Unit Risk Factors for the Calculational Receptor at $0.5 \mathrm{~km}$ and $1.0 \mathrm{~km}$ From Source . . . . . . . . . . . . . . . D.8

D.5 Unit Risk Factors for Radionuclides of Concern $\ldots \ldots \ldots \ldots \ldots \ldots \ldots$

D.6 Unit Risk Factors for Hazardous Chemicals of Concern . . . . . . . . . . D.45

D.7 Estimated Quantities of Contaminants of Concern by Waste Type . . . . . . . . D.47 


\title{
Appendix D
}

\author{
Risk Analysis
}

\section{D.1 Introduction}

Before a risk-based strategy could be established, a common framework for understanding risk was developed. This appendix describes that framework and the supporting analyses. The analyses address risks to the public, workers, and environment from exposure to radionuclides, toxic and dangerous chemicals, and industrial hazards.

\section{D.1.1 Definition and Description of Risk}

Risk is considered in terms of the potential of a hazard to cause harm to a receptor. The harm can be measured both in immediate and long-term effects based on a receptor's exposure to hazards. The receptors are the public, workers, and ecosystem.

Risk is generally described as the product of the consequences and likelihood of a receptor being exposed to a hazard. A graphical representation of the concepts involved in risk is presented in Figure D.1. The harm or consequences to a receptor are related to the hazard source. The important features of the hazard source are the quantity of material and the material's toxicity, form, and dispersability. The likelihood of release is a function of the available energy sources, the release processes, and functioning barriers. The various pathways for a receptor to be exposed to a hazard are through the air, soil, groundwater, and surface water.

\section{D.1.2 Four Dominant Hazard Categories}

The important elements involved in risk will vary during the different phases of Hanford Site cleanup and are specific to a receptor. In an effort to simplify the evaluation of various risk-based strategic alternatives, four hazard categories and three risk management time frames been defined. The four hazard categories are illustrated in Figure D.2. Each of these four hazard categories will be discussed later. Short descriptions are as follows.

(A) Near-term hazards--where hazards with potentially large consequences could result from the release of radionuclides and chemical contaminants in the current or remediation phase. The major pathway to the receptors is via the air. Near-term releases are characterized by a relatively low likelihood of occurrence with moderate-to-high consequences. The time frames of interest are primarily during current and remediation operations.

(B) Workplace hazards--where harm results from accidents (e.g., slips, falls,), routine exposure to radiation and hazardous chemicals, and accidental releases of radioactive and hazardous materials. Workplace risks are characterized by a relatively high likelihood of occurrence with consequences directly to the workforce. The time frames of concern are primarily during current and remediation operations. 


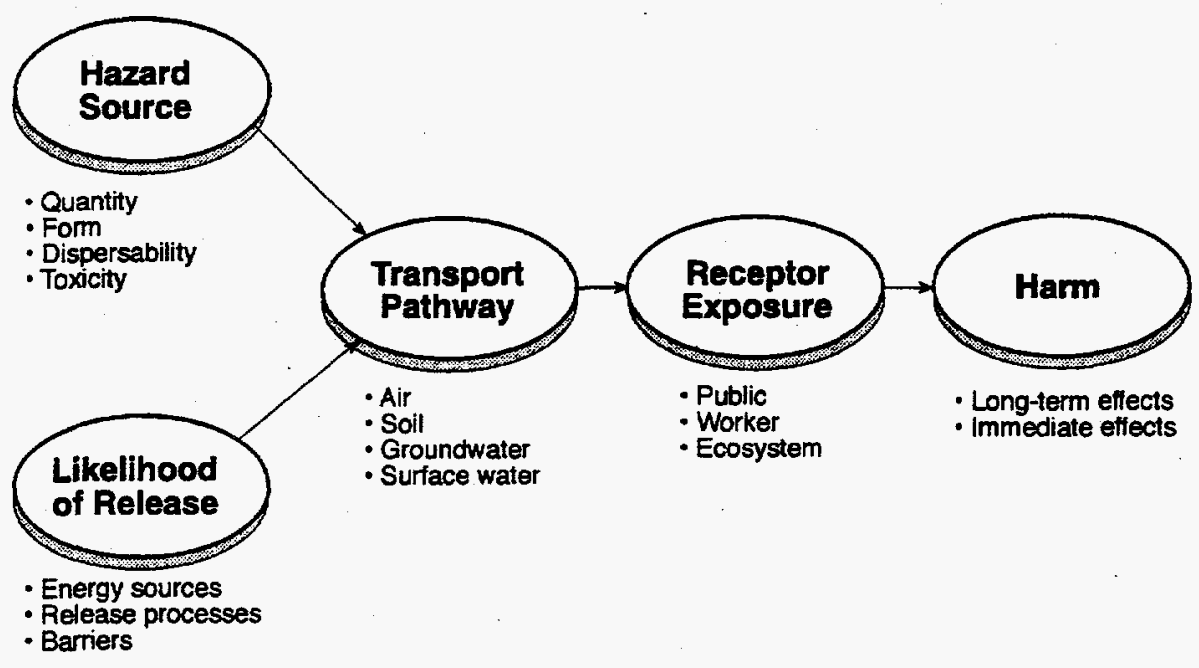

0412001.100.

Figure D.1. Parameters Used in Determining Risk

\section{Hazard Categories}

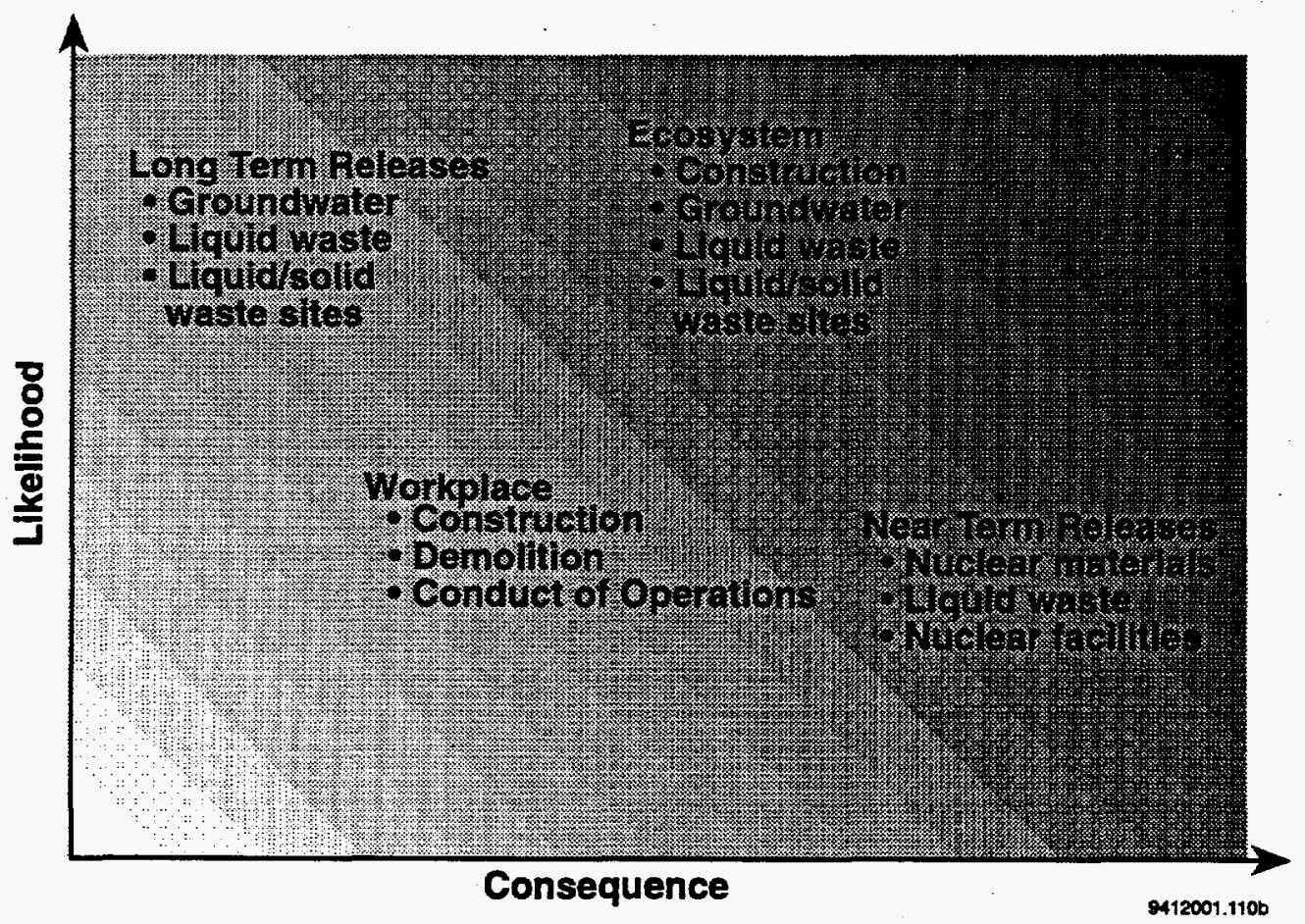

Figure D.2. Four Dominant Hazard Categories 
(C) Long-term hazards--where harm results from transport of radionuclide and chemical contaminants through the groundwater to human receptors. Long-term risks are characterized by a relatively high likelihood of occurrence but releases occur over a long time. The time frame of concern is primarily post-closure (e.g., $100 \mathrm{~s}$ or 1000 s of years). Long-term hazards are also associated with intruder scenarios.

(D) Ecosystem hazards-where harm results from chemical and radionuclide contamination of plant and animal life and physical disruption of natural habitats. Harm to cultural, archeological, and historical resources are included in this category. Likelihood and consequence of physical disruption are a function of the remediation actions. The time frames of concern are primarily during current and remediation operations.

The three risk management time frames are as follows.

(1) Current state--when actions are taken to manage the existing hazard sources in their current form, condition, and location.

(2) Remediation--when actions are taken to transition the hazards to a lower risk condition. Examples of these actions would be changing liquid waste to a solid, installing barriers, or packaging and disposing of solid waste.

(3) Post-closure--when actions are taken to manage the Site after the cleanup mission has been completed. These actions may include long-term monitoring and controlling access to the groundwater.

Table D.1 identifies the four hazard categories, the three time frames, and the sources of hazards most appropriate for each hazard category and time frame. The unshaded boxes in Table D.1 identify the primary areas of interest, while the shaded boxes identify secondary areas of interest during a particular time frame. The potential release mechanisms, transport pathway, receptors, and harm for each hazard category and time frame are discussed in the following sections.

\section{D.2 Near-Term Release Hazards}

\section{D.2.1 Definition of Near-Term Releases}

Near-term releases refer to those potentially large hazards where the release to the receptor could occur in the current state or remediation time frame. The near-term release would expose the public, workers, and environment to radionuclides via airborne and ground pathways. These hazards are usually characterized by relatively moderate-to-high consequences, but moderate-to-low likelihood of release.

A primary objective of current Site activities is to prevent contamination and exposure of the public, workers, and environment from these potentially high-consequence events. To accomplish this objective, the hazards will be transitioned to safe, stable states, taking care not to preclude final disposition of the waste. Remediation should improve the cost effectiveness of risk management 
Table D.1. Applicable Hazard Sources by Hazard Category and Time Frame

\begin{tabular}{|c|c|c|c|}
\hline \multirow{2}{*}{$\begin{array}{l}\text { Hazard } \\
\text { Category }\end{array}$} & \multicolumn{3}{|c|}{ Time Frame } \\
\hline & Current State & During Remediation & Post-Closure \\
\hline $\begin{array}{c}\text { A } \\
\text { Near-term } \\
\text { Release }\end{array}$ & $\begin{array}{l}\text { Nuclear materials } \\
\text { Liquid wastes } \\
\text { Nuclear facilities } \\
\text { Solid waste }\end{array}$ & $\begin{array}{l}\text { Same }+ \\
\text { Remediation actions }\end{array}$ & Minimal impact \\
\hline $\begin{array}{c}\text { B } \\
\text { Work Place }\end{array}$ & $\begin{array}{l}\text { Aging facilities } \\
\text { Radionuclides } \\
\text { Bulk chemicals } \\
\text { Work activities }\end{array}$ & $\begin{array}{l}\text { Same }+ \\
\text { Transportation }\end{array}$ & Minimal impact \\
\hline $\begin{array}{c}\text { C } \\
\text { Long-term } \\
\text { Release }\end{array}$ & $\begin{array}{l}\text { Groundwater } \\
\text { Liquid waste } \\
\text { Solid waste } \\
\text { Environmental } \\
\text { contamination }\end{array}$ & & $\begin{array}{l}\text { Groundwater } \\
\text { Environmental } \\
\text { contamination }\end{array}$ \\
\hline $\begin{array}{c}\text { D } \\
\text { Ecosystem }\end{array}$ & & $\begin{array}{l}\text { Remediation actions } \\
\text { Groundwater }\end{array}$ & \\
\hline Key $=$ & $\begin{array}{c}\text { Primary } \\
\text { Consideration }\end{array}$ & $\begin{array}{l}\text { Secondary } \\
\text { Consideration }\end{array}$ & \\
\hline
\end{tabular}

activities that are presently required to maintain the potentially high hazards in a safe state. During remediation, those processes should be selected that will not increase the likelihood of a release with large consequences.

\section{D.2.2 Exposure Pathways and Receptors}

The relevant exposure pathways for near-term releases are the air pathway, the surface water pathway, and the ground pathway through the soil. The primary receptors are the public and workers. A secondary receptor is the environment where release of contamination to the environment introduces a source term that may eventually migrate through the soil and groundwater to a receptor (i.e., a long-term release). The harm that may be inflicted on the receptors includes both near-term or immediate effects (acute) caused by the contamination and long-term effects (chronic) caused by the contamination residing within the body.

For near-term releases and the associated analysis, the primary focus will be on the exposure of a receptor from radionuclides transported through the air (air pathway) and inhaled into the receptor's 
body (inhalation dose). Surface water transport will be bounded by the inhalation radiological dose, and transport through the ground will be considered in long-term releases.

\section{D.2.3 Analysis Process}

The basis of the analysis process is the air pathway and inhalation radiological dose. Two receptors are considered. The first receptor is an average member of the public (within $80 \mathrm{~km}$ ) using present Hanford Site and surrounding area population distributions. The second receptor is a calculational receptor defined to be a receptor located at a distance of 0.5 kilometers from the radionuclide source in the direction of the movement of the maximum contamination (maximum dispersion coefficients, $\chi / Q$ ). The radiological dose consequences for a member of the public are the annual average radiological dose consequences for all individuals within $\mathbf{5 0}$ kilometers of the Hanford Site. For the calculational receptor, the radiological dose consequences are a 50-year committed effective dose equivalent. by:

The radiological dose consequences to a receptor due to inhalation of the jth radionuclide is given

$$
C_{j}=Q_{j} D_{j} B R\left(\frac{\chi}{\dot{Q}}\right)
$$

where:

$$
\begin{aligned}
Q_{j} & =\text { the quantity of the jth radionuclide }(\mathrm{Ci}), \\
D_{j} & =\text { the committed effective dose equivalent for the jth radionuclide (rem/Ci), } \\
B R & =\text { the breathing rate }\left(\mathrm{m}^{3} / \mathrm{sec}\right), \text { and } \\
\frac{\chi}{\dot{Q}} & =\text { the dispersion coefficients }\left(\mathrm{sec} / \mathrm{m}^{3}\right) .
\end{aligned}
$$

Note that the breathing rate and the dispersion coefficients are the same for each radionuclide. The radiological dose consequences can be written in terms of a radionuclide quantity, a transport factor, and a health factor as follows:

$$
C=\sum_{j} C_{j}=\sum_{j} Q_{j} T F H F_{j}
$$

where:

$$
\begin{aligned}
T F & =\frac{\chi}{\dot{Q}}, \text { the transport factor (same for each radionuclide), and } \\
H F_{j} & =D_{j} B R, \text { the health factor which is different for each radionuclide. }
\end{aligned}
$$

For a finite set of accident sequences with consequences $C_{k}$ and frequency of occurrence $f_{k}$, the total risk is written as: 


$$
R_{T}=\sum_{k=1}^{N} R_{k}=\sum_{k=1}^{N} p_{k} C_{k} f_{k}
$$

where $p_{k}$ is a normalizing constant used to obtain a consistent set of units for the risk from each accident sequence. Combining the consequences from the release of radionuclides with the frequency of the event that released the radionuclides, the total risk can be written as:

$$
\begin{aligned}
R_{T} & =\sum_{k} p_{k} \sum_{j} Q_{j} T F_{k} H F_{j k} f_{k} \\
& =\sum_{k} p_{k}\left(\sum_{j} Q_{j} H F_{j k}\right) T F_{k} f_{k}
\end{aligned}
$$

This approach suggests a modular analysis where the transport factor and health factor can be analyzed for a unit release of radionuclides. The risk for an accident sequence is then obtained by multiplying the modular factors by the total quantity of a specific radionuclide and summing over all of the applicable radionuclides. The total quantity of a specific radionuclide can be expressed as the available source term times a total release fraction. The total risk is then given by:

$$
R_{T}=\sum_{k} p_{k} \sum_{j} Q_{j} H F_{j k} T F_{k} R F_{k} f_{k}
$$

The model used in the analysis is the modular risk analysis approach developed by Pacific Northwest Laboratory (Whelan 1994) and used in the Integrated Risk Assessment Program (Mahaffey et al. 1994). The modular risk analysis considers the total risk as the product of the source term, a unit transport factor, a unit risk factor, a release fraction, and an event frequency. The unit transport factor and unit risk factor consider the transport and harm caused by a unit release of radionuclides (i.e, one curie of each isotope). In this analysis, the unit transport factor and unit risk factor were combined in a total unit risk factor. The total risk is given by:

$$
R_{T}=\sum_{k=1}^{N} R_{k}=\sum_{k=1}^{N} p_{k}\left(\sum_{j} Q_{j k} * U R F_{j}\right) * R F_{k} * f_{k}
$$

where:

$$
\begin{aligned}
\mathrm{Q}_{\mathrm{jk}}= & \text { the quantity of the jth radionuclide, } \\
\mathrm{URF}_{\mathrm{j}}= & \text { the unit risk factor for the jth radionuclide and includes both the unit transport factor } \\
& \text { and the unit health factor, } \\
\mathrm{RF}_{\mathrm{k}} & =\text { the total release fraction, and } \\
\mathrm{f}_{\mathrm{k}} & =\text { the sequence frequency. }
\end{aligned}
$$

The quantity of radionuclides, $\mathbf{Q}_{\mathrm{jk}}$, was taken from the Integrated Risk Assessment Program tables for each facility and/or operation. The total release fractions for the air exposure pathway were also taken from the Integrated Risk Assessment Program analysis for gas, liquid, powder, dust and solids. 
New unit risk factors were calculated for an average member of the public and the calculational receptor at 0.5 kilometers in the direction of the largest $\chi / Q$. The unit risk factors presented in Table D. 2 for the average member of the public give the incremental increase in lifetime cancer for an average member of the population per Curie of radionuclide released to the atmosphere. The analysis of the unit risk factors was performed using population distributions and atmospheric joint frequency data for each of the four major areas at the Hanford Site. These data sets are based on recommendations in Recommended Environmental Dose Calculation Methods and Hanford-Specific Parameters (Schreckhise et. al 1993) for performance of radiological dose calculations at the Hanford Site. The unit risk factors were calculated using the U.S. Environmental Protection Agency radionuclide specific slope factors (EPA 1994). The unit risk factors are based on inhalation exposure and external exposure from material deposited on the ground. Other pathways are not included. The unit risk factors were evaluated using typical 90 th percentile parameter values and the average individual was assumed to be present for the full 70 -year lifetime. Thus, the unit risk factors represent a conservative estimate of the risk to an average member of the population.

The unit risk factors for the calculational receptor are given in Table D.3. The unit risk factors are presented for each of the four primary areas at the Hanford Site and for two downwind distances from the release point ( 0.5 kilometers and 1.0 kilometers). The only pathway included is exposure by inhalation of contaminated air. The location of the exposed receptor is at 0.5 kilometers and 1.0 kilometers in the direction of the maximum $\chi / Q$ for each of the areas. The $\chi / Q$ values were based on Schreckhise et al. (1994) for ground-level releases.

Table D.2. Unit Risk Factors for Population Exposures

\begin{tabular}{|l|c|c|c|c|}
\hline & \multicolumn{3}{|c|}{ Unit Risk Factors (Increased Cancer Incidents/Ci Released) } \\
\hline Radionuclide & 100 Area & 200 Area & 300 Area & 400 Area \\
\hline Co-60 & $1.7 \mathrm{e}-09$ & $2.2 \mathrm{e}-09$ & $8.8 \mathrm{e}-09$ & $5.4 \mathrm{e}-09$ \\
\hline Sr-90 & $7.9 \mathrm{e}-11$ & $1.1 \mathrm{e}-10$ & $4.1 \mathrm{e}-10$ & $2.7 \mathrm{e}-10$ \\
\hline Y-90 & $5.4 \mathrm{e}-12$ & $7.4 \mathrm{e}-12$ & $2.8 \mathrm{e}-11$ & $1.8 \mathrm{e}-11$ \\
\hline Cs-137 & $1.2 \mathrm{e}-09$ & $1.6 \mathrm{e}-09$ & $6.3 \mathrm{e}-09$ & $3.9 \mathrm{e}-09$ \\
\hline Pu-238 & $3.8 \mathrm{e}-08$ & $5.2 \mathrm{e}-08$ & $2.0 \mathrm{e}-07$ & $1.3 \mathrm{e}-07$ \\
\hline Pu-239 & $3.7 \mathrm{e}-08$ & $5.1 \mathrm{e}-08$ & $1.9 \mathrm{e}-07$ & $1.3 \mathrm{e}-07$ \\
\hline $\mathrm{Pu}-240$ & $3.7 \mathrm{e}-08$ & $5.1 \mathrm{e}-08$ & $1.9 \mathrm{e}-07$ & $1.3 \mathrm{e}-07$ \\
\hline $\mathrm{Pu}-241$ & $2.3 \mathrm{e}-10$ & $3.1 \mathrm{e}-10$ & $1.2 \mathrm{e}-09$ & $7.6 \mathrm{e}-10$ \\
\hline $\mathrm{Am}-241$ & $3.1 \mathrm{e}-08$ & $4.3 \mathrm{e}-08$ & $1.6 \mathrm{e}-07$ & $1.1 \mathrm{e}-07$ \\
\hline
\end{tabular}


Table D.3. Unit Risk Factors for the Calculational Receptor at $0.5 \mathrm{~km}$ and $1.0 \mathrm{~km}$ From Source

\begin{tabular}{|c|c|c|c|c|c|}
\hline & \multicolumn{5}{|c|}{ Unit Risk Factors (Increased Cancer Incidents $/ \mathrm{Ci}$ Released) for Receptor at $0.5 \mathrm{~km}$} \\
\hline Radionuclide & $\begin{array}{c}100 \text { Area } \\
0.5 \mathrm{~km} \text { East }\end{array}$ & $\begin{array}{c}200 \text { Area } \\
0.5 \mathrm{~km} \text { ESE }\end{array}$ & $\begin{array}{c}300 \text { Area } \\
0.5 \mathrm{~km} \text { North }\end{array}$ & $\begin{array}{c}400 \text { Area } \\
0.5 \mathrm{~km} \text { North }\end{array}$ & Average \\
\hline Sr-90 & $3.7 \mathrm{e}-07$ & $3.0 \mathrm{e}-07$ & $2.2 \mathrm{e}-07$ & $1.2 \mathrm{e}-07$ & $2.5 \mathrm{e}-07$ \\
\hline Y-90 & $6.2 \mathrm{e}-08$ & $5.1 \mathrm{e}-08$ & $3.7 \mathrm{e}-08$ & $2.1 \mathrm{e}-08$ & $4.3 e-08$ \\
\hline Cs-137 & $1.2 \mathrm{e}-07$ & $9.7 e-08$ & $7.1 \mathrm{e}-08$ & $4.0 \mathrm{e}-08$ & $8.2 \mathrm{e}-08$ \\
\hline Pu-238 & $1.7 \mathrm{e}-04$ & $1.4 \mathrm{e}-04$ & $1.0 \mathrm{e}-04$ & $5.7 e-05$ & $1.2 \mathrm{e}-04$ \\
\hline Pu-239 & $1.7 \mathrm{e}-04$ & $1.4 \mathrm{e}-04$ & $1.0 \mathrm{e}-04$ & $5.8 \mathrm{e}-05$ & $1.2 \mathrm{e}-04$ \\
\hline Pu-240 & $1.7 \mathrm{e}-04$ & $1.4 \mathrm{e}-04$ & $1.0 \mathrm{e}-04$ & $5.8 e-05$ & $1.2 \mathrm{e}-04$ \\
\hline Pu-241 & $1.8 \mathrm{e}-06$ & $1.4 \mathrm{e}-06$ & $1.0 \mathrm{e}-06$ & $5.9 e-07$ & $1.2 \mathrm{e}-06$ \\
\hline \multirow[t]{2}{*}{$\mathrm{Am}-241$} & $2.4 \mathrm{e}-04$ & $2.0 \mathrm{e}-04$ & $1.4 \mathrm{e}-04$ & $8.0 e-05$ & $1.7 e-04$ \\
\hline & \multicolumn{5}{|c|}{ Unit Risk Factors (Increased Cancer Incidents $/ \mathrm{Ci}$ Released) for Receptor at $1.0 \mathrm{~km}$} \\
\hline Radionuclide & $\begin{array}{l}100 \text { Area } \\
1.0 \mathrm{~km} \text { East }\end{array}$ & $\begin{array}{c}200 \text { Area } \\
1.0 \mathrm{~km} \text { ESE }\end{array}$ & $\begin{array}{c}300 \text { Area } \\
1.0 \mathrm{~km} \text { North }\end{array}$ & $\begin{array}{c}400 \text { Area } \\
1.0 \mathrm{~km} \text { North }\end{array}$ & Average \\
\hline Sr-90 & $1.1 \mathrm{e}-07$ & $8.7 e-08$ & $6.5 \mathrm{e}-08$ & $5.1 \mathrm{e}-08$ & $7.8 e-08$ \\
\hline Y-90 & $1.8 \mathrm{e}-08$ & $1.4 \mathrm{e}-08$ & $1.1 \mathrm{e}-08$ & $8.5 e-09$ & $1.3 e-08$ \\
\hline Cs- 137 & $3.5 \mathrm{e}-08$ & $2.8 \mathrm{e}-08$ & $2.1 \mathrm{e}-08$ & $1.6 \mathrm{e}-08$ & $2.5 e-08$ \\
\hline $\mathrm{Pu}-238$ & $5.0 \mathrm{e}-05$ & $4.0 \mathrm{e}-05$ & $3.0 \mathrm{e}-05$ & $2.4 \mathrm{e}-05$ & $9.0 e-05$ \\
\hline Pu-239 & $5.1 \mathrm{e}-05$ & $4.1 e-05$ & $3.0 \mathrm{e}-05$ & $2.4 \mathrm{e}-05$ & $3.7 e-05$ \\
\hline $\mathrm{Pu}-240$ & $5.1 e-05$ & $4.1 e-05$ & $3.0 \mathrm{e}-05$ & $2.4 e-05$ & $3.7 e-05$ \\
\hline $\mathrm{Pu}-241$ & $5.1 e-07$ & $4.1 e-07$ & $3.1 \mathrm{e}-07$ & $2.4 \mathrm{e}-07$ & $3.7 e-07$ \\
\hline Am-241 & $7.1 \mathrm{e}-05$ & $5.6 e-05$ & $4.2 \mathrm{e}-05$ & $3.3 e-05$ & $5.1 \mathrm{e}-05$ \\
\hline
\end{tabular}

Note that for each radionuclide listed in Table D.3, the unit risk factors for each of the four Hanford Site areas are within the same order of magnitude for both receptor locations. Therefore, an average unit risk factor for the four areas can be used causing the results to be independent of the radionuclide source location. A calculational receptor at a distance of $0.5 \mathrm{~km}$ was chosen for comparative purposes because the exact future location of the public relative to the radionuclide sources is unknown.

An event frequency was developed based on a simple event tree that considered the initiating event frequency, the ability of the energy source to disperse material, and the number and condition of available barriers. The initiating event frequencies for natural phenomena events were taken from Appendix A of the Integrated Risk Assessment Program study. A sample of the simple event tree is shown in Figure D.3. The initiating event frequency is shown as equal to one in Figure D.3; 


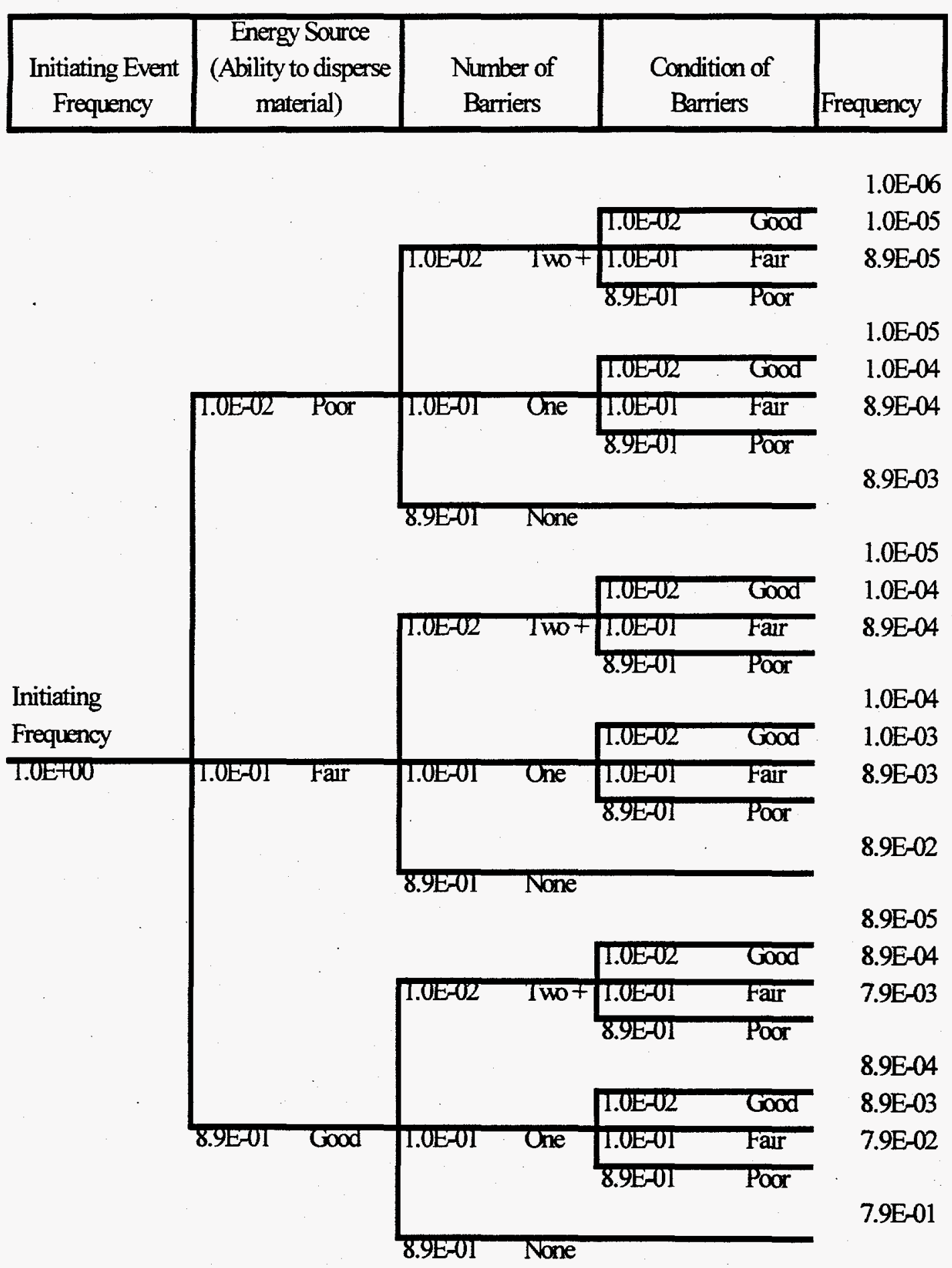

Figure D.3. Event Tree Used to Develop Event Frequencies.

D.9 
however, in the analysis the actual initiating event frequency was used instead. The branch point probabilities in Figure D.3 are complementary (i.e., add to one), even though the number of significant figures may suggest otherwise.

\section{D.2.4 U. S. Department of Energy Nuclear Safety Policy Criteria}

The U. S. Department of Energy (DOE) Nuclear Safety Policy (DOE 1991) was used as the basic criterion of acceptable risk. A single accident frequency-consequence risk acceptance criterion was developed (Muhlestein 1995) from DOE (1991). The risk acceptance criterion used as a basis the safety goal relative to allowable increased cancer incidences for members of the public from operation of DOE facilities.

The safety goal is an annual average increase of latent cancer fatalities from the DOE activities of less than $2 \times 10^{-6}$ latent cancer fatalities per year for members of the public. In the development of the risk acceptance criteria it was assumed that the consequences of a finite set of accidents could be represented by a lognormal distribution. It should be noted that the form of the distribution used is not important; rather, a defined distribution was used to simplify the calculations. The consequences were ranked ordered and then a complementary cumulative distribution function was developed from the consequence distribution. The complementary cumulative distribution function represents the frequency per year of exceeding a specified consequence and the area under the complementary cumulative distribution function is equal to the total risk; therefore, the area under the complementary cumulative distribution function was normalized to be equal to the safety goal of $2 \times 10^{-6}$ latent cancer fatalities per year. The exceedance frequency was then converted to an event frequency. The result is an accident-by-accident risk acceptance criteria shown by the solid curve in the frequencyconsequence space in Figure D.4. If all of the event frequency-consequence pairs are below the risk acceptance criterion in Figure D.4, then the total risk will be less than the safety goal. The developed risk acceptance criterion provides a sufficient, but not necessary, limit for acceptable risks from individual accident sequences. That is, if all of the frequency-consequence pairs do not lie below the risk acceptance criteria the total risk may still be less than the safety goal; however, if all of the frequency-consequence pairs do lie below the risk acceptance criteria, then the total risk will be less than the safety goal.

\section{D.2.5 Results}

There are several important fundamental results that can be understood by considering the contributions to the total risk as illustrated in Equation D-6. First, the total risk is proportional to the unit risk factor which is a product of a unit transport factor and a unit health factor. The unit transport factor, which is proportional to the dispersion coefficients $(\chi / Q)$, decreases logarithmically with distance. Therefore, the risk to a receptor also decreases logarithmically with distance of the receptor from the source of radionuclides. That is, an order of magnitude increase in the distance will reduce the risk by an order of magnitude (linear on a log-log scale).

Second, the unit health factor is different for each radionuclide. From Tables D. 2 and D. 3 the radionuclides $\mathrm{Pu}-238, \mathrm{Pu}-239, \mathrm{Pu}-240$ and $\mathrm{Am}-241$ have the largest unit risk factors (from the unit 


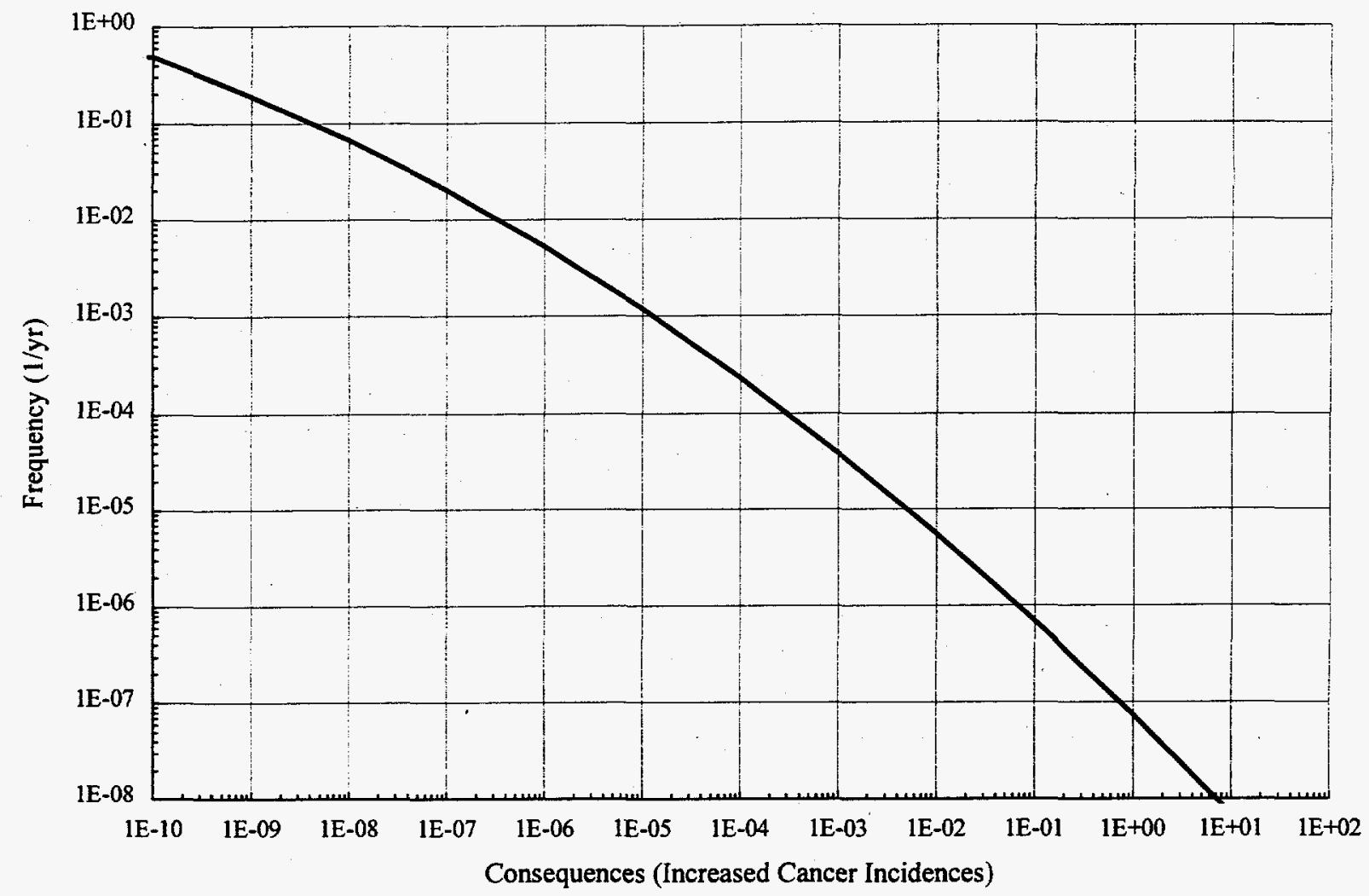

Figure D.4. Frequency-Consequence Space with Risk Acceptance Criterion

health factors) and would be expected to provide the largest contributions to the total risk, however, for the Hanford Site wastes the quantities of Cs-137, Sr-90 and Am-241 are such that the risk is dominated by the contributions from Cs-137, Sr-90, and Am-241.

Third, the total risk is directly proportional to the quantity of available radionuclides that can be released in an accident situation. . Decreasing the quantity of available radionuclides at risk decreases the risk proportionally. Specifically, the total risk is dominated by the quantity of Cs-137, Sr-90 and Am-241 that is available to be released.

Fourth, the total risk is directly proportional to the total release fraction. The release fraction varies from 1.0 for a gas, to $1 \times 10^{-3}$ for a liquid or powder, to $1 \times 10^{-6}$ for a solid. Therefore, the risk can be reduced by orders of magnitude depending on the form and/or dispersability of the material. This fact is important in defining potential intermediate remediation states. If the material can be transformed from a liquid or powder to an immobile solid, then the risk can be reduced by three orders of magnitude. 
Fifth, the total risk is also directly proportional to the frequency of the event that leads to the release of radionuclides. If the event frequency can be significantly reduced by either barriers or changing the potential energy sources, then the total risk can also be significantly reduced.

Using the modular risk analysis approach, the risks were calculated for each event sequence considered in the Integrated Risk Assessment Program analysis for each facility or operation. The risks were calculated for the following major facilities or operations in their present state.

- $\quad$ N Reactor fuel

- Waste Encapsulation and Storage Facility cesium and strontium capsules

- $\quad 324$ B cell debris

- $\quad$ Plutonium Finishing Plant

- PUREX

- Fast Flux Text Facility fuel

- Waste tanks

- 100 Area reactors

- B Plant

- REDOX

To analyze the results, the data from the individual accident sequences were graphed in the frequency-consequence space of the risk acceptance criteria (Figure D.4). An example is shown in Figure D.5 for the cesium and strontium capsules in the Waste Encapsulation and Storage Facility. The solid points in Figure D.5 are the individual accident frequency-consequence pairs. An ellipse was drawn on the figure to envelope and emphasize the risk dominant sequences, but does not contain all of the sequences. An ellipse, such as that shown in Figure D.5, will be used to represent the riskdominant accident sequences for an activity because it would be difficult to display and distinguish all data points for each facility on one figure. For each facility or activity analyzed the individual risk dominant accident frequency-consequence pairs are represented by an ellipse in the frequencyconsequence space of the risk acceptance criteria.

The results for each of the facilities are shown in Figure D.6. The largest contributors to the risk to an average member of the public are the $\mathrm{N}$ fuel stored in the $\mathrm{K}$ Basins, the cesium and strontium capsules stored in the Waste Encapsulation and Storage Facility, the debris in the 324 B cell and the safety high-level waste tanks. These facilities have not been listed in any specific order. These facilities provide the largest contribution to the risk because of the quantity of available radionuclides and their health effects and because the radionuclides are in changing or deteriorating facilities. The debris in the $324 \mathrm{~B}$ cell represents a significant contribution to the risk to an average member of the public because of the close proximity of the public to the 300 Area. The Plutonium Finishing Plant gloveboxes and ducts also represent a significant contribution to the public risk because of the quantity of plutonium and its toxicity. PUREX, the 100 Area reactors, B Plant, REDOX, Fast Flux Test Facility, and the non-safety high-level waste tanks contribute less to the public risk. Note that within the uncertainty of the calculations, the risk from each of the facilities is within the safety goal. 


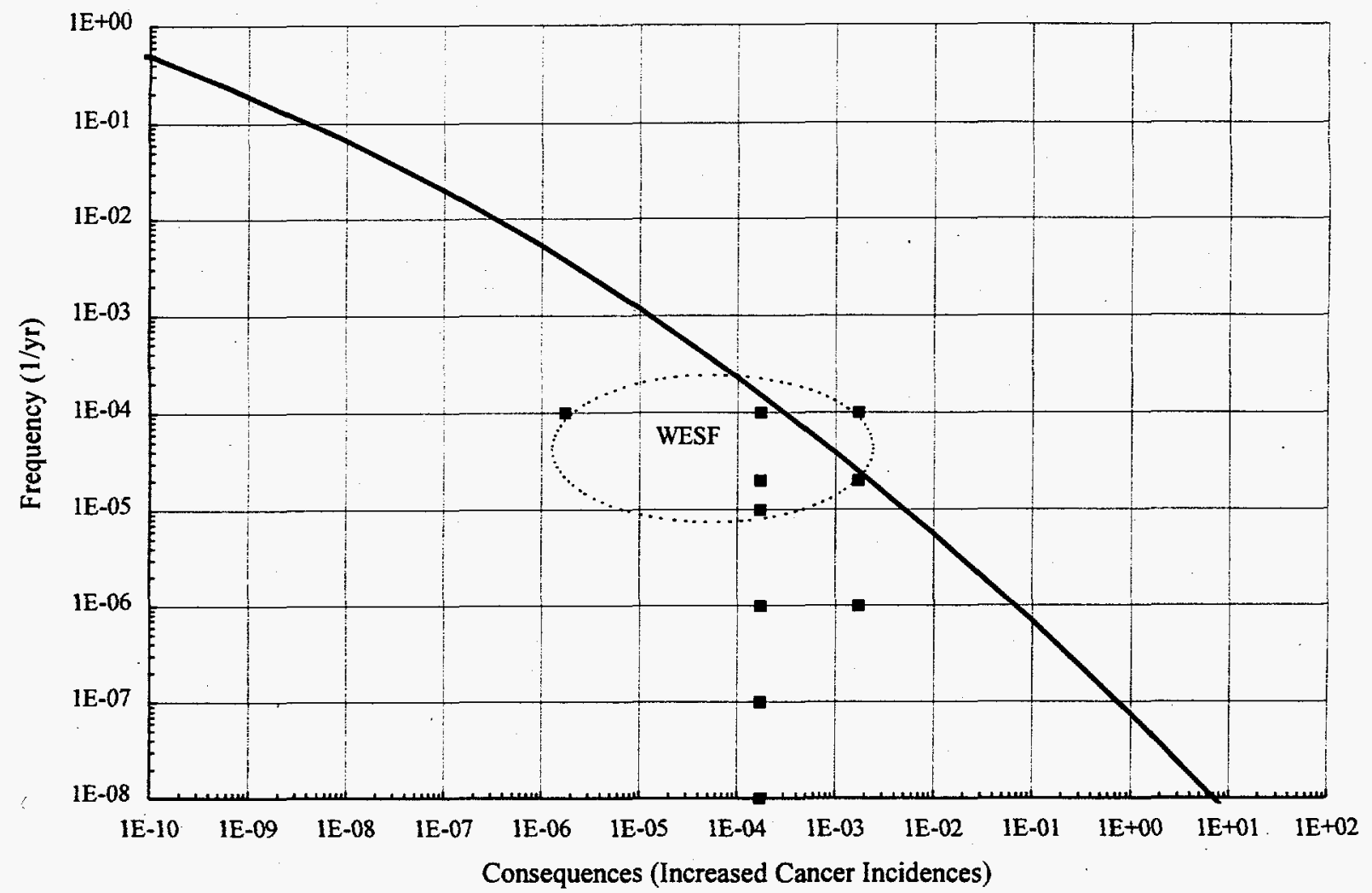

Figure D.5. Example of Risk Results for an Average Member of the Public (with present population distribution)

As noted, the risk to the average member of the public was calculated with the present Hanford Site area population distribution. Following remediation, it is not known where the public may reside relative to the radionuclide sources and the Hanford Site boundaries. For this reason, the calculational receptor was used in further analysis. The risk acceptance criterion for an average member of the public was conservatively applied to the calculational receptor. That is, the criterion used for the calculational receptor was that the increased cancer incidences from the DOE activities on the Hanford Site will not be more than $2 \times 10^{-6}$ latent cancer fatalities per year. Certainly this criterion is conservative because of the large difference in distance between the calculational receptor (at $0.5 \mathrm{~km}$ ) and an average member of the public (within $50 \mathrm{~km}$ ).

The contributions to the risk to the calculational receptor for the facilities and activities analyzed are shown in Figure D.7. The risk acceptance criterion used for the public was also used for the calculational receptor and is shown by the solid line in Figure D.7. Note there has been some relative shifting of the results in Figure D.6 relative to the results in Figure D.7 due to the relative location differences. It should not be construed from Figure D.7 that the present risks to the public are unacceptable, but, rather, if not remediated, the risks would be unacceptable to a future public residing on or closer to the Site. 


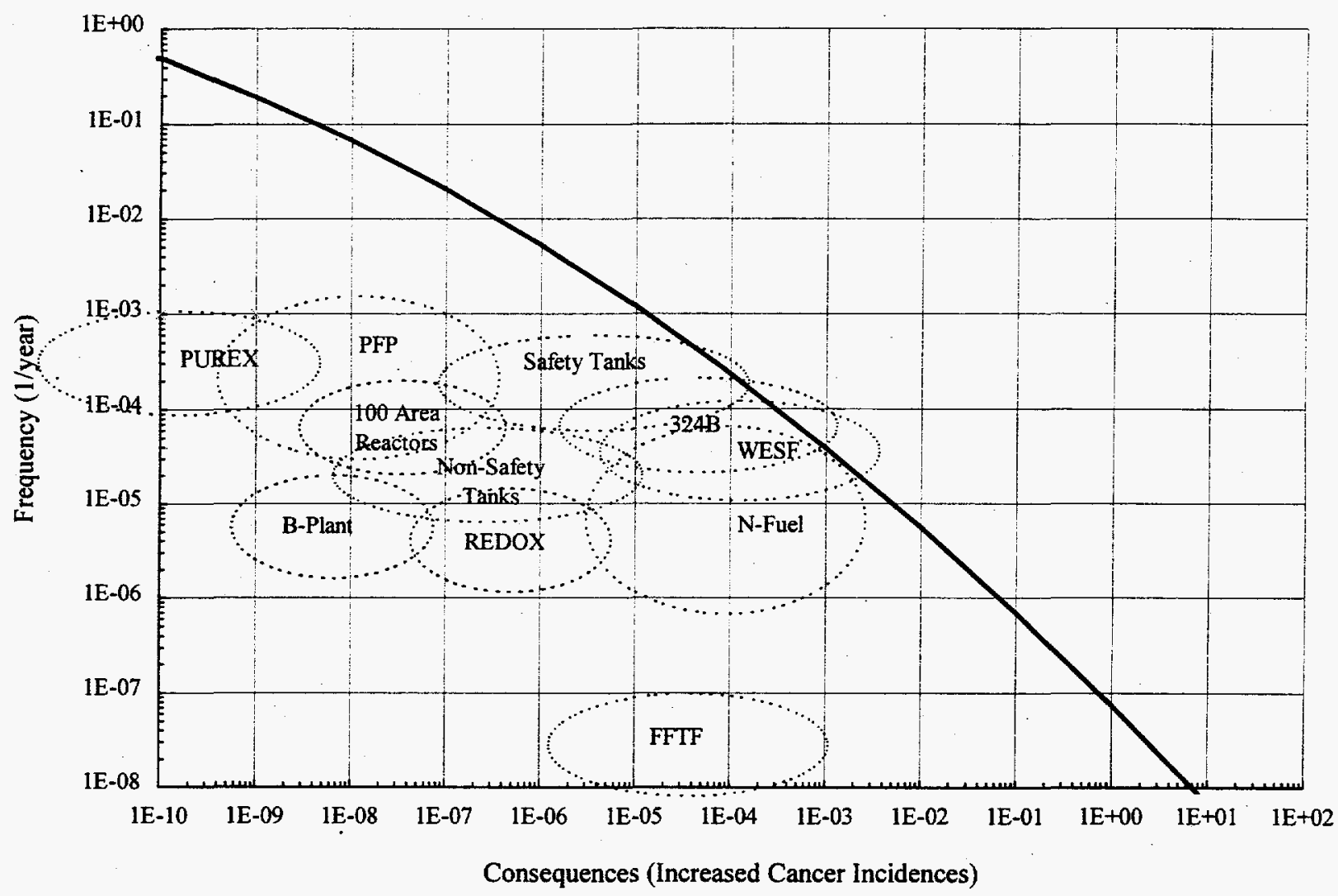

Figure D.6. Contributions to the Risk to an Average Member of the Public from Listed Activities or Facilities (present population distribution).

The same facilities or activities that provided the largest contributions to the risk to the public also provide the largest contributions to the risk to the calculational receptor. These facilities or activities, therefore, are those that must be considered first in reducing the risk from near-term hazards. Thus, the facilities or activities that contain the most significant hazards from radionuclide sources are as follows.

- $\quad \mathbf{N}$ fuel stored in the $\mathrm{K}$ Basins.

- Cesium and strontium capsules stored in Waste Encapsulation and Storage Facility.

- Debris stored in the 324 B cell.

- Safety high-level waste tanks.

- Plutonium in the Plutonium Finishing Plant.

\section{D.2.6 Cost-risk Benefit Analysis}

The most significant contributors to the risk from the near-term hazards have been identified along with the major elements that contribute to the risk. From this analysis one can identify those characteristics of a waste form in an intermediate remediation state that would provide the largest 


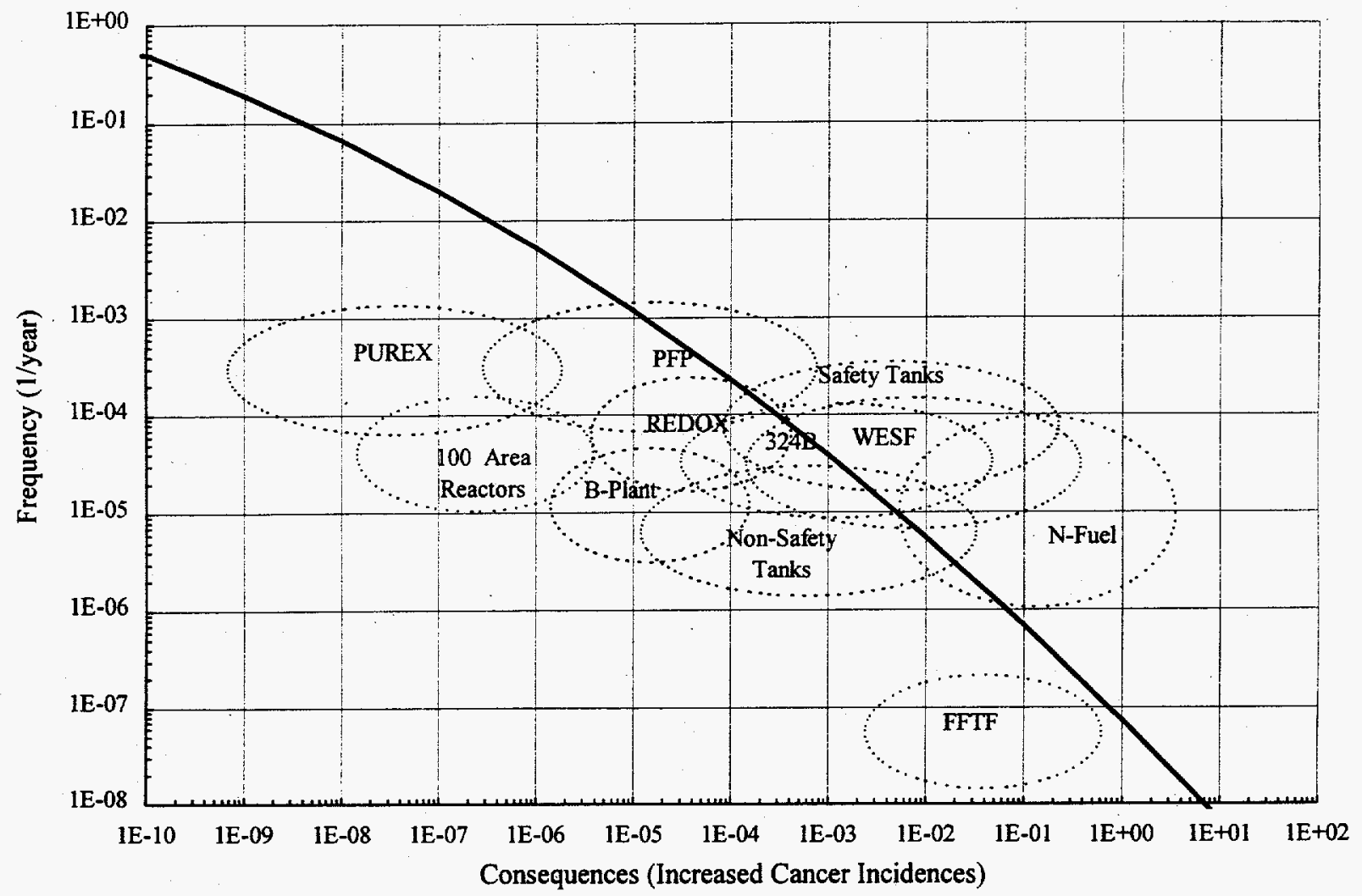

Figure D.7. Contributions to the Risk to the Calculational Receptor from Listed Activities or Facilities

reduction in the risk. It should be noted that the logarithmic decrease in risk with receptor distance from the radionuclide source is not a consideration because the public is assumed to be the same distance from all radionuclide sources. Those considerations that are possible in defining an appropriate intermediate remediation state are as follows. Since the risk is directly proportional to the quantity of available radionuclides that can be released in an accident situation, one consideration for an intermediate remediation state is a state where the quantity of Cs-137, Sr-90, Am-241, Pu-238, $\mathrm{Pu}-239$, and $\mathrm{Pu}-240$ has been eliminated. This situation would correspond to a state where the radionuclides were removed from the Hanford Site.

- $\quad$ Perhaps a more credible situation is one where the quantity of radionuclides that can be released has been reduced. This would correspond to reducing the total release fraction. Since the total risk is directly proportional to the total release fraction, an appropriate intermediate remediation state would be one where the form of the radionuclides has been changed to an immobile solid. 
- The risk can also be reduced significantly by reducing the likelihood of the radionuclides being released, or, in other words, reducing the event frequency. The event frequency can be reduced by either improved barriers, the number of barriers, or by changing the potential energy sources.

Thus, an appropriate intermediate remediation state would be one where the form of the material has been changed to an immobile solid and the material has been placed in effective barriers. Such a reduction in the contributions to the risk are shown in Figure D.8 where the dotted ellipses represent the present contributions to the total risk and the solid ellipses represent the contributions to the total risk once the radionuclides have been placed in an appropriate intermediate remediation states. It should be noted that an appropriate intermediate remediation state from a reduction in risk perspective may not be the same as an intermediate remediation state required because of other considerations, such as considerations for final disposal.

Assuming the waste can be placed in an intermediate remediation state where the radionuclides have been immobilized and placed in effective barriers, one can then evaluate the most cost-effective way to achieve a reduction in risk--the cost--benefit. The benefit is the reduced risk achieved by

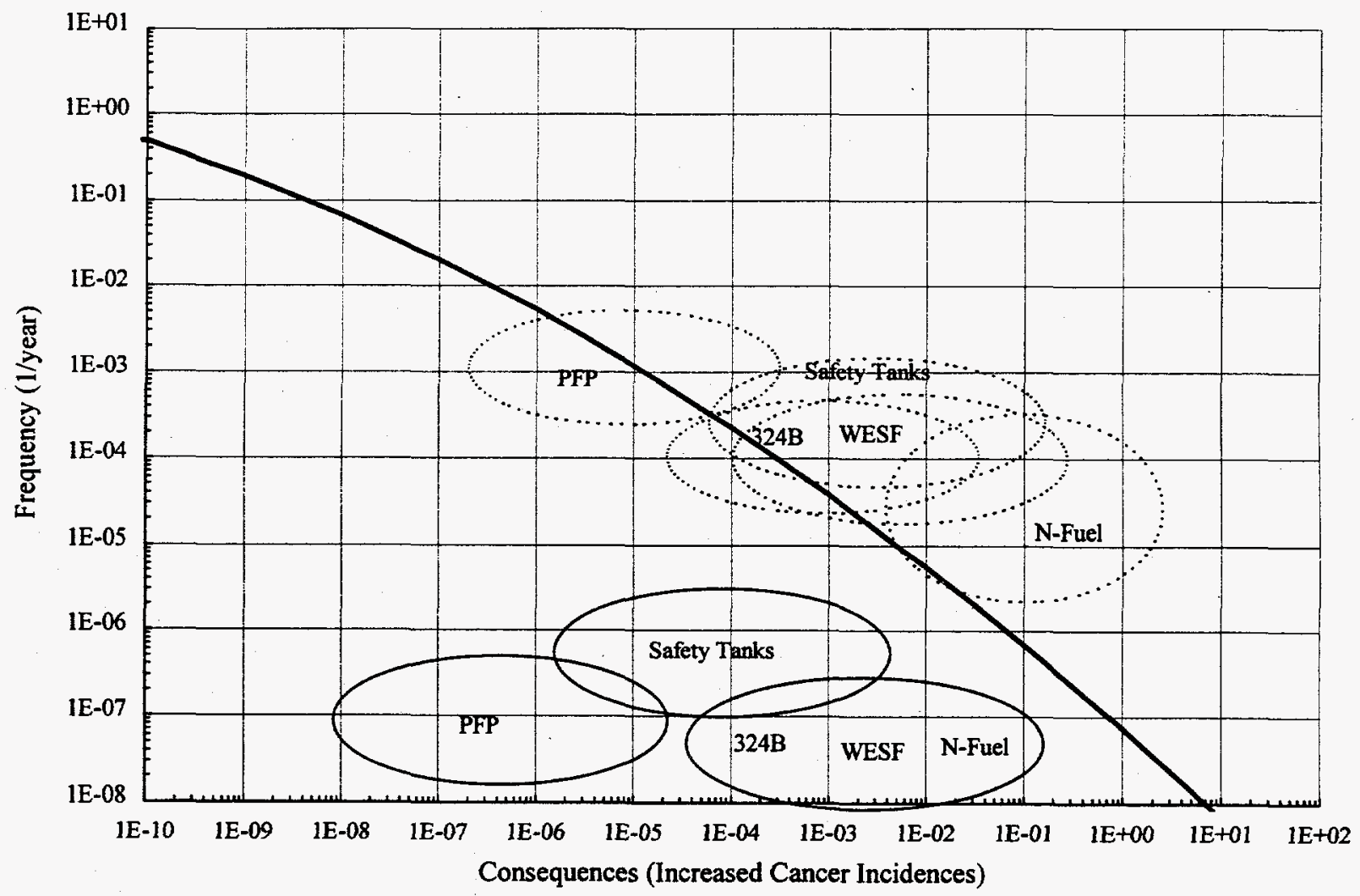

Figure D.8. Changes in the Contributions to the Risk to the Calculational Receptor by Choosing Acceptable Intermediate Remediation States 
placing the radionuclides in the intermediate remediation state. Consider an example where there are several potential intermediate states with reduced risk and potential costs. The costs required to achieve a specific risk reduction can then be compared as shown in Figure D.9. For example, State A costs 50 million dollars to achieve a risk reduction from $3 \times 10^{-5}$ latent cancer facilities per year to $1 \mathrm{x}$ $10^{-6}$ latent cancer fatalities per year. State B costs 75 million dollars to reduce the risk from $3 \times 10^{-5}$ latent cancer fatalities per year to $8 \times 10^{-7}$ latent cancer fatalities per year and then an additional 125 million dollars to further reduce the risk to $2 \times 10^{-7}$ latent cancer fatality per year. State $\mathrm{C}$ costs 400 million dollars to reduce the risk from $3 \times 10^{-5}$ latent cancer fatality per year to $1 \times 10^{-9}$ latent cancer fatality per year, and State $D$ costs 300 million dollars to reduce the risk from $3 \times 10^{-5}$ latent cancer fatality per year to $3 \times 10^{-7}$ latent cancer fatality per year.

Based on the safety goal, a risk less than $2 \times 10^{-6}$ latent cancer fatalities per year is acceptable so the reduced risk achieved by any of the intermediate states is permissible. From a risk perspective what is required is to reduce the public risk to acceptable levels. Consequently achieving the reduced risk of State A with an expenditure of 50 million dollars is acceptable; however, from a long-term waste disposal perspective there may be additional requirements with added costs that may further reduce the risk (for example State B or State C).

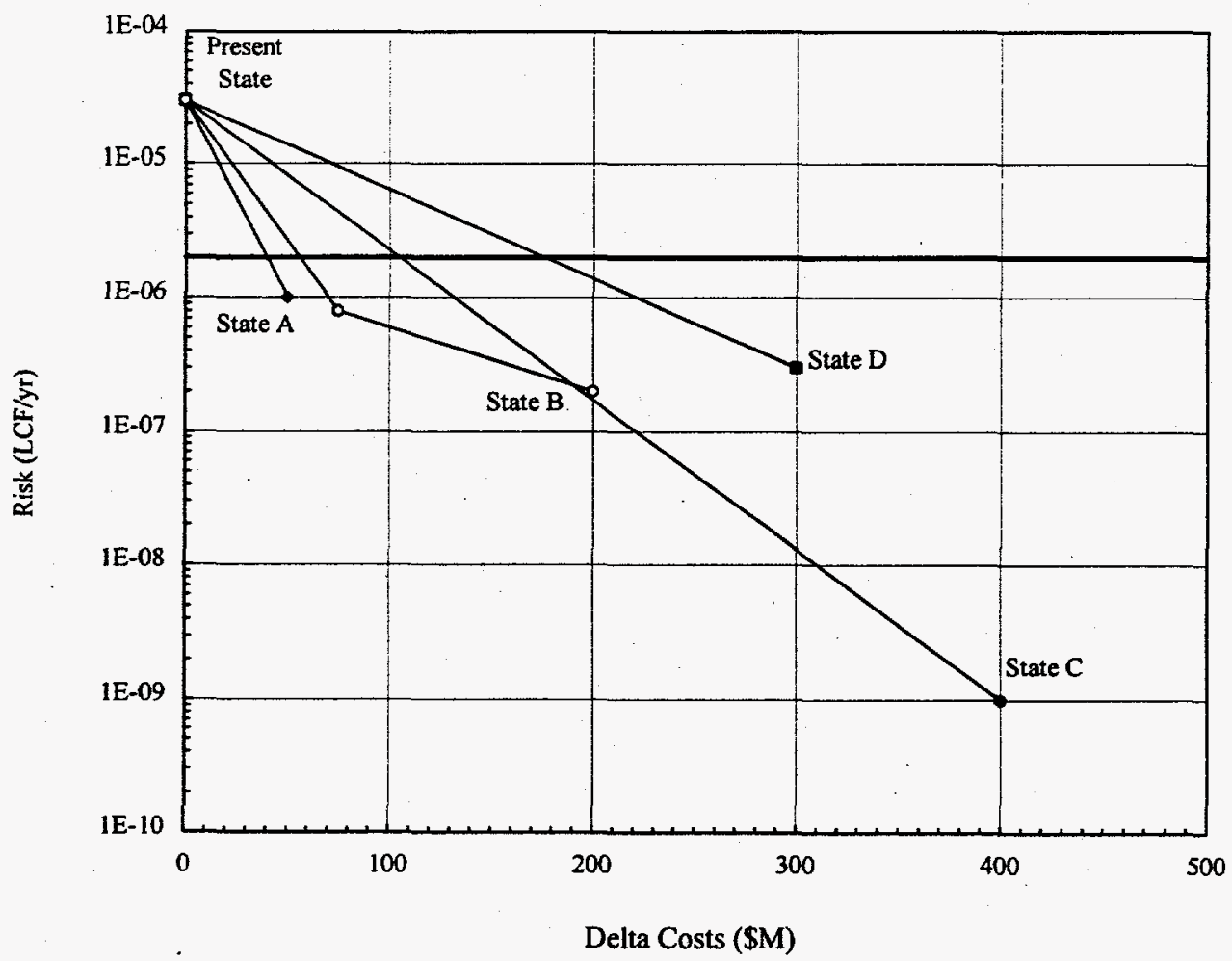

Figure D.9. Examples of Reduced Risk - Cost Evaluation 
A cost-benefit evaluation can also be completed for comparison of the effectiveness of different activities to reduce public risk; however, in this case it is important that the cost estimates have the same basis. In Figure D.10 the reduced risk for each of the intermediate remediation end states of the risk dominant activities is graphed as a function of the delta cost. In these cases the delta costs do not have the same basis so one needs to be careful in making comparisons. For example, the delta costs shown for the $\mathrm{N}$ fuel in the $\mathrm{K}$ Basins includes not only the cost of removing the fuel, but also the costs of passivation and preparations for long-term dry storage. This total cost would not be necessary to achieve the reduced risk state.

Note the present risk of the Plutonium Finishing Plant is below the safety goal. Therefore, any expenditure of funds to further reduce the risk must be considered from a cost-benefit perspective. There may be, of course, other reasons why the plutonium should be removed from the Plutonium Finishing Plant.

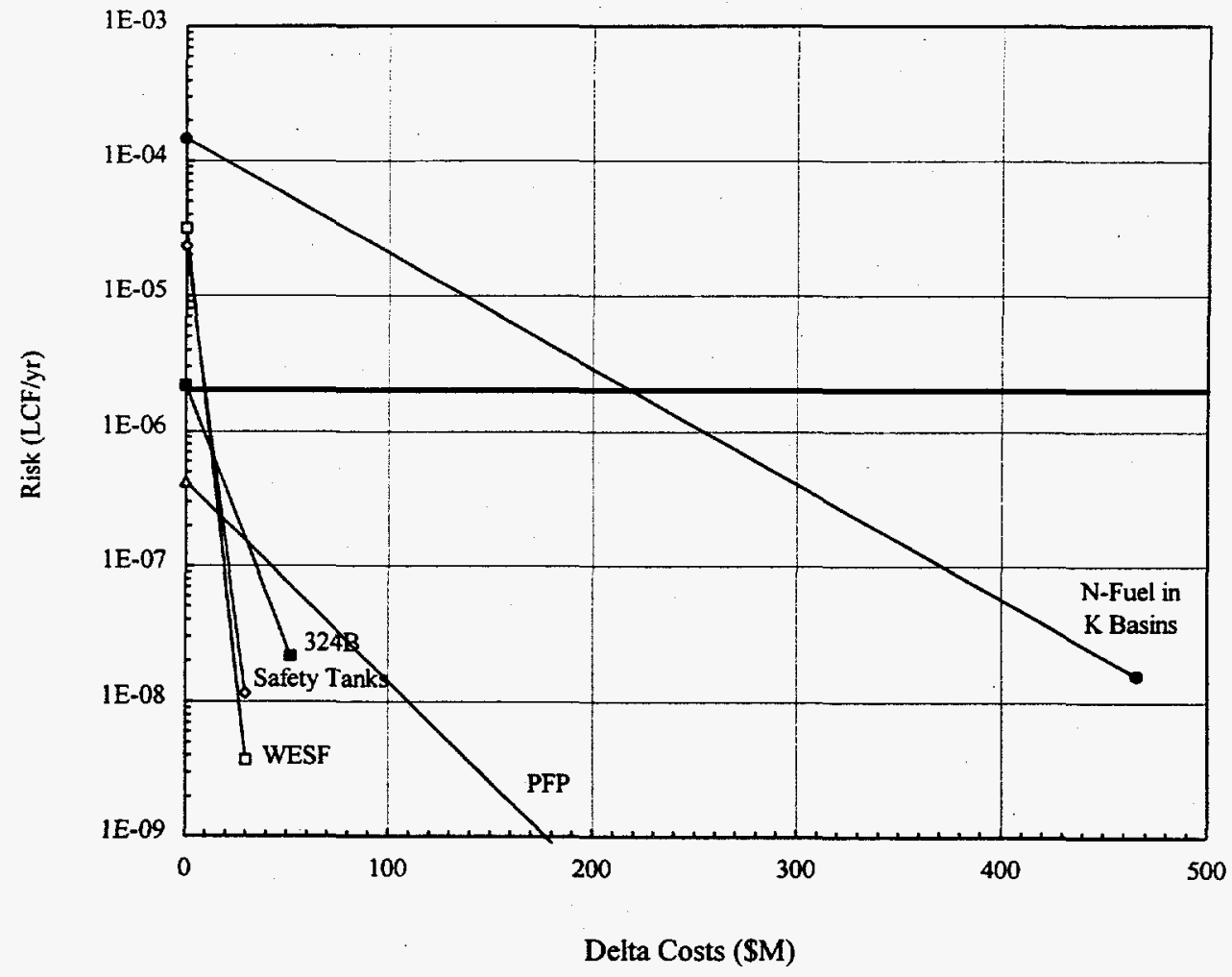

Figure D.10. Reduced Risk - Cost Considerations 


\section{D.2.7 Conclusions}

Several significant conclusions are possible from the near-term hazards analysis that are important in a risk-based strategy. They are as follows.

1) The most significant hazards to the public from radionuclide sources are the $\mathrm{N}$ fuel stored in the $\mathrm{K}$ Basins, the cesium and strontium capsules stored in the Waste Encapsulation and Storage Facility, the debris in the $324 \mathrm{~B}$ cell, the safety high-level waste tanks, and the plutonium in the Plutonium Finishing Plant.

2). An appropriate intermediate remediation state would be one where the form of the radionuclides has been changed to an immobile solid. For such a state the quantity of radionuclides that can be released has been reduced, thus reducing the total release fraction, and hence reducing the total risk.

3) The risk can also be reduced significantly by reducing the event frequency. Reducing the event frequency can be accomplished by improved barriers, the number of barriers, or by changing the potential energy sources.

4) Evaluating reduced risk versus the costs required to reduce the risk is an effective cost-benefit tool that can be used to evaluate various risk reduction alternatives and focus on the most cost-effective risk-reduction opportunities. Once the total risk has been reduced below the safety goal, further risk reduction should be considered based on other potential benefits.

\section{D.3 Work Place Hazards}

\section{D.3.1 Definition of Workplace Hazards}

Workplace hazards consist of the potential harm to which workers are exposed from radiological and hazardous chemical sources as well as potential accidents that do not involve radiological or chemical sources. This hazard category includes industrial (e.g., slips, falls, electrical accidents), radiological (external and internal dose), and chemical exposure (external and internal) hazards to which Hanford Site workers are currently exposed or could be exposed to in the future. This category includes routine workplace exposures to radiation and hazardous chemicals as well as accidents that would be confined to processing areas.

The key sources of current workplace hazards include the old reactors, canyon buildings, support facilities, $\mathrm{K}$ East Basin, $\mathrm{K}$ West Basin, and $\mathrm{N}$ Reactor. During remediation, the key hazard sources include deactivation and final dispositioning of the old facilities, new facility construction, and cleanup actions involving liquid wastes, buried solid wastes, contaminated soils, and special nuclear materials. Workplace hazards during the post-closure phase are not significant because only a small workforce, performing predominantly monitoring activities, would remain on-site.

The objectives of cleanup relative to workplace hazards are to protect workers from unacceptable risks and to implement remediation actions that minimize worker risks. With regard to the former 
objective, exposures to workplace hazards are controlled on an individual worker basis through procedures, training, and protective equipment. These administrative controls will remain an important aspect of worker safety in all phases of cleanup. With regard to the latter objective, it is recognized that an increase in short-term worker (and public) risk is necessary to achieve a reduction in longer-term worker and public risk. This fundamental tradeoff, which can be represented by the magnitude of the increase in worker risk relative to the public risk reduction achieved, should be considered in the decision process for selecting remediation actions.

\section{D.3.2 Exposure Pathways and Receptors}

The receptors referred to in this instance are Hanford Site workers. The important pathways include direct external radiation exposures, exposures to industrial-type accidents, and possibly exposures to airborne radioactive materials and hazardous chemicals. This analysis focuses primarily on industrial accidents and routine radiological exposures. Qualitative information on minor accidental releases to process areas is also presented. In general, hazardous chemical risks were not addressed.

In general, the current industrial hazards have resulted from deteriorating structural integrity of the old reactors, canyon buildings, and support facilities that are a threat to workers who perform surveillance, maintenance, and monitoring activities. ${ }^{\text {(a) }}$ The key radiological hazards result primarily from accumulation of radiologically contaminated materials on surfaces, piping, and equipment that represent external and internal exposure hazards to facility workers. During remediation, construction of new facilities and remediation activities in the old facilities and waste sites would tend to dominate the industrial hazards. Radiological hazards during remediation would be dominated by activities involving direct handling of radioactive materials.

For the most part, workplace hazards are increasing at the Hanford Site due to facility deterioration, equipment aging, loss of institutional knowledge, and spread of contamination. Facility deterioration increases workplace hazards because of the accompanying loss of structural strength and degradation of confinement and worker protection systems. Loss of institutional knowledge results from departure of workers who are familiar with sites and processes and their associated hazards. Contamination spread generally occurs slowly and builds over time to higher and higher levels.

\section{D.3.3 Analysis Process}

Traditional approaches were taken to calculate the worker risks associated with the various decisions. It should be noted that worker hazards are managed on an individual basis and are reduced through appropriate controls (e.g., individual radiation exposure limits), training and qualifications, and personnel protective equipment (e.g., safety harnesses, anti-contamination equipment). Individual workers would not be subjected to life-threatening conditions or activities without precautions being taken. Consequently, controlling workplace hazards can be viewed as a cost issue. For example, if radiation exposure rates are such that one or more persons would be exposed at their respective limits, additional personnel would be hired to supplement the work force. This may not appear as an increased risk to the individual workers because the radiation exposure limits are established at safe

(a) In fact, a fatality recently occurred when a worker fell through a degraded panel at an old reactor while preparing for maintenance work. 
levels, but it would appear as an increase in project cost.On the other hand, cumulative worker risks can be viewed as an indication of the level of hazards workers would be exposed to during an activity. Intuitively, construction of a one story building represents smaller workplace hazards than construction of a ten-story building of the same design. This is because far more labor hours are needed to construct the ten story building than the one story building, even though the activities, hazards, and individual controls are the same in both situations. This is an illustration of the accumulation concept used in this analysis to evaluate the differences in worker risks between options. Keep in mind that no single individual worker would be subjected to risks above the limits in place when the activities are being undertaken; however, the cumulative risks to the collective workforce will be used as a measure of workplace hazards for the various options.

Cumulative industrial hazards to workers are measured in terms of short-term traumatic fatalities associated with the various remediation options. Other aspects of short-term worker risks (e.g., cumulative injuries and lost work-days could also be evaluated, but this assessment focuses on fatalities. For the most part, the number of injuries and lost work-days would be proportional to the number of fatalities so no additional insights would be expected from estimating these other parameters. The cumulative projected industrial fatalities to workers for a given remediation action were calculated using the following general formula:

$$
\text { Cumulative fatalities }=\Sigma_{t} \Sigma_{l c} \quad(\text { staff } h r s)_{l c, t} \quad(\text { fatality rate })_{l c, t}
$$

where:

$$
\begin{aligned}
\mathrm{t} & =\text { subscript denoting time } \\
\mathrm{lc} & =\text { subscript denoting labor categories. }
\end{aligned}
$$

Using this formula allows the higher workplace hazards of certain labor categories or occupations to be weighted higher than those of less hazardous occupations. For example, truck drivers and laborers have higher occupational fatality rates than managers and surveyors, so the labor hours in the former categories would be weighted higher than those of the latter; however, the total industrial risk would be the sum of the risks to all job categories over the applicable time. This requires the labor estimate to complete remediation activities be separated into in the different job categories. In some cases, this information was available. In others, some simplifying assumptions were necessary, for example, to convert total project construction costs into total staff-hours and then convert total staffhours into staff-hours in the different job categories. These assumptions are specified where they occur.

Existing occupational radiation exposure estimates were used where they existed to characterize worker exposures for remediation activities. For example, occupational exposure estimates were available for $\mathrm{N}$ Reactor deactivation activities and were used in the assessment; however, there were many instances in which only estimates of staff-hours or rad-worker hours were available. For these cases, the cumulative projected occupational radiation exposures were calculated using a method similar to that used for industrial hazards. The general formula is:

$$
\text { Cumulative exposures }=\Sigma_{t}(\text { rad-worker hrs) })_{t} \text { (avg. exposure rate). }
$$


In this formula, a first-order estimate of the cumulative occupational exposures is calculated by summing the product of the number of staff-hours and average exposure rate.

It should be noted that the uncertainties in the estimates produced using these formulae and the uncertainties in the input data (e.g., staff-hours by job category, rad-worker hours) are relatively large. The only meaningful differences between the estimates are those that are orde0rs-of-magnitude. Smaller differences, such as factor of two or three or five, were judged to be insignificant; however, by evaluating the worker hazards on a common basis to the extent possible, it is believed than an order of magnitude difference in the estimates would represent a significant difference in worker risks.

\section{D.3.4 Risk Acceptance Criteria}

Worker risks are managed to acceptable levels on an individual basis. Acceptable individual worker risk criteria are specified in many regulations, including those promulgated by the Occupational Safety and Health Administration, U.S. Nuclear Regulatory Commission, U.S. Department of Transportation, U.S. Environmental Protection Agency, and the DOE. These regulations provide either expressed or implied individual exposure limits, which, if met, would limit all worker activities to acceptable risks. There are no criteria for the amount of increased worker risk that would be acceptable to achieve a reduction in public risk. Again, the increase in worker risks would be managed such that the individual risks are within the levels specified in the regulations (e.g., individual radiological exposure limits). Worker risk information could be used along with other elements (e.g., cost, public risk, schedule) as input to decisions relative to selection of remediation alternatives but should not be used to preclude alternatives on its own.

\section{D.3.5 Results}

Some key tradeoffs in which worker risks could be of sufficient magnitude to outweigh the potential public risk reduction benefit have been identified in this and other sections of this report. The worker risks associated with these fundamental tradeoffs and decisions were analyzed to provide preliminary quantitative input to decisions regarding the cleanup strategy. The fundamental tradeoffs are described below.

- Facility transition may be viewed as workplace hazard "mortgage reduction" similar to cost mortgage reduction. Deactivation activities that remove and stabilize contamination reduce the workplace hazards associated with maintaining facilities in a safe condition but require some increase in hazards to perform the deactivation.

- Leave versus retrieve tank wastes means a fundamental tradeoff exists between the worker risks of retrieval and treatment of tank wastes versus in-place disposal alternatives, such as in-situ vitrification and drying and gravel-fill concepts. Worker risk is generally lower for inplace disposal alternatives.

- $\quad$ Leave versus retrieve buried solid wastes, contaminated soil, and liquid disposal sites means a fundamental tradeoff exists between the worker risks of excavation and removal of these wastes versus continued monitoring and in-place disposal alternatives. With regard to these materials, another tradeoff exists between public risk targets for remediation and the worker 
risks necessary to achieve them. Two options are evaluated here: one that remediates to the extent that the incremental lifetime cancer risk resulting from these materials is $1 \mathrm{E}-04$ and the other to $1 \mathrm{E}-06$.

- Entombment versus demolition of old facilities means a tradeoff exists between the worker risks associated with decontamination and decommissioning of old facilities through entombment versus demolition. The former leaves a de-facto solid waste burial ground at the site of the old facility whereas the latter leaves little residual contamination at the site.

- Increase in worker risk to achieve public risk reduction means a tradeoff exists between the objective of public risk reduction and the increased worker risks necessary to achieve it.

The worker risk analyses illustrating these tradeoffs are presented in the following subsections.

\section{Worker Hazard "Mortgage Reduction"}

An analysis explored the concept of workplace hazard mortgage reduction in transition facilities. An example of this concept was developed for $\mathrm{N}$ Reactor, primarily because quantitative occupational exposure estimates were available for the deactivation activities (RL 1995 and Walsh 1994). An additional case was evaluated to explore the mortgage reduction for PUREX.

N Reactor Deactivation. Deactivation and stabilization of $\mathrm{N}$ Reactor are scheduled to be completed by 1997 . The key activities include: documentation of the remaining industrial, radiological and environmental hazards; removal of radioactive and mixed wastes; stabilization of contaminated surfaces; and cleanup of the fuel storage basin. The data used to derive estimates and the results of the industrial and routine radiological exposure hazard calculations for deactivation of $\mathrm{N}$ Reactor relative to those of maintaining the current state (no-deactivation) are presented in the following subsections. A qualitative assessment of worker risks from process-related accidents is also presented.

Industrial Accidents. Industrial hazards estimates for the $\mathrm{N}$ Reactor deactivation and nodeactivation cases were calculated based on the annual cost estimates derived in Appendix $\mathrm{H}$. A number of assumptions were required to convert the annual costs into staff-hours in different labor categories (e.g., surveillance and maintenance, project management). These assumptions are provided below:

- Staff-labor charges were assumed to be 56 dollars per hour, including overheads.

- The labor charges were assumed to be broken into the following three components: 60 percent labor, 30 percent overheads, and 10 percent utilities and services.

- Where only total annual costs were available for surveillance and maintenance activities, it was assumed that 10 percent of the total costs were for program management and 90 percent were due to surveillance and maintenance costs.

The remaining data needed to calculate the industrial hazards are the fatality rates by labor category. National Safety Council data were used to represent the occupational fatality rates 
(NSC 1994). Program management and supervision activities were represented by the "Services" category in the National Safety Council data, which amounted to 1.67E-08 fatalities per staff-hour. For surveillance and maintenance activities, the "All Industries" category was used, which was 4.44E-08 fatalities per staff-hour. Deactivation activities were assigned to the "Construction" labor category, amounting to $1.22 \mathrm{E}-07$ fatalities per staff-hour. Although these fatality rates may not precisely reflect the types of work being performed by the different labor categories, the relative magnitudes were judged to be adequate to represent differences in job-related hazards across the labor categories.

The results of the industrial hazard calculations for $\mathrm{N}$ Reactor deactivation are presented in Figures D.11a and D.11b. Figure D.11a shows the annual projected fatalities for the deactivation and no-deactivation (continue current active management activities) cases. Note that, for the deactivation case, there is a relatively steep increase in projected fatalities resulting from deactivation activities followed by a steep drop and then a long period of lower annual fatalities. The no-deactivation case, which starts in 1995 assuming that $\mathrm{N}$ Reactor is taken to its "minimum-operations level" defined in Appendix C by 1996, is flat after 1996 at a level substantially higher than the level period for the deactivation case.

Figure D.11b shows the cumulative industrial hazards for both cases. As shown, cumulative industrial hazards for the deactivation case are initially higher than the no-deactivation case, are equal to each other in about 2004 , and thereafter the cumulative worker risks for the deactivation case are always lower than the no-deactivation case. The "pay-back" time for worker risks occurs in about 2004. Again, it must be stressed that the purpose of this analysis was to illustrate trends. The actual values used to create the curves have large uncertainties; however, the general trends are valid because the evaluation of the two cases was performed in a consistent manner. Based on the general trend illustrated in Figure D.11b it appears that deactivation of the major facilities would be favored over maintaining current active risk management activities.

Routine Radiological Exposures. Radiological exposure estimates were developed for surveillance, maintenance, and monitoring staff using the labor-hours discussed above. Exposure estimates calculated in the $N$-Reactor Deactivation Program Plan (Walsh 1994) were used to characterize the actual deactivation activities. The key dose-producing activities were determined to be removal and packaging of irradiated fuel spacers from silos and $\mathrm{N}$ Basin cleanout. The total occupational exposures from $N$ Reactor deactivation were estimated in Walsh (1994) to be about 172 person-rem.

To convert from total staff-hours per year to total rad-worker hours per year, a 40 percent factor was used. The rest of the time (60 percent) was assumed spent in nonradiation or low-exposure areas, such as the time spent in training, change rooms, lunch rooms, and outdoors.

The average exposure rate was assumed to be about 1E-04 person-rem per person-hour spent in radiation zones for the pre-deactivation doses and 5E-05 person-rem per person-hour for postdeactivation activities. The former was derived from an estimated annual maximum exposure rate for individuals of 200 millirem per person per year divided by 2000 person-hours/person-year ( 50 weeks/year times 40 hours/week). The latter was derived by dividing the pre-deactivation exposure rate by two to account for the lower overall exposure rates in the deactivated facility. This 


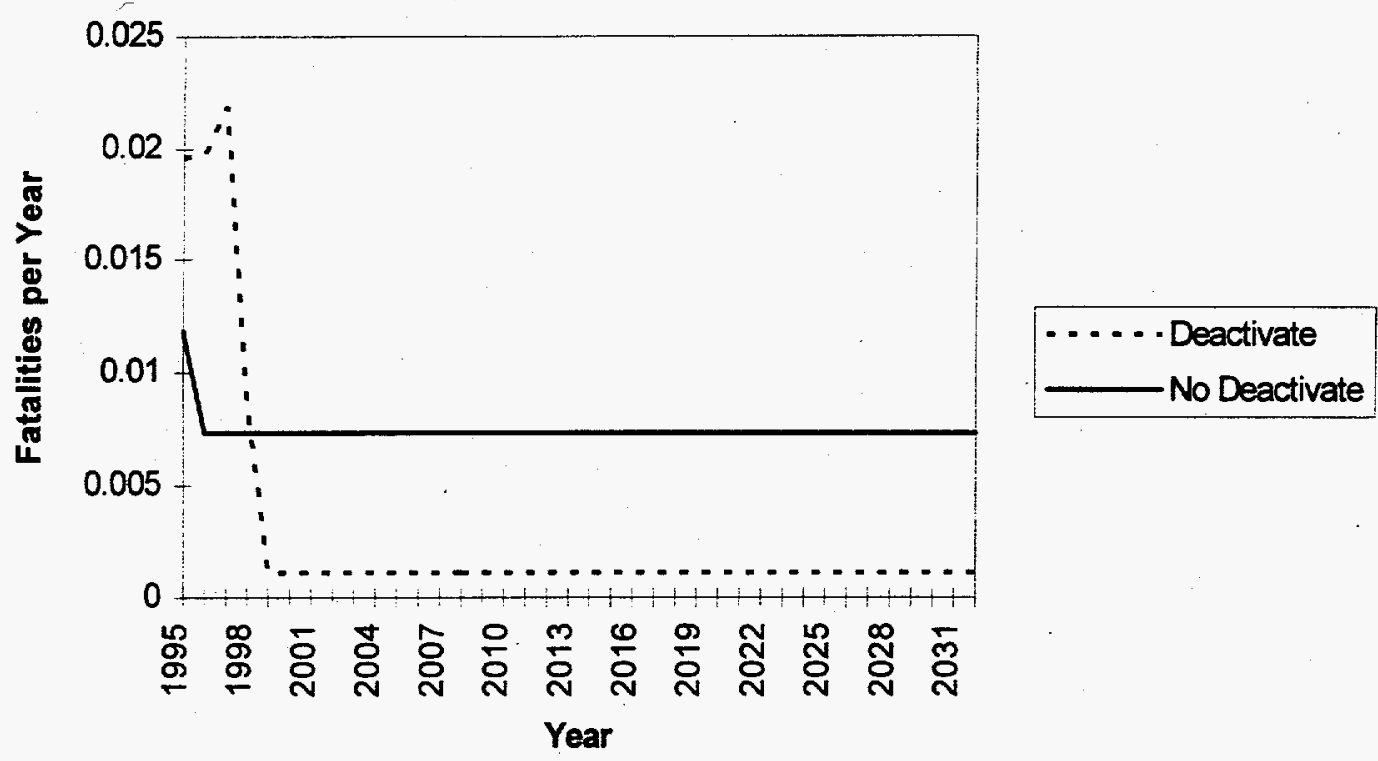

Figure D.11a. Annual Industrial Hazards for N Reactor Deactivation

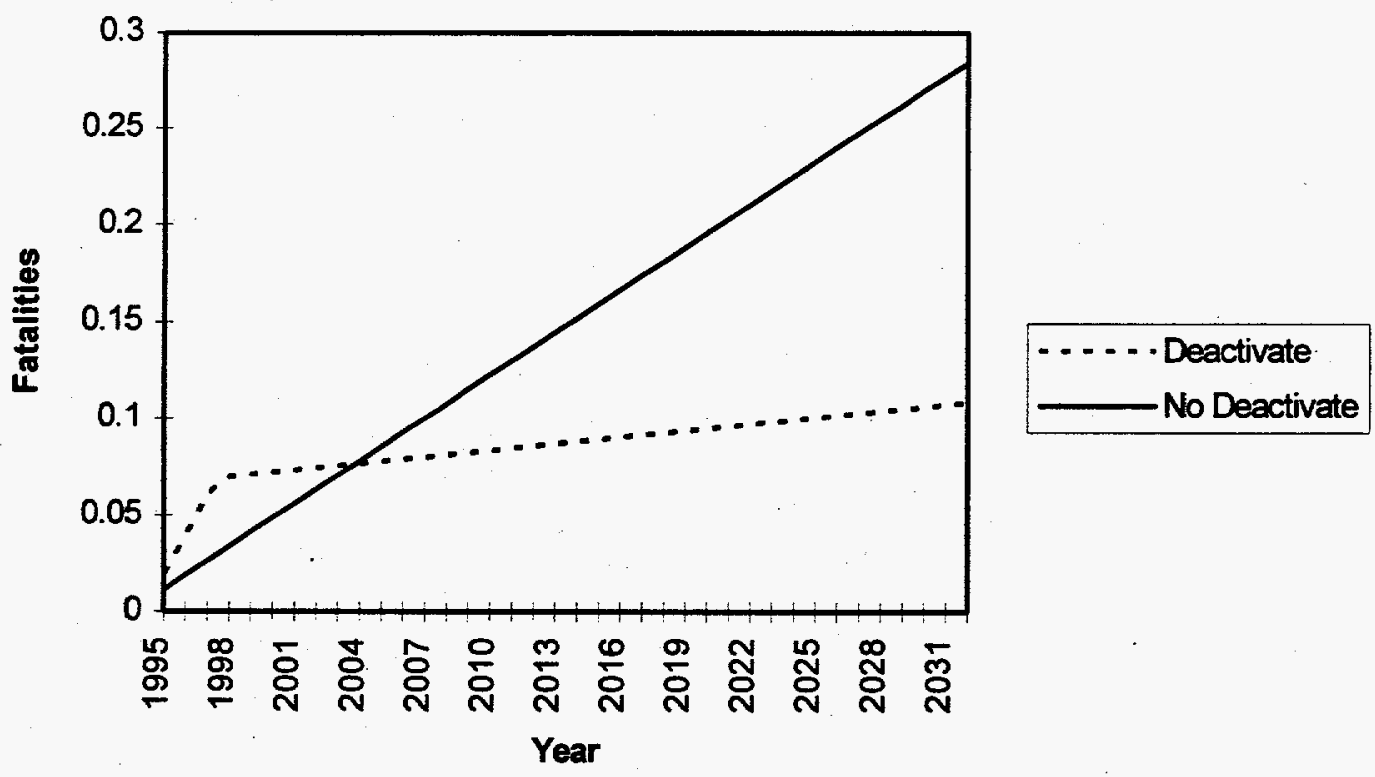

Figure D.11b. Cumulative Industrial Hazards for N Reactor Deactivation 
is believed to be conservative (i.e., understates the actual exposure reduction) as the overall exposure rates in most areas would be reduced by more than a factor of two, particularly when $\mathrm{N}$ Basin cleanout is completed.

The results of this evaluation are illustrated in Figures D.12 and D.13. Figure D.12 presents the annual exposure estimate by year for the deactivation and no-deactivation cases for $\mathrm{N}$ Reactor. Note a relatively large increase in exposures in the first three years of the deactivation case followed by a large reduction corresponding to the minimal surveillance and maintenance doses following deactivation. Figure D.13 shows the cumulative exposures over time for both cases. As shown, the "pay-back" time for the deactivation case occurs in about 2022. This is longer than the pay-back period for industrial hazards, primarily because the radiological exposures hazards for deactivation are significant relative to the current state whereas the industrial hazards, though greater during the deactivation period, are less significant relative to the current industrial hazards at $\mathbf{N}$ Reactor.

Process Accidents Involving Radiological and Chemical Materials. Based on the preceding discussion, the effort and expense to deactivate $\mathrm{N}$ Reactor are more than paid back in terms of reduced industrial hazards and radiological routine exposures. Following the logic presented for the former two elements of worker risk, the process accident element would also be paid back in the relatively near term, unless there is a large disparity in the process accident risks associated with deactivation versus continued active management. For process accidents, the pay-back period would be longer if the deactivation hazards are much larger than those for the existing risk management activities and shorter if deactivation activities represent only a small increase in worker risks relative to current activities. The long-term surveillance and maintenance hazards would be smaller for the deactivation case.

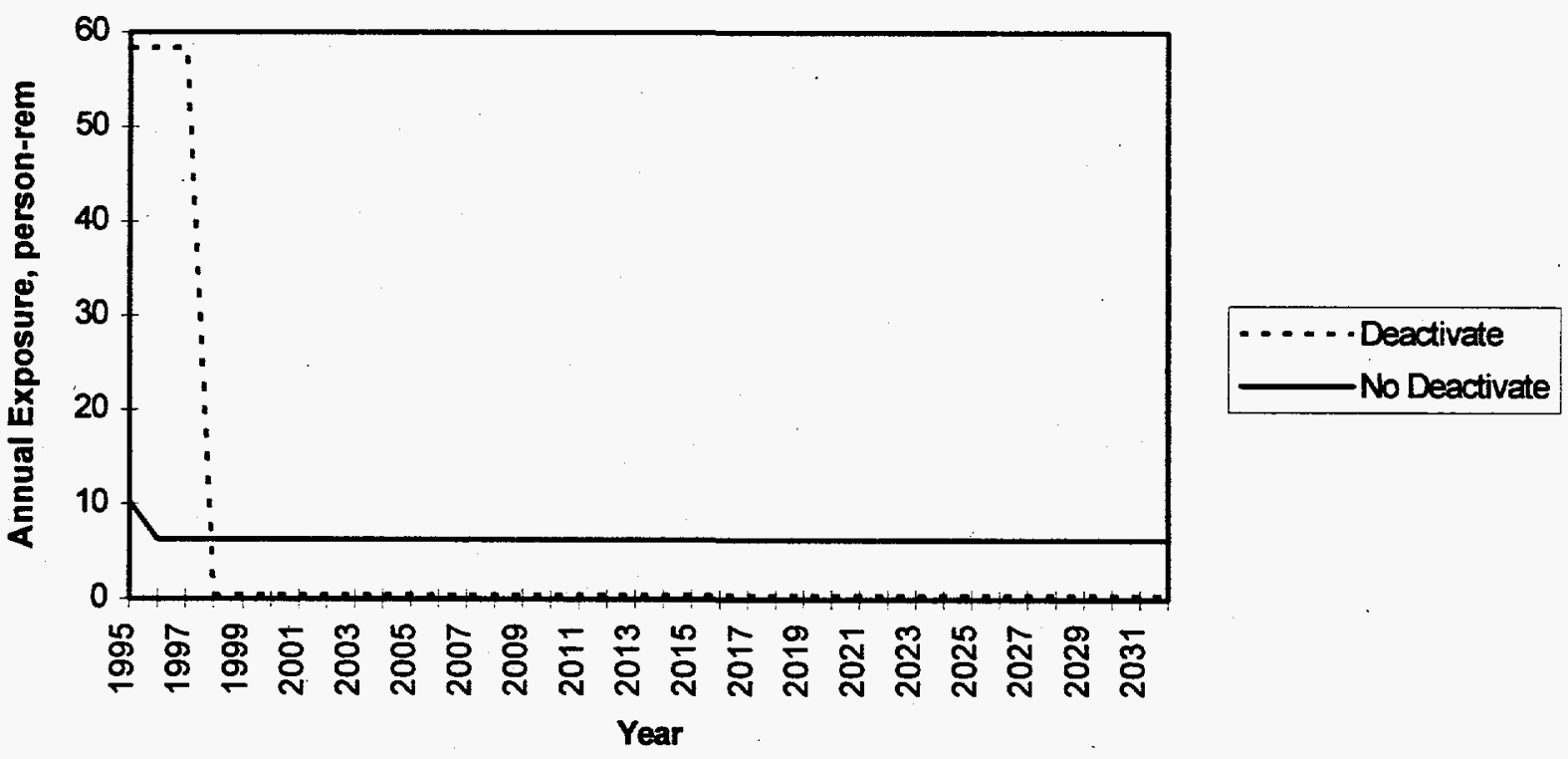

Figure D.12. Annual Routine Radiological Exposures for N Reactor Deactivation 


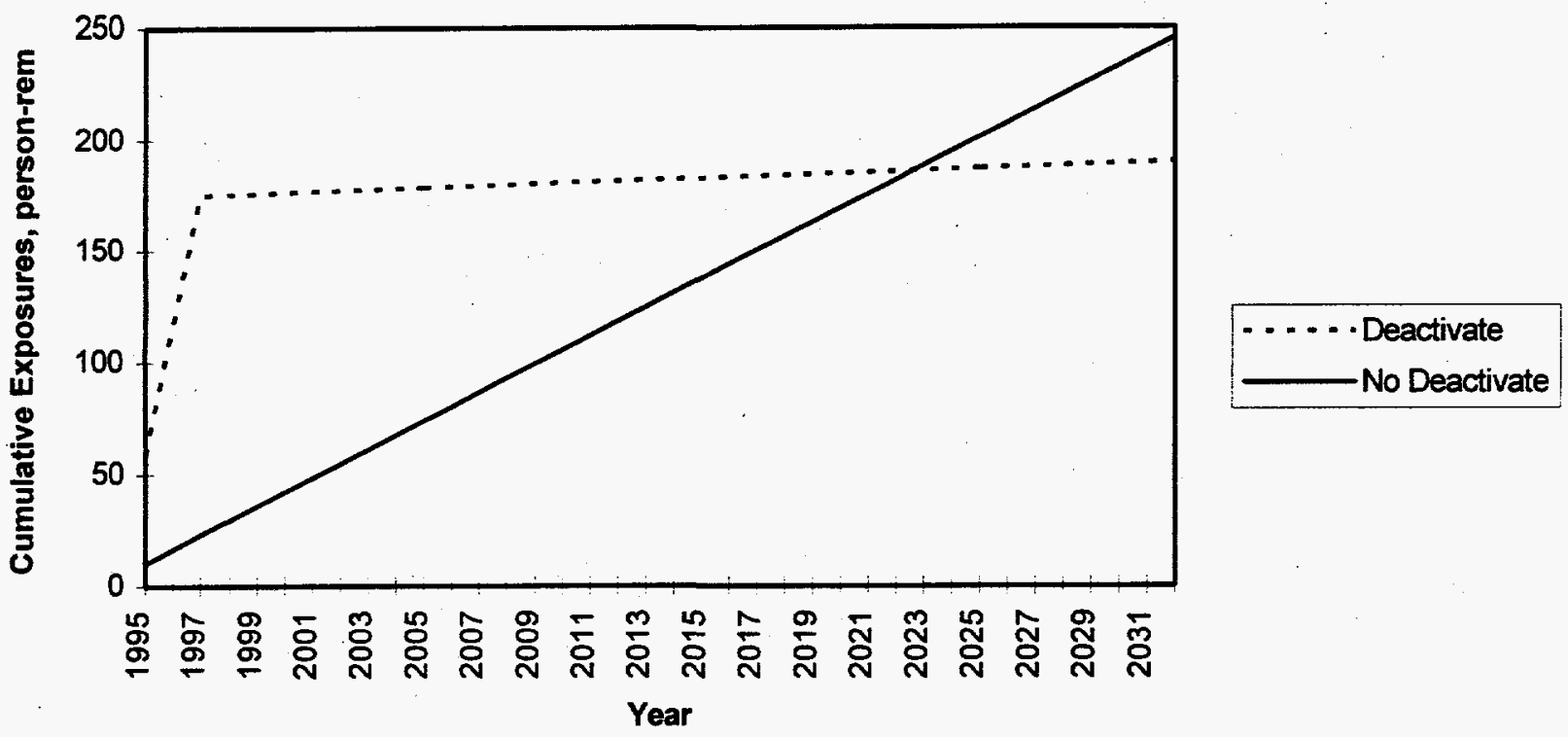

Figure D.13. Cumulative Radiological Exposures for N Reactor Deactivation

Processes that might result in a long pay-back period would include those involving hightemperatures, high-energies, extremely-hazardous or explosive chemicals, fissile materials (criticality concern, particularly if the concentrations of fissile materials are not well-characterized), intensive . contact or hands-on activities, new or novel approaches, or in which few or degraded barriers between potential airborne contamination and workers exist. A review of Walsh (1994) indicated that none of these elements are included other than potential intensive hands-on activities involving contaminated surfaces, materials, and equipment. The technology exists and has been used extensively in the past for all of the deactivation program activities. No high-temperature processes were mentioned, and only spraying fixatives and steam-cleaning were mentioned as possible high-energy processes. These technologies are commonly used today and so are not considered as significant processing risks, although if they were not appropriately-controlled serious injuries could result. There are no fissile, extremely-hazardous, or explosive materials involved and the potential for increasing airborne contamination levels in normally-occupied areas appears to be minimal. Based on these observations, it was concluded deactivation would have a short (within 30 years) pay-back period for process-related worker risks.

PUREX Mortgage Reduction. PUREX is a transition facility currently undergoing deactivation; however, a fair amount of work remains to be completed before the facility would be deactivated. The key activities include removal of single-pass reactor fuel from the slug basin, removal of $\mathrm{N}$ Reactor fuel elements from the dissolver cells, stabilization of zirconium heels, removal of inprocess materials and organics, and canyon flushing. An analysis was performed to develop the worker risk mortgage reduction profiles for the deactivation and no-deactivation cases for PUREX. 
Industrial Accidents. The cost profiles for PUREX developed in Appendix $\mathrm{H}$ were used as the bases for the evaluation of industrial accident potential at PUREX, similar to the approach used for $\mathrm{N}$ Reactor deactivation. The annual costs for surveillance/maintenance, deactivation, and postdeactivation monitoring activities were converted to occupational fatality estimates using the same assumptions and data that were described for $\mathrm{N}$ Reactor.

The cumulative industrial fatality projections for the deactivation and no-deactivation cases are illustrated in Figure D.14 (the annual projections are similar to the trends shown in Figure D.10 and are not shown here). As shown, the pay-back period for industrial hazards is about 1999, a relatively short pay-back period, which is consistent with the cost results discussed for the mortgage reduction strategy.

Routine Radiological Exposures. Radiological exposure estimates for the deactivation activities were not readily available so estimates were developed using methods and data similar to those used for $\mathbf{N}$ Reactor surveillance/maintenance and post-deactivation monitoring. This involved converting the total staff-hours estimated for these activities into estimated staff-hours in radiation zones followed by multiplying by an assumed radiological exposure rate. The resulting cumulative personnel exposures are presented in Figure D.15. As shown, the pay-back period is about 2004, even though substantial occupational exposures are involved in the deactivation activities. This means the current occupational exposures are relatively high; deactivation is recommended as soon as possible so the facility can be taken to a post-deactivation monitoring status.

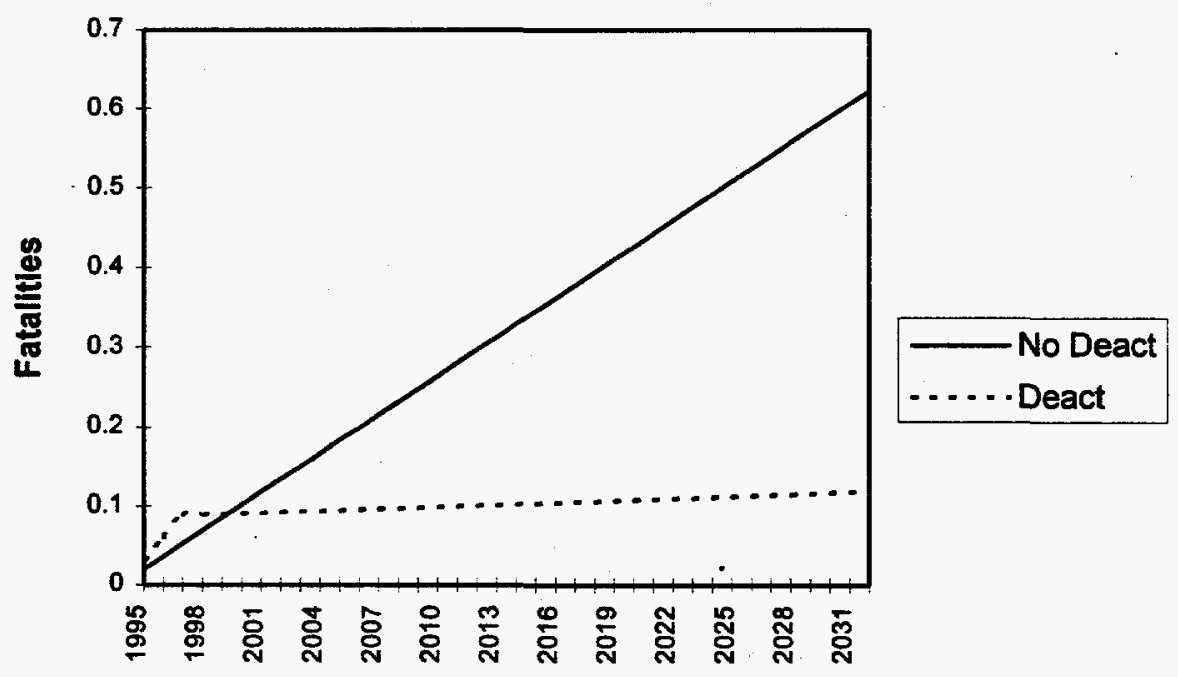

Figure D.14. Cumulative Industrial Hazards for PUREX Deactivation 


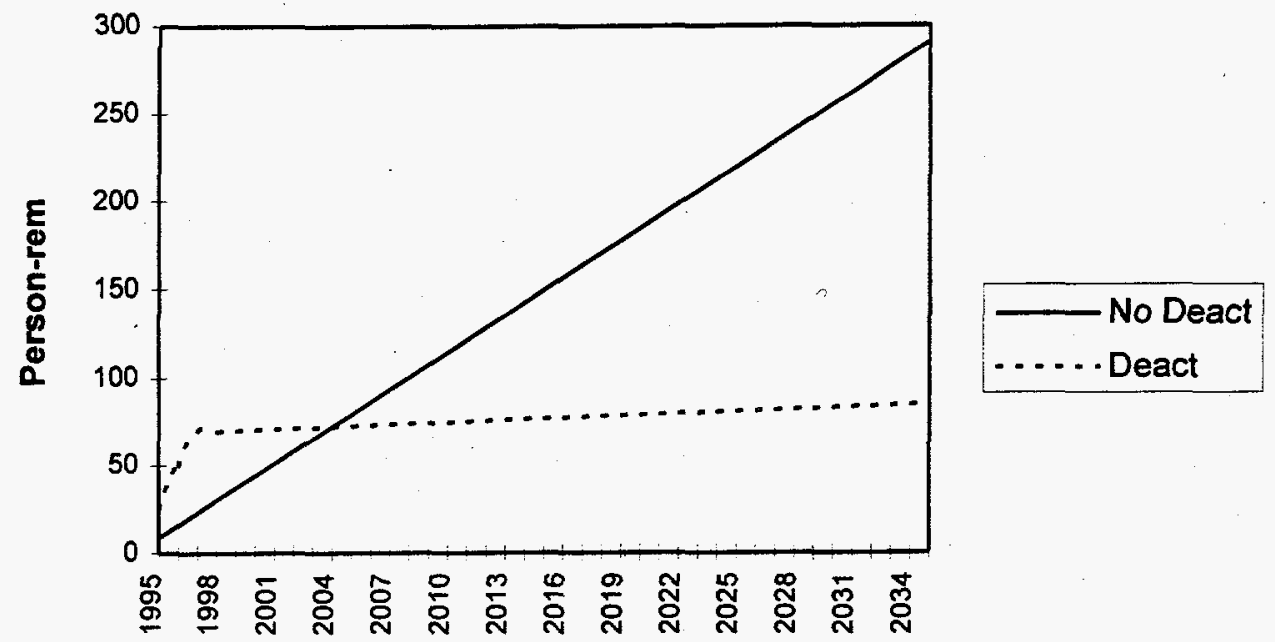

Figure D.15. Cumulative Radiological Exposures for PUREX Deactivation

Process Accidents Involving Radiological and Chemical_Materials. It was previously stated that long payback periods would result if deactivation involved high-process accident, risk-related activities. Examples included high-energy processes, fissile materials, unstable chemicals, explosives, and degraded containment barriers. Deactivation of PUREX involves substantially more hazardous operations than $\mathbf{N}$ Reactor, primarily because of the high exposure rates involved, handling of fissile materials, and the potential chemical instability of some materials (pyrophoric forms of uranium, plutonium, and zirconium metal). Activities involving potentially unstable metals and fissile materials increase the likelihood of accidental releases and high exposure rates in process areas. In addition, some areas of PUREX have relatively high external exposure rates (canyon) and provide the opportunity for airborne releases into occupied areas (N-cell, Q-cell, and sample gallery clean out). Consequently, it was concluded that a relatively long payback period would result from consideration of this risk element; however, this should not be interpreted to mean that these activities cannot be conducted safely. Rather, significant administrative controls, training, and worker protection would be required to perform these activities safely. These controls and protection requirements affect the costs of PUREX deactivation.

\section{Leave versus Retrieve Tank Wastes}

The current baseline plan is to remove all tank wastes from single- and double-shell tanks (except some residual fraction), separate it into high- and low-level fractions, solidify the high- and low-level fractions in separate vitrification facilities, send the high-level vitrified fraction to an off-site disposal repository, and dispose of the low-level vitrified fraction on-site. These activities are somewhat technically uncertain, due to the uncertainties in the tank waste characteristics and the technology development needed to retrieve, pretreat, and vitrify the wastes. A fundamental tradeoff exists between the worker risks of retrieval and treatment of tank wastes versus in-place disposal alternatives, such as in-situ vitrification and in-situ drying and gravel-fill concepts. 
Industrial Accidents. The worker industrial risk estimates for the baseline Tank Waste Remediation System Program were derived in much the same manner that was described for $N$ Reactor deactivation. In this instance, however, total operating and construction labor requirements were available in the Single-Shell and Double-Shell Tank Waste Inventory Data Package for the Tank Waste Remediation System Environmental Impact Statement (Goldberg 1995) for the various options (Retrieval - Fredenburg 1994; Tri-Party Agreement Alternative - Slaathaug 1995; Closure - Scanlon, Hampt, and Skelly 1995; and In-Situ Disposal - McConville 1995) and were used to characterize the annual construction and operating labor requirements. The annual labor-hour requirements were calculated by dividing the total values specified in data packages by the processing schedules also provided in the data packages. It was assumed that 60 percent of the total labor estimate was for direct staff-labor and the remainder were overheads that were not applicable to the construction hazards.

The overall worker risk profiles for the baseline, in-situ vitrification, and in-situ drying and gravel-fill options are presented in Figure D.16. Based on the overall trends shown in the figure, the current baseline (retrieval) results in higher worker industrial hazards than in-situ vitrification and is significantly higher than the option of drying and gravel-filling the tanks. All options include installation of a barrier over the tanks wastes remaining in the 200 Areas (including barriers over residual contamination left in-place after retrieval as well barriers over in-situ disposed tanks) and long-term monitoring of the barriers.

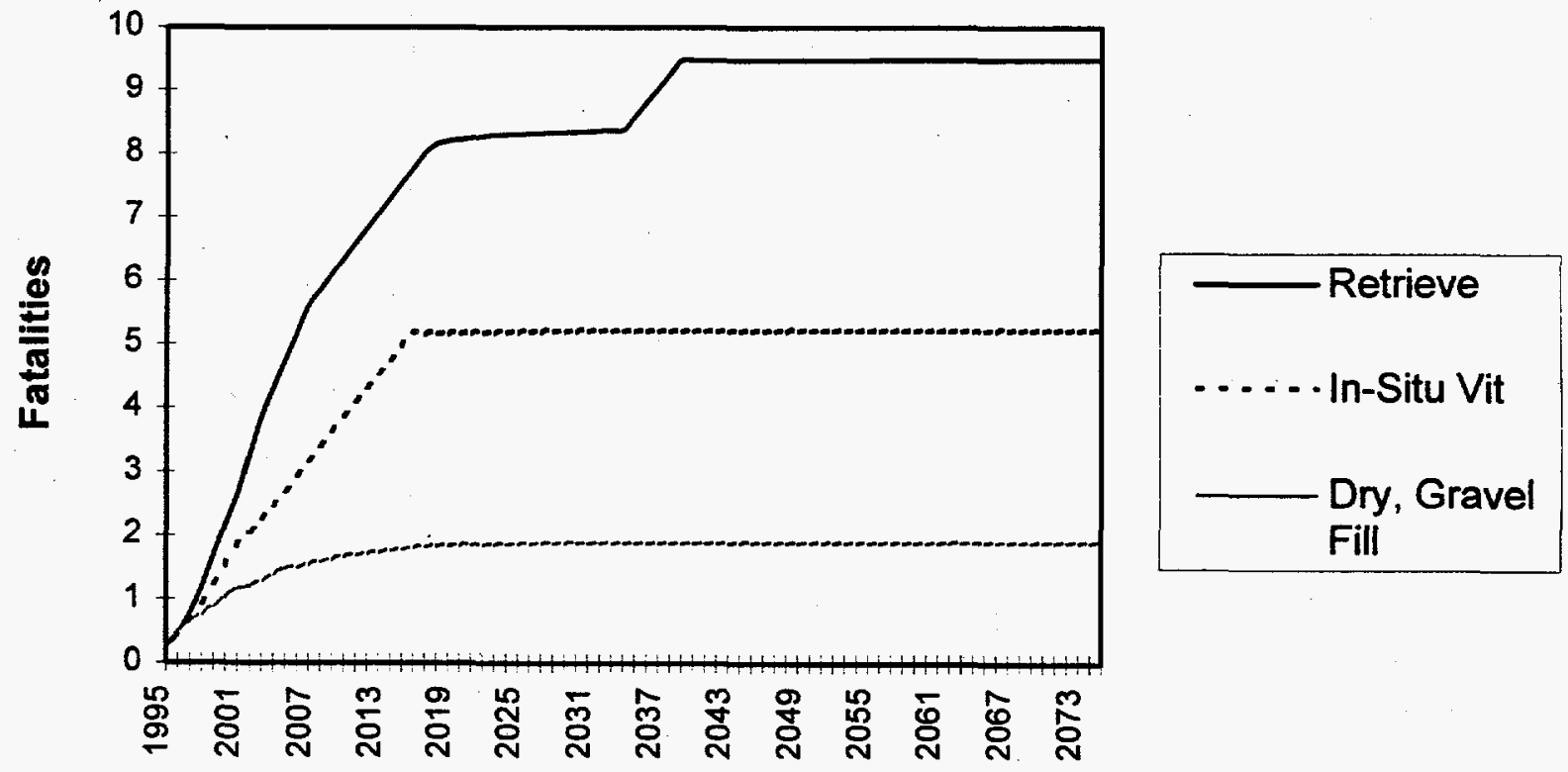

Figure D.16. Tank Waste Remediation Industrial Hazards for Retrieval and Two In-Situ Disposal Options 
Although in-situ vitrification does not include construction of large facilities (e.g., vitrification plants), a substantial amount of construction labor is included in the estimates provided in Tri-Party Agreement Alternative Engineering Data Package for the Tank Waste Remediation System Environmental Impact Statement (Slaathaug (1995). The construction in the in-situ vitrification alternative is for installation of a portable containment facility that is erected over a tank (or tank farm) to control potential airborne emissions. Such a containment system is not included in the drying and gravel-fill option, which accounts for most of the difference in projected fatalities between these options. There are also substantial differences among the three options in operating labor requirements, which translates to higher industrial fatality rates for the current baseline than in-situ vitrification which is higher, in turn, than the drying and gravel-fill option. Facility construction fatalities are approximately equal for the baseline and in-situ vitrification cases but are much lower for the drying and gravel-fill option. Projected fatalities during operations are highest for the baseline and lower for the in-situ disposal options. Surveillance and maintenance and closure hazards are approximately the same for all three options.

Routine Radiological Exposures. Routine radiological exposures were also calculated for the baseline program, in-situ vitrification, and in-situ drying and gravel-fill options. Due to limitations in the data, only a simple scoping calculation was possible to characterize the routine radiological exposures to workers for the three general Tank Waste Remediation System options. For the scoping calculations, the total radiation-worker hours provided in Goldberg (1995) are multiplied by an assumed individual annual exposure rate of 200 millirem per year, which was converted to an average hourly exposure rate of 1E-04 person-rem/person-hour of radiation-worker labor $(1$ worker-year $=$ 2000 hrs). The results of these calculations are presented in Figure D.17.

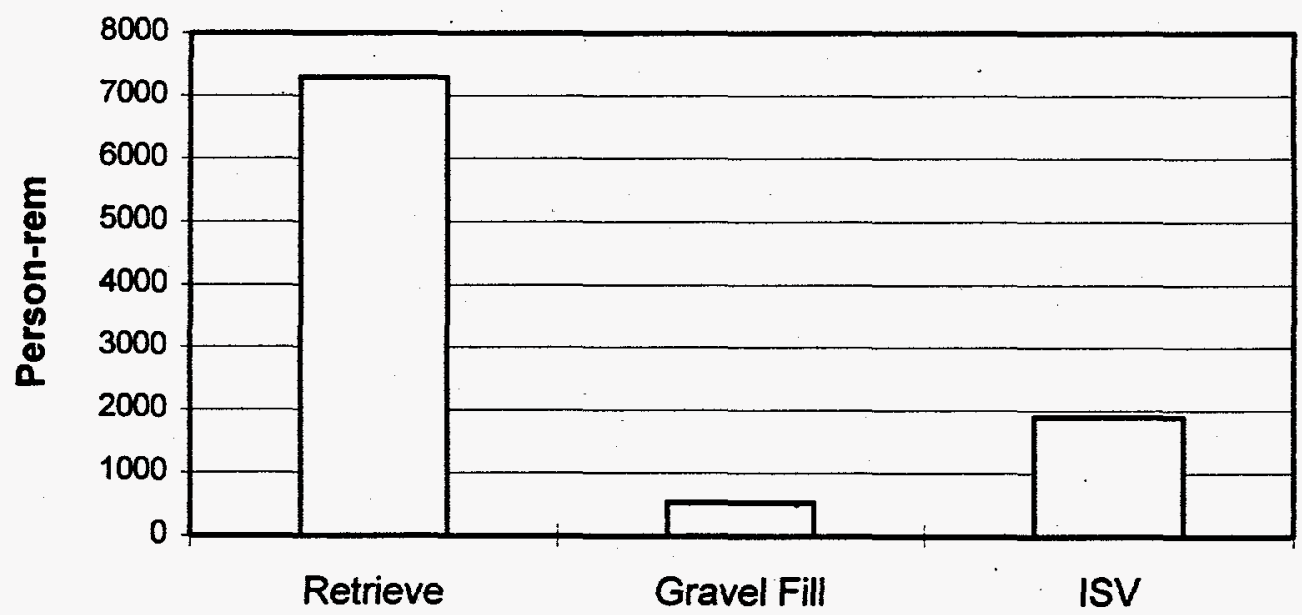

Figure D.17. Tank Waste Remediation Occupational Exposures for Retrieval and Two In-Situ Disposal Alternatives 
Figure D.17 indicates the routine occupational exposures for the full-scale retrieval program in the current baseline are significantly higher than those for in-situ disposal options. This is because far more worker-intensive activities are envisioned for the retrieval case, including substantially more work in the tank farms to retrieve the wastes and substantially more processing (pretreatment and vitrification), than for in-situ disposal. It is concluded based on the information presented in Figures D.16 and D.17 that in-situ disposal of tank wastes would be favored over the tank waste retrieval baseline program from a worker-hazard perspective.

Process Accidents Involving Radiological and Chemical Materials. Process accidents may be a significant discriminator in this tradeoff. The retrieval option may involve significant worker risks from minor process accidents because large quantities of liquid wastes would be removed from tanks using some form of high-pressure system, transferred under pressure, and treated using a hightemperature process. Furthermore, at the present time the chemical and radiological characteristics of tank wastes are not well known, which results in substantial uncertainties in the potential for chemical reactions, explosions, etc. Liquid waste transfers provide opportunities for spray releases that can result in high external exposure rates or airborne releases into occupied areas. Vitrification involves high temperatures that can volatilize radioactive materials, increasing the likelihood of airborne releases. This is common to both the baseline and in-situ vitrification processes, so the baseline may actually represent lower worker risks in this respect because vitrification would occur in a more controlled environment than an outdoor containment structure in the in-situ case; however, drying/gravel-fill does not involve the high temperatures of vitrification so it would be favored in this respect.

Although it is believed that the retrieval and treatment processes can be conducted safely, with adequate protection for workers, options that minimize operations involving tank wastes would most likely result in lower worker risk levels from processing accidents; however, this type of information has not been developed in past studies, so the existing information is insufficient to quantify the differences. It appears that there are differences favoring in-situ disposal options but these can be described only qualitatively at the present time.

\section{Leave versus Retrieve Buried Solid Wastes, Contaminated Soil, and Liquid Disposal Sites}

As with tank wastes, there are similar tradeoffs relative to retrieval versus in-situ disposal options for buried solid waste sites, liquid waste disposal sites, and contaminated soil sites located throughout the Hanford Site. The current baseline program, in general, calls for excavation and retrieval of the waste materials from these sites, treatment if necessary, and disposal in the 200 Areas. The current baseline also calls for retrieval of the retrievably-stored and newly-generated transuranic wastes in the 200 Areas, treatment and/or repackaging, and off-site shipment to the Waste Isolation Pilot Plant for disposal. Another option is to leave these wastes in place, place a barrier over them to prevent water infiltration and their subsequent movement to groundwater, restrict access to prevent inadvertent intrusion into the sites and use of the already-contaminated groundwater, and monitor. A third option involving in-situ vitrification of contaminated soil sites is also under consideration. In this section, a preliminary analysis of worker risks is performed to determine the worker risks associated with these options.

Industrial Accidents. Industrial accidents were analyzed using a similar approach to that used previously. Labor estimates for the three options were derived using the computer models developed 
for the Hanford Site Environmental Setting Data Developed for the Unit Risk Factor Methodology in Support of the Programmatic Environmental Impact Statement (PEIS) (Shramke et al. 1994). This model develops cost and manpower information on a site-by-site basis for the contaminated sites at the Hanford Site (about one-third to one-half of these sites are represented in the computer model) and is capable of developing these estimates for application of different technologies and for different risk target levels. Labor-hours are provided by the model for the following labor categories: supervisors, operators/engineers, and laborers for both construction and operating phases for each site.

Three cases were run using this model: (1) excavate and retrieve the wastes and pump-and-treat groundwater; (2) cap and cover the wastes and continue monitoring while restricting access to the waste site sites and groundwater; and (3) in-situ vitrify the contaminated soil sites, cap/cover and continue monitoring the other waste sites, and monitor/restrict access to groundwater.

The industrial accident risks were estimated by multiplying the labor-hours in each job category by the fatality rates presented previously. The fatality rates for supervisors were set to the National Safety Council rates for "Services" (1.67E-08 fatalities per worker-hour), the fatality rate for operators/engineers was set to "All Industries" (4.44E-08 fatalities per worker-hour), and laborers was set to the "Construction" fatality rate (1.22E-07 fatalities per worker-hour). The total industrial risk is the sum over all the labor categories.

Figure D.18 presents the results of the industrial fatality calculations for the three remediation options. As shown, the option involving full retrieval of the waste sites and pump-and-treat groundwater is projected to result in significantly more worker fatalities than the cap-and-contain option. In-situ vitrification is between these two options. Based on these results, it can be concluded that, from a worker industrial hazard perspective, in-place disposal (predominantly cap and contain the waste sites) would be favored over full-scale retrieval.

Figure D.18 also presents a comparison of the industrial fatalities projected to occur for two remediation risk targets (1E-04 and 1E-06 probability of latent cancer fatality to an individual over a lifetime). As shown, there are only relatively small differences between the two risk targets. This indicates that the worker industrial hazard risks are not extremely sensitive to the specific risk targets, and there is not a great difference in material retrieved, capped-and-contained, or vitrified between the two risk targets.

Figure D.19 shows the industrial hazards by area for the three remediation options (the 1E-04 risk target was used for this illustration).

As shown, the bulk of the industrial hazards occurs during remediation of the 200 Area sites followed by the 100 Areas and then the 300 Area. This indicates that most of the remediation sites are located in the 200 Areas and that, if partial retrieval is an option, in-situ disposal of the 200 Area sites and retrieval in the 100 and 300 Areas would represent a significant improvement in worker safety relative to full-scale retrieval in all areas.

Boutine Radiological Exposures. Insufficient information was available to quantify the tradeoffs in occupational exposures for the three remediation options. There is a general lack of information on external dose rates, waste characteristics, etc., to adequately characterize the occupational exposures. The exposure rates are likely to vary significantly from site to site and would be difficult 


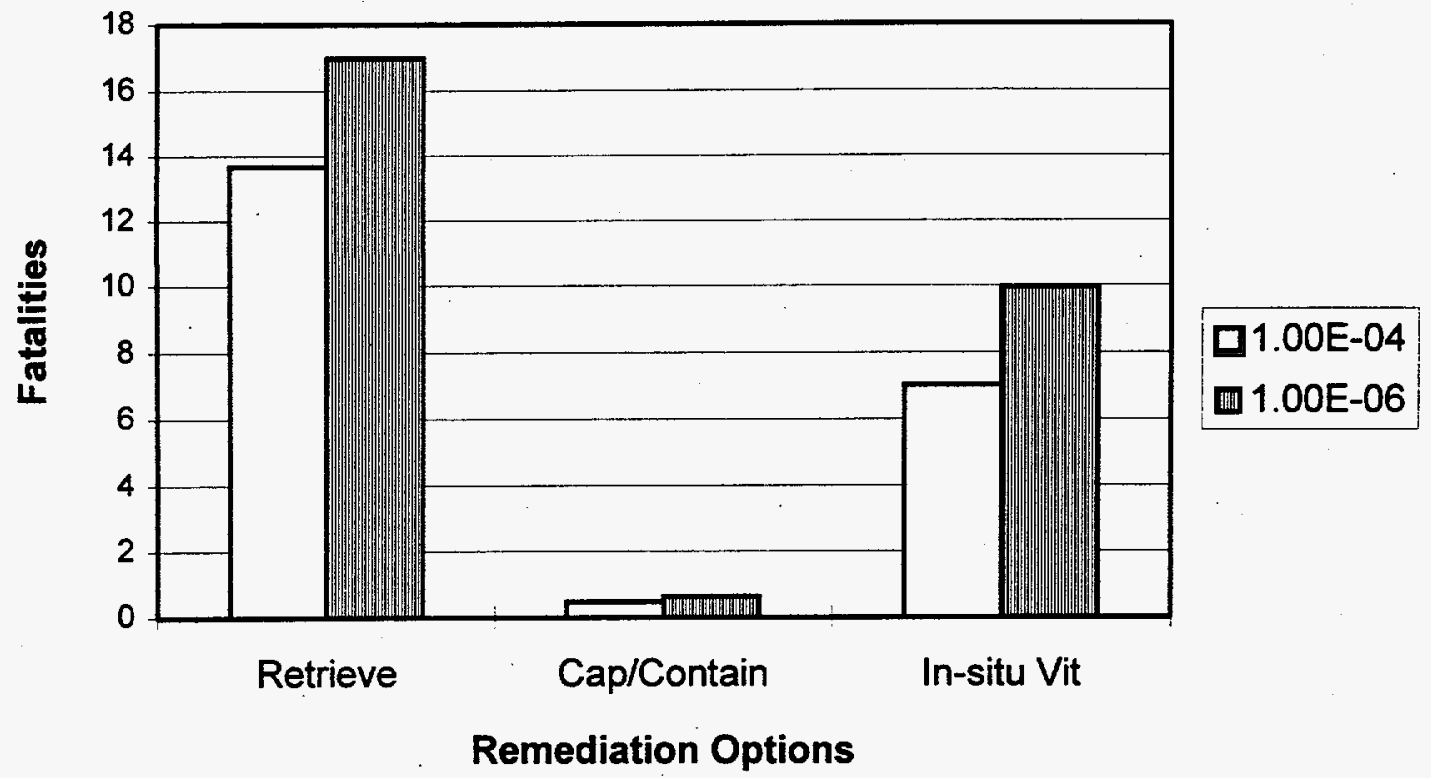

Figure D.18. Industrial Hazards for Remediation of Soil, Liquid, and Solid Waste Disposal Sites for Two Risk Targets

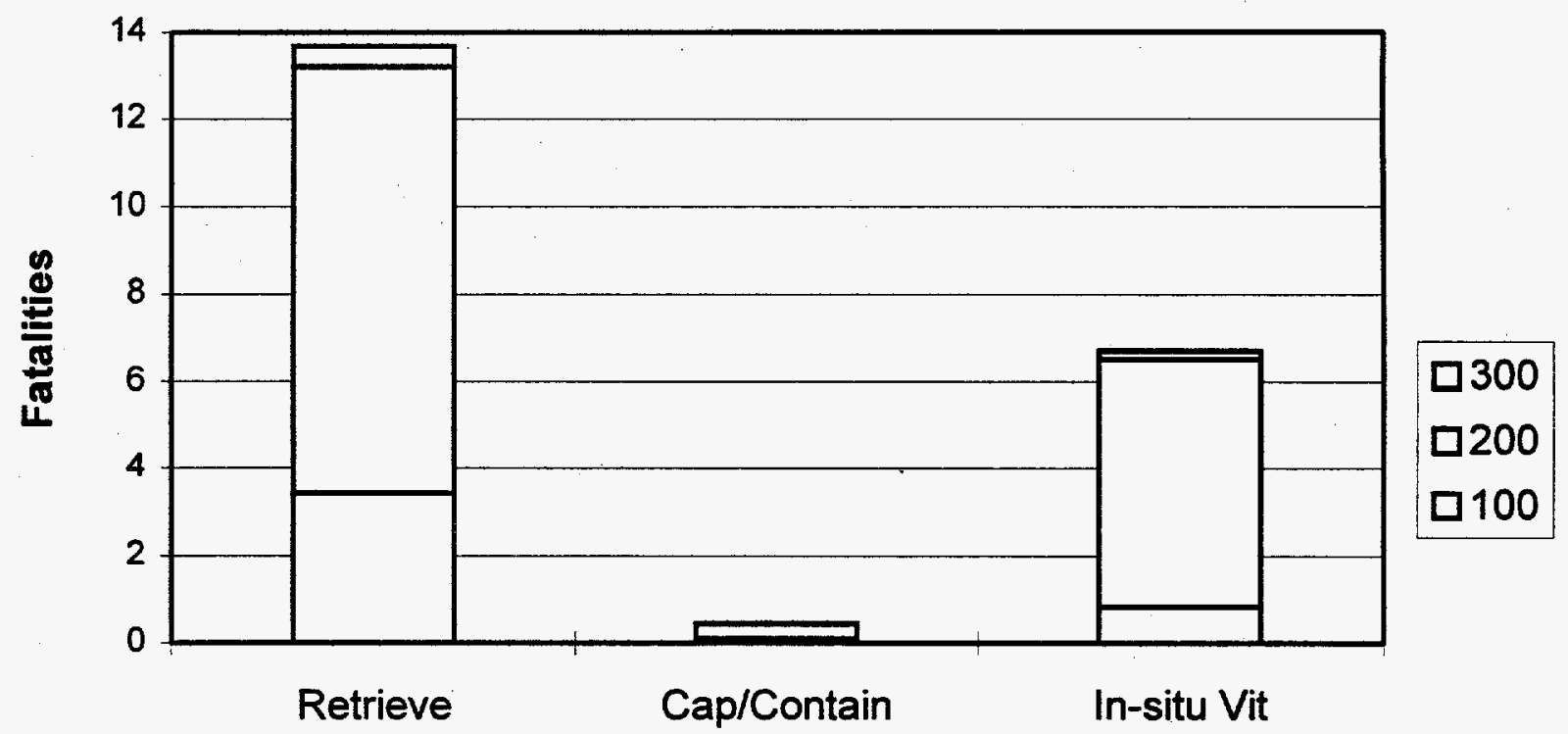

Figure D.19. Industrial Hazards by Area for Remediation of Soil, Liquid, and Solid Waste Disposal Sites 
to generalize. Some sites, particularly the solid waste sites, may have significant external exposure (and perhaps airborne contamination) hazards whereas groundwater pump-and-treat are likely to result in minor exposures. Due to this overall uncertainty and inability to generalize across sites, no quantitative estimates of occupational exposures are provided; however, it is clear that minimizing direct worker contact with the waste sites and materials would result in lower occupational exposures than options that involve direct contact. Since direct contact is minimal in the cap-and-contain option and is significant in the retrieval option, it can be concluded that cap-and-contain (or dispose in-place) would be favored from an occupational exposure perspective.

Process Accidents Involving Radiological and Chemical Materials. As with tank waste retrieval versus dispose-in-place options, it can be concluded that minor process accident risks to workers would most likely be highest for the retrieval option for remediation of soil, solid waste, and liquid disposal sites. This is primarily because of the uncertainties involving the waste characteristics, particularly the chemical and radiological characteristics of buried solid waste sites, potential generation of methane or other potentially-explosive gases, concentrations of fissile materials, and the conditions of the buried waste packages (most likely deteriorated). All of these elements would have some impact on workplace safety. Furthermore, direct contact and handling of waste materials present an additional risk related to waste handling accidents (e.g., forklift punctures, dropped waste packages) that could result in loss and dispersal of radioactive materials. Although the remediation technologies are currently available for the retrieval and cap-and-contain options and most likely do not represent substantial technology development uncertainties, it appears that the options that minimize direct handling and contact with the waste materials would represent lower worker risks from process-related accidental releases. Therefore, from this perspective, it was concluded that dispose-in-place options would be favored over the full-scale retrieval of these sites.

\section{Entombment versus Demolition of Old Facilities}

A tradeoff exists between the workplace hazards associated with the final disposition of the old and contaminated facilities on the Hanford Site. The facilities under consideration include the old reactors along the Columbia River as well as the canyon buildings in the 200 Areas (e.g., PUREX, REDOX, B Plant/Waste Encapsulation Storage Facility, and T Plant). Two options for the final disposition of these building, referred to here as decontamination and decommissioning options, were evaluated. The first involves entombment (in-place disposal) of the buildings by covering them with a barrier and the second involves dismantlement and demolition. The entombment option leaves a defacto low-level waste burial ground where the buildings are and the demolition option results in an essentially clean area. A third option of filling the void spaces in the canyon buildings with low-level wastes (e.g., contaminated soil) and then entombing the buildings was not evaluated with respect to workplace hazards.

Several sources of information were examined to estimate the workplace hazards associated with these two options. These included the Environmental Impact Statement - Decommissioning of Eight Surplus Production Reactors at the Hanford Site, Richland, Washington (DOE 1989), the Hanford Strategic Analysis Study (Pajunen et al. 1994), the Transition Projects FY-1995 Multi-Year Program Plan (MYPP)/Fiscal Year Work Plan (FYWP) (Cartmell 1994), and the PUREX/UO3 Deactivation Project Management Plan (Sinema 1993). The relevant information from these documents was used to develop estimates of workplace hazards for decontamination and decommissioning of the PUREX 
canyon building. Worker risk information is also presented for decontamination and decommissioning of the reactors, which is essentially a summary of the information from DOE (1989).

A number of decontamination and decommissioning activities occur in both demolition and entombment concepts. Common activities, which may occur during facility deactivation or decontamination and decommissioning, include removal of process materials, salvageable materials, equipment, combustible materials, flammable liquids, and organics. Contaminated surfaces would be decontaminated or the contamination fixed, effluents would be terminated, and steam and water lines would be isolated in both concepts. Surveillance and maintenance activities following deactivation would also be similar, such as major roof maintenance/replacement every 20 years (approximately), and minor ongoing surveillance and maintenance activities to ensure operating equipment (e.g., ventilation systems) is properly maintained and residual contamination is monitored. Some of the key differences between decontamination and decommissioning concepts are as follows.

\section{Entombment}

Fill plant void areas with grout or gravel to prevent subsidence

Cover or entomb facility with contaminated soil, clean soil, gravel, clay, or other materials .

Long-term groundwater monitoring

\section{Demolition/Removal}

Remove contaminated surfaces (e.g., concrete surface removal)

Remove contaminated equipment and piping

Remove hazardous and radioactive wastes

Demolish structure

Short-term groundwater monitoring

The key differences between demolition-and-removal and entombment concepts, then, are: (1) the level of activities to remove contamination from the facility (higher for demolition); (2) capping and covering versus removing structures, and; (3) post-decontamination and decommissioning monitoring requirements. The industrial, radiological exposure, and process accident hazards that arise from these differences are evaluated in the following subsections.

Industrial Accidents. The basis for the industrial hazard calculations for the entombment option was primarily DOE (1989). The reactor entombment data were scaled upward by a factor of two to account for the larger building footprint for PUREX. The approach taken for deactivation of $N$ Reactor was used to quantify the worker industrial hazards.

The principal basis for the facility demolition-and-removal option was the decontamination and decommissioning assessment performed for the Hanford Strategic Analysis Study (Pajunnen et al 1994). This study provided cost and labor information for, among other things, decontamination and decommissioning of canyon buildings by removing excessive contamination in all areas of the plant, demolishing to about five feet below grade level, and covering the structure location with clean backfill material. The costs of the major activities involved in this concept were converted to laborhours and then industrial fatalities were calculated using the same methodology and data described above. 
The cumulative surveillance/maintenance and monitoring hazards may also be significantly different for these two options. If it is assumed that there are no timing differences between demolition and entombment of PUREX, the post-deactivation surveillance and maintenance would not be significantly different. It would be required in both options to replace roofs on a periodic basis and also to perform minor maintenance activities on the deactivated facility. Since demolition results in a clean site, there would be no need for post-decontamination and decommissioning monitoring of a demolished structure location, however, since entombment creates a low-level waste disposal site, site monitoring activities become a significant cost and industrial hazard.

Figure D.20 presents a comparison of the industrial hazards of entombment and demolition of the PUREX. As shown, there is a difference between options that favors entombment but this difference is probably insignificant (i.e., less than an order of magnitude); however, if deactivation and postdeactivation surveillance/maintenance hazards are removed from the figure, the difference between demolition/removal and entombment/post-entombment monitoring becomes more than an order of magnitude and is most likely significant. The key difference is that a larger labor force is required to demolish a facility than to fill a facility with grout and place a backfill cover over it, even though significant labor is required to excavate and haul the cover material to the facility location.

Therefore, it may concluded from an industrial hazard perspective, that entombment would be favored over demolition.

Routine Radiological Exposures. First-order estimates of radiological routine exposures were developed to compare the differences between entombment and demolition options. The routine exposures were estimated from the total direct staff-hours using the same methods and assumptions that were used to develop exposure estimates for deactivation of the $\mathrm{N}$ Reactor and PUREX facilities.

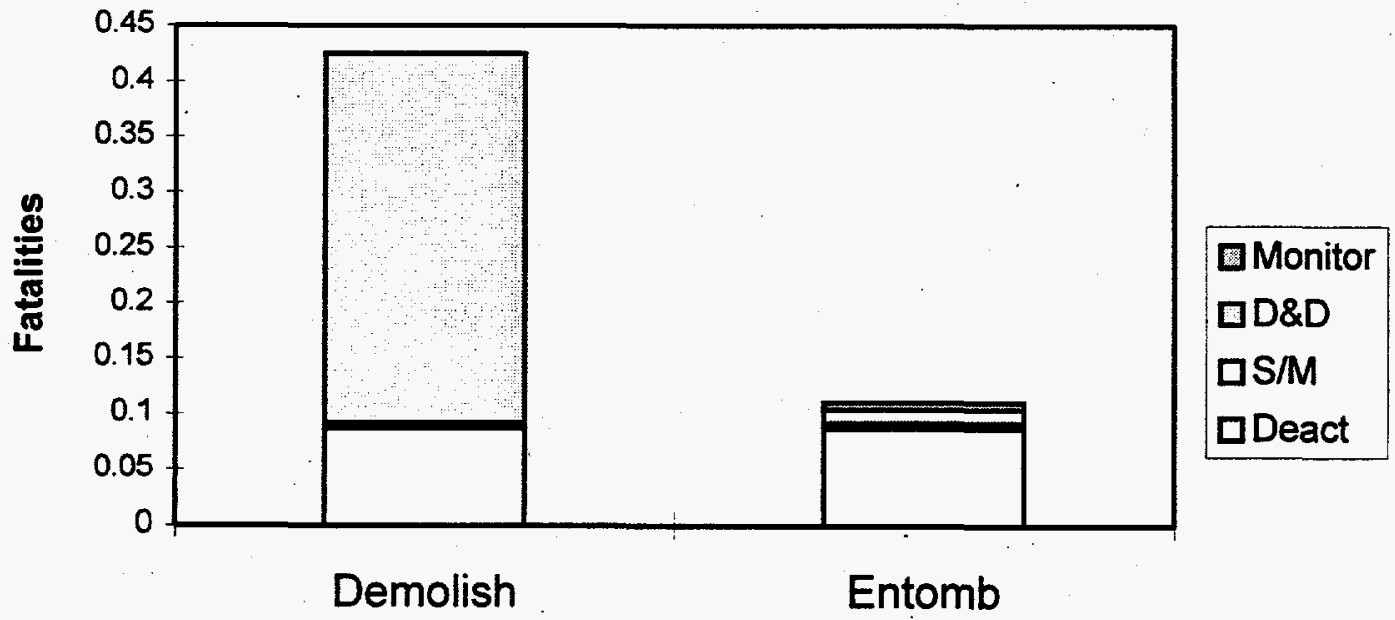

Figure D.20. Comparison of Industrial Hazards for Two D\&D Options for the PUREX Facility 
The results of the occupational exposure calculations for PUREX disposition are presented in Figure D.21. As shown, there is little difference in the total exposures, which include exposures from deactivation as well as the other three phases. However, if the exposures from deactivation are removed, the difference becomes more than order of magnitude, which can be considered a significant difference. Much of the difference in exposures arises from the extensive removal of contamination (removal of contaminated concrete, surfaces, piping, and equipment) that occurs in the demolition concept but not in the entombment concept. The exposures resulting from void filling and extensive monitoring of an entombed PUREX are much smaller than the exposures received during contamination removal in preparation for demolition.

For the reactors, in-place disposal was determined to result in lower occupational exposures than the options involving immediate or deferred one-piece reactor block removal and deferred dismantlement. It was also determined that waiting for 75 yrs to remove the reactor blocks offers significant worker exposure reductions. This delay allows Co-60, the most significant contributor to occupational exposures, to decay to insignificant levels. This delay allows the occupational exposures to be reduced by about a factor of three relative to immediate one-piece removal of the reactor block. This may not, however, apply to decontamination and decommissioning of the PUREX and other canyon facilities. The key radionuclides at PUREX include various plutonium isotopes, Am-241, $\mathrm{Cs}-137$, and Sr-90. In the case of plutonium and americium, these radionuclides have long half-lives and will not undergo significant decay within the next hundred years. In fact, Am-241 contamination is most likely growing at the present time due to Pu-241 decay. This is particularly applicable to the $\mathrm{N}$ cell and other plutonium-contaminated areas of PUREX. Other areas that are contaminated primarily by fission products, such as the dissolver cells, would be experiencing a slow reduction in exposure rates, most likely following the decay curves for the dominant fission products, Cs-137 and Sr-90. These two radionuclides have longer half-lives than Co-60 and will be significant contributors

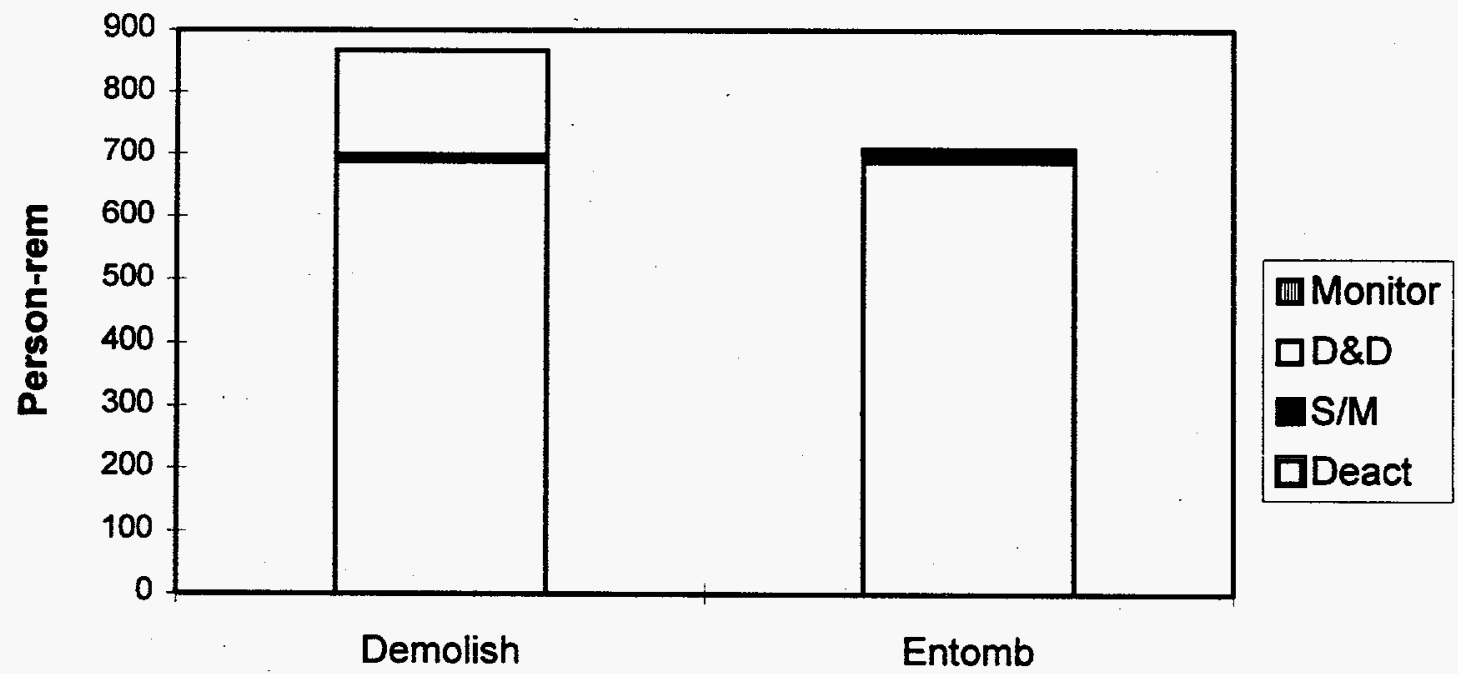

Figure D.21. Comparison of Routine Exposures for Two D\&D Options for the PUREX Facility 
to exposure rates for a longer period of time than $\mathrm{Co}-60$; therefore, there appears to be less incentive to delay 75 or 100 years to decontamination and decommissioning PUREX than there would be to delay decontamination and decommissioning an old reactor.

Process Accidents Involving Radiological and Chemical Materials. As with process accident risks for the other tradeoffs addressed in this appendix, there is insufficient information to quantitatively characterize the differences between facility demolition and entombment; however, based on reviews of the decontamination and decommissioning and deactivation planning document referenced above, it would appear that demolition risks are higher than entombment risks. This conclusion was based on the observation that far less direct contact with radioactive waste and contaminated equipment and surfaces is necessary to prepare a facility for entombment than demolition. As discussed above, entombment requires less direct contact with the interior of the building than would demolition. Furthermore, equipment and surface contamination removal would involve some high-energy processes, (e.g., concrete scabbling, welding/cutting, and lifting) that do not occur during facility entombment. It is believed the hazards associated with these relatively high-energy processes would outweigh the hazards associated with filling a facility with grout or gravel in preparation for entombment, which is the principal in-facility activity for entombment. Consequently, entombment would be favored over demolition from this perspective.

\section{Increase in Worker Risk to Achieve Public Risk Reduction}

One of the objectives of site cleanup is to reduce public risks. Performing cleanup activities implies construction of facilities, handling of radioactive and hazardous materials, movement and transportation of construction materials, transportation of wastes, excavation, etc. These activities will increase short-term worker risks to achieve a net reduction in long-term public risks. A short-term increase in public risk is also likely to occur while the cleanup activities are ongoing. The public risks after cleanup is completed should be lower than the current state so that a net reduction is achieved. This net reduction should be considered in relation to the increased worker risks necessary to achieve it.

An analysis was performed to illustrate the tradeoff between worker and public risks. The analysis draws on information from the Hanford Spent Nuclear Fuel Project Recommended Path Forward (Fulton 1994). Public radiological risk and worker industrial and routine exposure hazard data were taken from this document and plotted over time to develop risk profiles. The risk profiles for the Path Forward Alternative 1 are used here for illustration purposes. Alternative 1 involves overpacking the $\mathrm{N}$ Reactor fuel in the KE Basin and storage of the fuel in $\mathrm{K}$ Basins until a fuel stabilization and interim storage system is available. The passivation system was assumed to be installed in the Fuels and Materials Examination Facility in the 400 Area. Following passivation, the fuel would be placed in interim dry storage in vaults in the 200 Area. The alternative was used to illustrate the tradeoffs but similar conclusions could be derived for other alternatives.

The resulting risk profiles are presented in Figure D.22. The figure shows the risks, by year, for the three hazard categories in this analysis. As shown, the worker industrial risks are in the range from about 0.01 to 0.5 fatalities per year, worker radiological exposures range from about 0.0001 to 0.005 fatalities per year, and public risks from accidental releases range from about 1E-07 to 1E-05 fatalities per year. Clearly, in terms of the estimated risk values presented in the figure, worker risks are two to four orders of magnitude greater than public risks. Furthermore, the worker risk estimates 


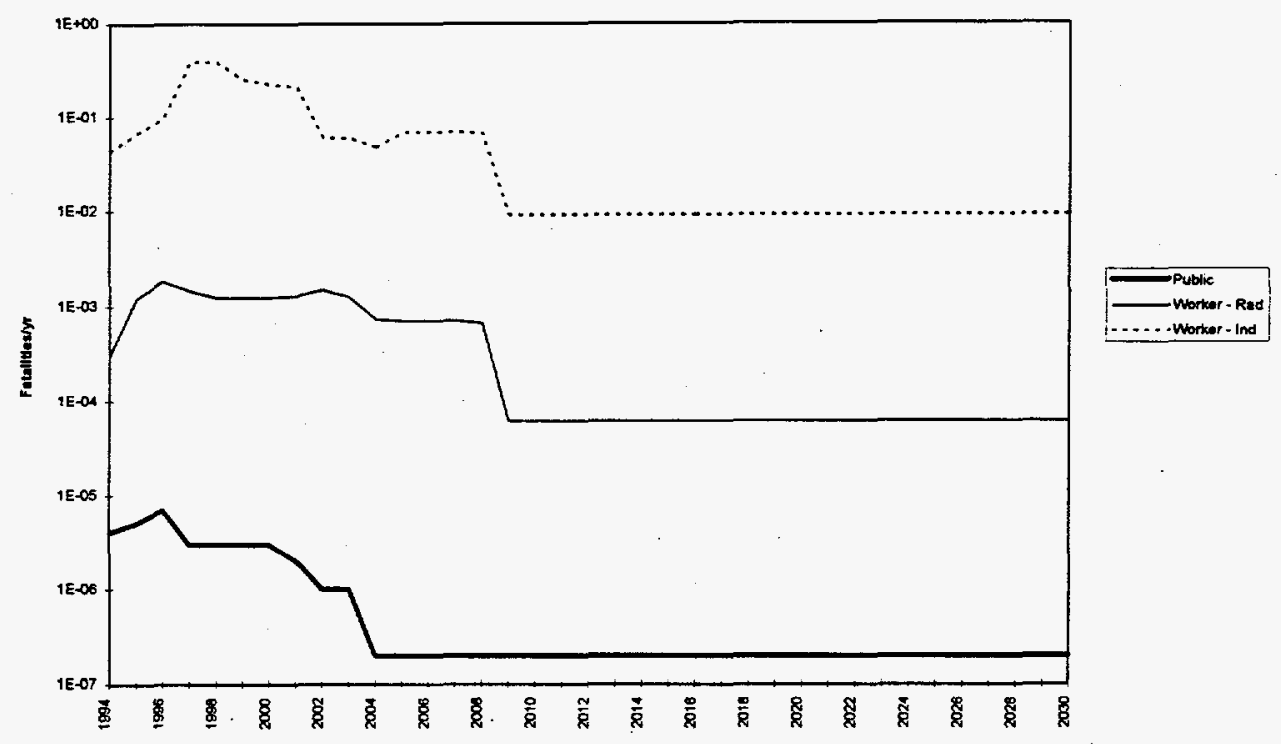

Figure D.22. Illustration of Tradeoffs Between Worker and Public Risks for an N Reactor Fuel Remediation Example Alternative

presented in the table are not probabilistic (i.e., they result from events that will occur [with certainty equals 1.0], although there is a substantial uncertainty associated with the actual values). This contrasts with the public accident risks depicted in the figure which are probabilistic (i.e., the probability of an accidental release is less than 1.0). It is likely that no accidental releases would occur because of the safety precautions and controls that would be implemented to prevent accidental releases. This tradeoff is complicated by the fact that the worker risks are known and will occur (although the actual worker risk values may be more or less than those shown in the figure) and the public risks are potential risks.

The figure also illustrates trends in the risk profiles over time. As shown, as spent fuel activities begin to occur, the annual risks in all three categories increase. Public risks increase by a factor of about two over the present levels. This represents the risk increase from handling and packaging fuel in the KE Basin, which are higher in the short term than the risks from continuing storage in the basin. Similarly, the worker industrial and worker routine exposure hazards increase initially by factors of about nine and six, respectively. This illustrates that worker risks increase more rapidly than public accident risks, presumably due to the worker proximity to the hazard sources, including direct external exposures which are not significant for members of the public and direct exposures to slips, falls, and electrical types of accidents in the old facility.

The overall public risk reduction achieved by the example alternative is about a factor of 20 , from the present state of about $4 \mathrm{E}-06$ to about $2 \mathrm{E}-07$ fatalities per year during the interim dry storage state. To achieve this reduction, the cumulative worker risks amount to about two fatalities, dominated by 
the exposures to industrial accidents. Note, also, that there is a net reduction in worker annual risks from the present state to the interim storage state. This illustrates the worker hazard mortgage reduction concept discussed previously in which, after the fuel is removed from the basins, passivated, and placed in long-term passive storage, worker risks are lower due to reduced monitoring, maintenance, and surveillance requirements, both at the $\mathrm{K}$ Basins and at the dry storage facility. Therefore, although there is a relatively large increase in worker risks required to achieve a reduction in a relatively small public risk, both worker and public annual risks are lower after the materials have been placed in long-term, stable, passive storage.

This assessment demonstrated several important points. First, worker risks are relatively large compared to public risks, perhaps two to four orders of magnitude greater. Second, short-term worker (and public) risks would increase to achieve a long-term reduction in worker and public risks. Third, the spent fuel stabilization alternative considered in this assessment, and other remediation alternatives for $\mathrm{N}$ Reactor fuel and other materials result in a net reduction in annual worker and public risks. Taken together, these conclusion indicate that the magnitudes of the risk reductions, and the short-term increases necessary to achieve the reduced annual risks, need to be considered in comprehensive risk-cost-benefit analyses to choose among remediation alternatives. At the present time, there is no acceptable worker risk criterion that could be used to determine whether or not a specific remediation alternative is acceptable. As a result, the risk-cost-benefit alternatives would be useful only for distinguishing among alternatives and would not be capable of eliminating options based on worker risks alone.

\section{D.3.6 Conclusions}

The key conclusions and observations from the workplace hazard analyses are presented below.

- An increase in short-term worker (and public) risk is necessary to achieve long-term public and worker risk reduction.

- Worker risks are managed to acceptable levels on an individual worker basis in accordance with specific regulations. Administrative controls (e.g., training requirements, procedures) and protective equipment (respiratory protection, safety-harnesses, etc.) will continue to be critical elements of worker safety during cleanup.

- Facility upgrades are necessary to control/minimize hazards to monitoring and decontamination and decommissioning workers in the future; however, the facility upgrades may result in a temporary, near-term increase in worker risks.

- Deactivation of retired facilities is favored over current risk management activities. The investment in increased industrial and radiological hazards that is necessary to complete deactivation activities is quickly paid back in terms of reduced industrial and radiological hazards for managing a deactivated facility. Deactivation accomplishes the goal of reducing the workforce required to maintain and monitor the facilities.

- Dispose-in-place alternatives for tank wastes result in lower worker industrial and radiological exposure risks than remediation alternatives involving retrieval and treatment of tank wastes. 
- Remediation alternatives involving in-place-disposal of solid, liquid, and contaminated soil sites result in lower worker risks than alternatives involving excavation and removal of contaminants and subsequent processing (e.g., packaging or treatment).

- Entombment options for facilities would be favored over options involving extensive removal of contaminated materials and surfaces followed by demolition of structures.

\section{D.4 Long-term Release Hazards}

\section{D.4.1 Definition of Long-term Releases}

This category of hazards includes those mechanisms that release contaminants slowly over very long time periods (e.g., 100s or 1000s of years). Typically, exposures will be relatively low concentrations over extended time periods, just the opposite of the near-term release hazards. These long-term releases are generally associated with groundwater contamination. Hazards within this category must be considered from all three time frames--current state, during remediation, and postclosure. For this analysis, however, we have focused primarily on post-closure hazards. A hierarchy of potential hazard sources is considered in the identification and evaluation of long-term releases:

- Existing plumes of contaminated groundwater

- Deep soil contamination sites (especially old liquid disposal sites) that actively contribute to groundwater

- Other near-surface soil sites and burial grounds that may be releasing contaminants that could reach the groundwater

- Waste and materials that are presently contained but that are vulnerable to future release to the soil (e.g., single-shell tanks, K Basins)

- $\quad$ Future disposal sites (e.g., Environmental Restoration Disposal Facility, solid waste burial grounds, vitrified low-level tank waste).

The remediation objective is to prevent long-term releases and exposures to the public and the environment that exceed acceptable levels. In today's current state these hazards are managed or controlled through access and use restrictions on land and groundwater. In the future these restrictions may change or may no longer exist. Planned disposal actions must recognize these potential changes and ensure that actions are protective of public health and the environment.

\section{D.4.2 Exposure Pathways and Receptors}

The principal exposure pathway of concern is public consumption of groundwater. In the past, however, airborne and surface water exposure routes were significant, but these have declined substantially with the end of the Hanford Site production mission (Dirkes et al. 1994; Farris 1994). Previous Environmental Impact Statements and disposal system Performance Assessments have 
indicated that exposure to groundwater is the dominant long-term risk contributor. This study focuses primarily on the risk contributions of post-closure materials to hypothesized future on-site receptors through the groundwater pathway. An analysis of an intruder scenario is included. A summary is also included of potential exposure from existing conditions and during remediation actions.

\section{D.4.3 Analysis Process}

\section{Overview of Methods and Approach.}

Within the time frame and scope of this analysis it was not possible to evaluate all potentially relevant contaminants. Instead, a subset of radionuclides and hazardous chemicals was selected based on the findings of prior studies ${ }^{(a)}$. Contaminants of potential concern (both hazardous chemicals and radionuclides) were selected based on previous indications of their potential importance to long-term exposures. Contaminants tended to fall into three groups: (1) those that are long-lived and mobile (Tc-99, I-129, nitrate, and C-14); (2) those that are long-lived and relatively immobile, but of such quantity as to create significant exposures through intrusion scenarios (e.g., $\mathrm{Pu}$ isotopes and other transuranics); and (3) those that are of such large quantity to warrant attention (e.g., Sr-90 and Cs137). The following radionuclides were selected:

- Np-237

- Pu-239 and 240

- I-129

- C-14

- Tc-99

- Sr-90

- Cs-137

- U-235 and 238

The following hazardous chemical constituents were selected:

- Nitrate

- Uranium

- Carbon tetrachloride

- Arsenic

- Chromium

Long-term release hazards during post-closure are analyzed using the modular risk assessment approach developed in Modular Risk Analysis for Assessing Multiple Waste Sites (Whelan et al. 1994). This approach provides a powerful tool for quickly evaluating the potential long-term exposure from many different contaminant sources, in different locations, and different levels of treatment or isolation. Unit risk factors were generated using the Multimedia Environmental Pollutant Assessment System (MEPAS) Application Guidance (Buck et al. 1995) for each contaminant of concern. A unit transport factor was estimated for a single "unit" source (e.g., curie, gram,) of each contaminant, in

(a) See, for example, the Hanford Defense Waste EIS (DOE 1987), Droppo et al. (1991), Buck et al. (1991), Kincaid (1994), Wood (1994), and Napier (1995). 
different Hanford Site locations (e.g., 200 East Area, 200 West Area) and in different waste forms (e.g., buried waste, soil). An exposure factor was similarly estimated for each unit of concentration (e.g., $\mathrm{Ci} / \mathrm{ml}, \mathrm{g} / \mathrm{ml}$ ) contaminant. The unit exposure factors show the health effects resulting from exposure to a single "unit" of each contaminant to the maximally exposed individual through the groundwater pathway. The unit exposure factor for each contaminant is estimated to result from a full 70-year lifetime exposure to the maximum concentration after the 10,000 year modeling period.

Three categories of exposure effects were considered: (1) excess carcinogenic incidence from exposure to radionuclides; (2) carcinogenic incidence from exposure to hazardous chemicals; and (3) non-carcinogenic adverse health effects from hazardous chemicals.

Detailed environmental data and assumptions for the Hanford Site are contained in Shramke et. al (1994). Both the 200 East and 200 West Areas are modeled. Separate unit exposure factors were calculated for contaminants contained in buried waste, soil, and groundwater. A recharge rate of $3.0 \mathrm{~cm} /$ year was assumed. Unless noted otherwise for the results that follow, no benefits were assumed for either barriers or waste forms. The unit exposure factors for "buried waste" were applied to all buried solid waste sources and to tank waste ${ }^{(a)}$.

Unit exposure factors were calculated for a residential scenario (Strenge 1994) with exposure only through the use of contaminated groundwater. The receptor well was assumed to be 1000 feet down gradient from the waste site along the centerline of the groundwater plume. Separate unit exposure factors are reported for carcinogenic effects of radionuclides, carcinogenic effects of hazardous chemicals, and non-carcinogenic effects of hazardous chemicals. Carcinogenic effects are reported for exposure to the peak concentration over the entire lifetime of the exposed individual. The risk measure is reported in terms of the individual's increased lifetime incidence of cancer. Non-carcinogenic effects are reported as the ratio of the average daily intake (based on the maximum groundwater concentration) to the reference dose ${ }^{(b)}$ below which no toxic effects would be expected.

Table D.5 shows the unit transport factors and unit exposure factors for the radionuclides included in the analysis of long-term releases and exposure to groundwater. Table D. 6 shows the same information for the hazardous chemicals included in this analysis.

(a) The unit transport factor for transport of C-14 from entombed reactors was assumed to be two orders of magnitude lower than that for buried waste. This adjustment was derived from the C-14 leach rate 5E-07/year from DOE (1989).

(b) The reference dose is a chronic exposure level that is likely not to show an adverse effect over a receptor's lifetime. For more information see DOE/RL (1993). 
Table D.5. Unit Risk Factors for Radionuclides of Concern.

\begin{tabular}{|c|c|c|c|c|c|c|c|c|c|}
\hline \multirow[b]{2}{*}{ Radionuclide } & \multirow[b]{2}{*}{$\begin{array}{c}\mathbf{K d} \\
(\mathrm{ml} / \mathrm{g})\end{array}$} & \multirow[b]{2}{*}{$\begin{array}{c}\text { Half-life } \\
\text { (years) }\end{array}$} & \multicolumn{3}{|c|}{$\begin{array}{c}\text { Unit Transport Factors for } 200 \\
\text { East, }(\mathrm{Ci} / \mathrm{ml}) / \mathrm{Ci} \\
\text { Source Location }\end{array}$} & \multicolumn{3}{|c|}{$\begin{array}{l}\text { Unit Transport Factors for } 200 \\
\text { West, }(\mathrm{Ci} / \mathrm{ml}) / \mathrm{Ci} \\
\text { Source Location }\end{array}$} & \multirow{2}{*}{$\begin{array}{l}\text { Unit Exposure } \\
\text { Factor for } \\
\text { Groundwater } \\
\text { Pathway, } \\
\text { Risk } /(\mathrm{Ci} / \mathrm{ml})\end{array}$} \\
\hline & & & $\begin{array}{l}\text { Buried } \\
\text { Waste }\end{array}$ & Groundwater & $\begin{array}{c}\text { Surface } \\
\text { Soil }\end{array}$ & $\begin{array}{l}\text { Buried } \\
\text { Waste }\end{array}$ & Groundwater & $\begin{array}{c}\text { Surface } \\
\text { soil }\end{array}$ & \\
\hline C-14 & 0 & $5.73 E+03$ & $1.78 \mathrm{E}-15$ & 7.48E-15 & $1.68 \mathrm{E}-15$ & $4.66 \mathrm{E}-14$ & 1.37E-13 & $4.73 \mathrm{E}-14$ & $1.37 \mathrm{E}+08$ \\
\hline Sr-90 & 15 & $2.81 \mathrm{E}+01$ & 0 & $2.83 \mathrm{E}-18$ & 0 & 0 & $3.01 \mathrm{E}-17$ & 0 & $2.92 E+09$ \\
\hline Tc-99 & 0 & $2.12 \mathrm{E}+05$ & $1.95 \mathrm{E}-15$ & $7.50 \mathrm{E}-15$ & $1.86 \mathrm{E}-15$ & $5.01 \mathrm{E}-14$ & $1.37 \mathrm{E}-13$ & $5.12 \mathrm{E}-14$ & $3.45 \mathrm{E}+08$ \\
\hline I-129 & 0 & $1.70 \mathrm{E}+07$ & $1.96 \mathrm{E}-15$ & $7.50 \mathrm{E}-15$ & 1.87E-15 & $5.01 \mathrm{E}-14$ & $1.37 \mathrm{E}-13$ & $5.13 \mathrm{E}-14$ & $1.42 \mathrm{E}+10$ \\
\hline Cs-137 & 50 & $3.02 \mathrm{E}+01$ & 0 & 8.01E-20 & 0 & 0 & $2.00 \mathrm{E}-19$ & 0 & $2.03 E+09$ \\
\hline U-235 & 1 & $7.10 \mathrm{E}+08$ & $1.85 \mathrm{E}-16$ & $1.34 \mathrm{E}-15$ & $1.82 \mathrm{E}-16$ & $4.11 E-15$ & $2.41 \mathrm{E}-14$ & $4.02 \mathrm{E}-15$ & $1.63 \mathrm{E}+09$ \\
\hline U-238 & 1 & $4.51 \mathrm{E}+09$ & $1.85 \mathrm{E}-16$ & $1.34 \mathrm{E}-15$ & $1.82 \mathrm{E}-16$ & $4.11 \mathrm{E}-15$ & $2.41 \mathrm{E}-14$ & $4.02 \mathrm{E}-15$ & $1.54 \mathrm{E}+09$ \\
\hline Np-237 & 1 & $2.14 E+06$ & $1.85 \mathrm{E}-16$ & $1.34 \mathrm{E}-15$ & $1.82 \mathrm{E}-16$ & 0 & 1.33E-16 & 0 & $1.13 \mathrm{E}+11$ \\
\hline Pu-239 & 100 & $2.44 \mathrm{E}+04$ & 0 & $1.17 \mathrm{E}-16$ & 0 & 0 & $1.17 \mathrm{E}-16$ & 0 & $9.25 \mathrm{E}+10$ \\
\hline Pu-240 & 100 & $6.58 \mathrm{E}+03$ & 0 & $1.17 \mathrm{E}-16$ & 0 & 0 & 1.17E-16 & 0 & $(9.25 E+10)$ \\
\hline Am-242m & 50 & $1.52 \mathrm{E}+02$ & 0 & 0 & 0 & 0 & 0 & 0 & $2.44 \mathrm{E}+07$ \\
\hline
\end{tabular}

Table D.6. Unit Risk Factors for Hazardous Chemicals of Concern

\begin{tabular}{|c|c|c|c|c|c|c|c|c|c|}
\hline \multirow[b]{2}{*}{ Chemical } & \multirow[b]{2}{*}{$\begin{array}{c}\mathrm{Kd} \\
(\mathrm{ml} / \mathrm{g})\end{array}$} & \multicolumn{3}{|c|}{$\begin{array}{l}\text { Unit Transport Factors for } 200 \\
\text { East, }(\mathrm{g} / \mathrm{ml}) / \mathrm{g} \\
\text { Source Location }\end{array}$} & \multicolumn{3}{|c|}{$\begin{array}{l}\text { Unit Transport Factors for } 200 \\
\text { West, }(\mathrm{g} / \mathrm{ml}) / \mathrm{g} \\
\text { Source Location }\end{array}$} & \multicolumn{2}{|c|}{ Unit Exposure Factors } \\
\hline & & $\begin{array}{l}\text { Buried } \\
\text { Waste }\end{array}$ & Groundwater & $\begin{array}{c}\text { Surface } \\
\text { Soil }\end{array}$ & $\begin{array}{l}\text { Buried } \\
\text { Waste }\end{array}$ & Groundwater & $\begin{array}{c}\text { Surface } \\
\text { Soil }\end{array}$ & $\begin{array}{l}\text { Non- } \\
\text { carcinogen, } \\
\mathrm{HI} /(\mathrm{g} / \mathrm{ml})\end{array}$ & $\begin{array}{l}\text { Carcinogen, } \\
\text { Risk } /(\mathrm{g} / \mathrm{ml})\end{array}$ \\
\hline Nitrate & 0 & $1.96 \mathrm{E}-15$ & $7.50 \mathrm{E}-15$ & $1.87 \mathrm{E}-15$ & $5.01 \mathrm{E}-14$ & $1.37 \mathrm{E}-13$ & $5.13 \mathrm{E}-14$ & --- & $1.10 \mathrm{E}+07$ \\
\hline Uranium & 1 & $1.85 \mathrm{E}-16$ & $1.34 \mathrm{E}-15$ & $1.82 \mathrm{E}-16$ & 4.11E-15 & $2.41 \mathrm{E}-14$ & $4.02 \mathrm{E}-15$ & - & $1.45 \mathrm{E}+07$ \\
\hline $\begin{array}{l}\text { Carbon } \\
\text { Tetrachloride }\end{array}$ & 0 & $1.96 \mathrm{E}-15$ & $7.50 \mathrm{E}-15$ & $1.87 \mathrm{E}-15$ & $5.01 \mathrm{E}-14$ & $1.37 \mathrm{E}-13$ & $5.13 \mathrm{E}-14$ & $4.62 \mathrm{E}+03$ & $2.09 \mathrm{E}+08$ \\
\hline Arsenic & 3 & 9.07E-29 & $4.77 \mathrm{E}-16$ & $1.63 \mathrm{E}-30$ & $1.20 \mathrm{E}-30$ & $8.58 \mathrm{E}-15$ & $1.66 \mathrm{E}-32$ & $2.97 \mathrm{E}+04$ & $1.32 \mathrm{E}+08$ \\
\hline Chromium & 50 (or 0 ) & 0 & $2.96 \mathrm{E}-17$ & 0 & 0 & $5.32 \mathrm{E}-16$ & 0 & -- & $1.15 \mathrm{E}+07$ \\
\hline
\end{tabular}

\section{Source Term Data}

Source term data have been assembled from several sources to provide a comprehensive set of data describing potential post closure material inventories at the Hanford Site. 
Tank Waste. Aggregate data for double-shell and single-shell tanks contaminant inventories were obtained from Goldberg (1995). In addition, an estimate of the quantity of soil contaminated by prior single-shell tanks leaks and the inventory of contaminants was obtained from Pajunen et al. (1994 Table B.2). Tank specific inventories were obtained from the Integrated Risk Assessment Program database (Mahaffey et al. 1994). Other sources were reviewed to ensure these estimates were similar and to identify potential sensitivity studies.

Buried Solid Waste. Estimates of quantities and contaminant inventories for buried solid waste were obtained from Pajunen (1994, Table B.3). Specifically, estimates were used for the pre-1970 unsegregated buried waste, the post-1970 low-level buried waste, the post-1970 retrievably-stored transuranic waste, and the 30-year forecast of low-level waste to be received and disposed at Hanford. Inventory estimates for the commercial low-level waste disposal site operated by U.S. Ecology were examined, but there was not sufficient detail to develop an estimate for the inventories of contaminants of concern.

Environmental Contamination. Both contaminated soil and groundwater inventory estimates were compiled for this analysis. For contaminated soil sites, aggregate data were used from Pajunen (1994, Table B.4.1). For contaminated groundwater, estimates were derived from the Hanford Remedial Action Draft Environmental Impact Statement (DOE 1994, Table D-5).

Facilities. For most facilities, the inventory estimates for the dominant mobile isotopes of concern were unavailable. Carbon-14 estimates were obtained for the surplus production reactors from DOE (1989, Tables A.4 through A.11).

Nuclear Materials. Nuclear materials are assumed to be managed in a manner that precludes any contribution to onsite environmental contamination. We assume that these materials will be disposed of offsite or indefinitely stored. Table D.7 summarizes the inventory estimates for each of these material categories.

Several limitations of this analysis approach must be considered before drawing definitive conclusions from the following results.

- The analysis approach is not intended to have the degree of resolution necessary to definitively determine the acceptability of post closure risks. All results are preliminary and provide order of magnitude comparisons.

- In general, the results are conservative in that sources are assumed to be consolidated in a single point and risks from different constituents, which actually occur at different times, are assumed to be additive. Thus, we assume that the receptor is exposed to the peak concentrations from all sources simultaneously.

- Much of the underlying data contains large uncertainties. Source term estimates are subject to large changes as better information is obtained. 


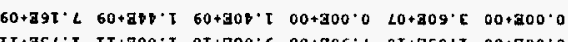

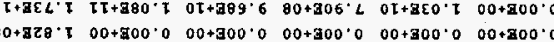

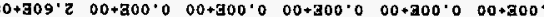
$\angle 0+305 \cdot 100+800 \cdot 000+300 \cdot 000+300 \cdot 0 \quad 00+200 \cdot 000+300 \cdot 0$

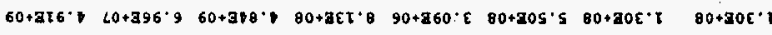

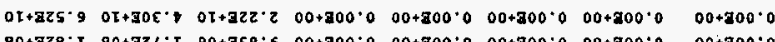

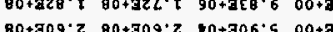

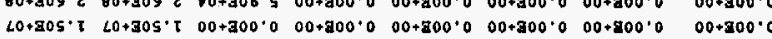

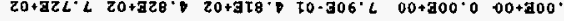

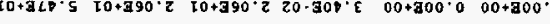

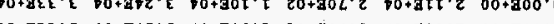

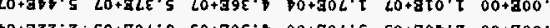

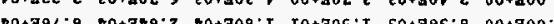

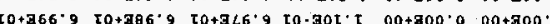

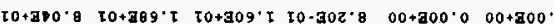

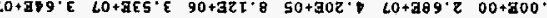

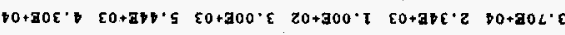

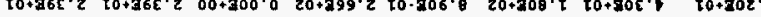

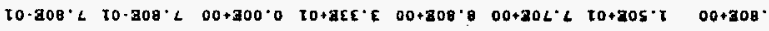

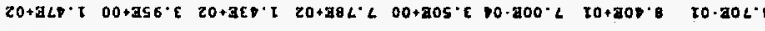

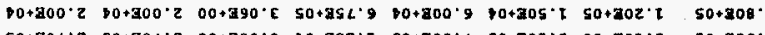

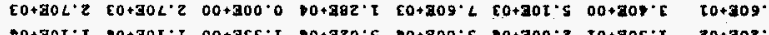

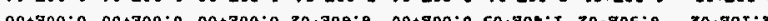

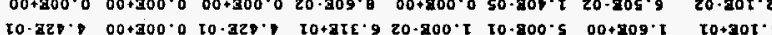

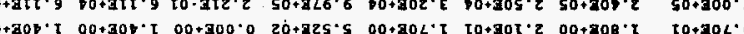

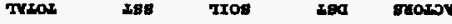

TEq0I

200

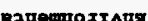

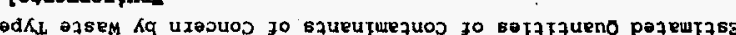




\section{D.4.4 Acceptance Criteria}

Many potential criteria could be used for evaluating the residual or end-state risk through the groundwater pathway. DOE Order 5820.2A, Radioactive Waste Management, identifies performance objectives for DOE waste disposal activities. Objectives are described for a maximum exposed individual, general population, intruder protection, and groundwater protection. A limit of four milirem/year through the groundwater pathway is often a binding constraint in Hanford Site assessments of long-term disposal system performance. Also, a lifetime incremental cancer incidence of $10^{-4}$ is an acceptance standard used in many U. S. Environmental Protection Agency risk assessments. The latter standard is comparable to the DOE (1991) described in Section D.2.4 and is used here as the primary standard for acceptability of long-term risks through the groundwater pathway ${ }^{(a)}$.

\section{D.4.5 Results}

Results are described below for long-term release hazards during the current state, during remediation activities, and during the post-closure period. For the latter, we summarize the results for both exposure to groundwater and intrusion.

\section{Current State.}

The following points summarize observations and findings relative to current state exposures to existing long-term release hazards.

- Current exposures (airborne, groundwater, and surface water) to the public are much lower than background levels, generally, about two to three orders of magnitude lower than background (Dirkes et al. 1994).

- $\quad$ Risk to the public is managed by access restrictions and use restrictions on the groundwater. Contaminated groundwater on the Hanford Site does not (Dirkes et al. 1994) and has not (Freshley 1992) contributed significantly to public dose.

- Remediation of the groundwater is very high cost and has not been shown to be effective for the Site. The largest, most widespread, contaminant plume (600 Area tritium plume) releases tritium to the Columbia River, but levels within the Columbia River are well within regulatory limits (Dirkes et al. 1994). Natural decay of tritium will reduce the potential contributions of this plume with time.

- Historically, contaminant flux into the soil, from the vadose zone into the aquifer, and from the aquifer into the river was driven by large contaminant and liquid discharges into the soil

(a) The DOE Nuclear Safety Policy (SEN-35-91) restricts risk from routine nuclear operations to an increase of 0.1 percent in the latent cancer fatality rate to members of the public. This is equivalent to $2 \times 10^{-6}$ latent cancer fatality/year. Over a 70 year lifetime this would be roughly $1.4 \times 10^{-4}$ latent cancer facility/lifetime. Thus, the $10^{-4}$ standard is the same order of magnitude as the DOE Nuclear Safety Policy. 
column from 200 Area operations and from reactor operations. With the discontinuance of these discharges, contaminant movement has slowed and in many areas aquifer levels are receding thus further slowing the release of contaminants from the vadose zone to the aquifer.

The central conclusion from the assessment of existing long-term release hazards is that the correction of these hazards is not urgent. Institutional controls are adequate to manage risks for the foreseeable future. The end of Hanford Site production operations with its artificially high recharge rate has slowed the migration of contaminants and will continue to do so. The only potential exception is the threat posed by large new releases of contaminants to the environment such as those that could occur from tank leaks and liquids contained in $\mathrm{K}$ Basins.

\section{During Remediation.}

During remediation, incremental risks due to fugitive dust emissions or releases to the river during excavation operations could create exposure routes of concern. Remediation operations will need to be designed to minimize the potential for such hazards. In general, however, hazards during remediation will be dominated by risks to workers and direct harm to the ecosystem rather than through new exposure routes to the public.

\section{Results for Long-Term Groundwater Risk}

Figure D.23 shows the primary contaminants that contribute to carcinogenic risk through the groundwater pathway from each of the major waste types. These results show the effects of groundwater exposure to the calculational residential receptor with a well 1000 feet down gradient from each source. Five carcinogens are compared: C-14, I-129, Tc-99, Np-237, and $\mathrm{CCl}_{4}$. All results are for the conditions and inventories described above in Section D.4.3. No credit is assumed for eventual waste treatment or for disposal system performance including infiltration barriers or waste containers.

The combined carcinogenic risk from all tanks (including prior tank leaks) is about $20 \%$ (the increased lifetime cancer incidence for an individual exposed to the peak concentration of each contaminant). Tc-99 is the largest contributor to this risk. It is roughly one order of magnitude greater than the individual effects from C-14, I-129 and Np-237.

For buried waste, the combined carcinogenic risk is about $6 \%$ with I-129, Tc-99, and C-14 the most significant contributors. For existing soil and groundwater contamination the combined carcinogenic risk is also about $6 \%$ with $\mathrm{CCl}_{4}$ the largest single contributor, almost two orders of magnitude greater than either Tc- 99 or I-129. For the former production reactors, total carcinogenic risk is estimated to be about $0.2 \%$.

Figure D.24 shows the non-carcinogenic hazard for the four waste types and several important contaminants. Non-carcinogenic hazard is measured by the Hazard Quotient, which is the ratio of the projected average daily intake of the maximum waste concentration (based on the maximum 20-year average) through to the reference dose (below which no toxic effects would be expected). Nitrates in both the tanks and existing soil and groundwater contamination dominate this impact. Potential doses are indicated to be four to five orders of magnitude greater than the reference dose. $\mathrm{CCl}_{4}$ shows a 


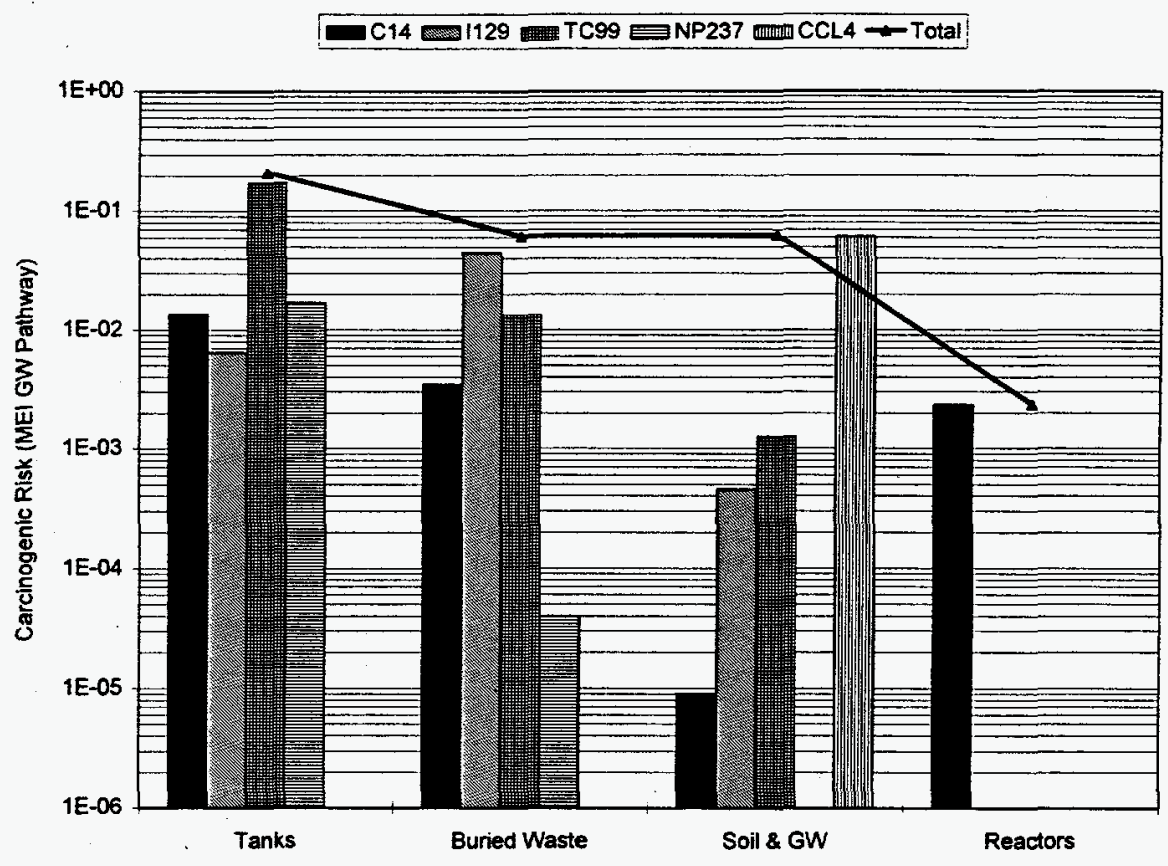

Figure D.23. Radiological and Chemical Carcinogenic Risks

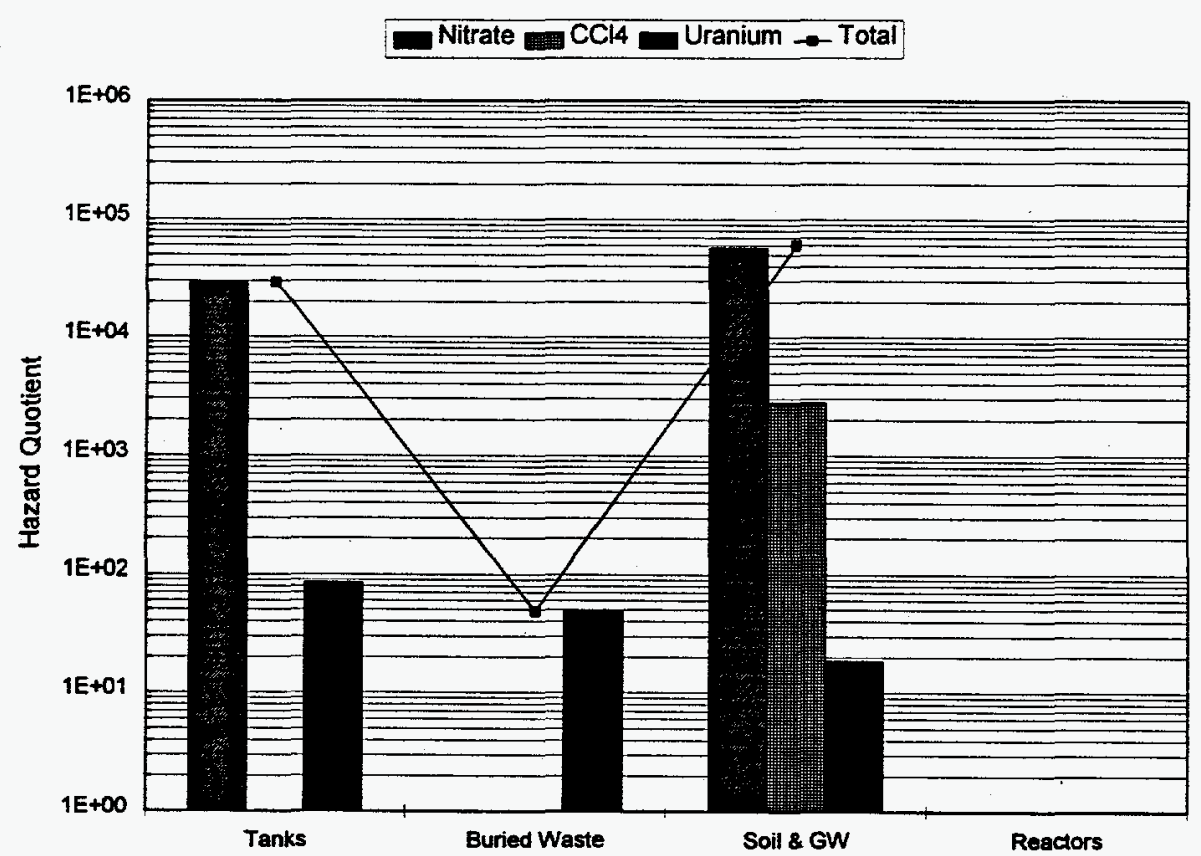

Figure D.24. Non-carcinogenic Risk 
potential dose over three orders of magnitude greater than the reference dose. Uranium is present in tanks, buried waste and existing soil and groundwater contamination and could result in doses one to two orders of magnitude greater than the reference dose.

Figure D.25 shows the carcinogenic risk for each of four buried solid waste inventories resulting from the three dominant long-lived mobile radionuclides: Tc-99, I-129, and C-14. The estimated risk from existing low-level waste burial grounds is two to three orders of magnitude greater than from the pre-1970 unsegregated waste and the post-1970 retrievably-stored transuranic waste. The latter waste type is planned for retrieval, treatment, and repackaging for potential disposal in the Waste Isolation Pilot Plant.

\section{Results for Tank Waste Disposal Options}

Using tank specific inventory estimates, we estimated a radiological hazard for each tank, again considering only long-term exposure through the groundwater pathway to a residential receptor.

Ordering the tanks from highest to lowest risk (for the mobile constituents, Tc-99, I-129, and C-14) results in the cumulative distribution of radiological hazard shown in Figure D.26. Based on existing tank inventory estimates, over 99 percent of the long-term groundwater risk from radionuclides is

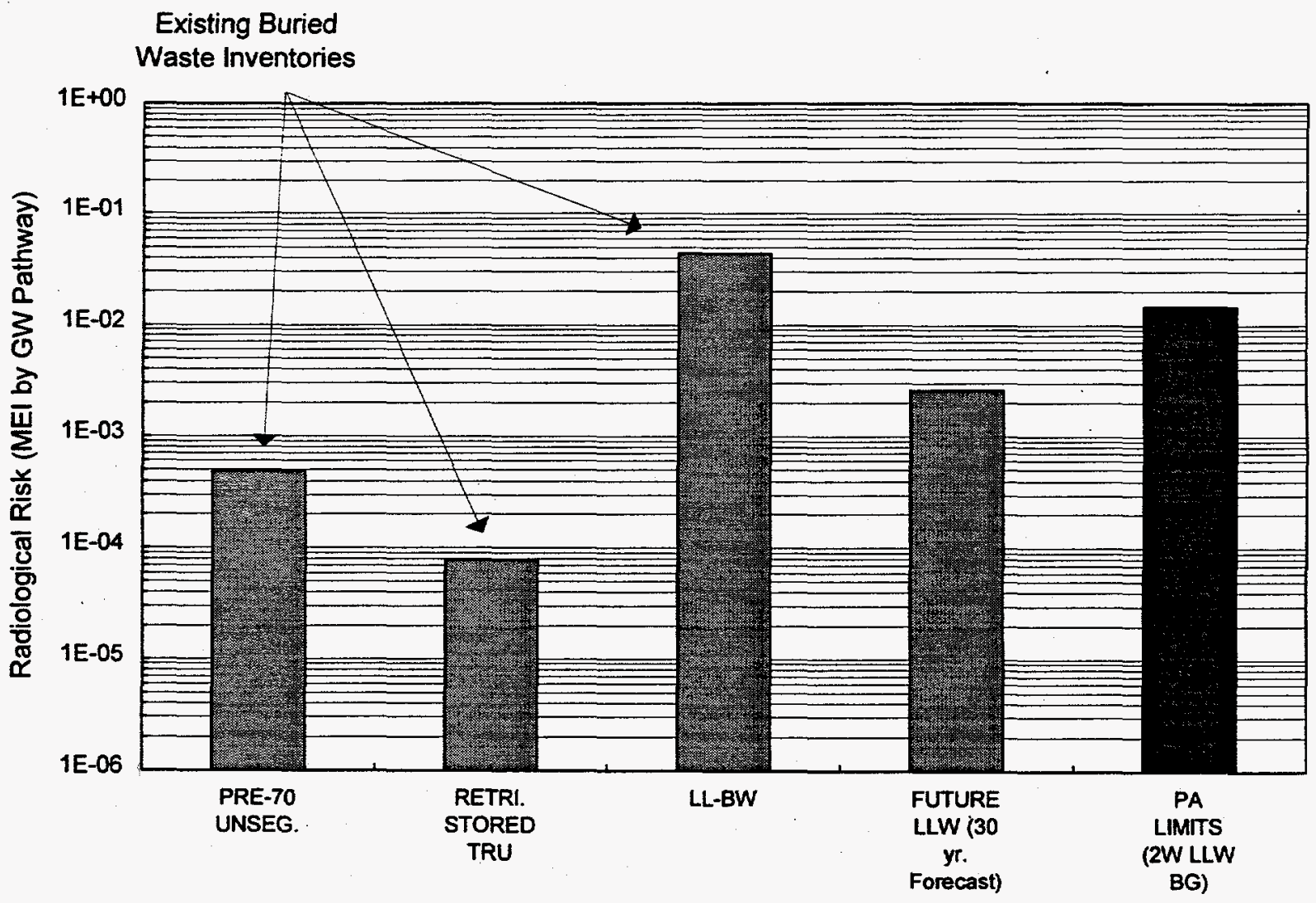

Figure D.25. Radiological Risk for Buried Waste 


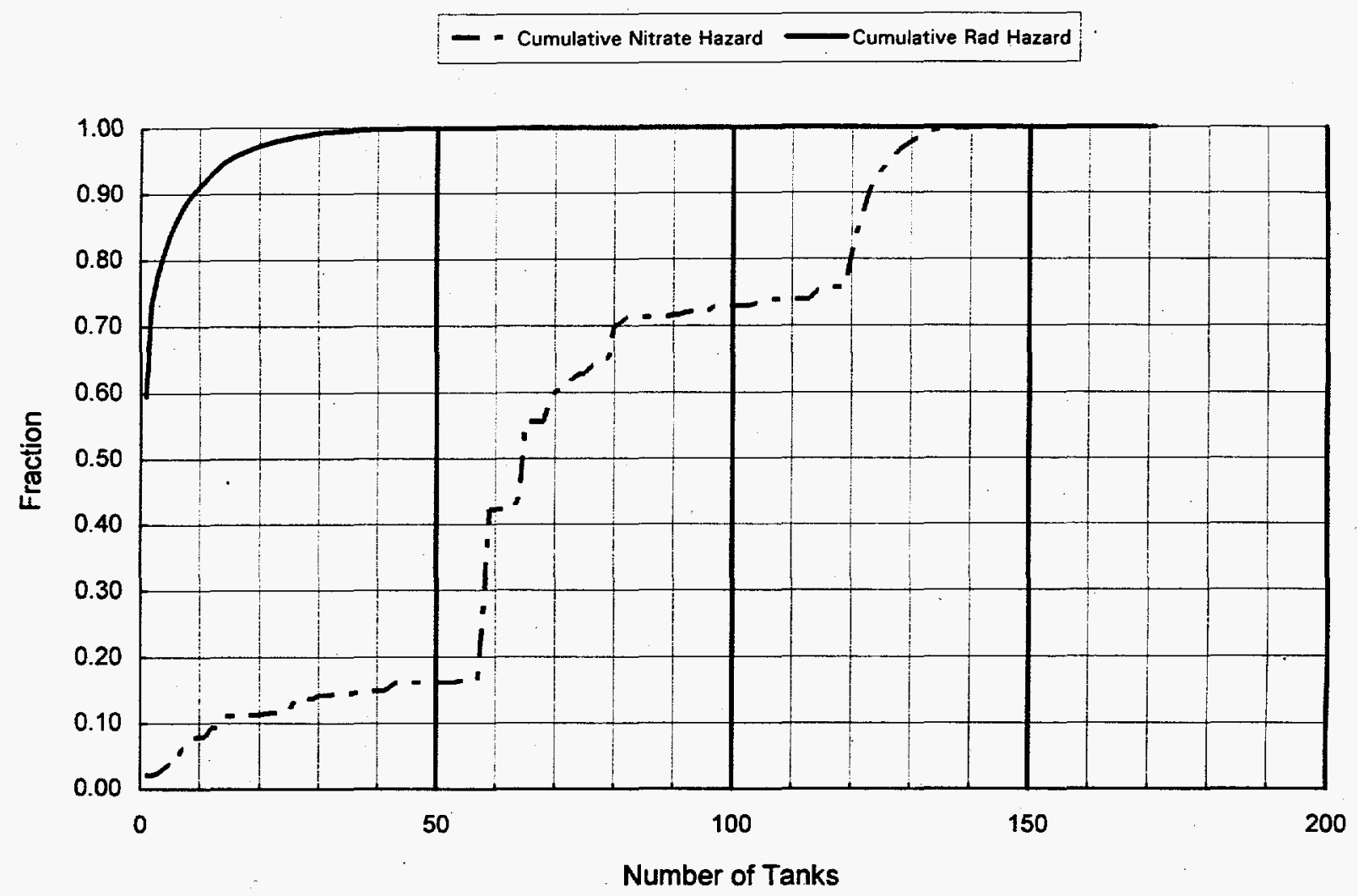

Figure D.26. Fraction of Radiological Hazard by Number of Waste Tanks

\section{Risk sensitivity for tank treatment options}

Figure D.27 expands on this analysis by showing the risk reduction effects of several tank treatment options. This figure shows that with no treatment the total radiological risk through the groundwater pathway for all tanks is about $0.08^{(a)}$. First, the impact of a total (100 percent) retrieval action is shown. As noted previously, retrieval of the first $\mathbf{4 0}$ tanks results in more than two orders of magnitude of risk reduction. Also, after retrieval of about 100 tanks there is no further reduction in estimated risk since the inventory estimates for the remaining tanks show no presence of the long-lived mobile radionuclides that are of concern.

Next, Figure D.27 shows the impact of an assumed 99 percent retrieval option. Again, after the 40 worst tanks have been retrieved, there is essentially no further reduction in risk. The one percent residual from the first $\mathbf{4 0}$ tanks contributes more to risk than the entire contents of the last $130+$ tanks. Retrieval of 99 percent of the contents from all tanks reduces risk to just below $10^{-3}$.

(a) This differs from the estimate of $20 \%$ shown in Figure B.4.1 because two separate sources of tank inventory estimates were used. The earlier estimate result from aggregate tank inventory data (not tank specific) used to support the ongoing Tank Waste Remediation System Environmental Impact Statement. 


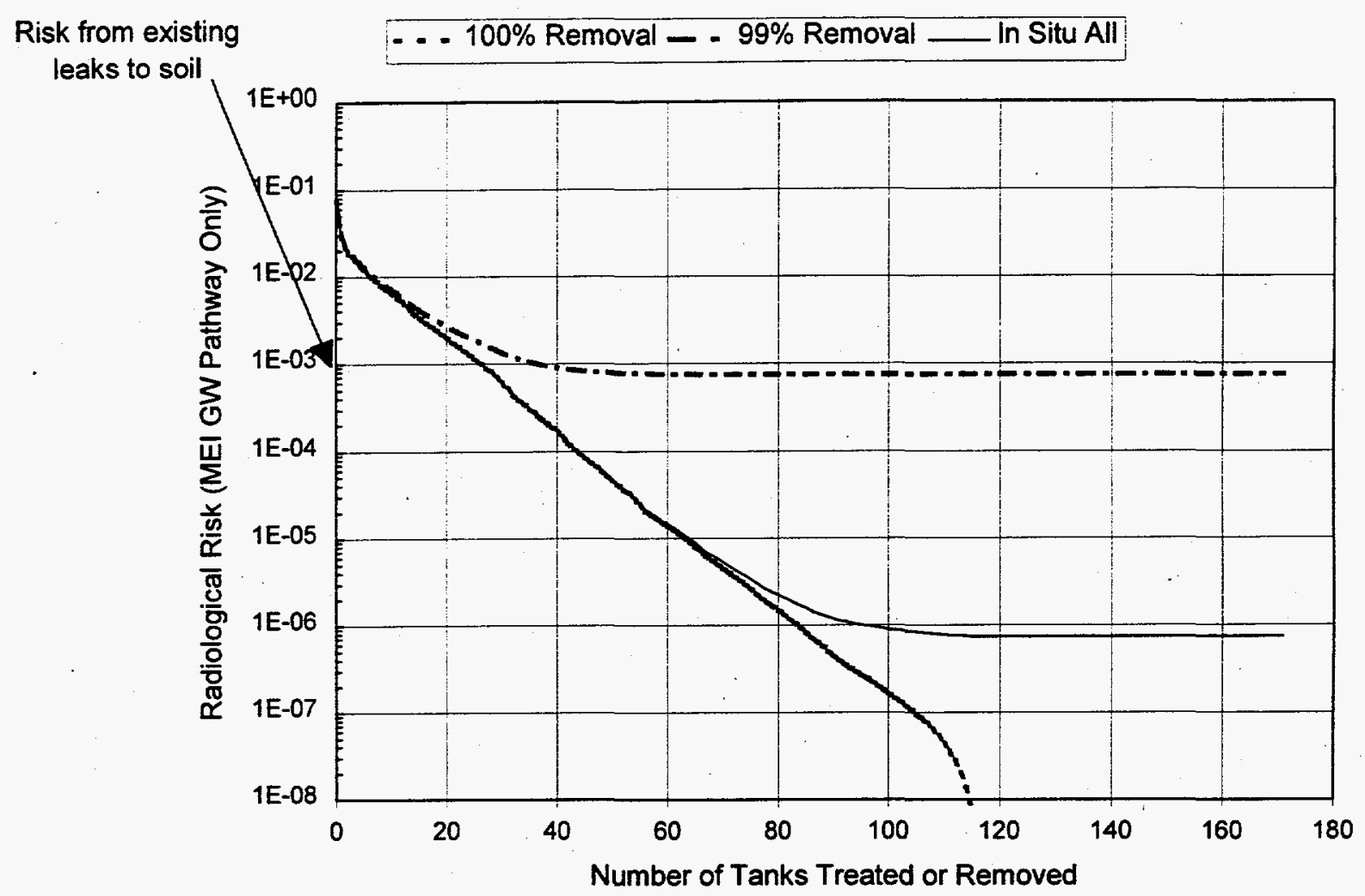

Figure D.27. Risk Sensitivity for Tank Treatment Options

contained in fewer than 40 tanks. While inventory data are not of sufficient quality to finalize tankspecific retrieval and treatment decisions, the shape of this distribution curve will probably be relatively insensitive to new characterization data. A very similar distribution curve is shown for all of the contaminants considered in this analysis. This suggests that a risk-based strategy for treating tanks should recognize that the risk contributions of the tanks vary by several orders of magnitude. There is potentially a high value to knowing which tanks pose the greatest threat.

According to these results, a retrieval efficiency on the order of 99.9 percent would be required to achieve a maximum end state risk of $10^{-4}$. However, one must also consider the potential contribution of the prior tank leaks. These have been estimated to be between one and two percent of the existing tank contents (Pajunen 1994, Table B-2). Consequently, this places an additional floor below which further tank retrieval will not have a net effect on long-term risk reduction.

Figure D.27 also shows the risk-reduction effect of a hypothetical in situ treatment option that results in $10^{-5}$ improvement in the unit transport factor due to an improved waste form (e.g., glass) or the combined effect of an improved waste form and an infiltration barrier. Treatment of approximately 25 percent of the tanks will drive total residual risk down to $10^{-4}$. 


\section{Results for Intruder Scenarios}

A second approach for assessing the long-term hazard for end state materials is to evaluate potential doses to intruders. Waste form classifications from 10 CFR 61, "Licensing Requirements for Land Disposal of Radioactive Waste," (Class A, B, C, etc.) also serve as benchmarks for comparing the potential endstate disposal inventories. To simplify the current analysis, several of the potential endstate inventories were compared with the intruder limits $\left(\mathrm{Ci} / \mathrm{m}^{3}\right)$ that were derived in the performance assessment for the 200 West Area low-level waste burial grounds ${ }^{(a)}$. Typically, these limits are less restrictive than either the Nuclear Regulatory Commission Class $\mathrm{C}$ disposal limits or the $100 \mathrm{nCi} / \mathrm{gram}$ limit for disposal of transuranic wastes.

Figure D.28 shows the ratio of the aggregate concentrations of key constituents to the intruder limits. Only two constituents actually exceed the intruder concentration limits according to these data, Am-241 in double-shell tanks and Pu-239 in the retrievably-stored transuranic waste. The latter exceeds the limit by less than a factor of four. Figure D.29 shows the tank data desegregated by tank farm. Pu-239 and Am-241 exceed the intruder concentration limit by a factor of two at most.

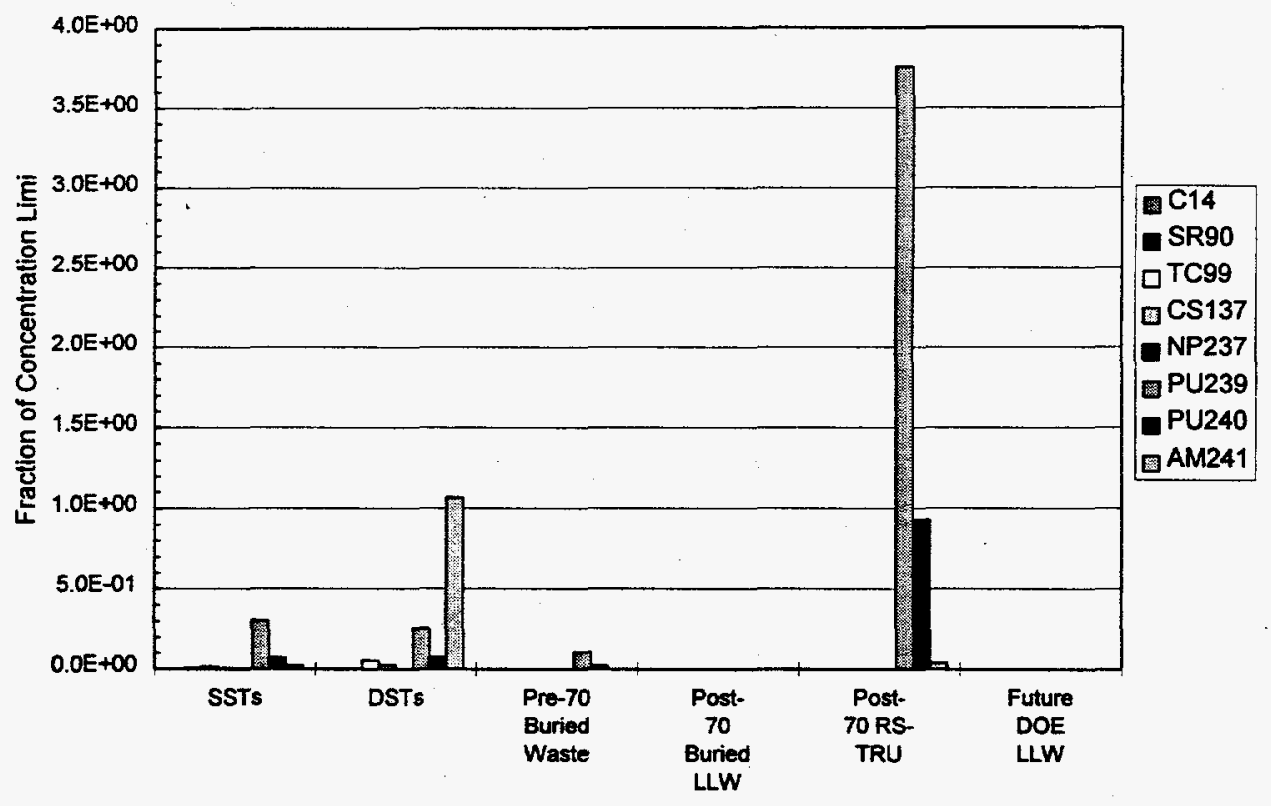

Figure D.28. Intruder Dose Contributors

(a) Wood (1994) considers the limits derived for the Category 3 disposal facility that includes a Hanford barrier. This barrier is assumed to prevent accidental or intentional intrusion for 500 years, thus eliminating the contribution of the high-activity constituents, such as Cs and Sr. 


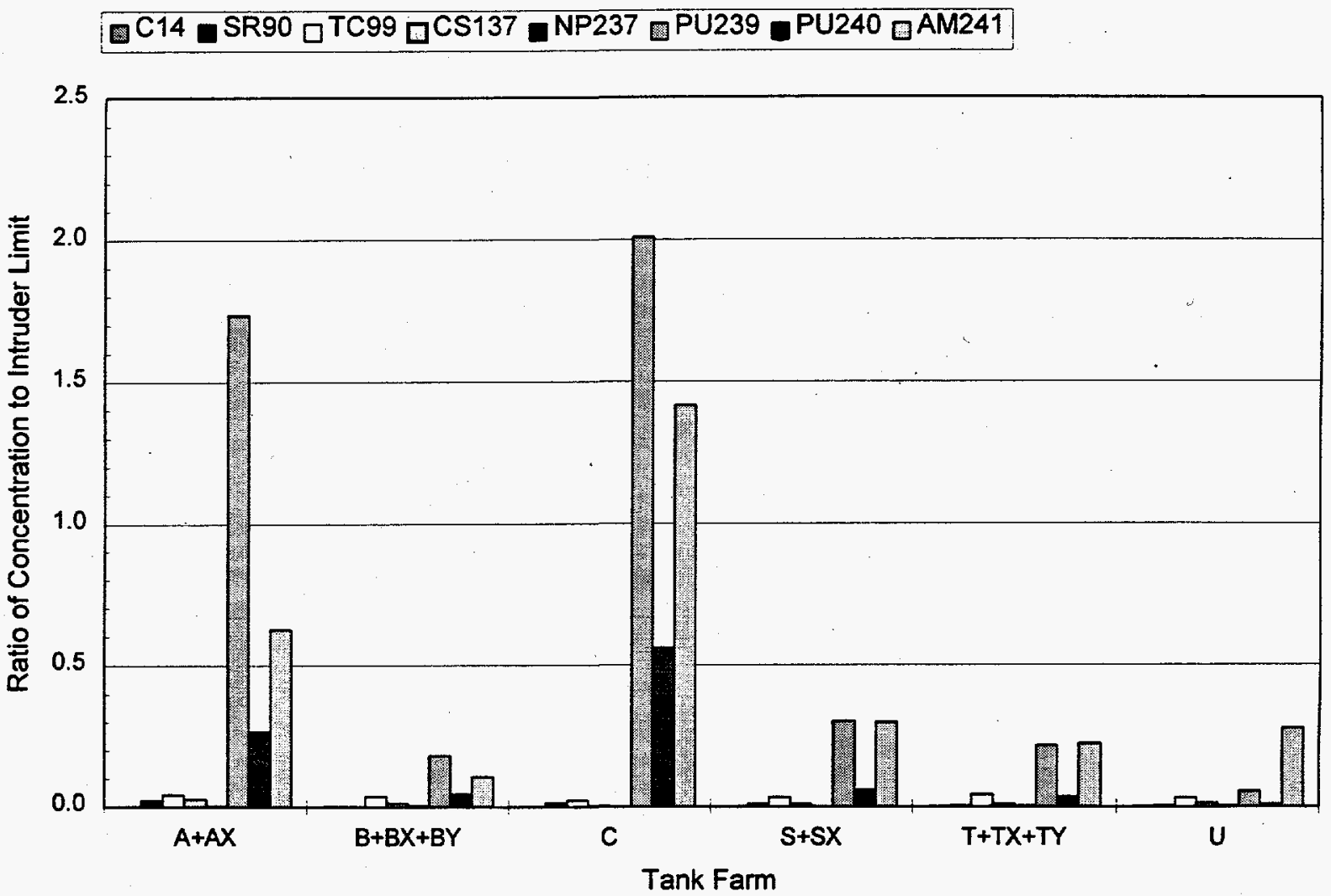

Figure D.29. Ratio of SST Inventories to Intruder Limits from 200W PA

Based on this cursory analysis existing inventory data suggest that Hanford Site potential endstate materials fall mostly within intruder concentration limits assuming engineered barriers prevent intrusion for at least 500 years. Those few situations that exceed the limits only do so by relatively small factors, at least when contrasted with groundwater risk contributors that exceed potential control limits by two to three orders of magnitude.

\section{D.4.6 Conclusions}

- Long-term release hazards through the groundwater pathway are dominated by seven longlived, mobile constituents: C-14, Tc-99, I-129, Np-237, carbon tetrachloride, nitrate, and uranium.

- $\quad$ Potential contributions from tank waste, buried solid wastes, and existing environmental releases are roughly of the same order of magnitude.

- $\quad$ Assuming no treatment or isolation of potential post closure inventories, carcinogenic risks appear to be about two to three orders of magnitude higher than acceptable limits while noncarcinogenic risks (chiefly nitrate) appear to be four to five orders of magnitude higher than acceptable limits. 
- The long-term release hazard posed by existing low-level waste burial grounds is roughly two orders of magnitude higher than that posed by the pre-1970 unsegregated buried waste and the post-1970 retrievably stored transuranic waste. Results of a recent performance assessment indicate that suitable infiltration barriers can reduce the risk from of buried solid waste inventories to acceptable levels. These findings call into question the priority given to retrieval of transuranic and suspect transuranic wastes.

- Potential restrictions on post-closure inventories from regulatory or intruder risk assumptions appear to be far less restrictive than the potential constraints from exposure to groundwater.

- For tank waste, roughly one fourth of the tanks contribute $99+$ percent of the long-term release risk. Also, the residual contamination following retrieval and the contamination from prior tank leaks place a floor below which risk cannot be reduced without some form of insitu treatment.

\section{D.5 Ecosystem Hazards}

\section{D.5.1 Definition of Ecosystem Hazards}

This category of hazards includes the contamination of plant and animal wildlife from chemicals and radionuclides and the physical disruption of natural habitats. We also consider hazards to cultural, archeological and historical resources in this category. Typically, these hazards arise from physical disruptions and other intrusions by man.

\section{D.5.2 Exposure Pathways and Receptors}

Receptors considered within this hazard category are primarily plant and animal species. Exposure routes include direct ingestion and inhalation of contaminated materials and uptake from groundwater and surface water.

\section{D.5.3 Analysis Process}

No separate analyses were performed for this hazard category. Instead, prior and ongoing studies and analyses were reviewed for results that would be applicable to the current assessment.

\section{D.5.4 Results}

- Ecological exposures from Hanford operations are routinely monitored and evaluated in Dirkes et al. (1994). This report indicates that current and past ecological exposures are low and no impacts of such exposures have been detected.

- The potential for adverse ecosystem impacts from remediation activities is substantial. A primary potential impact is the physical disruption of the habitat by soil and waste excavation 
and construction of new facilities, including disposal facilities, treatment facilities, and roads. In addition, there is the potential for additional adverse effects from the accidental release of contaminants during remediation actions.

- Hanford Site isolation for the last 50 years has resulted in a large, relatively undisturbed shrub-steppe habitat. Both plant and animal species have been protected and have flourished with this isolation. Similar habitats in surrounding, unprotected areas have been largely overtaken in the last 50 years by agricultural and other development interests.

- $\quad$ As Hanford Site cleanup proceeds, Site access restrictions will progressively be relaxed. Increased human intrusion and potential agricultural and industrial development pose additional threats to the protected habitats. A balance is necessary between the benefits of increased site access and the potential harm of new intrusions.

- The Hanford Site contains significant cultural, archeological, and historic resources. Many of the cultural resources at the Site are highly valued by Native Americans. At present, access restrictions and contamination prevent desired uses by Native Americans. Remediation activities should enable desired uses but not damage valued resources in the process. Also, relaxed access and use restrictions have the potential to adversely affect the preservation of these resources (e.g., from vandalism).

\section{D.5.5 Recommendations}

- Remediation actions must be designed and carried out to minimize harm to historically protected ecological and cultural resources. Disruption of pristine land for disposal or new construction should be avoided where viable alternatives are available.

- A difficult balance must be found between increasing use of formerly restricted areas of the Site and the potential for new harm to ecological and cultural resources from the loss of restrictions.

\section{D.6 Major Considerations for a Risk-Based Cleanup Strategy} follows.

There are four major considerations that form the basis of a risk-based strategy. They are as

1. The Site will prevent potential near-term releases that pose an unacceptable hazard to the public, workers, and ecosystem.

2. Workers will be protected from unacceptable hazards.

3. The ecosystem and cultural resources will be protected during remediation.

4. The Site will minimize long-term releases that might affect the public and ecosystem. 
With the major considerations as the basis, there are more specific decision rules associated with the each hazard category during the time frames of concern. These specific decision rules are as follows.

\section{A. Near-term releases}

In the current state;

- Contamination and exposure from high consequence events will be prevented,

- The quantity of new environmental contamination will be minimized,

- Potential high hazards will be transitioned to safe, stable intermediate states taking care to not preclude final disposition, and

- The cost effectiveness of risk management activities will be improved.

During remediation;

- Remediation processes will be considered that do not increase the likelihood of large consequence events.

B. Work place hazards

In the current state;

- Industrial worker hazards will be minimized based on life cycle risk reduction,

- Unnecessary contact in old facilities will be minimized.

During remediation;

- Construction will be minimized,

- Low energy, inherently safe processes will be utilized,

- Worker exposure versus benefit analysis or threshold limits will be utilized, and,

- Unnecessary contact in old facilities will be minimized.

C. Long-term releases

In the current state;

- New releases of contamination will be minimized,

- The spread of existing contaminants will be minimized,

- Institutional control of groundwater will be continued, and,

- There will be a trade-off between land use and institutional control.

For post-closure;

- The endstate disposal standards should drive consistent disposal actions. 
D. Ecosystem

During Remediation;

- The disruption of pristine land will be minimized,

- The use of existing structures and contaminated land will be maximized,

- The impacts to sensitive susceptible areas will be minimized, and

- Sound eco/cultural risk management practices will be emphasized.

\section{D.7 Summary Conclusions}

In developing a risk-based cleanup strategy the total risk can best be considered in terms of four hazard categories with associated receptor and exposure pathways. The hazard categories are (1) near-term releases via the air pathway with the public as the primary receptor, (2) workplace hazards, (3) long-term releases with the public as the primary receptor and the groundwater as the primary pathway, and (4) ecosystem hazards. The principal conclusions are as follows.

- The most significant near-term hazards are from radionuclide sources associated with the $\mathrm{N}$ fuel stored in the $\mathrm{K}$ Basins, the cesium and strontium capsules stored in Waste Encapsulation and Storage Facility, the debris in the $324 \mathrm{~B}$ cell, the safety high-level waste tanks, and the plutonium in the Plutonium Finishing Plant. These hazards are dominated by the quantities of Sr-90, Cs-137, and Am-241.

- Increased worker risk during the remediation timeframe is one of the costs associated with reducing the long-term public and worker risk.

- Maintaining acceptable worker risks will usually be associated with increased costs; however, some remediation alternatives could result in significantly increased worker risks compared to other remediation alternatives.

- Long-term release hazards through the groundwater pathway are dominated by seven longlived, mobile constituents: C-14, Tc-99, I-129, Np-237, carbon tetrachloride, nitrate, and uranium.

- The potential contributions to ground water contamination from tank waste, buried solid wastes, and existing environmental releases are roughly of the same order of magnitude.

- The long-term release hazard posed by existing low-level waste burial grounds is roughly two orders of magnitude higher than that posed by the pre-1970 unsegregated buried waste and the post-1970 retrievably-stored transuranic waste. Suitable infiltration barriers can reduce the risk from of buried solid waste inventories to acceptable levels. 
- If there were no treatment or isolation of potential post-closure hazardous material inventories, carcinogenic risks appear to be about two to three orders of magnitude higher than acceptable limits while non-carcinogenic risks (chiefly nitrate) appear to be four to five orders of magnitude higher than acceptable limits.

- For tank waste: (1) the near-term risks are dominated by those few tanks that have the highest Cs-137, Sr-90, and Am-241 contents; (2) roughly one fourth of the tanks contribute more than 99 percent of the long-term release risk; and (3) the residual contamination following retrieval and the contamination from prior tank leaks place a lower limit below which risk cannot be reduced without some form of in-situ treatment.

- The greatest risk to the ecosystem and cultural resources is from physical disruption during demolition, construction, retrieval, and transport operations.

\section{D.8 References}

10 CFR 61, "Licensing Requirements for Land Disposal of Radioactive Waste," Code of Federal Regulations, as amended.

Buck, J. W., M. S. Peffers, and S. T. Hwang, 1991, Preliminary Recommendations on the Design of the Characterization Program for the Hanford Site Single-Shell Tanks - A System Analysis, Volume 2 -Closure Related Analyte Priorities, Concentration Thresholds, and Detection Limit Goals Based on Public Health Concerns, PNL-7575, Vol. 2, Pacific Northwest Laboratory, Richland, Washington.

Buck, J. W., G. Whelan, J. G. Droppo, D. L. Strenge, K. J. Castleton, J. P. McDonald, C. Sato, and G. P. Streile, 1995, Multimedia Environmental Pollutant Assessment System (MEPAS) Application Guidance, PNL-10395, Pacific Northwest Laboratory, Richland, Washington.

Cartmell, D. B., 1994, Transition Projects FY1995 Multi-Year Program Plan (MYPP)/Fiscal Year Work Plan (FYWP), WHC-SP-1126, Westinghouse Hanford Company, Richland, Washington.

Dirkes, R. L., R. W. Hanf, and R. K. Woodruff, 1994, Hanford Site Environmental Report for Calendar Year 1993, PNL-9823, Pacific Northwest Laboratory, Richland, Washington.

DOE, 1987, Final Environmental Impact Statement (EIS) Disposal of Hanford Defense High-Level, Transuranic and Tank Wastes, DOE/EIS-0113, U.S. Department of Energy, Washington, D.C.

DOE, 1989, Environmental Impact Statement - Decommissioning of Eight Surplus Production Reactors at the Hanford Site, Richland, Washington, DOE/EIS-0119D, U.S. Department of Energy, Washington, D.C.

DOE, 1991, Nuclear Safety Policy, SEN-35-91, Department of Energy, Washington, D.C. 
DOE, 1994a, Hanford Remedial Action - Draft Environmental Impact Statement, Volume 1 of 2, DOE/DEIS-0222, U.S. Department of Energy, Washington, D.C.

DOE Order 5820.2A, Radioactive Waste Management, U.S. Department of Energy, Washington, D.C.

Droppo, Jr., J. G., J. W. Buck, J. S. Wilbur, D. L. Strenge, and M. D. Freshley, 1991, Single-Shell Tank Constituent Rankings for Use in Preparing Waste Characterization Plans, PNL-7572, Pacific Northwest Laboratory, Richland, Washington.

EPA, 1994, Health Effects Assessment Summary Table: Annual Update FY-1994, EPA 540-R- 94-020, U.S. Environmental Protection Agency, Office of Emergency and Remedial Response, Washington, D.C.

Fredenburg, E.A., 1994, Waste Retrieval and Transfer Engineering Data Package for the Tank Waste Remediation System Environmental Impact Statement, WHC-SD-WM-EV-097, REV. A, DRAFT. Westinghouse Hanford Company, Richland, Washington.

Freshley, M. D. and P. D. Thorne, 1992, Ground-Water Contribution to Dose from Past Hanford Operations, PNWD-1974 HEDR, Pacific Northwest Laboratory, Richland, Washington.

Goldberg, C.E., 1995, Single-Shell and Double-Shell Tank Waste Inventory Data Package for the Tank Waste Remediation System Environmental Impact Statement, DRAFT, Rev. C, WHC-SD-WM-EV-102, Westinghouse Hanford Company, Richland, Washington.

Kincaid, C. T., J. W. Shade, G. A. Whyatt, M. G. Piepho, K. Rhoads, J. A. Voogd, J. H. Westsik, Jr., M. D. Freshley, K. A. Blanchard, and B. G. Lauzon, 1994, Performance Assessment of Grouted Double-Shell Tank Waste Disposal at Hanford, WHC-SD-WM-EE-004, Rev. 1, Westinghouse Hanford Company, Richland, Washington.

Mahaffey, J. A., B. L. Harper, T. A. Ikenberry, R. D. Stenner, J. W. Buck, J. S. Dukelow, Jr., L. H. Staven, P. S. Kaae, S. F. Snyder, N. C. Batishko, G. M. Gelston, S. W. Gajewski, N. C. Van Houten, K. J. Castleton, B. R. Warren, and M. S. Peffers, 1994, Integrated Risk Assessment Program: Methodology and Results from Qualitative Evaluation of Current Hanford Site Risks to the Public, PNL-10154, Pacific Northwest Laboratory, Richland, Washington.

McConville, C. M., 1995, In Situ Treatment and Disposal of Radioactive Waste in Hanford Site Underground Storage Tanks Engineering Data Package for the Tank Waste Remediation System Environmental Impact Statement, WHC-SD-WM-EV-101, Rev. B, Draft, Westinghouse Hanford Company, Richland, Washington.

Muhlestein, L. D., 1995, An Individual Accident Risk Acceptance Criteria Developed From The DOE Nuclear Safety Policy, ARES-95-03, ARES Corporation, San Francisco, CA.

NSC, 1994, Accident Facts, 1994 Edition, National Safety Council, Washington, D.C. 
Pajunen, A. L., C. K. Allen, A. B. Carlson, et al., 1994, Hanford Strategic Analysis Study, WHC-EP-0549, Westinghouse Hanford Company, Richland, Washington.

RL, 1995, Closure Report for the N-Reactor Facility, DOE/RL-94-152, Rev. 0. U.S. Department of Energy Richland Operations Office, Richland, Washington.

Scanlon, P. L., H. Hampt, and W. A. Skelly, 1995, Closure Technical Data Package for the Tank Waste Remediation System Environmental Impact Statement, WHC-SD-WM-EV-107, Rev. B, Draft, Westinghouse Hanford Company, Richland, Washington.

Schreckhise, et al., 1993, Recommended Environmental Dose Calculation Methods and HanfordSpecific Parameters, Rev. 2, PNL-3777, Pacific Northwest Laboratory, Richland, Washington.

Shramke, J. A., C. D. Glantz, and G. R. Holdren, 1994, Hanford Site Environmental Setting Data Developed for the Unit Risk Factor Methodology in Support of the Programmatic Environmental Impact Statement (PEIS), PNL-9801, Pacific Northwest Laboratory, Richland, Washington.

Sinema, S., 1993, PUREX/UO3 Deactivation Project Management Plan, WHC-SP-1011D, Westinghouse Hanford Company, Richland, Washington.

Slaathaug, E. J., 1995, Tri-Party Agreement Alternative Engineering Data Package for the Tank Waste Remediation System Environmental Impact Statement, WHC-SD-WM-EV-104, Rev. B, DRAFT, Westinghouse Hanford Company, Richland, Washington.

Strenge, D. L., and P. J. Chamberlain, 1994, Evaluation of Unit Risk Factors in Support of The Hanford Remedial Action Environmental Impact Statement, PNL-10190, Pacific Northwest Laboratory, Richland, Washington.

Walsh, J. L., 1994, N-Reactor Deactivation Program Plan, WHC-SP-0615, Rev. 4, Westinghouse Hanford Company, Richland, Washington.

Whelan, G., Buck, J. W., and Nazarali, A., 1994, Modular Risk Analysis for Assessing Multiple Waste Sites, PNL-SA-24239, Pacific Northwest Laboratory, Richland, Washington, 99352.

Wood, M. I., R. Khaleel, P. D. Rittmann, A. H. Lue, et al. 1994. Performance Assessment for the Disposal of Low-Level Waste in the 200 West Area Burial Grounds. WHC-EP-0645, Westinghouse Hanford Company, Richland, Washington. 


\section{D.9 Bibliography}

Napier, B. A., N. C. Batishko, D. A. Heise-Craff, M. F. Jarvis, and S. F.

Snyder, 1995, Identification of Contaminants of Concern - Columbia River Comprehensive Impact Assessment. PNL-10400. Pacific Northwest Laboratory, Richland, Washington.

RL, 1993, Hanford Site Risk Assessment Methodology, DOE/RL-91-45, Rev. 2, U.S.

Department of Energy Richland Operations Office, Richland, Washington 


\section{Appendix E}

\section{Alternative I: Existing Baseline Strategy}


•

-

• 


\section{Contents}

\section{Appendix E - Existing Baseline Strategy}

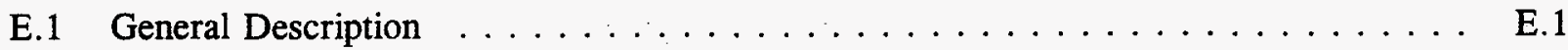

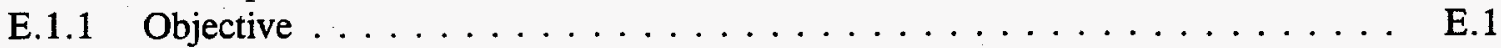

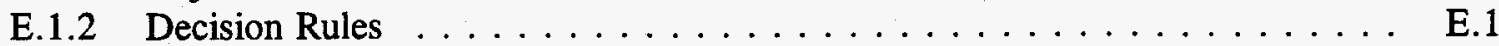

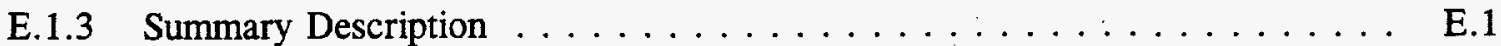

E.2 Development of the Existing Baseline Strategy $\ldots \ldots \ldots \ldots \ldots \ldots \ldots$

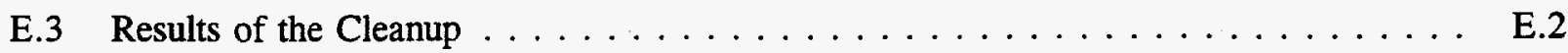

E.3.1 Geographic Results . . . . . . . . . . . . . . . . . . . E.2

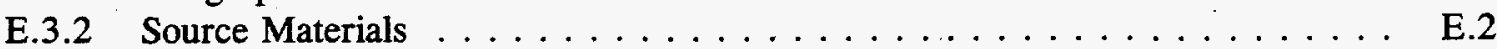

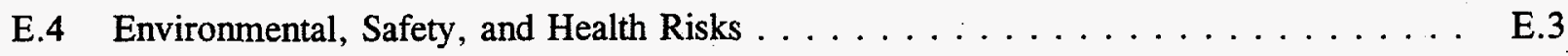

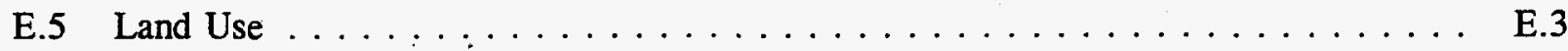

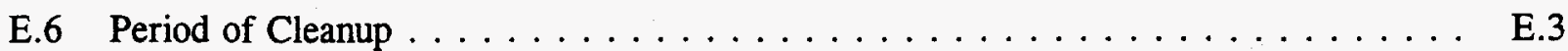

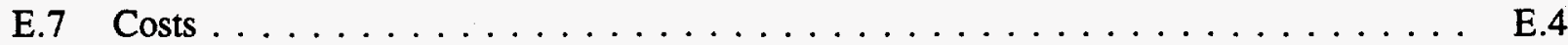

E.8 Programmatic Risks $\ldots \ldots \ldots \ldots \ldots \ldots \ldots \ldots \ldots \ldots \ldots \ldots$

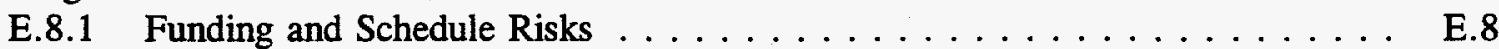

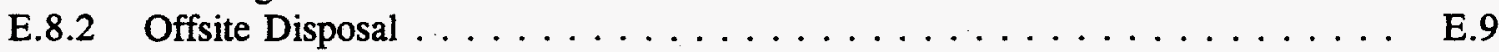

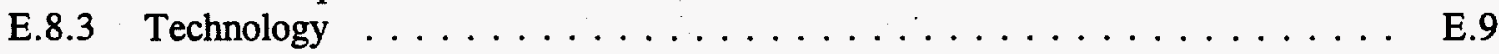

E.9 Stakeholder Issues and Regulatory Impacts $\ldots \ldots \ldots \ldots \ldots \ldots$

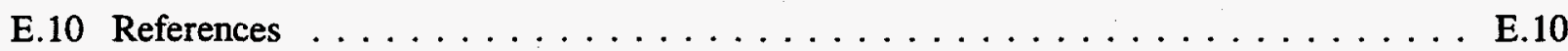

Attachment E1 - Existing Baseline Strategy Assumptions . . . . . . . . . . . E1.1 


\section{Figures}

E.1 Baseline Strategy Cost Profile $\ldots \ldots \ldots \ldots \ldots \ldots \ldots \ldots$

E.2 A Blowup of the Small Programs at the Bottom of Figure E.1 $\ldots \ldots \ldots \ldots$

E.3 Existing Baseline Strategy Cost Profile with 20 Percent Productivity Improvement . . . E.7

E.4 Existing Baseline Strategy Cost Estimates with Tank Waste Remediation System Disposal Deferred . . . . . . . . . . . . . . . . . E.8

E.5 Existing Baseline Strategy Funding Profile with Significant Extensions _ . . . . . . E.9

\section{Tables}

E.1 Cost Basis Summary for Existing Baseline Strategy $\ldots \ldots \ldots \ldots \ldots$ 


\section{Appendix E}

\section{Alternative I: Existing Baseline Strategy}

\section{E.1 General Description}

This Appendix describes the Existing Baseline Strategy that reflects amendments to the Hanford Federal Facility Agreement and Consent Order (Ecology et. al 1994), commonly known as the Tri-Party Agreement, as of May 1995. This Existing Baseline Strategy is presented as a description of the current Hanford Site planning basis to indicate the impact of potential future funding constraints on Site plans.

\section{E.1.1 Objective}

The objective of the Existing Baseline Strategy is essentially to maintain compliance with current agreements as negotiated with the regulators. The activities identified in the agreement represent one approach for reducing near-term and long-term risks while progressing toward reducing the Site land area committed to waste management activities. As new information is accumulated on the Site cleanup activities, the cleanup approach is renegotiated. Since the Tri-Party Agreement includes processes for renegotiating the agreement elements, the baseline evolves over time. Therefore, the baseline described below reflects only the current status of the agreement.

\section{E.1.2 Decision Rules}

A clear set of decision rules across major cleanup activities is not apparent in the Existing Baseline Strategy. The focus of the strategy is to attempt to complete the Site cleanup actions on parallel paths, assuming no funding constraints. Decision rules for prioritization of major action against one another are embedded in the consensus building process used during Tri-Party Agreement milestone negotiations; however, the negotiations typically consider one major group of activities at a time rather than considering the Site cleanup as a single entity.

\section{E.1.3 Summary Description}

The Existing Baseline Strategy goals, inferred from Site planning documents, are (1) to cleanup all waste and demolish all former defense facilities outside the central plateau, (2) dispose of waste materials in the 200 Area, and (3) retain the 200 Area as an exclusive disposal and storage facility for the foreseeable future. Tank waste and some solid waste (primarily post-1970 transuranic waste) in the 200 Area would be retrieved and prepared for storage or disposal on-site or shipment off-site. The land outside the central plateau would be made available for use by others.

In general, the Existing Baseline Strategy attempts to reduce all public risks to a minimum level (essentially zero outside the 200 Area), disposition all facilities, cleanup all the land outside the 200 Area, and satisfy all stakeholder and regulatory requirements. This strategy is primarily driven by regulatory and Tri-Party Agreement requirements. 
The Existing Baseline Strategy is developed from the latest Tri-Party Agreement negotiations and from current Hanford Site program plans and generally describes the strategy the Site is executing today. Appendix A of the Hanford Mission Plan, which contains summary assumptions about the disposition of waste inventories, was written early in fiscal year 1994. These assumptions were reviewed by the task team and modified in accordance with later information. Attachment E1 contains a revised description of the Existing Baseline Strategy assumptions.

Execution of the Existing Baseline Strategy is likely to be confounded by current actions by level. The funding constraints become a new factor to be considered in future Tri-Party Agreement negotiations.

\section{E.2 Development of the Existing Baseline Strategy}

The Existing Baseline Strategy description is derived from the latest Tri-Party Agreement renegotiations and from current program plans.

\section{E.3 Results of the Cleanup}

The Existing Baseline Strategy will, over time, dispose of all waste and will make land outside the central plateau available for unrestricted use.

\section{E.3.1 Geographic Results}

When cleanup is complete, the central plateau will be a permanent waste disposal site for entombed nuclear facilities, liquid and solid waste sites (capped and covered), including pre-1970 transuranic solid waste and tank structures. Access to the 200 Area and its groundwater will be controlled indefinitely.

The 100 and 400 Areas will be cleaned up to allow unrestricted use of the surface areas; however, groundwater access, even though the water will be treated, will be controlled for the foreseeable future. Research and develop activities will be consolidated in the 300 Area with excess facilities demolished and the area cleaned up to allow unrestricted use of the surface. Groundwater access will be controlled for the foreseeable future. The 600 Area will be cleaned up to allow unrestricted use of the surface area; however, the potential for contaminant plumes to be present or emanate from the 200 Area will result in control of groundwater access for the foreseeable future.

\section{E.3.2 Source Materials}

When cleanup is complete, unirradiated uranium, special nuclear materials, and spent nuclear fuels will be stored safely in the 200 Area pending final disposition. A majority of tank waste will be retrieved and partitioned into high- and low-level fractions that are vitrified. The low-level fraction is disposed in the 200 Area while the high-level fraction, along with cesium and strontium capsules, is disposed in an off-site geologic repository. Tank structures with residual tank waste and contaminated soil underneath the tanks will be disposed in-situ. 
Solid waste will be disposed in the 200 Area or retrieved for off-site disposal, depending upon waste classification. In general, solid waste outside the 200 Area will be retrieved for disposal on the plateau. Within the 200 Area, only post-1970 transuranic solid waste will be retrieved with the remainder of existing solid waste disposed in the 200 Area. Newly generated solid waste will be segregated by classification, with transuranic and non-radioactive hazardous waste disposed off-site. Newly generated low-level and low-level mixed waste will continue to be disposed in the 200 Area.

Contaminated soil outside the 200 Area will be excavated and bulk-disposed in the 200 Area. Contaminated soil inside the 200 Area will be remediated in-situ (e.g., capped in-place).

Contaminated groundwater outside the 200 Area will be remediated using pump-and-treat systems to the extent technically and economically practical. Groundwater access control will be used as a method for reducing exposure to groundwater contaminants in regions where pump-and-treat technologies are ineffective. Facilities outside the 200 Area will be dismantled, with rubble transported to the plateau for disposal. Major facilities within the 200 Area will be entombed.

\section{E.4 Environmental, Safety, and Health Risks}

The Existing Baseline Strategy addresses all environmental and public health risks. Spent fuel will be removed from $\mathrm{K}$ Basins, tank waste will be retrieved, and facilities will be decommissioned. Nuclear materials and waste will be safely stored or disposed. Overall public health and environmental risks would be very low in the endstate and well within acceptable limits during remediation activities.

Worker risk would be greatest during retrieval and treatment of spent fuel, tank waste, and solid waste, and during final disposition of facilities. Reactor core removal would be deferred to later years specifically to reduce worker exposure during removal.

\section{E.5 Land Use}

The Existing Baseline Strategy assumes the 200 Area will remain restricted through and beyond the cleanup period. Most areas outside the central plateau would be released for unrestricted use; however, unrestricted groundwater utilization outside the 200 Areas is not explicitly required by the Tri-Party Agreement. The 300 Area would be available for industrial use.

\section{E.6 Period of Cleanup}

The cleanup period for the Existing Baseline Strategy is assumed to be 80 years (1995 through 2075). This period is driven by the retention of reactor cores in place for 75 years to permit radioactive decay. A majority of cleanup activities are completed by 2040 with completion of shipping the high-level fraction of retrieved tank waste to a geological repository. Consistent with the Tri-Party Agreement, tank wastes would be vitrified by 2028 and waste sites would be remediated by 2018. 


\section{E.7 Costs}

The total lifecycle cost to complete cleanup under the Existing Baseline Strategy would be approximately 84 billion dollars. In order to proceed with cleanup according to the most recent TriParty Agreement, major capital investment would be required, especially in the near-term. Cleanup of all waste is planned to proceed in parallel in order to satisfy the Tri-Party Agreement schedule, with the result that funding for cleanup exceeds two billion dollars annually for a 20 year period beginning late this decade. Funding peaks approach 2.5 billion dollars in the first decade of the $21 \mathrm{st}$ century.

Figure E.1 is an approximate representation of costs to execute the current strategy and meet Tri-Party Agreement milestones. Table E.1 summarizes the basis for cost data used to develop the funding profile. Ongoing mortgage reduction activities (e.g., PUREX deactivation) are reflected in these estimates. The reader should realize that this graphic representation of costs is accurate only through about 2001 ; cost estimates after that are very rough. Nevertheless, the figure clearly illustrates the magnitude of the costs of the Existing Baseline Strategy. The costs during 2035-2040 assume the national repository is available to receive vitrified high-level waste. Figure E.2 is a blowup of the small programs at the bottom of Figure E.1; it allows the reader to better understand the contribution of these programs to the total Site cleanup effort.

Figure E. 3 is a variation of the funding profile for the Existing Baseline Strategy in which a 20 percent cost reduction is achieved through productivity improvements. It is clear from Figure E. 3 that annual funding requirements greatly exceed the 1.05 billion dollars per year expected over the period. There are other actions that could close the gap, including privatization, regulatory relief, and additional mortgage relief in the early years. These improvements would have to further reduce the total Site budget by approximately 30 to 50 percent in order to execute the Existing Baseline Strategy within projected funding constraints. These reductions would also be required to occur within the next year.

Figure E.4 is another variation on the Existing Baseline Strategy. It assumes Tank Waste Remediation System disposal activities are deferred to about 2015. This profile shows the amount of savings required to live within the 1.05 billion dollar per year budget and conceptually models recent discussions by the U.S. Department of Energy Richland Operations Office.

Recent government actions indicate preference toward executing the Tri-Party Agreement strategy at much less cost over a longer period. The cost savings are expected from privatization, productivity enhancements, regulatory relief, and some up-front mortgage reductions. Estimates for these cost savings are not available, and it is left to the reader to determine how likely it is that they can be achieved; however, the cost profiles available at this time indicate that even with a 20 -year delay of all Tank Waste Remediation System disposal funding, the productivity, regulatory, and privatization actions need to reduce annual Site costs by 200 to 500 million dollars for the next ten years. 


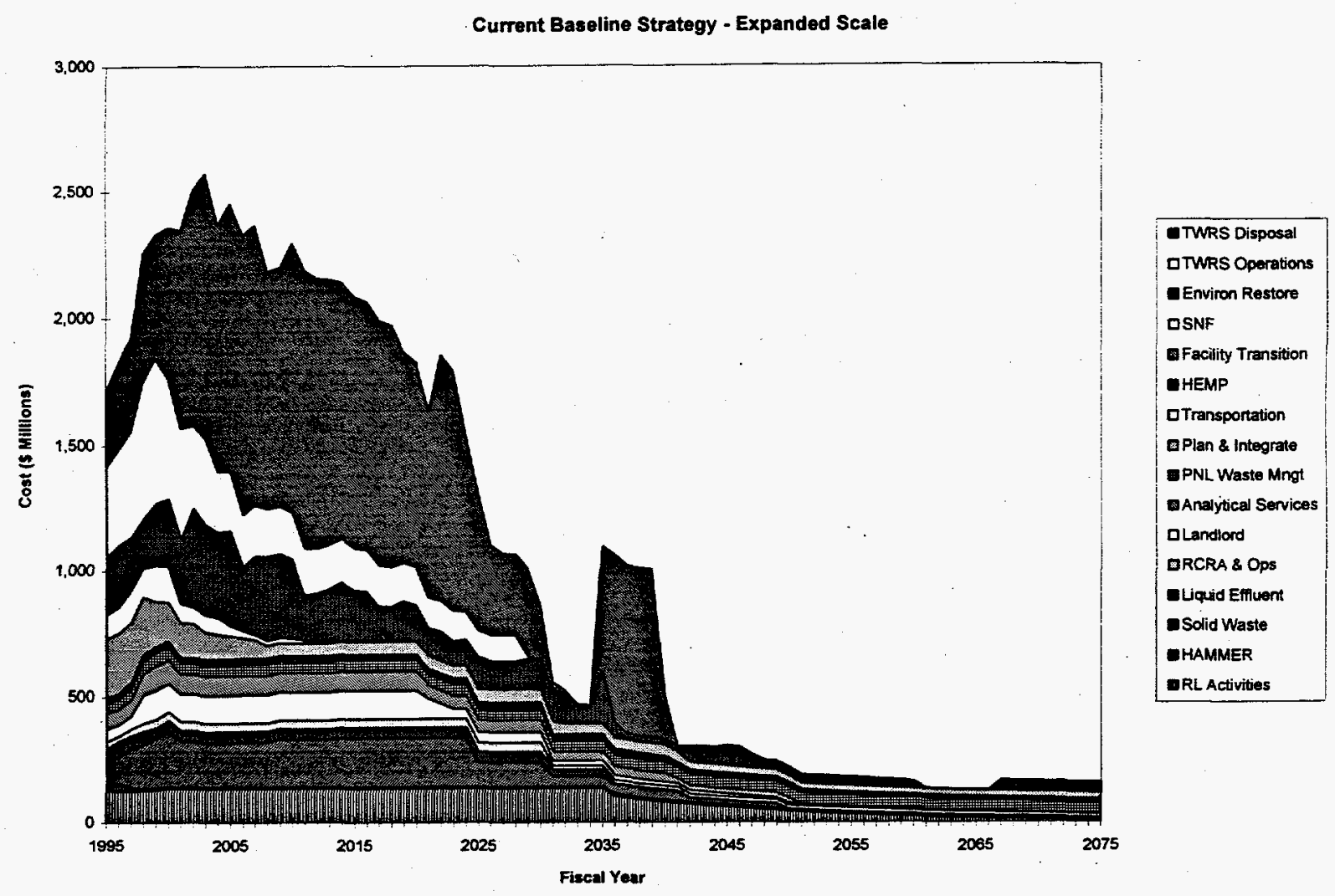

Figure E.1. Baseline Strategy Funding Profile 
Table E.1. Cost Basis Summary for Existing Baseline Strategy

\begin{tabular}{|c|c|}
\hline Programs & Assumptions \\
\hline TWRS & $\begin{array}{l}1996 \text { ADS for } 1995 \text { to } 2000 . \\
\text { Projection from TWRS MYPP for } 2001 \text { to } 2040 .\end{array}$ \\
\hline SNF & $\begin{array}{l}\text { Cost profile from Hanford Spent Nuclear Fuel Project Recommended Path Forward } \\
\text { (Bergman 1994). }\end{array}$ \\
\hline $\begin{array}{l}\text { EM-30 } \\
\text { transition }\end{array}$ & $\begin{array}{l}\text { - } 1997 \text { ADS for } 1995 \text { to } 2001 \text {. } \\
\text { Continues to store capsules until end of TWRS activities, then deactivated by a cost profile } \\
\text { developed from the } 1997 \text { ADS elements. } \\
\text { Capsule storage assumed completed by } 2028 \text {. }\end{array}$ \\
\hline Solid waste & $\begin{array}{l}\text { Based on } 1996 \text { ADS for } 1995 \text { to } 2000 \text {. } \\
\text { Surveillance, maintenance, and operations extended to end of TWRS activities } \\
\text { supplemented by estimate of out-year funding from solid waste program-based on 30-year } \\
\text { forecast and factors for waste-type disposal. }\end{array}$ \\
\hline Liquid effluents & $\begin{array}{l}\text { Based on } 1996 \text { ADS for } 1995 \text { to } 2000 \text {. } \\
\text { Assumes observations continue at year } 2000 \text { level for } 2001 \text { to } 2030 \text {. } \\
\text { After } 2030 \text {, major cleanup complete, but still assume } 200 \text { Area system operates at reduced } \\
\text { funding. }\end{array}$ \\
\hline Analytical services & $\begin{array}{l}\text { Based on } 1996 \text { ADS for } 1995 \text { to } 2000 \text {. } \\
\text { Laboratory operations and maintenance extend at } 2000 \text { funding level, } 2001 \text { through } 2020 \\
\text { to support TWRS disposal activities. } \\
\text { Ramped down during } 2020 \text { to } 2040 \text { as activities decrease. }\end{array}$ \\
\hline $\begin{array}{l}\text { RCRA and Ops } \\
\text { monitoring }\end{array}$ & $\begin{array}{l}1996 \text { ADS for } 1995 \text { to } 2000 \text {. } \\
\text { Year } 2000 \text { extended through } 2020 \text { assuming constant funding to end of TWRS disposal } \\
\text { Reduced from } \$ 35 \mathrm{M} / \mathrm{yr} \text { to } \$ 15 \mathrm{M} / \mathrm{yr} \text { for } 2030 \text { and beyond as major activities are completed. }\end{array}$ \\
\hline PNL & $\begin{array}{l}1996 \text { ADS for } 1995 \text { to } 2000 \text {. } \\
\text { Year } 2000 \text { less } \$ 10 \mathrm{M} \text { (assuming cell cleanouts complete) extended to } 2001 \text { and beyond } \\
\text { based on ADS details. }\end{array}$ \\
\hline HEMP & $\begin{array}{l}1996 \text { ADS for } 1995 \text { to } 2000 . \\
\quad \text { Year } 2000 \text { extended to } 2001 \text { and beyond. }\end{array}$ \\
\hline Planning and integration & $\begin{array}{l}\text { Based on } 1996 \text { ADS for } 1995 \text { to } 2000 \text {. } \\
\text { Extended year } 2000 \text { through } 2040 \text { assuming level planning support until TWRS complete. } \\
\text { Reduced by half for } 2040 \text { and beyond. }\end{array}$ \\
\hline Transition projects EM-60 & $\begin{array}{l}\text { Based on } 1997 \text { ADS for } 1995 \text { to } 2001 . \\
\text { Assumes PFP stabilization complete in } 2002 . \\
\text { Deactivated to } \$ 25 \mathrm{M} / \mathrm{yr} \text { by } 2008 \text {. } \\
\text { Program management ramped down as PFP deactivated. }\end{array}$ \\
\hline FFTF & $\begin{array}{l}\text { Based on } 1997 \text { ADS for } 1995 \text { to } 2001 \text {. } \\
\text { Extended year } 2001 \text { to } 2002 \text { and beyond until decontamination and decommissioning } \\
\text { complete. }\end{array}$ \\
\hline \multicolumn{2}{|c|}{ FFTF = Fast Flux Test Facility. } \\
\hline \multicolumn{2}{|c|}{ HEMP = Hanford Environmental Management Program. } \\
\hline \multirow{2}{*}{\multicolumn{2}{|c|}{$\begin{array}{l}\text { MYPP }=\text { multi-year pr } \\
\text { Ops } \quad=\text { operations. }\end{array}$}} \\
\hline & \\
\hline \\
\hline \multicolumn{2}{|r|}{ aboratory. } \\
\hline \multicolumn{2}{|c|}{ RCRA = Resource Conservation and Recovery Act of 1976.} \\
\hline \multicolumn{2}{|l|}{$\begin{array}{l}\text { SNF } \\
\text { TWRS }\end{array}$} \\
\hline
\end{tabular}




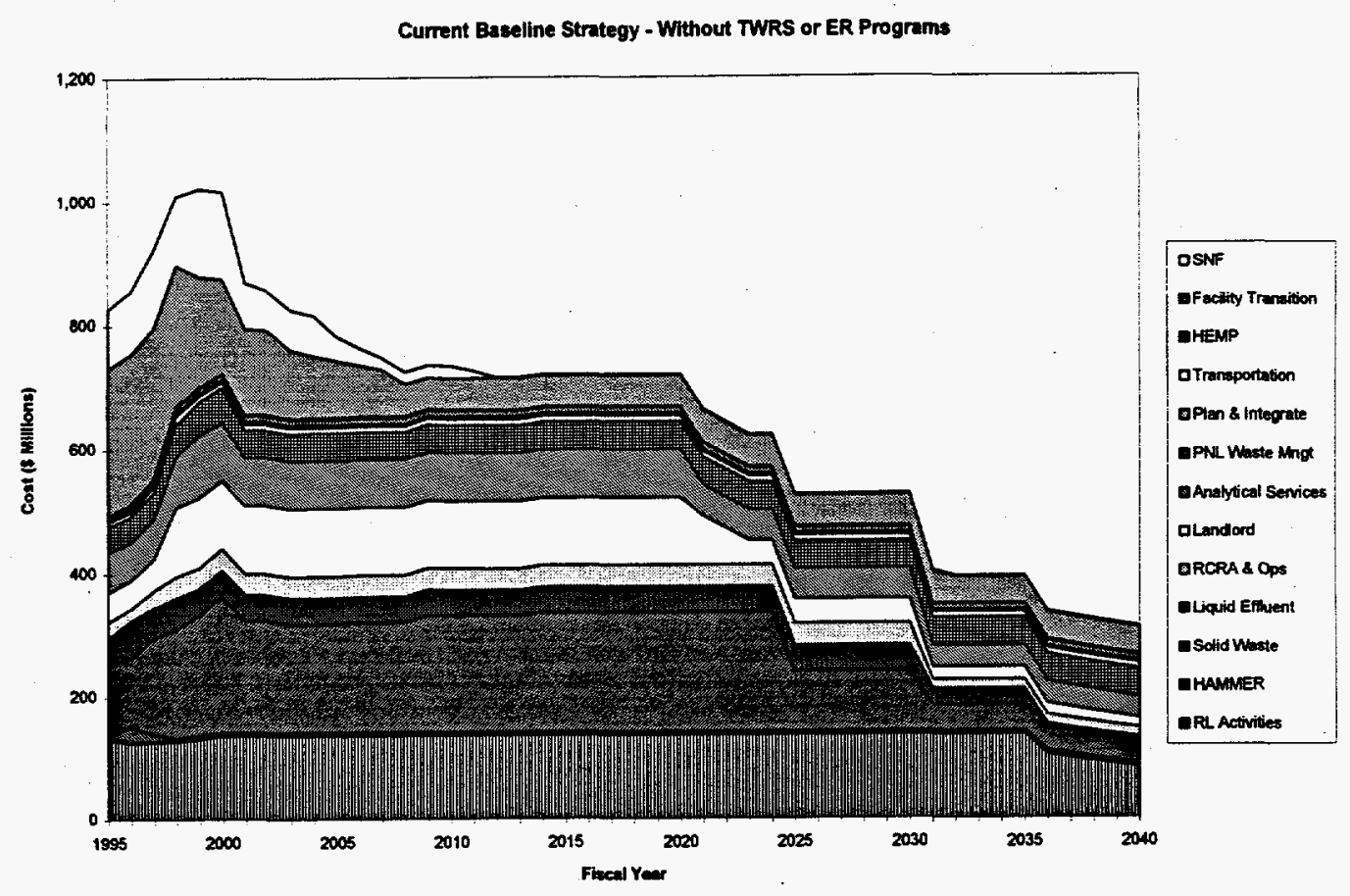

Figure E.2. A Blowup of the Small Programs at the Bottom of Figure E.1

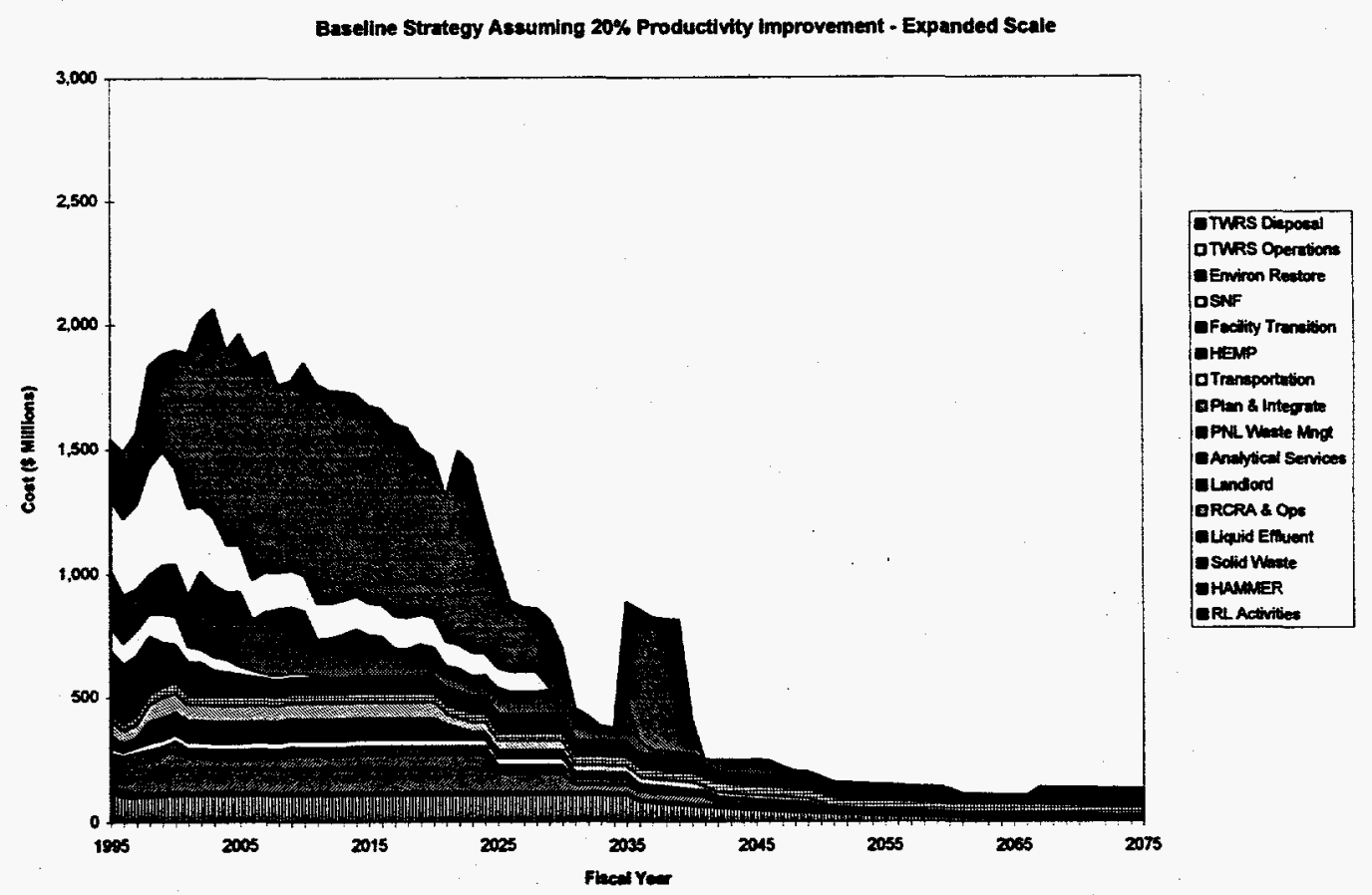

Figure E.3. Existing Baseline Strategy Funding Profile with 20 Percent Productivity Improvement 


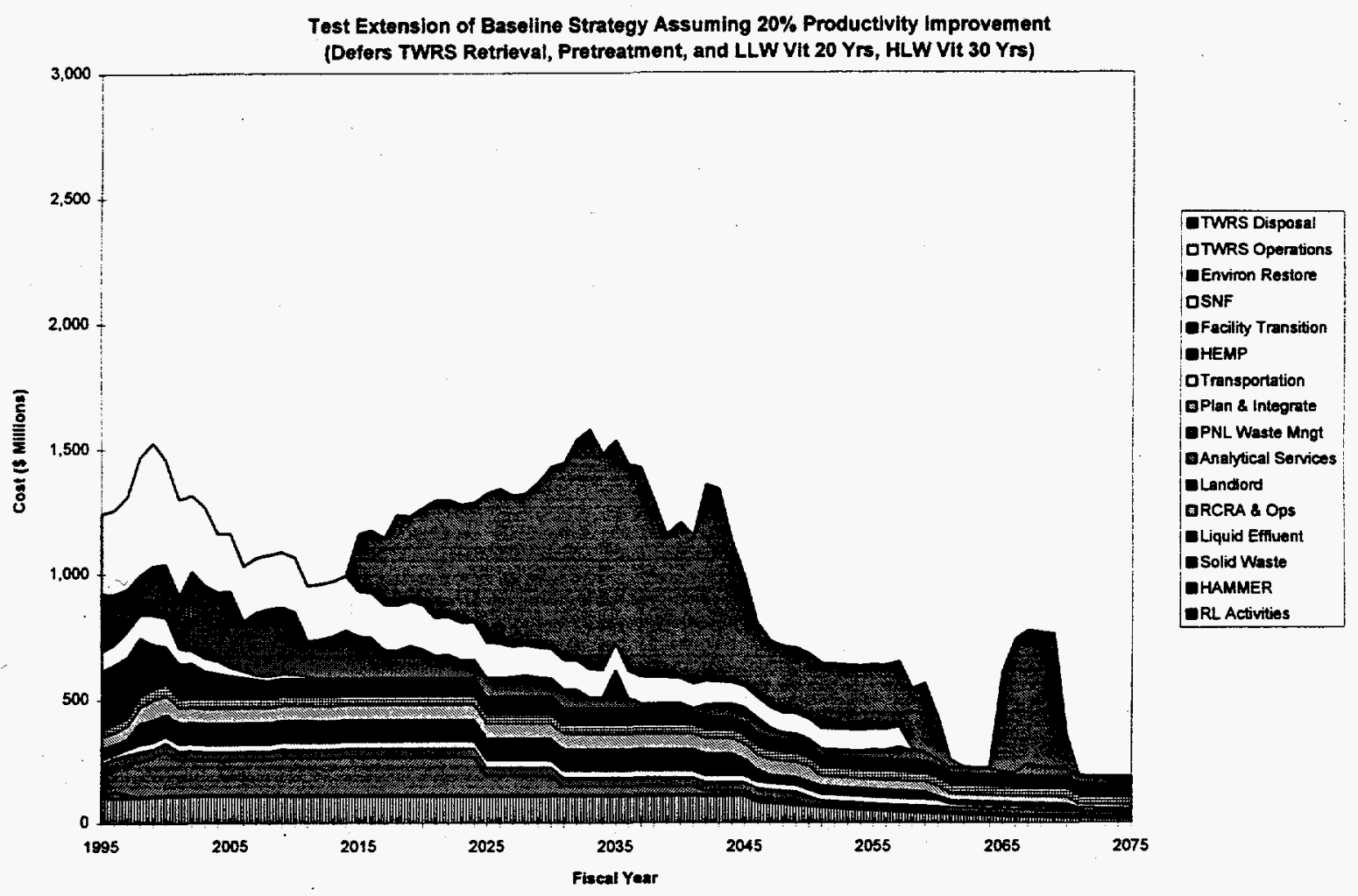

Figure E.4. Existing Baseline Strategy Funding Profile with Tank Waste Remediation System Disposal Deferred

\section{E.8 Programmatic Risks}

\section{E.8.1 Funding and Schedule Risks}

Funding is expected to be substantially less than required to execute the Existing Baseline Strategy. Although efforts to reduce the annual funding requirements through productivity initiatives and privatization are being pursued, it is clear that the Existing Baseline Strategy cannot be executed on the currently planned schedule and may not be executable at all. Figure E.5 illustrates this latter point by assuming dramatic deferrals in major cleanup actions to approach satisfying the budget constraint. This graphic illustrates the time required to execute the Existing Baseline Strategy at a funding profile of approximately 1.05 billion dollars. The figure assumes the total cost to execute a given program's strategy remain constant. The bulk of the cleanup is not complete until 2065. In addition, the funding constraint would not be satisfied in the out-years when major tank disposal construction actions begin. This indicates that simple deferral of programs is insufficient to achieve the projected budget and work scope changes (either a different endstate or method for achieving the same endstate) will be necessary. 


\section{E.8.2 Offsite Disposal}

The Existing Baseline Strategy assumes ultimate off-site disposal of spent nuclear fuel, high-level vitrified waste, and transuranic waste. Such disposal requires national policies for the final disposition of these materials, and closure allowing implementation of the current policies is not anticipated in the near future. The disposition of spent nuclear materials likewise requires national policy decisions regarding the future disposal of plutonium.

\section{E.8.3 Technology}

Moderate technology risks are associated with activities incorporated in the Existing Baseline Strategy with the greatest risks being associated with the retrieval, separation, and vitrification of tank waste, and relocation of reactor cores to the 200 Area.

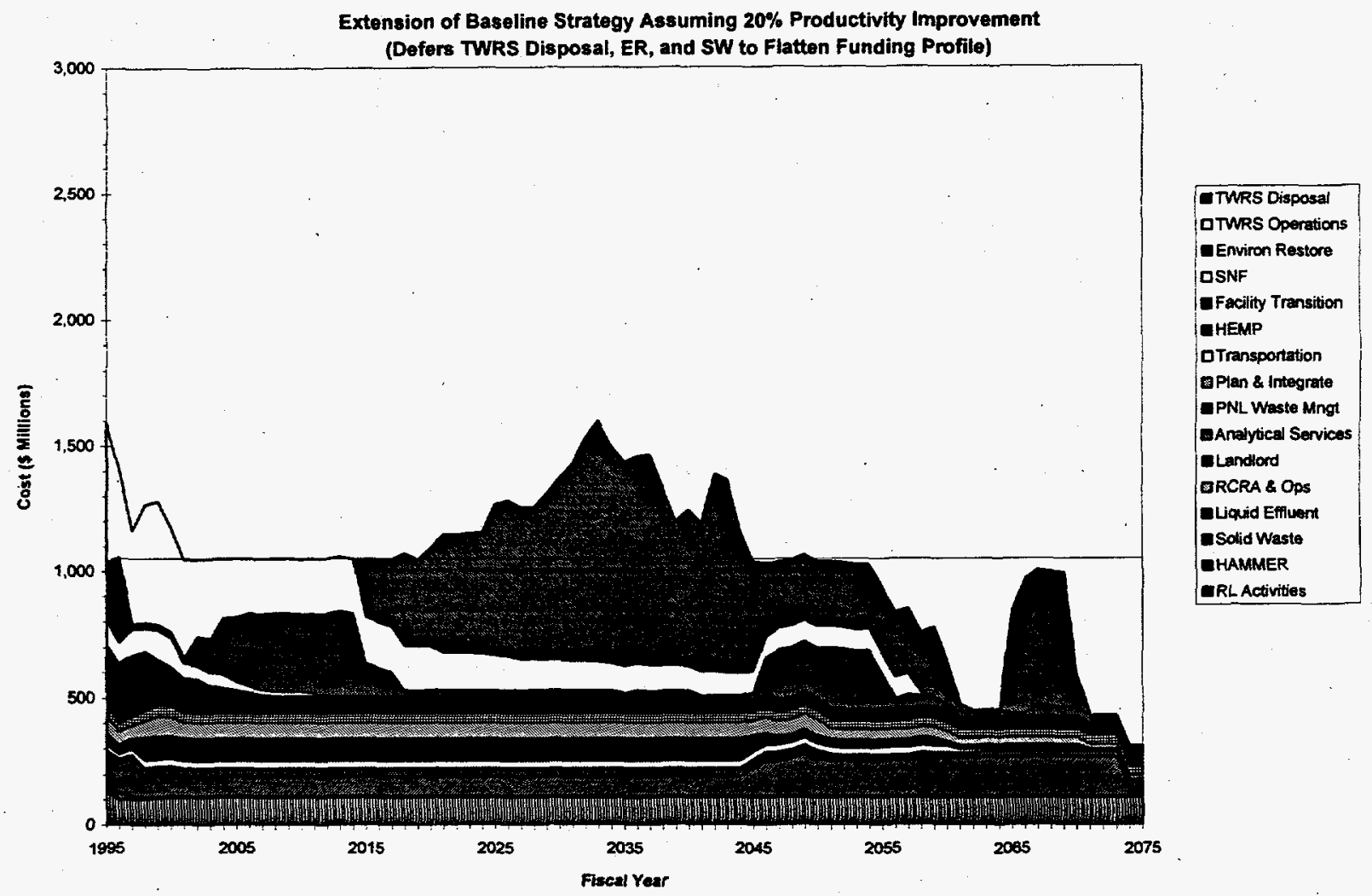

Figure E.5. Existing Baseline Strategy Funding Profile with Significant Extensions 


\section{E.9 Stakeholder Issues and Regulatory Impacts}

The Existing Baseline Strategy is specifically designed to address stakeholder concerns and values. If all activities are funded, the resulting endstate and land use should be acceptable. The Indian Tribes, have consistently insisted, however, that the land ultimately be restored to its original condition. Terms such as "100 years after closure" have been used to define the time after which the land should be available for other uses. This would require exhuming and segregating environmental contamination within the 200 Area, significantly increasing the Existing Baseline Strategy cost well beyond the current estimates presented.

The U.S. Congress and national stakeholders may take issue with any cleanup strategy that costs on the order of 80 billion dollars. Extensions of the schedule to accomplish the Existing Baseline Strategy is theoretically possible to reduce annual funding requirements; however, extension will likely increase the total lifecycle cleanup costs and further add to concerns over those costs.

\section{E.10 References}

Bergman, T. B., 1994, Hanford Spent Nuclear Fuel Project Recommended Path Forward, Westinghouse Hanford Company, Richland, Washington.

Ecology, EPA, and DOE, 1994, Hanford Federal Facility Agreement and Consent Order, as amended, Washington State Department of Ecology, U.S. Environmental Protection Agency, and U.S. Department of Energy, Olympia, Washington.

Resource Conservation and Recovery Act of 1976, 42 USC 6901, et seq. 


\section{Attachment E1}

\section{Existing Baseline Strategy Assumptions}

\section{E1.1 Current Baseline Strategy Description}

The current baseline strategy represents the current Hanford Federal Facility Agreement and Consent Order (Ecology et al. 1994) (Tri-Party Agreement), including recently negotiated environmental restoration Refocusing and Facility Transition Change Packages. The strategy is described by a series of assumed activities that will be accomplished during cleanup. The general future use of Hanford Site land areas achieved by the current baseline strategy is as follows.

- The 200 Area plateau is maintained as a waste disposal site (exclusive use). Groundwater use within many of the Hanford Site areas is excluded.

- All contaminated areas outside the 200 Area are available for unrestricted use except the 300 Area, which is planned for industrial use.

\section{E1.2 Key Strategy Assumptions for the Current Baseline Strategy}

The following key assumptions are provided as a description of cleanup activities included in the current baseline strategy. These assumptions are provided by major groupings of materials which form the site inventory to be addressed by cleanup actions. These assumed actions describe what is projected to be accomplished by the current baseline funding profiles.

\section{E1.2.1 Nuclear Material Assumptions}

\section{Unirradiated Uranium}

- No further uranium processing is assumed.

- Uranium will be stored onsite in its current forms (as bulk oxide, metal billets, or zircaloy-clad metal) and offered for off-site use.

\section{Cesium and Strontium Capsules}

- Capsules are assumed to be stored in the Waste Encapsulation and Storage Facility until disposed of off-site, along with high-level waste.

- It is assumed that an overpack configuration of the existing capsule material will be accepted for repository disposal. 


\section{Irradiated Fuel}

- Irradiated fuel is assumed to be transferred to on-site interim dry storage prior to disposal off-site. This interim storage period could extend as long as 40 years.

- Metal fuel stored in PUREX is assumed to be transferred to the K Basins as a preliminary step toward interim dry storage.

- All metal fuel stored in the $\mathrm{K}$ Basins, along with some sludges, is assumed to be packaged, transferred to a wet staging system, dried, and passivated by partial oxidation prior to transfer to an interim storage facility. The facilities supporting wet staging, drying/passivation, and interim storage are assumed to be located in the 200 Areas.

- Shipping port PWR Core 2 fuel is continued to be stored in T Plant.

- Fast Flux Test Facility fuel is assumed to be transferred to interim storage casks that are placed on a pad in the 400 Area for temporary storage.

- Other fuels are packaged in interim storage containers that are temporarily stored in the 400 Area.

- Fuel in temporary storage in the 400 Area and T Plant is assumed moved to the 200 Area or to Idaho Nuclear Engineering Laboratory for interim storage, depending on finalizing logistics and timing which implement the record of decision for spent fuel management in the DOE complex (DOE 1995, 60 FR 28680).

- All fuel remaining in on-site in interim storage is assumed to be ultimately disposed of off-site after the interim storage period. Due to uncertainty in specific disposal requirements, final disposal costs for irradiated fuel are not currently included in the baseline strategy cost profiles.

\section{Special Nuclear Material}

- Special nuclear material is assumed to be stored on-site until dispositioned at an off-site location.

- Current inventories are assumed to be processed before off-site shipment using processes that emphasize stabilization rather than purification.

\section{E1.2.2 Tank Waste}

\section{Single-Shell Tank Waste}

- Single-shell tank waste is assumed to be retrieved for processing in the Tank Waste Remediation System.

- Retrieval efficiency is assumed to be 99 percent. 
- The tank waste is assumed to be partitioned into high-level and low-level fractions via a sludge washing process that uses solid/liquid separation combined with multiple contacts of the solids with caustic to direct radionuclides (e.g., strontium and transuranic) to the high-level waste fraction.

- The low-level waste fraction supernates are assumed to be processed in an ion exchange system to remove cesium, which is added to the high-level waste fraction. Other radionuclides may be removed from the low-level fraction to satisfy additional processing and/or disposal requirements.

- Both waste fractions are converted to a solid form using vitrification processes generating high-level waste glass for off-site disposal and low-level waste glass for on-site disposal.

- The high-level waste fraction will be interim stored on-site prior to off-site disposal.

\section{Double-Shell Tank Waste}

- Double-shell tank waste is assumed to be retrieved for processing in the Tank Waste Remediation System.

- Retrieval efficiency is assumed to be 99 percent and retrieved waste is processed using the same system described for use on single-shell tank waste.

\section{Tank Structures}

- The tank structures containing waste residuals are assumed to be disposed of in-situ by dome-filling with materials to prevent subsidence and installing a barrier cover.

\section{Underlying Contaminated Soil}

- Soil that is contaminated from earlier tank leaks and is located beneath single-shell tanks is assumed to be left in place without treatment, protected by the same barrier cover installed over the tank structures.

\section{E1.2.3 Solid Waste}

\section{Pre-1970 Buried Unsegregated Solid Waste}

- All buried unsegregated waste that is contaminated and located outside the 200 Area is assumed retrieved for disposal in the 200 Area vicinity.

- The retrieved waste is assumed to be bulk disposed without conversion to alternative forms.

- Waste located outside the 200 Area containing transuranic components in excess of 100 nanocuries per gram ( $\mathrm{nCi} / \mathrm{g})$, if any, is processed for off-site disposal using solid waste transuranic stabilization and packaging systems.

- Unsegregated waste containing transuranic components in excess of $100 \mathrm{nCi} / \mathrm{g}$, in the 200 Area is 
assumed to be disposed of in-situ.

- In general, unsegregated waste trenches in the 200 Area are assumed to be disposed of by stabilization barrier cover.

\section{Post-1970 Buried Segregated non-Transuranic Solid Waste}

- Post-1970 segregated non-transuranic waste is primarily located in the 200 Area. This waste is assumed to be disposed of in-situ after necessary stabilization and installation of a barrier cover.

\section{Stored Solid Waste}

- Solid waste is stored in facilities and 20-year retrievable-storage trenches. Trench-stored waste is assumed to be retrieved and segregated into transuranic, low-level, and low-level mixed waste fractions.

- The transuranic and low-level mixed waste fractions are treated via a combination of shred/grout, compaction, thermal treatment, and miscellaneous other processes.

- Low-level waste is disposed directly into on-site disposal systems located in the 200 Area vicinity.

- Treated low-level mixed waste is also disposed of on-site.

- Treated transuranic waste is disposed of off-site.

- Any nonradioactive hazardous waste identified during waste processing is assumed to be shipped off-site for treatment and disposal.

Note: It is assumed that some waste will be stored on the Hanford Site after cleanup pending availability of treatment, if required, before final disposal or storage.

\section{Newly-Generated Solid Waste}

- Newly-generated solid waste is assumed to be handled in the same treatment and disposal systems described for stored waste.

\section{E1.2.4 Environmental Contamination}

\section{Contaminated Soil}

- Surface and subsurface soils located outside the 200 Area and containing contaminants at concentrations prohibiting unrestricted use are assumed to be excavated and bulk-disposed in the 200 Area vicinity.

- No treatment is assumed to be required for the bulk-disposed material, relying on the disposal facility design for contaminant containment. 
- Surface and subsurface contaminated soils located in the 200 Area are assumed to be disposed of insitu using barriers to reduce the mobility of contaminants.

\section{Contaminated Groundwater}

- Contaminant groundwater plumes outside the 200 Area vicinity that exceed unrestricted-use concentration criteria are assumed to be remediated via appropriate pump-and-treat systems to allow unrestricted use.

- Contaminant groundwater plumes in the 200 Area are assumed to be treated at areas of high concentrations in combination with hydraulic control to isolate the groundwater in the 200 Area using barriers to separate the contaminated groundwater from groundwater in adjacent regions.

\section{E1.2.5 Facilities}

- Facilities located outside the 200 Area are assumed to be dismantled. The radioactively contaminated rubble is transported to the 200 Area for disposal. Uncontaminated or hazardous only rubble is transported off-site for disposal.

- Facilities within the 200 Area are assumed to be partially decontaminated after deactivation. These facilities are then assumed to be entombed by razing above-grade structural components to fill below-grade facility regions and covering the rubble with a protective barrier.

\section{E1.3 References}

60 FR 28680, "Programmatic Spent Nuclear Fuel Management and Idaho National Engineering Laboratory Environmental Restoration and Waste Management Programs," Federal Register.

DOE, 1995, Department of Energy Programmatic Spent Fuel Management and Idaho National Engineering Laboratory Environmental Restoration and Waste Management Programs Final Environmental Impact Statement, DOE/EIS-0203-F, U.S. Department of Energy, Office of Environmental Management, Idaho Operations Office, Idaho Falls, Idaho.

Ecology, EPA, and DOE, 1994, Hanford Federal Facility Agreement and Consent Order, as amended, Washington State Department of Ecology, U.S. Environmental Protection Agency, and U.S. Department of Energy, Olympia, Washington. 


\section{Appendix F}

Alternative II: Baseline Extended Strategy 
-

○

• 


\section{Contents}

\section{Appendix F - Alternative II: Baseline Extended Strategy}

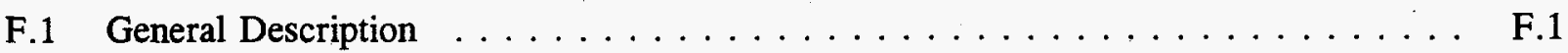

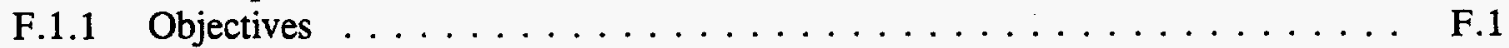

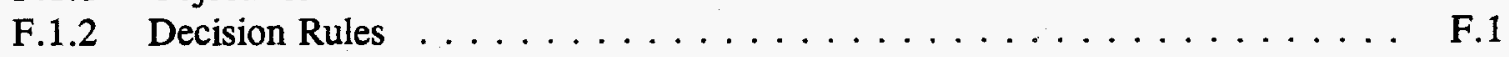

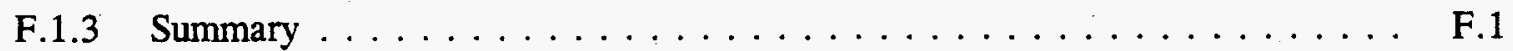

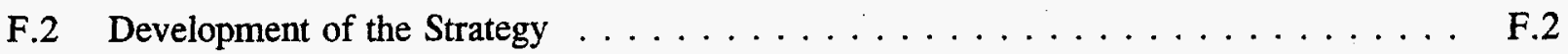

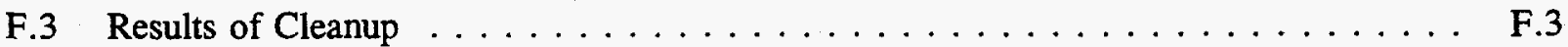

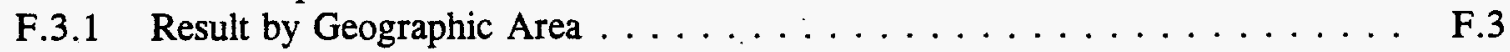

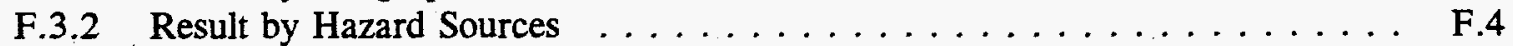

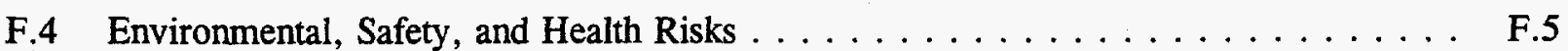

F.5 Future Land Use Implications $\ldots \ldots \ldots \ldots \ldots \ldots \ldots \ldots$

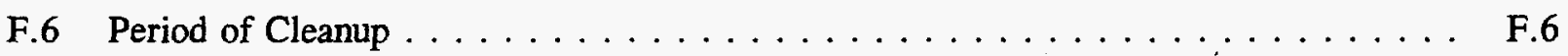

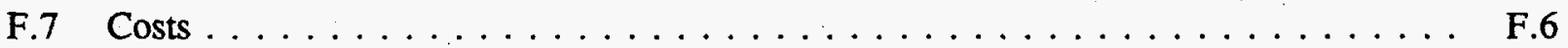

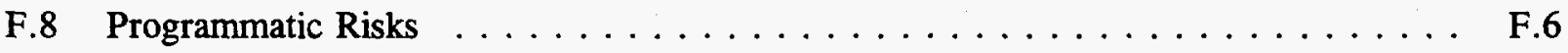

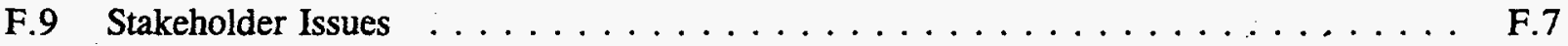

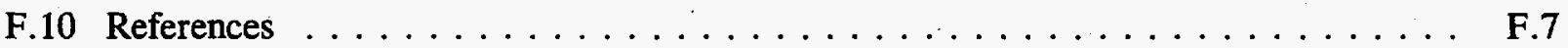

\section{Figures}

F.1 Baseline Strategy with Alternative Tank Disposal Concept $\ldots \ldots \ldots \ldots \ldots$. . . . . F

F.2 Baseline Strategy with Alternative Tank Disposal and Program Deferrals

F.3 Baseline Extended Strategy $\ldots \ldots \ldots \ldots \ldots \ldots \ldots \ldots \ldots \ldots \ldots \ldots$ 


\section{Appendix F}

\section{Alternative II: Baseline Extended Strategy}

\section{F.1 General Description}

\section{F.1.1 Objectives}

The objective of the Baseline Extended Strategy is to achieve the Existing Baseline Strategy endstate and its objectives within the constrained funding profile.

\section{F.1.2 Decision Rules}

The following decision rules set priority for this strategy:

1. First, address near-term release hazards

2. Second, address high benefit-to-cost ratio actions that are already in progress. This will facilitate mortgage reduction to enable additional cleanup actions to be executed earlier.

3. Third, address high benefit-to-cost ratio actions until the endstate is achieved.

\section{F.1.3 Summary}

The Baseline Extended Strategy endstate is the same as for the Existing Baseline Strategy. It is based on the Hanford Federal Facility Agreement and Consent Order (Ecology et al. 1994), commonly called the Tri-Party Agreement; existing Environmental Impact Statement records of decisions; The Future for Hanford: Uses and Cleanup (Working Group 1992), Tank Waste Task Force, and Site planning assumptions regarding future actions. The Baseline Extended Strategy endstate uses the 200 Areas and the central plateau for the collection, storage, and disposal of waste materials that will remain on-site. In general, waste outside of the central plateau will be recovered and transported to the central plateau. Former defense facilities outside of the central plateau will be dismantled and the waste will be transported to the central plateau. Tank waste and post-1970 transuranic solid waste will be retrieved and prepared for storage and eventual disposal (transuranic and high-level waste will be disposed of at off-site repositories). Nuclear materials and irradiated fuel will be consolidated in the 200 Areas as an interim measure until they are dispositioned off-site. Groundwater plumes will be pumped and treated to remove contaminants. The land outside the central plateau will be made available for non-U.S. Department of Energy (DOE) use.

In general, the Baseline Extended Strategy attempts to reduce all risks to an acceptable level, disposition all facilities, cleanup the land, and satisfy all stakeholder and regulatory requirements. 
This strategy is constrained by the projected funding profile while driven by regulatory requirements, primarily the Resource Conservation and Recovery Act of 1976, the Comprehensive Environmental, Response, Compensation, and Liability Act of 1980, and the Tri-Party Agreement. Execution of this strategy will require renegotiation of the approach, sequence, and timing of individual milestones in the Tri-Party Agreement.

\section{F.2 Development of the Strategy}

The Existing Baseline Strategy requires approximately 84 billion dollars and will complete cleanup (including 200 Area facility disposition) by 2075 (Figure E.1). Tank waste vitrification will be complete in 2028 and waste site remediation will be complete in 2018 per the Tri-Party Agreement. The Existing Baseline Strategy does not meet the anticipated funding profile. A productivity reduction of 20 percent reduces the cost to 68 billion dollars, retains the previous schedule, and still exceeds the funding profile (Figure E.3). This requires further reductions (e.g., implementing the Tank Waste Remediation System single-facility concept). The prior actions plus the single-facility concept reduces the cost to 57 billion dollars, retains the same schedule and still exceeds the funding profile (Figure F.1). Delaying/extending the schedule will bring the funding

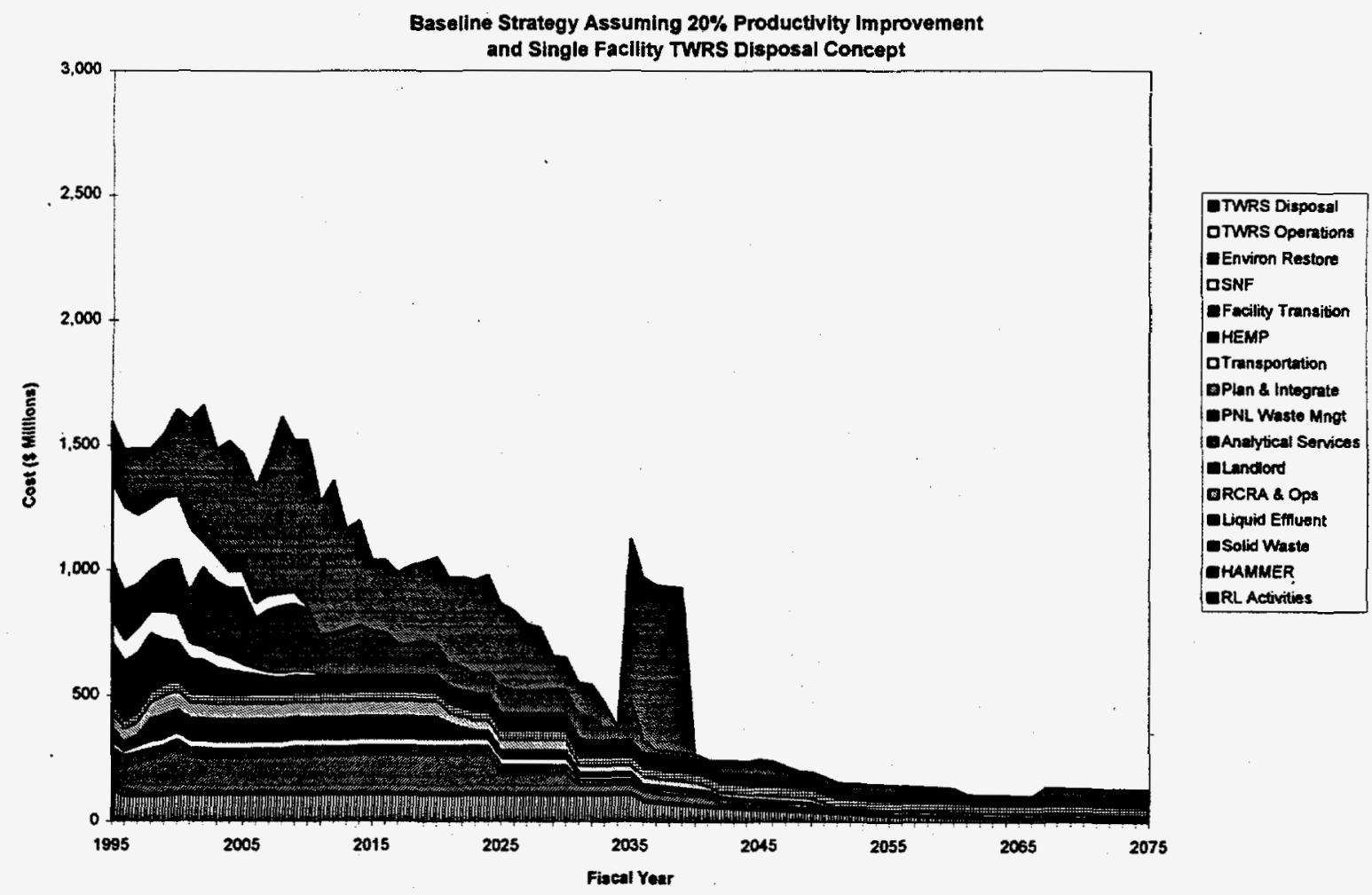

Figure F.1. Baseline Strategy with Alternative Tank Disposal Concept 
profile into agreement with the 1.05 billion dollar/year constraint at the expense of an additional 15 years and six billion dollars. The cost increase is due to delays in implementing actions that reduce minimum operating costs (Figure F.2). Reassignment of the sequence of cleanup to implement actions that reduce the minimum operating costs earlier reduces the total cost to 56 billion dollars and shortens the schedule to complete cleanup (including 200 Area facility disposition) in 2058

(Figure F.3). This last approach shows the relationship between productivity reduction, innovative approaches, and fitting to the funding profile. A combination of all actions forms a strategy that reduces cost and shows substantial progress within the existing schedule for the Existing Baseline Strategy. In all of these cases, disposition of reactors will continue until 2075 to allow for radioactive decay prior to one-piece reactor block removal.

\section{F.3 Results of Cleanup}

The Baseline Extended Strategy will consolidate and dispose of waste on the central plateau. High-level waste and retrievably-stored transuranic waste will be treated, packaged, and shipped to

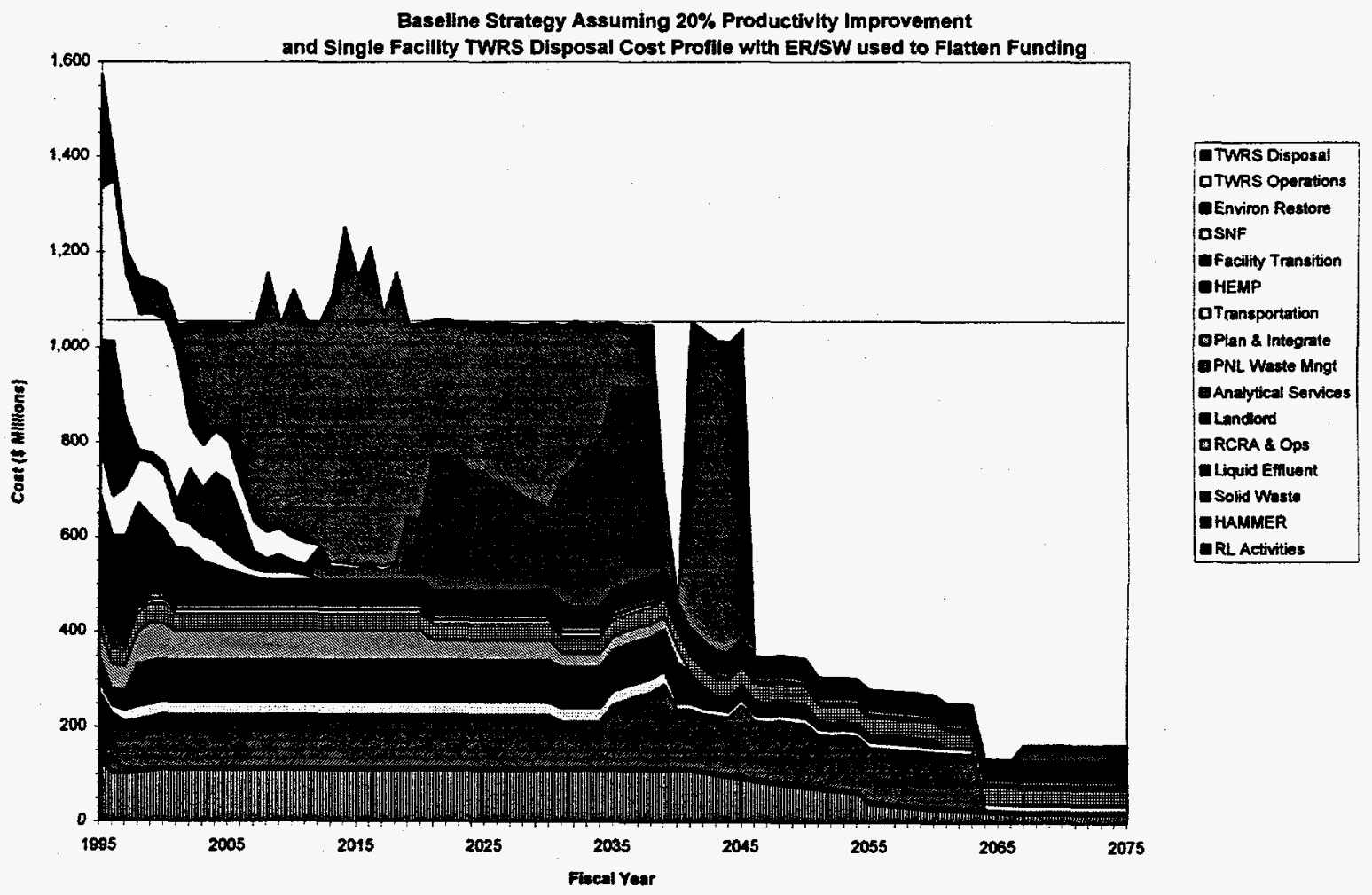

Figure F.2. Baseline Strategy with Alternative Tank Disposal and Program Deferrals 


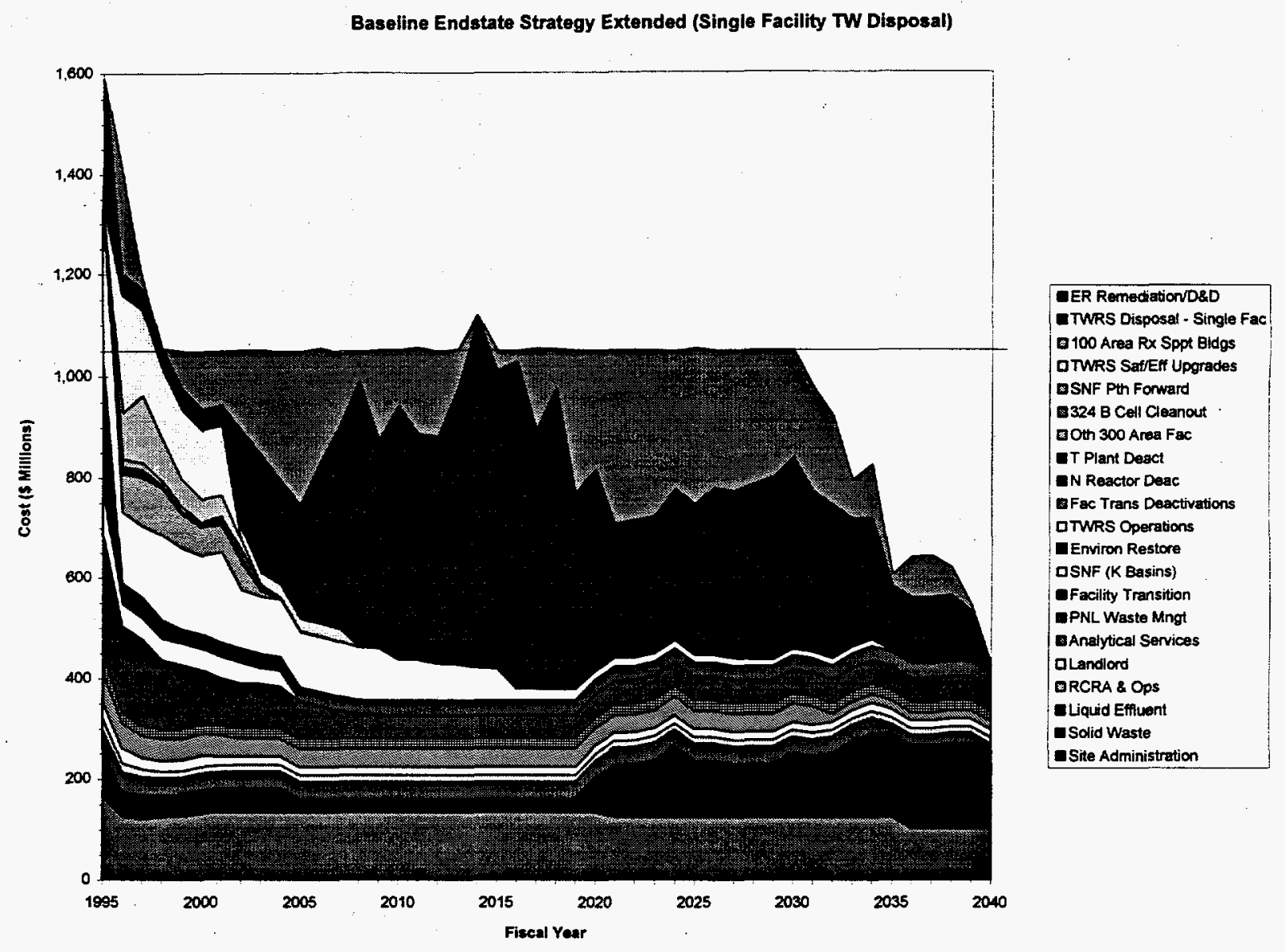

Figure F.3. Baseline Extended Strategy

off-site repositories. The central plateau land (approximately 50 square miles) will remain restricted. Land outside of the central plateau (approximately 510 square miles) will be available for unrestricted use. Restrictions would remain on the groundwater for up to 180 years even with the treatment activities (DOE 1994).

The following are Baseline Extended Strategy results by hazard sources.

- Nuclear materials, including unirradiated uranium, cesium and strontium capsules, irradiated fuel, and special nuclear material, will be stabilized and stored in the 200 Areas pending future disposition off-site.

- $\quad$ Tank waste will be retrieved, separated into high-level and low-level fractions and vitrified (single facility). The vitrified high-level waste will be stored and later shipped to the high-level waste repository. The vitrified low-level waste will be disposed of in the 200 Areas. The tank structures and contaminated soils will be disposed in-situ. 
- Low-level solid waste will be disposed in the 200 Areas. Transuranic solid waste outside of the 200 Areas will be retrieved, processed, and stored in the 200 Area pending future disposition off-site. Retrievably-stored post- 1970 transuranic waste will be retrieved, processed, and stored pending future off-site disposition.

- Contaminated soil outside the 200 Area will be retrieved and disposed of in the 200 Area. Contaminated soil in the 200 Area will be remediated in-situ.

- Groundwater outside the 200 Areas will be remediated using pump-and-treat systems to the extent technically practical. Barriers will isolate the 200 Area contaminated groundwater.

- Contaminated facilities outside of the 200 Area will be demolished and the contaminated waste will be disposed of in the 200 Areas (the reactors will be a one-piece reactor block removal after a 75 year waiting period). Major facilities in the 200 Areas (e.g., canyon buildings) will be partially demolished and then entombed.

\section{F.4 Environmental, Safety, and Health Risks}

The Baseline Extended Strategy addresses the near-term release hazards first (e.g., fuel storage in K Basins, waste tank safety issues, Plutonium Finishing Plant, 324 B cell, and cesium and strontium capsule storage in the Waste Encapsulation and Storage Facility). These are followed by actions that will generate high benefit/cost and are already initiated to assure earliest completion (e.g., deactivation of major facilities and removal of inventories). Lastly, lower benefit-to-cost ratio activities are addressed. Groundwater pump-and-treat (a long-term release hazard) has the lowest benefit-to-cost ratio. Developing more economical and effective groundwater treatment technology is supported by this strategy.

Overall, public risks are very low for this strategy endstate. Public, worker, and environmental risks are higher during remediation due to increased exposure associated with extensive retrieval, processing, handling, and transport activities associated with this strategy. The delay in tank waste retrieval and processing from the Existing Baseline Strategy may increase risk to workers since the tank structures will continue to deteriorate. Environmental/ecosystem risk is large considering the amount of waste retrieved and disposed of in the 200 Area, new processing facilities, backfill material excavations, and road networks for transport (including support to single-piece reactor block removal).

\section{F.5 Future Land Use Implications}

The endstate for this strategy is the same as that for the Existing Baseline Strategy. The central plateau usage will be restricted during and following waste management and cleanup operations. Most areas outside of the central plateau will be released for unrestricted use. The Tri-Party Agreement does not explicitly require that the groundwater be treated to unrestricted levels. The 300 Area will be available for industrial use. 


\section{F.6 Period of Cleanup}

The cleanup period for this strategy is from fiscal year 1995 through 2058 (2075 including reactor disposition). By 2001 the 324 B cell will be cleaned out and tanks safety actions will be completed. Deactivation of PUREX, N Reactor, B Plant, Fast Flux Test Facility, and 300 Area fuel supply will be complete by the end of 2001 as well. These actions will be followed by $\mathrm{K}$ Basin deactivation (2002), Plutonium Finishing Plant deactivation (2003), T Plant deactivation (2004), Waste Encapsulation Storage Facility deactivation (2006), waste site remediation (2034), tank waste vitrification and single-shell tank closure (2041), 200 Area facility disposition (2058), and reactor disposition (2075).

\section{F.7 Costs}

The total lifecycle cost to complete this strategy is approximately 56 billion dollars. This includes allowance for a 20 percent productivity savings, changing to a single-facility tank waste disposal, resequencing work to reduce minimum safe operations costs earlier, and extending the schedule to meet the funding profile.

\section{F.8 Programmatic Risks}

There are numerous technical risks associated with this strategy. The technology is complex for the retrieval of waste, vitrification of tank waste, transport of reactor blocks, and groundwater treatment. Groundwater pump-and-treatment and barrier technologies have not been demonstrated for several of the contaminants and/or the scale far exceeds most applications.

The environmental, safety, and health risks associated with DOE facilities at other sites may be greater or more urgent than those that would be addressed during out-year phases of Hanford Site cleanup. Those competing facilities may adversely affect the Hanford Site funding profile by causing a shift of Hanford Site funds to other DOE sites that may have more urgent risk-related needs. Conversely, should risks associated with the Hanford Site exceed the other sites, funding may be enhanced.

The cost and schedule estimates for this strategy are a rough order of magnitude. Elements such as facility decommissioning have not been estimated for all major facilities and there is large uncertainty regarding the extent of contaminated soil and the estimated cost of remediation. The ability to achieve the assumed 20 percent productivity challenge will have to be evaluated at a greater level of detail than this analysis will permit.

The benefit functions are based on the Revised Priority Planning Grid (Appendix B, Attachment B1) which has weights based on Site management values. Stakeholders may not share the same values and weights. Different weights could shift the priorities/sequence of execution.

This cost profile will meet the projected funding profile (within the nominal 1.05 billion dollars per year). Renegotiation of Tri-Party Agreement milestones will require that the cost and schedule 
uncertainties be reduced to increase confidence in meeting the new milestones. The current organization, work breakdown structure, and technical baseline would support this strategy.

\section{F.9 Stakeholder Issues}

This strategy addresses, to the extent practical, the primary stakeholder concerns of protecting the Columbia River and addressing the groundwater cleanup issues. Major sources of contamination would be moved away from the river and pump-and-treat technology applied to reduce groundwater contamination.

This strategy complies with applicable regulations, provided the milestones in the Tri-Party Agreement are renegotiated to permit the longer completion schedule. Local and regional stakeholder concern are addressed. National stakeholders may seek additional cost reductions that may reduce the proportion of land cleaned up to unrestricted levels.

\section{F.10 References}

Comprehensive Environmental, Response, Compensation, and Liability Act of 1980, 42 USC 9601, et seq.

DOE, 1994, Hanford Remedial Action - Draft Environmental Impact Statement, Volume 1 of 2, DOE/DEIS-0222, U.S. Department of Energy, Washington, D.C.

Ecology, EPA, and DOE, 1994, Hanford Federal Facility Agreement and Consent Order, as amended, Washington State Department of Ecology, U.S. Environmental Protection Agency, and U.S. Department of Energy, Olympia, Washington.

Tank Waste Task Force, 1993, Hanford Tank Waste Task Force Final Report, Chairman Marshall Drummond, Submitted to Washington State Department of Ecology, U.S. Department of Energy, and U.S. Environmental Protection Agency.

Resource Conservation and Recovery Act of 1976, 42 USC 6901, et seq.

Working Group, 1992, The Future for Hanford: Uses and Cleanup, prepared by the Hanford Future Site Uses Working Group for the U.S. Department of Energy, U.S. Environmental Protection Agency, and the State of Washington. 
Appendix G

Risk Strategy 
$\bullet$

-

- 


\section{Contents}

\section{Appendix G - Risk Strategy}

G.1 General Description $\ldots \ldots \ldots \ldots \ldots \ldots \ldots \ldots \ldots \ldots \ldots$

G.2 Development of the Strategy $\ldots \ldots \ldots \ldots \ldots \ldots \ldots \ldots$

G.3 Results of the Clean Up . . . . . . . . . . . . . . . G.3

G.4 Environmental, Safety, and Health Risks $\ldots \ldots \ldots \ldots \ldots$ G.4

G.5 Land Use $\ldots \ldots \ldots \ldots \ldots \ldots \ldots \ldots \ldots \ldots \ldots \ldots$

G.6 Cleanup Period $\ldots \ldots \ldots \ldots \ldots \ldots \ldots \ldots \ldots \ldots \ldots$

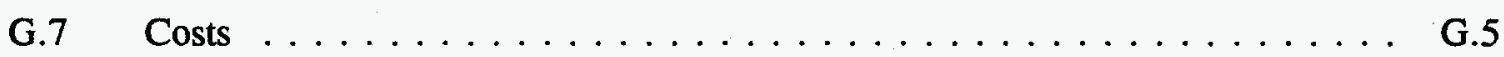

G.8 Programmatic Risks $\ldots \ldots \ldots \ldots \ldots \ldots \ldots \ldots \ldots$

G.9 Stakeholder Issues $\ldots \ldots \ldots \ldots \ldots \ldots \ldots \ldots \ldots \ldots$

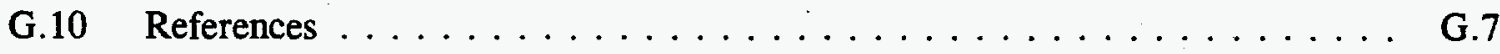

Figures

G.1. Risk Strategy Funding Profile $\ldots \ldots \ldots \ldots \ldots \ldots \ldots \ldots$ 


\section{Appendix G}

\section{Risk Strategy}

\section{G.1 General Description}

This single-objective Risk Strategy was established by assuming the overriding objective was risk reduction or effective risk management. Costs and land use were considered only as secondary objectives. This strategy focuses on reducing or.managing risks from the Hanford Site to acceptable levels for the public, workers, and environment. The sources of risks are radionuclides, toxic and dangerous chemicals, and industrial hazards. The following rules were used to make decisions relative to the risk-based cleanup strategy and actions.

- Reduce the potential for near-term, high-consequence releases that pose unacceptable risks to the public, workers, or environment.

- $\quad$ Protect workers from unnecessary and unacceptable workplace hazards.

- Minimize the use of remediation activities that pose high risks to workers but provide only minimal reduction of public or environmental hazards.

- Provide on-site waste management and disposal systems that protect current and future generations and the environment.

- $\quad$ Protect ecological and cultural resources during remediation.

Implementation of the Risk Strategy would result in nuclear material consolidated and stored onsite pending final disposal, liquid waste disposed in-situ, solid waste disposed in-situ, and major facilities entombed in-place. This strategy would leave the environmental contamination in-place (capped and covered as necessary). In general, the 100,300, 400 and 600 Areas could be released for other non-U.S. Department of Energy (DOE) uses but the 200 Area could not. The 100, 300, and 400 Areas would be used for long-term disposal of major facilities. The 200 Area would be used for permanent disposal of tank waste, solid waste, and major facilities as well as for long-term storage of nuclear materials.

\section{G.2 Development of the Strategy}

The Risk Strategy was developed by considering the contributions to risk for each of the four hazard categories described in Appendix D. A general set of cleanup alternatives was defined, and risks for the various alternatives were analyzed. An initial set of decision rules was developed for each hazard category and application of the decision rules resulted in the following strategy. 
There appear to be three fundamental cleanup alternatives for each category of waste material. Within these alternatives there are almost unlimited combinations and intermediate states that could be defined. The strategy would deal with the fundamental alternatives and some limited number of intermediate states. It is not intended to cover all possible combinations or alternatives. The fundamental alternatives are defined as follows.

1. Continue active risk management (as-is) - maintain the waste inventory in nearly the same condition it is in today and continue to actively manage the associated risks.

2. Dispose waste in-place (in-situ) - this alternative can range from relatively simple (just walk away) to fairly complex (vitrification). Installation of protective caps or covers are considered on a case-by-case basis.

3. Remove, treat, and dispose waste (ex-situ) - this alternative can also range from relatively simple (re-package solid waste) to fairly complex (retrieval, separations and vitrification of tank waste) disposal processes. Decisions on what to do with residual waste (the waste that could not be recovered) are considered on a case-by-case basis.

Intermediate states might be selected when the final state can not be adequately defined (e.g., tank waste), when the existing conditions are determined to be unacceptable (e.g., $\mathrm{N}$ fuel), or to support long-term storage pending final disposal (e.g., nuclear materials). The Site activities would reduce the potential for high-consequence releases that pose unacceptable risks to the public, workers, and environment.

- Rapidly transition near-term hazards to safe, stable, interim states:

- Remove N fuel from K Basins and prepare it for long-term storage

- Remove and dispose 324 B hot cell debris

- Address safety tank waste

- Remove plutonium from the Plutonium Finishing Plant and prepare it for long-term storage.

- Transition the following to long-term, passive, cost-effective storage pending decisions on the ultimate disposition:

- $\quad$ Spent nuclear fuel

- Cesium and strontium capsules

- Plutonium.

The Site activities would protect workers from unnecessary and unacceptable workplace hazards.

- Transition (deactivate and stabilize) surplus and deteriorated facilities to a minimum safe condition pending final disposition.

The Site activities would minimize the use of remediation activities that pose high risks to workers but provide only minimal reduction of public or environmental hazards.

- Leave reactor cores in a minimum-safe condition for a period of time, then entomb.

- Dispose tank waste in-situ, if technically feasible. 
- Dispose stored solid waste in-situ, if technically feasible.

- Leave environmental contamination in-place; cap and cover if necessary.

The Site activities would provide on-site waste management and disposal systems that protect current and future generations and the environment by achieving a consistent set of risk-based treatment and disposal standards.

- Restrict access to groundwater for the foreseeable future.

- Prevent new releases to the groundwater by removing liquid from single-shell tanks and other sources (e.g., $\mathrm{K}$ and $\mathrm{N}$ Basins).

- Develop groundwater and soil treatment technology to support solutions to long-term releases.

- Entomb facilities after deactivation.

The Site activities would protect ecological and cultural resources during remediation.

- Minimize physical disruption of sensitive or susceptible areas.

- Minimize impact of new construction and remediation actions on historically protected (pristine) habitats.

\section{G.3 Results of the Clean Up}

Most of the Site land area could be released for other uses; however, the 200 Area would not be available for other non-DOE uses and use of the groundwater in all areas would be controlled for the foreseeable future. Specifically, the following would apply.

- 100 Area. Limited radioactive waste disposal for entombed reactor cores and liquid and solid waste sites (capped and covered as necessary). Support facilities would be cleaned out, deactivated, removed, and disposed. Nuclear materials would be moved to the 200 Area for long-term storage and groundwater use would be restricted and monitored.

- 200 Area. Permanent radioactive waste disposal site for entombed nuclear facilities, liquid and solid waste sites (capped and covered as necessary), pre- and post-1970 transuranic waste, and most of the tank waste (high- and low-level) solidified and disposed in-place. Support facilities would be cleaned out, deactivated, removed, and disposed. Groundwater use would be restricted and monitored. Nuclear materials would be interim-stored pending final disposition.

- $\quad 300$ Area. Limited radioactive waste disposal site for the liquid and solid waste sites (capped and covered as necessary). Nuclear operations would be consolidated, excess facilities would be cleaned out and deactivated. Nuclear materials would be moved to the 200 Area for longterm storage and groundwater use would be restricted and monitored. 
- 400 Area. Limited radioactive waste disposal site for the entombed Fast Flux Test Facility reactor. Support facilities would be cleaned out, deactivated, removed, and disposed.

Nuclear materials would be moved to the 200 Area for long-term storage and groundwater use would be restricted and monitored.

- 600 Area. Limited radioactive waste disposal site for the liquid and solid waste sites (capped and covered as necessary). Area from Columbia River to perimeter road would be released for appropriate uses. Groundwater use would be restricted and monitored. Access to areas between perimeter road and 200 Area would be controlled as a buffer zone until the 200 Area waste management activities are completed.

The hazardous materials (including tank waste) and contaminated facilities would be converted to a safe, stable state and disposed on-site. The nuclear materials would be converted to a form suitable for long-term storage or disposal. A more detailed description of the waste material endstates follow:

- Nuclear materials would be moved to the 200 Areas for safe, stable, passive, long-term storage, pending final disposal.

- $\quad$ Liquid waste (tank waste) would be disposed (solidified) in-place where technically feasible and cost effective.

- Solid waste (newly generated) would be moved to the 200 Area and disposed. Existing solid waste would be disposed in-place where technically feasible and cost effective.

- Environmental contamination would encompass solid and liquid waste sites and groundwater.

- Solid and liquid waste sites with mobile inventory would be stabilized. Waste sites in the 100,300 and 600 Areas would be capped and covered where technically feasible and cost effective.

- Groundwater use would be restricted for the foreseeable future.

- $\quad$ Facilities would include nuclear and nonnuclear facilities.

- Nuclear facilities would be transitioned to a minimum, long-term surveillance and monitoring mode pending final disposition. Nuclear facilities would be entombed in-place if technically feasible and cost effective.

- Nonnuclear facilities would be cleaned out, deactivated, dismantled and disposed.

\section{G.4 Environmental, Safety, and Health Risks}

The Risk Strategy is focused on reducing environmental, safety, and health risks. There is a detailed description of these risks in Appendix D. 


\section{G.5 Land Use}

The 100, 300, 400 and 600 Areas would be available for limited industrial and recreational use. The 200 Area would not available for other non-DOE uses. Groundwater use would be restricted in all areas.

\section{G.6 Cleanup Period}

The Site clean up period would depend on the required remediation activities and the available resources. The initial conversion to safe, stable conditions should proceed as rapidly as possible. Final remediation and disposal should proceed as the resources allow. For this strategy, the cleanup period would extend to 2043 with completion of 200 Area facility and reactor disposition; however, most of the cleanup would be accomplished by 2030 with completion of tank waste disposal and tank closure. Most waste sites would be remediated by 2026 .

\section{G.7 Costs}

The costs to implement the Risk Strategy would be considerably lower than the costs to implement the Existing Baseline Strategy because much of the waste would be disposed in-place. The cost estimate assumes 10 billion dollars for in-situ disposal of tank waste and nine billion dollars for environmental restoration. The total cleanup cost is estimated at 44 billion dollars. See Figure G.1 for a general funding profile for this strategy.

\section{G.8 Programmatic Risks}

The Risk Strategy is less costly and can be implemented sooner than the Existing Baseline Strategy because the waste would be disposed in-place; however, there are technology issues associated with in-place disposal of tank waste. A technology development and proof of concept path would need to be established.

\section{G.9 Stakeholder Issues}

The on-site disposal options would not satisfy some of the stakeholder values. The following is a brief discussion relative to some of the values from the Future Site Uses Working Group.

- Protect the Columbia River. The Columbia River would be protected by controlling the near-term releases. 


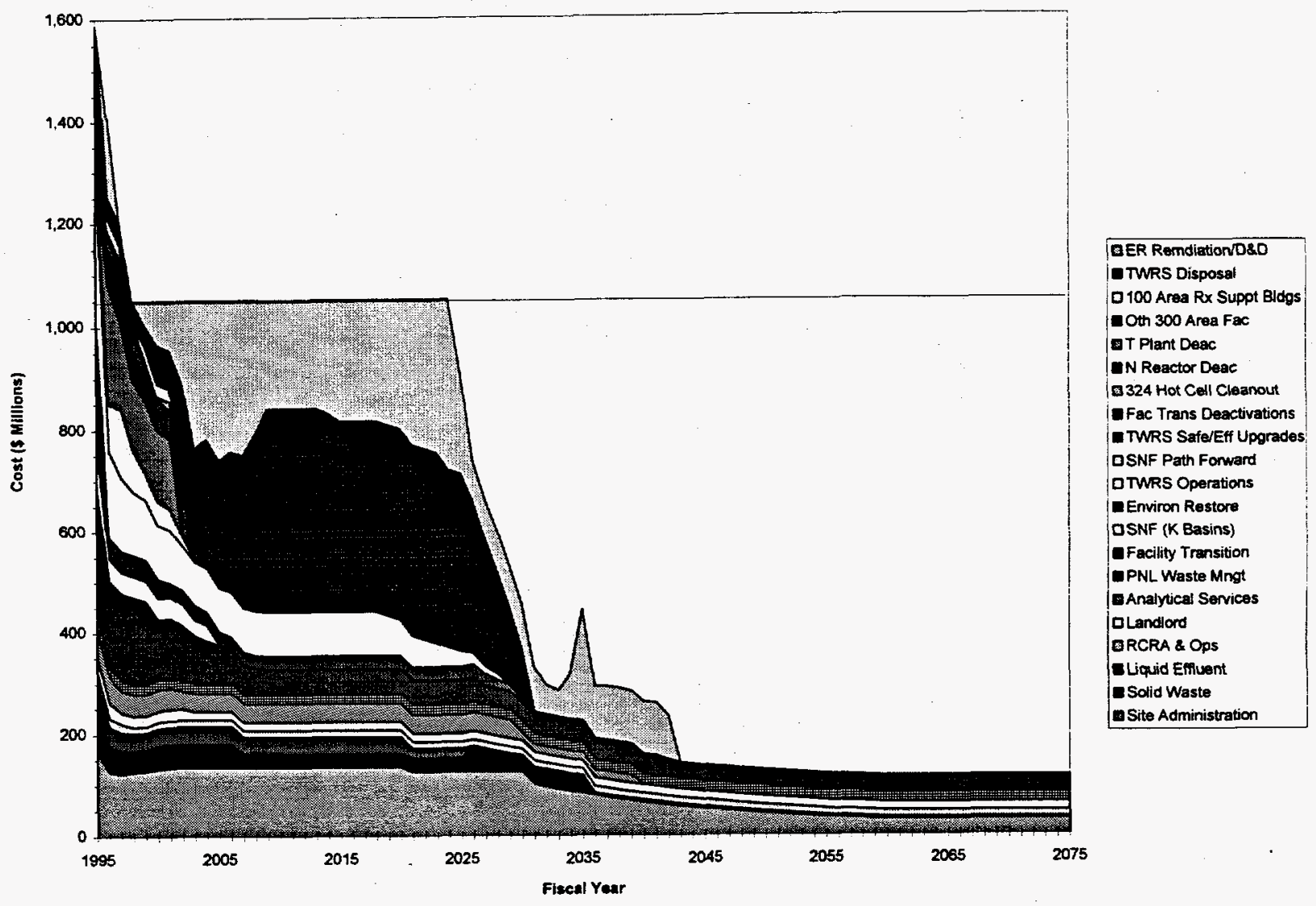

Figure G.1. Risk Strategy Funding Profile

- Deal realistically and forcefully with groundwater contamination. Groundwater would be protected by controlling near-term releases. It would not remediate existing contamination in the soil or the groundwater.

- Do no harm during cleanup or with new development. This strategy is focused on protecting the ecosystem and cultural resources by minimizing extensive remediation activities.

- Transport waste safely and be prepared. Attempts would be made to minimize the amount of waste being transported. When waste must be transported it would be done in a safe, compliant manner.

- Use central plateau wisely for waste management. The 200 Areas would be reserved as a permanent disposal site. 
- Clean up to the level necessary to enable future use options to occur. Most of the Site land area would be released a limited set of other non-DOE uses; however, the 200 Area would not be available for other non-DOE uses and use of the groundwater would be controlled for the foreseeable future.

- Clean up areas of high value first. There would not be a high value on land availability.

- Comply with regulations. Several regulations or statutes would need to be modified to allow this strategy to be implemented. Some of the major statutes that would need to be evaluated are the Comprehensive Environmental, Response, Compensation, and Liability Act of 1980, the Resource Conservation and Recovery Act of 1976, the Nuclear Waste Policy Act of 1982, and the State of Washington Hazardous Waste Management Act of 1976.

\section{G.10 References}

Comprehensive Environmental, Response, Compensation, and Liability Act of 1980, 42 USC 9601, et seq.

Nuclear Waste Policy Act of 1982, 42 USC 10101.

Resource Conservation and Recovery Act of 1976, 42 USC 6901, et seq.

State of Washington Hazardous Waste Management Act of 1976, Revised Code of Washington, Chapter 70.105 et seq., Olympia, Washington. 
Appendix H

Composite Strategy 



\section{Contents}

\section{Appendix H - Composite Strategy}

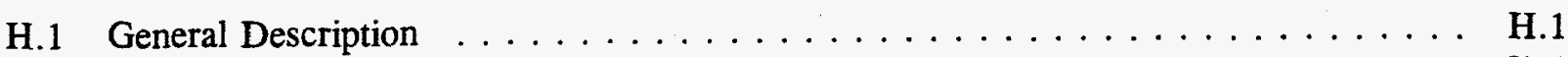

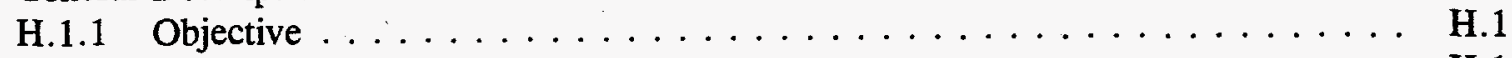

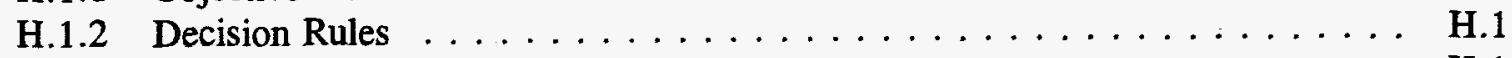

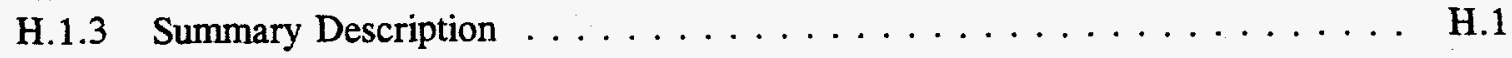

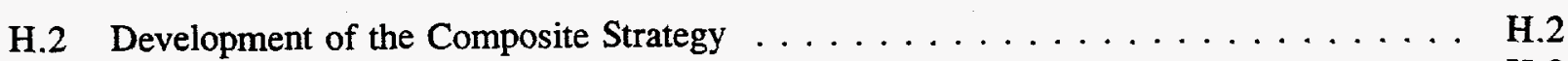

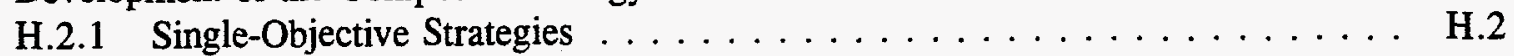

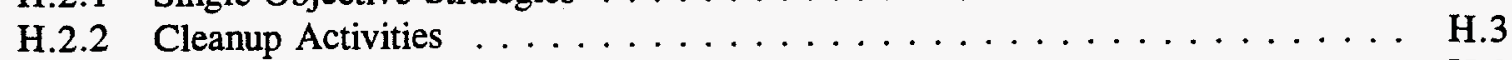

H.2.3 Priority and Sequencing . . . . . . . . . . . . . . .

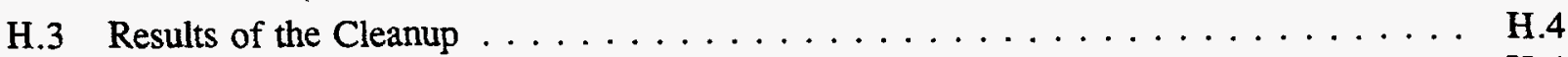

H.3.1 Geographic Results . . . . . . . . . . . . . . . . . . . H.4

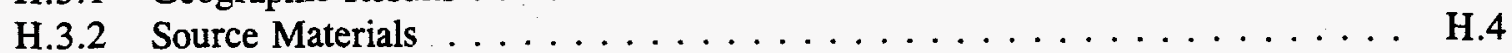

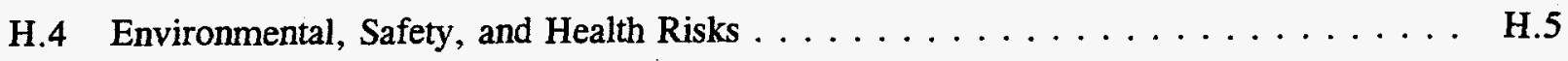

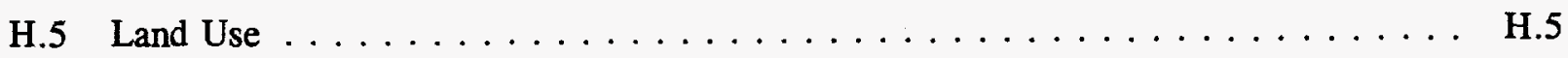

H.6 Period of the Cleanup $\ldots \ldots \ldots \ldots \ldots \ldots \ldots \ldots \ldots$

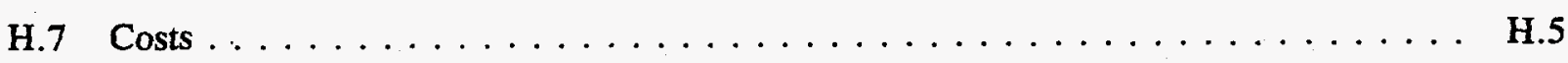

H.8 Programmatic Risks $\ldots \ldots \ldots \ldots \ldots \ldots \ldots \ldots \ldots \ldots$

H.9 Stakeholder Issues and Regulatory Impacts $\ldots \ldots \ldots \ldots \ldots \ldots$

H.10 References $\ldots \ldots \ldots \ldots \ldots \ldots \ldots \ldots \ldots \ldots \ldots \ldots \ldots$

Attachment $\mathrm{H} 1$ - Composite Strategy Statements $\ldots \ldots \ldots \ldots \ldots \ldots \ldots \ldots \ldots$ H1.1

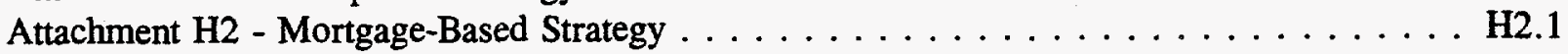

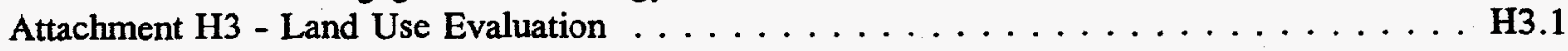

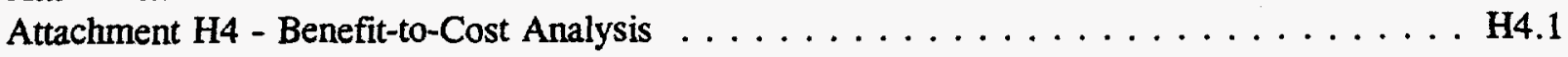

H.iii 


\section{Figures}

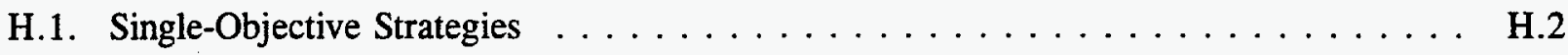

H.2. Composite Strategy Cost Profile $\ldots \ldots \ldots \ldots \ldots \ldots$

\section{Tables}

H.1. Near-Term Funding Allocations for Composite Strategy . . . . . . . . . . H.7 


\section{Appendix H}

\section{Composite Strategy}

This appendix describes a Composite Strategy for cleaning up the Hanford Site that addresses all cleanup objectives. "Composite," as used herein, reflects the development of the strategy by first examining single-objective strategies and by combining many of the best parts of those strategies into a new strategy.

\section{H.1 General Description}

\section{H.1.1 Objective}

The Composite Strategy was developed to address the total benefit across all six objectives described in Section 3.0 of the Main Body and in Appendix B.

\section{H.1.2 Decision Rules}

This strategy addresses the most urgent, near-term risks first. Specifically, K Basin spent nuclear fuel, 324 B cell, tank safety upgrades, and plutonium in Plutonium Finishing Plant are given priority. Cesium and strontium capsules are removed from the Waste Encapsulation and Storage Facility as soon as possible and placed in safe storage in the 200 Area. Second priority is given to ongoing, high-benefit activities, (e.g., deactivation of PUREX, N Reactor, and Fast Flux Test Facility and restoration of the 1100/3000 Area.

Other activities were analyzed in terms of their overall contribution to Site objectives, as well as costs. A benefit-to-cost ratio was determined using the weights from the Revised Priority Planning Grid (Appendix B, Attachment B1) to determine an overall priority and sequence of effort.

\section{H.1.3 Summary Description}

This strategy is similar to the Risk Strategy, except for the priority and sequence of effort and the treatment of contaminated solid and liquid waste sites outside the 200 Area. The key elements of the Composite Strategy are as follows.

All reactors would be entombed as permanent disposal sites. Liquid and solid waste sites outside the 200 Area (with exception of those sites that would be entombed with the reactors) would be cleaned up and transported to the central plateau for disposal. The central plateau would be a permanent waste disposal site for entombed nuclear facilities, liquid and solid waste disposal sites (capped and covered) and, pre- and post-1970 transuranic waste, and tank waste (which would be disposed in-place. Access to the 200 Area plateau would be controlled indefinitely, and access to groundwater would be controlled for the foreseeable future. 
Nuclear materials would be removed from current locations and placed in interim storage in the 200 Area, pending final disposition. Facilities outside the 200 Area (except reactors) would be dismantled, as appropriate, or consolidated to reduce operation and maintenance costs.

The Composite Strategy would not treat solid and liquid waste sites prior to disposal in the 200 Area, and stored solid waste in the 200 Area would be disposed without treatment. Groundwater would not be treated. Attachment $\mathrm{H} 1$ contains a detailed strategy description.

\section{H.2 Development of the Composite Strategy}

The Composite Strategy was developed in two steps: (1) analysis of single-objective strategies, and (2) construction of a Composite Strategy from them. Figure H.1 illustrates this process.

\section{H.2.1 Single-Objective Strategies}

The three single-objective strategies reflect three of the objectives of the cleanup: risk reduction, mortgage reduction, and land-release. The Existing Baseline Strategy is represented in the middle of the triangle, indicating all objectives are equally important. With recent budget cuts, however, the center circle has been moved toward the mortgage reduction vertex of the triangle--to the detriment of the land objective and the environmental restoration program.

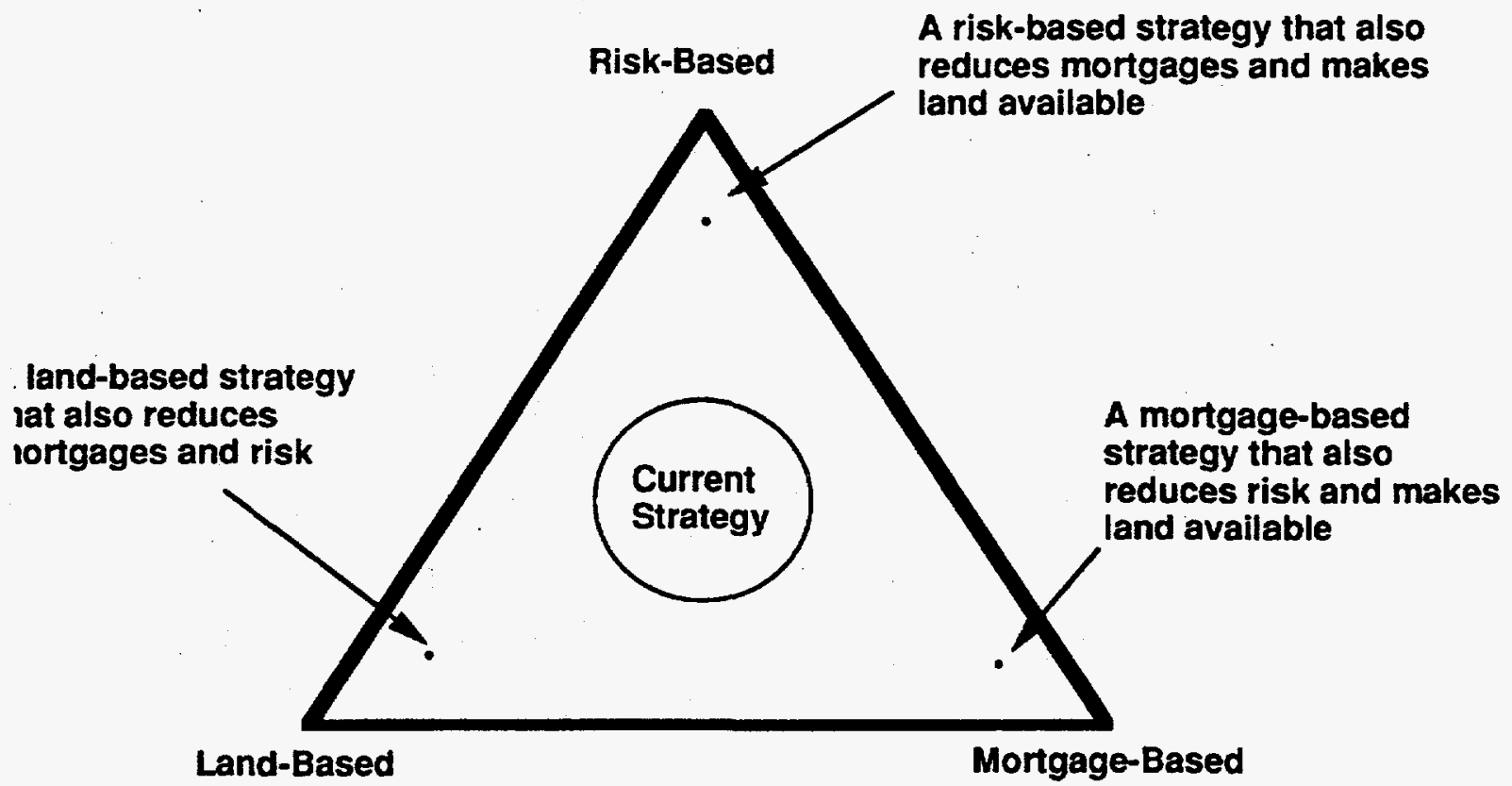

Figure H.1. Single-Objective Strategies 
The task team developed a Mortgage-Reduction Strategy and a Land-Use Analysis to gain insights into the cleanup activities and the priorities for these strategies. Attachments $\mathrm{H} 2$ and $\mathrm{H} 3$ describe these strategies in detail. The third single-objective strategy, Risk, is described in Section 7.3 of the Main Body and in Appendix G.

\section{H.2.2 Cleanup Activities}

Once the three single-objective strategies were constructed, they were combined in several different ways to build a composite strategy that optimized across all six of the cleanup objectives. Several composite strategies were built using different techniques. It was realized there could be many different strategies which were viable.

It was fairly straightforward to choose the cleanup activities that would be supported in any composite strategy because both the risk and mortgage strategies were consistent in recommending most actions. For example, disposal in-place for tank waste, solid waste, reactors, and major facilities' was preferred both from a risk and a mortgage-reduction perspective. Similarly, groundwater treatment and retrieval of solid waste and soil from waste sites were not recommended by either of these strategies. Note the land strategy did not make choices about cleanup activities (e.g., tank disposal, facility transition in 200 Area) that did not support the release of land.

In the final analysis, a representative composite strategy was built that was very similar in its activities to the Risk Strategy. The major difference was in the retrieval of contaminated waste and soil from solid and liquid waste sites outside the 200 Area. Attachment $\mathbf{H 1}$ describes the remedial actions that will transform existing material inventories into safe interim and final forms.

\section{H.2.3 Priority and Sequencing}

Although the cleanup activities for the Composite Strategy would be mostly the same as those for the Risk Strategy, there would be some major differences in the priority of those activities. The Revised Priority Planning Grid (Attachment B1) was used to help select the order in which cleanup actions would be executed. The grid was used because it had been used previously to help make funding decisions for the fiscal year 1997 Activity Data Sheets and because it reflected U.S. Department of Energy Richland Operations Office management's values. All activities were scored to determine their benefit across the six cleanup objectives. A benefit-to-cost ratio was then calculated to order the workscope. Attachment $\mathrm{H} 4$ contains these ratios. The Composite Strategy reflects the following decision rules:

1) Address urgent, near-term risks to the public first

2) Support ongoing mortgage-reduction and land release actions second

3) Support subsequent cleanup activities in accordance to their benefit-to-cost ratio.

The first rule was adopted because the revised Priority Planning Grid does not give adequate benefit to low-probability, high-consequence events, and those risks needed to be addressed.

The second rule was adopted for PUREX, N Reactor, Fast Flux Test Facility, and 1100/3000 Area because it made practical sense to continue these activities which were underway and, in some 
cases, almost finished. They also generally had high benefit-to-cost ratios In terms of benefit-to-cost ratio, this strategy would execute the following activities in the following order:

a. 600 Area within $1 / 4$ mile of the Columbia River

b. 300 Area miscellaneous facilities deactivation and demolition

c. B Plant deactivation

d. 600 Area from the $1 / 4$ mile mark to the perimeter road

e. 300 Area fuel supply facilities

f. T Plant deactivation

g. 100 Area support facilities

h. 300 Area retrieval of contaminated solid and liquid waste sites

i. 400 Area support facilities and contaminated sites

j. 100 Area environmental restoration of contaminated solid and liquid waste sites

k. Tank waste disposal in-place

1. 200 Area environmental restoration activities, including entombment of canyon facilities

m. 600 Area environmental restoration activities from the perimeter road to the plateau

n. Entombment of the reactors along the Columbia River.

\section{H.3 Results of the Cleanup}

If the above activities were executed in the sequence indicated, the results of the cleanup could be described in terms of geographic area and hazard sources.

\section{H.3.1 Geographic Results}

When cleanup is complete, the central plateau would be a permanent waste disposal site for entombed nuclear facilities, liquid and solid waste disposal sites (capped and covered), pre- and post-1970 transuranic and tank waste (which would be disposed in-place). Access to the 200 Area and its groundwater would be controlled indefinitely.

The 100 and 400 Areas would be permanent disposal sites for entombed reactors; however, all other facilities would be demolished and the areas would be cleaned up. Groundwater access would be controlled for the foreseeable future.Research and development activities would be consolidated in the 300 Area, with excess facilities demolished and the area cleaned up. Groundwater access would be controlled for the foreseeable future.The 600 Area would be cleaned up throughout.

\section{H.3.2 Source Materials}

When cleanup is complete, nuclear materials would be stored safely in the 200 Area pending final disposition (possibly in a national repository). Tank waste and stored solid waste in the 200 Area will be disposed in place. Solid waste outside the 200 Area would be retrieved for burial on the plateau, and solid and liquid waste sites would be retrieved and buried in the 200 Area. Reactors and canyon facilities would be entombed; other facilities would be demolished. Groundwater would not be treated. 


\section{H.4 Environmental, Safety, and Health Risks}

The environmental, safety, and health risks for the Composite Strategy would be comparable to those of the Risk Strategy, especially in the 200 Area and K Basins, however, the Composite Strategy would impact environmental risk slightly by retrieving solid and liquid waste sites outside the central plateau. Like the Risk Strategy, the disposal of solid and tank waste disposal in-place and the entombment of canyons and reactors would reduce overall worker risk significantly. Overall, there would be no unacceptable environmental, safety, and health risks in this strategy.

\section{H.5 Land Use}

The 200 Area would be a permanent disposal site, with controlled access. Groundwater access throughout the remainder of the Site would be controlled for the foreseeable future (at least 180 years). The area along the Columbia River would be available for recreational use, and the 100 , 300 , and 400 Areas would be available for limited industrial use. Use of the 600 Area would be restricted until waste management operations are completed in the 200 Area. The 600 Area would then be made available for other uses progressively.

\section{H.6 Period of the Cleanup}

The cleanup period would extend to 2045 , with completion of reactor entombment and facility disposition; however, most of the cleanup would be completed by approximately 2034, with completion of tank waste disposal and closure. Remediation of waste sites would be complete by 2026.

\section{H.7 Costs}

Figure H.2 is a cost profile for the Composite Strategy. It assumes in-situ disposal of tank waste at a cost of 10 billion dollars and total environmental restoration costs of nine billion dollars. Total lifecycle costs would be about 45 billion dollars for the cleanup.

The near-term program costs associated with this strategy are shown in Table H.1. This distribution of funding assumes minimum-operations for many of the programs. Unless programs can reduce operating costs to those minimum levels, the allocation of funding for cleanup actions cannot occur. The environmental restoration program would be most vulnerable in this respect. For example, fiscal year 1996 funding for environmental restoration is $\mathbf{2 5 0}$ million dollars, more than is currently budgeted. This provides money to carry out those high-benefit environmental restoration activities in the near term; however, that money has to come from some place. And that some place is other programs that are currently budgeted above the minimum-operations level, especially solid waste, landlord, and tank disposal. 


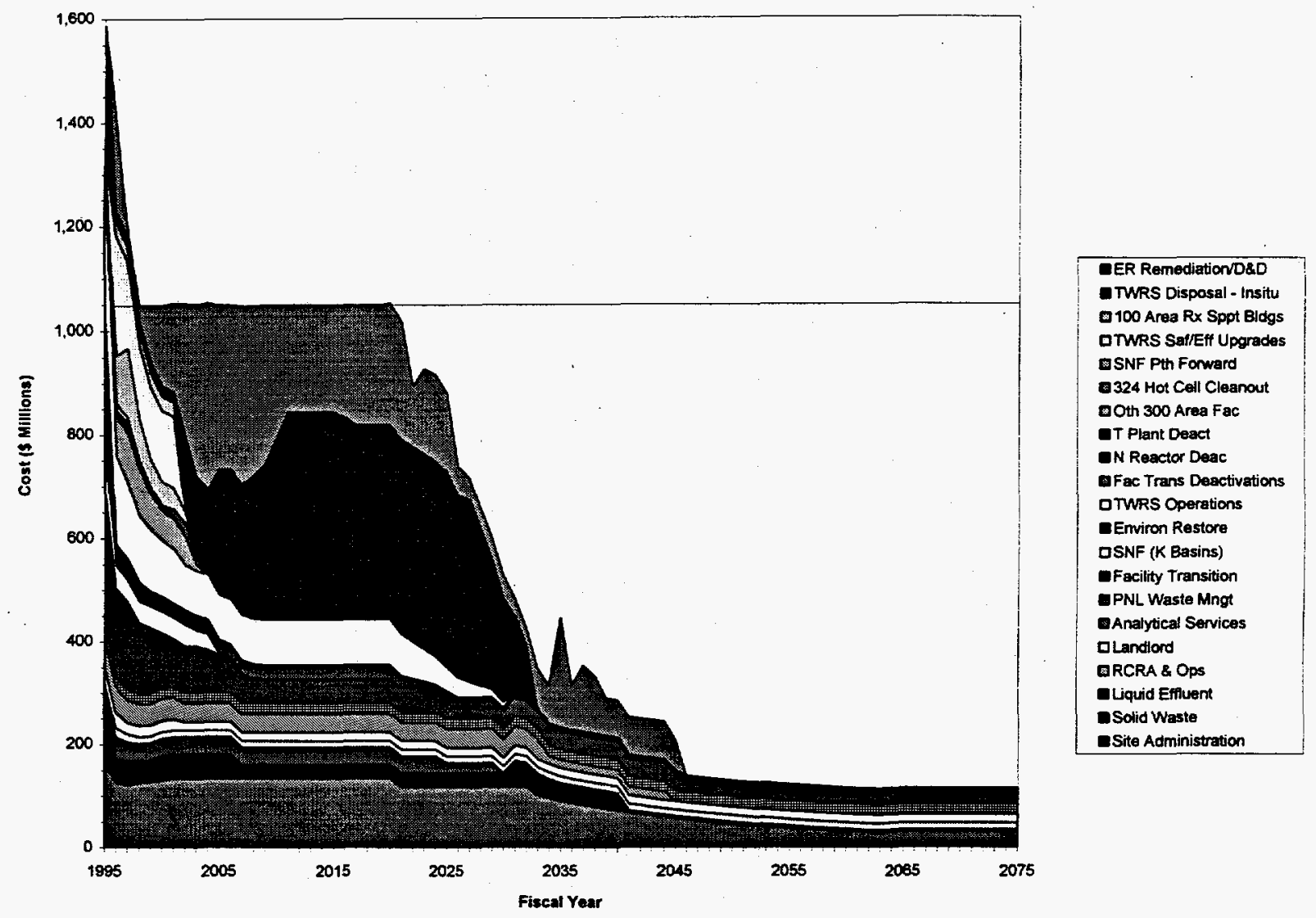

Figure H.2. Composite Strategy Cost Profile

It remains to be seen whether the Site has the discipline to get to minimum-operations levels, especially if modifications of the regulations are required. If it is not, the money will have to come from the 250 million dollars allocated to environmental restoration.

Another key point is the $\mathbf{2 0}$ million dollars annually for the tank disposal program. Although Tank Waste Remediation System operations has full funding, the Composite Strategy essentially defers most work on tank disposal until 2002 (recall this study did not address EM-50 technology development). This may not be enough for tank disposal, especially if planning for in situ disposal is to proceed at a healthy pace. If not, again, the money would come from environmental restoration.

Finally, we suggest that Table H.1 not be taken out of context. It was used to build the Composite Strategy in this study. It is not a recommended allocation of the Hanford Site budget over the near-term; however, it is representative of what a funding allocation would look like if the Site were to adopt a risk-based cleanup strategy. 
Table H.1. Near-Term Funding Allocations for Composite Strategy

\begin{tabular}{|c|c|c|c|c|c|c|}
\hline \multirow[b]{2}{*}{ Program element } & \multicolumn{6}{|c|}{ Summary of Near-term program costs in the Composite Strategy } \\
\hline & 1996 & 1997 & 1998 & 1999 & 2000 & 2001 \\
\hline Solid waste & 25.0 & 25.0 & 25.0 & 25.0 & 25.0 & 25.0 \\
\hline Liquid effluents & 40.0 & 35.0 & 34.0 & 33.0 & 33.0 & 33.0 \\
\hline Liquid waste/decontamination (T Plant) & 23.1 & 23.3 & 20.4 & 18.9 & 25.2 & 39.3 \\
\hline Advanced reactor & 60.0 & 60.0 & 55.0 & 43.0 & 29.0 & 14.0 \\
\hline Tank waste disposal & 20.0 & 20.0 & 20.0 & 20.0 & 20.0 & 20.0 \\
\hline Environmental restoration & 250.1 & 106.4 & 96.7 & 167.0 & 211.0 & 226.0 \\
\hline Landlord & 29.0 & 25.7 & 24.7 & 24.7 & 24.7 & 24.7 \\
\hline PNL - waste management & 35.2 & 33.5 & 30.6 & 30.9 & 24.2 & 20.5 \\
\hline Transition projects & 187.2 & $208 . \dot{4}$ & 174.6 & 153.6 & 137.0 & 134.6 \\
\hline Spent fuel & 136.0 & 175.0 & 123.0 & 95.0 & 88.0 & 84.0 \\
\hline Tank safety \& operations & 400.3 & 314.3 & 264.3 & 256.3 & 245.3 & 242.3 \\
\hline HAMMER & 5.0 & 5.0 & 5.0 & 5.0 & 5.0 & 5.0 \\
\hline RCRA/operational monitoring & 18.0 & 16.0 & 13.0 & 13.0 & 13.0 & 13.0 \\
\hline HEMP & 7.0 & 7.0 & 7.0 & 7.0 & 7.0 & 7.0 \\
\hline RL activities & 102.0 & 97.0 & 101.0 & 103.0 & 107.0 & 110.0 \\
\hline Transportation & 3.0 & 3.0 & 3.0 & 3.0 & 3.0 & 3.0 \\
\hline Economic transition & 0.0 & 0.0 & 0.0 & 0.0 & 0.0 & 0.0 \\
\hline Plans and budgets & 10.0 & 10.0 & 10.0 & 10.0 & 10.0 & 10.0 \\
\hline Analytical services & 51.0 & 44.0 & 43.0 & 42.0 & 43.0 & 43.0 \\
\hline TOTAL & 1401.9 & 1208.6 & 1050.3 & 1050.4 & 1050.4 & 1054.4 \\
\hline
\end{tabular}

HAMMER = hazardous materials and emergency response.

HEMP $\quad=$ Hanford Environmental Management Program.

PNL = Pacific Northwest Laboratory.

RCRA = Resource Conservation and Recovery Act of 1976.

\section{H.8 Programmatic Risks}

Cost and schedule estimates in this strategy are a rough order of magnitude beyond the Activity Data Sheet period. This is especially true for tank in-situ disposal and entombment of facilities. Errors in the range of $\mathbf{5 0}$ percent are likely.

Technical risks would be mostly associated with in-situ tank disposal. The strategy does not require vitrification (although the 10 billion dollars tank disposal costs are associated with that option); 
however, if vitrification were determined to be the treatment preferred, there may be significant technical risk. Experts are divided on the estimate of technical risk. Most thought it higher than retrieval, separation, and vitrification of high- and low-level fractions, although retrieval, itself, is not without technical risk.

Politically, the Composite Strategy would face considerable uncertainty. It would take the best efforts of planners and managers to implement the strategy because many different factions will oppose parts of it. Political pressure would be brought to bear mainly on issues of retrieval versus inplace disposal, treatment of groundwater, and entombment of facilities and reactors.

\section{H.9 Stakeholder Issues and Regulatory Impacts}

Stakeholders would support the early resolution of near-term, public health risks: K Basins, 324 B cell, safety tanks, Plutonium Finishing Plant, and Waste Encapsulation and Storage Facility. They will also concur with environmental restoration actions in the 600 and 300 Areas which make those areas available quickly. Retrieval of waste and contaminated soil from solid and liquid waste sites outside the 200 Area would be viewed favorably by stakeholders; however, many local stakeholders would not be comfortable with any strategy that leaves high-level waste in the ground in the 200 Area. Many also would not like entombment, versus removal, of the reactors. Stakeholders want the Columbia River protected at all costs, so any decision to stop pump-and-treat of groundwater would not be viewed favorably. Restrictions on the use of the land would be opposed by many stakeholders.

Nationally, stakeholders would find much in the strategy to like, as it reduces costs and finishes the cleanup sooner. Congress, representing all constituents, would find the Composite Strategy generally attractive. Appendix $\mathrm{J}$ contains a discussion of regulatory impacts of various cleanup decisions. In general, the Composite Strategy would have major impact on the Hanford Federal Facility Agreement and Consent Order (Ecology et al. 1994), commonly referred to as the Tri-Party Agreement, and environmental regulations, especially the Resource Conservation and Recovery Act of 1976.

\section{H.10 References}

Ecology, EPA, and DOE, 1994, Hanford Federal Facility Agreement and Consent Order, as amended, Washington State Department of Ecology, U.S. Environmental Protection Agency, and U.S. Department of Energy, Olympia, Washington.

Resource Conservation and Recovery Act of 1976, 42 USC 6901, et seq. 


\section{Attachment H1 - Composite Strategy Statements}

\section{General Site}

This attachment provides detailed strategy statements for each hazard source.

\section{Nuclear Materials}

Nuclear materials generally consist of discrete packages of separated radionuclides currently stored on-site. These materials include spent nuclear fuels, special nuclear materials, cesium and strontium capsules and inventories of unirradiated uranium which are located in a variety of facilities in the 100 , 200,300 , and 400 Areas. The material generally represents the most concentrated forms of radionuclides on-site. Combined with the relatively unstable or dispersable chemical form for a portion of the inventory, this makes the material susceptible to release during accidents. Storage in facilities that are currently 25 to 50 years old results in maintaining relatively high-cost administrative and physical systems. In addition, the required disposal form for these material is relatively uncertain at this time. Based on these characteristics, the general strategy for handling nuclear materials is as follows.

a) Convert all nuclear materials to a stable form and package suitable for on-site storage over an extended period (e.g. 40 years) while attempting to retain maximum flexibility in the storage form to allow conversion to a different form or package once disposal requirements are defined. Where the objectives of stability during storage conflicts with retaining future flexibility, storage stability will be preferred.

Storage of nuclear materials is emphasized due to the current uncertainty in the ultimate material disposition. In general, definition of the criteria for ultimate disposition is controlled by one, or a number of off-site entities that require a significant time period to develop a consensus for action. Storage criteria can generally be defined using existing criteria or criteria approved within by the DOE community. An emphasis on storage would provide a definable goal for moving the materials of largest near-term release risk into modern storage systems rather than waiting for ultimate disposition decisions that may not occur before existing storage system age creates a critical risk situation.

b) Transition nuclear material to storage systems/facilities suitable for supporting storage for up to 40 years. The storage systems should minimize reliance on administrative and actively maintained controls for mitigation of potential accidents to minimize both acute risks in the future and operating costs during the extended storage period.

The transition to alternate storage will be based first on the current stability of the storage system, second on economic considerations, third on current storage location, and fourth on the projected capability of the existing system to adequately perform over the entire 40 -year storage period. 
c) Consolidate nuclear materials in the 200 Area. Consolidation in the 200 Areas takes advantage of the distance from the central plateau to potential off-site receptors to the extent possible while buffer zones are available from the current Site land area. This relocation minimizes the risk presented by the on-site storage of nuclear materials to the public under accident conditions; however, design of new storage systems should not rely on continued maintenance of the this distance for reducing facility costs due to the potential for contraction of the Site boundaries over the storage period.

d) Minimize receipt of additional nuclear materials from off-site until materials of a similar type are transferred to long-term storage. Minimizing the receipt of additional nuclear materials minimizes the growth of sources that represent the largest near-term release risks for the Site. Once all of the current inventory of a particular nuclear material type (e.g., special nuclear material) is transitioned to an acceptable long term storage configuration, an argument could be made that additional inventory could be added to a storage system with minimal increase in the overall site risk.

\section{Liquid Waste}

Liquid waste is currently stored in the 100 Area $\mathrm{K}$ and N Basins and in the 200 Area tank farms. A detailed description of the liquid waste is contained in Appendix A. The liquid waste in the $\mathrm{K}$ Basins is currently leaking to the environment and significant safety issues have been identified for several of the 200 Area tanks. There is concern that under accident conditions the tank waste could be released and spread throughout the environment. A detailed risk analysis was performed and is described in Appendix D. The following strategy for tank waste was developed based on considerations of near-term release risks, worker risks, long-term release risks, and ecosystem risks.

a) Manage tank safety issues by prevention mitigation techniques. Characterize the tank waste to the extent necessary to assure there are no emerging tank safety issues and to effectively plan the disposal program.

b) Move all liquid waste on site that is too contaminated to be discharged as effluent into the doubleshell tanks. By area, this would require the following actions.

100 Area - remove liquid waste from $\mathrm{K}$ and $\mathrm{N}$ Basins. Until removal is effected the leaks should be reduced as much as practicable.

200 Area - complete single-shell tank stabilization.

300 Area - move liquid from the 327 ponds.

400 Area - continue sending liquid waste to 200 Area. 
c) Continue safe storage in double-shell tanks, pending final disposal. The minimum upgrades necessary to assure continued safe storage should be defined and completed. Once the waste has been moved into double-shell tanks and the safety issues are resolved, from a risk perspective, the disposal program can be deferred for a reasonable time until funding and technology become available.

d) Ensure adequate storage capacity and contingency space exist in case the double-shell tanks start to leak. This will be accomplished by minimizing receipt of new waste, concentration of existing waste, and consolidation of similar waste types.

e) The disposal alternatives for tank waste include (1) continue active management; (2) dispose waste in place (in-situ); (3) remove, treat, and dispose (ex-tank). Any one of these or any combination of them may be implemented. In general, in-situ disposal is favored over continued active management and ex-tank disposal. In-situ is technically effective, leaves comparable residual hazards, is less expensive, and is less complex. In-situ disposal can range from a relatively simple technical approach (gravel fill) to a complex technical approach (vitrification). The decision on which approach to take should be made on a tank-by-tank basis, based on technical effectiveness, residual hazards, and cost.

\section{Solid Waste}

Solid waste is buried in trenches, stored in facilities, or stored in specially-designed retrievablestorage trenches. The solid waste primarily consists of inert materials contaminated with radionuclides, hazardous chemicals, or both. The inert materials that become waste vary across a wide range of inorganic and organic material types (e.g., metals, paper, plastic, cloth, rubber, soil, biological solids, structural material). The trenches used for burial are generally located in the 100 , 200 , and 300 Areas, while the storage facilities and retrievable-storage trenches are generally located in the 200 Area. Additional solid waste will be generated by other Site cleanup actions and will be received from off-site generators in the future.

The material stored or buried is not projected to be a dominant near-term risk under accident conditions at this time, so long as access controls are maintained until final disposition is completed. Current baseline plans project that most existing buried waste will be disposed in-situ or will be moved to the 200 Area for disposal, depending on land use objectives. Within the 200 Area, retrievably-stored transuranic solid waste in trenches is planned to be retrieved for combination with newly-generated transuranic waste and stored prior to disposal off-site in the Waste Isolation Pilot Plant; however, the schedule of the Waste Isolation Pilot Plant availability for Hanford Site waste continues to be uncertain. Other existing buried waste in the 200 Area is planned to be disposed insitu, while most non-transuranic categories of stored waste are planned to be disposed in the 200 Area after treatment. Assuming non-homogeneity of older waste creates a difficult situation for developing a consistent disposition method based on comparative risks. Based on these characteristics, the general strategy for handling solid waste is proposed as follows.

a) Continue to control access to areas where solid waste is buried or stored until disposition activities in a particular area is complete. This provides a cost-effective method of controlling near-term risks using existing distances to off-site receptors as the primary exposure control. 
b) Continue to receive off-site generated solid waste to meet current commitments. While it would be preferable to limit off-site receipts to waste types that have a complete disposition path in place on-site, minimizing the addition of capacity to interim storage facilities, it is recognized that current commitments to off-site generators must be fulfilled.

c) Expand stored waste capacity in increments until waste disposition paths are completed. Off-site generators and on-site cleanup programs will continue to generate categories of waste which must be stored while disposition paths are finalized. Storage systems will be installed in increments to minimize development of excess capacity.

d) Limit solid waste retrieval outside the 200 Area to that necessary to accomplish land use objectives.

e) Dispose of as much solid waste on-site and in-situ as risk, regulatory, and land use objectives allow.

f) Defer retrieval of any 200 Area retrievable transuranic solid waste in trenches until development of a methodology for evaluating exposure hazards from nonradioactive hazardous constituents and radionuclides on a comparable basis, or Waste Isolation Pilot Plant approaches an operational phase allowing disposal of Hanford Site waste. Until Waste Isolation Pilot Plant reaches an operational state, uncertainties will continue to exist in package acceptance criteria and whether capacity will exist for all Hanford Site transuranic waste. Early retrieval of transuranic waste from trench storage creates the need for additional facility storage capacity. In addition, the waste would be examined and qualified to standards that continue to have the potential for future changes. Leaving trench stored waste in current storage until Waste Isolation Pilot Plant is operational limits storage capacity to that needed for newly generated material and minimizes the potential for rework. In addition, should capacity and priority constraints limit the use of Waste Isolation Pilot Plant for Hanford Site material, the quantity of Hanford Site transuranic waste stored for Waste Isolation Pilot Plant disposal would be minimized allowing this quantity to be tailored in the future to the disposal system capacity available.

In the interim, hazard evaluation methods should be developed to allow comparison of risks from hazardous constituents with long-lived radionuclides, with particular emphasis on intruder scenarios. Until this issue is closed, the potential exists for expending resources on transuranic waste retrieval from the 200 Area that does not significantly reduce the overall long-term Site risk.

\section{Environmental Contamination}

With the exception of $\mathrm{N}$ Reactor deactivation and some limited 100 Area remediation, the ongoing Environmental Restoration Project activities are delayed three years from 1996 to 1999. Additionally, the overall completion of the Environmental Restoration Project is delayed to beyond 2050. Some waste would be removed from the 100,300 , and 400 Areas and disposed of in the 200 Area; however, most of the waste would be disposed of in-place in the 100,200,300, and 400 Areas and the reactors would be entombed. The groundwater use for the entire Site would remain restricted. 5. Facilities 
The term "facilities" refers to the nuclear and nonnuclear former production, research, and support facilities in the 100,200,300, and 400 Areas. This includes the old reactors and their support buildings on the Columbia River (100 Areas), the chemical processing (canyon buildings) and support facilities (e.g., the 222-A Evaporator) located in the 200 Area, the nuclear research, uranium fuel fabrication, and support facilities located in the 300 Area, and the Fast Flux Test Facility reactor and support facilities in the 400 Area. There are both contaminated and uncontaminated facilities. Contaminated facilities may be heavily-contaminated (e.g., the canyon buildings) or lightlycontaminated (e.g., the uranium fuel fabrication facilities). Most of the contaminated facilities are currently or will in the future be undergoing deactivation, which consists primarily of immobilizing or removing radioactive and chemical inventories and deactivating facility systems that are no longer necessary. Deactivation is performed to minimize long-term surveillance and maintenance activities and to prepare facilities for decontamination and decommissioning. Minimal surveillance and maintenance is desirable because it reduces the annual facility costs as well as reduces occupational exposure and industrial hazards. Facility decontamination and decommissioning represents the final disposition of the facilities. Following decontamination and decommissioning, the costs, worker risks, public risks, and potential environmental contamination risks drop to zero or near-zero, depending upon the decontamination and decommissioning option implemented.

Three general options for final disposition of facilities have been examined, including: (1) full entombment of a building, which involves installation of a barrier over a facility location after filling void spaces with grout, cement, gravel, or other material), (2) partial entombment, consisting of removal of above-ground structures and entombment of below-grade portions of the buildings; and (3) full-scale demolition, which includes removal of contamination from the building followed by demolition and removal of building rubble. The first two options leave contamination in-place and thus create a low-level disposal facility at the building location, requiring that access to the location remains restricted as well as monitoring of groundwater. The third option removes all contamination, thus freeing the location for other uses (access restrictions and groundwater monitoring would not be required). Based on these characteristics, the general strategy for final disposition of the facilities is as follows.

a) Entomb or dispose-in-place the reactors along the Columbia River and demolish the lightlycontaminated support facilities. Reactor building entombment was chosen because it has been shown that leaving a residual radionuclide inventory at the reactor locations does not represent a significant public health risk. Entombment has also been shown to result in significantly lower worker risks. In addition, the ecological damage associated with reactor block removal, including construction of a large road system to support the transportation of reactor blocks to the 200 Area, appears to favor the entombment option. Based on these conclusions, entombment of the reactor buildings would be favored over the current plan to remove the reactor blocks and transport them to 200 Area for disposal. The reactor location would become a low-level waste disposal facility and would require access restrictions and groundwater monitoring. Since there is little contamination in the support facilities relative to the reactor buildings, the support facilities would be demolished and the land made available for other uses. 
b) Consolidate nuclear research operations in the 300 Area and demolish surplus facilities. The nuclear research facilities, including the $324,325,327$, and possibly 308 , Buildings would be consolidated to the extent possible. They would continue to operate as long as a mission for them exists. The surplus facilities would be demolished, making the land available for other uses. In addition, the 309 Building (former Prototype Research Test Reactor) would be demolished to free the land for other uses.

c) Demolish 300 Area fuel supply facilities. The former fuel fabrication facilities located in the 300 Area would be demolished to make the land available for other uses. Prior to demolition, the unirradiated uranium fuel material currently located in these buildings would be moved to a storage location outside the 300 Area to facilitate demolition.

d) Entomb 400 Area reactor building and demolish support facilities. The Fast Flux Test Facility reactor building would be entombed in place for the reasons outlined for the old reactors (minimal public risk and relatively large worker risk for demolition). Consequently, a part of the 400 Area would be a low-level waste disposal facility with continuing access restrictions and groundwater monitoring. The support facilities would be demolished and contamination removed to the 200 Area for disposal. The locations of the support facilities would be available for other uses.

e) Entomb 200 Area heavily-contaminated facilities. Heavily-contaminated facilities in the 200 Area, including PUREX Facility, B Plant/Waste Encapsulation and Storage Facility, T Plant, REDOX Plant, AR Vault, 242 A Evaporator, and a limited number of other facilities would be entombed in-place. Some of the contaminated materials in the buildings would be removed during deactivation, including most of the transuranic contamination and irradiated fuel elements and fragments. The degree to which contamination is removed prior to entombment would differ among the facilities. For example, it may be advisable to remove as much of the transuranic contamination as possible to minimize long-term public risks in these locations. This would mean that contamination removal from the heavily transuranic-contaminated Plutonium Finishing Plant would be more intensive than facilities or areas in facilities that are predominantly contaminated with shorter half-life fission products.

Entombment would require a large quantity of clean earthen cover material to construct a barrier over the buildings, thus increasing ecological damage in currently uncontaminated areas. To minimize the amount of barrier material required, the decontamination and decommissioning option of removing aboveground portions of buildings and covering the below-grade structures with a barrier may be preferable. Both the full and partial entombment options result in a low-level waste disposal facility, requiring access restrictions and groundwater monitoring; however, this is consistent with the planned use of the 200 Area as a long-term disposal facility for various wastes.

f) Demolish lightly-contaminated facilities and support facilities in the 200 Area. The lightlycontaminated facilities and support facilities for the former chemical processing operations would be demolished and the rubble removed and disposed. 


\section{Attachment H2 - Mortgage-Based Strategy}

\section{H2.1 General Description}

The Mortgage-Based Strategy focuses on reducing the costs for maintaining facilities. It was pursued primarily due to the high costs for maintaining the Hanford Site. At projected funding levels, only a small percentage would be available to attack risks and progress with cleanup without reducing the mortgage. Even though this strategy has been developed with consideration of all activities necessary to reach a cleanup endstate, its primary benefit is to support other cleanup strategies. Therefore it has not been included by itself as one of the alternative strategies as part of this study. Because of the need to maximize the resources available for cleanup, the three alternatives have included the mortgage reductions with high paybacks in their respective strategies.

\section{H2.1.1 Objective of the Strategy}

The objective of this strategy is to reduce the surveillance, operations, and maintenance costs (the "mortgage") of Hanford Site activities as soon as possible to free those funds for other purposes. This strategy was developed to understand better the implications of such a strategy when there was only a single objective. This objective is in agreement with December 16, 1994, DOE - Richland Operations Office and contractor managers guidance to programs for development of the fiscal year 1997 Activity Data Sheets. It is also in agreement with recent budget actions, in which facility transition activities were exempted from budget cuts because they were reducing the mortgage.

\section{H2.1.2 Decision Rules by Which Activities are Chosen}

Several decision rules for mortgage reduction were considered. The simplest is to minimize the payback time (i.e., that time required to recover the investment cost). Another rule is to maximize the ratio of the cost savings to the investment. This rule requires an endpoint that determines the total savings. In general, the benefit-to-cost ratio was considered the best single measure for choosing among mortgage-reduction alternatives.

\section{H2.1.3 Summary Description of the End State and Cleanup Activities}

The Mortgage-Based Strategy includes the same activities and results in the same endstate as the Risk Strategy (see Appendix G). The primary difference is that near-term priority is given to mortgage reductions in order to make more discretionary funds available sooner to better attack the risks.

\section{H2.2 Strategy Development}

Mortgage reduction in the context of this strategy is interpreted in the broadest sense and includes virtually every cleanup activity. The most straightforward example is that of former defense production facilities with large operations and maintenance costs that are reduced after facility 
transition. For example, PUREX surveillance and maintenance costs in fiscal year 1995 are about 37 million dollars; however, there will be only two million dollars after deactivation and transition to the environmental restoration program for surveillance and maintenance.

Major facilities may be the most common example of mortgage reduction, but they certainly are not the only one. For example, Tank Waste Remediation System disposal activities may be thought of as reducing the mortgage of operating and maintaining the tank farms (approximately 140 million dollars in fiscal year 1995). Thus, if waste can be removed from single-shell tanks and the tank farms deactivated, the operation and maintenance costs will be reduced greatly. Even the environmental restoration program can be viewed from a mortgage reduction viewpoint. For example, the two million dollar cost for PUREX after transition can be considered a mortgage to be reduced by dispositioning of PUREX, either by dismantlement or entombment.

Other activities may be considered as mortgage reduction, as well. For example, activities that directly affect operation and maintenance costs, (e.g., productivity enhancements) could fall into this category. So could changes in regulatory requirements and changes in technical strategies within a program. Also, privatization can be used to either reduce the total cost or lower peak costs by spreading them over time. The latter can also be a mortgage reduction if it is necessary to allow work to proceed in a timely manner. In general, the Mortgage-Based Strategy considered all such activities.

The Mortgage-Based Strategy proscribes the activities and their sequence that produce the 'best' mortgage reduction over the cleanup period. This strategy produces a different endstate than the Existing Baseline Strategy. The strategy is defined as follows.

- Support nondiscretionary minimum operations, which include Site administration, solid and liquid waste, Resource Conservation and Recovery Act of 1976 and operational monitoring, landlord, analytical services, and Pacific Northwest Laboratory waste management. No treatment, retrieval, and alternative storage and disposal efforts associated with these programs are funded.

- In the near-term (through approximately 2003), the Site invests as many of its discretionary resources as possible in the transition of major facilities (PUREX, N Reactor, B Plant, Fast Flux Test Facility, T Plant, 300 Area, etc.). B Plant is decoupled from Waste Encapsulation and Storage Facility as soon as possible and deactivated. Cesium and strontium capsules are subsequently removed from Waste Encapsulation and Storage Facility and stored in the spent nuclear fuel dry storage facility, when available.

- The spent nuclear fuel program proceeds on the Path Forward schedule, to include acceleration of the stabilization facility.

- Tank Waste Remediation System upgrades, the Waste Tank Safety Program, and Tank Waste Remediation System characterization are completed as soon as possible to reduce annual tank farm operations from current operating budgets in excess of 140 million dollars to about 87 million dollars.

- Tank waste is disposed in-situ. 
- The environmental restoration program is funded at a level to support minimum operations until the facility transition, Tank Waste Remediation System upgrades/Waste Tank System/characterization, and spent nuclear fuel programs are completed (about seven years). Thereafter, the environmental restoration program is supported to the limit of the available funding. The environmental restoration program conducts minimum remediation actions, especially in the 200 Area. Solid and liquid waste sites are capped and covered; reactor and canyon facilities are entombed. The environmental restoration program is stretched to fit within the funding profile.

- Post-1970 transuranic waste is disposed in-place; stored solid wastes are disposed without treatment; groundwater is not treated.

\section{H2.3 Results of the Cleanup}

The Mortgage-Based Strategy resulted in the same endstate as the Risk Strategy. See Appendix G for the results of the cleanup by geographic area and hazard sources.

\section{H2.4 Environmental, Safety, and Health Risks}

The Mortgage-Based Strategy addresses the principal environmental, safety, and public health risks, especially spent nuclear fuel, cesium and strontium capsules, Tank Waste Remediation System watch list tanks, and spent nuclear material. It does not support buried solid waste, 324 B Cell cleanout, or contaminated soil and groundwater. In general, transition of major facilities, (e.g., PUREX and Fast Flex Test Facility) reduce worker risks. The risks associated with the resultant endstate would be the same as for the Risk Strategy (see Appendix G).

\section{H2.5 Future Land Use Implications}

In general, activities that directly cleanup the land do not fare well under this strategy because current operations and maintenance costs for these activities are minimal, compared to major facilities, spent nuclear fuels, and underground storage tanks. The result is that the majority of land use continues to remain restricted until the end of cleanup, after most other mortgage-reduction activities have been completed. Under this strategy, the 200 Area is a permanent storage and disposal area, groundwater use is restricted throughout the Site, and access to burial grounds is controlled. Access to areas with previously transitioned facilities will be controlled until the facilities are disposed. Additional discussion concerning longer-term land use implications is provided in the Risk Strategy (see Appendix G). 


\section{H2.6 Period of Cleanup}

The major cleanup activities, which include in-situ disposal of tank wastes and stabilization of waste sites, are completed by 2030 . Facility decommissioning activities continue beyond that date, ending in 2043 with entombment of the 100 Area reactors.

\section{H2.7 Costs}

This strategy is focused on mortgage-reduction alternatives to achieve cost reduction. It is recognized, however, that there are significant problems with cost estimating, especially for the outyears. Most budget profiles extend only for seven years (through 2001 for the fiscal year 1997 Activity Data Sheets), and, generally, estimates beyond 2001 exist only for Tank Waste Remediation System and environmental restoration programs. In addition, there are significant changes in cost estimates in recent months, as funding cuts have impacted program planning. An analysis of fiscal year 1996 and fiscal year 1997 Activity Data Sheets clearly illustrates these changes. The overall funding profile resulting from this strategy is shown in Figure H2.1.

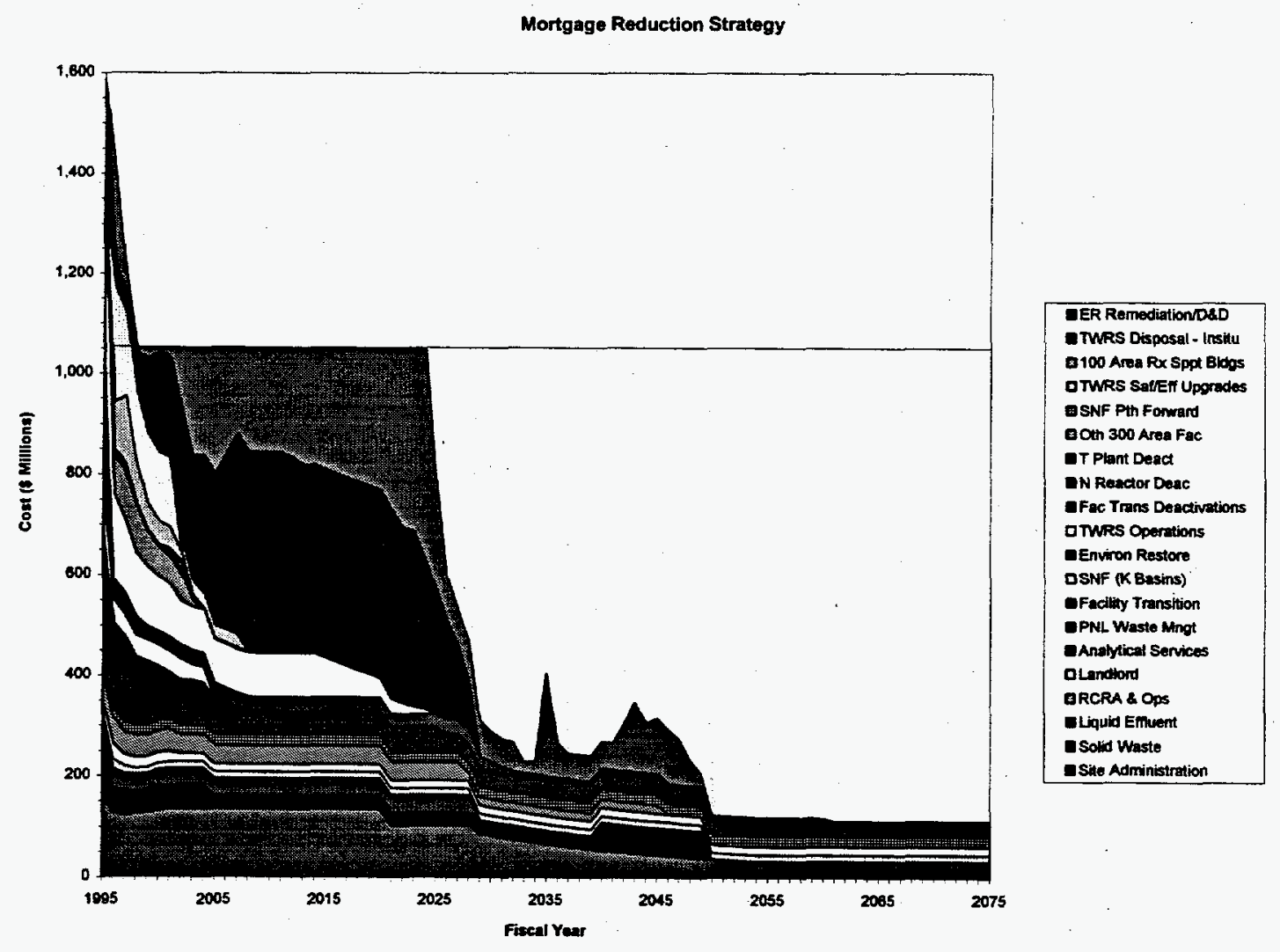

Figure H2.1. Mortgage-Reduction Strategy Funding Profile 


\section{H2.7.1 Mortgage Reduction of Major Facilities}

Described below are major facility mortgage reduction profiles. These figures reflect current plans as described in the fiscal year 1997 Activity Data Sheets. Fiscal year 1997 Activity Data Sheet costs were used, as they better reflect the recently negotiated approaches for facility transition. They could, in some cases, be accelerated if funding were provided. Facilities that have already been deactivated are not included (e.g., REDOX, U Plant, $\mathrm{UO}_{3}$ Plant).

H2.7.1.1 PUREX. Costs to maintain PUREX will be drastically reduced following deactivation. Figure $\mathrm{H} 2.2$ shows the investment required during the next couple of years to reduce operation and maintenance costs from 36.5 million dollars in its current configuration to 2.0 million dollars after transition. This results in an annual savings by 1999 of at least 34.5 million dollars and possibly more, depending on some assumptions about future operation and maintenance costs. For example, Figure $\mathrm{H} 2.2$ shows operation and maintenance costs at a constant 36.5 million dollars; however, facility transition program personnel estimated a small, gradual growth in operation and maintenance costs as the facility continues to degrade. The $\mathbf{3 4 . 5}$ million dollars annual savings is a conservative estimate.

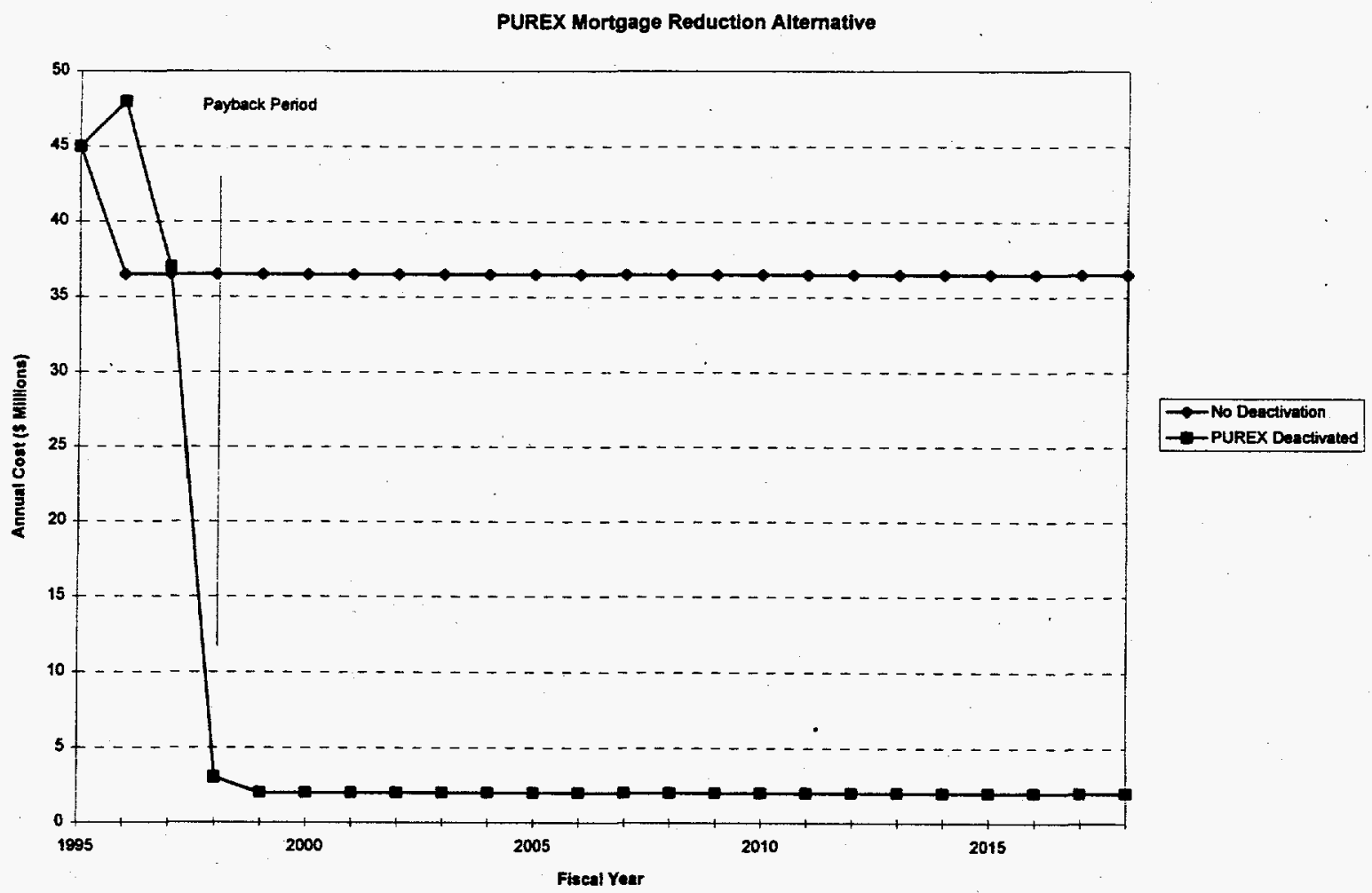

Figure H2.2. PUREX Mortgage Reduction Cost Profile 
Two additional points need to be made about PUREX deactivation: ' (1) The time required to recover the investment costs ("payback period") is about three years. Note that PUREX deactivation has already started and investment to date can be considered sunk. (2) If the initial cleanup period extends to 2018 (the original Hanford Federal Facility Agreement and Consent Order [Ecology et al. 1994-Tri-Party Agreement] goal for the end of cleanup), a savings-to-cost ratio can be calculated. In this case, it is about 60 . This says we save almost 60 dollars for every dollar we invest in PUREX transition, the highest benefit-to-cost ratio of any mortgage reduction alternative. A longer payback period, 2030, produces a ratio of 95 .

Fast Flux Test Facility. Fast Flux Test Facility deactivation started in fiscal year 1994 and will continue through the end of the century. The fiscal year 1997 Activity Data Sheet cost profile is shown in Figure H2.3, which shows the 20-plus million dollars in annual investment through 2000. Surveillance and maintenance costs are reduced from 35.5 million dollars annually now to 12 million dollars after deactivation. The payback period is through 2003 . The benefit-to-cost ratio is 6.5 through 2018.

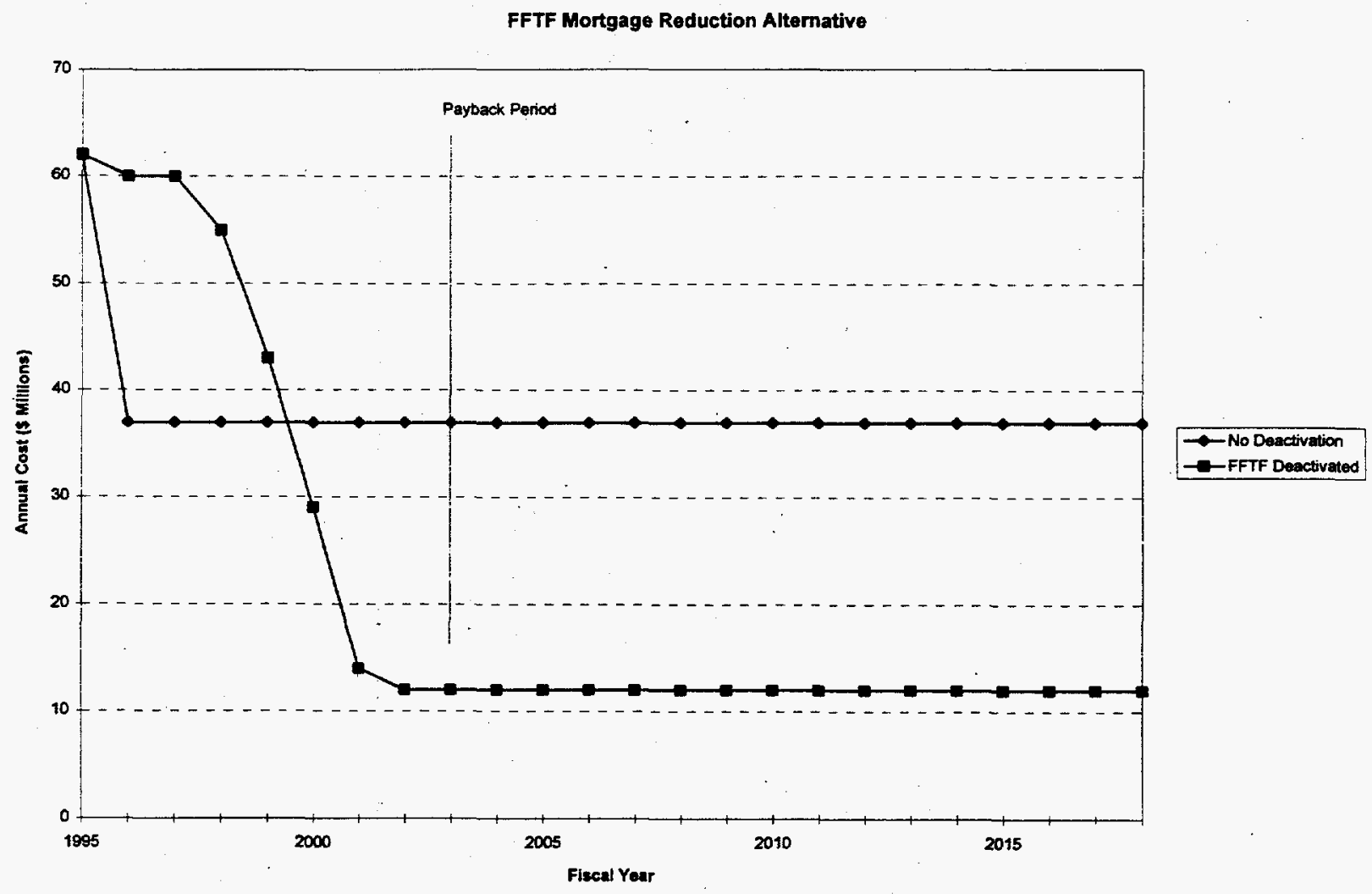

Figure H2.3. Fast Flux Test Facility Mortgage Reduction Cost Profile 
Plutonium Finishing Plant. Cleanout of Plutonium Finishing Plant is the most complex of all facility transition projects, mostly because of the absence of decisions and national policies for the ultimate disposition of plutonium and future uses of the plant. An environmental impact statement is being prepared to address the clean out of the Plutonium Finishing Plant, the conversion of special nuclear materials in the Plutonium Finishing Plant complex to a form suitable for long-term storage, and the storage of stabilized material until final disposition decisions are made. Existing special nuclear material vault storage would continue pending future disposition decisions for the materials.

Figure H2.4 shows that Plutonium Finishing Plant minimum operating costs could be reduced to approximately 60 million dollars annually (including 20 million dollars of DP safeguards and security funds) in the current plan configuration. The top curve shows Plutonium Finishing Plants deactivation costs for the budget planning case, which include an estimate for actions required by Defense Nuclear Facility Safety Board recommendation 94-1 and resolution of plutonium vulnerabilities. The bottom curve does not include those costs. In either case, the surveillance, operations, and maintenance costs are about 25 million dollars after deactivation. Most of this ( 20 million dollars) is for safeguards and security. The DP program may quit paying for safeguards and security in the near future.

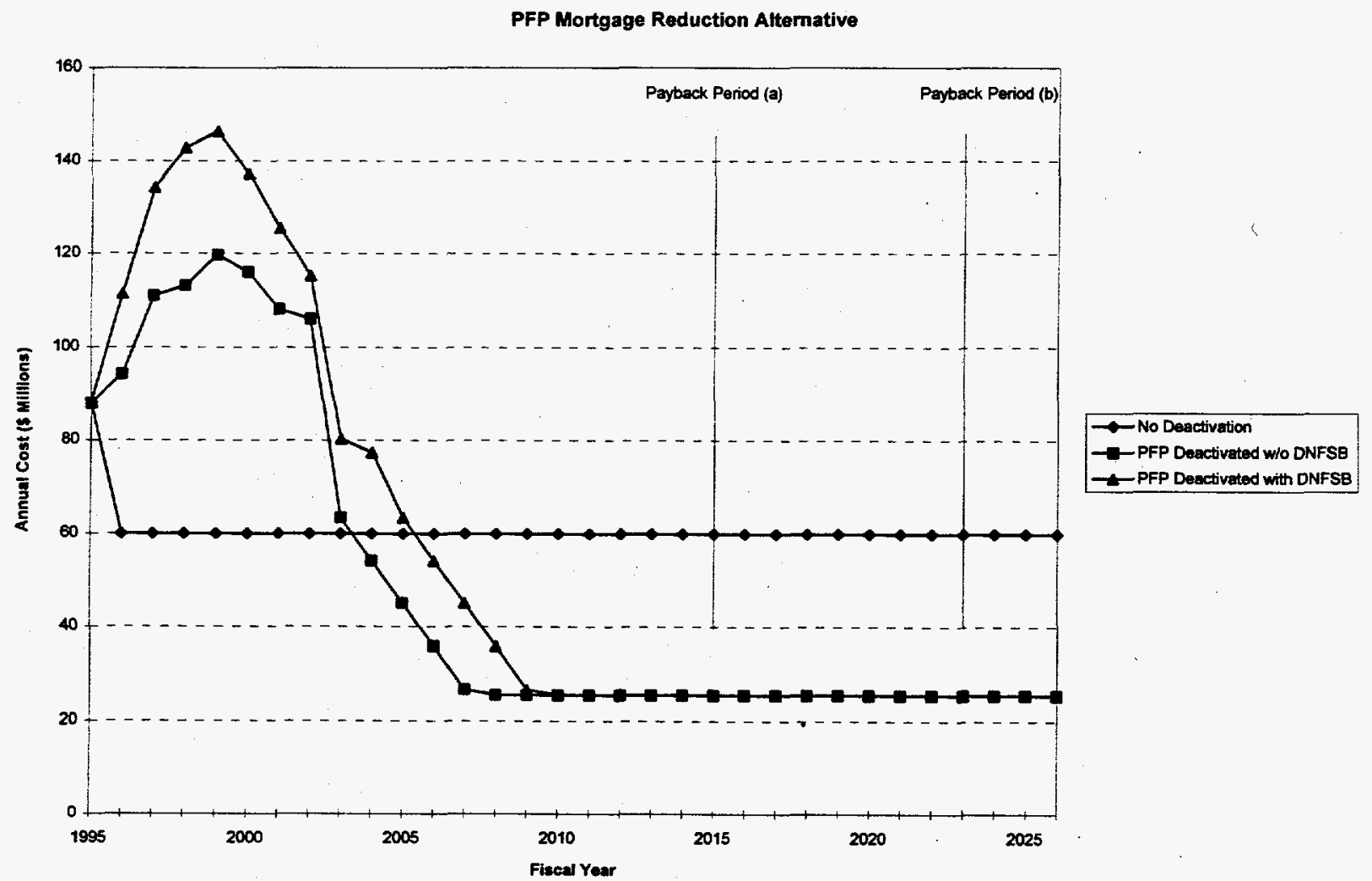

Figure H2.4. Plutonium Finishing Plant Mortgage Reduction Cost Profile 
Payback periods are shown for each cleanout plan. The cheaper alternative recovers the investment costs by 2015; however, paying for the Defense Nuclear Facility Safety Board requirements moves the payback period out to 2023. In the final analysis, we did not consider the Defense Nuclear Facility Safety Board requirements as mortgage reduction options. If they are required; they are part of operations. If they are not required, we recommend against doing them from a mortgage-reduction perspective. We included them only for completeness.

$\mathbf{K}$ Basin. There are several reasons for executing the spent nuclear fuel path forward plan, one of which is the reduction of the mortgage for operating and maintaining the $\mathrm{K}$ Basins. The annual costs for $\mathrm{K}$ Basins are approximately 42 million dollars and are expected to increase as the facility degrades in the future. However, if we assume the spent nuclear fuel program accurately represents the mortgage reduction costs for $\mathrm{K}$ Basins, it takes a very long time to recover these costs. Figure $\mathrm{H} 2.5$ illustrates this point.

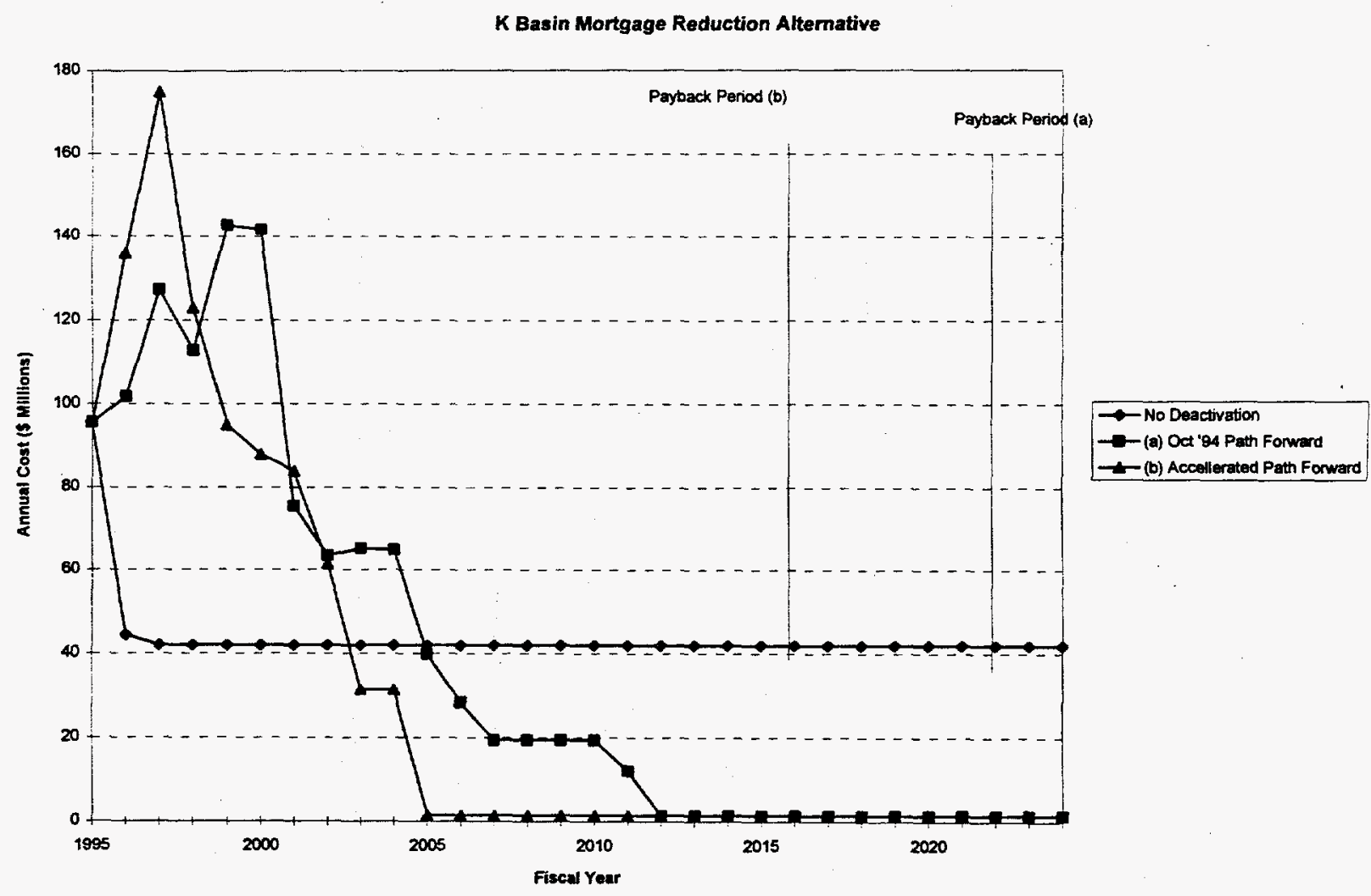

Figure H2.5. K Basin Mortgage-Reduction Cost Profile 
Total deactivation costs for $\mathrm{K}$ Basins include repackaging of the fuel, passivation, disposal of contaminated water and sludge, and deactivation of the facilities themselves, among other things. Based on the path forward plans in October 1994, it is not until 2005 that total program costs are equal to expected surveillance and maintenance costs, and the payback period is not until 2021. The benefit-to-cost ratio is about 0.8 through 2018 , one of the lowest of all facilities. This implies that, based on mortgage reduction alone, there are more attractive deactivation alternatives than $\mathrm{K}$ Basins.

Recent modifications to the spent fuel path forward propose acceleration of $\mathrm{K}$ Basin fuel removal activities. This funding profile estimated from these actions is also shown in Figure H2.5.

Acceleration moves forward the payback period to 2015 and increases the benefit-to-cost ratio through 2018 to 1.2 .

N Reactor. Annual N Reactor costs are about 16.5 million dollars, which can be reduced to three million dollars with an investment of about 22.5 million dollars. The payback period ends at 2000 , and the benefit-to-cost ratio is 12 . Figure $\mathrm{H} 2.6$ shows the mortgage-reduction cost profile.

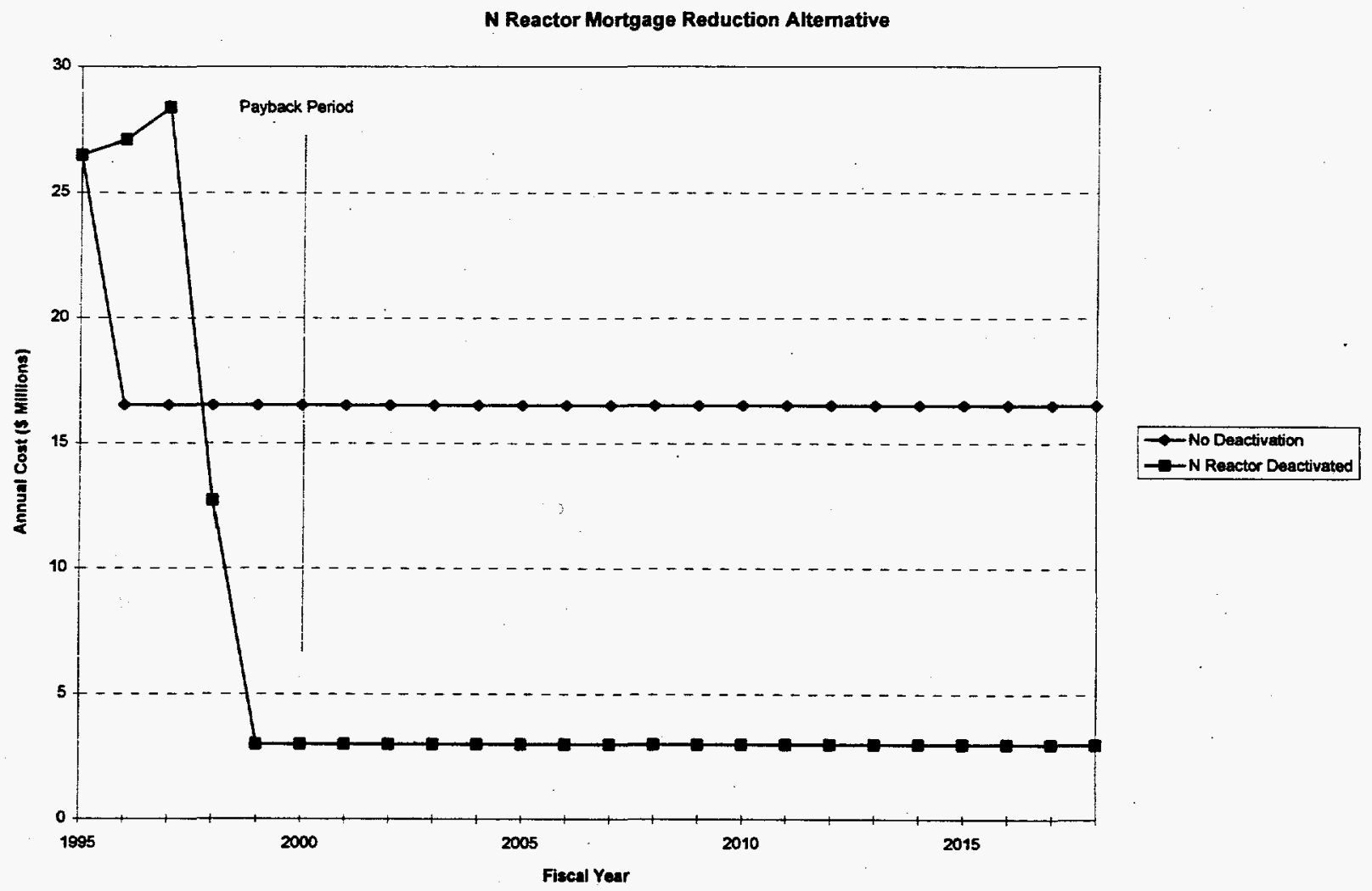

Figure H2.6. N Reactor Mortgage-Reduction Cost Profile 
B Plant/Waste Encapsulation and Storage Facility. The deactivation of this facility is complicated by the need to continue to store the cesium and strontium capsules safely. The mortgage reduction cost profile in Figure H2.7 assumes a separation of Waste Encapsulation and Storage Facility from B Plant and a resulting two-phased, deactivation sequence. Deactivation of B Plant, itself, occurs during the remainder of the decade, thereby reducing total operation and maintenance costs from 32 million dollars to 11 million dollars by 2001. At that time, Waste Encapsulation and Storage Facility could be deactivated, further reducing the operation and maintenance costs to three million dollars annually. This assumes, of course, that the capsules are stored elsewhere, such as in the spent fuel dry-storage facility.

The payback period for the B Plant deactivation is very short, and the benefit-to-cost ratio is almost 11. The decision for Waste Encapsulation and Storage Facility can possibly be made later, depending upon the availability of the spent fuel facility, resolution of safety concerns, etc. The cost profile could look quite different from that depicted in Figure H2.7.

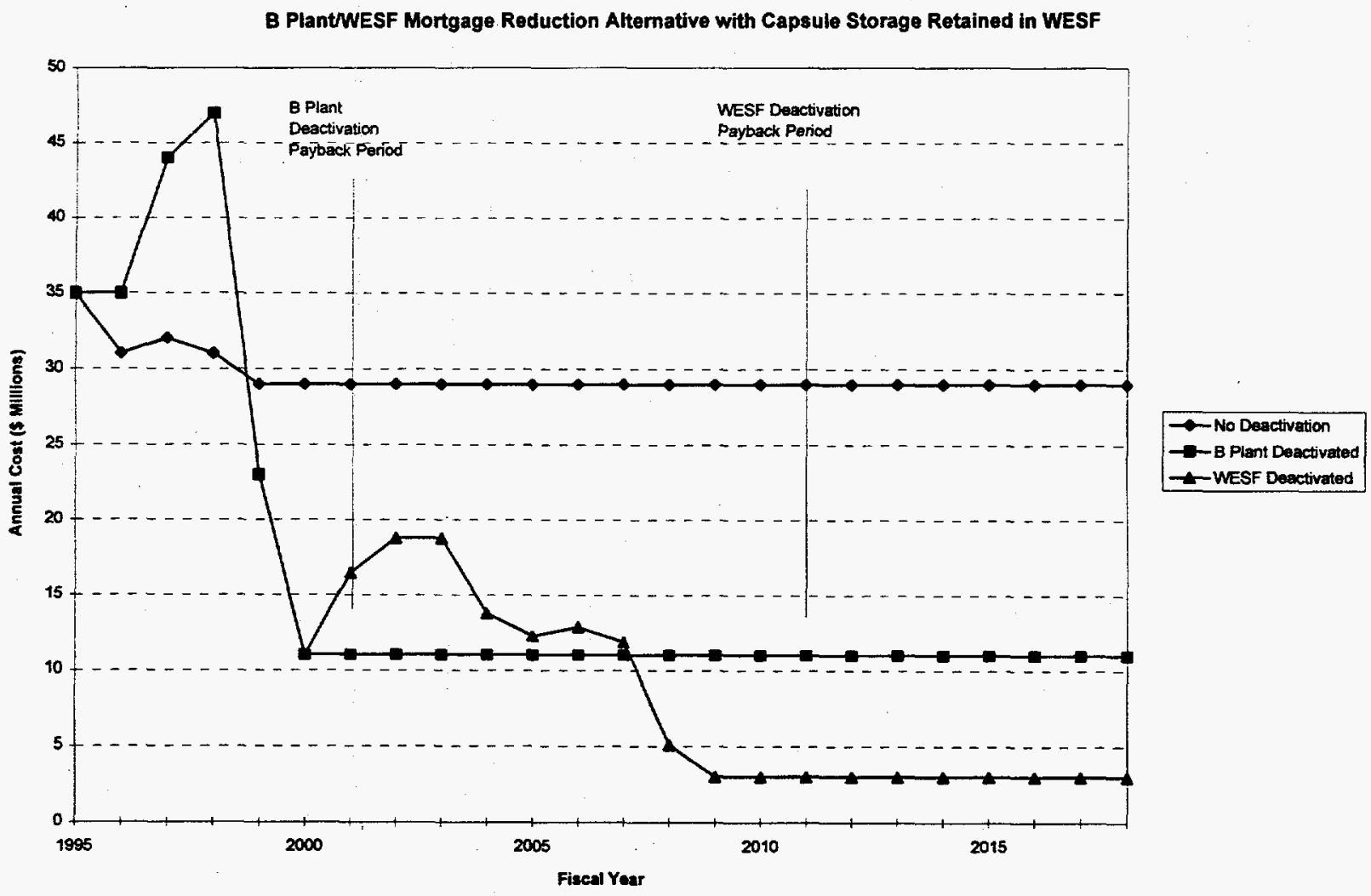

Figure H2.7. B Plant/Waste Encapsulation and Storage Facility Mortgage Reduction Cost Profile 
T Plant. This facility, managed by the solid waste program, will continue to be used for solid waste decontamination through 1999 and storage of Shippingport PWR Core 2. Fuels must be moved to a dry storage system, which can be acquired from a commercial vendor as part of $T$ Plant deactivation. Deactivation at that time will reduce the annual operating and maintenance costs from about 23 million dollars to two million dollars, assuming the PUREX model applies. The payback period is only a couple of years after deactivation is complete, and the benefit-to-cost ratio is about 5.3 through 2018. If a decision were made to deactivate $T$ Plant earlier, the deactivation curve shown in Figure H2.8 could be moved to the left.

300 Area Fuel Supply. Annual mortgages for 300 Area facilities are minor compared to the facilities described above. The Fuel Supply Facilities (buildings 313, 314, etc.) have only a four million dollars annual operation and maintenance cost. Deactivation costs several times that, and the payback period is one of the longest of any facility, 2014. Annual operating costs are about two million dollars after deactivation. If these costs could be reduced, this alternative would be much more attractive. Through 2018, the benefit-to-cost ratio is about 1.4. Figure H2.9 shows the cost profile.

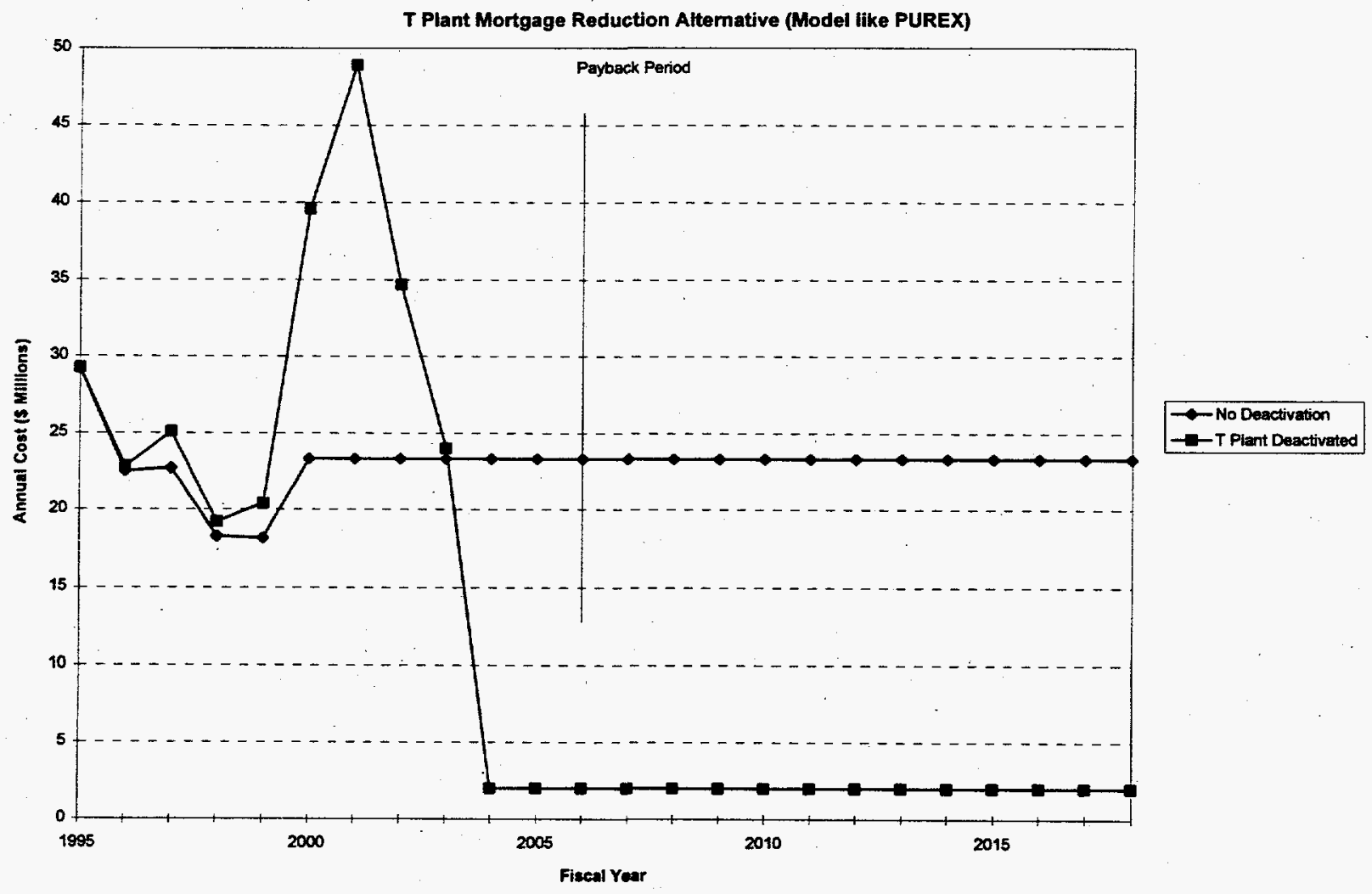

Figure H2.8. T Plant Mortgage Reduction Cost Profile 


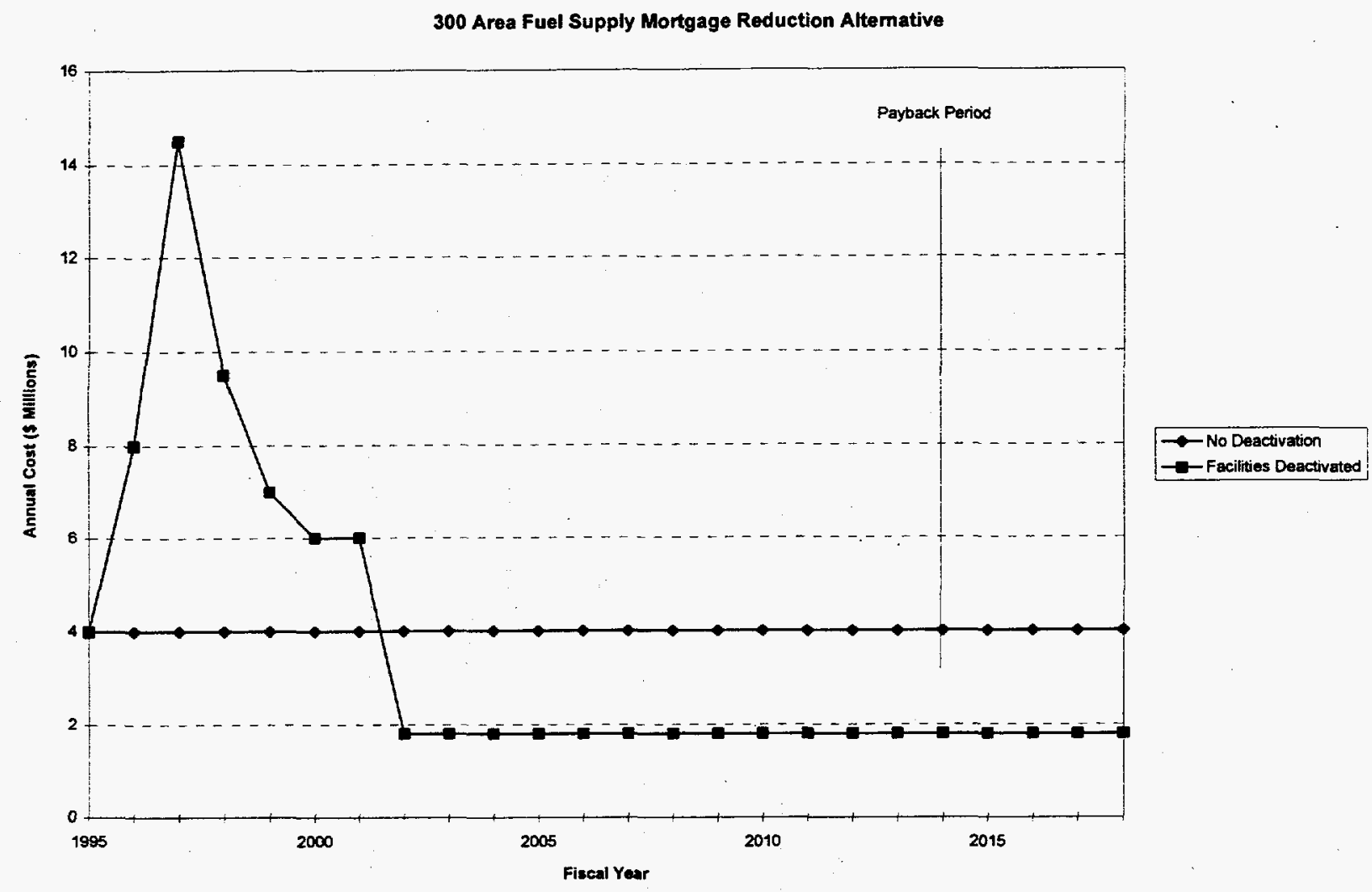

Figure H2.9. 300 Area Fuel Supply Mortgage-Reduction Cost Profile

Other 300 Area Facilities. Other 300 Area facilities were discussed with Pacific Northwest Laboratory and ICF Kaiser Engineering Hanford personnel. Pacific Northwest Laboratory said they could reduce the annual mortgage for excess Pacific Northwest Laboratory facilities (e.g., 303C, $303 \mathrm{~J}, 3731 / 3731 \mathrm{~A}, 3723,3718 \mathrm{E}, 314,3745,323,3730,306 \mathrm{~W}, 3708,3745 \mathrm{~A}, 3720,3762$ ) from about three to 0.5 million dollars with an investment of five million dollars over two years. ICF Kaiser Engineering Hanford planners looked at the entire 300 Area and estimated they could reduce annual operating costs for those facilities that could be easily demolished (MO-009, MO-026, MO-036,MO-046, MO-051, MO-059, MO-394, MO-395, M0-902/903/904, MO-926, MO-933, MO-935, 303C, 303J, 308, 309E, 321, 331A, 331J, 3701U; 3702, 3703, 3706, 3706A, 3707B/C/D, $3713,3717 \mathrm{C}, 3718,3718 \mathrm{~B} / \mathrm{E} / \mathrm{O}, 3722,3723,3731,3731 \mathrm{~A}, 3732,3745 \mathrm{~B}, 3746 \mathrm{~A}, 3762,3765$ ). They estimated an annual operating cost of five million dollars could be reduced to zero with an 18.4 million dollar investment over five years.

Figure H2.10 illustrates the savings. The small investment, the short payback period (2004), and the benefit-to-cost ratio of about 5.0 through 2018 make this mortgage reduction alternative attractive. 


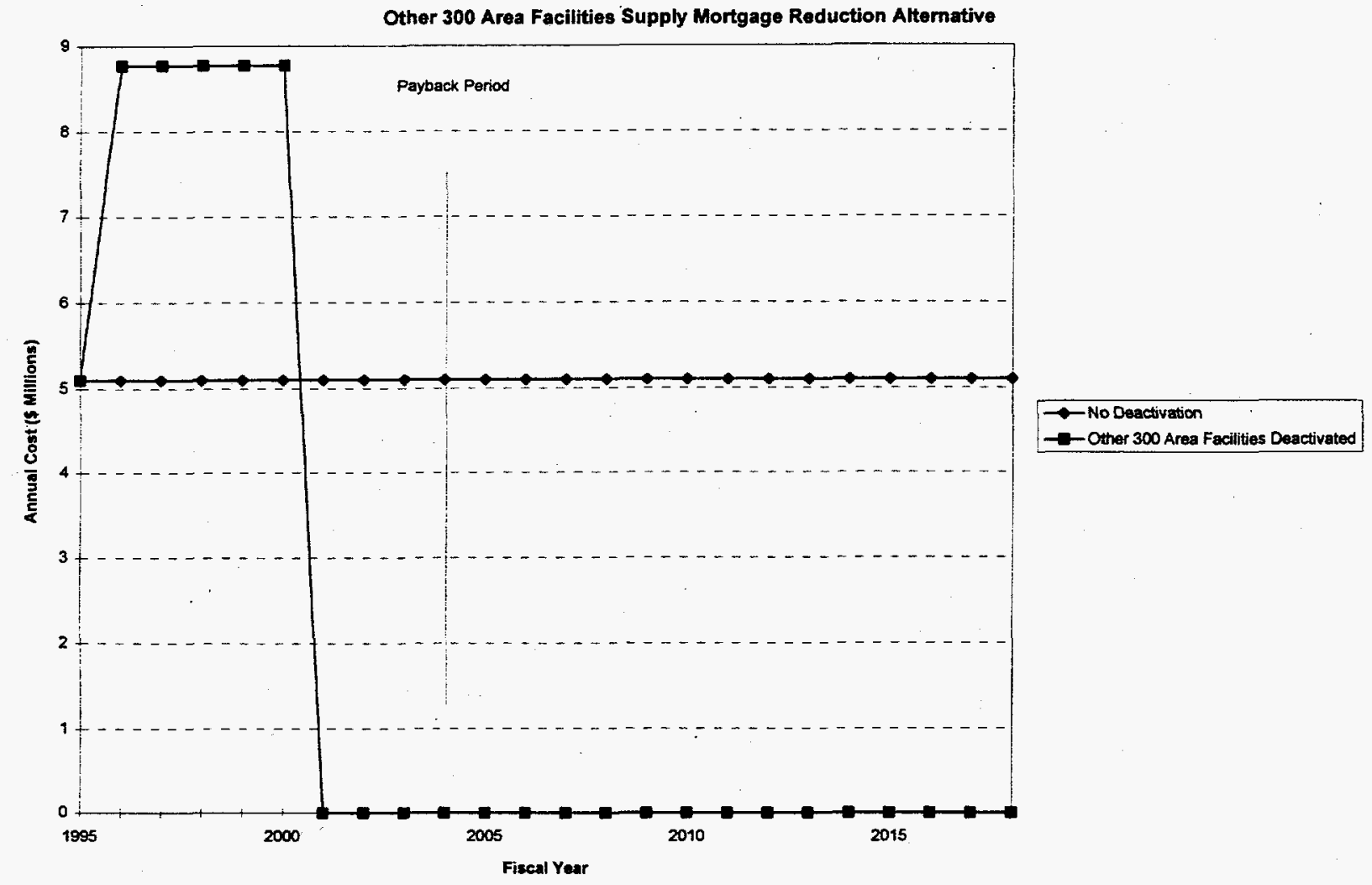

Figure H2.10. Other 300 Area Facilities Mortgage-Reduction Cost Profile

\section{H2.7.2 Cost Analysis of Major Facilities}

The mortgage reduction opportunities offered by the above facilities were analyzed from three perspectives: (1) total investment required, (2) payback period, and (3) benefit-to-cost ratio.

Table H2.1 shows how the facilities compared for the three measures. The table summarizes the information contained in the figures above and sorts the mortgage-reduction alternatives by the benefitto-cost ratio. As mentioned earlier, 2018 was used as the period over which the investment and savings would be analyzed. The year 2030 was also considered to see how the rankings would change with a longer savings period.

It is apparent that PUREX (with a benefit-to-cost ratio of about 60), B Plant, and other facilities that ranked high provide excellent savings for the investments. It is apparent, as well, that the Plutonium Finishing Plant and K Basins are poor investments from a mortgage-reduction perspective. There may be very good reasons for addressing the spent nuclear fuels problem in $\mathrm{K}$ Basins or the cleanout of Plutonium Finishing Plant, but mortgage reduction is not one of them. 
Table H2.1. Mortgage-Reduction Alternative Prioritized by Benefit-to-Cost Ratio

\begin{tabular}{||l|c|c|}
\hline \multicolumn{1}{|c|}{ Activity } & 2018 & 2030 \\
\hline PUREX & 60.3 & 94.8 \\
\hline N Reactor & 12.2 & 19.4 \\
\hline B Plant & 10.9 & 17.6 \\
\hline FFTF & 6.5 & 10.8 \\
\hline T Plant & 5.3 & 9.6 \\
\hline Other 300 Area facilities & 5.0 & 8.3 \\
\hline WESF & 3.1 & 6.5 \\
\hline 300 Area fuel supply & 1.4 & 2.4 \\
\hline PFP & 1.3 & 2.5 \\
\hline K Basins (accelerated Path Forward) & 1.2 & 2.3 \\
\hline TWRS safety upgrades & 1.0 & 1.7 \\
\hline K Basins (10/94 Path Forward) & 0.8 & 1.8 \\
\hline 100 Area support facilities & 0.3 & 0.6 \\
\hline TWRS disposal & 0 & 0 \\
\hline ER & 0 & 0 \\
\hline
\end{tabular}
ER = Environmental Restoration.
FFTF $\quad=$ Fast Flux Test Facility.
PUREX = Plutonium Uranium Finishing Plant.
TWRS = Tank Waste Remediation.
WESF $\quad=$ Waste Encapsulation and Storage Facility.

\section{H2.7.3 Tank Waste Operations as Mortgage Reduction}

Without Tank Waste Remediation System upgrades, characterization, and safety tank resolution, the operation and maintenance costs for Tank Waste Remediation System are 147 million dollars annually. With these activities, the operation and maintenance costs would be about 87 million dollars.

In some ways assuming level operation and maintenance costs without retrieval of the tank waste, however, is misleading. Most experts think without some form of disposal tank operations costs will increase dramatically as tanks fail and have to be replaced. Nevertheless tank upgrades, single-shell 
tank stabilization, characterization and associated activities are worthwhile mortgage-reduction activities. The benefit-to-cost ratio are 1.0 by 2018 and 1.7 by 2030 . Figure $\mathrm{H} 2: 11$ shows the cost profile.

\section{H2.8 Programmatic Risks}

Programmatic risks are not significant in the near-term. The costs for mortgage reduction of major facilities are easier to estimate than many other cleanup activities, mostly because the Site has many of these activities ongoing. The biggest programmatic risk and the largest cost uncertainty are in the Tank Waste Remediation System in-situ disposal. Tank Waste Remediation System costs have been extremely variable, depending upon who is doing the estimating and what the assumptions are. Confidence in the ten-billion-dollar estimate for in-situ disposal could be in error by as much as 50 percent. Environmental restoration of nine billion dollars costs in the outyears are also uncertain.

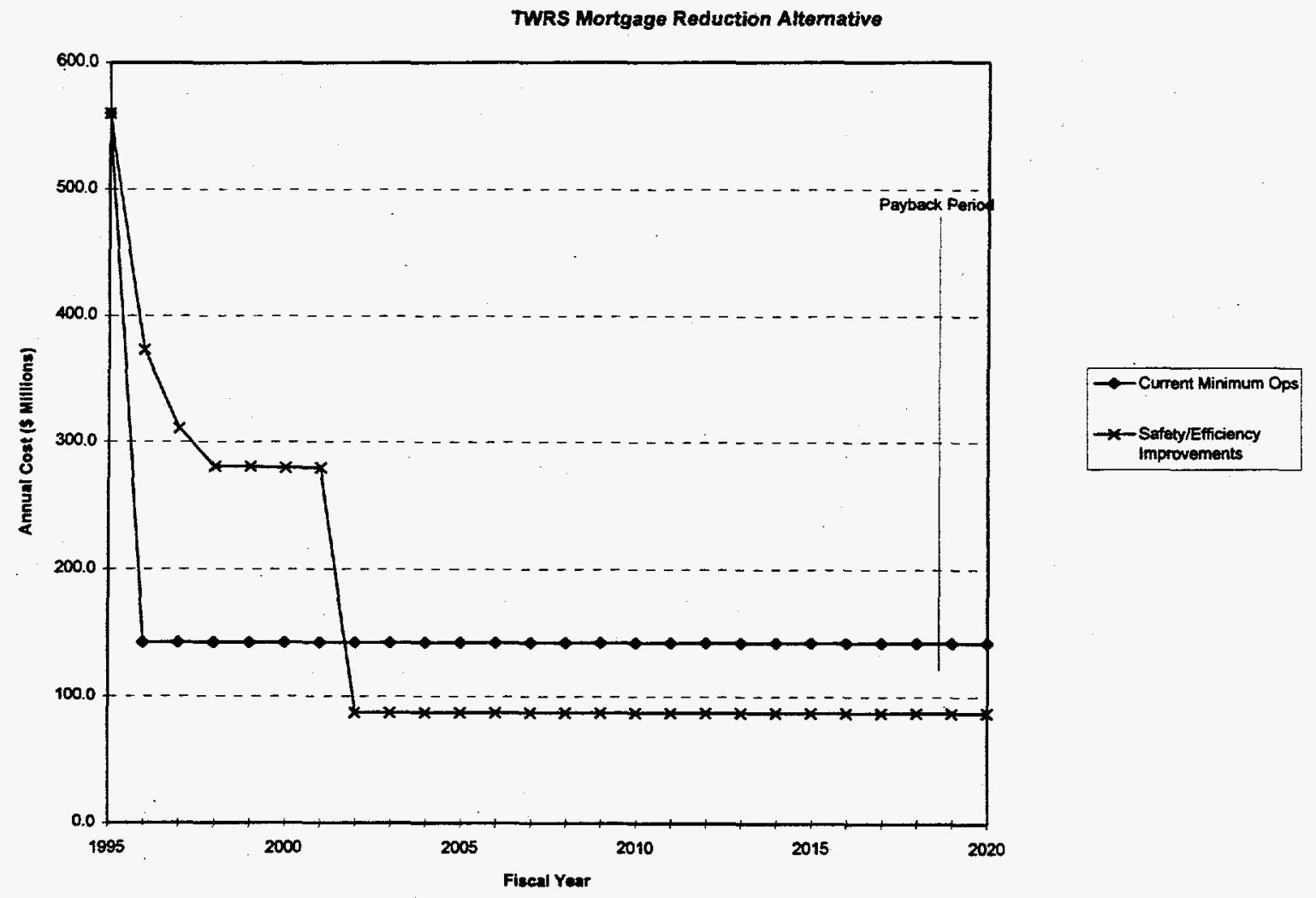

Figure H2.11. Tank Waste Remediation System Mortgage-Reduction Alternative 
Schedule variance for most major facilities should not be significant, if recent history with facilities such as $\mathrm{UO}_{3}$ is a good indicator. Tank Waste Remediation System and environmental restoration schedule variance may be another story. Also, storage of cesium and strontium capsules in the spent nuclear fuel dry storage is dependent upon that facility being available as planned, which is, in turn, dependent upon sustained funding.

The major technical uncertainty is, again, in-situ disposal tank waste. Transition of Plutonium Finishing Plant could produce some technical challenges (certainly greater than other facilities). There could be technical uncertainty with storing the capsules in a new dry storage, also.

\section{H2.9 Stakeholder Issues and Regulatory Impacts}

Stakeholders, especially regulators, will take issue with the concept of "minimum operations." They will not agree with any strategy that, up front, is not in compliance with all regulatory requirements, including the Tri-Party Agreement; however, they will support lower program costs and lower administrative costs.

This strategy does not invest in groundwater treatment, puts little emphasis on environmental restoration retrieval cleanup, and does not retrieve tank waste. It also does not support retrieval of post-1970 transuranic waste or reactors. Many stakeholders will oppose all of these elements of strategy.

Stakeholders will support spent nuclear fuel removal from K Basins, and early facility transition actions. Stakeholders should support having a definitive, consistent cleanup strategy that will fit within expected funding profiles.

The mortgage reduction strategy will have major impacts on the Tri-Party Agreement and environmental regulations. The Tri-Party Agreement will require major revision to proceed. Both statutory and regulatory changes will probably be necessary to allow in situ disposal of the tank wastes. See Appendix $J$ for further discussion of these impacts.

\section{H2.10 References}

Ecology, EPA, and DOE, 1994, Hanford Federal Facility Agreement and Consent Order, as amended, Washington State Department of Ecology, U.S. Environmental Protection Agency, and U.S. Department of Energy, Olympia, Washington.

Resource Conservation and Recovery Act of 1976, 42 USC 6901, et seq. 


\section{Attachment H3 - Land Use Evaluation}

\section{H3.1 General Description}

This Land Use Evaluation looks at cleaning up areas of land at the Hanford Site to make them available for use by others (Native Americans, public, and industry). Initial areas targeted for cleanup focus on land of high-value, desirability to others, and cost-effectiveness. In addition, this strategy would employ a progressive use policy, allowing increased durations in occupancy as land contamination is reduced by decay and natural processes.

\section{H3.1.1 Objective of Strategy}

The primary objective of this section is to evaluate the single-objective strategy of Land Use and its effect on cleanup at the Hanford Site. The evaluation focuses entirely on making land available for other non-DOE uses as quickly and cost-effectively as possible. This evaluation provides a better understanding of the implications and characteristics of such a strategy. This strategy does not agree entirely with December 16, 1994, DOE Richland Operations Office and contractor managers guidance to programs for development of the fiscal year 1997 Activity Data Sheets. In addition, it does not agree with recent budget actions which include budget cuts to environmental restoration activities and other cuts that conflict with some of the objectives of a land-use strategy.

Land use in the context of this strategy is interpreted as cleanup of well-defined areas of land at Hanford Site for the purpose of making it available for use by others (Native Americans, the public and industry). For example, cleanup of all Arid land Ecology Reserve was recently completed, making it available for other uses. This strategy goes one step further by focusing first on land that is highly valued by others and is cost-effective to cleanup; therefore, land adjacent to the Columbia River between the old reactor sites would be a prime area because it can be cleaned up cheaply, quickly, and offers the highest value for several uses, such as a Wild and Scenic designation. This strategy generally does not differentiate among activities in the 200 Area (e.g., retrieval of tank waste) that do not contribute to land release.

\section{H3.1.2 Decision Rules}

The land-based strategy defines areas to be cleaned up, cleanup requirements, and the sequence in which cleanup will occur in accordance with the following decision rules.

- Give priority to land that is highly valued to users other than DOE.

- Give priority to land that can be made available quickly and cheaply. Establish a set of attributes that minimizes both time and cost to cleanup.

- Employ a consistent set of criteria for cleanup of waste sites, hazards, and facilities across the Hanford Site. 


\section{H3.1.3 Summary description of the endstate and cleanup activities}

Endstate description and the sequence that areas are to be cleaned up are summarized as follows.

Table H3.1. Area Endstates

\begin{tabular}{|l|l||}
\hline \multicolumn{1}{|c|}{ Area } & \multicolumn{1}{c|}{ Endstate and Cleanup Actions } \\
\hline \hline $\begin{array}{l}\text { 600 Area, } \\
\text { Columbia River to } \\
\text { perimeter road }\end{array}$ & $\begin{array}{l}\text { All solid and liquid waste sites are remediated and waste materials are } \\
\text { moved to the 200 Area. }\end{array}$ \\
\hline $3000 / 1100$ Areas & $\begin{array}{l}\text { All structures decontaminated and decommissioned and all waste sites } \\
\text { remediated and waste materials moved to 200 Area. }\end{array}$ \\
\hline 600 Area Inland & $\begin{array}{l}\text { All solid and liquid waste sites remediated and waste materials moved to } \\
\text { the 200 Area. }\end{array}$ \\
\hline 300 Area & $\begin{array}{l}\text { The lab facilities are consolidated and their final decontamination and } \\
\text { decommissioning is deferred until their use is no longer required. The } \\
\text { remaining structures are decontaminated and decommissioned and cleaned } \\
\text { up. In general, solid and liquid waste sites will be capped in-place. }\end{array}$ \\
\hline 100 Area & $\begin{array}{l}\text { Reactors are entombed in-place, and all auxiliary buildings are } \\
\text { decontamination and decommissioned. In general, all solid and liquid } \\
\text { waste sites near the reactors are capped in place; all other sites are } \\
\text { remediated, and the waste material is moved to the 200 Area. }\end{array}$ \\
\hline 400 Area & $\begin{array}{l}\text { The reactor is entombed, and all other nuclear facilities are decontamination } \\
\text { and decommissioned. All hazard sources are cleaned up and waste } \\
\text { materials moved to the 200 Area. }\end{array}$ \\
\hline 200 Area & $\begin{array}{l}\text { Provides long term storage for all nuclear materials and is a permanent } \\
\text { waste disposal site. In general, all wastes and nuclear/chemical materials } \\
\text { will be move to the 200 Area for final disposal or storage pending final } \\
\text { disposition. Final endstate for liquid wastes, tanks, nuclear facilities, etc. } \\
\text { was not considered in this strategy because they do not contribute to release } \\
\text { of the land. }\end{array}$ \\
\hline
\end{tabular}

The groundwater endstate is uncertain in this strategy. Groundwater cleanup actions are deferred until all other cleanup activities are completed. 


\section{H3.2 Development of the Strategy}

The Land-Use strategy was developed by first defining the areas to be cleaned, then selecting decision rules that determine what is to be done and in what order, and then constructing a decision model to determine the level of work and sequence to be done.

\section{H3.2.1 Area Selections}

This strategy differs from other strategies in that its primary focus is on areas of land that can be made available for other uses rather than dealing with waste materials or facilities. As an initial assumption, all cleanup activities must be completed within a section of land before it can be made available. The areas selected, found in Table H3.2, provide distinct advantages in the land use strategy. Each area can be easily separated from the rest of the Hanford Site area.

Table H3.2. Area Locations

\begin{tabular}{|c|c|c|}
\hline Location & Area & Justification \\
\hline $\begin{array}{l}600 \text { Area, } 1 / 4 \text { mile long } \\
\text { Columbia River }\end{array}$ & 20 & $\begin{array}{l}\text { Provides a continuous strip of land along the Columbia } \\
\text { River. It also is the most valuable area of land, } \\
\text { currently selected as a candidate for Wild and Scenic } \\
\text { designation. }\end{array}$ \\
\hline $\begin{array}{l}600 \text { Area, } 1 / 4 \text { mile from } \\
\text { Columbia River to the } \\
\text { boundary road }\end{array}$ & $80-90$ & $\begin{array}{l}\text { This area provides inland access to the } 1 / 4 \text { mile } \\
\text { Columbia River stretch, without it access is only } \\
\text { available by river. In addition it provides an easier } \\
\text { means of controlling access to the rest of the Site. }\end{array}$ \\
\hline 600 Area, Inland & 140 & The remaining 600 Area. \\
\hline $3000 / 1100$ Areas & 1 & $\begin{array}{l}\text { Currently provides a well-defined area of land, with } \\
\text { cleanup requirements and endstate different than the } \\
\text { surrounding land. }\end{array}$ \\
\hline 100 Areas & 30 & $\begin{array}{l}\text { The reactor areas are nearly identical concerning } \\
\text { location to river, cleanup approach, and endstates. }\end{array}$ \\
\hline 300 Area & 1 & $\begin{array}{l}\text { Currently provides a well defined area of land, with } \\
\text { cleanup requirements and endstate different than the } \\
\text { surrounding land. }\end{array}$ \\
\hline 400 Area & 1 & $\begin{array}{l}\text { Currently provides a well defined area of land, with } \\
\text { cleanup requirements and endstate different from } \\
\text { surrounding land. }\end{array}$ \\
\hline 200 Area Plateau & 30 & $\begin{array}{l}\text { Currently provides a well defined area of land, with } \\
\text { cleanup requirements and endstate different from } \\
\text { surrounding land. }\end{array}$ \\
\hline
\end{tabular}


For example, a piece of land should be selected to provide easy access by users without restricting DOEs ability to control access to the remaining Site. In addition areas should be selected to aid in releasing the more valuable land early. The following decision rules were selected.

- Take advantage of existing boundaries whenever possible (e.g., 200, 300, 400 Areas).

- User access to an area should be considered. For example, identifying and releasing a small piece of land inside a nonreleased site is not desirable, since it may not be accessible.

- Separate areas when attributes change significantly. For example, $100 \mathrm{H}$ has very different characteristics than the surrounding 600 Area.

- Combine areas with similar attributes. The 100 Area, although separate, has very similar characteristics and should employ the same priority and cleanup strategy.

In general, the existing Site areas (e.g., 100, 200, 300) work very well in this strategy. The exception to this is the 600 Area. Due to a wide range of values and potential uses, it is appropriate to divide it into three pieces; however, in the end most all of the 600 Area is cleaned up first, primarily because it is extremely cheap and releases the largest amount of land.

\section{H3.2.2. Cleanup Scope and Prioritization}

The land-based strategy focuses on appropriate degrees of cleanup necessary to make land available quickly and cheaply. Essentially, this means that cleanup will be performed only when absolutely necessary or when it is cost-effective. The decision rules selected for determining cleanup in an area are as follows.

- Defer cleanup of groundwater in all areas. In general, areas can be made available while restricting groundwater use.

- Employ a progressive use concept to cleanup. This means cleaning to levels that allow limited land use in the beginning. For example, recreational land use assumes individuals are on the land for two weeks out of the year; therefore, their exposure duration to hazardous material(s) is limited to a maximum of two weeks.

- When possible, employ cost-effective cleanup options to accelerate land transfer. This includes options like cap-and-cover of waste sites and entombment of canyons and reactors.

Priority is the next issue to be addressed in which land areas will be cleaned and made available for non-DOE uses. Several attributes were selected that are important to this prioritization. They can be separated into two categories: values and time/cost. In each category, fundamental attributes were defined and a measurement for each selected (Table H3.3). Values include attributes that are considered important by the Native Americans, public, and industry. The values selected are as follows.

- Columbia River access - access to the river is high-value. 
- Distance from hazard - The further away land is from hazards in the 200 Area, the more valuable it is.

- Distance from population - The closer the land is to public access, the higher the value.

- Infrastructure availability - Existing infrastructures add value.

- Cultural/natural resources - Areas with cultural and/or natural resources add value.

- $\quad$ Aesthetics - Undisturbed views of the Columbia River and desert are of higher value.

The above list is not considered all inclusive, rather it focuses on significant, easily measured attributes that can be used to determine land value.

Once the method of measuring values was determined, the areas were evaluated and given a rating for each value (Table H3.4). Each set of attributes was given various weightings to evaluate the sensitivity of the different values on priority of cleanup by area, uses (recreational, industrial, and agricultural), cost, and combinations thereof. It is clear prioritization of cleanup by area is not significantly affected by various attribute weightings. In general, areas that were highly valued were also cheaper to cleanup. The one exception is the 300 Area. Cleanup priority for the 300 Area moves up if the "industrial" attributes are weighted higher. This is because the 300 Area infrastructure is ideally suited for industrial use.

Table H3.3. Attributes

\begin{tabular}{|c|c|c|c|}
\hline AttributelMagnitude & High & Medium & Low \\
\hline \multicolumn{4}{|l|}{ Values } \\
\hline River access & river - low bank & river - high bank & away from river \\
\hline Distance from hazard & $>5$ miles & 5 miles & adjacent \\
\hline Distance to population & $0-5$ miles & $5-10$ miles & $>10$ miles \\
\hline Infrastructure availability & $\begin{array}{l}\text { adjacent to current operational } \\
\text { facilities and Richland }\end{array}$ & $\begin{array}{l}\text { former operational facilities } \\
\text { with available resources }\end{array}$ & $\begin{array}{l}\text { no available } \\
\text { infrastructure nearby }\end{array}$ \\
\hline $\begin{array}{l}\text { Cultural/Natural } \\
\text { Resources } \\
\end{array}$ & $\begin{array}{l}\text { religious value } \\
\text { - endangered species }\end{array}$ & $\begin{array}{l}\text { fishing, hunting \& } \\
\text { gathering }\end{array}$ & $\begin{array}{l}\text { no significant } \\
\text { cultural aspects }\end{array}$ \\
\hline Aesthetics & $\begin{array}{l}\text { undisturbed views of } \\
\text { river, desert, and mtns }\end{array}$ & $\begin{array}{l}\text { - simulated nature } \\
\text { restored }\end{array}$ & $\begin{array}{l}\text { manmade } \\
\text { structures in view }\end{array}$ \\
\hline \multicolumn{4}{|l|}{ TIME AND COST } \\
\hline Cost per area & $<\$ 500 / a c$ & $\$ 500 / a c$ & $>>\$ 500 / / a c$ \\
\hline \multicolumn{4}{|l|}{ Total cost } \\
\hline Area available per time & $>>5 \mathrm{sqmi} / \mathrm{yr}$ & $\sim 5$ sqmi/yr & $<<5$ sqmi/yr \\
\hline Cost profile & level & gradual change & sharp peaks \\
\hline Complexity of cleanup & $\begin{array}{l}\text { Difficult cleanup, technology } \\
\text { not available }\end{array}$ & $\begin{array}{l}\text { Moderately difficult cleanup, } \\
\text { complex technology required }\end{array}$ & $\begin{array}{l}\text { Easy cleanup, low- } \\
\text { tech activity }\end{array}$ \\
\hline
\end{tabular}


Table H3.4. Value Ratings

\begin{tabular}{|c|c|c|c|c|c|c|c|c|c|c|c|}
\hline & NS & ALE & 1100 & 3000 & 300 & 400 & 200 & $600 \mathrm{R}$ & $600 \mathrm{Rd}$ & 6001 & 100 \\
\hline \multicolumn{12}{|l|}{ VALUE } \\
\hline River Access & $\mathrm{H}$ & L & $\mathbf{L}$ & $\mathbf{H}$ & $\mathbf{H}$ & L & $L$ & $\mathbf{H}$ & $\mathrm{L}$ & $\mathbf{L}$ & H \\
\hline Distance from River & $\mathbf{H}$ & $\mathrm{H}$ & $\mathbf{M}$ & $\mathbf{M}$ & L & L & L & $\mathbf{M}$ & $\mathbf{M}$ & M & $\mathrm{L}$ \\
\hline Distance to Population & L & L & H & H & H & $\mathbf{M}$ & L & L & $\mathrm{L}$ & L & L. \\
\hline Infrastructure & L & L & $\mathrm{H}$ & $\mathrm{H}$ & H & H & $\mathbf{H}$ & L & L & L & $\mathbf{M}$ \\
\hline Cultural/Natural resources & $\mathbf{H}$ & H & 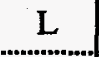 & L & L & L & L & H & $\mathbf{M}$ & $\mathbf{M}$ & H \\
\hline Aesthetics & $\mathrm{H}$ & H & $\mathrm{L}$ & $\mathrm{L}$ & $\mathrm{L}$ & $\mathrm{L}$ & $\mathrm{L}$ & $\mathbf{M}$ & $\mathbf{M}$ & $\mathbf{M}$ & $\mathbf{L}$ \\
\hline \multicolumn{12}{|l|}{ COST AND TIME } \\
\hline Cost per Acre & $\mathrm{H}$ & H & M & L & $\mathrm{L}$ & L & L & H & $\mathrm{H}$ & $\mathbf{H}$ & L \\
\hline Total Cost & $\mathrm{H}$ & H & L & L & L & $L$ & $\mathrm{~L}$ & H & $\mathbf{H}$ & $\mathbf{H}$ & $\mathrm{L}$ \\
\hline Time to Cleanup & $\mathrm{H}$ & H & $L$ & L & L & L & $\mathrm{L}$ & $\mathrm{H}$ & $\mathbf{H}$ & $\mathrm{H}$ & L \\
\hline Technical Complexity & $\mathrm{H}$ & $\mathrm{H}$ & H & $\mathbf{H}$ & $\mathbf{M}$ & $\mathrm{H}$ & L & $\mathbf{H}$ & H & $\mathbf{H}$ & $\mathrm{H}$ \\
\hline
\end{tabular}

Table H3.5. Prioritization Ranking Summary

\begin{tabular}{||l|c|c|c|c|c|c|c|c|c|c|c||}
\hline & NS & ALE & 1100 & 3000 & 300 & 400 & 200 & $600 \mathrm{R}$ & $600 \mathrm{Rd}$ & $600 \mathrm{I}$ & 100 \\
\hline Recommended priority & - & - & - & 4 & 5 & 7 & 8 & 1 & 2 & 3 & 6 \\
\hline $\begin{array}{l}\text { 10,5,1 weighting (High - 10 points, } \\
\text { medium - 5 points, low - 1 point) }\end{array}$ & 1 & 2 & 8 & 7 & 4 & 10 & 11 & 3 & 4 & 4 & 9 \\
\hline $\begin{array}{l}4,2,1 \text { weighting (High - 4 points, } \\
\text { medium - 2 points, low - 1 point) }\end{array}$ & 1 & 2 & 7 & 6 & 8 & 10 & 11 & 3 & 4 & 4 & 8 \\
\hline $\begin{array}{l}3,2,1 \text { weighting (High 3 points, } \\
\text { medium - 2 points, low - 1 point) }\end{array}$ & 3 & 1 & 7 & 6 & 8 & 10 & 11 & 1 & 4 & 4 & 8 \\
\hline Even weighting of each attribute & 1 & 2 & 7 & 4 & 8 & 10 & 11 & 3 & 5 & 5 & 9 \\
\hline Recreational weighting & 1 & 3 & 9 & 6 & 8 & 10 & 11 & 2 & 4 & 4 & 7 \\
\hline Agricultural weighting & 1 & 2 & 7 & 6 & 8 & 10 & 11 & 3 & 4 & 4 & 8 \\
\hline Industrial weighting & 1 & 3 & 7 & 6 & 8 & 10 & 11 & 2 & 4 & 4 & 9 \\
\hline Value/Industrial weighted & 1 & 2 & 8 & 4 & 5 & 10 & 11 & 3 & 6 & 6 & 9 \\
\hline Value/Recreational weighted & 1 & 3 & 9 & 6 & 7 & 10 & 11 & 2 & 4 & 4 & 8 \\
\hline Cost weighted & 1 & 2 & 6 & 6 & 8 & 10 & 11 & 3 & 4 & 4 & 8 \\
\hline Area weighted & 1 & 2 & 7 & 6 & 10 & 9 & 11 & 3 & 4 & 4 & 8 \\
\hline
\end{tabular}




\section{H3.3 Results of the Cleanup}

The Land-Based Strategy accomplishes its goal to make available large areas of the Hanford Site most desirable land in a relatively short period of time; however, it is uncertain whether it achieves the same endstate as the Existing Baseline Strategy. Major outcomes of this strategy include many capped waste sites outside the 200 Areas, deferred action on the groundwater, and entombed reactors. In general, retrieved wastes and nuclear materials are transported to the 200 Area for storage and/or disposal, where many final disposal decisions and actions are deferred because they do not contribute to land release.

\section{H3.3.1 Geographic Area}

The final cleanup sequence and work scope are summarized as follows.

- 600 Area, $1 / 4$ strip along Columbia River. Remove all wastes and contaminated soils. Deactivation of the $\mathrm{N}$ and $\mathrm{K}$ Basins must be completed prior to making this land available. This is necessary due to the highly mobile nature of the inventories and the possibility that a release would require reclaiming the land downstream. Defer groundwater cleanup indefinitely.

- 600 Area, $1 / 4$ mile from Columbia River to the perimeter boundary road. Remove all wastes and contaminated soils. This should be done in conjunction with the $1 / 4$ mile strip, providing a easily controlled section of land and allowing easy access from the inland side. Defer groundwater cleanup indefinitely.

- 3000 Area. Complete decontamination and decommissioning and remove all wastes and contaminated soils. Defer groundwater cleanup indefinitely.

- 600 Area Inland. Remove all wastes and contaminated soils. In addition, use of this area by the public will require additional controls at the 100,200,300, and 400 Areas in the form of additional hardware, administrative controls, and buffer zones. This is necessary to control hazards as the receptor distance decreases; that is, encroachment of the public. Defer groundwater cleanup indefinitely.

- 300 Area. Consolidate the lab facilities and defer decontamination and decommissioning until their use is no longer required, decontamination and decommissioning the excess structures and complete cleanup. In general, most solid and liquid waste sites will be capped in-place. Defer groundwater cleanup indefinitely.

- 100 Areas. Entomb the reactors and decontamination and decommissioning all auxiliary buildings. Cap all solid and liquid waste sites near the reactors and remediate all other sites and move waste materials to the 200 Area. Defer groundwater cleanup indefinitely:

- 400 Area. Entomb the reactor and decontamination and decommission all other nuclear facilities. Make available nonnuclear facilities for other uses and cleanup all other sources. Defer groundwater cleanup indefinitely. 
- 200 Area Plateau. Use for long-term storage of nuclear materials and as a permanent waste disposal site. In general, all wastes and nuclear/chemical materials will be move to the 200 Area for final disposal or disposition. Final 200 Area cleanup is not addressed in this strategy. Defer groundwater cleanup indefinitely.

\section{H3.3.2 Cleanup Description by Hazard Sources}

Nuclear Materials - All nuclear materials are stored indefinitely in the 200 Area until final disposition is determined.

Liquid Waste - In general, treatment and disposal of liquid waste is deferred until last. Final endstate was not determined because it does not in itself make land available.

Solid Waste - Solid wastes are capped in place in the 300 and 100 Areas and all other sites are remediated and the waste material is moved to the 200 Area for storage pending final disposition. No action is defined for the 200 Area solid wastes.

Environmental Contamination - Liquid waste sites in the 600 Area are remediated and soils moved to the 200 Area. Sites in the 100 and 300 Areas are capped in-place. Groundwater cleanup is deferred until last. Cleanup of 200 Area contamination is deferred until last; no final action is defined.

Facilities - Reactors are entombed, and, in general, all other structures outside the 200 Area are demolished and waste materials moved to the 200 Area for final disposal or storage. Disposition of 200 Area facilities is deferred until last; no final action is defined.

\section{H3.3.3 Environmental, Safety, and Health Risks}

This strategy in general assumes all risks on-site are managed to minimum safe levels. All discretionary funds are used on cleanup solely for the purpose of making land available; however, even a single-objective land use alternative can not totally ignore risks. Indeed, ensuring the health and safety of the public, worker, and environment requires some action to control the hazard as land around it is made available to the public for various uses. The 200 Area, where the majority of the hazardous materials will be consolidated, will impact the management of these materials as the LandBased Strategy is implemented. As the public encroaches on the 200 Area this may require additional safety systems, administrative controls, and buffer zones to ensure adequate levels of safety.

\section{H3.3.4 Future Land Use Implications}

This strategy maximizes future land use to the greatest degree possible. It does so, however, with some key implications. The most significant is restricted use of the groundwater. In order to make land available quickly and cheaply, remediation of contaminated plumes in the groundwater must be deferred or canceled altogether. This means that any land made available for other uses will be restricted to surface use only. In addition, this strategy employs a progressive-use policy. This means that land will initially be available for limited uses, (e.g., recreation). The idea is to limit the duration of time that an individual spends in the released zone, ensuring that the individuals exposure to hazardous materials does not exceed allowable limits. Another implication is that capped sites in 
the 300 and 100 Areas will require long-term restricted access. This also applies to the entombed reactors. And finally, the 200 Area, slated to as the collection area for the majority of Site wastes and nuclear materials, will require significant change in controls (i.e., safety class hardware, administrative controls, and buffer zones).

\section{H3.3.5 Period of the Cleanup}

It is assumed that the land-use strategy will be initiated in fiscal year 1996. The span of time during which land is made available is between 75 and 100 years. Approximately 260 square miles (Arid Land Ecology and North Slope) are cleaned up and available for other beneficial, non-DOE uses. By the end of 2001 an additional 230 square miles will be available $(600,1100$, and 3000 Areas). The rate of land made available slows significantly after 2001 with only 30 square miles added by $2018(100,300$ and 400 Areas). This rate of release is demonstrated in Figure H3.1. By 2095 cleanup and capping of the 200 Area should be complete and the land made available for other uses. The contaminated groundwater plumes that cover approximately 200 square miles of the Site will remain restricted. Restrictions will be lifted as decay and natural processes reduce the concentration of radionuclides and contaminants. The range of available land uses will increase over the span of cleanup and through the period of institutional control after management activities are concluded.

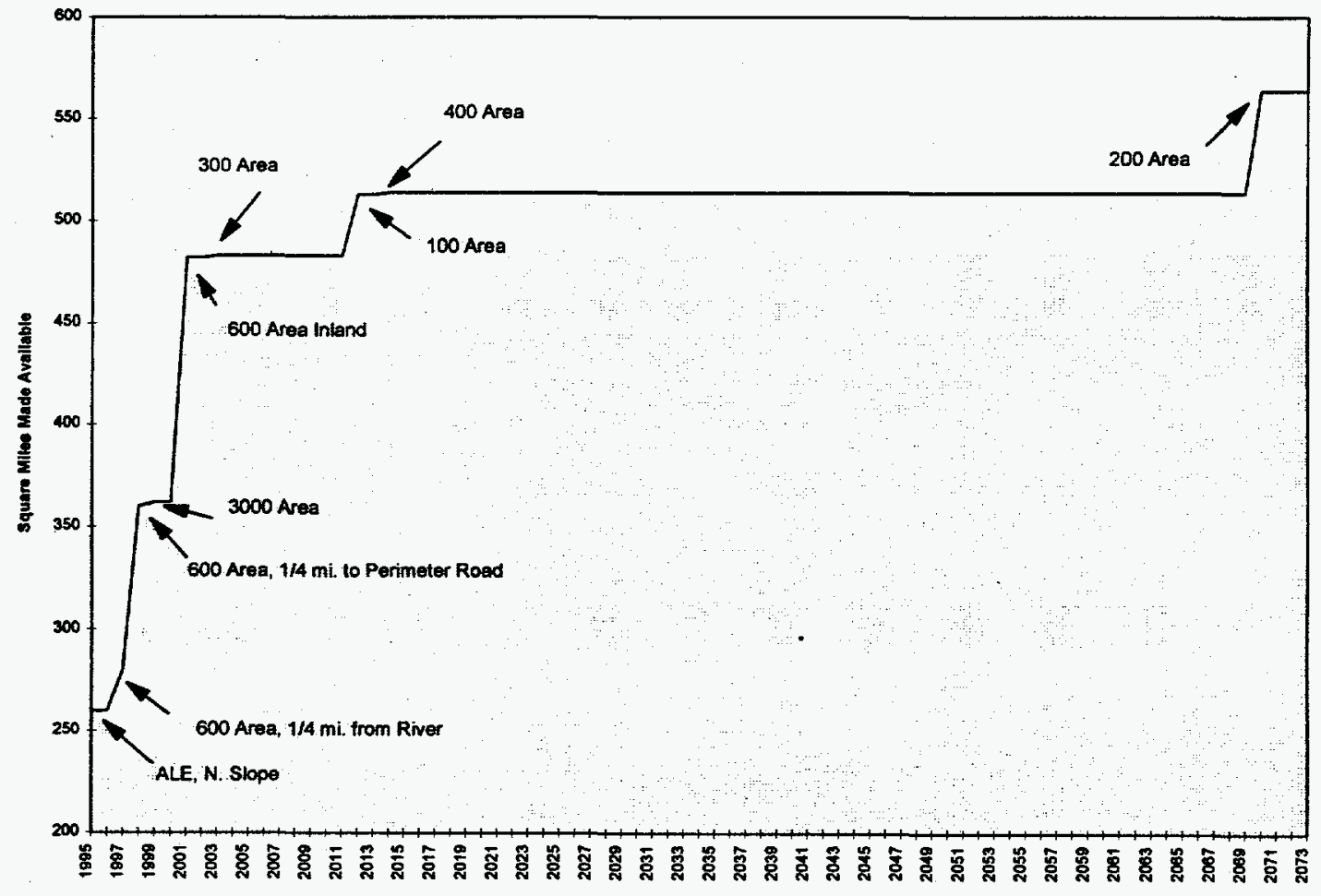

Figure H3.1. Land Release Curve 


\section{H3.3.6 Costs}

The total cost of making the entire 560 square miles available is dependent on the disposal/ disposition of the wastes and nuclear materials consolidated in the 200 Area that are assumed to be a permanent waste disposal site. The cost to execute the single-objective strategy is approximately 65 billion dollars.

Another meaningful evaluation is the cost of cleanup per acre of land. It is important to note that there is a significant difference in cost to clean some areas land versus others. The cost per acre of land cleaned is substantially less (by at least several orders of magnitude) for the 600 , and 3000 Areas than for the 100, 200, 300 and 400 Areas. Figure H3.3 shows the cost per square mile of cleaning up various parts of Hanford Site Land

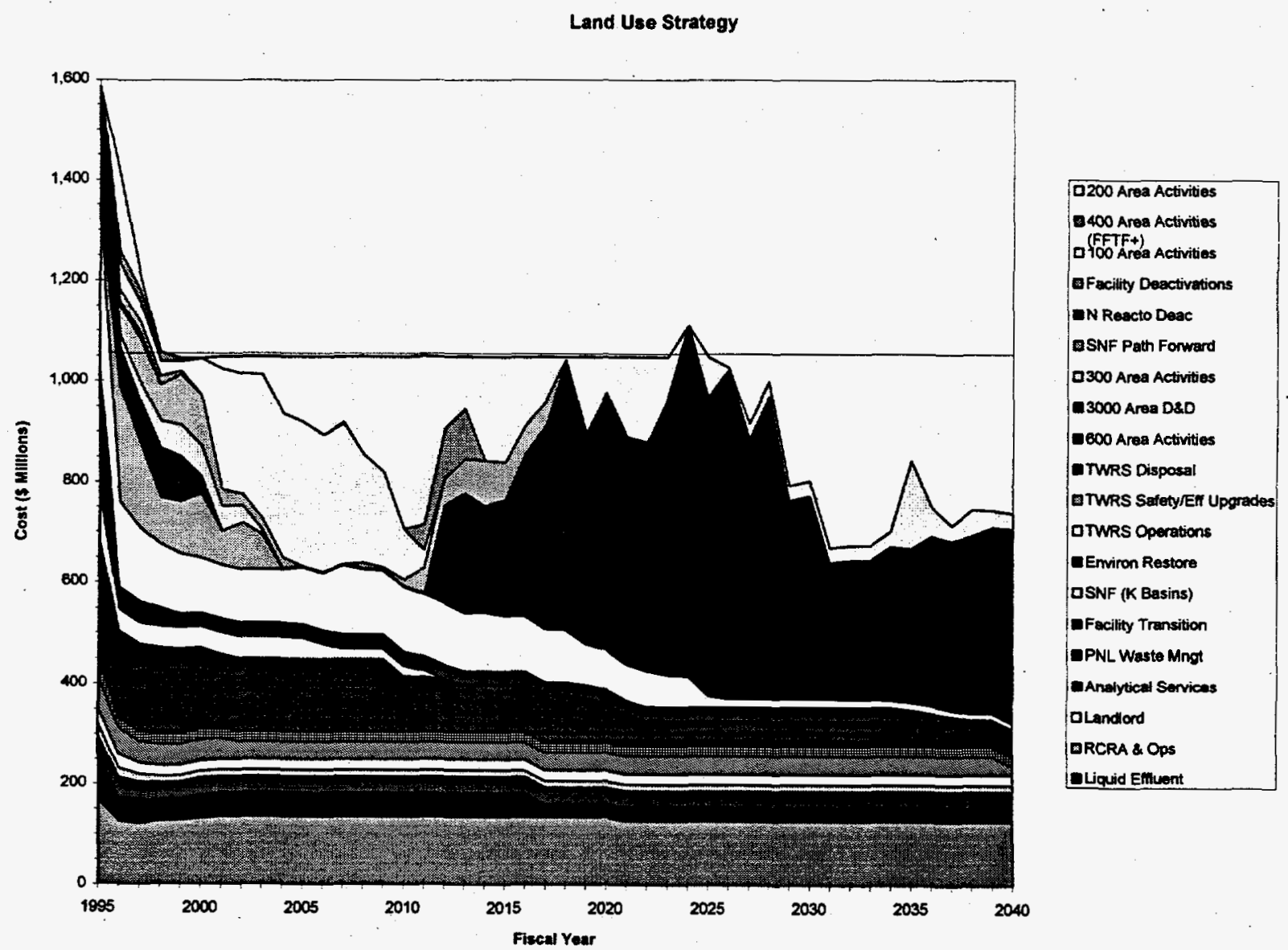

Figure H3.2. Land Use Cost Profile 


\section{H3.3.7 Programmatic Risks}

There is a potential two to three year delay in implementation of this strategy. Moving from the current cleanup framework to a land use strategy will require changes in land use planning, National Environmental Policy Act of 1969, Comprehensive Environmental, Response, Compensation, and Liability Act of 1980, and Resource Conservation and Recovery Act of 1976. In addition, there will be increases in cost to the minimum safe operating costs in the 200 Area to manage the deteriorating facilities in a safe operating condition.

\section{H3.3.8 Stakeholder Issues}

In general, by maximizing cleanup and transfer of land, the Land-Based Strategy satisfies many stakeholder issues; however, the strategy raises some issues that must be resolved.

- This strategy will employ near-surface disposal of long-lived radionuclides on the Hanford Site that is considered unacceptable by many stakeholders.

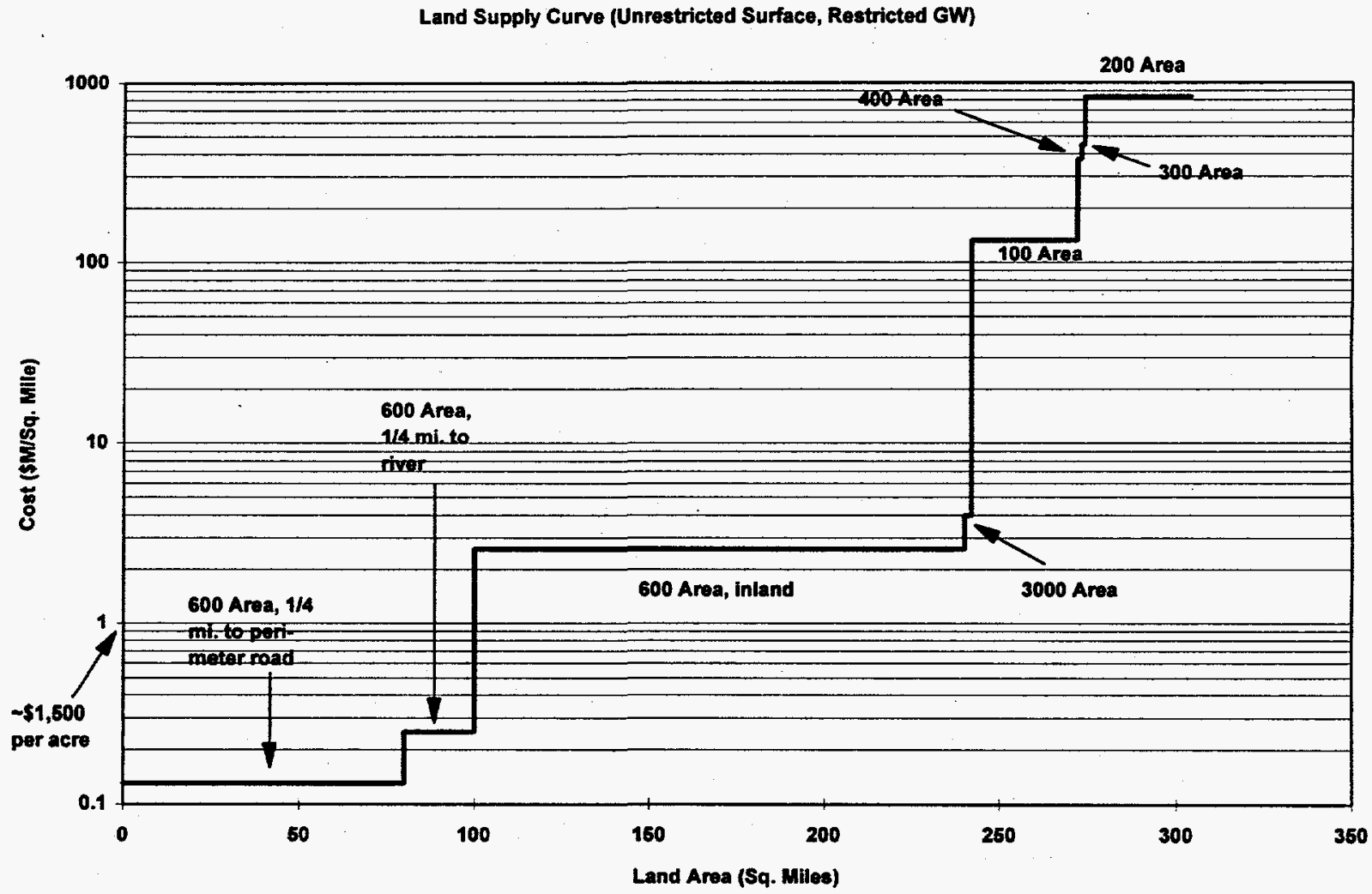

Figure H3.3. Land Supply Curve 
- It will restrict groundwater consumption indefinitely.

- This strategy protects the groundwater from additional insults of contamination; however, the Columbia River is not protected from migration of contaminated groundwater plumes.

- It perpetuates the time frame during which the 200 Area plateau is used for long-term storage and disposal. This will, in turn, require a significant buffer zone around the area to provide adequate distance from the public.

- This strategy will employ in-situ disposal of the 100 Area reactors and adjacent waste sites.

Implementation of the Land Use Strategy creates many open issues in the regulatory arena. Some of these are as follows.

- Hanford Federal Facility Agreement and Consent Order (Ecology et al. 1994), RCRA, CERCLA - Current regulations require cleanup of all waste sites concurrently. The land use strategy would focus cleanup on a specific area until completed. In addition, the regulations presumably do not allow postponement of groundwater treatment in lieu of other cleanup activities.

- $\quad$ Nuclear Waste Policy Act of 1982 - This strategy will delay shipment of high-level wastes and transuranic wastes to Waste Insolation Pilot Plant and Nevada.

- CERCLA Natural Resources Damage Assessment - Migration of groundwater issue requires further examination.

- Land Use Planning - This strategy establishes levels of cleanup that, in turn, determine land uses. This is contrary to land use planning, which traditionally defines land use, which in turn defines levels of cleanup.

- Treaty of 1855 - Future restrictions to land use may conflict with Native American Treaty rights.

\section{H3.4 References}

Comprehensive Environmental, Response, Compensation, and Liability Act of 1980,42 USC 9601, et seq.

Ecology, EPA, and DOE, 1994, Hanford Federal Facility Agreement and Consent Order, as amended, Washington State Department of Ecology, U.S. Environmental Protection Agency, and U.S. Department of Energy, Olympia, Washington.

National Environmental Policy Act of 1969, 42 USC 4321, et seq. 
Nuclear Waste Policy Act of 1982, 42 USC 10101.

Resource Conservation and Recovery Act of 1976, 42 USC 6901, et seq.

Treaty of 1855, Treaty with the Yakama, 12 Stat 951; Treaty with the Walla Walla, Cayuse, and Umatilla, 12 Stat 945; Treaty with the Nez Perce, 12 Stat 957. 


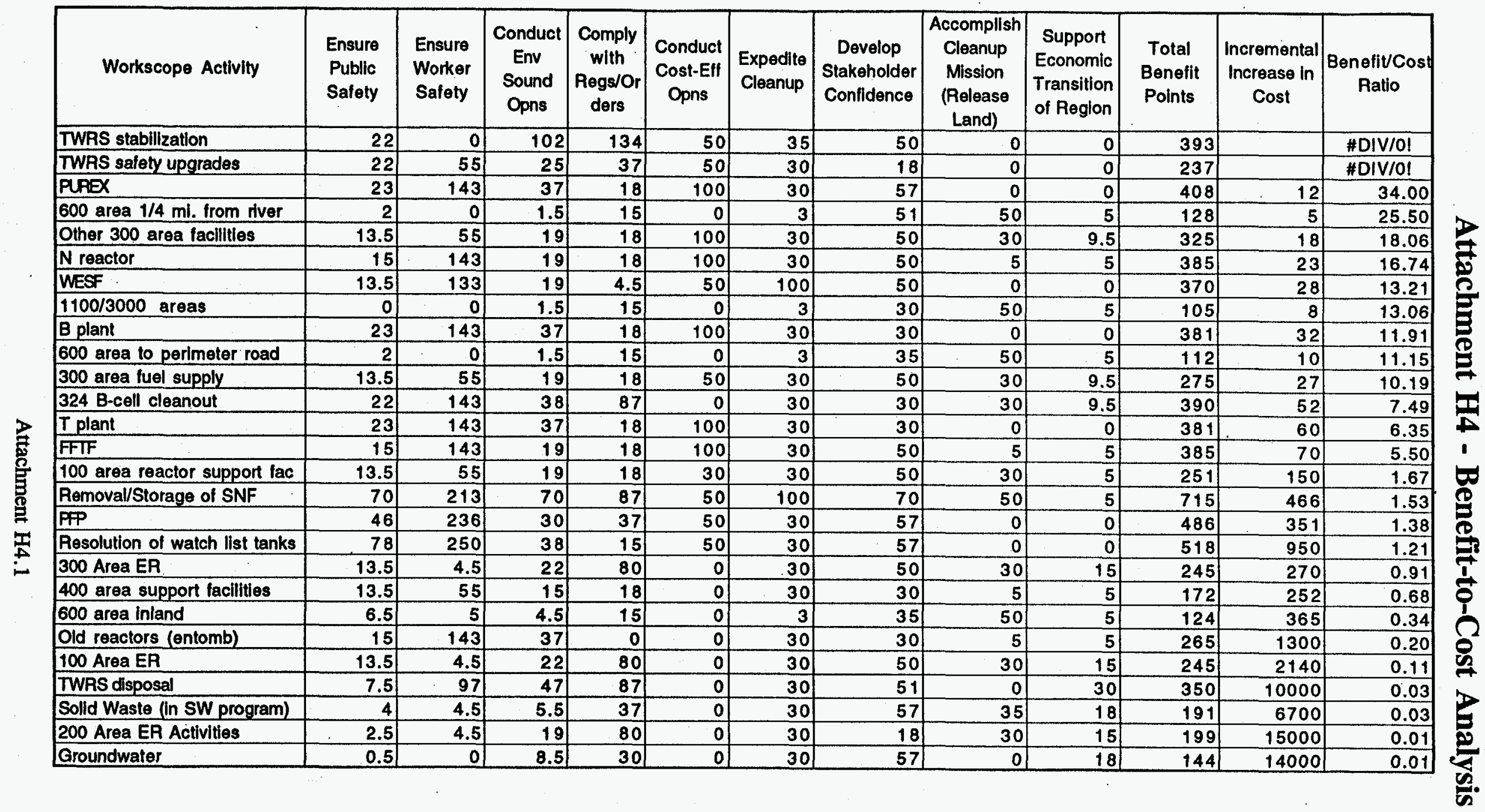


Altemative \#4

Benefit Points by Activity

\begin{tabular}{|c|c|c|c|c|c|c|c|c|c|c|c|c|}
\hline Workscope Actlvity & $\begin{array}{l}\text { Ensure } \\
\text { Public } \\
\text { Safety }\end{array}$ & $\begin{array}{l}\text { Ensure } \\
\text { Worker } \\
\text { Safety }\end{array}$ & $\begin{array}{l}\text { Conduct } \\
\text { Env } \\
\text { Sound } \\
\text { Opns }\end{array}$ & $\begin{array}{c}\text { Comply } \\
\text { with } \\
\text { Regs/Or } \\
\text { ders }\end{array}$ & $\begin{array}{c}\text { Conduct } \\
\text { Cost-EIf } \\
\text { Opns }\end{array}$ & $\begin{array}{l}\text { Expedite } \\
\text { Cleanup }\end{array}$ & $\begin{array}{c}\text { Develop } \\
\text { Stakeholder } \\
\text { Confidence }\end{array}$ & \begin{tabular}{|c|} 
Accomplish \\
Cleanup \\
Mission \\
(Release \\
Land) \\
\end{tabular} & $\begin{array}{c}\text { Support } \\
\text { Economic } \\
\text { Transition } \\
\text { of Region }\end{array}$ & $\begin{array}{l}\text { Total } \\
\text { Benefit } \\
\text { Points }\end{array}$ & $\begin{array}{c}\text { Incremental } \\
\text { Increase in } \\
\text { Cost }\end{array}$ & $\begin{array}{c}\text { Benefit/Cost } \\
\text { Ratio }\end{array}$ \\
\hline TWRS stabilization & 22 & 0 & 102 & 134 & 50 & 35 & 50 & 0 & 0 & 393 & & \#DIV/O! \\
\hline TWRS salety upgrades & 22 & 55 & 25 & 37 & 50 & 30 & 18 & 0 & 0 & 237 & & \#DIV/OI \\
\hline 200 Area EA Activities & 2.5 & 4.5 & 19 & 80 & 0 & 30 & 18 & 0 & 0 & 154 & & \#DIV/OI \\
\hline Groundwater & 0.5 & 0 & 8.5 & 30 & 0 & 30 & 57 & 0 & 18 & 144 & & \#DIV/O! \\
\hline Solld Waste (in SW program) & 4 & 4.5 & 5.5 & 37 & 0 & 30 & 35 & 0 & 0 & 116 & & \#DIV/OI \\
\hline PUREX & 23 & 143 & 37 & 18 & 100 & 30 & 57 & 0 & 0 & 408 & 12 & 34.00 \\
\hline 600 area $1 / 4 \mathrm{ml}$. from river & 2 & 0 & 1.5 & 15 & 0 & 3 & 51 & 50 & 5 & 128 & 5 & 25.50 \\
\hline Other 300 area facilities & 13.5 & 55 & 19 & 18 & 100 & 30 & 50 & 30 & 9.5 & 325 & 18 & 18.06 \\
\hline N reactor & 15 & 143 & 19 & 18 & 100 & 30 & 50 & 5 & 5 & 385 & 23 & 16.74 \\
\hline WESF & 13.5 & 133 & 19 & 4.5 & 50 & 100 & 50 & 0 & 0 & 370 & 28 & 13.21 \\
\hline $1100 / 3000$ areas & 0 & 0 & 1.5 & 15 & 0 & 3 & 30 & 50 & 5 & 105 & 8 & 13.06 \\
\hline B plant & 23 & 143 & 37 & 18 & 100 & 30 & 30 & 0 & 0 & 381 & 32 & 11.91 \\
\hline 600 area to perimeter road & 2 & 0 & 1.5 & 15 & 0 & 3 & 35 & 50 & 5 & 112 & 10 & 11.15 \\
\hline 300 area fuel supply & 13.5 & 55 & 19 & 18 & 50 & 30 & 50 & 30 & 9.5 & 275 & 27 & 10.19 \\
\hline 324 B-cell cleanout & 22 & 143 & 38 & 87 & 0 & 30 & 30 & 30 & 9.5 & 390 & 52 & 7.49 \\
\hline T plant & 23 & 143 & 37 & 18 & 100 & 30 & 30 & 0 & 0 & 381 & 60 & 6.35 \\
\hline FFIF & 15 & 143 & 19 & 18 & 100 & 30 & 50 & 5 & 5 & 385 & 70 & 5.50 \\
\hline 100 area reactor support fac & 13.5 & 55 & 19 & 18 & 30 & 30 & 50 & 30 & 5 & 251 & 150 & 1.67 \\
\hline Removal/Storage of SNF & 70 & 213 & 70 & 87 & 50 & 100 & 70 & 50 & 5 & 715 & 466 & 1.53 \\
\hline PFP & 46 & 236 & 30 & 37 & 50 & 30 & 57 & 0 & 0 & 486 & 351 & 1.38 \\
\hline Resolution of watch list tanks & 78 & 250 & 38 & 15 & 50 & 30 & 57 & 0 & 0 & 518 & 950 & 1.21 \\
\hline 300 Area EA & 13.5 & 4.5 & 22 & 80 & 0 & 30 & 50 & 30 & 0 & 230 & 270 & 0.85 \\
\hline 400 area support facilities & 13.5 & 55 & 15 & 18 & 0 & 30 & 30 & 5 & 5 & 172 & 252 & 0.68 \\
\hline 600 area Inland & 6.5 & 5 & 4.5 & 15 & 0 & 3 & 35 & 50 & 5 & 124 & 365 & 0.34 \\
\hline Old reactors (entomb) & 15 & 143 & 37 & 0 & 30 & 0 & 0 & 5 & 5 & 235 & 820 & 0.29 \\
\hline 100 Area ER & 13.5 & 4.5 & 22 & 80 & 0 & 30 & 50 & 30 & 0 & 230 & 2140 & 0.11 \\
\hline TWRS disposal & 7.5 & 97 & 47 & 87 & 0 & 36 & 51 & 0 & 0 & 326 & 5252 & 0.06 \\
\hline
\end{tabular}


Appendix I

Comparison of Alternatives 
○

-

0 


\section{Contents}

\section{Appendix I - Comparison of Alternatives}

I.1 Minimize Environmental, Safety, and Health Risks . . . . . . . . I.1

I.2 Maximize Landuse Potential $\ldots \ldots \ldots \ldots \ldots \ldots \ldots \ldots$ I.2

I.3 Maximize Progress $\ldots \ldots \ldots \ldots \ldots \ldots \ldots \ldots \ldots \ldots$

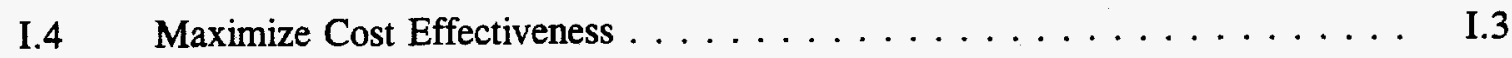

I.5 Maximize Likelihood of Success $\ldots \ldots \ldots \ldots \ldots \ldots$

I.6 Maximize Stakeholder Confidence $\ldots \ldots \ldots \ldots \ldots \ldots \ldots \ldots$

I.7 Summary Comparison of Alternatives $\ldots \ldots \ldots \ldots \ldots \ldots$

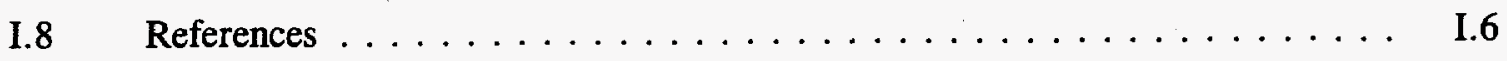

Attachment I - Comparison of Alternative Strategies $\ldots \ldots \ldots \ldots \ldots \ldots \ldots$ 


\section{Appendix I}

\section{Comparison of Alternatives}

In this Appendix, alternatives are compared against strategy objectives and criteria. Since the Existing Baseline Strategy is not executable within the anticipated funding profile, it is used only for reference. The Existing Baseline Strategy is not considered a viable strategy since it does not meet the fiscal constraint of 1.05 billion dollars.

Data used to compare alternatives are of several types. In some cases, especially regarding risk estimates, information from the Final Environmental Impact Statement (EIS) Disposal of Hanford Defense High-Level Transuranic and Tank Wastes (DOE 1987) is used to compare alternatives. This is appropriate in those cases where in-situ disposal of solid or tank waste is part of a strategy. Other hard data, (e.g., costs and schedule) are derived from the analysis.

Some data are simply discussions of how the alternatives differ and reflect subjective evaluations (e.g., technical complexity), and some data are simply yes or no. Attachment I1 contains a summary of the criteria, metrics, and information associated with the four strategies. The four strategies are as follows:

Alternative I: Existing Baseline Strategy

Alternative II: Baseline Extended Strategy

Alternative III: Risk Strategy

Alternative IV: Composite Strategy

Each section below compares the alternatives across the six objectives described in Appendix B, as indicated.

\section{I.1 Minimize Environmental, Safety, and Health Risks}

Public health effects are generally the same for all alternatives. These risks are generally associated with low-probability; high-consequence events (e.g., major releases of radioactivity to off-site receptors). The overall probability of increased pubic cancer deaths is extremely unlikely in all cases, and the radiological exposure to the maximum exposed individual is the same for all alternatives. The likelihood of a near-term release is extremely unlikely for all alternatives, although it is increased somewhat for alternatives that take longer. No estimate was made as to the increase in likelihood due to a longer schedule because, overall, public risk is not a discriminator across alternatives.

There is a significant difference across alternatives for worker risks. This difference is associated with choices of retrieval or in-place disposal of solid and tank wastes. Thus, the Baseline Extended and the Existing Baseline Strategies are the same, as are the Risk and Composite Strategies. The amount of lost work days and worker deaths are not large in magnitude; however, depending upon a 
given perspective, they could be given importance beyond the actual numbers. For example, 880 lost work days is about four years, which is certainly less than a million dollars, even including medical costs. Nevertheless, managers may consider $\mathbf{8 8 0}$ lost workdays to reflect a large amount of injuries to the workforce. Similarly, eight statistical worker lives may be only worth 40 million dollars or so (five million dollars is a commonly used figure in the U.S. Department of Energy (DOE) for the value of a statistical death), but we commonly pay much more than that to prevent even a single death.

Considering that DOE Richland Operations Office managers view workers as almost as important as the public (in the ratio of four to five in the Revised Priority Planning Grid; see Appendix B, Attachment B1), disposal in-place is concluded to be preferred to retrieval in terms of worker risk.

Ecosystem risk is measured in terms of the land area disturbed or contaminated. In both cases, the Risk Strategy is better than the other alternatives, with the Composite Strategy second best, mainly because reactors are entombed in-place. The removal of the contaminated soil, solid waste, and (especially) the reactors would damage the environment in the 100 Areas, the road network, and the 200 Area (for the Environmental Restoration Disposal Facility). Entombment of the reactors would disturb the land in the footprint, but that damage would be partially offset by the elimination of a storage area on the central plateau. Overall, ecosystem risk would probably be minor in any case and would not be a major discriminator across alternatives. In summary, public and ecosystem risks generally would not discriminate across alternatives, but Alternatives III and IV are preferred from a worker risk perspective.

\section{I.2 Maximize Landuse Potential}

This objective was evaluated by the amount of the Site cleaned up, the amount of land available for unrestricted use, and the use of groundwater. Alternatives I and II would be better than III and IV because they would have unrestricted use of the land as their goal. Note, however, that access to groundwater would be restricted in all strategies for the next 180 years, at least. Also, Alternatives III and IV would provide industrial use for the 100/300/400 Areas, while 200 Area use would be essentially the same for all alternatives.

\section{I.3 Maximize Progress}

This objective reflects the desire to get on with cleanup and to demonstrate progress, especially in the near-term. Progress is frequently in the eye of the beholder, but total cleanup time, time to complete initial actions, and time to complete cleanup of specific land areas were used as criteria for this objective.

The Risk Strategy would be completed earlier (2043) than Alternatives II and IV, mostly because it would do less work. The Composite Strategy would take slightly longer (2045) because the 100/300/400 Areas are addressed differently. In both Alternatives III and IV, reactors would be entombed last, but that entombment may be accomplished without the 75-year wait of Alternative II. 
The Existing Baseline Strategy obviously makes the most near-term progress, but does not meet the anticipated funding profile. If this alternative was pursued and additional funding above the anticipated level of 1.05 billion dollars were not provided, progress could be delayed significantly.

The time to complete Alternative II is not entirely clear because solid waste retrieval and groundwater treatment are delayed until at least 2048. The removal of reactors is postponed for 75 years to permit natural decay to lessen worker risks. Overall, the Baseline Extended Strategy takes longer than either Alternative III or IV.

We also looked at the time to complete some initial actions and the different areas. Since all strategies address near-term risks as a matter of priority, there is no difference in such things as cleaning out Plutonium Finishing Plant, $324 \mathrm{~B}$ cell, and spent nuclear fuel. Completion of the deactivation of major facilities, such as PUREX, Fast Flux Test Facility, and N Reactor are about the same for all alternatives, also. It is only the lower-priority activities that are delayed in some cases and not in others.

A good example of these differences is for tank disposal. It starts during 2000-2002 for alternatives II through IV, but it is completed earlier for both the Risk and Composite Strategies. Overall, the Risk Strategy is slightly preferred.

\section{I.4 Maximize Cost Effectiveness}

Cost effectiveness is measured by the percent and amount of funding being applied directly to cleanup. These metrics were determined by subtracting minimum-operations costs from total costs over the length of cleanup. Total lifecycle costs are also a measure of cost-effectiveness.

Total costs are estimated at 68 , (currently 84 without estimated productivity) 56,44 , and 45 billion dollars, respectively for Alternatives I through IV. The costs for Alternative II are quite uncertain because stretching the same activities will probably cost more. In general, increases in costs due solely to shifting activities to the future have not been incorporated.

The total amount and the percent of the budget applied to cleanup were considered. Alternative II provides the largest amount of funding going to cleanup, as well as the highest percentage.

Alternatives III and IV are comparable. In any case, the metrics are not very helpful.

\section{I.5 Maximize Likelihood of Success}

It was not feasible to evaluate programmatic risk as thoroughly as preferable, primarily because there were not good confidence intervals on cost and schedule estimates. Therefore, technical risk, programmatic risk in terms of funding profile, and political risk were considered to be the metrics for this objective.

In terms of technical risk, the Risk and Composite Strategies are higher risk than the Existing Baseline Strategy because in-situ disposal of tank waste has greater uncertainty than retrieval and 
vitrification. Several experts were asked about the question of in-situ technical risk as compared to retrieval, and most thought in-situ technology development was more uncertain; however, it was agreed that retrieval itself was not without technical risk.

Technical risk for groundwater treatment is also a consideration for the Existing and Baseline Extended Strategies; however, by postponing it for 50 years in Alternative II, that risk is mitigated considerably. In terms of funding profile, all alternatives except the existing Baseline Strategy meet anticipated funding.

Political risk is hard to estimate, of course, but the study team is pretty confident the local/regional perspective is the exact opposite to the national view. The Existing Baseline Strategy will be supported politically by local and regional groups, but not funded because it is not as important as other federal programs. Local interests will oppose delays in Hanford Federal Facility Agreement and Consent Order (Ecology et. al 1994) (Tri-Party Agreement) milestones and will oppose the 200 Area as a permanent disposal area, the failure to treat groundwater, the failure to retrieve tank and solid waste, and entombment of reactors. The local groups also will not like capping and covering solid and liquid waste sites. Congress, on the other hand, will support any efforts that control costs and get the job done earlier. Overall, political risk depends upon whether local/regional political considerations are greater or less than those for the nation as a whole. No alternative is clearly better.

\section{I.6 Maximize Stakeholder Confidence}

Stakeholder confidence in, and acceptance of, a given strategy are dependent upon the degree to which that strategy addresses their concerns. Confidence and acceptance are not measurable directly; therefore, surrogate measures were used in this study. In general, stakeholders will favor the Existing Baseline Strategy or the Baseline Extended Strategy over the Risk or Composite Strategies. Of the latter two, the Risk Strategy will probably be less preferred.

- Columbia River. All alternatives remove the spent nuclear fuel from near the river, which is a key concern of all stakeholders. Stakeholders will not like cap and cover in the 100/300 areas and will not like reactors entombed near the river. They want all facilities near the river demolished and all contamination removed. Any alternative which does not do so will face some opposition. Alternative III will be least preferred; Alternative IV next.

- Regulatory Impacts. The Baseline and Baseline Extended will comply with regulatory requirements (with delays in Alternative II); however, Alternatives III and IV will require regulatory relief. There will be major impacts on compliance with Resource Conservation and Recovery Act of 1976 land disposal restrictions, especially for in place disposal of tank and solid waste. There may be Comprehensive Environmental, Response, Compensation, and Liability Act of 1980 impacts, as well. Stakeholders will oppose regulatory relief.

- Tri-Party Agreements Impacts. Stakeholders are resigned to the need to renegotiate the Tri-Party Agreement; however, they will oppose strategies that change the cleanup activities agreed to previously. There will be major opposition to leaving high-level waste in the 
200 Area, capping and covering waste sites outside of the plateau, and entombing facilities and reactors. They also want groundwater cleaned up. Alternative II will be much preferred; with IV and III following. All strategies except the Existing Baseline Strategy will require renegotiating the Tri-Party Agreement; however, only schedule, approach, and sequence are affected in the Baseline Extended Strategy.

- Economic Benefit. There could be economic benefit to the region from having a clean 100 Area that could be used for industrial use. Alternative II would be preferred in this case, with Alternative III the worst because of capped and covered waste sites and the entombed reactors. The 300 Area would also provide potential economic benefit, so Alternatives II and IV would be preferred over Alternative III in this regard.

- High Stakeholder Interests. Several issues with high stakeholder interest were examined: Spent nuclear fuel, tank waste, groundwater, solid waste, and access by Indian tribes. Except for spent nuclear fuel (which is the same for all alternatives), the Baseline Extended Strategy is preferred over the Risk and Composite Strategies. Alternative IV should be slightly preferred to Alternative III.

In general, local and regional stakeholder confidence is maximized by executing a strategy that complies with regulatory and Tri-Party Agreement requirements. Alternative II is preferred by all measures. Nationally, however, Alternatives III and IV will be preferred.

\section{I.7 Summary Comparison of Alternatives}

The Existing Baseline Strategy is not executable within anticipated funding and is not a viable alternative. Overall, the Risk Strategy and the Composite Strategy provide more protection for workers, are more economical and finish cleanup earlier than the Baseline Extended Strategy. They are likely to be supported by the U.S. Congress, are more restrictive of the land, and will be opposed by local stakeholders. They may have higher technical risk and will require significant regulatory and Tri-Party Agreement modifications.

The Baseline Extended Strategy has higher worker risk, costs more, and takes longer than either the Risk or Composite Strategy; however, it will be more acceptable to local stakeholders (but not the Congress), except for delays due to budget cuts. There is probably less technical risk and considerably less impact on regulatory requirements and the Tri-Party Agreement.

As compared to the Risk Strategy, the Composite Strategy is slightly more costly and will take a little longer; however, it should be more acceptable to stakeholders because it is addressing areas outside the central plateau more in accordance with current plans. It also has makes the 300 Area available for industrial use earlier. Overall, a Composite Strategy is preferred over the Risk and Baseline Extended Strategies if significant technology uncertainties and regulatory changes can be overcome and stakeholders are willing to accept the endstate. These are major concerns and if they cannot be addressed successfully, the Extended Baseline Strategy is preferred. 


\section{I.8 References}

DOE, 1987, Final Environmental Impact Statement (EIS) Disposal of Hanford

Defense High-Level, Transuranic and Tank Wastes, DOE/EIS-0113, U.S. Department of Energy, Washington, D.C.

Comprehensive Environmental, Response, Compensation, and Liability Act of 1980,42 USC 9601 , et seq.

Ecology, EPA, and DOE, 1994, Hanford Federal Facility Agreement and Consent

Order, as amended, Washington State Department of Ecology, U.S. Environmental Protection Agency, and U.S. Department of Energy, Olympia, Washington.

Resource Conservation and Recovery Act of 1976, 42 USC 6901, et seq. 
Comparison of Alternative Strategies Against Objectives and Criteria

\begin{tabular}{|c|c|c|c|c|c|c|}
\hline Objectives & Criteria & Metric & $\begin{array}{c}\text { Alternative 1: } \\
\text { Baseline Strategy }\end{array}$ & $\begin{array}{l}\text { Altemative 2: } \\
\text { Baseline Extended } \\
\text { Strategy }\end{array}$ & $\begin{array}{l}\text { Alternative 3: } \\
\text { Risk Strategy }\end{array}$ & $\begin{array}{l}\text { Alternative 4: } \\
\text { Composite Strategy }\end{array}$ \\
\hline \multirow[t]{8}{*}{$\begin{array}{l}\text { Minimize environmental, } \\
\text { health, and saftry risks }\end{array}$} & \multirow[t]{3}{*}{ Minimize public effects } & Latent cancer deaths & $\begin{array}{l}\text { Extremely unlikely } \\
(<1 / 1000)\end{array}$ & $\begin{array}{l}\text { Extremely unlikely } \\
(<1 / 1000)\end{array}$ & $\begin{array}{l}\text { Extremely unlikely } \\
(<1 / 1000)\end{array}$ & $\begin{array}{c}\text { Extremely unlikely } \\
\quad(<1 / 1000)\end{array}$ \\
\hline & & \begin{tabular}{|l|}
$\begin{array}{l}\text { Acute event } \\
\text { exposure }\end{array}$ \\
exadiological
\end{tabular} & 7000 man-rem & 7000 man-rem & 7000 man-rem & 7000 man-rem \\
\hline & & Acure event likelihood & $\begin{array}{l}\text { Extremely unlikely } \\
(<1 / 1000)\end{array}$ & $\begin{array}{l}\text { Extremely Unlikely } \\
(<1 / 1000)\end{array}$ & $\begin{array}{c}\text { Extremety unlikely } \\
\quad(<1 / 1000)\end{array}$ & $\begin{array}{l}\text { Extremely unlikely } \\
(<1 / 1000)\end{array}$ \\
\hline & \multirow{3}{*}{$\begin{array}{l}\text { Minimize worker health } \\
\text { effects }\end{array}$} & Lost workday (a) accidents & 880 lost work days & 880 lost work days & 110 lost work days & 110 lost work days \\
\hline & & $\begin{array}{l}\text { Worker exposure }{ }^{(a)}(200 / y r \\
\text { current) }\end{array}$ & 15,000 man-rem & 15,000 man-rem & 2400 man-rem & 2400 man-rem \\
\hline & & Worker deaths (a) & $\begin{array}{l}8 \text { (including } 2 \text { from shipment } \\
\text { to repository) }\end{array}$ & $\begin{array}{l}8 \text { (including } 2 \text { from } \\
\text { shipment to repository) }\end{array}$ & $<1$ & $<1$ \\
\hline & \multirow[t]{2}{*}{$\begin{array}{l}\text { Minimize environment } \\
\text { and ecosystem injury }\end{array}$} & Area of land disturbed $\left(\mathrm{mi}^{2}\right)$ & $\begin{array}{l}\text { Roads for reactor shipment; } \\
\text { burial grounds in 200; new } \\
\text { fac. for tank waste disposal } \\
\text { (total } 8 \mathrm{mi}^{2} \text { plus reactor } \\
\text { transport and burial) } \\
\end{array}$ & $\begin{array}{l}\text { Roads for reactor shipment; } \\
\text { burial grounds in } 200 \text {; new } \\
\text { fac. for tank waste disposal } \\
\text { (total } 8 \mathrm{mi}^{2} \text { plus reactor } \\
\text { transport and burial) } \\
\end{array}$ & $\begin{array}{l}\text { Reactor fooprint area } \\
\left(<7 \mathrm{mi}^{2}\right)\end{array}$ & $\begin{array}{l}\text { Reactor foopprint area }(<7 \\
\text { mit. }^{2} \text { plus roads/disposal site } \\
\text { for removal of solid/liquid } \\
\text { waste sites) }\end{array}$ \\
\hline & & \begin{tabular}{|l}
$\begin{array}{l}\text { Area of land contaminated } \\
\left(\mathrm{mi}^{2}\right)\end{array}$ \\
\end{tabular} & 2-cell ERDF & 2-cell ERDF & none & 2-cell ERDF \\
\hline \multirow[t]{3}{*}{$\begin{array}{l}\text { Maximize land use } \\
\text { potential }\end{array}$} & $\begin{array}{l}\text { Maximize amount of } \\
\text { land cleaned up }\end{array}$ & Area cleaned up $\left(\mathrm{mi}^{2}\right)$ & $\begin{array}{l}\text { Total Site } \\
\left(560 \mathrm{mi}^{2}\right)\end{array}$ & $\begin{array}{l}\text { Total Site } \\
\left(560 \mathrm{mi}^{2}\right)\end{array}$ & $\begin{array}{l}\text { Total Site less } 200 \text { Areas } \\
\text { and reactor areas; cap and } \\
\text { cover outside } 200 \text { Area; } \\
510 \mathrm{mi}^{2} \text {; no groundwater } \\
\text { cleamup }\end{array}$ & $\begin{array}{l}\text { Total Site less } 200 \text { Area and } \\
\text { reactor areas; } 510 \mathrm{mi}^{2} ; \text { no } \\
\text { groundwater }\end{array}$ \\
\hline & \multirow{2}{*}{$\begin{array}{l}\text { Maximize amount of } \\
\text { land available for } \\
\text { unrestricted use }\end{array}$} & $\begin{array}{l}\text { Area of land avaiable for } \\
\text { unrestricted surface use }\left(\mathrm{mi}^{2}\right)\end{array}$ & $510 \mathrm{mi}^{2}$ & $510 \mathrm{mi}^{2}$ & \begin{tabular}{|l|}
$\begin{array}{l}480 \\
\text { industrial) }\end{array}$ \\
\end{tabular} & 480 (100/300/400 industrial) \\
\hline & & Groundwater use & $\begin{array}{l}\text { Restricted access foresseable } \\
\text { fuure (100 yrs) }\end{array}$ & $\begin{array}{l}\text { Restricted access } \\
\text { foresceable fuare (100 yrs) }\end{array}$ & \begin{tabular}{|l} 
Restricted access \\
foreseeable future (100 \\
yrs)
\end{tabular} & $\begin{array}{l}\text { Restricted access } \\
\text { foreseable fuare (100 yrs) }\end{array}$ \\
\hline
\end{tabular}




\begin{tabular}{|c|c|c|c|c|c|c|}
\hline 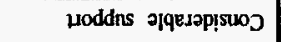 & рәнәуәа & Hoddns ןeuu!u!W & 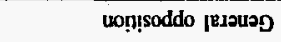 & [ewo!̣te & & \\
\hline 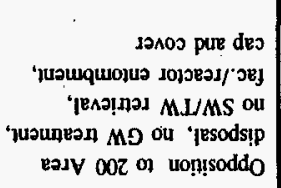 & 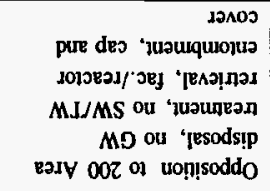 & 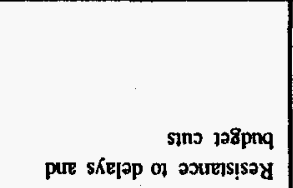 & Hoddns waly & 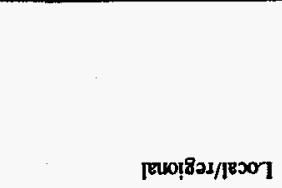 & 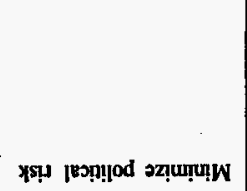 & \\
\hline 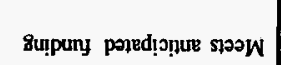 & 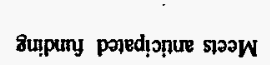 & 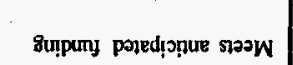 & 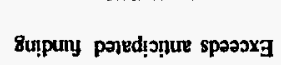 & शाjodd 128png & 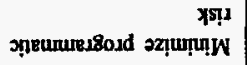 & \\
\hline 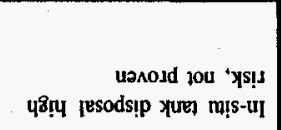 & 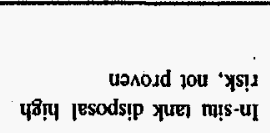 & 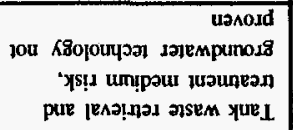 & 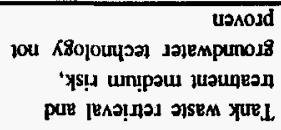 & 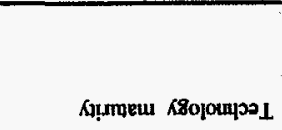 & & \\
\hline 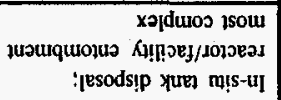 & 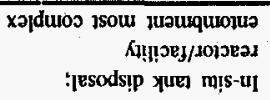 & 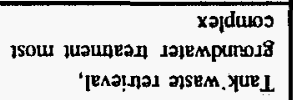 & 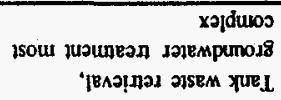 & 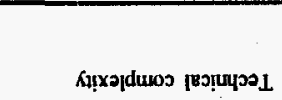 & 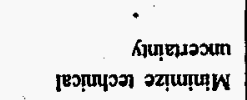 & 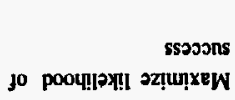 \\
\hline atos & gtts & 89s\$ & 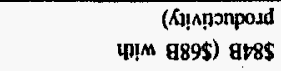 & -- & 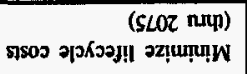 & \\
\hline gozs & goz\$ & goE\$ & $\mathbf{g \varepsilon} \$$ & 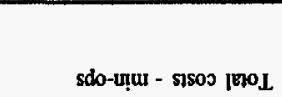 & 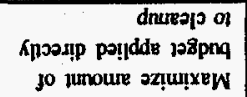 & \\
\hline$\% S t$ & $\% 9 t$ & \%s & \% IS & 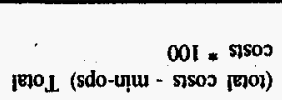 & 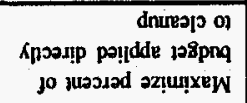 & 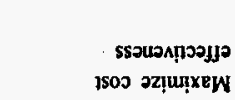 \\
\hline $600 z$ & 6002 & 6002 & $8 Z 0 Z$ ol $1011 \mathrm{~d}$ & $\operatorname{ISIM}$ & \multirow{4}{*}{ 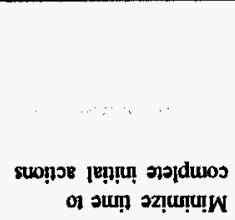 } & \multirow[b]{5}{*}{ 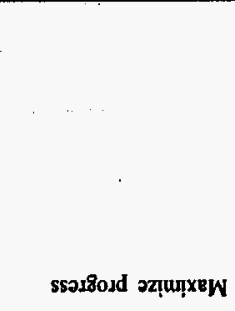 } \\
\hline $666 \mathrm{I}$ & 6661 & 6661 & 6661 & wo!!ısurn Xaynd & & \\
\hline$t \varepsilon 0 z / 200 z$ & oE0z/0002 & uodsury snjd itoz/000z & Hodsuen snjd $8 z 0 z / 9661$ & $\begin{array}{l}\text { (spir/sulfaq) } \\
\text { |Esods!p yurL. }\end{array}$ & & \\
\hline 8002 & 8002 & $800 z$ & 8002 & dedd & & \\
\hline stoz & Et0Z & 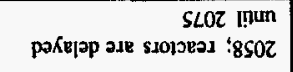 & 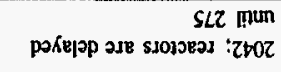 & 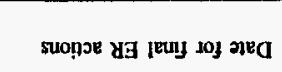 & 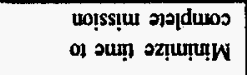 & \\
\hline 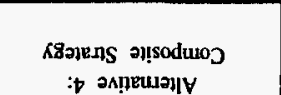 & 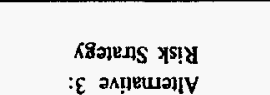 & 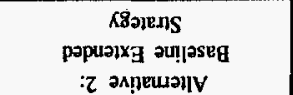 & 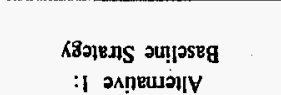 & गุमวพ & 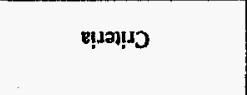 & $\operatorname{ssinps!q0}$ \\
\hline
\end{tabular}

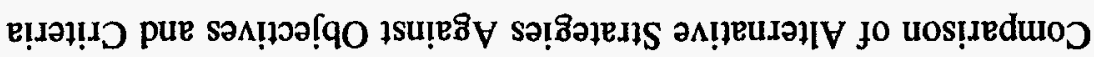


Comparison of Alternative Strategies Against Objectives and Criteria

\begin{tabular}{|c|c|c|c|c|c|c|}
\hline Objectives & Criteria & Metric & $\begin{array}{c}\text { Alternative 1: } \\
\text { Basefine Strategy }\end{array}$ & $\begin{array}{l}\text { Allemative 2: } \\
\text { Baseline Extended } \\
\text { Strategy }\end{array}$ & $\begin{array}{l}\text { Alternative 3: } \\
\text { Risk Strategy }\end{array}$ & $\begin{array}{l}\text { Alternative 4: } \\
\text { Composite Strategy }\end{array}$ \\
\hline \multirow[t]{9}{*}{$\begin{array}{l}\text { Maximize stakeholder } \\
\text { confidence }\end{array}$} & $\begin{array}{l}\text { Minimize threat to } \\
\text { Columbia River }\end{array}$ & $\begin{array}{l}\text { TSD of source terms niear } \\
\text { river }\end{array}$ & $\begin{array}{l}\text { SNF removed; } 100 / 300 \\
\text { cleaned; unrestricted use; N } \\
\text { Springs treatment }\end{array}$ & $\begin{array}{l}\text { SNF removed; } 100 / 300 \\
\text { cleaned; unrestricted use; N } \\
\text { Springs treatment }\end{array}$ & $\begin{array}{l}\text { SNF removed; } 100 / 300 \\
\text { cap and cover; reactor } \\
\text { entombed; industrial use } \\
\text { 100/300; recreation use } \\
600 \text {; no groundwater } \\
\text { treatment }\end{array}$ & $\begin{array}{l}\text { SNF removed; reactor } \\
\text { entombed; industrial use } \\
\text { 100/300; recreation use } 600 \text {; } \\
\text { no groundwater treatment }\end{array}$ \\
\hline & $\begin{array}{l}\text { Maximize regulatory } \\
\text { compliance }\end{array}$ & Required regulatory changes & none & none & $\begin{array}{l}\text { RCRA/FFCA for } \\
\text { TW/SW/GW and LDR }\end{array}$ & $\begin{array}{l}\text { RCRA/FFCA for } \\
\text { TW/SW/GW and LDR }\end{array}$ \\
\hline & $\begin{array}{l}\text { Maximize TPA } \\
\text { compliance }\end{array}$ & Does it require TPA changes & no & yes (milestones only) & $\begin{array}{l}\text { yes (milestones and } \\
\text { activities) }\end{array}$ & $\begin{array}{l}\text { yes (milestones and } \\
\text { activities) }\end{array}$ \\
\hline & $\begin{array}{l}\text { Maximize economic } \\
\text { benefit }\end{array}$ & $\begin{array}{l}\text { Area available for industrial } \\
\text { use }\left(\mathrm{mi}^{2}\right)\end{array}$ & $\begin{array}{l}\text { Widd and scenic; clean } 100 \\
\text { Areas facilitate recreational } \\
\text { use }\end{array}$ & $\begin{array}{l}\begin{array}{l}\text { Wild and scenic; clean } 100 \\
\text { Areas facilitate recreational } \\
\text { use }\end{array} \\
\end{array}$ & $\begin{array}{l}\text { Postpone } 300 \text { Area } \\
\text { availability; cap and cover }\end{array}$ & $\begin{array}{l}\text { Accelerates } 300 \text { Area } \\
\text { cleanup }\end{array}$ \\
\hline & \multirow{5}{*}{$\begin{array}{l}\text { Maximize cleamup of } \\
\text { high stakeholder } \\
\text { interests }\end{array}$} & Years to remove fucl basin & 1999 & 1999 & 1999 & 1999 \\
\hline & & Tank waste removal & yes & yes & no & no \\
\hline & & Treat groundwater & yes & yes (delayed) & no & no \\
\hline & & Solid waste & yes & yes (delayed) & no & partial \\
\hline & & Indian access & yes & yes (delayed) & limited & limited \\
\hline
\end{tabular}


Sensitivity of Com

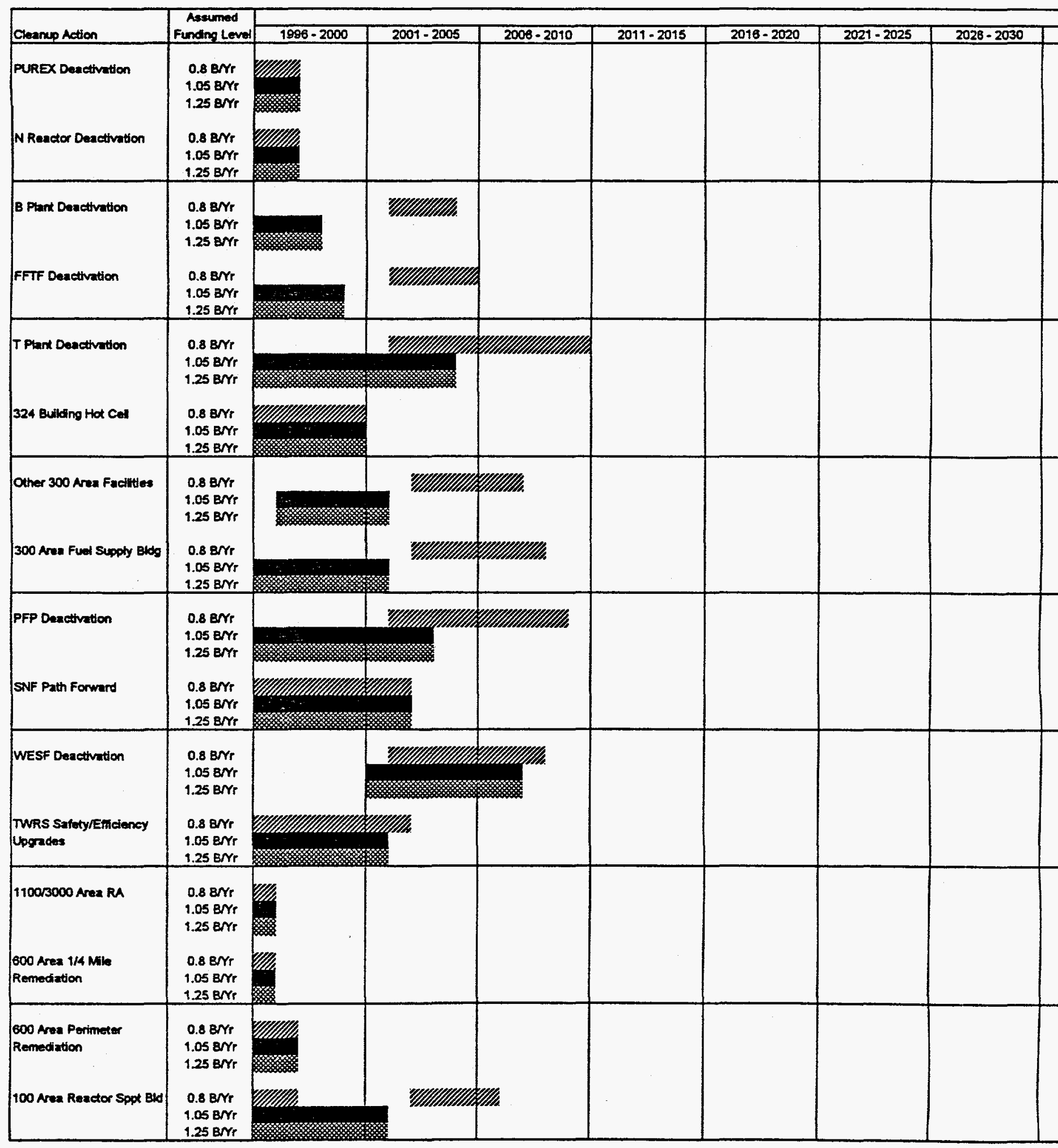


site Strategy to Funding Level

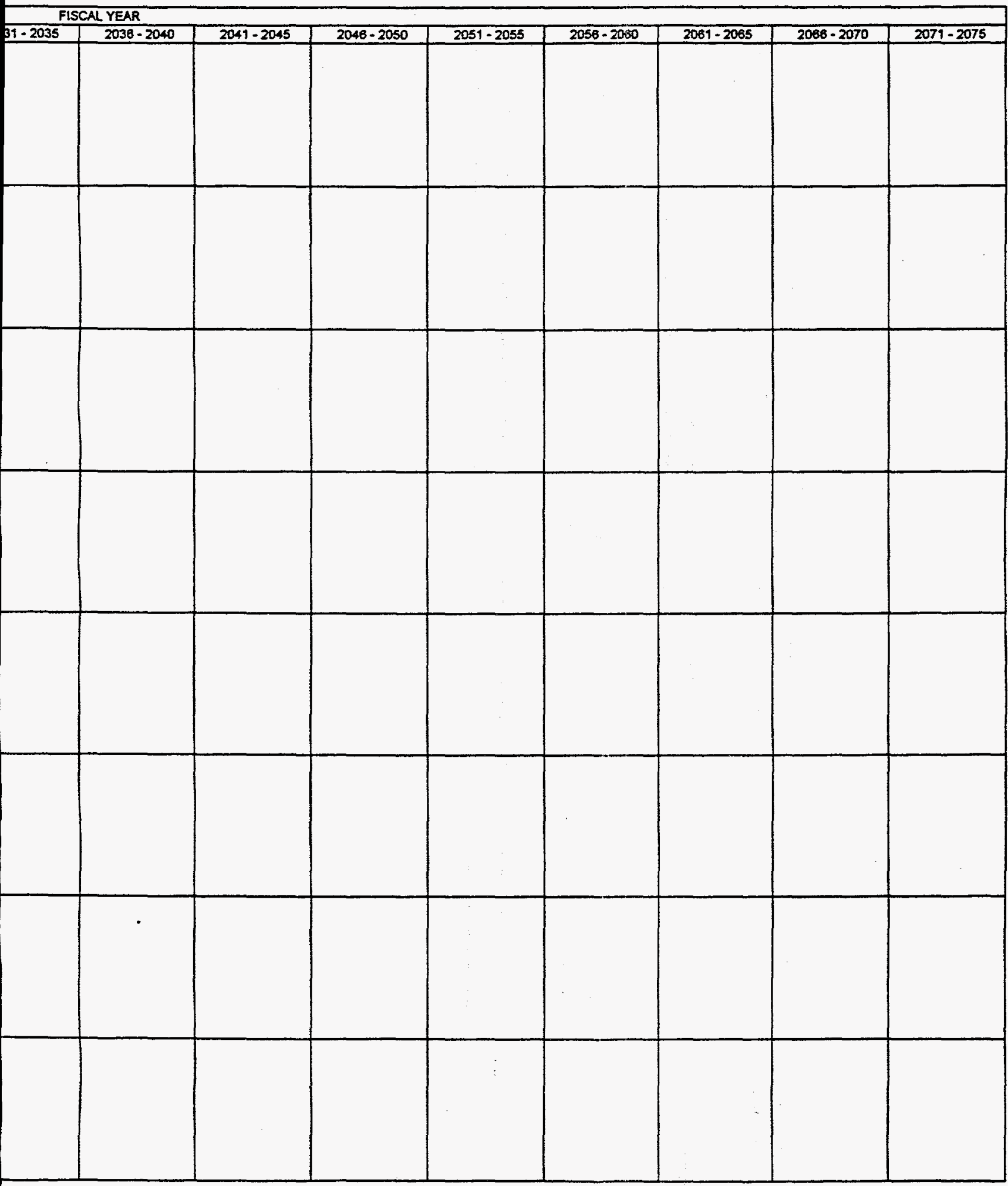


Sensitivity of Com

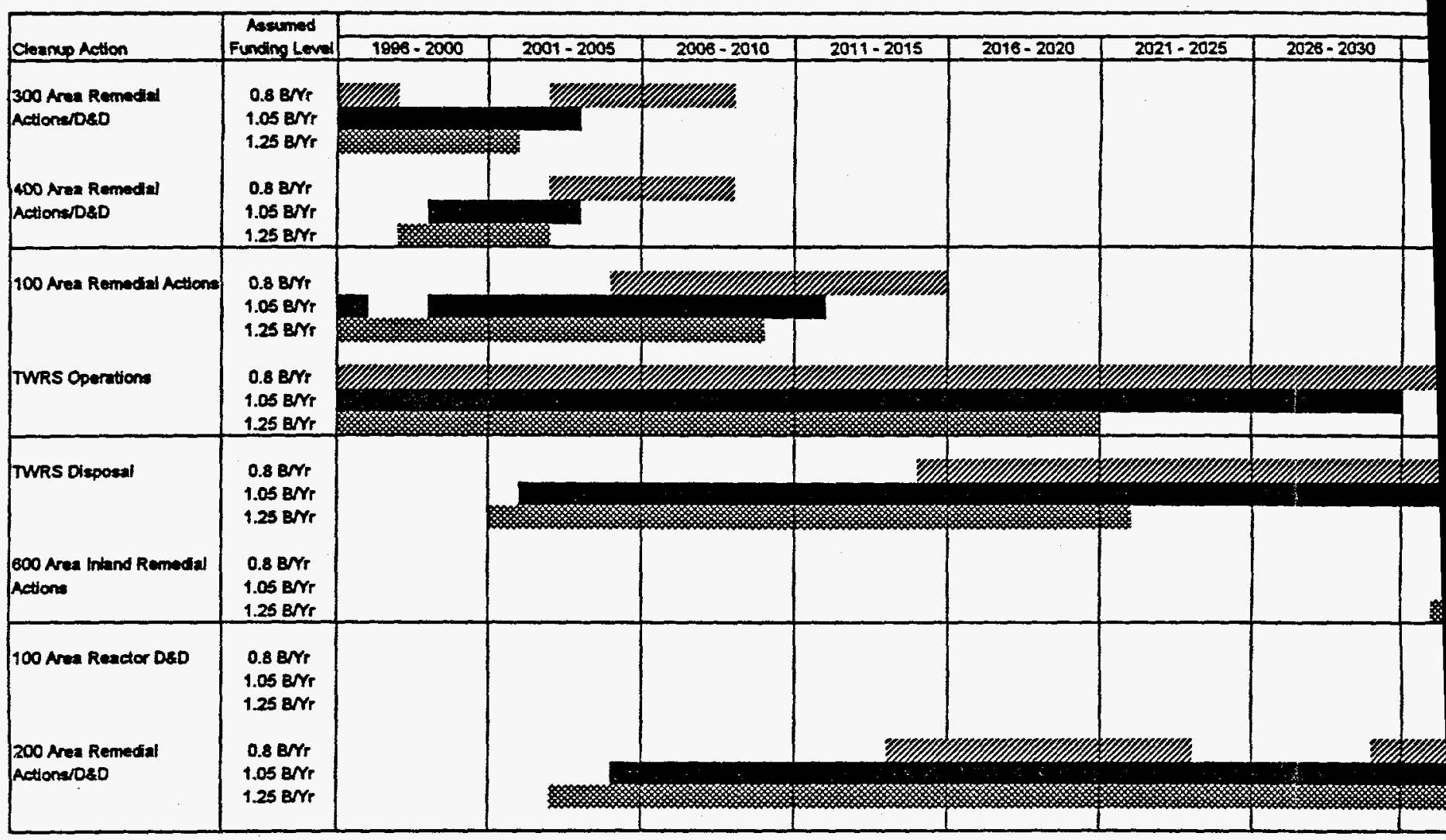




\begin{tabular}{|c|c|c|c|c|c|c|c|c|c|}
\hline & Anowmed & & & & & & & & \\
\hline Chomep Action & 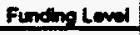 & $1996-2000$ & $2001 \cdot 2005$ & $2006-2010$ & $2011-2015$ & $2016-2020$ & $2021-2025$ & $2028-2030$ & $2091-20$ \\
\hline 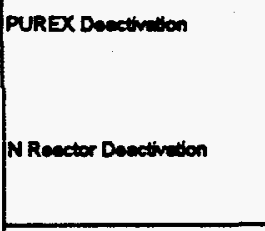 & $\begin{array}{l}0.8 \mathrm{BNr} \\
1.05 \mathrm{BNr} \\
1.26 \mathrm{BNr} \\
0.2 \mathrm{BNr} \\
1.05 \mathrm{BNr} \\
1.25 \mathrm{BNr} \\
\end{array}$ & & & & & & & & . \\
\hline 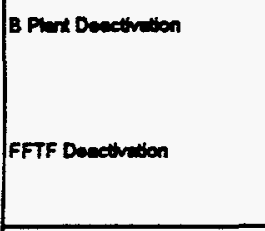 & $\begin{array}{l}0.0 \mathrm{BMr} \\
1.05 \mathrm{BNr} \\
1.25 \mathrm{BMr} \\
0.8 \mathrm{BNr} \\
1.05 \mathrm{BMr} \\
1.25 \mathrm{BMr}\end{array}$ & & & & & & & & \\
\hline T2 Plext Douctivition & $\begin{array}{l}0.8 \mathrm{BNr} \\
1.05 \mathrm{BNr} \\
1.25 \mathrm{ENr} \\
\\
0.8 \mathrm{EMr} \\
1.05 \mathrm{Brr} \\
1.25 \mathrm{gNr}\end{array}$ & & & & & & & & \\
\hline 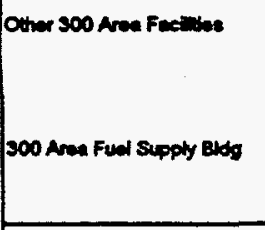 & $\begin{array}{l}0.8 \mathrm{BMr} \\
1.05 \mathrm{BMr} \\
1.25 \mathrm{BMr} \\
0.8 \mathrm{BNr} \\
1.05 \mathrm{BNr} \\
1.25 \mathrm{BMr} \\
\end{array}$ & & & & & & & & \\
\hline 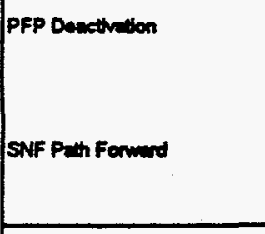 & $\begin{array}{l}0.0 \mathrm{BNr} \\
1.05 \mathrm{BNr} \\
1.25 \mathrm{BMr} \\
0.8 \mathrm{BNr} \\
1.05 \mathrm{BNr} \\
1.25 \mathrm{BMr} \\
\end{array}$ & & & & & & & & \\
\hline 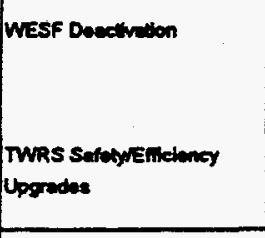 & $\begin{array}{l}0.8 \mathrm{BMr} \\
1.05 \mathrm{BNr} \\
1.25 \mathrm{BNr} \\
0.8 \mathrm{BNr} \\
1.05 \mathrm{BNr} \\
1.25 \mathrm{BNr} \\
\end{array}$ & & & & & & & & \\
\hline 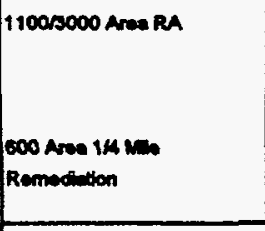 & 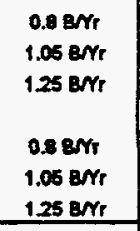 & & & & & & & & \\
\hline 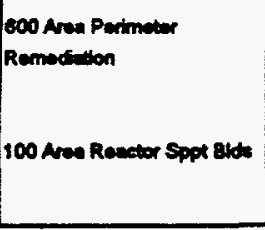 & $\begin{array}{l}0.0 \mathrm{gNr} \\
1.05 \mathrm{gmr} \\
1.25 \mathrm{BNr} \\
0.8 \mathrm{BNr} \\
1.05 \mathrm{gNr} \\
1.25 \mathrm{gNr}\end{array}$ & & & & & & & & \\
\hline
\end{tabular}



Sensitivity of Extended

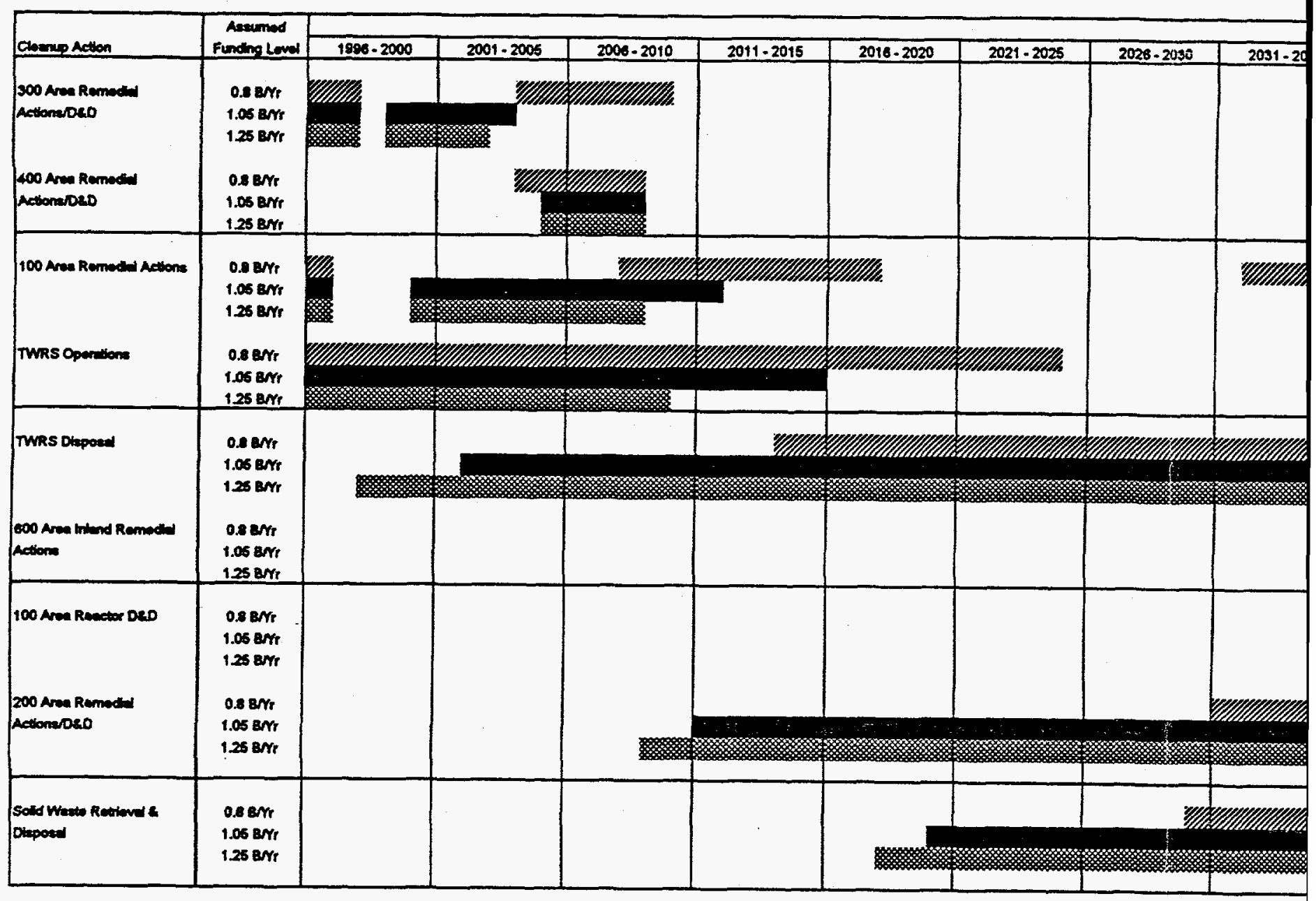




\section{Appendix J}

\section{Tri-Party Agreement and Regulatory Analysis}





\section{Contents}

\section{Appendix J - Tri-Party Agreement and Regulatory Analysis}

J.1 Hanford Federal Facility Agreement and Consent Order Analysis . . . . . . . . J.1

J.1.1 Introduction . . . . . . . . . . . . . . . . . . . . . . . .

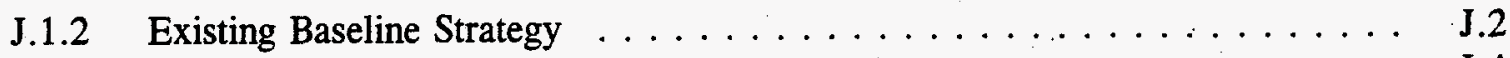

J.1.3 Baseline Extended Strategy . . . . . . . . . . . . . . . . . . J.4

J.1.4 Risk Strategy . . . . . . . . . . . . . . . . . . . . . . J.6

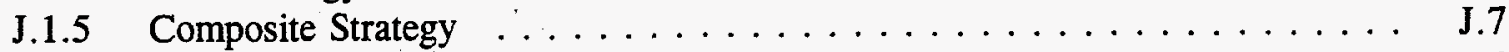

J.1.6 Funding Sensitivity $\ldots \ldots \ldots \ldots \ldots \ldots \ldots \ldots \ldots \ldots \ldots$

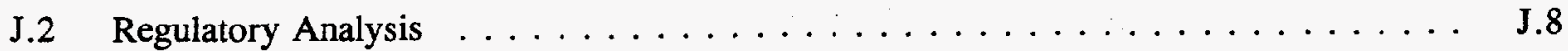

J.2.1 Background . . . . . . . . . . . . . . . . . . .

J.2.2 Effect of Major Environmental Laws on Baseline Extended Strategy . . . . . J.10

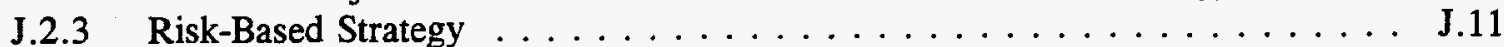

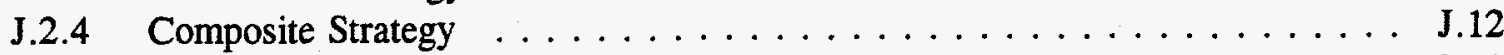

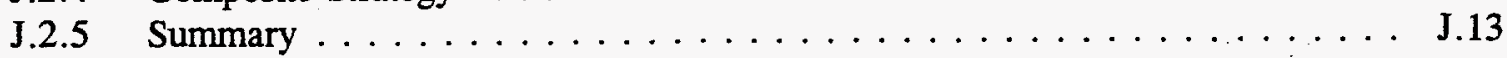

J.3 References $\ldots \ldots \ldots \ldots \ldots \ldots \ldots \ldots \ldots \ldots \ldots \ldots \ldots \ldots \ldots$

\section{Tables}

J.1 Schedule Comparison $\ldots \ldots \ldots \ldots \ldots \ldots \ldots \ldots \ldots$ 


\title{
Appendix $\mathbf{J}$
}

\section{Tri-Party Agreement and Regulatory Analysis}

\author{
J.1 Hanford Federal Facility Agreement and Consent Order \\ (Tri-Party Agreement) Analysis
}

The Hanford Federal Facility Agreement and Consent Order (Ecology et al. 1994) (Tri-Party Agreement) is a three party agreement between the U.S. Department of Energy (DOE), the U.S. Environmental Protection Agency (EPA), and the Washington State Department of Ecology (Ecology). The Tri-Party Agreement was initially signed in May 1989.

\section{J.1.1 Introduction}

DOE recognized the need to enter into an agreement in early 1987 primarily due to two significant events. First, the 1986 amendments to the Comprehensive Environmental Response, Compensation and Recovery Act of 1980 (CERCLA) required federal facilities that are qualified to be placed on the National Priorities Listing. In 1987 DOE and the EPA initiated the process for placing the Hanford Site on the National Priorities Listing, and CERCLA Section 120 requires interagency agreements for federal facilities on the National Priorities Listing. Second, the mixed-waste ruling in support of the Resource Conservation and Recovery Act of 1976 (RCRA) was issued by the EPA in June 1986 making the hazardous component of source, byproduct, and special nuclear waste materials subject to RCRA. The EPA was in the process of providing this authority to the State of Washington, which subsequently happened in 1987. DOE was clearly out of compliance with RCRA and the associated State laws and regulations in many areas. An agreement with the State was necessary to establish reasonable time-frames for achieving compliance.

Many of the problems and issues that the three parties are dealing with today are not a consideration in the initial Tri-Party Agreement. Examples include resolution of tank safety issues and cleanout of $\mathrm{K}$ Basins. These along with other factors have significantly increased the scope, and therefore cost, for eventual cleanup of the Hanford Site. As a result, the Tri-Party Agreement has undergone major revisions since 1989, as well as numerous changes to existing milestones. This should be expected as the road to cleanup becomes more definitive. Major revision included incorporation of (1) specific actions for interim status compliance, (2) language to address land disposal restriction requirements, (3) language and actions to address the management of liquid effluents on the Hanford Site, (4) a revised and comprehensive strategy for final disposition of the single- and double-shell storage tanks, and (5) actions to address waste tank compliance requirements. Recent negotiations have addressed a more integrated approach for the environmental restoration of the Hanford Site to establish a process and commitments for transitioning and, eventually, dispositioning key facilities on the Hanford Site, and to address compliance for wastes stored in the 324 Facility. These changes are scheduled to be incorporated into the agreement within the next couple months, but are considered part of the existing Tri-Party Agreement baseline for purposes of this analysis. 
The end result is that the scope and number of milestones contained in the agreement has grown significantly since 1989 . It has gone far beyond the original intent of addressing regulatory compliance under RCRA and CERCLA, and has become a comprehensive cleanup agreement for the Site. Some feel that the Tri-Party Agreement is driving DOE to perform activities beyond those required by the regulations. In some areas this may be true. At the same time, the agreement is providing DOE with needed relief from the normal regulatory requirements. For example, RCRA closures are being deferred far into the future so that they can be more effectively performed in conjunction with other common work, systems are allowed to continue to operate awaiting enhancements to meet standards, and land disposal restricted wastes are being stored for long periods while awaiting treatment capability, therefore, the existing Tri-Party Agreement baseline described below already provides DOE and its contractors necessary regulatory relief. The alternative strategies that follow place additional burden on the Tri-Party Agreement to further extend or enhance such relief.

\section{J.1.2 Existing Baseline Strategy}

The Tri-Party Agreement, through its milestones, establishes some endstate conditions, but does not establish a complete endstate for the Hanford Site, therefore, an overall cleanup strategy cannot be fully determined from the Tri-Party Agreement. For example, the extent of contamination removal within the 200 Area plateau is not specified. For purpose of this study, the endstate assumptions defined in Appendix E for the Existing Baseline Strategy are assumed to be consistent with the currently negotiated Tri-Party Agreement. These endstate assumptions are consistent with the existing baseline funding profiles contained in this study, and represent an integration of the Tri-Party Agreement, the Fiscal Year 1995 Hanford Mission Plan (RL 1994), and current multi-year program plans.

The existing baseline would result in the disposition of tank wastes in 2028 and waste disposal sites in 2018. All facilities not in use outside the 200 Areas--with exception of the reactors-would also have been dispositioned. Efforts remaining beyond 2028 would include disposition of the reactors and the majority of the 200 Area facilities. Treated wastes and materials would still be in storage awaiting their final disposition (e.g., vitrified high-level waste).

Tank Waste Remediation System The Tank Waste Remediation System baseline would end in 2028 with all tank wastes being vitrified and placed in storage, or disposed. The only remaining actions would be the closure of the double-shell tank farms and decommissioning of the facilities used to treat the wastes. The current Tri-Party Agreement baseline calls for separate pretreatment and vitrification facilities for both the high-level and low-level fractions. Specifically, the baseline provides for the following.

- Additional double-shell tank capacity in 1998 (a change to the current baseline is currently proposed to delete this requirement).

- Completion of single-shell tank characterization in 1999.

- Completion of single-shell tank stabilization in 2000.

- Resolution of tank safety issues in 2001 . 
- $\quad$ Completion of tank upgrades in 2005.

- Initiation of low-level waste pretreatment in 2004 , followed by initiation of low-level waste vitrification in 2005 .

- Initiation of high-level waste pretreatment in 2008 , followed by initiation of high-level waste vitrification in 2009.

- Completion of retrieval of wastes from single-shell tanks in 2018 , followed by closure of all single-shell tank farms in 2024.

Environmental Restoration The Environmental Restoration Project would be completed in fiscal year 2018. The wastes from the 100,300, and 600 Areas would be removed and disposed in the Environmental Restoration Disposal Facility on the 200 Area plateau. All surplus facilities currently assigned to the project would be decommissioned, with exception of the nine reactors which would be handled as one-piece removals and buried in the 200 Area after 2018. The wastes in the 200 Area would be stabilized and capped in place. Groundwater remediation would be carried out consistent with records of decisions for the 100 and 300 Areas. The 200 Area groundwater approach would be mass reduction of contaminants and containment of the existing plumes. Specifically, the currently negotiated baseline provides for the following.

- Deactivation of N Reactor in 1997.

- $\quad$ Completion of all 100 and 300 Area assessments in 1999.

- Submittal of all RCRA closure plans for regulated units in 2000.

- Completion of all 200 Area assessments in 2008.

- Completion of all 100 Areas waste site remediations and facility dispositions (except for reactors) in the 100 Areas in 2018.

Currently, the existing baseline does not address those facilities not currently assigned to the Environmental Restoration Project for disposition, but it is expected that the majority of these facilities would be dispositioned past 2018.

$\mathbf{K}$ Basins The Tri-Party Agreement for remediation of $\mathrm{K}$ Basins is out-of-date with the current path forward. Renegotiations are currently ongoing. The path forward would result in removal of fuel from the basins on a schedule that is earlier than the 2002 date currently depicted in the Tri-Party Agreement.

Facility Transition The recently negotiated Tri-Party Agreement changes for facility transition provide for the following.

- Transition of UO3 Plant in 1995.

- $\quad$ Transition of PUREX in 1998. 
- Transition of Fast Flux Test Facility in 2001.

- $\quad$ Completion of initial Plutonium Finishing Plant stabilization actions in 1998.

Negotiations will also commence for transition of miscellaneous 300 Area facilities.

324 Cleanout The recently negotiated Tri-Party Agreement change for addressing the unpermitted mixed waste units in the 324 Facility calls for completion of B Cell cleanout and removal of the resultant mixed wastes in 1999 , followed by waste unit closure per the agreed to closure plan.

Liquid Effluents The Tri-Party Agreement for liquid effluents provides for facilities to properly treat and dispose of Phase I liquid-effluent streams in 1995, followed by achieving required standards for Phase II streams in 1997.

Solid Wastes The Tri-Party Agreement for solid waste management provides for the following.

- Construction and operation of a facility starting in 1997 that would sort and repackage wastes retrieved from the retrievable storage units for subsequent shipment to the Waste Isolation Pilot Plant.

- Construction and operation of a facility starting in 1999 that would treat mixed wastes in accordance with land disposal restriction standards prior to disposal. DOE is currently proposing a change to outsource this capability, with the commitment to still achieve the 1999 date for treatment capability.

DOE is also committed in 1995 to submit a proposed change package for other new facilities, modifications to planned facilities, or modifications to existing facilities to support the future storage, treatment, and disposal of solid wastes and materials.

\section{J.1.3 Baseline Extended Strategy}

The Baseline Extended Strategy is designed to achieve the same endstate as defined above for the Existing Baseline Strategy, but at a restricted funding level of 1.05 billion dollars per year starting in fiscal year 1998. In order to even consider achieving this endstate at such a funding level, a more cost-effective approach for Tank Waste Remediation System disposal has been assumed, that consolidates all low-level and high-level waste pretreatment and vitrification functions into one facility.

The strategy emphasizes achieving mortgage reductions as soon as feasible to make funds available for cleanup activities. High priority is also applied in the near-term to address near-term risks (e.g., $\mathrm{K}$ Basins, 324 wastes, tank safety issues).

The Baseline Extended Strategy would result in an overall delay in cleanup of tank wastes and waste disposal sites from 2028 to approximately 2048, or 20 years. The tank waste and waste disposal site cleanups would be complete by 2041 , including tank closure. The primary effort from 
2040 to 2048 would deal with completion of solid waste retrieval and treatment activities. Effort would still remain beyond fiscal year 2048 to disposition reactors and 200 Area facilities. The following describes the specific Tri-Party Agreement impacts in proceeding with the Baseline Extended Strategy.

Tank Waste Remediation System The Tank Waste Remediation System Program would be delayed 13 years with completion of vitrification in 2041 versus 2028 . Retrieval of wastes from single-shell tanks and subsequent closure of the single-shell tanks would be delayed eight years from 2024 to 2032. Start of low-level waste processing would be delayed from 2004 to 2011 following construction of the single processing facility in 2010. Using the single-facility concept, the high-level waste fraction would be stored while the low-level waste fraction would be vitrified. A significant delay in initiating high-level waste vitrification would be realized.

No new double-shell tanks would be constructed in the near-term. Single-shell tank characterization, tank farm upgrades, tank stabilization, and resolution of tank safety issues would be completed by the current baseline dates in support of near-term risk reduction and the deactivation of single-shell tank farms.

Environmental Restoration With the exception of N Reactor deactivation, ongoing Environmental Restoration Project cleanup activities would be significantly curtailed for six years from 1996 to 2002. In addition, the completion of the project would be extended from 2018 to 2034, or a 16 year delay. The major portion of the project would be completed by 2032 . Environmental restoration activities would continue beyond 2034 to complete disposition of reactors and 200 Area facilities.

K Basins Cleanout and subsequent placement of the spent nuclear fuel in dry storage would be accomplished on an accelerated path forward schedule, resulting in fuel being removed from the basins in 1999 versus 2002. This would allow for earlier cleanout and transition of the basins. In addition to reducing the risk earlier, the accelerated program improves $\mathrm{K}$ Basins as a mortgage reduction, thereby making resources available earlier for other cleanup actions.

Facility Transition All facility transition activities contained in the current Tri-Party Agreement would be completed as planned. Additional transitions would be proposed to further reduce the Site mortgage. These include B Plant, T Plant, and the Waste Encapsulation and Storage Facility. Transition of the Waste Encapsulation and Storage Facility, which requires transfer of the strontium and cesium capsules, would also be a risk reduction. The plan would be to co-locate the capsules in dry storage along with the spent nuclear fuel.

324 Cleanout There would be no change in the 324 waste unit strategy from that contained in the current Tri-Party Agreement baseline.

Liquid Effluents There would be no change in the liquid effluent strategy from that contained in the current Tri-Party Agreement baseline.

Solid Wastes Both retrieval of wastes from the retrievable storage units and treatment of mixed wastes would be delayed significantly under this strategy. Such operations would not start until 2020 , a delay of approximately 20 years. The WRAP I facility construction would be completed and 
mothballed, and operation would be delayed until the retrieval process is initiated. Mixed wastes that are currently stored awaiting treatment prior to disposal would continue to be stored. This would also include future generated wastes. Facilities or contracts for such treatment would not be put in place until they were needed. Continued storage of wastes would maximize use of existing facilities on-site in order to minimize cost of additional new storage facilities. Completion of solid waste retrieval and treatment activities would extend to 2048 .

\section{J.1.4 Risk Strategy}

The Risk Strategy is designed to achieve an endstate that could be accomplished under the same funding restriction as the Baseline Extended Strategy, and that achieves an acceptable level of risk as early as practicable. The highest priority is given to initially mitigating near-term risks on the Hanford Site, and then reduce the long-term risk to an acceptable level. Like the previous cases described above, reducing Site mortgages would continue to be a key to achieving these priorities.

The Risk Strategy would result in a delay in the disposition of tank farms and waste disposal sites from 2028 to 2030 , or only two years. Even though this date would be earlier than the date for the Baseline Extended Strategy (2041), the primary impact to the Tri-Party Agreement would be the resultant endstate, in that tanks wastes and waste disposal sites off the 200 Area plateau, would be disposed in-situ. Like the previous strategies discussed, final disposition of reactors and 200 Area facilities would extend beyond this end-date.

Tri-Party Agreement impacts for facility transition, K Basin, 324 cleanout, and liquid effluents would be the same as for the Baseline Extended Strategy described above. The following discusses specific impacts associated with Tank Waste Remediation System, environmental restoration, and solid wastes.

Tank Waste Remediation System Under the Risk Strategy both single-shell and double-shell tank wastes would be disposed in-situ, versus removal and subsequent treatment and disposal. Even though alternative in-situ methods exist, the cost profile for this strategy assumes that the wastes would be vitrified in-situ. In situ disposal, to include closure of the tank farms, would be completed in 2030, which is two years later than the Existing Baseline Strategy for completing the current Tank Waste Remediation System Program.

Like the Baseline Extended Strategy, no new double-shell tanks would be constructed in the nearterm, and single-shell tank characterization, tank farm upgrades, tank stabilization, and resolution of tank safety issues would continue basically as planned. Characterization and upgrade activities may be modified to better support in-situ disposal. The current tank waste disposal program (retrieval, pretreatment, and vitrification) would be replaced by a program directed at in-situ disposal of the wastes.

Environmental Restoration With the exception of $\mathbf{N}$ Reactor deactivation and some limited 100 Area remediation, continuation of the ongoing environmental restoration project activities at a substantive level would be delayed four years from 1996 to 2000 . Additionally, the overall completion of the Environmental Restoration Project would be delayed from 2018 to 2026 . Disposition of reactors and 200 Area facilities would continue beyond 2026 . The waste sites in the 
100,300 , and 600 Areas would not be exhumed; instead they would be disposed of in-place like the 200 Area waste sites. The reactors would be entombed in-place. Groundwater would not be treated, and its use for the entire Hanford Site would remain restricted.

Solid Waste Under the Risk Strategy would the post-1970 retrievably-stored wastes would be disposed in-situ, and the mixed wastes currently being stored for treatment would be disposed in the 200 Area burial grounds without treatment. The WRAP I Facility would be used for other purposes, and WRAP IIA (or equivalent contracts) would not be pursued, except for special treatment requirements.

\section{J.1.5 Composite Strategy}

The Composite Strategy would recognize that some areas of the Hanford Site can be cleaned up for eventual use by others at minimal additional costs. It basically consists of the same elements of the Risk Strategy, with exception that the some of the liquid and solid waste disposal sites off the 200 Area plateau would be exhumed and the resultant wastes would be disposed on the 200 Area plateau.

The additional resources required in comparison to the Risk Strategy would result in delaying completion of waste tank disposal an additional four years from 2030 to 2034 . Like the Risk Strategy, reactors and 200 Area facilities would remain to be dispositioned after 2034 . The Composite Strategy would provide additional near-term funds for waste site cleanup, thereby accelerating the start of substantive work from 2000 to 1999.

\section{J.1.6 Funding Sensitivity}

The three strategies described above assumed 1.05 billion dollars per year starting in fiscal year 1998. A sensitivity analysis was performed for both the Baseline Extended Strategy and Composite Strategy looking at 800 million dollars per year and 1.25 billion dollars per year.

For the Baseline Extended Strategy, at 800 million dollars per year, it was determined that sufficient funding per year would not be available to support retrieval and treatment of tank wastes. Therefore the Baseline Extended Strategy was not considered feasible at this level. At 1.25 billion dollars, a significant improvement in schedule would be realized, primarily in the area of waste-site cleanup. Completion of the Tank Waste Remediation Program would only be accelerated from 2041 to 2036. This would result primarily from allowing the disposal program to start earlier than planned, as the funding profile for tank waste disposal using one facility would already be at its optimum at the 1.05 billion dollar level. Completion of waste disposal site cleanup and solid waste disposition would only be accelerated from 2048 to 2046 , primarily due to solid waste activities. The most significant impact of increased funding would be that completion of the major portions of the Environmental Restoration Project would be accelerated from 3032 back to 2019, which is only one year later than the Existing Baseline Strategy. In addition, the Environmental Restoration Project would be maintained at a higher level of funding while awaiting the completion of mortgage reductions, thereby allowing substantive cleanup to proceed earlier. 
For the Composite Strategy, at 800 million dollars per year, waste disposal site cleanup would be extended from 2032 to approximately 2047 . In-situ disposal of single- and double-shell tanks would be delayed from 2034 to approximately 2053 , or 19 years. At 1.25 billion dollars, waste disposal site cleanup would be accelerated six years from 2026 to 2020. In-situ disposal of tank wastes would be accelerated six years from 2034 to 2028 to include tank closure. Like the Baseline Extended Strategy, the increased funding level would allow cleanup activities to proceed in the near-term while risks and mortgage reductions are being addressed. Table J.1 compares the schedules for each strategy, including different finding levels.

\section{J.2 Regulatory Analysis}

Risk-based strategies that extend or modify the Existing Baseline Strategy would be impacted primarily by (1) the current requirements to meet land disposal restrictions for "actively managed" mixed wastes, (2) potential difficulties in achieving appropriate RCRA/CERCLA coordination for past practice cleanup activities (e.g. long-term extension of RCRA closures), and (3) compliance with national policies for the disposal of high-level and transuranic wastes.

\section{J.2.1 Background}

The CERCLA provides federal authority to respond to any release of a hazardous substance to the environment from a facility or vessel. With the passage of the Superfund Amendments and Reauthorization Act of 1986 (SARA), federal facilities became subject to CERCLA in the same manner as private entities. In particular, CERCLA Section 120 delineates specific requirements applicable to federal facilities. As currently structured, authority to administer the CERCLA cannot be delegated to states by the EPA; however, CERCLA does require the EPA to encourage meaningful state involvement.

Subtitle C of the RCRA was established to provide for "cradle-to-grave" management of hazardous wastes: however, in the original RCRA enactment, Congress failed to incorporate comprehensive provisions for cleanup of past hazardous waste disposal sites. In passing the Hazardous and Solid Waste Amendments of 1984 (HSWA), Congress established broad RCRA corrective action requirements. Corrective action applies to facilities seeking, or required to have, a RCRA permit. The provisions of corrective action are analogous to the provisions for cleanup under the CERCLA. The EPA announced its intent to regulate radioactive mixed wastes (wastes that have both RCRA and AEA components) on July 3, 1986 (51 FR 24504). The Federal Facility Compliance Act of 1992 (FFCA) waived sovereign immunity from the RCRA for federal facilities (with limited exceptions). Authority to implement most of the RCRA, including corrective action, has been delegated to the Ecology by the EPA. 
Table J.1. Schedule Comparison

\begin{tabular}{|c|c|c|c|c|c|c|c|c|}
\hline Strategy & $\begin{array}{l}\text { Existing } \\
\text { Baseline }\end{array}$ & \multicolumn{3}{|c|}{ Baseline Extended } & Risk & \multicolumn{3}{|c|}{ Composite } \\
\hline Funding & Per plan & $\$ 0.8 \mathrm{~B}$ & $\$ 1.05 \mathrm{~B}$ & $\$ 1.25 \mathrm{~B}$ & $\$ 1.05 \mathrm{~B}$ & $\$ 0.8 \mathrm{~B}$ & $\$ 1.05 \mathrm{~B}$ & $\$ 1.25 \mathrm{~B}$ \\
\hline $\begin{array}{l}\text { Tank waste disposition } \\
\text { (includes SST closure) }\end{array}$ & $1996-2028$ & not achievable & $2000-2041$ & $1996-2036$ & $2000-2030$ & $2014-2053$ & $2002-2034$ & $2001-2028$ \\
\hline Waste site remediation* & $1996-2018$ & 2009-2062 & 2002-2034 & 1998-2019 & $2000-2026$ & 2002-2047 & $1999-2026$ & $1996-2020$ \\
\hline Solid waste retrieval & 2025 & 2060 & 2048 & 2046 & $\mathrm{n} / \mathrm{a}$ & $\mathrm{n} / \mathrm{a}$ & $\mathbf{n} / \mathbf{a}$ & $\mathrm{n} / \mathrm{a}$ \\
\hline $\begin{array}{l}200 \text { Area facility } \\
\text { disposition }\end{array}$ & post 2028 & 2071 & 2058 & 2049 & 2043 & 2058 & 2045 & 2043 \\
\hline Reactor disposition & 2075 & 2075 & 2075 & 2075 & 2043 & 2058 & 2045 & 2043 \\
\hline
\end{tabular}

*Includes non-200 Area facilities except for reactors.

$\mathrm{B}=$ Billion.

$\mathrm{n} / \mathrm{a}=$ not applicablé. 


\section{J.2.2 Effect of Major Environmental Laws on Baseline Extended Strategy}

Many environmental laws compel regulated entities to adopt a compliance-based response strategy. Placement of the Hanford Site on the National Priorities Listing provides considerable flexibility for the establishment of priorities for past practice cleanup efforts. States cannot be delegated the authority to direct CERCLA cleanup activities; therefore, many states exert their RCRA authority in order to voice their cleanup priorities.

Comprehensive Environmental Response, Compensation and Liability Act The CERCLA provides for response authority to releases of hazardous substances to the environment. Because the Hanford Site is on the National Priorities Listing (four listings), the provisions of the CERCLA "National Oil and Hazardous Substances Pollution Contingency Plan," 40 CFR 300, are applicable. Much of the waste generated from past practice activities could be legally managed under CERCLA authority; however, cleanup of National Priorities Listing sites must be consistent with the National Contingency Plan (particularly 40 CFR 300.430). In other words, the National Priorities Listing sites must be investigated and response actions must be subsequently determined in accordance with the requirements of the National Contingency Plan. The selected strategy must be consistent with the provisions of the National Contingency Plan for all activities undertaken pursuant to CERCLA authority. The selected strategy must also provide for appropriate integration with cleanup activities undertaken pursuant to RCRA corrective action authority.

Resource Conservation and Recovery Act Cleanup of past practice sites must proceed pursuant to either RCRA or CERCLA authority. Agreements with federal and state authorities can be used to account for much of the necessary integration of cleanup activities.

For hazardous or radioactive mixed wastes that are actively managed (e.g., wastes managed in regulated units), there is very limited flexibility available for meeting statutory obligations imposed by the RCRA Land Disposal Restrictions Program. The Baseline Extended Strategy could jeopardize the ability to comply with the RCRA Land Disposal Restrictions Program. The RCRA Section 3004(j) states,

"In the case of any hazardous waste which is prohibited from one or more methods of land disposal under this section (or under regulations promulgated by the Administrator under any provision of this section) the storage of such hazardous waste is prohibited unless such storage is solely for the purpose of the accumulation of such quantities of hazardous waste as are necessary to facilitate proper recovery, treatment, or disposal."

The above requirement has been the source of much concern at DOE facilities. Because mixed waste treatment technologies are not generally available, it is impossible to comply with $3004(\mathrm{j})$ for many mixed wastes. In passing the FFCA, Congress delayed the effective date of the waiver of sovereign immunity from 3004(j) for "certain mixed waste" for three years from the October 6, 1992 date of FFCA enactment. In other words, after October 6, 1995, departments, agencies, and instrumentalities of the executive branch of the Federal Government shall be subject to civil, criminal, and administrative penaities and fines for violations of 3004(j) as it pertains to mixed waste. An exception exists for the DOE, provided that compliance with the FFCA, section $101(\mathrm{c})(3)(B)$ is 
maintained. Compliance with 101(c)(3)(B) requires the DOE to continue moving forth with plans for mixed waste treatment and requires that an order requiring compliance with these plans is in effect. At the Hanford Site, the Tri-Party Agreement plays a critical role in maintaining sovereign immunity from 3004(j). The EPA has not yet delegated the authority to Ecology to implement the Land Disposal Restrictions Program. Because of the statutory obligation of 3004(j) and the fact that regulatory relief is contingent upon continued progress in developing treatment technologies, the DOE and regulators would be particularly vulnerable to third-party lawsuits if they were to pursue any options that ignore or substantially delay land disposal restrictions treatment for actively managed mixed wastes without the provision of a statutory pathway by Congress.

RCRA also requires that regulated units (currently referred to as TSD units), which are removed from operation are closed within 180 days. Whereas the current Tri-Party Agreement currently provides relief from this reant. The Baseline Extended Strategy would significantly extend those closures being coordinated with waste site cleanup.

Clean Air Act The Clean Air Act provides for regulation of both radioactive and nonradioactive emissions to ambient air. The actual impact to Clean Air Act compliance would depend on which emission sources would be required by the selected strategy. If continued or increased emissions would be required by the strategy, emission monitoring/reporting and routine maintenance activities could be impacted if relief could not be obtained and funding would not be available to ensure regulatory compliance. On the other hand, reductions in air emissions could conceivably result in reduced requirements under the Clean Air Act.

Clean Water Act At Hanford, the Clean Water Act primarily provides for regulation of river discharges from point sources. The impact to Clean Water Act compliance would primarily depend on the extent to which the selected strategy would require discharge to the river. If it is expected that the strategy will require continued or increased river discharges, and relief could not be obtained, monitoring/reporting activities and routine maintenance could be impacted by lack of available funds to ensure regulatory compliance. Currently, Hanford Site discharges to the Columbia River are essentially innocuous, and compliance is not particularly complicated.

Occupational Safety and Health Act The Occupational Safety and Health Act provides for regulation of employers in an effort to assure safe and healthful working conditions. The Occupational Safety and Health Act does not apply to working conditions of employees that DOE or other Federal agencies, pursuant to the Atomic Energy Act, exercise statutory authority to prescribe or enforce standards or regulations affecting occupational safety or health. The impact to Occupational Safety and Health Act compliance would not likely be of special concern unless extraordinary circumstances are encountered.

\section{J.2.3 Risk Strategy}

Pursuit of the Risk Strategy would require that stakeholder negotiations result in modifications to existing priorities and schedules for past practice cleanup activities. In addition, the Risk Strategy would require statutory relief from the land disposal restrictions for wastes that are actively managed under the RCRA, such as tank wastes and radioactive mixed wastes in storage. 
The Risk Strategy contemplates in-situ disposal of both single-shell and double-shell tank wastes. Both single-shell and double-shell tank wastes are actively managed in TSD units which must be closed pursuant to Ecology RCRA closure requirements of WAC 173-303-610 and WAC 173-303-640(8). Technically, the closure of a RCRA tank system must typically include removal or decontamination of all waste residues, contaminated structures, and contaminated soils. However, in a final rule issued in the July 14, 1986 Federal Register (51 FR 25436), the EPA clarified the meaning of this requirement by stating, "If all contaminated compounds [sic], soils, structures, and equipment cannot be decontaminated or removed at closure, or if the ground water is found to be contaminated, the site must be provided with post-closure care similar to that required for landfills."

In the same rule (51 FR 25457), the EPA adds, "the final rule requires the removal or decontamination of all contamination at closure of the tank system. If this is not practicable, the regulation provides for post-closure care of the unit. This regulation does not define the level of decontamination. EPA is currently developing policy on the broad issue of defining acceptable levels of contamination (i.e., how clean is clean) outside the scope of this rulemaking."

It is important to recognize that (1) the EPA believes that the option to close as a landfill is not limited to situations where contaminated soils cannot be removed; (2) if wastes must be left in place because removal would be inconsistent with Atomic Energy Act provisions, supporting information must be made available to RCRA authorities; and (3) TSD owners/operators cannot decide unilaterally to close their tank system(s) as a landfill.

Of additional concern is the impact of the land disposal restrictions on in-situ disposal. Because actively managed hazardous wastes are subject to RCRA treatment standards at the point of generation and because these standards must be met prior to land disposal of the affected waste, in-situ treatment of tank wastes may require that a treatability variance or statutory relief be obtained.

The Risk Strategy also contemplates entombment of certain wastes within existing facilities. For facilities with RCRA TSD units, entombment would likely equate to closure as a landfill. For other facilities, entombment would depend on whether the wastes placed within would be subject to the RCRA land disposal restrictions. For wastes that trigger the land disposal restrictions, treatment standards must be met, unless a treatability variance or statutory relief is obtained. Additionally, entombment of CERCLA wastes would have to be consistent with applicable cleanup standards. The Risk Strategy may also require reclassification of the groundwater beneath the Hanford Site.

The Nuclear Waste Policy Act addresses permanent disposal of high-level wastes in a geologic repository. It is currently a national policy that high-level wastes at DOE sites be sent to a geologic repository. Such a policy also exists for post-1970 transuranic wastes. All alternatives that contemplate leaving high-level wastes in place or transuranic wastes will require further detailed regulatory assessment and changes in national policy.

\section{J.2.4 Composite Strategy}

Like the Risk Strategy, the Composite Strategy would require modifications to existing agreements concerning past practice cleanup and would require statutory relief from the land disposal restrictions. 
The Composite Strategy is similar to the Risk Strategy, except that wastes would be moved from outer areas to the 200 Area for permanent disposal.

Radioactive mixed wastes were not identified by the EPA for regulation under RCRA until is issuance of a notice by EPA on July, 31986 (51 FR 24504). Mixed wastes that have been disposed of prior to the applicable effective date of regulation (for Washington, the date was November 23, 1987), would not be considered as actively managed under RCRA unless and until the waste were exhumed. Movement of such wastes under the Composite Strategy would trigger land disposal restrictions.

\section{J.2.5 Summary}

All strategies that affect the Existing Baseline Strategy would require development of a legal pathway for dealing with land disposal restriction concerns. Radioactive mixed wastes that are managed in TSD units or are moved from a past practice site in a manner the constitutes "placement" are subject to land disposal restriction treatment prior to disposal. It is not likely that relief from the land disposal restriction for such wastes could be obtained without statutory amendment(s).

The basic objective and the fundamental schemes for CERCLA and RCRA past practice cleanup are similar, but the rules for implementation differ. The EPA and the DOE had developed model language for cleanup of DOE facilities with the intent of achieving cleanup coordination on a case-bycase basis at individual facilities by the DOE, EPA, and affected states.

The DOE continues to engage in efforts to resolve RCRA/CERCLA coordination problems. Disagreements over how to implement the details of cleanup plans and issues with respect to regulatory interpretations have plagued coordination efforts at many DOE facilities. The DOE is expected to issue guidance this spring to improve efforts to negotiate coordination strategies.

\section{J.3 References}

40 CFR 300, "National Oil and Hazardous Substances Pollution Contingency Plan," Code of Federal Regulations, as amended.

51 FR 24054, 1986, "Civilian Health and Medical Program of the Uniformed Services (CHAMPUS); Technical Revision of DoD 6010.8-R," Federal Register, July 1.

51 FR 25436, 1986, "Hazardous Waste Management System; Standards for Hazardous Waste Storage and Treatment Tank Systems," Federal Register, July 14.

51 FR 25457, "Hazardous Waste Management System; Standards for Hazardous Waste Storage and Treatment Tank Systems," Federal Register, July 14.

Atomic Energy Act of 1954, 41 USC 2011 et. seq.

Clean Air Act, 42 USC 7401 et. seq. 
Comprehensive Environmental, Response, Compensation, and Liability Act of 1980, 42 USC 9601, et seq.

Ecology, EPA, and DOE, 1994, Hanford Federal Facility Agreement and Consent

Order, as amended, Washington State Department of Ecology, U.S. Environmental Protection Agency, and U.S. Department of Energy, Olympia, Washington.

Federal Facility Compliance Act of 1992, Public Law 102-386, 106 Stat. 1505.

Hazardous and Solid Waste Amendments of 1984, 42 USC 6912(a), 6921, 6922, 6924, $6925,6926,6930,6935,6937,6939,6991$, and 6993.

Nuclear Waste Policy Act of 1982, 42 USC 10101 et. seq.

Occupational Safety and Health Act of 1970, 29 USC 651 et seq.

Resource Conservation and Recovery Act of 1976, 42 USC 6901, et seq.

RL, 1994, Fiscal Year 1995 Hanford Mission Plan, Volume 1, "Site Guidance," DOE/RL93-102, U.S. Department of Energy Richland Operations Office, Richland, Washington.

Superfund Amendments and Reauthorization Act of 1986, 42 USC 6921, et seq.

WAC 173-303, "Dangerous Waste Regulations," Washington Administrative Code, as amended. 